


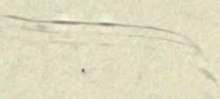





\title{
BRITISH ANTARCTIC EXPEDITION 190\%-9
}

\author{
UNDER 'PHE COMMAND OF SIR E. H. SHACKLETON, C.V.O.
}

\section{REPORTS ON THE SCIENTIFIC INVESTIGATIONS}

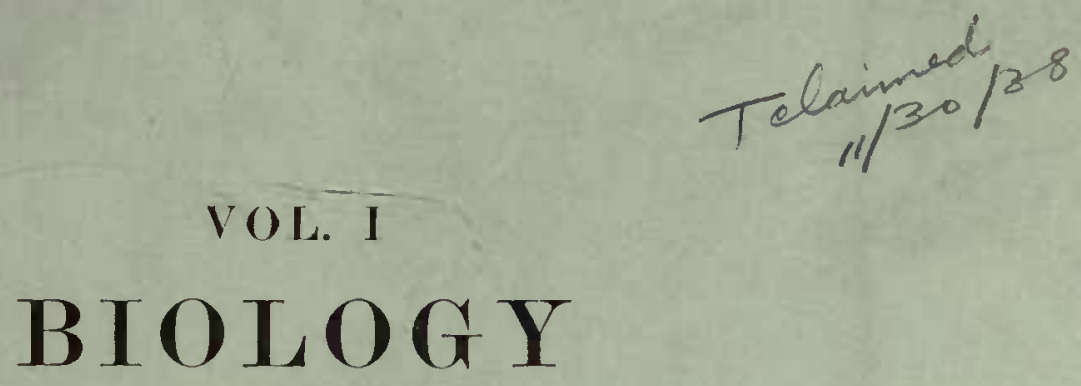

\section{EDI'TOR - - JAMES MURRAY}

\author{
PAR'TS I To IV \\ I. ON COLLECTING AT CAPE ROYDS \\ BY JAMES MURRAY \\ 1I. ON MICROSCOPIC LIFE AT CAPE ROYDS \\ BY JAMES MURRAY \\ III. ANTARCTIC ROTIFERA \\ BY JAMES MURRAY \\ IV. MUSCI \\ BY JULES CARDOT
}

(WITH THIRTEEN PLATES AND TIIREE

FIGURES IN TIIE TEXT)

LONDON

PIBLISHEI) FOR 'THE EXPLDITION BY IVILIAM IIEINEMANY

21 BEDFORD STRTET, W.C.

1910

PRTCE TWBINE SIILLIXGS AXI SIXPFCOE NET

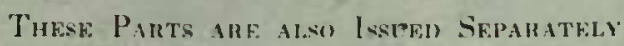





\section{PAR'T I}

\section{ON COLLECTING A'T CAPE ROYDS*}

\section{BY JAMES MURRAY}

Is making the biological collections, almost every member of our small party lent more or less assistance. Though busy with other occupations, all were ready to bring home to the biologist anything strange which they noticed. Armytage found a seaurchin during a walk on the sea-ice before we had made a landing, and while landing he picked up the first scrap of sea-weed. Mr. Shackleton brought in some moss and lichen soon after the Nimrod departed. Wild got specimens of the lake vegetation. Adams found a starfish on the beach, and the others in like manner helped when opportunity offered.

All these indications that there was life in the district, coming as they did before the biological work was properly started, were encouraging for the future.

When the dredging operations began there were many willing helpers. Mr. Shackleton, with David, Mawson, and Priestley, were always interested in the dredging and ready to help, not only at hauling the dredge, but at the more disagreeable labour of conveying the collections to the hut. It is no disparagement to others to acknowledge the share which Priestiey took in the biological work. Without him the greater part of the collections would not have been made. When the biologist was debarred by some trifling but mastering indisposition from active participation in the dredging during the midwinter weeks, Priestley kept the dredging-holes open, no small labour with the temperature sometimes as low as from minus $30^{\circ}$ to minus $40^{\circ} \mathrm{Fahr}$. With the assistance of Mr. Shackleton, David, and others, he kept up the dredging and brought home the proceeds to be examined.

Throughout the entire season practically the whole of the arduous labour of digging holes in the sea-ice and of sinking shafts in the lakes fell upon Priestley, and he did the active hauling of the dredge as well. It does not lessen our indebtedness to him to tell that he enjoyed his self-imposed task, and his voice might be heard issuing in light-hearted song from some deep shaft in lake or sea.

The Field of Operations.-This was extremely limited. The great majority of the collections were made within a radius of a few miles from our base camp at Cape

* Cape Royds is the westernmost point of Ross Island, South Victoria Land, and is situated in about latitude $77^{\circ} 32^{\prime} \mathrm{S}$., longitude $166^{\circ} 12^{\prime} \mathrm{L}$.

BRIT. ANTARCT. EXPED. 1907-9. vOL. I. PART 1, ISSUED APRIL 1910 
Royds. Those who went on the long sledging journeys brought back specimens from more distant points. Mr. Shackleton brought lake vegetation and Joyce brought moss from Hut Point (the Discovery's winter quarters, twenty miles south of Cape Royds); Priestley brought rotifers, mosses, lichens, and some marine organisms from the neighbourhood of the Ferrar Glacier and the Stranded Moraines, when he visited the west with Armytage's party; and Brocklehurst on the same journey obtained some lichens at an elevation of about 4000 feet at New Harbour Heights; David brought moss and lichen from near Cape Irizar, the most distant point from our camp at which any biological specimens were collected. So far as known, the species were the same in all the localities.

The promontory of Cape Royds, round which most of the collecting was done, is a hilly tract of triangular form, separated from the main mass of Mount Erebus by a valley in which there is a series of small lakes, and terminating at its southernmost point in a bluff rising vertically from the sea to a considerable height. This culminating-point of the Cape was familiarly known as Flagstaff Point, from a pole which we erected there for the purpose of signalling to the ship. In the hollow between it and the hut was Pony Lake, and between the lake and the shore was the rookery of Adelie Penguins.

The triangular area is just about a mile in length and half a mile in greatest breadth. It includes many little sharp rocky peaks, composed of kenyte, with ridges of the same rock diverging from the peaks. The valleys are filled with a gravelly debris resulting from the decomposition of the kenyte, and contain many little lakes or ponds. Considerable stretches of morainic material occur. The highest point of land is no more than 300 feet above the sea. The greater part of the shore-line consists of low cliffs with a few small patches of sandy beach. The most extensive of these beaches, known as Black Sand Beach, is about a mile to the north of the hut.

On the shore there is no vestige of marine life, animal or vegetable, such as is found in the littoral zone of other coasts. The beaches are formed of a coarse, hard, black sand, with boulders of kenyte and other rocks. The presence of an ice-foot throughout the greater part of the year, and the grinding of ice along the coast when there is open sea, must destroy any living things which attempt to establish themselves. The zone thus kept devoid of life is of no great depth. Standing on the edge of the ice-foot at Black Sandy Beach, when the Sound was open, various living things could be seen at a depth of from one to two fathoms. Starfish were commonest in this situation, but a living Pecten Colbecki was got in equally shallow water at Back-door Bay.

The larger lakes were given distinguishing names. Pony Lake, close beside the hut, formed the exercising ground for the ponies during the long night. A short distance to the north was Green Lake, named from the colour of its ice. A mile north of the hut and close to the shore was Coast Lake, remarkable for its level smooth ice, which would have served for skating and curling. Close by was Clear Lake, named 


\section{ON COLLECTING AT CAPE ROYDS}

Fig. 1.

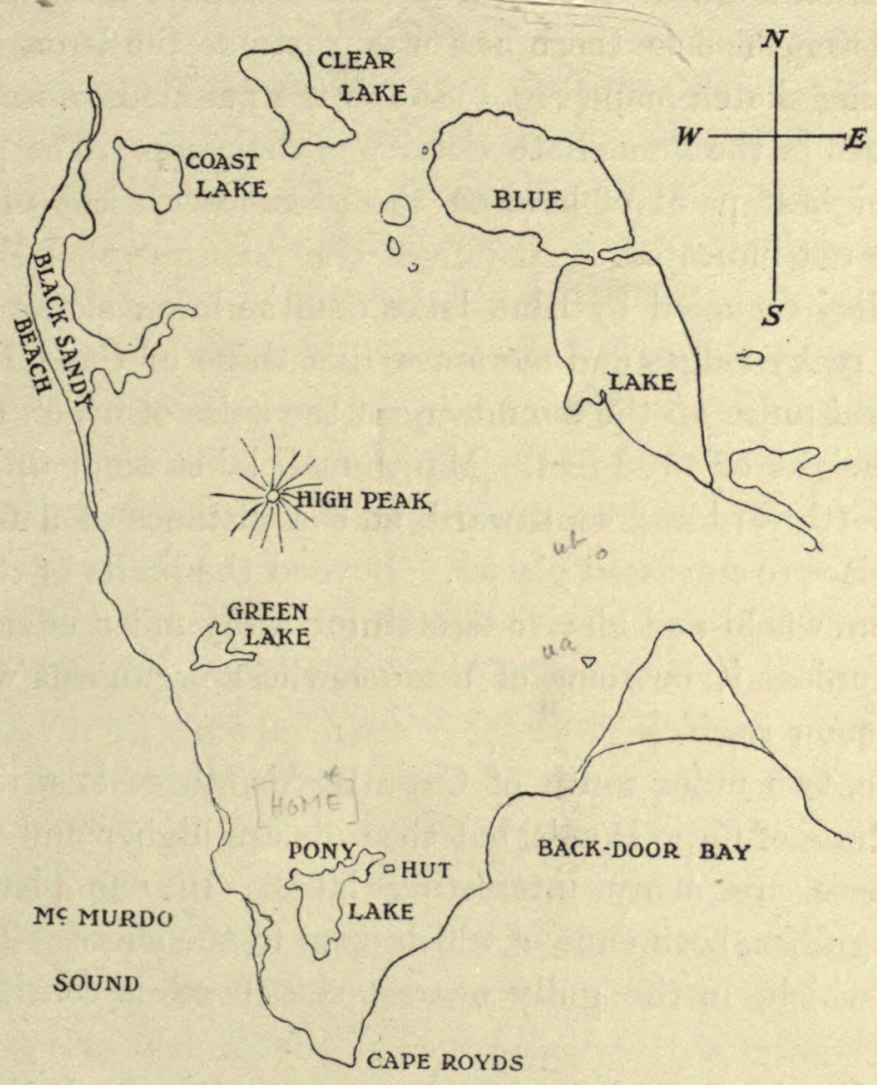

SKETCH-MAP OF THE IMMEDIATE NEIGHBOURHOOD OF CAPE ROYDS Showing the positions of the lakes, \&c.

Copied from Map lent by R. E. Priestley. 
from the clear transparent ice, through which on our first arrival we could see the vegetation growing on the bottom at a depth of several feet. The largest of all was Blue Lake, which most nearly deserved the name of "lake." It was nearly half a mile in length, and filled about half of the valley separating the promontory of Cape Royds from Mount Erebus. The lake was divided into two portions by a very narrow strait, known as the "Narrows," in which the depth was only about three feet. The northern half was deeper, and was found to have a few feet of water under twenty-one feet of ice. The southern half was frozen to the bottom.

The accompanying sketch-map (Fig. 1) shows the positions of some of the principal geographical features in the immediate vicinity of the camp. The principal lakes are marked, and the highest point of land on the promontory, known as "High Peak." The lower hills are not indicated.

Beyond the valley occupied by Blue Lake rise the lower slopes of Mount Erebus. This is a region of rocky ridges and moraines like those of Cape Royds promontory, extending for several miles up the mountain, on the sides of which the moraines have been traced to a height of 1100 feet. Many small lakes occur up to a height of at least 500 feet. Northward and southward, at the distance of a few miles, the rock and moraine give place to crevassed glacier. Beyond the limits of the small area thus briefly described, snowfield and glacier stretch for many miles, offering no support for any living thing, unless it be some of those lowliest organisms which can exist on the surface of the snow itself.

At Cape Barne, two miles south of Cape Royds, there is a district of hill and valley similar to those of Cape Royds, but the hills are higher and the valleys deeper. In this region there are many interesting lakes. In one place there are two concentric curved gullies, both ends of which open to the shore. These are occupied by lakes, one of which, in the gully nearest the shore, is considerably below sealevel.

The bay immediately east of the hut was our customary dredging ground. All the dredging was done within a mile of the Cape, in shallow water, nowhere more than 100 fathoms in depth. Farther out the Sound deepened to 300 fathoms or more, but that region remained for ever inaccessible.

Collecting on Land.- - It is difficult to imagine a more unpromising field for biological study than Cape Royds appears on a first examination. Nothing is to be seen but a succession of ridges of black lava (shattered into loose blocks by the intense cold), moraines and snowdrifts, all apparently equally barren.

Near the shore the monotony is relieved by the busy Penguin Rookery, the Skua Gulls, the Weddell Seals, and an occasional Giant or Snowy Petrel. All these animals are only summer visitors, except the Weddell Seal, which comes ashore at all seasons. Apart from these there is no conspicuous life, animal or vegetable, in the whole area. Indeed, leaving the lakes out of account, the collecting which could be done on land was of the most meagre description. 
On the triangular promontory no moss or lichen was ever found. Higher up among the moraines on the slopes of Erebus dwarfed tufts of moss were fairly abundant, but so feeble is their growth that M. Cardot,* who examined them, describes them as "sickly plants, struggling painfully against exceptionally hard conditions." Lichens were more abundant, though scarcely more vigorous in their growth, and there were more kinds of them. The commonest was a pretty orangecoloured kind, closely encrusting the rocks, and crowded with apothecia. The Tripe de Roche, familiar in books of Arctic travel for its rôle in prolonging the lives of starving explorers, occurred in two forms. Its little scales, some half-inch in diameter, and attached by a single point on the under surface, were scarcely so abundant as to fulfil the same life-saving rôle in the Antarctic. The largest-growing lichen was a tufted kind, growing to an inch or more in height, and resembling Usnea in possessing a fragile cortex, which breaks on pulling the stalks and exposes a tougher elastic medullary portion. The Tripe de Roche and the tufted lichen could be picked off the rocks, but most of the other kinds could only be collected by selecting conveniently small stones on which they were growing. When the snow completely melted from some of the moraines in the height of summer, patches of the tufted species were found a yard or more in diameter.

In the valley bottoms, where water had run or at least percolated in summer, there was a faint scum of green, which consisted generally of dried-up green algæ. On some parts of the moraines, where there was some depth of soft soil, considerable masses occurred of a plant which seems to be identical with that which abounds in the lakes, and which will be more fully studied when dealing with them. It is of a whitish, yellowish, or pink colour, and is in sheets like thin paper, superposed to form masses of considerable thickness. In some eskers on Blue Lake it was traced to a depth of several feet, and on some flat moraines it was discovered occupying pockets underground. In all cases when found on land the plant was friable and had a bleached appearance. From this fact it is doubtful if it ever grew in the kind of situation it now occupies. It may have been preserved from a time when these were parts of lake bottoms.

Collecting in the Lakes.-Soon after landing at Cape Royds, on walking across the lake afterwards called Green Lake, some thin films of vegetation of a dull green colour were seen projecting above the surface of the ice. Shortly afterwards Wild found pieces of a similar plant, but of pink or brown colour, exposed on the surface of Clear Lake. At the margin of Clear Lake, where the ice was trunsparent, the same plant was seen at a depth of about a foot, of much brighter colour than that exposed at the surface. Pieces of this were cut out with an ice-pick, and taken home and melted, when several microscopic animals were found.

This was the introduction to the most prolific source of fresh-water life in the district. The plant was found embedded in the ice of nearly all the lakes, and when * "Musci," by J. Cardot, in Part IV. of this volume. 
the smaller ones melted in summer it was seen that it formed continuous sheets over the whole bed of some of them. Everywhere microscopic life swarmed on this weed. The method of collecting during the winter was very simple. A few pieces of ice containing plants were chipped out and taken to the house to thaw. When quite melted the weed was put into a coarse silk net, which was again put inside a very fine silk net, and the whole immersed in a bucket of water. When the nets were violently shaken in the water the microscopic organisms, animal and vegetable, were washed off the weed, and strained through the coarse net into the fine one, from which they could be easily transferred to a bottle. Thus were obtained multitudes of living things for study.

In summer the collecting was still simpler. The weed could be washed in the lake water without the need for preliminary thawing.

In this way we collected continually from the shallow lakes. There were some deeper lakes, which, as it proved, did not melt in summer. In Clear Lake a hole was dug through the ice. We came on water at a depth of about four feet. Here we dredged on the lake bottom, at a depth of seventeen feet. There was a quantity of vegetation brought up, but it was discoloured and dead, and there was no living thing upon it.

Late in the winter, Priestley sunk a shaft in the southern portion of Blue Lake, for the purpose chiefly of observing the temperatures of the ice. At a depth of nine feet some scraps of weed were got, and when thawed a number of living animals were found on it. At a depth of fifteen feet we came on the bottom of the lake, which was here composed of angular fragments. These were covered by a continuous film of yellow weed, and on this also there were numerous living things.

In autumn an attempt was made to use the tow-net in some of the lakes. The lakes being at this time covered by a thick sheet of ice, the net could not be drawn through the water. A hole was dug and some gallons of water taken up with a bucket and poured through the net. At this time the temperat:"'a of the air was about Zero Fahrenheit, and the net was soon filled with ice. When tharved out there was no living thing found in it. In summer, when the lakes were melted, and the air temperature was about freezing-point, the tow-net could be easily used, and good collections were got.

The vegetation of these lakes is so important a feature in the biology of the district that it merits some attention. Portions of it have been submitted to expert botanists, but no report has yet been received, so it cannot be stated to what group of the vegetable kingdom it belongs. Its appearance and method of growth will be described.

In Green Lake and many other lakes it is in the form of sheets, from a few inches to many yards in extent, sometimes continuously covering the bed of a pond from side to side. It varies in thickness, from one-eighth to half an inch or more, and is of a consistency like sodden paper, so that it was not possible to lift up sheets of any considerable size without breaking them. The upper surface is of a bright orange 
Fig. 2.

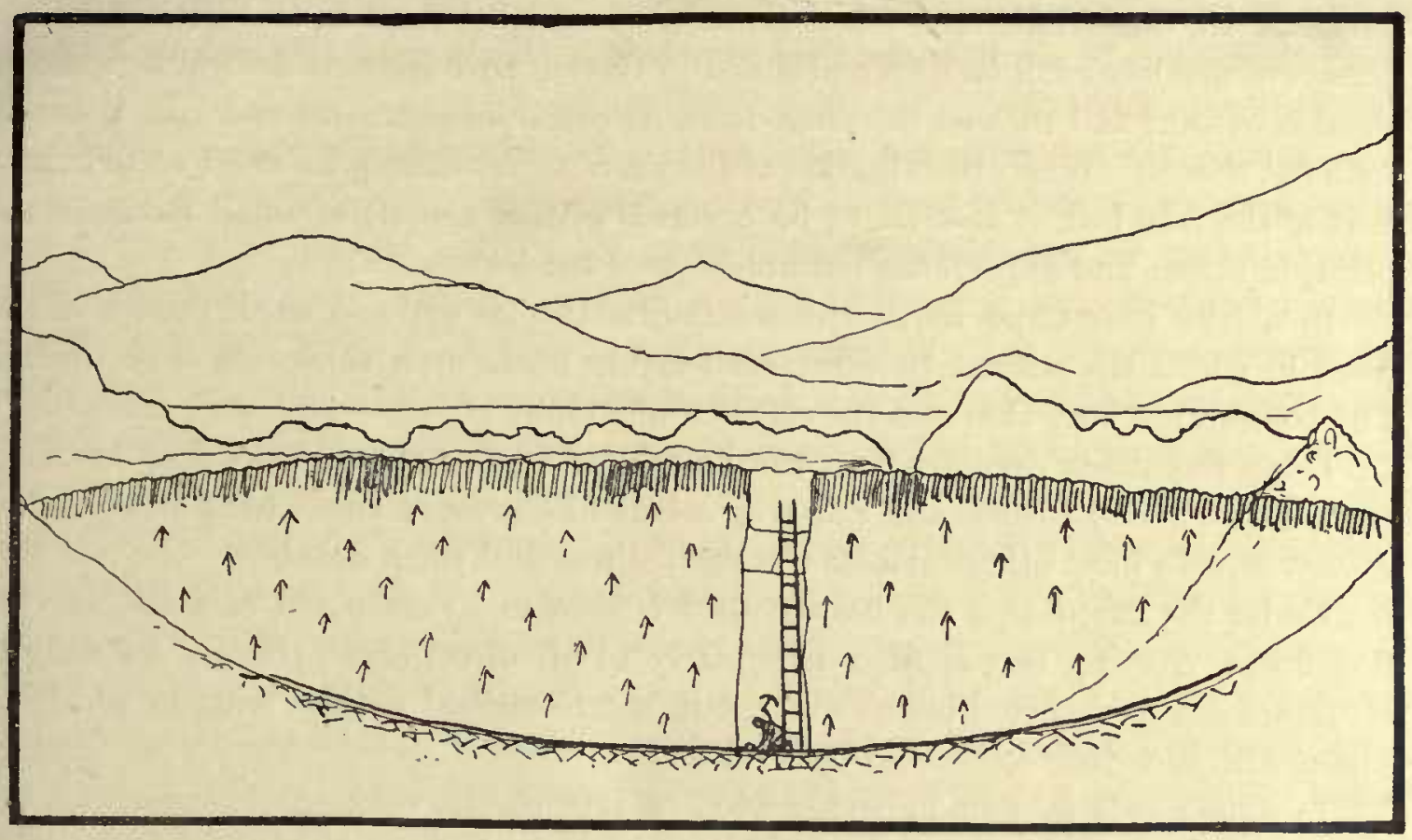

DIAGRAMMATIC SECTION OF BLUE LAKE

The part shaded with short vertical lines is the uppermost "prismatic" layer of ice. The convex upper surface of the lake is indicated, and the irregular thickness of the prismatic layer. The area marked by little arrows is the clear transparent ice which fills the whole lake to the bottom. The bed of the lake is of angular fragments, and the dark line over them is meant to represent the film of vegetation which covers the bottom. At the bottom of the shaft is seen the geologist chipping out some gravel and vegetation. 
colour, and is coarsely and irregularly wrinkled. It is composed of few or many layers, like superposed sheets of paper. The lower surface of the sheet is of a dirty green colour, and is composed of a tangled mass of many different algæ, green and blue-green. The whole mass was siimy to the touch.

The mode of growth differs in different lakes. The broad sheets above described are the commonest form. In Clear Lake it does not form flat sheets, but is coarsely lobed and undulate, and can be seen through the clear ice growing up from the bottom. In Coast Lake the lobed character is carried further, and little dendroid masses of fine lobes can be seen embedded in the ice near the surface. When one of these is cut out and thawed the plant loses its dendroid character and falls down to form flat sheets. When the ablation of the ice of Coast Lake goes so far as to expose part of the lake bed, it is seen to be covered with a deposit of small flakes of the plant, in colour and appearance not unlike used tea-leaves.

In a lake near Cape Barne the ablation of the ice exposed small masses of the weed in which the successive superposed layers made up a thickness of six inches. The layers were very thin and the colour a fine pink.

Large fragments dredged from the bottom of Clear Lake and dried on blottingpaper had a glossy surface and ash-grey colour like some of the lichens of the genus. Peltigera. In most other samples the surface was dull when dried.

Under the microscope the brown weed is seen to be composed of a felt of very fine fibres, crossing one another irregularly in all directions. Usually no definite structure can be detected in the fibres, but Mr. Scourfield noticed some in which an obscure division into cells could be seen.

In some ponds we found another weed of very similar colour and appearance, but in very small quantity. This was definitely composed of moniliform rows of cells of some blue-green alga, very probably of the large olive-green laminæ which we got in some streams and ponds in summer. The similarity of the two suggests that the commoner brown weed has in like manner originated in the blue-green filamentous algæ generally associated with it. Plausible though the suggestion is, it requires expert investigation before we can decide upon it. The filaments (Oscillatoria?) seem inadequate to the production of such masses, being to a large extent in the form of longer or shorter rods (as shown in Plate IV. Fig. 15).

The method of trenching a lake in order to get at the sheet of vegetation at the bottom is illustrated in the accompanying diagram (Fig. 2).

The shallow lakes were very easily trenched, a few hours' work sufficing to reach the bottom. The trenching of the deeper lakes, Clear Lake and Blue Lake, was a more laborious undertaking. The trench is marked out by a draft cut with the icepick, enclosing an area of about six feet long by three feet wide. The whole surface is then picked over to a depth of a few inches, and the chips are shovelled out. A very little chipping seems to make a great depth of chips, and frequent clearing out is necessary, or it becomes impossible to get at the solid ice on account of the loose: 
stuff. Thus alternately picking and shovelling, a few inches at a time, the trench gradually deepens to five or six feet. Up to this time everything is easy. The debris is easily shovelled out with force enough to carry it well clear of the hole. With every increase in depth this becones more difficult, till at last the chips come showering back on the worker below. It then becomes necessary to have another man to pull up the chips in a bucket, or if one man attempts to do everything, he must interrupt his work below every little while, climb out of the hole and pull up a load of chips. Beyond a depth of five feet it is necessary to construct a stairway. It was usual to have a few broad steps near the top, and lower down to cut niches for the feet alternately at one side and the other.

Blizzards are apt to interfere with the work, filling the trenches with snow. After some experience we learnt wisdom, and covered the trenches with sacking, which was secured with ice-picks whenever we had to go away for a time. The most laborious part of the picking was the squaring of the corners. Some of the latest shafts were made round, and of just the diameter at which a human arm can conveniently wield an ice-pick. In these the minimum of material had to be removed.

At depths of fifteen feet and more progress becomes very slow. It is necessary to have a ladder to get down. If there are two men the ladder can be drawn up out of the way after one man has gone down. If there is only one the ladder is very much in the way. The man below is in some danger when the bucket is being hauled up, as the breaking of the line would let it fall upon him.

Collecting in the Sea.-Mr. Hodgson has given an account* of his collecting at Hut Point, and he mentions some of the difficulties which attend the collector in polar regions. Though our location at Cape Royds was only twenty miles north of the Discovery winter quarters the local conditions differ very considerably. The temperature appears to be usually ten degrees or more (Fahrenheit) higher than at Hut Point. Being close to the spot where McMurdo Sound opens into the Ross Sea we had open water close by throughout the year. In fact, even in winter the edge of the permanent ice was never more than a mile from our camp. Beyond the fast ice the Sound frequently filled with pack-ice stretching as far as eye could see. Sometimes, in a period of calm, the pack was cemented into a solid field by new ice, but this was broken up by every storm, and it was therefore always unsafe to go out on it. The marginal zone of even the permanent winter ice was liable to be broken off in a severe storm.

From this cause marine dredging was confined within a very small area. We could work steadily during winter only in a little bay between Cape Royds and Cape Barne, where the ice formed early and stayed late. Here, as early as the beginning of May, the ice was strong enough to allow us to cut holes and put down traps. The traps were baited, and brought up Amphipods and Molluscs. Some pieces of a dendroid sponge were entangled in the net and from these we got a number of minute

* "On Collecting in Antarctic Seas." By T. V. Hodgson. "National Antarst. Exped. 1901-4," vol. iii. BRIT. ANTARCT. EXPED. 1907-9. VOL. I. 
molluses and other animals. A storm early in May broke up the ice and our dredging apparatus went out with it.

On May 11 ice again formed in the Bay, and proved to be permanent, remaining fast till February of the following year. As soon as the ice was strong enough dredging was begun. The first dredging-line was put down while the Bay was open, from the edge of a small area of fast ice which remained near the head of the Bay. Afterwards we had to take advantage of tide-cracks in order to get lines put down. It rarely happened that we found the cracks open and could get the line down without labour. Usually they were filled with new ice to a depth of 6 inches or a foot, and it was by hard labour with ice-pick and crowbar that we got a sufficient length open to serve for dredging. Foot by foot as the crack was cleared the rope was forced through, for with the low temperatures new ice quickly forms in the part we have opened. When the rope was through for a sufficient length it was secured at the two ends to bamboo poles, enough slack being paid out to allow the ends to hang nearly vertically, thus avoiding the danger of the rope being frozen in. It was then necessary to dig holes in the ice at the two ends of the rope, through which the dredge could be lowered and drawn up.

The holes were from fifty to one hundred yards apart, but the effective dredging distance was less than that on the ice, as the dredge would always leave the bottom some considerable time before arriving directly under the opening in the ice. Each time that we wished to dredge the holes had to be reopened with pick and crowbar. They would be frozen over with ice from a few inches to a foot or more in thickness, according to the temperature and the length of time they had been left undisturbed. In cold weather it was not well to leave them for more than a day, and Priestley sometimes opened them, although there was no intention of dredging, in order to lessen the labour next time. The Weddell seals were of assistance in keeping the holes open. They found them useful as breathing-holes and visited them frequently, sometimes arriving in an apparently exhausted condition, to judge from their laboured breathing.

In order to avoid dredging too frequently over the same ground it was necessary to cut trenches in the ice alougside the ends of the rope and at right angles to the line joining the two ends. In these trenches the rope could be shifted a yard or so. at each time of dredging and so the dredge covered entirely fresh ground. Sometimes the rope was left too long and got frozen in too solidly to be cut out in the usual way. A new hole was then cut close by the old one, and the line was fished up by means of a hook on the end of a long bamboo pole.

The arrangement of the apparatus and method of using it are illustrated in. Fig. 3, in which the Bay where we dredged is shown in section.

The dredge was fixed to the middle of the line so that it could be used in either direction. It was found that it often caught nothing when travelling downhill, so it was. usual to haul it downhill and then back again uphill before bringing it to the surface. 
FIG. 3.

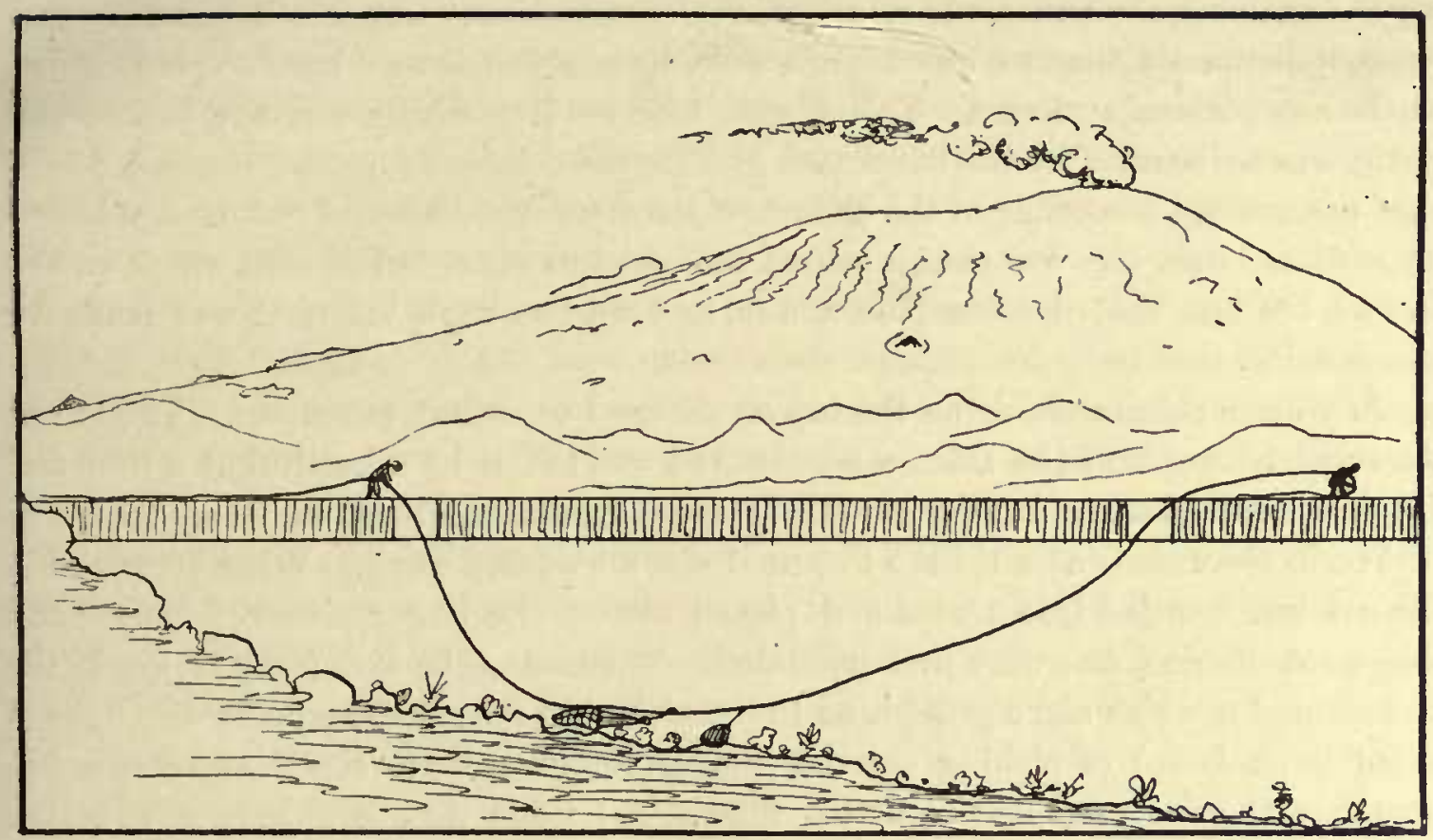

DIAGRAM ILLUSTRATING METHOD OF DREDGING

The ice (which is supposed to be five or six feet in thickness) and the bed of the sea are shown in section. The vertical lines mark the sea-ice, and their cessation indicates the positions of the two holes kept open for the purpose of dredging. One man is shown hauling the dredge, and another is paying out the spare line to lessen the strain which tends to lift the dredge off the ground. A few feet in front of the dredge a weight is seen, which serres to keep the dredge down, and at the same time by the length of its attaching cord maintains it in the right position. The weight was sometimes a lump of kenyte tied in a cloth, but generally some discarded parts of a motor-car were used. 
When the dredge reached the surface both men went to the opening, the one who had been hauling keeping the line taut to prevent it sinking again. The contents of the dredge, consisting of a thick black mud in which only the larger objects such as sponges, shells, blocks of kenyte, and sea-anemones could be distinguished, were emptied into a bucket. This was made from a 4-gallon kerosene tin provided with two wire handles. 'Ihe bucket was filled nearly to the top with sea-water in the hope of enabling the animals to remain alive for some time. At first it was conveyed home, a distance of about a quarter of a mile, by slinging it on a bamboo pole carried on the shoulders of two men. This caused too much splashing, and the bucket was thenceforward carried by the handles.

Generally all the water in the bucket was frozen into a kind of soft sludge before we reached home. It was placed behind the stove to thaw, but so cold was it on the floor of the hut that it often took a day, or even two days, before it'was ready for examination.

Any large objects visible on the top of the mud were first taken out. To get out the smaller organisms the thick coherent mud was taken by a handful at a time and put in a small silk net having a mesh of about one-sixteenth of an inch. This was shaken in clean sea-water till the fine mud was all washed away. What remained in the net was emptied into plates and picked over. The larger pieces of kenyte and shells, sea-urchins, \&c., were first separated. Then came the task (very trying in the dim gas-light, which alone penetrated to the biological lab., or the equally dim light of a hurricane lamp) of picking out the smaller things, minute crustacea, shells, \&c., requiring the use of a lens to detect them. All these various objects were serted according to their size and kinds, and stored in bottles.

When we had enough jars filled to occupy one of the compartment boxes provided for the purpose, they had to be removed, as there wasn't room in the hut for them. The first was put under the floor of the hut, as likely to be warmer than the outside air, and to escape filling with snow during blizzards. The air-lock under the house was so very difficult of access that the boxes were afterwards put outside, to take their chance of cold and snow. A few jars were broken by the cold, but there was no help for it. The formalin which was used for certain kinds of animals suffered a change from the low temperature, becoming milky, and did not again regain its clearness.

When not in use the dredge was left at the bottom of the sea. This kept the rope soft, and the dredge was ready for use whenever the holes were opened. The one-inch lines used lasted throughout the season. This may be partly attributable to leaving them in the sea and never allowing them to freeze solid. The part never immersed was air-dried and flexible.

The Bay, which was the only place where dredging was possible during almost the entire season, was very shallow, the depth varying from seven to eighteen fathoms. The sea bottom was everywhere covered with a deep layer of very fine 
black mud, in which there were many pebbles of kenyte. While this mud was favourable to certain forms of life it was unfavourable to others, and thus though life was abundant it was restricted to a comparatively small number of species.

Shells of the large mud-loving Mollusc (Anatina) were very plentiful (though we rarely found the living animal), as well as of Pecten Colbecki. The large predaceous Gastropod (Neobuccinum) crowded to any bait put down. Dendroid sponges and a large kind of yellow Sea-anemone adhered to the shells of Anatina or to the pebbles of kenyte, and rarely large turnip-like Tunicates came up. Ugly little fishes with enormous heads (Notothenia) were grubbing closely among the other organisms. In the mud were numerous worms of many kinds, echini, and multitudes of minute crustacea, \&c.

This shallow muddy dredging-ground was used constantly throughout the winter, and at intervals afterwards till February 1909. It was not till the beginning of July that there was an opportunity to dredge over fresh ground. At this time a crack opened which stretched from the cliff of Cape Royds away towards Cape Barne. This crack appeared to be caused by the contraction of the main icefield in McMurdo Sound. At any rate it only opened in cold spells and closed in warmer weather. When the cracks were open the dredge could be put down and dragged a long way without any need to cut through the ice.

Near the Cape this new ground was quite as shallow as the Bay but it was quite free from mud, and the collections differed a good deal in their composition. There were many loose stones near the shore, but as we extended our operations farther and farther out we reached greater depths and there were no more stones. The sea bottom here appears to be covered by a continuous carpet of living things.

The sponges were much more numerous and the siliceous kinds were first obtained. There were Sea-spiders (Pycnogonids), Lace-corals (Polyzoa), Holothurians, File-shells (Lima), Alcyonarian Corals, Star-fishes and Brittle-stars, pretty milky white Nudibranchs (Tritoniella), and many other things.

The greatest depth at which we dredged in this crack was about eighty fathoms. The dredge was not left down on the bottom when not in use as we did in the Bay, because the crack was apt to close at any time, and when it did so the one side of the floe was often caused to override the other, which would have snapped the line and lost the dredge.

On July 6, a crack opened from the Penguin Rookery westward out into the Sound, in which we were able to dredge once at 100 fathoms. Nothing strikingly different was obtained. In one haul pretty near the shore, the dredge was filled with the common red Star-fish, and there was almost nothing else.

Collecting Plankton. - Very little plankton collecting could be done in McMurdo Sound. As the Nimrod passed through the Ross Sea the tow-net was used several times, being kept clear of the ship by a long boom projecting about ten feet from the side. The last of these tow-nettings was made as we entered McMurdo Sound. The boom had then to be unshipped to prepare for the vessel lying alongside the ice-foot. 
While she remained for some days moored to the fast ice in the middle of the Sound, a number of hauls were made with the tow-net used vertically. The net was let down to a depth of 100 or 200 fathoms and hauled steadily to the surface. These hauls brought in a good many things, including two kinds of Pteropods, a small hyaline species, and a pretty red one about an inch in length.

No further collecting could be attempted till we were settled down on shore at Cape Royds and the ship had gone away. There was at this time open water all round, but the coast was too rugged to allow of any good tow-netting by throwing in the nets, and, moreover, we were too busy in other ways. When the ice formed for the winter it was always unsafe to go to the edge which bordered the open sea. There were no lanes where the net could be used. The only feasible method was to attach the net to the dredging-line and pull it from one of the holes to the other, under the ice. When this was attempted the net came up full of sludge, which probably came in early in the haul and so prevented much water passing through. The sludge took a long time to thaw, and when it was reduced to water there was almost nothing in it. In one such haul we got two phosphorescent Copepods, one Diatom, and one Peridinium.

The method of taking vertical hauls at the dredging-holes might have been practised had the depth been sufficient, but at our habitual dredging-ground the depth was only from seven to eighteen fathoms.

Early in July a crack opened to the west of the Cape. At a distance of a quarter of a mile from shore the depth was 100 fathoms. Our first concern was to dredge on this fresh ground, and as the temperature was very low fresh ice filled the crack before there was time to use the tow-net.

After the Nimrod returned on her second trip south, when the ice had broken up to beyond Glacier Tongue (twelve miles south of Cape Royds), we noticed a great many brown bodies, from one to six inches in length, floating in the sea. While the ship was moored to the Glacier Tongue some members of the ship's crew fished up a few of them in a tow-net. Some of them, at least, were Ctenophores. The ship's company also picked up a large medusa (of sorts), but as there were no conveniences available for preserving it, it was allowed to freeze in a jar of sea-water, and by the time it could be put in spirit it was in such a condition as to be unrecognisable. Occasionally shoals of Shizopods (mistaken by the sailors for fish fry) came alongside the ship.

The Fish-trap.-At the end of August, Day made a fish-trap, at Priestley's instigation, from Joyce's design, and with the object not so much of adding to scientific knowledge as replenishing the larder. It was constructed of copper wire, and was originally of the shape of a water-melon, with a small opening at each of the poles. From the openings several wires projected into the inside, converging inwards, so that the fish could easily push them aside to get in, but could not get out again. The trap was baited and put down in about twenty-five fathoms. After an hour or 
two it was drawn up and two dozen fish found in it. Put down on the same spot for a time there was nothing caught except star-fish and gigantic red worms.

The trap was used several times, and when put down at a fresh place always caught plenty of fish the first time used, but few or none afterwards. As the fish were not appreciated when cooked the trap fell into disuse. The big-headed fish caught in the trap were good collectors for the Expedition, for in their mouths we found Isopods and Opisthobranchs, larger and finer than any that ever came in the dredge, and frequently small fish, to all appearance of the same species as the big ones.

The fish-trap was the best collector of the giant worms, which came up hanging from it like long ribbons. As they contracted on feeling the cold, and thickened at the end inside as well as outside the trap, we could not get them out as complete specimens. The largest of our star-fish, nine inches across, came into the trap. 



\title{
PART II \\ MICROSCOPIC LIFE AT CAPE ROYDS
}

\author{
BY JAMES MURRAY
}

THE finding of an abundant microscopic fauna and flora at Cape Royds came somewhat as a surprise. It is true that the most northerly lands hitherto carefully examined (Spitsbergen and Franz Josef Land, in about latitude $80^{\circ} 0^{\prime} \mathrm{N}$.) have a rich microscopic fauna, but in these lands the higher summer temperature allows of a flora of the higher plants, and a luxuriant growth of mosses, among which so many microscopic animals have their haunts. In Grant Land at an equally high latitude there has recently been found a rich moss flora, which would undoubtedly be found to harbour plenty of animal life, though this has not yet been reported.

Cape Royds, though at a much lower latitude $\left(77^{\circ} 30^{\prime} \mathrm{S}\right.$.) and close by the open sea, has a much lower summer temperature. The mean temperature of a summer day rarely rises above freezing-point, and there is no vegetation higher than mosses. As contrasted with the northern lands the moss fauna is a very poor one. We found only four species, and from the whole of Victoria Land there are but eight species known. At Cape Royds they are very scarce, and are stunted and sickly in growth. The micro-fauna which they support is very meagre, a few water-bears and rotifers, one rhizopod, and little else. In some tufts of moss the individual animals were numerous; in others no life could be detected.

The kinds of animals which are usually to be found among mosses have at Cape Royds a shelter of another sort, which, judging from their numbers, appears to suit them better. This is furnished by the foliaceous vegetation which grows so abundantly in the lakes and ponds. On the surface and between the layers of this plant they abound both summer and winter. In summer, when the ponds are melted, they enjoy for some weeks a warm climate, the temperature rising as high as $60^{\circ} \mathrm{F}$. in some ponds. There they are sheltered from the air, which would freeze them every day if they lived among the mosses. In winter again they are frozen in the ice for many months, in some of the deeper lakes for many years. While the mosses appear to be dwarfed by the cold, the microscopic animals are not at all troubled by the rigours of the climate. When the cold comes they curl up and go to sleep, it may be for years, and when the thaw comes they go merrily on as though nothing had happened. Indeed, since the cold does not harm them, the ice BRIT. ANTARCT. EXPED. 1907-9. VOL. I, PART 2, ISSUED APRIL 1910 c 
preserves them, secure against all other dangers, except only the advent of explorers. Their numbers prove how completely they are adapted to the local conditions. I have never anywhere seen Bdelloid rotifers so plentiful as are the two dominant species at Cape Royds (Philodina gregaria and Adineta grandis).

Among the higher Invertebrata the Rotifers are easily first in numbers, both of individuals and species. The Water-Bears are of only a few kinds, but one of them (Macrobiotus arcticus) is extremely abundant. There are Nematode Worms of two or more kinds, Mites of several kinds, and two Crustacea belonging to the Entomostraca. The Ciliate Infusoria are very numerous, there are a good many Flagellata, but only two Rhizopods were observed.

The vegetation consists solely of Algæ, Blue-green and Green, in filaments, colonies, and single cells. The Diatoms are few and very small, and the Desmids very rare, only two filamentous kinds being seen.

In this paper a preliminary account will be given of the microscopic life, illustrated with photographs from life taken on the spot, and with drawings. Some of the groups, as the Rotifera and Tardigrada, will be worked up and reported upon in separate papers. Other groups, especially the Infusoria, cannot be worked up in a scientific manner. Such animals must be studied by a specialist on the spot. Most of them cannot be preserved in recognisable condition, or to thus preserve them requires special training and experience. Even were these objections inoperative there is not time on such an expedition, with a limited scientific staff, to overtake work of this kind. It is best that the specialist should give as much as possible of his available time to the line of work which he is best qualified to deal with, and outside of that do what he can.

Such information as we were able to collect upon the Antarctic Infusoria, \&c., in the form of notes and sketches, will be here presented, without supposing that it can be of much value to scientific students of these groups. A specialist looking at the sketches might make a guess at the genera of some of the animals. Lack of knowledge prevented observations being made on various organs (mouth, nucleus, \&c.) which are important in determining species.

Photographing the Microscopic Organisms. -The first microphotographs were made by Mawson, who had some previous experience. Mawson, however, could not spare much time for this work, since he had all the physical observations to attend to, as well as the preparations for a long sledge journey. After a few lessons from Mawson the biologist was able to continue the work when Mawson had left on his journey.

It was not easy to find an opportunity for microphotography in our crowded hut. During the day the tramping of feet caused too much vibration. We had to wait for the hours of the night-watch before anything could be done, and Mawson gave an entire night-watch to experimenting with different exposures and plates. 
The photographs were all made by acetylene light. This light was quite unsuitable for ordinary work with the microscope, at any rate with the lenses we used. We could never get good definition with it. Oil lamps were used, and though they were of a very poor quality for such purposes, being ordinary stable lamps with very inferior glass, they sufficed for the work. Photographs were tried by the light of the oil lamps and also by daylight, but the acetylene proved better than either for photography. The little daylight which filtered through the frostencrusted window was insufficient for microphotography, though it sufficed for ordinary photography.

In addition to difficulties with regard to light we had to contend against dust. In our small hut, with its large stove requiring frequent stirring up, its crowded sleeping accommodation and infinite paraphernalia of fifteen men, cleaning could be of but a perfunctory character, and there was always a great deal of dust settling.

The exposure varied, according to light, subject, and especially the degree of magnification, from two seconds to half an hour. With higher magnifications we got no satisfactory results, and we ordinarily used a magnification of about 100 diameters, at the eye, which would give about 200 at the full length of the camera. The eyepiece was sometimes removed, but the results were not so good. Two plates were exposed on each occasion and immediately afterwards developed, in order to check the time of exposure. This varied so much with different subjects that we could have no general rule. We wished to shorten the time to the utmost, as nearly all the auimals to be photographed were alive, and liable to change their positions. They were under the influence of a mild narcotic which quietened them down a little, but which had to be so weak as to permit them to feed in a natural way. Exposures of five, and even of two seconds were used, but they were too short, and the average was about half a minute. As the whole of a subject could never be in focus at one time it was customary when using long exposures to gradually alter the focus, with the view of giving every depth a chance. This was done too much by guess to be a conspicuous success, but in some instances it gave a clearer outline for the whole body of a thick animal than would have been possible otherwise.

The photographs, as such, are very poor, but since they have an interest as pictures from life of subjects which cannot be seen anywhere else but in the Antarctic Region, their shortcomings will perhaps be overlooked. Unfortunately, through some mischance the best negatives have been mislaid, and are not available for reproduction.

Crustacea.-In ice from Blue Lake, shortly after we landed, there were found immature examples of a Calanid of small size. It was not in condition to be identified, and we hoped to find the same species alive and mature when the lake melted, so the specimen was not mounted. As it happened the lake never melted and we 
never saw another example. It is possible that the species is not a native of the lake, which is situated only a few hundred yards to the north of a bay of the sea, and it is conceivable that in a severe summer gale microscopic crustacea and other organisms might get caught up with the spray and blown into the lake. Against this is the fact that Blue Lake is the freshest of all the lakes, and the water from it is as fresh as condensed water. No organism definitely recognisable as marine was ever got in it.

The only other Crustacean found, a small Harpacticid like Canthocamptus, was also got in Blue Lake. It was never found in the shallow part of the lake, called the Narrows, but only at a depth of from 9 to 15 feet below the surface in a shaft sunk by Priestley in July 1908. On July 13, we found a skin on some scraps of weed at a depth of 9 feet. On July 17, on a film of weed covering the gravel of the bed of the lake at a depth of 15 feet, another skin was got. There is more probability of this Crustacean being a native of the lake than the Calanid, as its relatives are not free-swimmers, but creep about on various plants. No drawings or photographs of the Crustacea were obtained.

Mites.-In Coast Lake, Blue Lake, Clear Lake, and Deep Lake (near Cape Barne) skins of small mites were got. During our stay in the Antarctic, none were seen alive, but after our return to England a living mite was obtained from vegetation brought from Deep Lake. It had probably hatched from an egg. In Coast Lake they were abundant, and of several species. No drawings or photographs were made, but a specimen of one kind was mounted, and it is hoped that enough examples will yet be got to enable us to report upon them.

Insect.-On Plate IV., Fig. 16, is the photograph of the only Antarctic insect which we obtained, a parasite on Maccormick's Skua. Two examples were got by Joyce on one Skua, and it appears to be rare, as very careful search failed to find any others. On an Emperor Penguin also a small louse was seen, but the specimen was lost.

Other Arthropods. - In the lakes we occasionally found fragments of Arthropods, but whether of Crustacean, Insect, or Acarid we did not find out. A probable explanation of such occurrences is that they were parts of small marine Crustacea, brought by penguins as food for their chicks, and blown into the lakes.

Worms.-In addition to the Rotifera we found worms belonging to several other groups-Gastrotricha, Turbellaria, and Nematoda.

Gastrotricha.-This small group, supposed to stand near the Rotifera, was represented by a single example of Chrotonotus found among weed from the Deep Lake at Cape Barne.

Turbellaria.-Microscopic Turbellaria were found in Coast Lake and Blue Lake. In the former they were at one time very abundant.

Nematoda.-The Nematodes of the lakes were microscopic and free-living. Two 
kinds were common, one of which is figured on Plate IV., Fig. 13. Another kind had the skin minutely annulate.

Injusoria.-In dealing with the lowest and simplest forms of life, which are easily carried about in the form of dust, there must always be some doubt as to whether many of the species are native or introduced by the expedition making the observations.

When we arrived at Cape Royds the season was-well advanced towards autumn, and nearly all the lakes were already frozen. When we cut out blocks of ice containing portions of the vegetation which so abounds in these lakes we found many kinds of Infusoria, some of them of large size, dead and embedded in the ice. These were undoubtedly native. Afterwards, when the lakes melted and living Infusoria appeared in them, we were able to recognise many of them as of the same kinds which we had previously found frozen into the ice. Some of them were encysted and probably alive when found in the ice, but we never observed any of them leaving the cysts while under observation.

One of the puzzling organisms which we first observed consisted of clusters of whitish elliptical bodies, in which no definite organs could be seen. They were supposed to be some kind of eggs. Long afterwards they were accidentally discovered to be Vorticellids. On treating with formalin an "infusion" in which a kind of Vorticellid abounded, it was found that they contracted into the puzzling egg-like bodies.

There is little doubt that most, if not all, of the Infusoria and other organisms hereafter figured were true natives of the lakes of Cape Royds. The number of kinds seen was much greater than the number noted and figured. Very many were seen at times when important observations were in progress, which allowed of no time being given to side issues. The Flagellata, on account of the greater difficulty attending their study, were generally passed over without note.

Rhizopoda. - The paucity of Rhizopods at Cape Royds was surprising, after it became known that so miny other kinds of microscopic life abounded in the lakes. In the lakes only two testaceous species were observed: the well-known Difflugia vas, and a very small kind which appears to be a Quadrula. Among the moss there was another species, not identified.

On one occasion, when the ice of a lake was melted, we found numbers of an amorphous granular organism, each with a round nucleus, which were probably Amobce, but being only seen dead nothing could be made of them.

When our material is submitted to a specialist it is expected that he will find other forms which we have overlooked.*

Heliozoa.-In Coast Lake in April 1908, there occurred an animal which appears

* Dr. Penard has, in fact, detected about a dozen species, which will be reported upon in a subsequent paper. 
to be a Heliozoan (Acanthocystis?). The spines are all of one kind, and they are few in number and of clavate form (Plate VIII., Fig. 23).

Microscopic Plants.-The Algæ, the majority of which are microscopic, will be reported upon in a separate paper.

Bacteria.-Many kinds abounded in the lakes in summer; but in this group it is impossible to discriminate between native and introduced kinds.

Organisms of Doubtful Position.-Many organisms occurred, of whose nature we had no guess. Certain of these are figured on Plates VII. and VIII. Perhaps the sight of these sketches may suggest some of their names to other naturalists.

Acinetaria. - No tentaculiferous Infusoria were definitely recognised, but while these pages are in the press, Mr. A. W. Sheppard, F.R.M.S., has identified the organism figured on Plate VII., Fig. 19, as the encysted condition of a species of Podophrya. 


\section{Plate I}




\section{PLATE I}

\section{MIOROPHOTOGRAPHS OF A ROTIFER}

Philodina gregaria, sp. n.

Figure 1.-Portion of the field of the microscope, crowded with the Rotifers, under a low power. These examples were brought by Priestley from a lake in the west. They were frozen solid when brought in. As soon as they were thawed some were transferred by a pipette to a slide and photographed. They were not narcotised, and were begimning to stretch themselves and creep about, so the exposure had to be very short. Many of them have moved and are blurred in the photograph.

Frgure 2.-One of the Rotifers feeding. It is under the influence of Eucaine, but its form has been little affected by it, and is nearly normal. The dark column in front of the head is formed of an accumulation of minute particles which have been swept towards the mouth by the cilia of the discs. The little clouds of particles on each side of the neck are those which have been rejected by the selectors in the gullet, while those chosen for food have passed down to the jaws.

Frgure 3.-Side view of an extremely large example. It has been narcotised and the constrictions bounding the turgid central trunk have been much deepened by the influence of the Eucaine on the muscles. (Photograph by Mawson.)

FigURE 4.-A Rotifer under slight pressure, to show some of the internal organs and the well-grown young. The dark central tract was coloured deep red, and the eyes, being also red, show more conspicuously than in life. 


\section{MIURRAY : MICROSCOPIC LIFE}

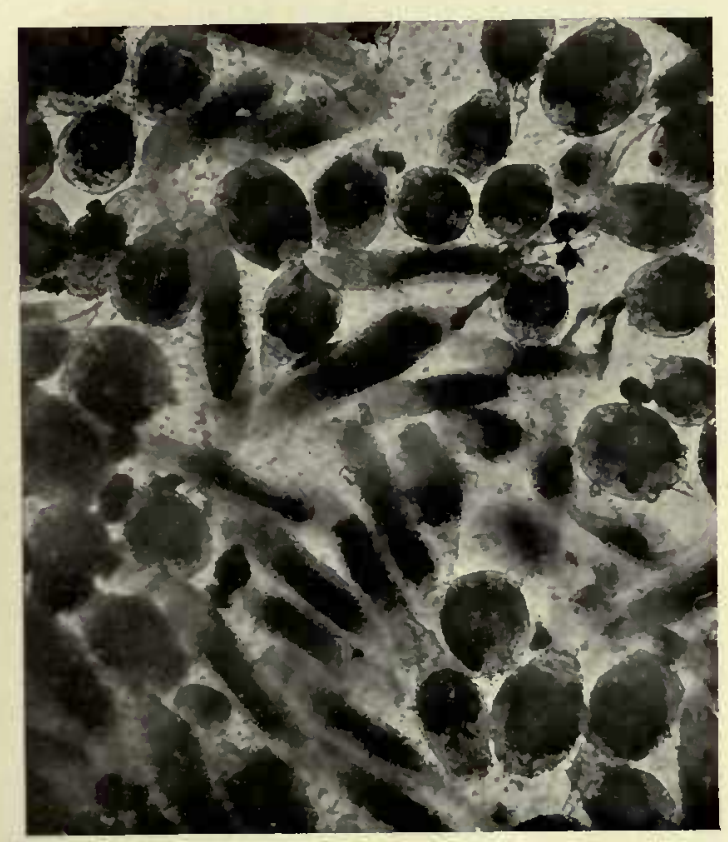

Figuk: 1.

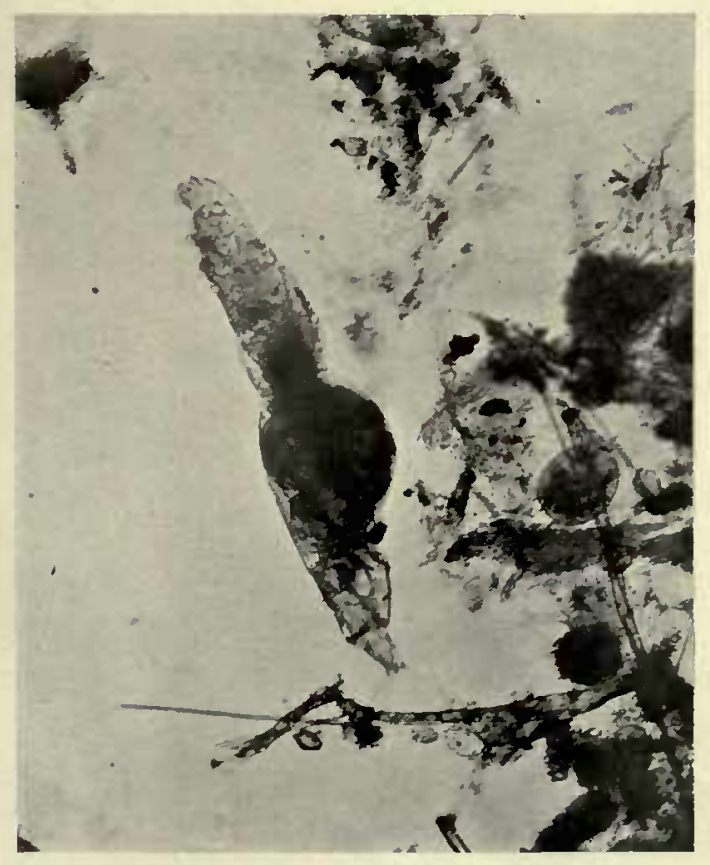

Figure 3.

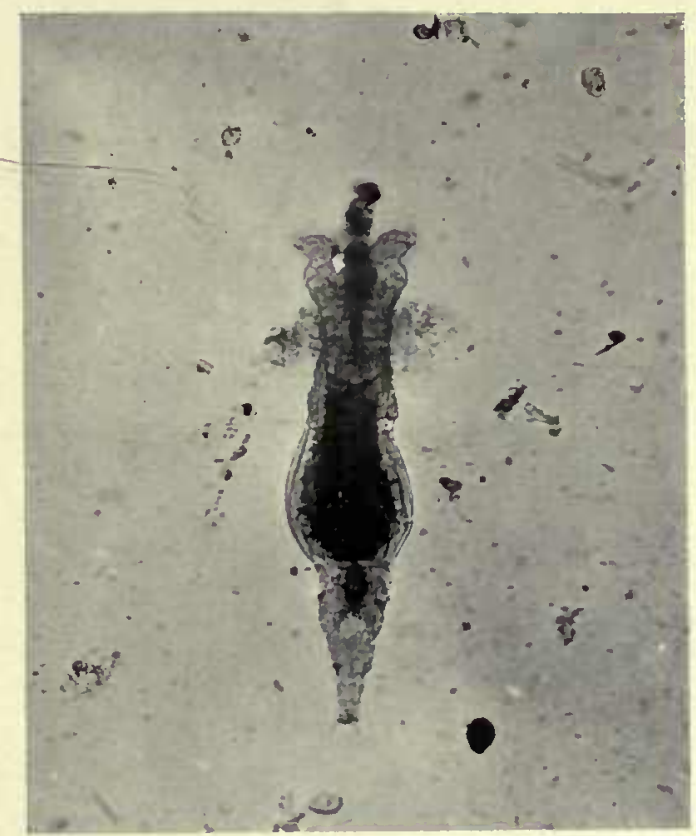

Figure: 2 .

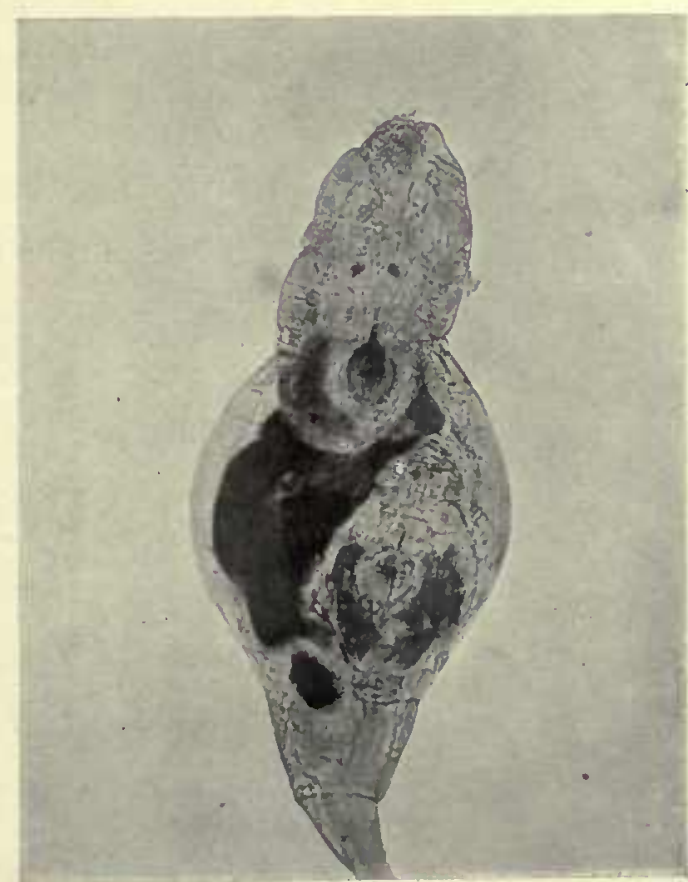

Figure 4. 

Plate II

BRIT. ANTAROT. EXPED. 1907-9. VOL. I. 


\section{PLATE II \\ MICROPHOTOGRAPHS OF ROTIFERS \\ Adineta, Hydatina, Diaschiza}

FIGURE 5.-Adineta grandis under the influence of Eucaine. The trunk and anterior part of the body are of the normal form. The Eucaine has caused the foot to be drawn in, which would not usually be the case in the natural condition. The two examples, of which portions are seen at the foot of the photograph, show the deep constrictions of the neck which are caused by the influence of the Eucaine on the muscles of the trunk.

FigUre 6.-A very large example of Adineta grandis. It is under slight pressure, so that the foot could not be drawn in. The head and neck have been moved while the photograph was being taken, but the central trunk shows clearly the six contained young.

FIGURE 7.-Hydatina senta, side view. This is the only free-swimming Rotifer which we obtained in the Antarctic. It appeared in Coast Lake in summer. The photograph is taken from a living example, under the influence of Eucaine, which causes the cilia to move very slowly. The natural shape was not affected by the narcotic in this instance, though it frequently causes some distortion.

Figure 8.-A small Rotifer, probably Diaschiza tenuior, seen from the side. It was narcotised, and was showing the natural form very well when the plate was put in, but at the very moment of exposure the body has become turgid, which is an indication that death is imminent.

Close under the head of the Rotifer can be seen one of the small Diatoms which are common in the lakes. 


\section{MURRAY : MICROSCOPIC LIFE}

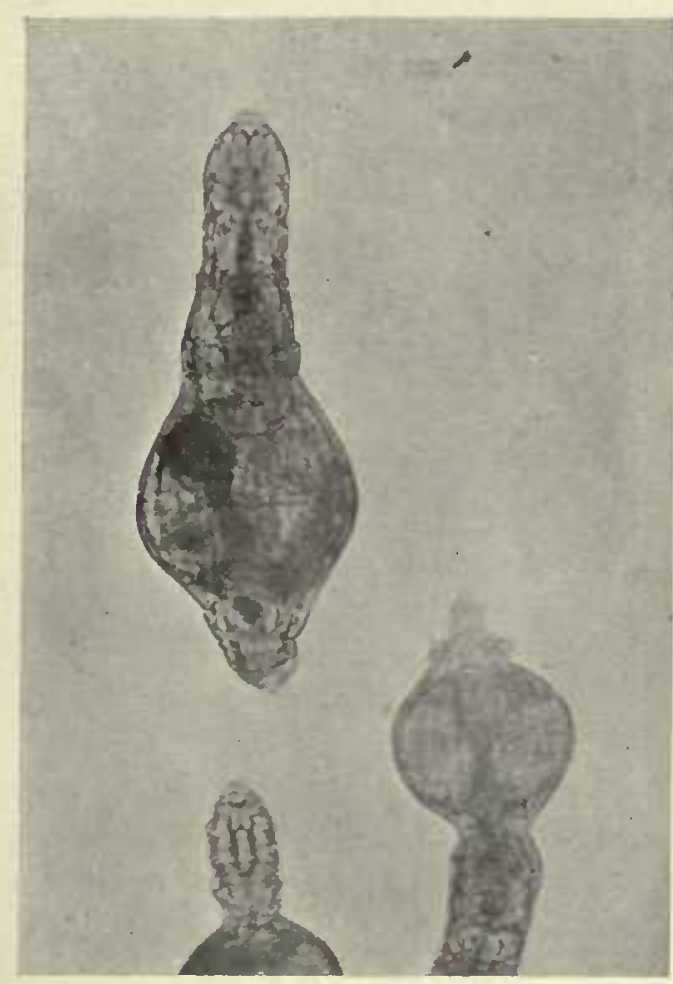

Figuie 5.

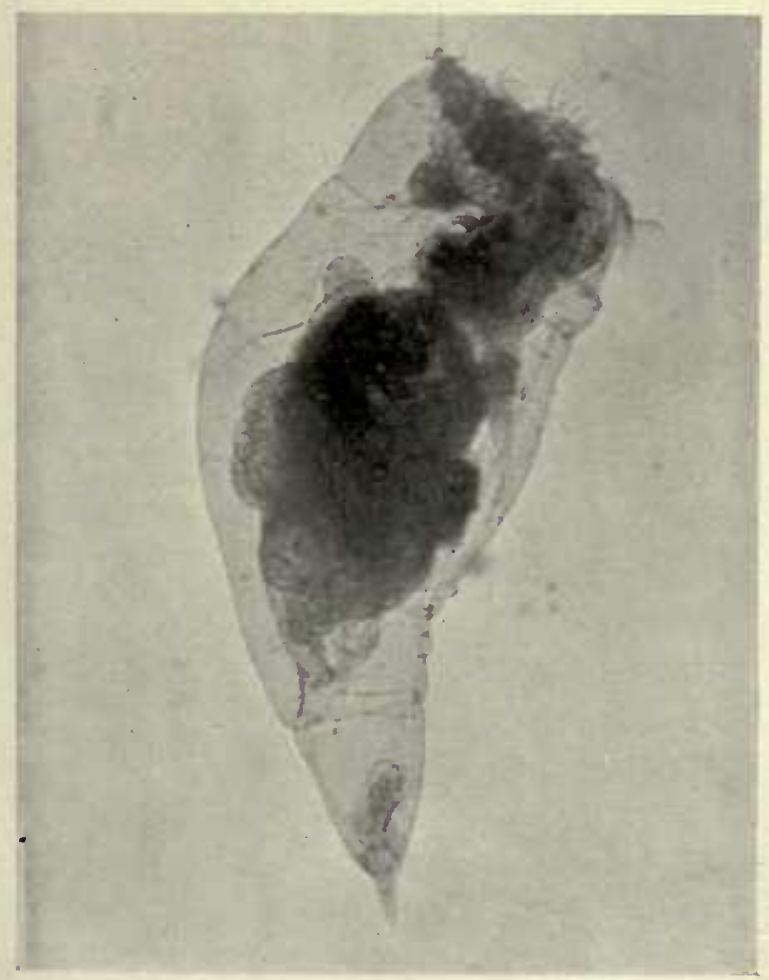

Figure 7.

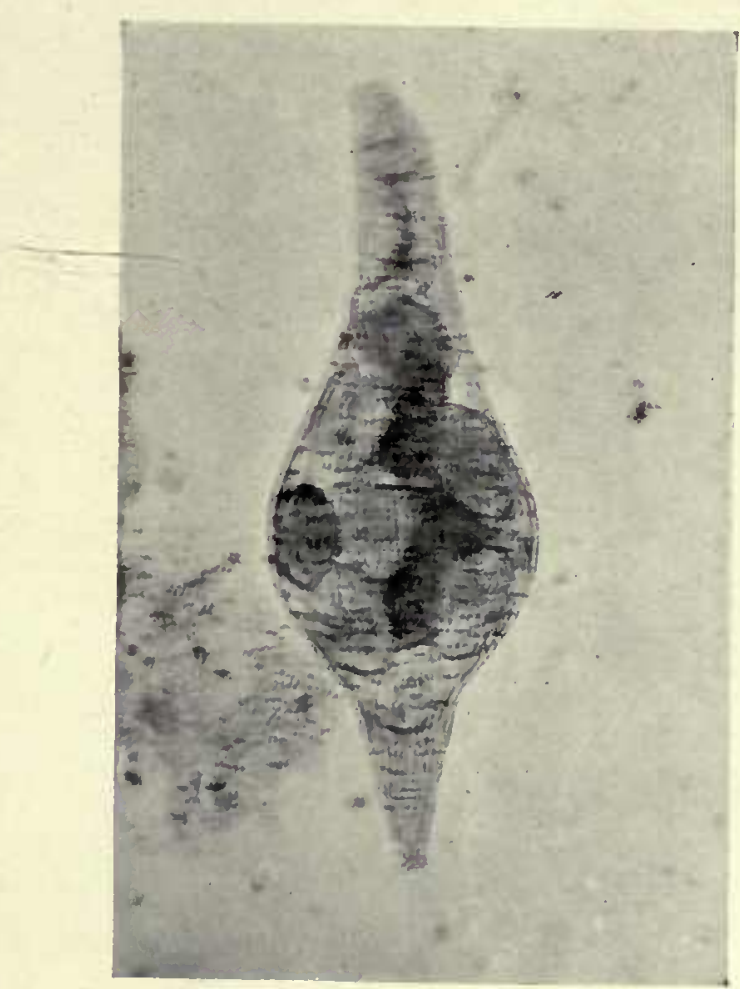

Figule: 6.

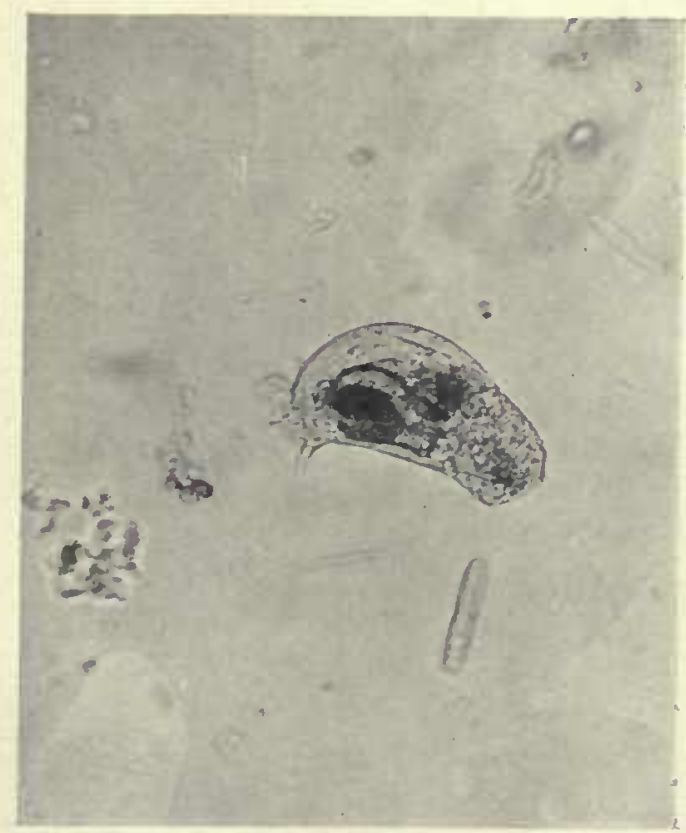

Figure 8. 



\section{PLATE III}




\section{PLATE III}

\section{MICROPHOTOGRAPHS OF WATER-BEARS}

Figure 9.-Side view of the common Antarctic species of Water-bear, Macrobiotus arcticus, which is also found in the Arctic Region. In the photograph may also be seen a Rotifer and some filaments of Algæ.

Figure 10.-Dorsal view of another example of the same species. Four eggs at an early stage of development can be seen in the body. To the left of the animal is one of the eggs of the species, but it is so encumbered by debris that its characteristic peculiarities cannot be seen.

FigURE 11.-A different species of Water-bear (Macrobiotus oberhäuseri) found among moss at Cape Royds. It has one excessively long claw on each foot, and the body is marked with a warm brown colour, forming longitudinal and transverse bands, indicated in the photograph.

Fradre 12.-Another example of Mlocrabiotus arcticus, containing six eggs not very far advanced in development. In the anterior part of the body the fat-cells in the body fluid can be distinguished. 
MURRAY : MICROSCOPIC LIFE

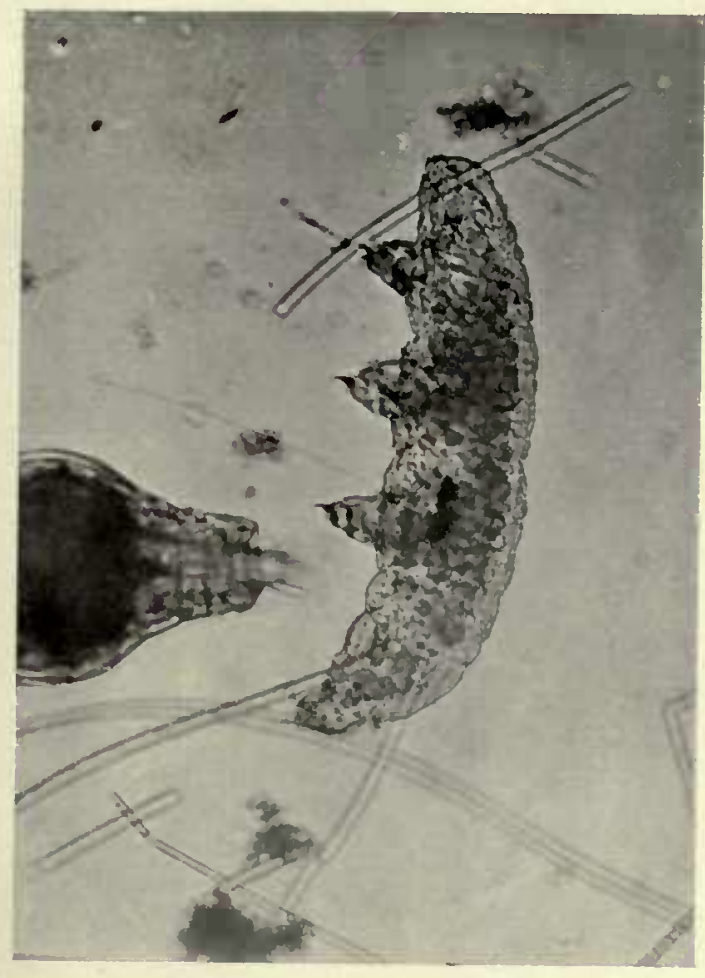

Figure:

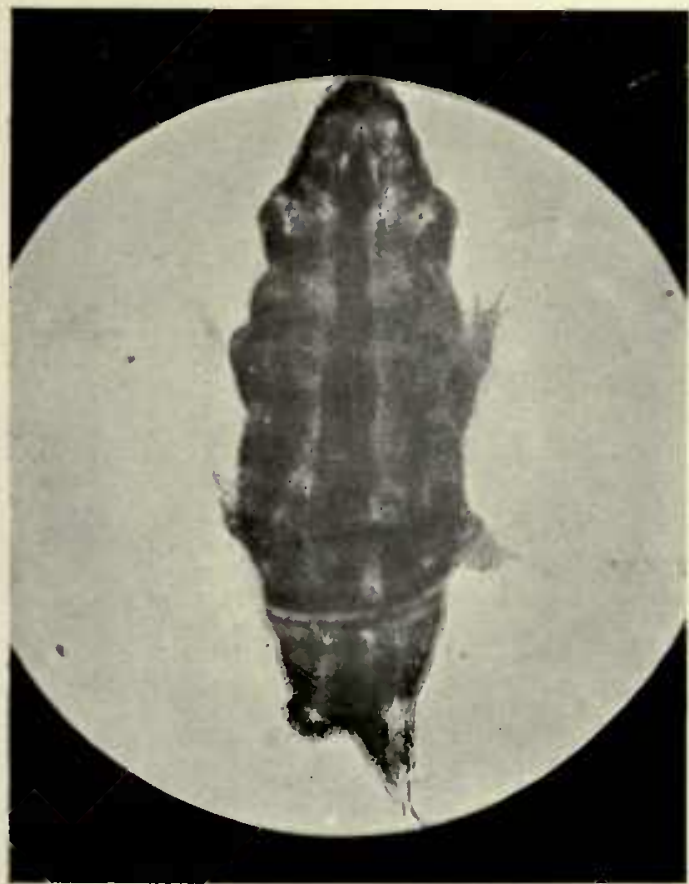

Figure: 11.

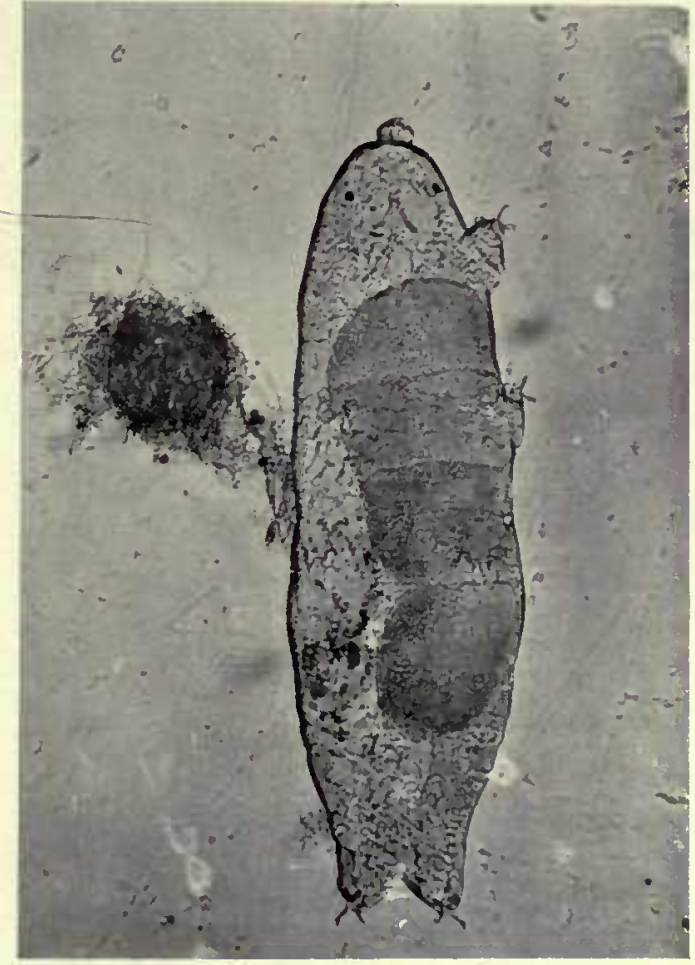

Figure: 10.

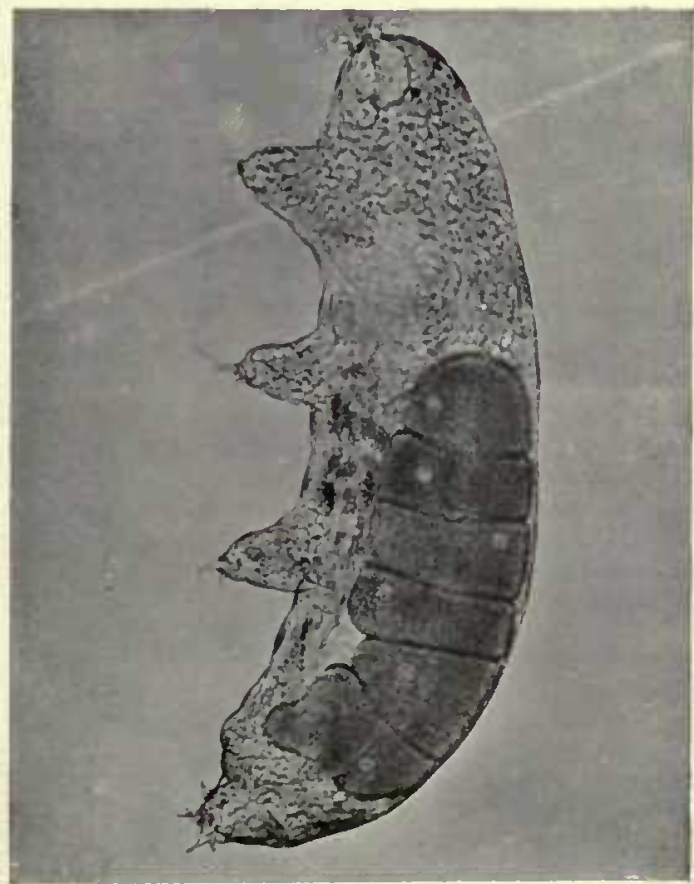

litgute 12. 

PLATE IV 


\section{PLATE IV \\ MICROPHOTOGRAPHS OF NEMATODE, ALGA, AND LOUSE}

Fiaure 13.-Part of the field of the microscope under a low power, showing many kinds of organisms. The largest is a Nematode of the commonest Antarctic kind. The pear-shaped pharynx can be seen. There is a Water-bear and the cast skin of another, a contracted Rotifer, and some Algæ in round colonies. Near the upper right-hand corner is a large egg, which is probably that of Hydatina senta. (Photograph by Mawson.)

Figure 14.-Fine filamentous Alga from Pony Lake. This is probably an Oscillatoria, but is different from the kind most commonly found in the other lakes.

FIGURE 15.-A short rod of the common blue-green Alga (probably Oscillatoria), highly magnified. Beside it are some narrower filaments of another kind.

Fiaure 16.-Photograph from life of the only parasite which we obtained from the feathers of Antarctic birds. Two examples were got on a Skua Gull (Megalestris Maccormicki). Though not so purely microscopic as the other animals photographed, it is a very small species. 
MURRAY : MICROSCOPIC LIFE

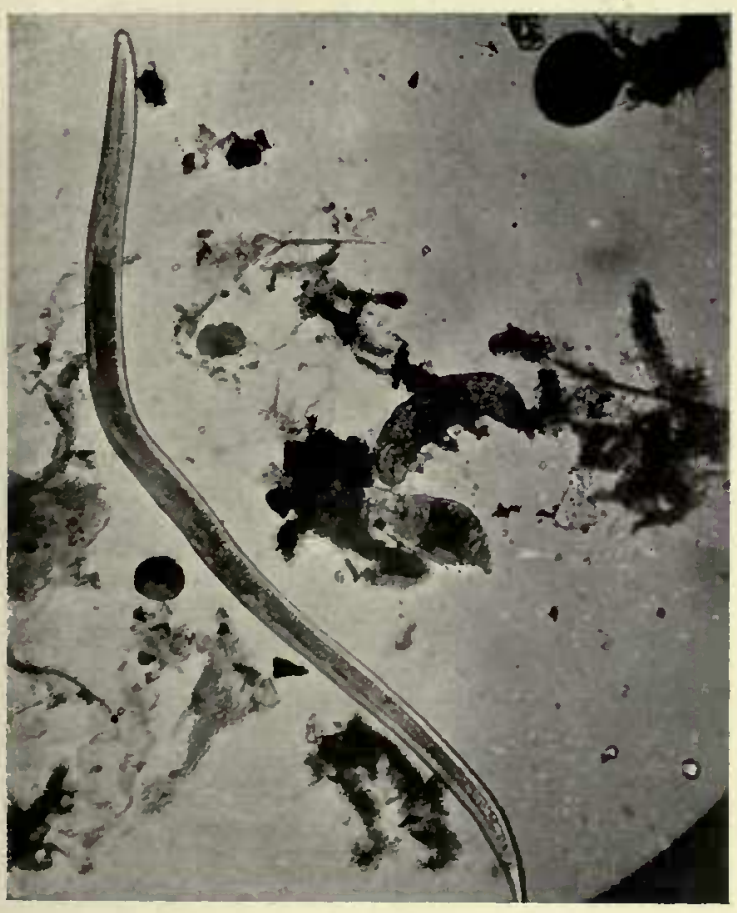

Figuke 13.

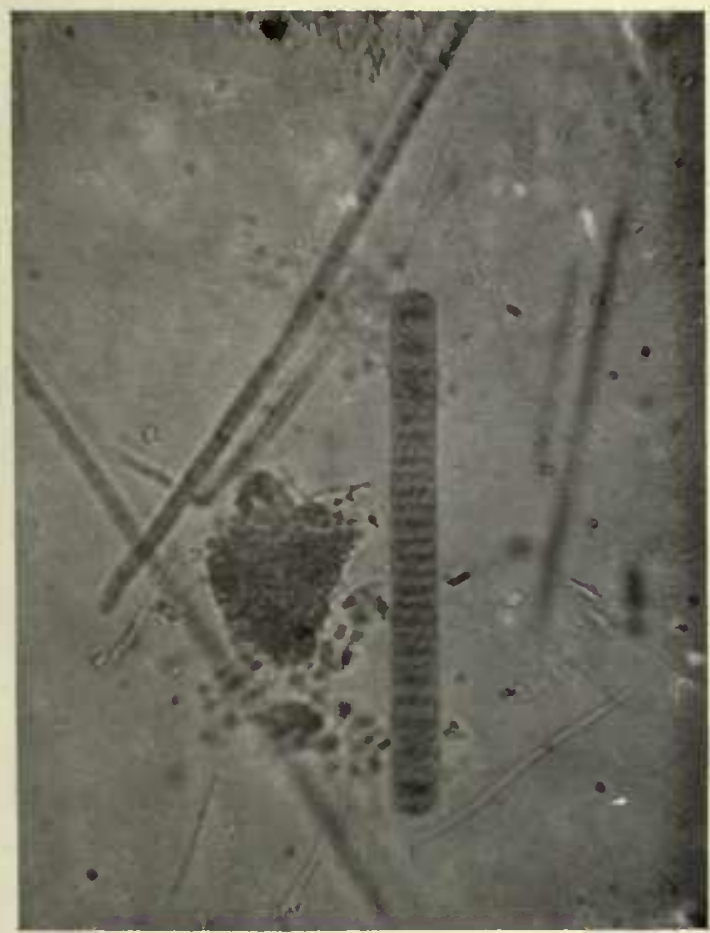

Figune 15.

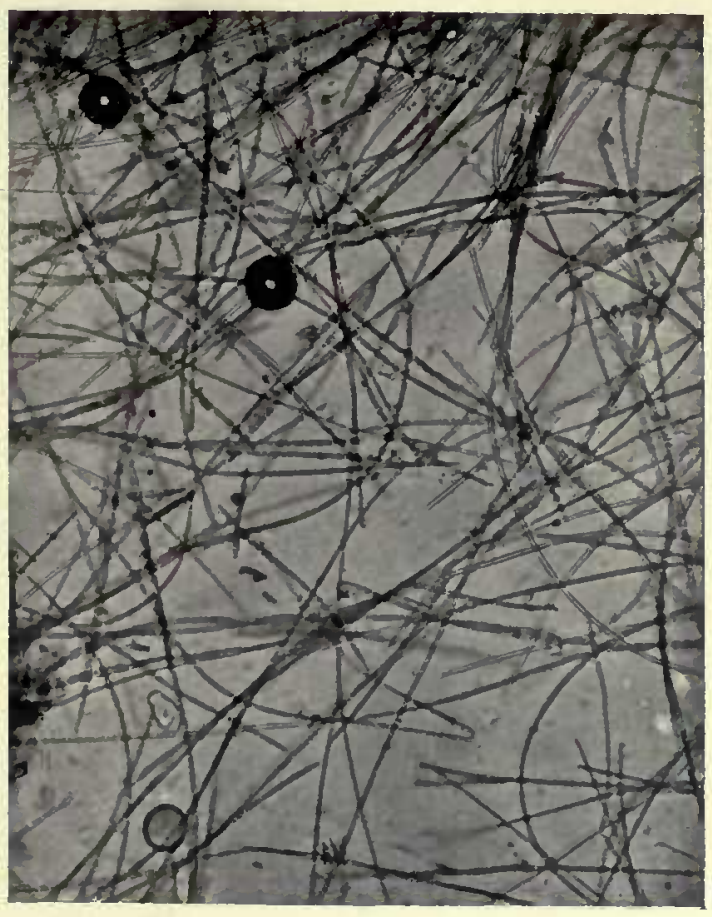

Figure 14.

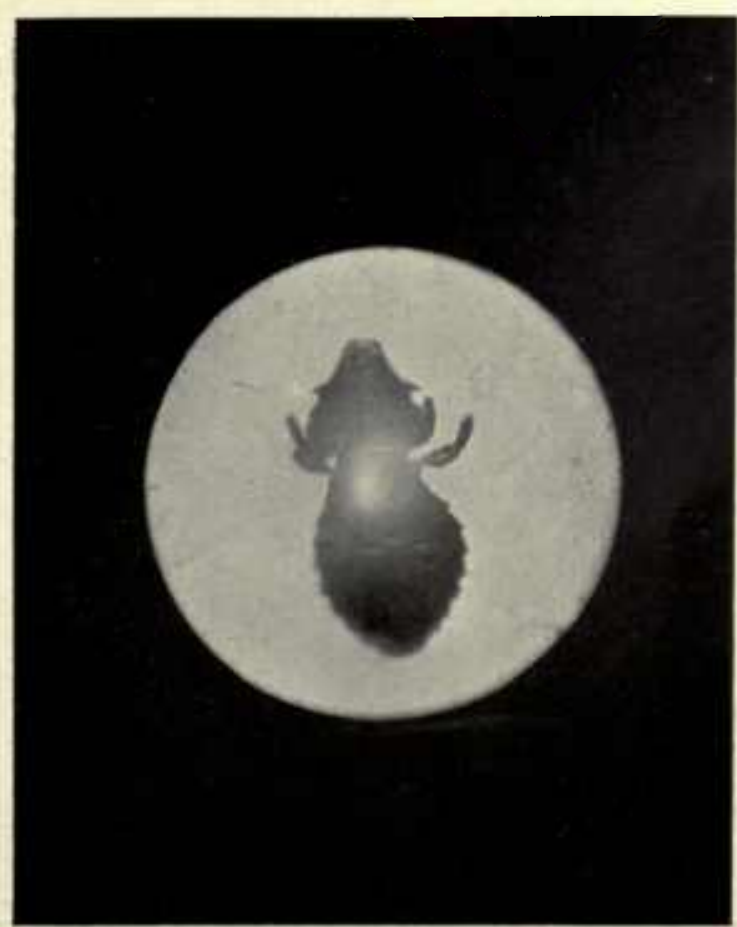

Figuike 16. 

Plate V 


\section{PLATE V}

CILIATE INFUSORIA; VORTICELLA AND SIMILAR FORMS

Figure 1.-Vorticella, a narrowly pyriform species, with slender contractile stalk, which can extend to five or six times the length of the body. The whole body was covered by papillæ, as in $V$. monilata Tatem, but the shape of the body is different.

FIGURE 2.-Vorticella, a species of conical form, widest at the mouth, and with a constriction separating a basal portion, one-third of the total length. There is only a short broad stalk, but it may have been broken off.

Figure 3.-Vorticella, mouth not expanded.

Figure 4.-Vorticellid, narrowly oblong; free-swimming example, with posterior ring of cilia and no stalk.

FIGURE 5.-Vorticella, long narrowly oval species, with narrow mouth.

FIgUre 6.-Vorticellids, two contracted individuals on one stalk.

Figure 7.-An animal of doubtful position, resembling the Vorticellids in possessing only a circlet of cilia round the mouth:

Figure 8.-Vorticellid, another free-swimming example. 


\section{Murray: Microscopic LifE.}
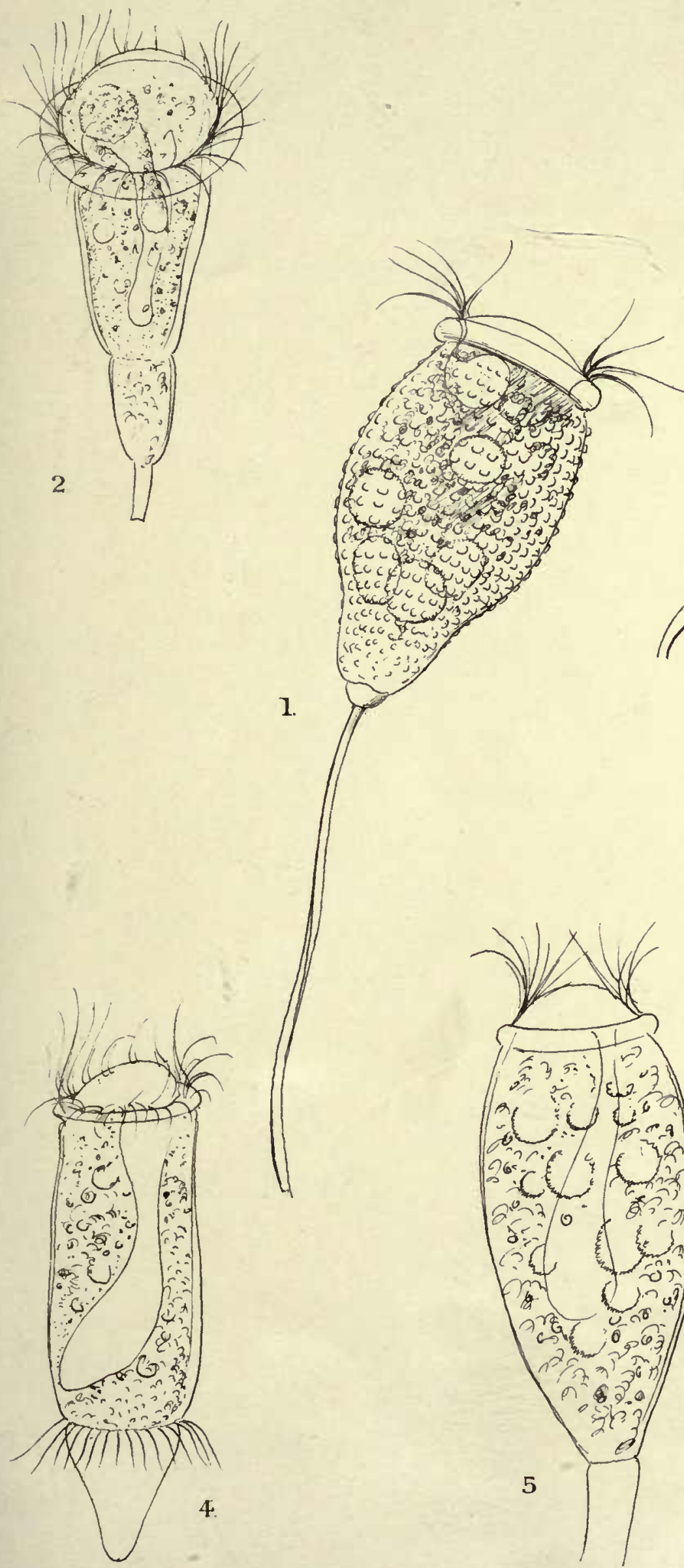

1.
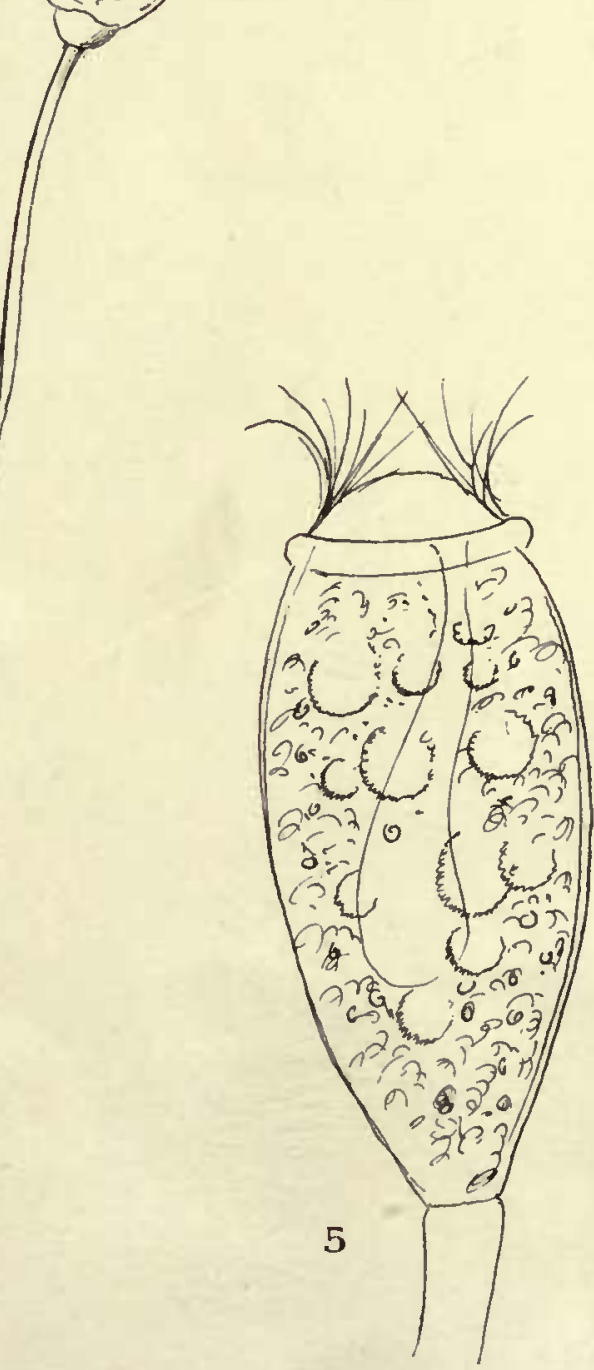

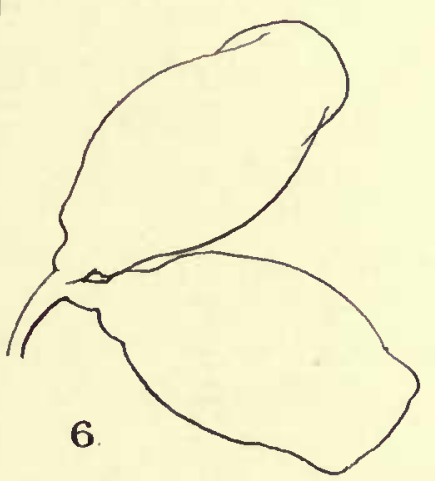

3
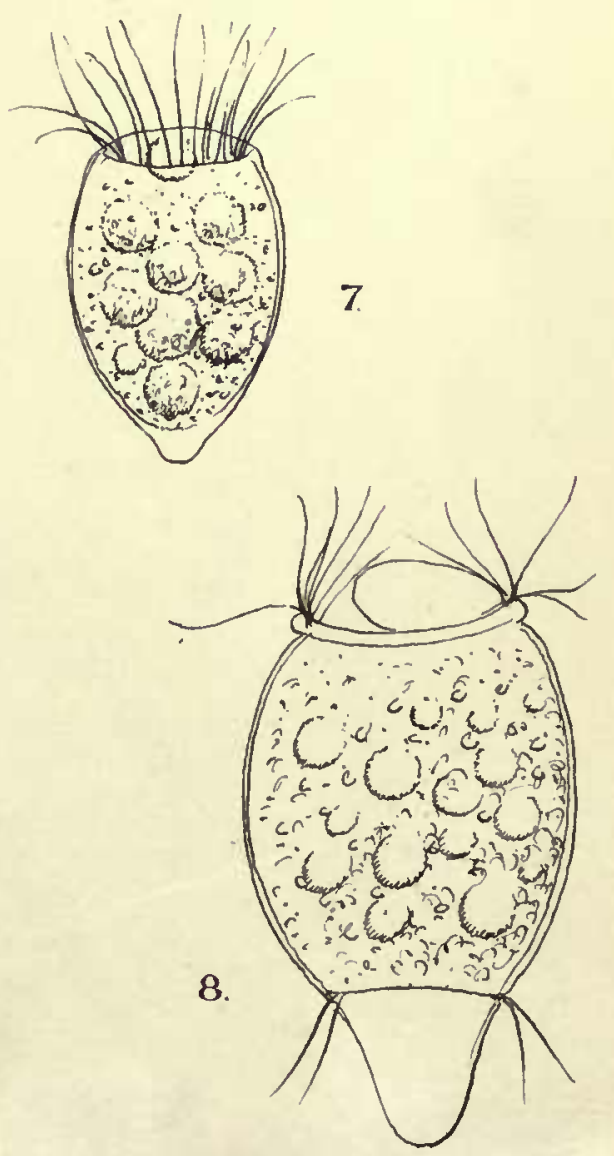



\section{PLATE VI}

BRIT. ANTARCT. EXPED. 1907-9. VOL. I. 


\section{PLATE VI \\ OILIATE INFUSORIA}

FIGURE 9a.-A large reddish brown animal, common in all the lakes. It is covered all over with short cilia, which appear to continue beneath the surface as short rods, making a thick skin. A bundle of pharyngeal rods forms a kind of narrow cage, tapering downwards, as in Nassula, \&c.

Figure 9b.-Probably the same animal as Fig. $9 a$, at a different stage in its lifehistory. The cage of pharyngeal rods is of the same form, and projects far above the surface. The skin is thin, and not ciliated. Many of these colourless examples were found at the same time.

FIGURE 10.-A narrow curved animal, narrowing to one end. It is marked longitudinally with faint ridges, which are seen in profile to be finely undulate. It is ciliated on all the ridges, the cilia being long and not very close together. They gradually elongate to the broad end. All are motile but only those on a limited area move actively. No mouth could be detected.

Figure 11.-A ciliate with projecting crest; no other details noted.

FIGURE 12.-Ciliate with a beak, a series of strong cilia at the mouth, and another series round half the circumference of the body.

FIGURE 13.-Large oval ciliate, ciliated all over, and with a vibrating nembrane occupying an elliptical area. The cilia appear to be continued under the skin as rods (as in the species figured in $9 a$ ).

FIGURE 14.-A dark brown ciliate, with cilia all over the body. It is elliptical in form, with the poles produced into rounded processes. No mouth or other organs could be seen. As it travels along in the direction of its long axis it at the same time revolves round it.

FIgURE 15.-An oval ciliate, marked with longitudinal ridges. There are four strong setæ at each end, a row of motile setæ half-way down one side, and a single seta on the same side. 
Murray: Microscopic Life.
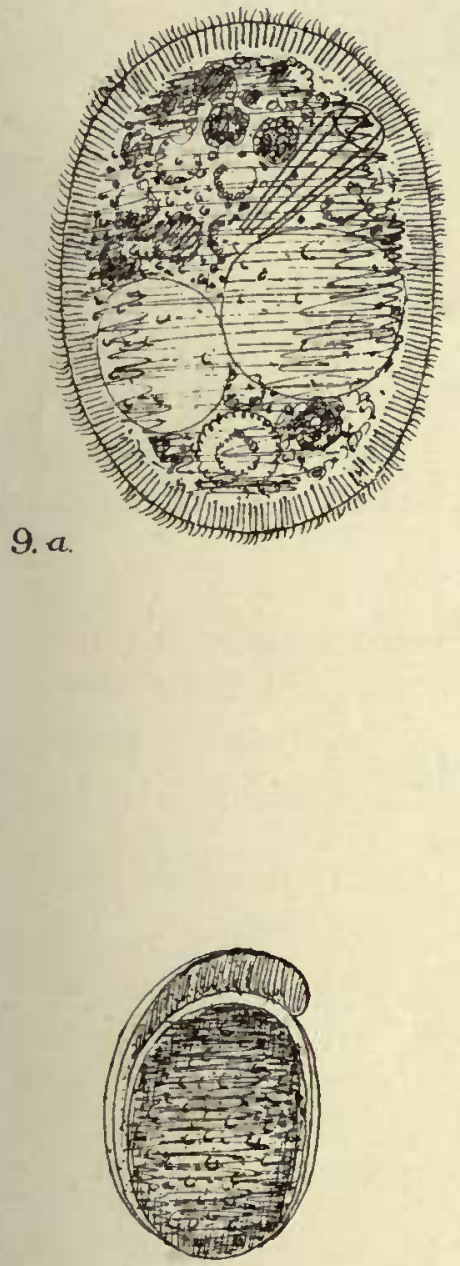

II.

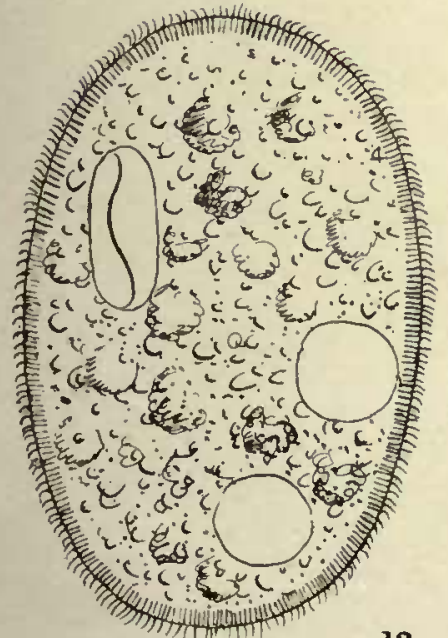

13

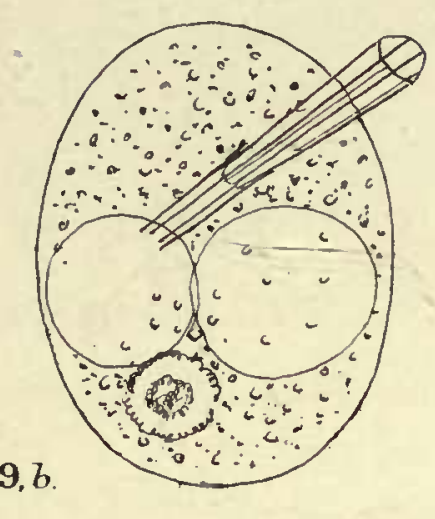

10.
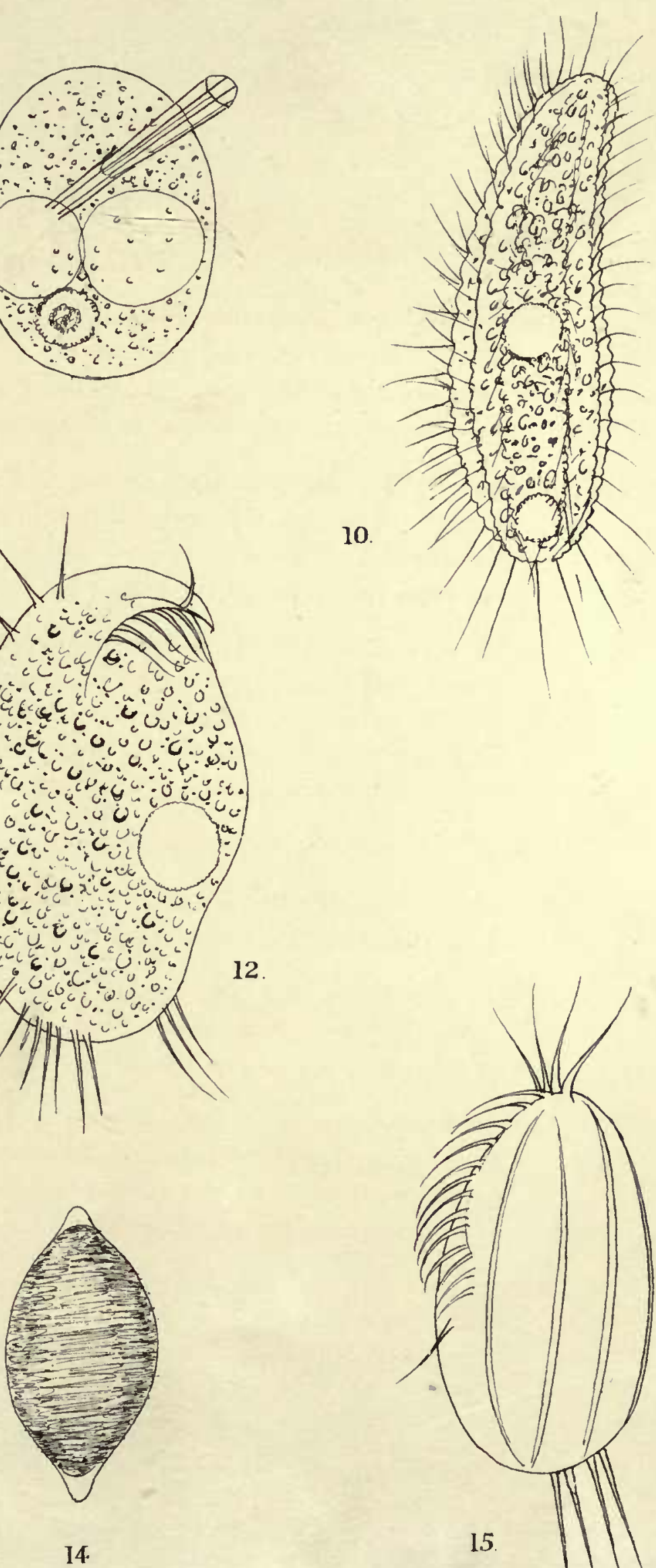

12

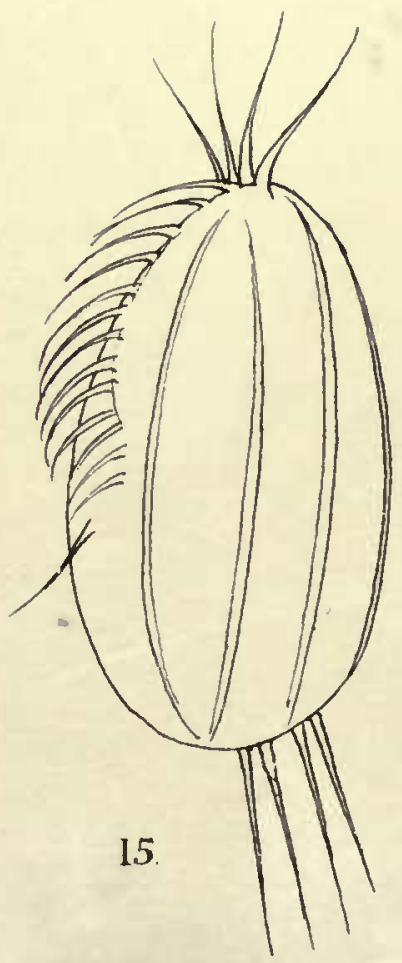



PLATE VII 


\section{PLATE VII}

FLAGELLATA; AND VARIOUS ORGANISMS OF DOUBTFUL POSITION

F[GURE 16.-An oval flagellate with green granular contents. One strong flagellum was seen.

Figure 17.-A cluster of four cells, with one flagellum visible on each. The cluster rotated rapidly with an irregular motion. The contents were green.

Figure 18.-A colourless flagellate, of ovate form with a long tail : one flagellum seen : contents granular.

Figure 19.-A hyaline, almost spherical body, set on a slender stalk. The body is marked with ten prominent annular ridges, about equidistant from one another, except near the pole to which the stalk is attached, where they are crowded. The protoplasmic contents form a globular mass much smaller than the envelope. Identified as an encysted Podophrya, by Mr. A. W. Sheppard, F.R.M.S. (see p. 22).

FIGURE 20.-A soft orange-coloured ciliated body issuing from a small opening in a hyaline shell.

Figure 21.-A cluster of oval bodies of sienna-brown colour, in a darker brown matrix.

FIGURE 22.-A soft thick-skinned animal, finely ciliate all over. Little internal structure could be seen except two cavities occupying the greater part of the interior. The granular part between the cavities is sienna-brown in coloul. Two vibrating membranes were seen, like those which are found in various sorts of worms. 
Murray: Microscopic LifE.

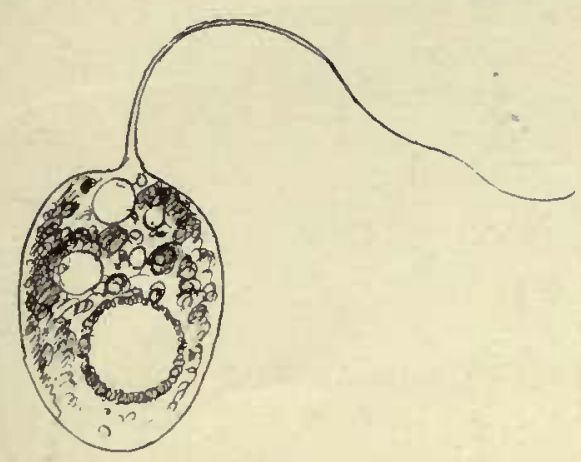

16

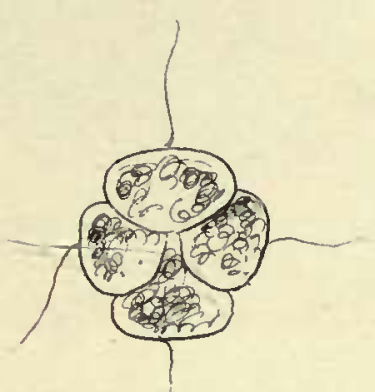

17
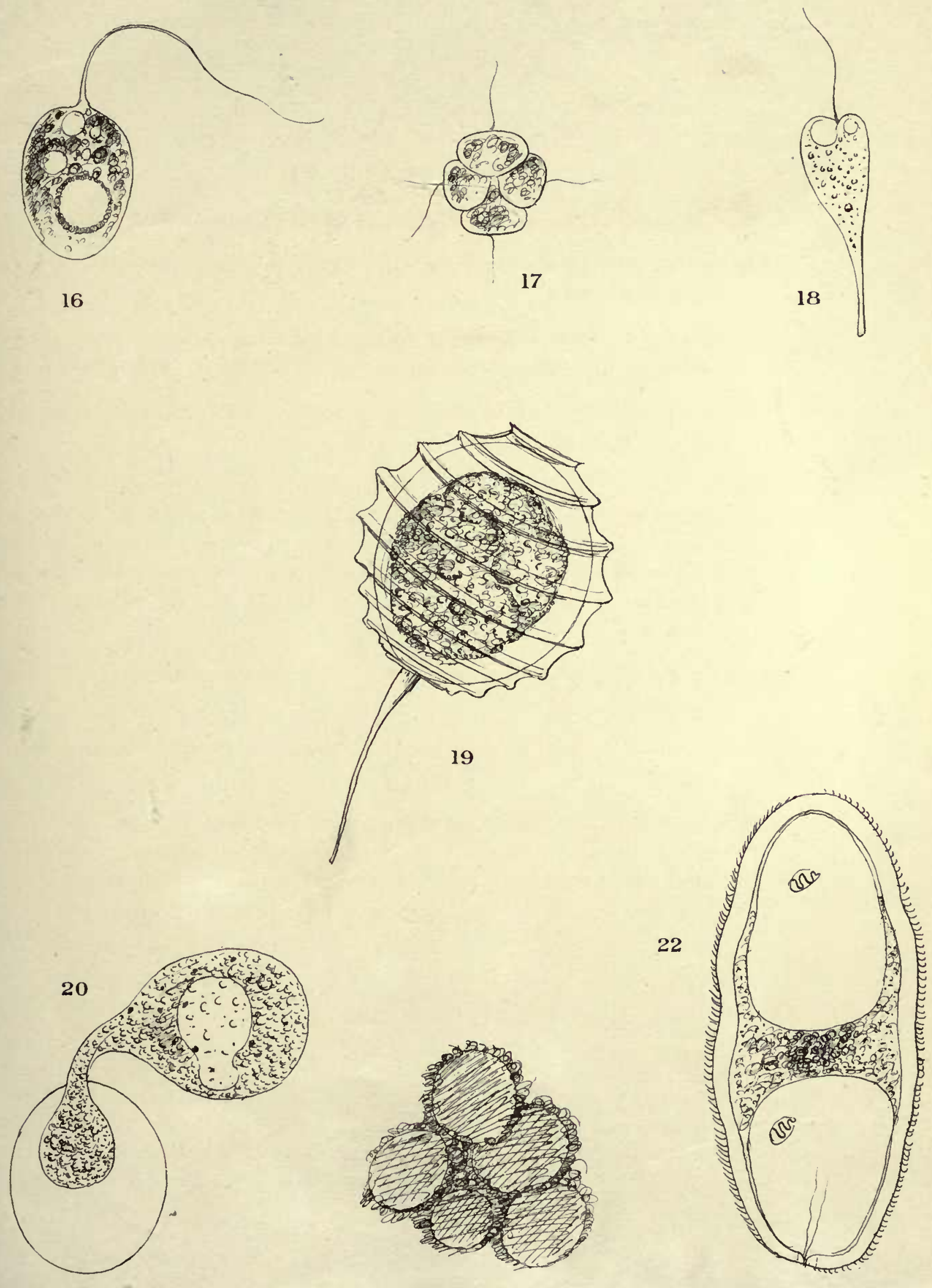

21

J. Murray del. ad nat. 

PLATE VIII 


\section{PLATE VIII}

\section{VARIOUS ORGANISMS OF DOUBTFUL POSITION}

Figure 23.-Possibly a heliozoou (Acanthocystis?). The spines are few and of one kind only, clavate in form. Plentiful in Coast Lake.

Figure 24.-Oval bodies of a dingy purple colour, always occurring in clusters, as many as eight together. They always included many round pellet-like bodies.

Figure 25.-Apparently a bit of vegetable tissue. Such a plant must have been introduced, but if so it must have been previous to our expedition, as it was found in the ice of a lake which was frozen when we arrived.

FIGURE 26.-An elliptical hyaline body, made up of eight rings.

FIGURe $27 a .-\mathrm{A}$ brown discoid body with finely reticulate surface. One pole is produced with a little point. There is no opening of any kind. Fig. $27 b$ shows a bit of the reticulate surface more highly magnified.

FIGURe 28.-Round vegetable cells, in irregular clusters and strings. A few were filled with green contents, like two of those figured; most had a little shrivelled dark mass as in four of the cells figured; the empty cells were open, as shown in the two cells at the ends of the series. 
Murray: Microscopic Life.

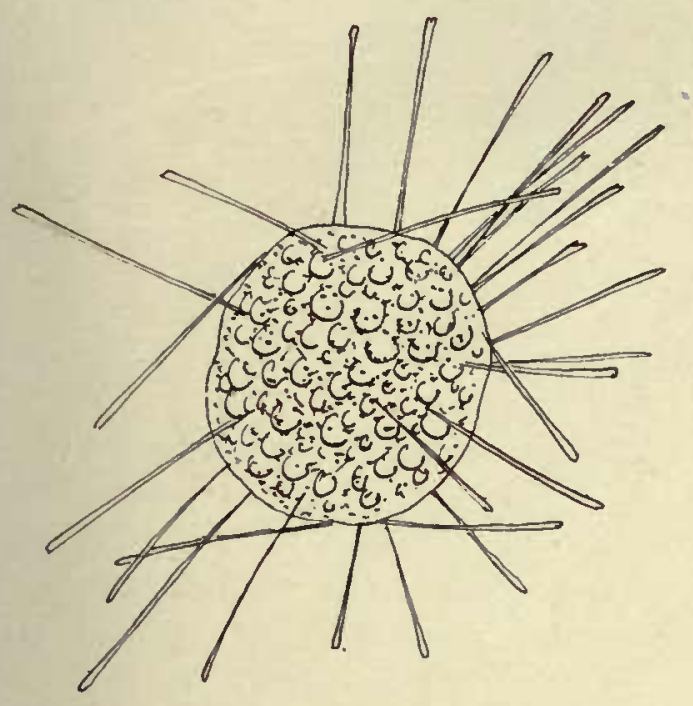

23
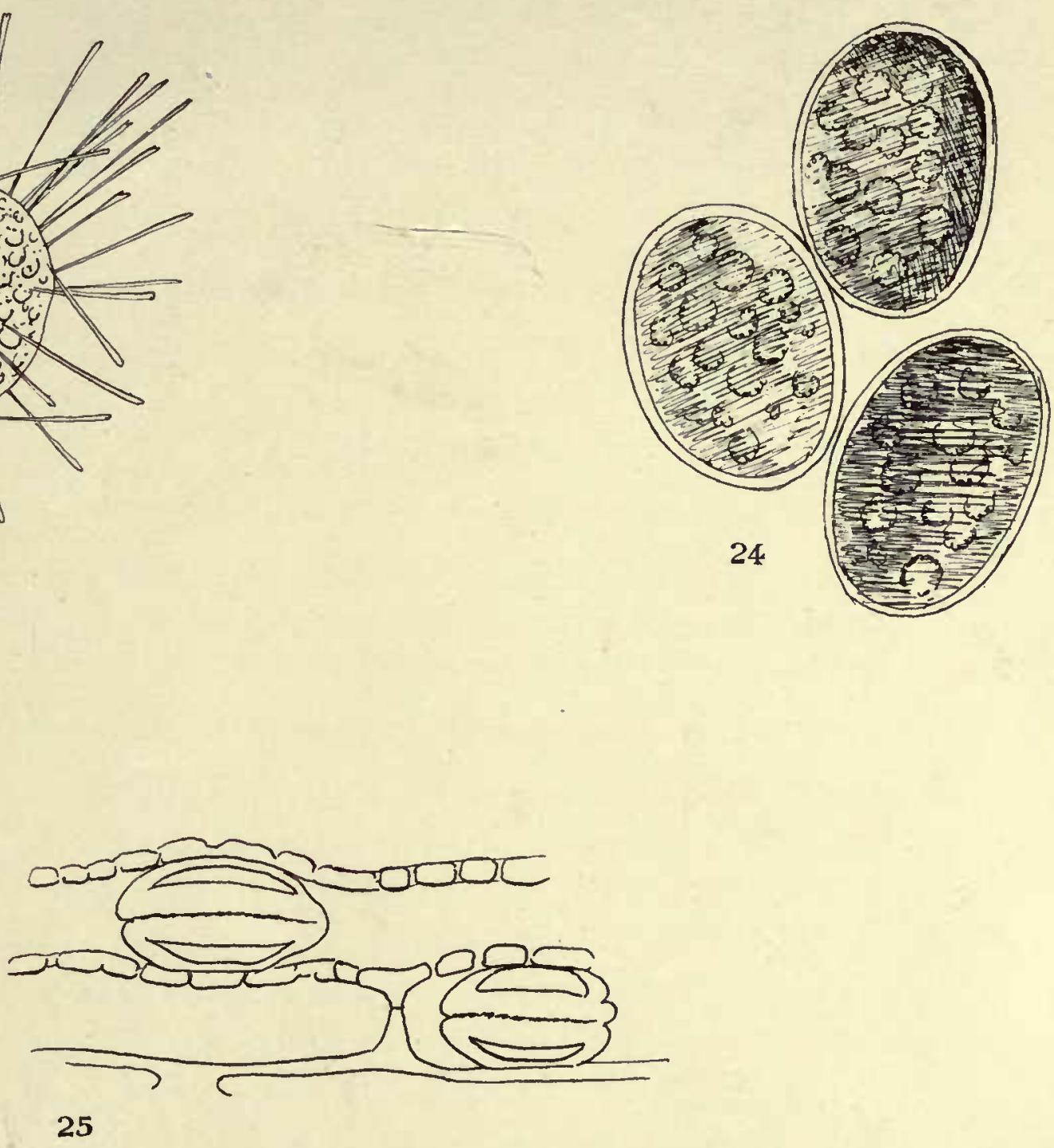

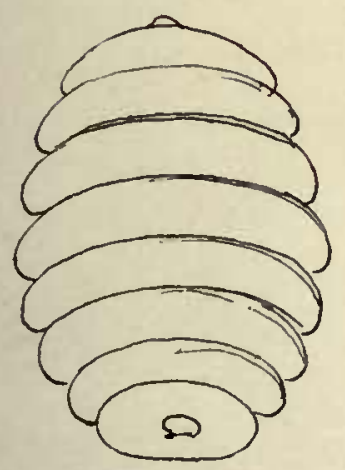

26

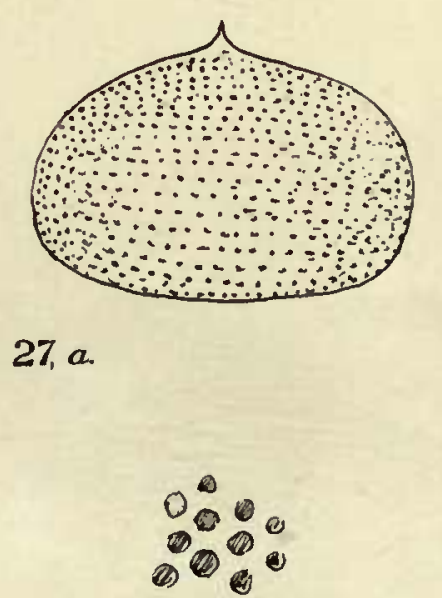

27.b.

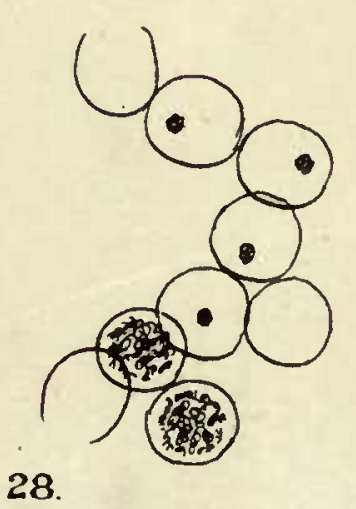

28. 



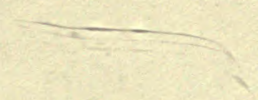

in 



\title{
PART III
}

\section{ANTARCTIC ROTIFERA}

\author{
BY JAMES MURRAY
}

Amovg the various forms of freshwater life the Rotifera were most conspicuons. They were found among mosses and in the lakes and ponds. In the former situation they were relatively scarce, while in the lakes they were extremely abundant, and were often associated in such numbers as to affect the colour of the water.

Some sixteen species were distinguished, representing three of the recognised orders, and five or six distinct families. The predominance of the Rotifera was entirely due to the Bdelloida, of which a dozen species were found. In the other orders there were only one or two members of each family present.

Five of the Bdelloids are species previously unknown. Most of the others differ more or less from the types of their species. Only two non-Bdelloids species were recognised (Hydatina senta and Diaschiza tenuior), the others were only assigned to their genera. No Rotifera were found in the sea.

I have been able to find no record of any species of rotifers found on the Antarctic Continent or on any of the islands which, though lying outside the Antarctic Circle, possess a polar climate. The German Expedition found Rotifers on the Gaussberg, just on the Antarctic Circle (Richters, 31) ; * the Swedish Expedition obtained them at Snow Hill Island, not far from the Circle (Richters, 32), and the Scottish Expedition at the South Orkneys, a little farther north (Murray, 26). $\dagger$ All of these were unrecognisable.

The only species doubtfully identified from this whole great area is Callidina papillosa, Thomp. (40). Richters found an egg in moss from the Gaussberg which resembled the egg of $C$. papillosa figured by Janson (20). The identification of this egg can never be certain, as there are several other Bdelloids which have similar eggs, covered with blunt processes.

To find definite records of Rotifera in the southern hemisphere we must go far

* Figures in beary type enclosed in brackets refer to list of books at the end of the paper.

† The Rotifer vulgaris casually recorded in that paper must be regarded with doubt. As all the others were dead, it had probably been accidentally introduced into the bottle.

BRIT. ANTARCT. EXPED. 1907-9. VOL. I. PART 3, ISSUED APRIL 1910 F 
beyond the Antarctic Region. A few species have been found in Gough Island (Murray, 29), and Amsterdam Island (Richters, 31). Hilgendorf (19) has published a list of over forty species from New Zealand, in about latitude $43^{\circ} \mathrm{S}$., and these are the nearest neighbours to the Antarctic Rotifers of which I can find any notice.

\section{Order-BDELLOIDA}

\section{Family-Philodinade}

\section{Genus-Philodiná}

Philodina gregaria, sp. n. (Plate XI., Figs. 7a-7e)

Specific characters. - Large, corona large, narrower than trunk, wider than collar, space between discs wide, the rounded lobes springing from collar large, the interspace with two smaller convexities; collar very prominent, but scarcely marked off from pedicels; rostrum short and broad; antenna short; eyes large, pale brown; teeth $2^{+1} / 1+2$; foot of four joints, spurs slender, acute, moderately divergent, separated by broad flat. interspace; viviparous; found aggregated in great numbers, forming larger or smaller patches.

Detailed description.-Size variable; smallest about $\frac{1}{60}$ inch long, in the feeding attitude $(=416 \mu)$; longest measured $\frac{1}{31}$ inch $(=800 \mu)$ when fully extended creeping : a fairly large example had the following measurements, diameter of corona ${ }_{150}$. inch $(=166 \mu)$, of collar $\frac{1}{19} \sigma$ (inch $\left.=132 \mu\right)$, of neck $\frac{1}{235}$ inch $(=106 \mu)$, of trunk $\frac{1}{17}$ inch $(=213 \mu)$, length of jaw $\frac{1}{530}$ inch $(=47 \mu)$, of spur $\frac{1}{1000}$ inch $(=25 \mu)$. Central setæ were not detected on the discs. The very prominent collar passes insensibly into the pedicels, the junction marked only by the line of fine cilia (secondary wreath). The rostrum bears short lamellæ, a brush of active cilia, and four stout straight setæ, corresponding to the tactile setæ of $P$. brevipes (25) and some other species, but they were not seen in motion. The length of the antenna is about equal to half the diameter of the neck segment which bears it.

The brain is fairly large. Each jaw bears two strong teeth and one thin one, and in addition the usual fine striæ. There is a prominent hook at the back of the ramus. The stomach is very voluminous, and of a very bright deep ruby or crimson colour, due to the presence of coloured granules and globules. The central trunk is the broadest part of the body, and varies in size with the number of young carried. It isregularly plicate, the folds shallower on the back, deeper on the sides.

The reproduction is viviparous. Usually there are two or three young carried at a. time. Whatever the number, they appear to be all at the same stage of development. At any rate they are all of the same apparent size, and after the jaws are developed they appear to be alike in all. It is very different with the genus Rotifer, in which. 
the young are obviously of very different ages, one being fully developed while another shows no detail at all. The yolk mass contains eight nuclei.

The spurs vary greatly in size, generally most closely resembling those of $P$. acuticornis (25). The interspace is relatively broader. Occasionally they are very long and apparently two-jointed. The last foot-joint is long. The ventral toes are very large, and the dorsal ones very small.

The vibratile tags are short, and broadly spindle-shaped. Three pairs have been seen.

Habitat.-In lakes and ponds at Cape Royds, Cape Barne, and at the Stranded Moraines on the west side of McMurdo Sound. It was absent from the very saline Green Lake, but was in nearly all the other waters examined. It was much the most abundant species in the district. Its abundance in Coast Lake and in the lake at the Stranded Moraines was remarkable. In winter it was got by digging out ice containing plants from the lakes. As soon as these were thawed the rotifers were found active in great plenty. In summer blood-red patches began to form on the stones at the margin of Coast Lake. These attained to a diameter of an inch. Similar patches were on the plants, but these were more difficult to detect owing to the orange-red colour of the plants. In the lake at the Stranded Moraines, Priestley reports that the patches reached to six or eight inches in diameter, and were of appreciable thickness. These patches were formed solely of $P$. gregaria, which were fixed side by side, as close as they could stand.

To obtain them a handful of weed was taken and washed in a bucket of water, being vigorously shaken in order to detach all the adherent microscopic organisms. The sediment thus obtained was strained through a coarse silk net, in order to remove the larger particles, and the fine sediment was then bottled and allowed to settle. At first it was of a dull green colour, from the preponderance of blue-green Algæ. After an hour or two a red film, like blood, appeared on the surface of the mud. The rotifers have crept out of the mud. After a time they leave the mud and creep up the sides of the bottle into the clear water above; eventually they reach the surface of the water and there form a ring of red round the bottle. They may then be collected in thousands with a brush and put into clean water. This process may be continued with one lot for days, an hour or two being sufficient time for new hosts of the endless procession to reach the surface.

Habits. - P. gregaria is ordinarily rather a restless animal. It is ready enough to feed, and remains fixed in one spot for a long time, but it swings about continually so that it is not easy to get a good portrait. Though normally anchoring itself, in company with its myriad neighbours, it occasionally casts off and goes swimming. In Coast Lake it was got in the tow-net, and a few might be seen if a bottle of the lake water was held up to the light. According to Priestley it was much more plentiful in the water of the lake at the Stranded Moraines.

It was particularly amenable to treatment with mild narcotics. When a very 
dilute solution of Eucaine was added to the water, it at once changed both habits and appearance. It ceased its restless swaying about and went on feeding so steadily that it could easily be photographed. The circular muscles were slightly contracted, thus deepening the constrictions between the principal divisions of the body. The foot was inclined to be further retracted than in the normal condition. Otherwise there was little change in form, and the corona was quite unaltered. The effect of the narcotic was much less than on $P$. laticeps. When that species is treated with Eucaine it partially retracts the foot, expands the usually narrow central trunk, and reduces the width of the corona, in fact it so completely alters its proportions that it is not recognisable for the same species, and might be mistaken for some species of the central group ( $P$. citrina, $P$. brevipes, \&c.) unless particular attention were paid to the spurs.

Affinities.-P. gregaria belongs to the central group of the genus, possessing eyes and tapering spurs of moderate size. There is nothing distinctive in the general form. The viviparous reproduction distinguishes it from all the species of that group. The red colour is differently distributed from that of $P$. roseola, in which the red is diffused. In this species it is limited to the stomach. The slender spurs, with broad interspace, are like those of $P$. laticeps and $P$. acuticornis. The short antenna separates it from both. It is of larger size than any of the other species in the central group, except perhaps $P$. citrina.

The large size, red stomach, viviparous reproduction, and slender spurs set far apart, will distinguish it from all known species of Philodina. The absence of a groove between the prominent collar and the pedicels is also a good character.

Natural history.-As the dominant species in the lakes of Cape Royds the natural history of $P$. gregaria received a good deal of attention, and many experiments were made to elucidate it. These will not be detailed here, but a short summary of the facts will be given." Its extraordinary abundance must indicate that it is possessed of great powers of resistance to all the adverse influences which would be supposed to attend upon it in such a rigorous climate, or else that it is of remarkable fecundity. It appears to triumph in both ways.

It is perhaps inaccurate to call it "gregarious." It is found in large "flocks," but it is doubtful if they ever "flocked" together. The great crowds in which they occur appear to arise from the rapidity with which they reproduce themselves. Several young, probably sometimes as many as six or eight, are produced at a time, and they seem to stay and fix themselves where they are born. Thus the patches increase till they reach inches in diameter, and as there is not foothold for all, they stand on one another's heads (so to speak) till a layer of measurable thickness is produced.

They withstood all the tests applied to Adineta grandis except the heating, which was not tried on them. They are normally frozen in the ice of the lakes for the greater part of the year, and revive at any time that the ice is thawed. When dried and exposed to the lowest air temperatures for a long time, they were not killed, nor

* The detailed account of the observations and experiments will be found in a paper on "Life under Polar Conditions," in a later number of this series of Reports. 
did they die when alternately thawed and refrozen at weekly intervals for several months. They lived for a month in sea-water and in a much more saline solution, and became active again immediately on being transferred to fresh water. They were dried while in the Antarctic by exposing to the air till all the ice passed off by ablation, and were then conveyed by a long voyage through the tropics to England, where they revived within an hour of being moistened and could be seen alive in London a year after they were collected.

In England they were subjected to a temperature of $-78^{\circ}$ Cent. for many hours, by Mr. J. H. Priestley, of Bristol, and survived.

\section{Philodina antarctica, sp. n. (Plate X., Figs. 5a-5c)}

Specific characters.-Large, elongate: corona of moderate breadth, wider than the prominent collar, discs with central papillax, each bearing several fine setæ; antenna long : teeth $2 / 2$ : foot four-jointed, long, slender; spurs with broad triangular basal portion, and narrow apical portion of about equal length (Fig. 5b); last joint of foot short, dorsal toes nearly as large as the ventral ones: pale brown eyes.

Detailed description. - The size is variable. The shortest measured was $380 \mu$ in length, in the feeding attitude, and with the foot well drawn in. The longest measured $714 \mu$, fully extended, creeping. In a large example the diameter of the corona was $96 \mu$, of the collar $73 \mu$, of the neck $60 \mu$, of the trunk $106 \mu$ : the length of the spur was $30 \mu$.

The stomach is of a deep ruby-red colour, the anterior part of the body of a faint brown, and the foot clear and hyaline. The longitudinal folds of the trunk are deep at the sides and shallow on the back. The discs are separated by a space equal to half the diameter of a disc. Into this come the low rounded lobes terminating the collar. They are slightly separated, and the part between is convex. The collar appears two-lobed in dorsal view, and is distinctly marked off from the pedicels. The rostrum is short and broad. The length of the antenna is equal to the diameter of the neck segment bearing it. The reproduction is unknown. Neither eggs nor embryos were ever seen. The yolk mass has the eight nuclei usual in the order. The vibratile tags were not detected.

It was an extremely difficult animal to study, on account of its restless disposition. It went wriggling and twisting and creeping about, often stopping to feed for a moment, but never still. There were no narcotics available when it was first found in considerable numbers, and it afterwards proved to be a rare species, and very uncertain in its occurrence. For this reason no photographs were obtained, and no specimens could be preserved.

Habitat.-Among plants in the ice of several lakes at Cape Royds and Cape Barne. It was never got except by thawing the ice of the lakes. Most of the lakes in which it lived did not melt in either of the two summers we spent in the district.

Affinities.-Belonging also to the central group of species, there is little in its general proportions and characters to distinguish it from several other species. It is more 
elongate than most of them, and in that respect comes nearest to $P$. erythrophthalma Ehr. (15). The characteristic spurs, consisting of a narrow blunt apical portion springing abruptly from a broad conical base, will separate it from that and all other known species when well developed. Sometimes the narrow part is considerably reduced. No other member of the genus has such spurs, but very similar spurs, differing only in being sharper pointed, are possessed by Callidina hexodonta, Bergendal (3), formerly regarded (from the possession of cervical eyes) as belonging to the genus Philodina.

The slender foot, which can be elongated much more than the drawing (Fig. 5a) shows, the lack of interspace between the spurs, and the deep red stomach are also good characters.

\section{Philodina alata, sp. n. (Plate X., Figs. $4 a-4 r$ )}

Specific characters.-Size moderate : corolla broad, diameter about equal to that of the trunk (exclusive of the processes) in ordinary extension; collar inconspicuous, the lobes going to the upper lip not reaching beyond the line of the bridge joining the pedicels: interspace between discs equal to diameter of disc; central setæ on discs : teeth $2 / 2$ : trunk plicate, bearing two large rounded lateral processes (one on each side) a little way in front of the widest part of the central segments : rump short, with a rounded boss in the middle of the preanal segment: foot short, fourjointed, spurs diverging, tapering, conical, rather blunt. Eyes brown.

General description. - Length $300 \mu$, in the feeding attitude. The stomach is of the same deep red as in $P$. gregaria, the colour being seated in small granules and globules. The rostrum is short and rather narrow. The length of the antenna is about equal to the diameter of the neck. On the fairly large brain are seated the pale brown eyes. The jaws are rather small, and bear two teeth each. The trunk is regularly plicate, the dorsal folds being wider and shallower than the lateral ones. The trunk is sometimes decidedly viscous, and has extraneous matter adhering to it, but this is not always so. It is sometimes quite clear.

The lateral processes are not thickenings, like most of the trunk processes of Bdelloids. They are large, hollow, approximately conical protuberances, with skin no thicker tban that of the trunk, unless at the extreme apex, where it is a little thicker. They are controlled by special muscles, by which the apex may be more or less pulled in and inverted, making the form truncate, as shown in Fig. 4a. Sometimes, when creeping or feeding, the processes are so far inverted that they are scarcely visible in dorsal view, but this is not always the case, as shown in Fig. 4c, where they are fully extended when the animal is creeping. In complete contraction of the animal they have their greatest projection, and are then more directed forward than at any other times.

No suggestion as to the function of these curious processes has been offered. In other Bdelloids having warts on the body they are supposed to have a defensive 
function. It can hardly be so with $P$. alata, as the processes are, from their form, more vulnerable than the trunk wall would be.

The boss on the preanal segment is of another nature. It is a thickening, and may have a protective function.

The vibratile tags are short and somewhat broadly spindle-shaped (Fig. 4e).

Habitat.-Among weeds from the Narrows between the two portions of Blue Lake, pretty numerous, March 27, 1908. Afterwards found in several lakes at Cape Royds and Cape Barne, always scarce and uncertain. A few could usually be got when wanted from the Narrows of Blue Lake.

It was living, among scraps of weed, at a depth of 11 feet in Blue Lake.

Habits. - A quiet animal and slow in its movements. When feeding, which it rarely did, it could be easily studied. Under the influence of a narcotic (Eucaine) it behaved in a very unsatisfactory manner. It kept the corona expanded and continued feeding, but contorted itself till it was not recognisable except by the side processes. No good photographs of it could be obtained, but under pressure some were made which showed the internal structure and the characteristic processes.

Affinities. - P. alata, like the other two Antarctic members of the genus, belongs to the central group of species. The lateral processes, which are unique in the order, serve to distinguish it from all other Philodince and Bdelloids. The boss on the preanal is an uncommon character. Without these processes it would be very diffecult to characterise.

\section{Philodina, sp. (Plate X., Fig. 6)}

Description.-Size moderate. Corona narrow, about equalling the prominent collar, and less than the trunk. Upper lip with two rounded lobes meeting in the middle line. Two pale or colourless eyes. Teeth 2/2. Foot short (number of joints?); spurs broad short cones slightly diverging and with no interspace.

This species, which is undoubtedly distinct from all the other Antarctic species, was only once seen, and is insufficiently studied. The form of the upper lip and spurs are like those of $P$. plena (4). There is little to separate it from that species except the possession of eyes. It is doubtful if the presence or absence of eyes constitute characters of even specific value, as several species are variable in this respect (P. rugosa, P. macrostyla, \&c.).

It had not the red stomach of nearly all the Antarctic Bdelloids, but that might merely indicate youth.

Habitat.-Among weed from the Narrows of Blue Lake.

\section{Genus-Callidina}

Note.-The genus Callidina contains a host of species, many of them not at all closely related, and offering material for many genera. C. constricta and C. angularis 
in our list should le in a different genus from $C$. habita. As the whole order requires revision by a competent authority, ${ }^{*}$ the old names are retained here.

\section{Callidina constricta, Duj. (14) (Pläte XII., Figs. 13a, 13b)}

Dujardin's meagre description would fit equally well a considerable number of those Callidino which mould the food into pellets, and which are distinguished from one another by characters requiring more careful examination than the Bdelloids usually receive. The commonest of those species which have numerous teeth on the jaws, the corona somewhat less in diameter than the widest part of the head, the discs close together, and the spurs short divergent cones, may be taken as the type of $C$. constricta.

To establish $C$. constricta, Duj., and $C$. elegans, Ehr. (15), and to distinguish them from the numerous related species, it would be necessary that both should be redescribed by a competent authority. Janson (20) briefly describes them, but scarcely with the detail necessary to firmly establish them, neglecting, for example, the form of the upper lip, a character of the utmost importance in all Philodinadæ. Janson gives $C$. constricta as having fewer teeth than $C$. elegans (8/8 instead of 10 or 11) and a shorter jaw. There is nothing so difficult as to make certain of the number of teeth in those pellet-making Callidino which have many teeth. They can be clearly enough seen, but the anterior ones are usually thickest, and the others diminish successively till they cannot be distinguished from the fine strix which are found on the rami of all Bdelloids. Very commonly there are four strong teeth, the fourth (counting from the anterior end) much thinner than the first; then there is an abrupt transition to finer teetl which are still thicker than the strix, but merge gradually into them.

The Cape Royds Callidina, which I identify as C. corstricta (see Plate XII., Fig. 13), is a small animal, about $\frac{1}{100}$ inch in length $(250 \mu)$. It is not much enlarged in the central trunk, which is fairitly plicate and not obviously stippled. The small discs are touching, and the whole diameter of the corona is distinctly less than the widest part of the head. The jaws are long and narrow, and each bears four distinct teeth, diminishing in thickness backwards, succeeded by finer teeth which continue to diminish in thickness to the posterior end of the jaw. The rump is clearly marked off from the central trunk, but its two segments are only seen as the animal extends itself in creeping. The foot is short, of three joints, and the spurs are very short, quickly tapering, and widely divergent.

Habits. - It is a quiet sedate animal, moving steadily and readily feeding. It oiten swims free, rotating on its long axis.

Habitat. - In most of the lakes at Cape Royds. Common, but not abundant. It is one of the two Bdelloids found in Green Lake.

Eggs.-In company with C. constricta two different forms of egg have been

- Mr. D. Bryce is at present engaged on such a revision. 
found, which may belong to this species or to C. angularis (Plate XII., Figs. 12c-12d). Each of these eggs was found with the jaws of the contained young so well grown that the numerous teeth could be seen. As there are only the two species known at Cape Royds which have many teeth, it is practically certain that these eggs belong to them, but as they were never found in the bodies of the rotifers it cannot be determined to which each belongs.

\section{Callidina angularis, sp. n. (Plate XII., Figs. 12a-12d)}

Specific characters.-Small, yellow, much widest in central trunk; strongly nodose from the lateral projection of certain segments, from the neck to the preanal : trunk strongly plicate, and stippled (except head, neck, and foot). The head is widest at the cheeks, and the corona is distinctly smaller, and about equal in diameter to the neck. Rump narrower than the fourth central segment, its two segments distinct. Foot short, of three segments. Spurs small, divergent, acuminate and acute. Food moulded into pellets. Jaws narrow, teeth many.

General description.-Length when feeding about $\frac{1}{100}$ inch, rather greater when creeping. The diameter of the corona is about $\frac{1}{500}$ inch $(50 \mu)$, and of the widest part of the trunk about $\frac{1}{250}$ inch $(100 \mu)$. The rostrum is short and broad and the antenna short. There are from eight to ten teeth in each jaw, and they diminish rapidly in thickness towards the posterior end of the jaw. The anterior edges of the three segments succeeding the neck are strongly produced outward, giving a nodose appearance to the anterior trunk. The mid-trunk is also laterally produced into an angle. The fourth central and preanal segments are also produced at their posterior edges. The trunk has few broad clearly marked folds. The preanal has two folds near the middle line. The three toes are short and obscure.

The upper lip is a somewhat triangular area. The central portion forms a pointed arch, or may be rounded or slightly cleft. The collar is very inconspicuous. The voluminous stomach is red or brown or pale yellow. The pellets are very obscure.

Habitat.-In most of the lakes at Cape Royds.

Reproduction.-The absence of living young makes it practically certain that the species is oviparous. Associated with it were eggs (already referred to under C. constricta) which could only belong to one of these species.

Affinities.-C. angularis is undoubtedly derived from C. constricta. There are so many points in common that they were for long considered to be identical. The outline of a Bdelloid rotifer can vary so much during the different movements that it was considered inadvisable to put much importance on the angular outline of this species. It was only when the peculiar form was found to be always associated with a stippled skin that it came to be regarded as distinct from $C$. constricta.

Eggs.-As to the eggs of this species, see remarks under C. constricta. BRIT. ANTARCT. EXPED. 1907-9. VOL. I. 


\section{Callidina habita, Bryce (4) Variety (Plate XI., Figs. 8a-8e)}

Description.-Large, stout, hyaline or yellowish, much widest in central trunk, which is plicate with broad folds. Length when feeding, up to $570 \mu$, diameter of trunk $125 \mu$ and upwards, of corona $95 \mu$. The corona is much wider than the collar, and that is much wider than the neck. The discs are large and bear central setæ. They are separated by a space equal to half the diameter of the disc. The collar is prominent and appears two-lobed in dorsal view. It is continued on to the upper lip as two large rounded lobes which meet in the middle line.

The rostrum is stout, and the lamellæ appear to be quite separated. The antenna is equal to one-third the diameter of the neck. The jaws are large and have a thickened border, sometimes coloured brown. The teeth are two in each jaw, witha thinner one.

The voluminous stomach is of a deep crimson colour, and the walls are filled with larger and smaller globules. The yolk-mass contains eight nuclei. The two segments of the rump are obscurely distinguishable. The foot is four-jointed, but there is often difficulty in making out more than three. The spurs are stout, almost cylindrical, quickly tapering to the acute points, divergent. The first foot-joint has a thickening forming a more or less distinct boss.

The egg is elliptical and is produced at each pole into a rounded prominence (Fig. 8d).

This variety, which is typical in every other respect, differs conspicuously in the form of the spurs. Those of the type are broad and very acuminate, the lower edge making an ogee curve. The highly coloured stomach is an important feature, but it cannot be considered of much specific value.

Another variety.-Rather smaller, the two lobes of the upper lip less distinct, separated only by a small notch. Spurs in form like the type, but smaller, and the curvature of the lower edge less marked. The foot-boss more distinct. Otherwise like the type (Plate XI:, Fig. 8b).

Both forms were fairly common in most of the lakes at Cape Royds. They did not occur in Green Lake. In Blue Lake at a depth of fifteen feet.

\section{Family-ADINETAdA}

\section{'Genus-Adineta}

The genus Adineta, the only one yet described in the family, is a small one. It contains at present some eight recognised species. It is better represented in the Antarctic Region than any of the other genera of Bdelloids.

Five species were recognised, of which one $(A$. grandis) is new to science. 
None of them, except $A$. grandis, is very common. That species swarms in numbers only inferior to those of Philodina gregaria.

\section{Adineta grandis, sp. n. (Plate XII., Figs. 10a-10d)}

Specific characters.-Very large, stout, rostrum philodinoid, with lamellæ and brush of cilia as in Philodina; posterior margin of mouth pectinate: spurs short broad cones, separated by straight interspace, reproduction viviparous.

Detailed description.-Large examples measure $750 \mu$ in length. The colour is light brown or yellowish, darker in the alimentary tract. It has the graceful form usual in the genus, very broad in the central region of the trunk and tapering to narrow extremities. The trunk is regularly, and not very deeply, plicate. The neck is slightly constricted below the head, then there is an expansion at the normal level of the mastax.

The head is ovate, and rounded in front. The rostrum is short and stout, and is quite like that of a typical philodine, except that it is not retractile. In ventral view the lamellæ, which are relatively smaller than is usual in the genus, appear to meet in the middle line. Beneath them is the brush of cilia, looking as they do in a philodine when contracted, but the tip was never seen everted so as to make the brush project. On each side, close to the edge of the lamellæ, is a longer cilium, moving like the tactile setæ occurring in the same situation in Philodina macrostyla, \&c. Only one could be distinguished at each side. The antenna is short and broad.

The pectinate part of the mouth appears to be a fold within the margin proper. The processes are flat plates, with the spaces between about equal to the thickness of the plates. They are rounded at the ends. The number varies from six to ten on each side. At the inner end of each series the terminal process is drawn out into a longer narrow rod, which appears to be attached to the flat surface of the corona. The furred surface is uninterrupted from side to side, but at the anterior end a tonthlike process projects backwards in the median line. The jaws are normal, with the usual two teeth on each.

The stomach is large and of a warm brown colour. The intestine is elliptical. The two segments can be distinguished in the rump, which tapers gradually in line with the stout four-jointed foot. The spurs are stout and subacute. They diverge widely and are separated by an interspace about equal to the diameter of the spur at its base. The terminal joint of the foot is of moderate length and the three toes are small and short.

The stoutness of the trunk varies greatly according to the number of young carried, and their degree of development: It becomes enormous when it contains six or seven young almost full-grown. The largest number observed was seven, but the usual number was three. It was noticed that when the young were well enough 
glown to show definite structures (such as the teeth) all of them were in the same degree of advancement, as far as could be perceived. This is different from what is the case in the genus Rotifer, in which all the species are viviparous. There the two or three embryos are at different stages. The yolk-mass, which could rarely be seen, contained eight nuclei. On one occasion (March 27, 1908) a yolk-mass was seen divided up into six portions, each containing a nucleus, no doubt a brood at an early stage. Three pairs of narrow spindle-shaped vibratile tags have been seen.

Habits.-A. grandis has not the restlessness which is characteristic of the genus. It is sufficiently active, but it creeps steadily, and "right side up," like many of the Philodinadæ, and can therefore be more easily studied. It feeds on minute organic particles, among which there is rarely any recognisable organism.

Habitat.-Among the brown vegetation in the lakes at Cape Royds. It was the most generally distributed of all the Antarctic rotifers, and occurred in saline lakes from which most of the other species were absent.

Natural history.-A detailed study of Adineta grandis will be made in another paper.* A summary of the ascertained facts will be here given. The species is the only rival to Philodina gregaria in abundance, and in this connection it is important to note that it shares with it the viviparous mode of reproduction. It is found in a greater number of lakes than $P$. gregaria, but it never appears to be in such prodigious numbers. This may be due merely to its less conspicious colouring, which is almost identical with that of the plant on which it lives.

It is not extremely abundant in the freshwater lakes, where it has many competitors, but in the very saline Green Lake, from which all the other species but Callidina constricta are absent, it is almost as abundant as $P$. gregaria is in Coast Lake, and may be collected in the same way. When the fine debris washed from the weed of Green Lake is allowed to stand undisturbed for some hours a pale brown layer appears on the surface. This may be taken up by the pipette and is found to be pure Adineta grandis, without admixture of other organisms. The rotifer has crept out of the mud to the surface. This habit allows quantities to be got for study and makes it easy to make simple experinents upon therm. It did not usually creep up the sides of the bottle, as $P$. gregaria does, but on one occasion, when a moderate number were mixed with that species, they also crept to the surface of the water. They could be obtained at any time during the winter by melting some ice from Green Lake enclosing some of the brown weed. They usually began to move as soon as released.

In its power to endure extreme changes of temperature and other adverse conditions, Adineta grandis is the most interesting of the Antarctic rotifers. From its large size and great abundance, it was the species selected for most of the experiments made with the object of finding the limits to the vitality of Rotifers. It survived the lowest temperatures experienced at Cape Royds $\left(-40^{\circ} \mathrm{F}\right.$.), and repeated 
freezing and thawing. It was the only species subjected to the heating experiment, in which a proportion of them lived after the bottle containing them (in the dry condition) was immersed in boiling water for a short time. It was one of the rotifers which was to be seen alive and active in London in September 1909, after being dry for about a year, and spending some months in tropical and subtropical climates. It revived in about an hour after being moistened. It was immersed in sea-water, and in the much more saline fluid obtained from under the ice of Green Lake (of which it is a native), and kept there for one month, after which it revived quickly when transferred to fresh water. The diameter of the contracted animal in fresh water was $225 \mu$-in the brine of Green Lake it contracted to $150 \mu$, or two-thirds of the normal diameter.

It is indifferent to the interruption of its active vital functions by freezing, often for long periods, and quickly resumes activity when thawed. The development of the young likewise does not appear to suffer fiom its interruption at any stage. In consequence of interruption development may often take many years for its completion, but in the periods when the lakes are melted it probably only occupies a few days, and many generations may be completed in the few weeks of summer.

Affinities. - A. grandis shows most resemblance to $A$. vaga Davis (12). The pectinate margin to the mouth is a character which may readily be overlooked in species of this genus, as the structures of the head of an Adineta are very difficult to see, on account of the restless contortions of the animal. The pectinate border is easily seen in $A$. grandis owing to its large size.

The species may be a derivative of $A$. vaga, but of very long standing, as the profound changes show. A different mode of reproduction has been adopted, and the form of spurs and rostrum, \&c., changed. The ciliated surface of the face of $A$. vaga is described as divided into two parts by an unciliated band. This is not the case with $A$. grandis, in which there is no perceptible interruption of the furred surface from side to side.

\section{Adineta barbata, Janson? (20) (Plate XII., Figs. 9a-9c)}

Description.-Of moderate size. Head ovate; rostral tip produced laterally into little sharp points; lamellæ long, slender, curved, rounded, accompanied by several long bristles ; spurs divergent, curved, tapering, acuminate.

While corresponding in general to the type of $A$. barbata, the animal found at Cape Royds differs in two particulars: the spurs taper from the base and are acuninate; in the type the thickness is maintained to near the tip, and the tapering is thell abrupt; the processes on the rostrum which correspond to the lamellæ of the Philodinadæe are very long and slender, and in dorsal view look like antennæ of insects.

Janson does not describe the lamellæe as of this narrow elongate form, and his figure shows them quite moderate. The difference is of specific value, but as the 
Antarctic species was not at the time studied critically enough, and the knowledge of the peculiar lamellæ is only gathered from my sketches, I prefer to leave it meanwhile as a form of $A$. barbata, to which it appears to be closely related.

The pectinate border of the mouth was difficult to see, owing to the restless movements of the animal, but it was clearly seen in a well-grown young in the egg (Fig. $9 c$ ).

The first eggs found confirmed the belief that the animal is distinct from $A$. barbata. They were elliptical, and lacked the knobs characteristic of the egg of A. barbata. Later on a different egg was found, which had the knobs as in A. barbata, but much reduced in size (Fig. $9 c$ ).

\section{Adineta vaga, Davis (12)}

The type of this species (which is the var. minor of Bryce) was found in several lakes soon after we landed at Cape Royds. It was not seen later, and was thus never subjected to a very critical examination.

Habitat.-Blue Lake, Clear Lake, and Coast Lake.

\section{Adineta gracilis, Janson (20)}

Habitat.-Blue Lake, Clear Lake, and a little pond on the lower slopes of Mount Erebus. The examples appeared to be quite typical.

\section{Adineta longicornis, Murray? (27)}

Description.-Small, head ovate, rostral part divided into two large, evenly rounded lobes. The spurs are long, slightly divergent, and taper to acute points.

Habitat._Among moss from the High Moraines, Cape Royds, January 1909, one example seen.

It is with hesitation that this animal is referred to A. longicornis. The spurs are shorter than in the type, and the head is of slightly different shape. As the rostral structures were not clearly made out, it cannot be confidently separated from that species.

\section{NOTE}

Additional Species.-In April 1910, just as we go to press, an additional Bdelloid has been found alive, in moss collected by Priestley at the Stranded Moraines. It is a pellet-maker having three teeth in each jaw, and may be identified as Callidina (Macrotrachela) tridens, Milne. That species is very similar to C. constricta, except in the very distinct teeth. A more detailed description of it is wanted.

This addition, with the identification of the Floscularia as $F$. cornuta, brings up the list of recognised Antarctic Rotifera to 16 species. 


\title{
Order-RHIZOTA
}

\section{Family-Flosculariade}

Genus-Floscularia

\author{
Floscularia, sp. (Plate XIII., Fig. 15)*
}

On January 18, 1909, among weed from a pond between Cape Barne and Cape Royds, a species of Floscularia was found in some abundance. When examined after reaching the hut they were moving languidly and showing an inclination to expand. The long setæ, which exceeded the trunk in length, projected as a long brush. The lobes were not unfolded, and there was little time to wait for it.

Although there is no hope of identifying the species, a sketch of it in the partly contracted condition is given, in order to complete our records of the rotifera of the region.

In this state the length, exclusive of the setæ, was $284 \mu$. The foot is transversely wrinkled in the usual manner, and terminates in a conical portion, tapering to a narrow apex (probably the adhesive disc unattached at the time).

Neither tube nor eggs were observed. The teeth and the various viscera were seen, but detailed studies under pressure could not be made.

\section{Order-PLOÏMA \\ Family一Hydatinade \\ Genus-Hydatina}

Hydatina senta, Ehr. (Photograph from life. Plate II., Fig. 7)

No description need be given, as the Antarctic examples appear to be quite typical. The species was identified with certainty by Mr. Rousselet from preserved examples. It was found in great abundance in Coast Iake when it was tow-netted for the first time on January 2, 1909. It might have been found much earlier if the lake had been examined in a suitable manner, as there was some open water from the end of November 1908, and the temperature of the water, as early as December 4, was $+47^{\circ}$ Fahr. When the Hydatina was first found the temperature had gone down to $+40^{\circ}$. On January 18, 1909, the temperature had gone up again to $+45^{\circ}$, and the IYydatina was much less plentiful.

Large oval smooth brown eggs were known, which proved to be those of Hydatina.

Under the influence of Eucaine Hydatina behaved well, retaining the normal form

- An example having the corona fully expanded has since been found, which allows of its identification as $F$. cornutce, Dobie. 
perfectly, but remaining so still that it could easily be photographed while living and feeding.

Hydatina was only seen in Coast Lake. Its restriction to one lake led $\mathrm{Mr}$. Rousselet to suggest the possibility of its recent introduction, say by the Discovery Expedition. It is not impossible, though hardly probable. Hydatina is a common animal in ponds around farmhouses, and eggrs might readily enough adhere to furm produce such as hay or straw. When Captain Scott and Dr. Wilson camped for a short time at Cape Royds, close by the spot where we afterwards had our hut, they may have had some straw packing among their gear. In this connection it is worth noting that we dredged in Back-door Bay a stalk of old sodden straw on which a sponge had grown. This straw could hardly be of older date than the Discovery Expedition. Against the theory of the recent origin of Hydatina is the fact that Coast Lake is a mile from Captain Scott's camp, and that several suitable lakes lie nearer the camp. Still, one egg is enough for the introduction, and the straw bearing the one egg may have blown to Coast Lake.

\section{Family-Notommatade}

\section{Genus-Pleurotrocha}

\section{Pleurotrocha, sp. ? (Plate XIII., Figs. 14a-14c)}

Description.-Of large size, $520 \mu$ in length. In lateral view greatly elevated just behind the middle of the trunk. Head long, mouth narrow. Jaws very like those of $P$. grandis, Western, and some related species. Toes longer than those of $P$. grandis. Stomach large, orange-coloured.

This large active animal was found in Blue Lake early in the season, before the requisites for narcotising and preserving were available. It was fairly abundant then but was not obtainable afterwards, when it could have been photographed and preserved. We are therefore dependent for our knowledge of the animal on a few sketches by one little acquainted with the order to which it belongs. Mr. Rousselet has examined the sketches critically, taking such points as could be best trusted, and compared them with the same points in the species coming nearest to our one.

It is undoubtedly very near $P$. grandis (41), which is like it in size and activity. The jaws differ in being more ovoid in form, diminishing backward from the widest. part. In $P$. grandis the greatest width is maintained for some distance backward. The toes are considerably longer and narrower than in $P$. grandis. The general outline of the jaws is very similar to that of Diglena permollis, Gosse (16), as shown in a drawing by Mr. Dixon-Nuttall.

Reproduction.-Two kinds of egg have been seen which contained animals having jaws exactly like those of the Pleurotrocha (the drawing, Fig. 14c, is made from an example in an egg). One of the eggs was elliptical and smooth. The other was 
also elliptical but was thicker shelled, and was covered with little points projecting from the surface (Fig. 14b):

\section{Genus-Diaschiza}

\section{Diaschiza tenuior, Gosse? (17) (Plate XIII., Figs. 16a-16f)}

Of the species described in Dixon-Nuttall and Freeman's Monograph of the genus (13) the Antarctic Diaschiza can only be D.tenuior. It differs only in being somewhat laterally compressed, and in carrying the toes more ventrally than usual. The length of the toes easily separate it from $D$. cocca, Gosse:

With it was associated a much smaller animal, which may be the male of the same species (Figs. 14c-14d). It has a large head and comparatively insignificant body. The corona has the large strong cilia common to most males, and it swam powerfully. The dorsal cleft is seen on the trunk. The segment between the trunk and the toes is well marked. The toes are small, conical, divergent and decurved. Unlike most males it possesses teeth. The male organs were not definitely seen, nor were any viscera distinguished.

In the female the setæa at the base of the toes were not made out, but we were working with very poor light.

The elliptical, smooth, thin-shelled egg was seen, containing the young. A smaller egg, with thick shell, through which obscure lines passed obliquely in various directions (Fig. $16 f$ ), contained an animal with jaws like those of the supposed male.

\section{Remarks on the Antarctic Rotifer Fauna}

Its Composition.-The Rotifer Fauna of Cape Royds, comprising not much more than a fiftieth part of the known species, is very remarkable in its composition. When the number of species is so small it is curious that all the orders of Rotifera are represented [the Scirtopoda being, as a result of Beauchamp's studies (2), reduced from ordinal rank].

The great preponderance of the small order Bdelloida (with twelve species) over the Ploïma (with four species) is not surprising in view of the well-known remarkable vitality and facility of distribution of these animals.

The proportions in which the various genera of Bdelloids occur in the fauna are very curious and interesting. The four species of Philodina are all unknown elsewhere. The large genus Callidina, which elsewhere contains half, or more than half of the species in the entire order, has only three species at Cape Royds. Two of these are known species and one is new. The small genus Adineta, of which only seven species have been described, has no fewer than five species at Cape Royds. Only one of these is new to science. The genus Rotifer is absent.

BRIT. ANTARCT. EXPED. 1907-9. VOL. I. 
The sixteen species of Rotifera are thus distributed : eight known species, five new species, three not identified. While there are only five new species named, one of the others (Philodina, sp.) though not sufficiently studied to be named, is certainly new, and several of the known species differ more or less from their types, and may be incipient species resulting from long isolation in peculiar conditions.

Peculiarities.-The distinctive characters of the new species are not very remarkable. They consist in the forms and proportions of the spurs, head, upper lip, \&c., or in the possession of peculiar processes (Philodina alata). There are no peculiar types. Development has gone on lines similar to those it might have followed in any region. The rotifers may have acquired peculiar physiological properties, enabling them to resist the rigours of the Antarctic climate, but such adaptation (if it has taken place) is not correlated with any peculiarity in outward form.

Reviewing the rotifer fauna as a whole, its most notable features are the general prevalence of red colour among the Bdelloids, and the viviparous reproduction acquired by some of them belonging to groups which are rarely viviparous.

Colour of Bdelloids.-All the Philodince, except the unnamed species, have the voluminous stomach coloured of a vivid deep crimson. This colour is shared in equal degree by Callidina habita. Callidina constricta and $C$. angularis have the stomach sometimes red, sometimes brown, and occasionally pale yellow. None of the Adineta have red stomachs. A. grandis has the alimentary tract of a warm brown colour, the others are pale yellow or colourless.

The prevalent red colour may be related to the nature of the food. Callidina habita and C. constricta are not normally red in other countries. All the species. live among the same plants, which are of a warm orange colour, but associated with this are numerous green and blue-green Algæ, so that there is a variety of food available, and the different species may select different foods. We have no exact information as to the kinds of food actually eaten by the Antarctic species. Though they can be readily watched feeding, they rarely swallow organic matter in recognisable condition, but fine, flocculent material, the result of decomposition. Bdelloids. have the power of selecting their food. A pair of knuckle-like processes in the gullet can be brought together, and these are opened or closed according as the particles swept down the funnel are acceptable or not.

There were no red-coloured rotifers in Green Lake, which was very saline. The only two Bdelloids which occurred there were Adineta grandis and Callidina constricta. A. grandis was never red in any lake, but in freshwater lakes $C$. constricta. had sometimes a red stomach.

Reproduction.-Of the Antarctic rotifers seven are oviparous, two are viviparous, and the reproduction of the remaining seven is unknown. The genus Rotifer, all the members of which are viviparous, is unknown in the region.

The two viviparous species, Philodina gregaria and Adineta grandis, preponderate enormously in numbers over all the other species. This mode of reproduction 
appears therefore to be best adapted to secure success in the struggle for existence under the severe conditions experienced at Cape Royds.

Dispersal.-Most of the Bdelloid Rotifers were found generally distributed among the lakes of the district. Dispersal from one to another is therefore probably easy. The most striking exception is Green Lake, where there are only two of the species. There is little doubt that the qualities of the water are responsible for the limitation in that lake, as there are other lakes close by from which rotifers might be derived.

Hydatina is only known in Coast Lake. It is the only normally free-swimming rotifer in the region, and very likely its large eggs fall to the bottom in the deeper part of the lake, and are not likely to be in the marginal zone which is exposed by the ablation of the ice. Even so it is to be expected that some eggs would get among the weeds which are thus exposed.

No rotifers were found in Pony Lake, but the proximity of the penguin rookery renders the water so foul that it would be surprising if there were rotifers in it, always excepting Hydatina, which frequents such situations.

There are only two probable means by which rotifers can be transferred from one lake to another. One is by the agency of birds, and the other is by means of the wind. The skua gulls are the only birds which frequent the fresh water. They are very fond of bathing, and stand in the shallow parts of the lakes, where the water is a few inches deep and the bottom usually covered with weed and rotifers, and there they splash the water about with great gusto. Fragments of weeds may adhere to their feet or may get on their feathers as the water splashes over them. The skuas may visit several ponds in the course of their flights and thus distribute the rotifers over the countryside.

At the margins of the lakes there is generally a zone of dried weed, which increases in breadth as the winter advances, as a result of the ablation of the ice surface. This zone varies in colour from brown to dull green. The weed is strongly wrinkled and very light. Pieces of it might easily be torn off by the wind and blown about the country till the next summer, when it might happen to get into another body of water. Fragments of weed were often seen blowing about. In Coast Lake the ablation of the ice exposed the weed on the bottom, which was in small flakes. Shower's of these flakes were blown by the wind over the shore and out to sea.

Dispersal by the wind and conveyance from lake to lake in a small district like Cape Royds is easily understood. The prevalent strong winds in the region are all from the south, and it is therefore difficult to imagine that the plants and their living fieight could be transferred in this way over long distances where there are not intermediate resting-places, except from south to north. It is, however, possible that northerly gales occur at long intervals, which would help to disperse the species in the opposite direction.

Distribution.- Of the distribution of the Rctifera in the Antarctic Region there is 
nothing to be said, as there are no previous records, except the doubtful egg of Callidina papillosa mentioned by Richters (31). Richters gives details of the jaws and teeth of four species frorn the Caussberg, and figures them, as well as other details of two of the species. These are insufficient for certain identification, though if the rotifer fauna of the Gaussberg could be studied in life we might have a good guess as to what those four were. As our knowledge at present stands we cannot connect any of them with the species found at Cape Royds, though it may be suggested that the figures five and six on his Plate XVII. may be Callidina constricta, which was the only moss-dwelling species identified at Cape Royds.

As the thirteen species found at Cape Royds appear to be the first recorded for the continent, we can only study the distribution over the world of those of the species which are not new to science. The distribution is most clearly seen when the facts are given in tabular form. It is not claimed that the records tabulated are complete, but I have given all which I could find.

Table Showing the General Distribution of all Recorded Antarctic ROTIFERA.

\begin{tabular}{|c|c|c|c|c|c|c|c|c|}
\hline & 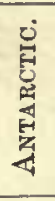 & 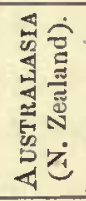 & 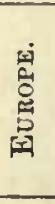 & $\frac{\dot{d}}{4}$ & 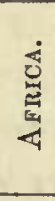 & 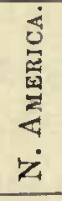 & 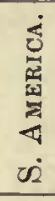 & 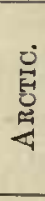 \\
\hline Philodina gregaria, sp. n. & $x$ & - & - & 一 & - & - & - & - \\
\hline$" \quad$ antarctica, sp.n. & $\hat{x}$ & - & - & - & - & - & - & 二 \\
\hline "alata, sp. n. & $x$ & - & - & - & 一 & 一 & 一 & - \\
\hline Callidina angularis, sp.n. & $x$ & - & - & - & - & - & 一 & - \\
\hline Adineta grandis, sp. n. . & $x$ & - & - & 一 & 一 & 一 & $\overline{\check{c}}$ & - \\
\hline Callidina constricta, Duj. & $x$ & $x$ & $x$ & - & $x$ & $x$ & $x$ & $x$ \\
\hline " haỏita, Bryce? & $x$ & $x$ & $x$ & $x$ & $x$ & $x$ & $x$ & $x$ \\
\hline " papillosa, Thomp. & ? & $x$ & $x$ & $x$ & - & $x$ & - & $x$ \\
\hline Adineta vaga, Davis : & $x$ & $x$ & $x$ & $x$ & $x$ & $x$ & $x$ & $x$ \\
\hline " barbata, Janson? & $x$ & $x$ & $x$ & - & $x$ & $x$ & - & $x$ \\
\hline "gracilis, Janson. & $x$ & $x$ & $x$ & 一 & $x$ & $x$ & $x$ & $x$ \\
\hline ", longicornis,Murray? & $x$ & $\stackrel{x}{x}$ & - & $x$ & $x$ & - & - & - \\
\hline $\begin{array}{l}\text { Hydatina senta, Ehr. } \\
\text { Diaschiza temuior, Gosse. }\end{array}$ & $\begin{array}{c}x \\
2\end{array}$ & $x$ & $x$ & - & $x$ & $x$ & ? & $x$ \\
\hline Draschrza temuror, Gosse. & & & $x$ & - & - & & & - \\
\hline
\end{tabular}

The facts made use of in the above table are compiled in part from the following sources : for the Antarctic from a paper by Richters (31): for Australasia from Hilgendorf's list (19) and from my own unpublished notes which will appear in a later number of this series: for Europe from papers by Bryce, Janson (20), and others: for Africa from a paper by Rousselet (33) and unpublished notes: for N. America from a paper by Jennings (21) and from unpublished notes: for the Arctic Region from papers by Bryce (5), Bergendal (3) and myself (28).

The new Antarctic species are placed at the top of the list in order that the other facts may be compactly grouped. The facts of distribution of the nine previously 
known species are given under eight headings, being a column for each continent, for Australasia, and for the Arctic and Antarctic regions. This covers the greater part of the earth's surface, only excluding oceanic islands. It may fairly be said that an animal which occurs in all of these broad divisions is "generally distributed."

Callidina habita and Adineta vaga are in every column; C. constricta, A. gracilis, and Hydatina senta are absent from one region only; C. papillosa and A. barbata from two; A. longicornis from four; and Diaschiza tenuior from five. These facts have very little significance, as some of the regions have been very little worked.

Considered in another way the table shows that all the previously known species are also in New Zealand, all but one in Europe, all but two in Africa, N. America, and the Arctic, all but four in S. America, and all but five in Asia. For the reason given in the preceding paragraph these facts have no special significance. Were the world more fully explored we would in all probability find that all the species are ubiquitous.

The Rotifera of the southern hemisphere, from which any migrants to the Antarctic have most probably come, are very imperfectly known. In New Zealand Hilgendorf's was the only work, and in the Index Faunæ Novæ-Zealandiæ (19) he gives a list of over furty species then known. In Australia short lists were published by Anderson (1) and Shephard (34 to 37), and Whitelegge (42) in 1889 summed up the known species, giving a list of 110. In Africa there were short lists by Milne (24) and Kirkman (22 and 23). Rousselet (33) in 1905 visited S. Africa, and in his paper summarises all that was known, giving a list of 156 species. In S. America Schmarda (39) found many rotifers, but his descriptions and figures are such that most of the species are unrecognisable. Recently Daday wrote upon the Rotifera of Patagonia (9), Chile (10), and Paraguay (11). He enumerates 106 species, including some noted by Wierzejski (43). There may be isolated references to rotifers of the southern hemisphere in works other than those cited, but they comprise almost all that was known till recently.

All those lists are noticeable for the very subordinate position occupied by the Bdelloids. This is due to the fact that it was not suspected that mosses supported a very rich fauna of rotifers and other animals. Some of the early investigators of these animals, who were more interested in their physiology than in the discrimination of species, distinguished between the moss-dwellers and water-dwellers.

In papers by Thompson (40) and Bryce (6) such terms as "moss-haunting" are found in use, and in Germany also the word "Moosbewobner" [Richters (32)] is recognised. So little was the existence of the moss-fauna known among naturalists that in some of the latest expeditions the mosses were taken only as botanical specimens, and were treated with preservatives which killed the fauna.

Much work has in recent years been done on the Rotifera of all parts of the globe, from specimens procured from moss. No easier method of collecting is possible than by bringing home dried mosses ; and it is to be hoped that future expeditions 
will realise the desirability of collecting some moss for the sake of its fauna. The moss-fauna of rotifers consists chiefly of Bdelloids, though there are a few others which have adopted the same habitat.

Origin of the Rotifer Fauna.-In the present state of our knowledge it would be premature to discuss the origin of the Antarctic Rotifer Fauna with any expectation of arriving at definite conclusions. We know almost nothing of the geological history of Antarctica, especially of its recent glaciation; we know nothing of the distribution of the Rotifera round the fringe of the continent (the heart we may infer to be as dead as anything on earth); and our knowledge of the Rotifera of the nearest land-masses and of the scattered islands of the southern hemisphere is inadequate.

It may, however, be permitted to discuss in a tentative manner the bearing of the known facts. It may safely be assumed that the Antarctic Region has known periods of greater glaciation or of greater cold than at present, and periods of temperate or warm climate. Is it possible that the rotifer fauna is aboriginal, and has survived through the various climatic changes of long geological ages?

Judging from the summer condition of the Antarctic coast at present, it does not seem too much to suppose that during the coldest periods there might always be some rock faces so inclined as to make the most of the northern sun, and so form little pools where the rotifers might live. The rotifers have been proven to survive a lower temperature than any yet known under natural conditions on the earth, and we have seen (under descriptions of Adineta grandis and Philodina gregaria) that they do not ask for much in the way of luxury. Give them a week or two of warm weather $\left(+40^{\circ} \mathrm{F}\right.$. or so) and they are content to be frozen up for years.

Periods of intense cold need not be periods of great precipitation, as we see in the present low snowfall in South Victoria Land, and thus the bearing of temperature on the problem falls to be separately discussed from that of glaciation. Has there ever been a period when the glaciation was such that the very mountain peaks were covered hy a thick ice-cap which would scrape the rotifers, in common with all other living things great or small, off the surface of the continent? That will not be discussed here, but short of such a mechanical destruction as extreme glaciation or complete submergence would achieve, I see no reason why there should not always have been rotifers on the coast at least of the Antarctic continent.

The peculiarities of the species of rotifers which at present appear to be peculiar to the Antarctic are not very great, morphologically considered, yet they are great enough to require us to presuppose a very long isolation if they have been acquired in their present location. For four of them it would be difficult to suggest a probable ancestor among known species. Although our list of fourteen species shows five new and nine previously known, the amount of peculiarity is greater than these figures would indicate. Three species indicated by marks of interrogation in the table given differ more or less from their supposed types elsewhere. It was doubtful whether they should be regarded as new species or as varieties. In such cases one has 
to decide whether the advance of knowledge will be better served by emphasising the affinities in using the old names or pointing the differences in bestowing new names.

If the rotifers are not aborigiual but have reached the Antarctic by immigration in comparatively recent times, since the last period in which the conditions were such as to prevent the continuance of life on the continent, we must look for some possible means of immigration.

The Rotifera share with the lowest forms of life that facility for distribution which makes them, as Jennings (21) puts it, "potentially cosmopolitan." The agent of distribution is the wind. When some rotifers, and the eggs of others, are dried they may be blown in the form of dust for long distances. There is no difficulty in supposing the Antarctic peopled in this way, though there is no region where such distances of sea must be crossed in the process ; but all round the Antarctic continent the storm-winds generally blow off the land, and so could play no part in bringing a rotifer population to the country.

There are numerous small islands scattered over the Antarctic Ocean, and there are some storms which blow from the north : even in the Antarctic they are known, though rare. While it is difficult to believe the wind currents of the lowest strata of the atmosphere adequate to transport rotifers over the wide ocean separating, for example, New Zealand and South Victoria Land, they might transport them from one island to another, and thus the rotifers might in long ages work their way by slow and intermittent steps from the one land to the other.

There is yet another way in which the wind might be supposed to effect the transference. If a violent local storm were capable of whirling rotifer dust up till it was caught in those high currents which set to the southward, then they might conceivably be carried all the way and dropped on land. If, however, it were as easy as all that, we would expect a much more extensive rotifer fauna.

In one region, south of Cape Horn, the Antarctic continent approaches very near one of the other continents, and there the rotifer dust might readily be blown across. From such a point of easy access the animals might get distributed all round the Antarctic coast by the aid of wind and birds.

The paucity of the rotifer fauna, as far as we know it, points to great difficulty of access. The varying degrees of peculiarity exhibited by the different species suggest that some have been longer resident in the Antarctic than others. Hydatina senta may be a recent immigrant, may even have taken passage with Captain Scott in the early days of the present century : Callidina habita and $C$. angularis may have been there for a few hundreds or thousands of years : whilst Philodina alata, P.gregaria. and Adineta grandis may be aborigines of immense antiquity.

That great difficulties lie in the way of emigration to the Antarctic, and difficulties quite apart from the climatic rigours which meet the immigrants, we have one more indication in the adaptability of many rotifers to various climates. Not only do a great many species extend from the temperate into the Arctic Region, but 
rotifers tiken from a subtropical forest in the extreme ncrth of New Zealand, and subjected to low temperatures at Cape Royds, revived on being moistened. Many Rotifers, Bdelloids at least, do not require much, if any, extension of their powers of endurance to fit them for life in the polar regions, so that if species are few in the Antarctic it is almost certainly because of mechanical difficulties in the way of getting there.

Vitality of Rotifers.-Observations on the Biology of the Rotifera constituted the most interesting part of the naturalist's work in the Antarctic. Many experiments, of a very simple nature, were made upon them in order to ascertain their powers of resistance to every kind of adverse circumstance which might affect them in the course of a migration to Antarctica, or from place to place in it.

These observations and experiments will be described in detail in a paper now in preparation. A short summary of the most interesting points will be found under the descriptions of Philodina gregaria and Adineta grandis in the preceding pages.

\section{LIST OF WORKS REFERRED TO IN THE TEXT}

1. Anderson, H. H. and Shepmard, J., Victorian Rotifers, Proc. Roy. Soc. of Victoria, iv., 1892, pp. 69-80.

2. Beaucinanp, P. DE, "Recherches sur les Rotifères," Arch. de Zool.Expériment. et Gên., t: x., p. 43, 1909.

3. Bergendal, D., "Beiträge zur Fauna Grönlands," K. Fysiograf. Saillskapets Handl., N.F., 1891-2, Bd. iii.

4. Brycy, D., "Further Notes on 'Macrotrachelous Callidine," Journ. Quekett Micr. Club, Se1. II., vol. v., 1894 , p. 451.

5. " ". "Contributions to the Non-Marine Fauna of Spitsbergen," Proc. Zool. Soc. London, 1897, pp. 793-9.

6. " " "Moss-dwelling Cathypnadæ," Science Gossip, 1892, p. 271.

7. Certes, A., "Mission à Cap Horn, 1889.

8. , " "Infusoires et Rotifères," Act. Soc. Scient. Chili, iv., 1894.

9. Daday, E. von, "Mikro-Suisswasserthiere aus Patagonien," Term. rajzi füi., Bd. 25, 1902, p. 201.

10. " " "Süsswasser-Mikrofauna von Chile," Term. rajzi füz., Bd. 25, 1902, p. 436.

11. " "Süsswasser-Mikrofauna Paraguays," in Chun's Zoologica, Bd. 18, H. 44, Stuttgart, 1905.

12. Davis, H., "A New Callidina," \&c., MIonth. Micr. Journ., ix., 1873, p. 201:

13. Dixon-Nutratl, F. R., and Freeman, R., "The Rotatorian Genus Diaschiza," Journ. Roy. Micr Soc., 1903, p. 1.

14. Dujardin, F., "Histoire Naturelle des Zoophytes," Suites à Buffon, 1841.

15. Ehrenbera, C. G., "Organisation der Infusorien," Abhandl. K. Akad. Wiss. Berlin (1831), 1832.

16. Gosse, P. H., "Catalogue of Rotifera found in Britain," Ann. Nat. Hist., vol. viii., 1851, p. 197.

17. " " In "The Rotifera," Hudson and Gosse, London, 1889, vol. ii., p. 81.

18. Hilgendorf, F. W., "A Contribution to the Study of the Rotifera of New Zealand," Trans. and Proc. of New Zealand Inst., vol. xxxi. (14 of New Series), 1898, pp. 107-134.

19. $"$,

"Rotatoria," in Index Faunce Novo-Zealandia, 1894.

20. JaNson, O., "Rotatorien-Familie der Philodinæen," Marburg, 1893.

21. Jennings, H. S., "Rotatoria of the United States," U.S. Fish. Comm. Bull. for 1899, p. 81.

22. Kinkmax, T., "Rotifera of Natal," Journ. Roy. Micr. Soc. London, 1901, pp. 229-241.

23. " " "Second List of Rotifera of Natal," Journ. Roy. Micr. Soc. London, 1906, pp. 263-268. 
24. Mrlne, W., "On the Function of the Water-vascular System in the Rotifera," Proc. Phil. Soc. Glasgow, 1907, pp. 1-12.

25. Murrar, J., "The Rotifera of the Scottish Lochs," Trans. Roy. Soc. Edin., vol. xlv., 1906, pp. 151-191.

26. " " "Scottish National Antarctic Expedition, Tardigrada of the South Orknoys," Trans. Roy. Soc. Edin., xlv., 1906, p. 323.

27. ". " "Some Rotifera of the Sikkim Himalaya," Joum. Roy. Micr. Soc., 1906, p. 643.

28. " " "Arctic Rotifers," Proc. Roy. Phys. Soc. Edin., vol. xvii., 1908, pp. 121-7.

29. " " "Microscopic Life in Gough Island," Proc. Roy. Phys. Soc. Edin., vol. xvii., 1908, pp. $127-9$.

30. " " "Some African Rotifers," Journ. Roy. Micr. Soc. London, 1908, p. 669.

31. Richters, F., "Fauna der Moosrasen des Gaussbcrgs und Einiger Südlicher Inseln," Deut. Südpol. Exped., 1903, Bd. ix. Zool., 1907261.

32. " " "Moosbewohner," Schwed. Südpol. Exped., 1901-3, Bd, vi., 1908.

33. 'Rousselet, C. F., "Rotifera of South Africa," Journ. Roy. Micr. Soc. London, 1907, pp. 395-414.

34. Suephard, J., "A New Rotifer, Lacinularia elongata," Victorian Naturalist, xiii., No. 2, May 1896, pp. $22-4$.

35. " " "A Now Rotifer, Lacinularia elliptica," Victorian Naturalist, October 1897.

36. " " "A Now Rotifer, Lacinularia striolata," Proc. Roy. Soc. of Victoria, August 1899, pp. 20-35.

37. Sinephand, J., and Strickland, W., "A Now Rotifer, Melicerta fimbriata," Victorian Naturalist, xvi., No. 3, July 1899, pp. $38-40$.

38. Strickland, W., "The Rotifer in Melbourne," Victorian Naturalist.

39. Schmarda, L., "Neue Wirbellose Thiere," Leipzig, 1859.

40. Trompson, P. G., "Moss-haunting Rotifers," Science Gossip, 1892, p. 56.

41. Westers, G., "Notes on Rotifers," Journ. Quekett Mior. Club, 1893, pp. 155-160.

42. Wattelegae, T., "Invertebrate Fauna of Port Jackson and Neighbourhood," Journ. and Proc. Roy. Soc. of New Sonth Wales for 1899, pp. 308-17.

43. Wierzejsir, A., " Rot. W. Argentinie," Bull. Acad. Cracovie, 1902, p. 158.

\section{NOTE}

In the preparation of this paper I have been indebted to several friends for assistance, which I desire here to acknowledge. Mr. D. Bryce examined the drawings of the Bdelloid rotifers, and gave me the advantage of his opinion on the values of the species. Mr. C. F. Rousselet did the same for the non-Bdelloid rotifers, and helped me with the list of literature. Mr. D. J. Scourfield experimented on the dried rotifers brought from the Antarctic, and demonstrated that some had survived the many changes of climate which they had experienced. Mr. J. H. Priestley subjected some of the rotifers to a temperature of $-78^{\circ} \mathrm{C}$. for many hours, and showed that some. were not killed by this, thus completing the simple series of experiments commenced in the Antarctic.

Mr. Rousselet was also good enough to remount the few specimens of the new species of Antarctic rotifers, which had been mounted.in a temporary way, thus saving them from destruction.

BRIT. ANTARCT. EXPED. 1907-9. VOL. I. 

PLATE IX 


\section{PLATE IX}

This plate is designed to illustrate the bright coloration which distinguishes most of the Antarctic Bdelloids. The brilliant red of the stomach of Philodina gregaria and Callidina habita (Figs. 1 and 3) may give the impression of being overdone. If we have not caught the precise shade of the red, it is not that it was less vivid than we show it. It was a deep, clear, pure crimson or ruby. When seen in large mass the colour approaches blood-red, but by transmitted light it appears crimson under the microscope.

When we succeeded in reviving a few examples of Philodina gregaria and showed them to a naturalist in London, he exclaimed, "Are they so red as all that."

Figure 1.-Philodina gregaria, lateral view, showing the red stomach and eyes, small antenna, and two young.

Fiaure 2.-Adineta grandis, dorsal view, showing the brown colour deepest in the alimentary tract.

Fiaure 3.-Callidina habita, dorsal view. The distinctive spurs of this variety are shown, and the prominent foot-boss. 
Brit. Antarct. Exped. I 907-9.

Murray : Antarctic Rothlera.

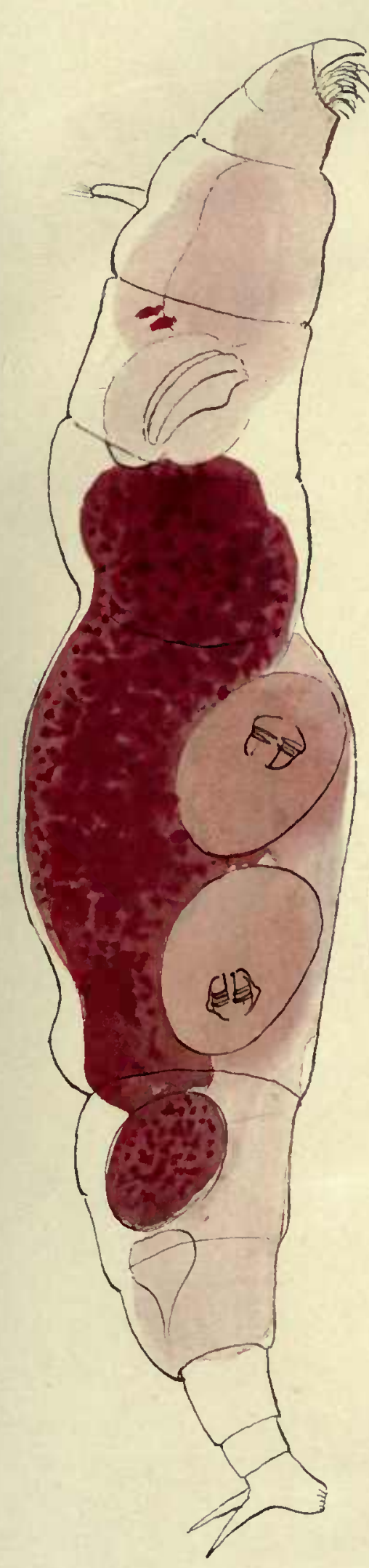

(I) P. gregaria.

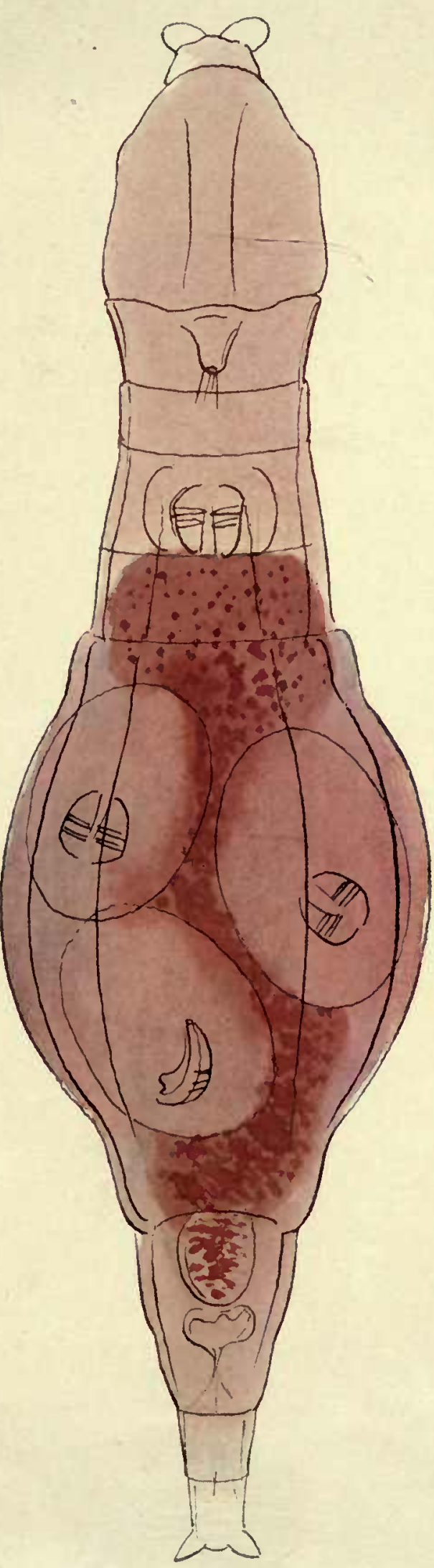

(2) A. grandis.

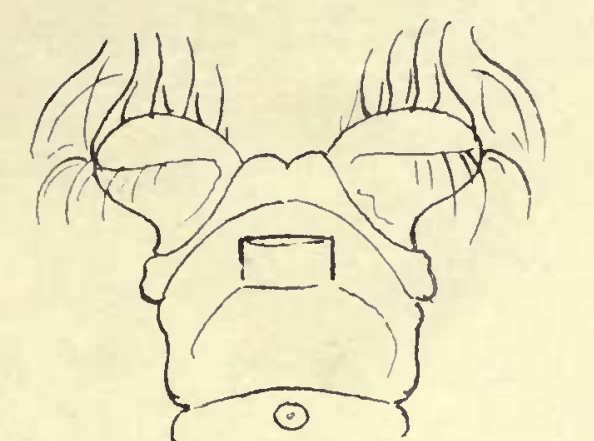

Q
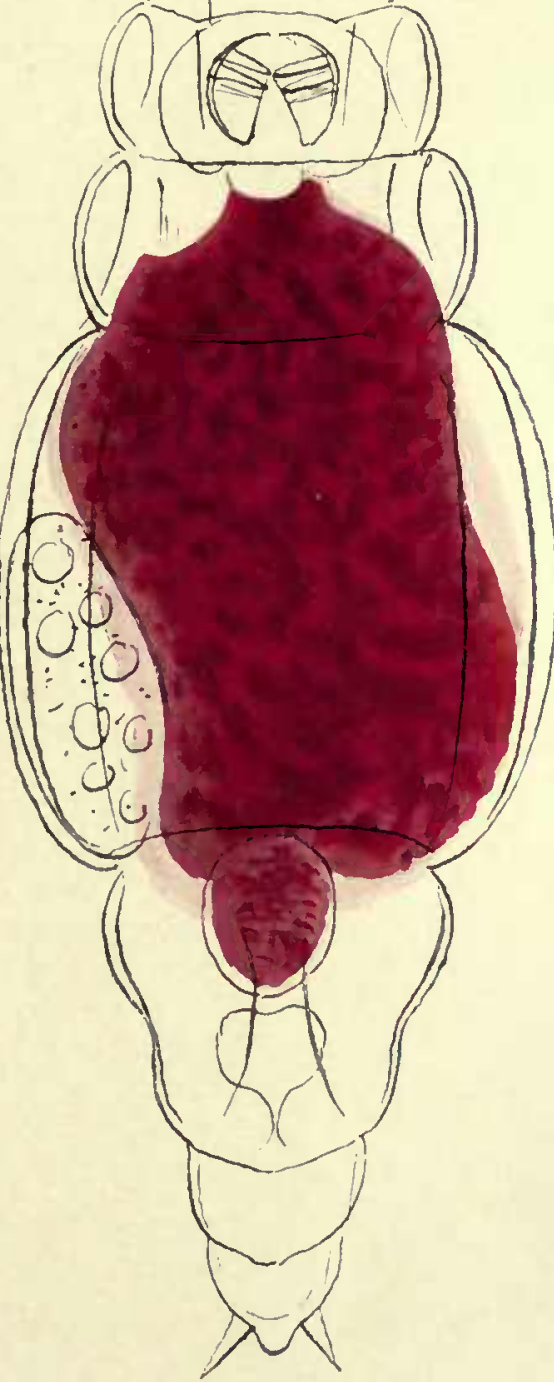

(3) C. habita.

Colours of Antarctic Rotifers.

J. Murray, del. ad. nat. 

Plate $\mathrm{X}$ 


\section{PLATE $\mathbf{X}$}

Figure 4a.-Philodina alata, sp. n., dorsal view, feeding : the lateral processes, which distinguish it flom all other known species, are in this figure slightly drawn in at the tips (which is accomplished by special muscles, shown in Fig. 4e).

FIgure 4b.-The same, fully contracted. The lateral processes are then turgid from the pressure of the body-fluid, and are projected to their fullest extent and somewhat forward.

Frgure 4c.-The same, in the creeping attitude: usually the lateral processes are drawn in, almost out of sight, among the skin-folds when creeping, but in this instance they were fully extended.

Fraure $4 d$. - Jaw of the same with its two teeth and wide border.

Figure $4 e$.- One of the lateral processes of the same. It is seen to be hollow, and special muscles enter it and are attached near the top. One of the vibratile tags is seen at the base of the process. It is unusually short and wide for a Bdelloid.

Figure 4f.-Foot and rump of the same seen from the side. The prominent boss of the preanal segment can also be seen as a curved line in Fig. $4 c$.

Figure 5a.-Philodina antarctica, sp. n. The figure shows the prominent collar, the eyes on a conspicuous brain, the elongate foot, and the peculiar spurs. The basal portion of the spurs is badly drawn in this figure (it is correctly shown in Fig. 5b).

Figure 5b. - Spurs of the same. These, with the broad triangular bases and peg-like apices, are the best character of the species. The distinction of the two parts is sometimes obliterated. Even then the absence of interspace will distinguish this from $P$. gregaria, and there are many other differences of general proportions and details, requiring, however, careful study.

Fiaure 5c.-Lateral view of the foot of the same. The dorsal toes are almost as thick as the ventral, though shorter. This is a point of difference from $P$.gregaria, in which the dorsal toes are relatively very small.

Figure 6.-Philodina, unnamed species. 
Murray: Antarctic Rotifera.

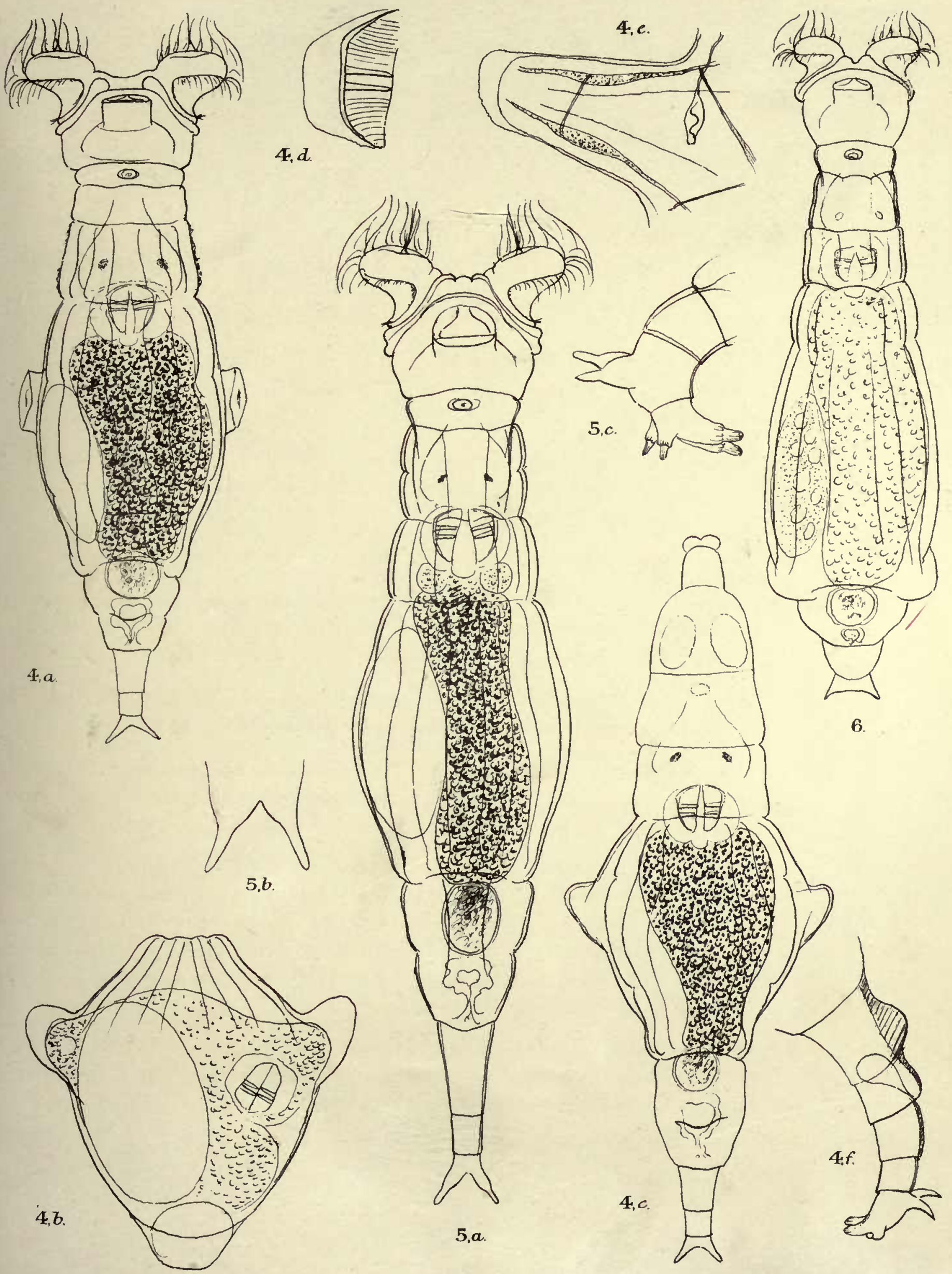

4. Philodina alata sp n

5, P. ANTARCTICA,spn.

6. Phizodina sp. 



\section{PLA'TE XI}




\section{PLATE XI}

Figure 7a.-Philodina gregaria, sp.n. dorsal view of the animal when feeding. The very prominent collar is only marked off from the pedicels by the cilia of the wreath. Two well-grown young are seen.

FiaURe 7b.-Spurs and toes of the same. The dorsal toes are seen to be greatly smaller than the ventral.

Figure $7 c$.-One of the spindle-shaped vibratile tags of the same.

Figure $7 d .-\mathrm{Jaw}$ of the same, with two strong teeth, one thinner tooth, and many fine striæ.

Figure 7e.-Lateral view of the jaw of the same, showing the process of the ramus behind.

FigtuRe 8a.-Callidina habita, dorsal view of a variety which differs from the type in the form of the spurs.

Figure $8 b$.-The same, a variety having spurs nearer the typical form, but smaller.

Figure $8 c$.-Lateral view of the foot of the same showing the thickened part of the first foot-joint which forms the boss.

FIGURE 8d.-Egg of the same, elliptical in form, with each pole produced into a process.

Figure 8e.-Tip of rostrum of the same. The lamellæ are widely separated. 
Murray: Antarctic Rotifera.
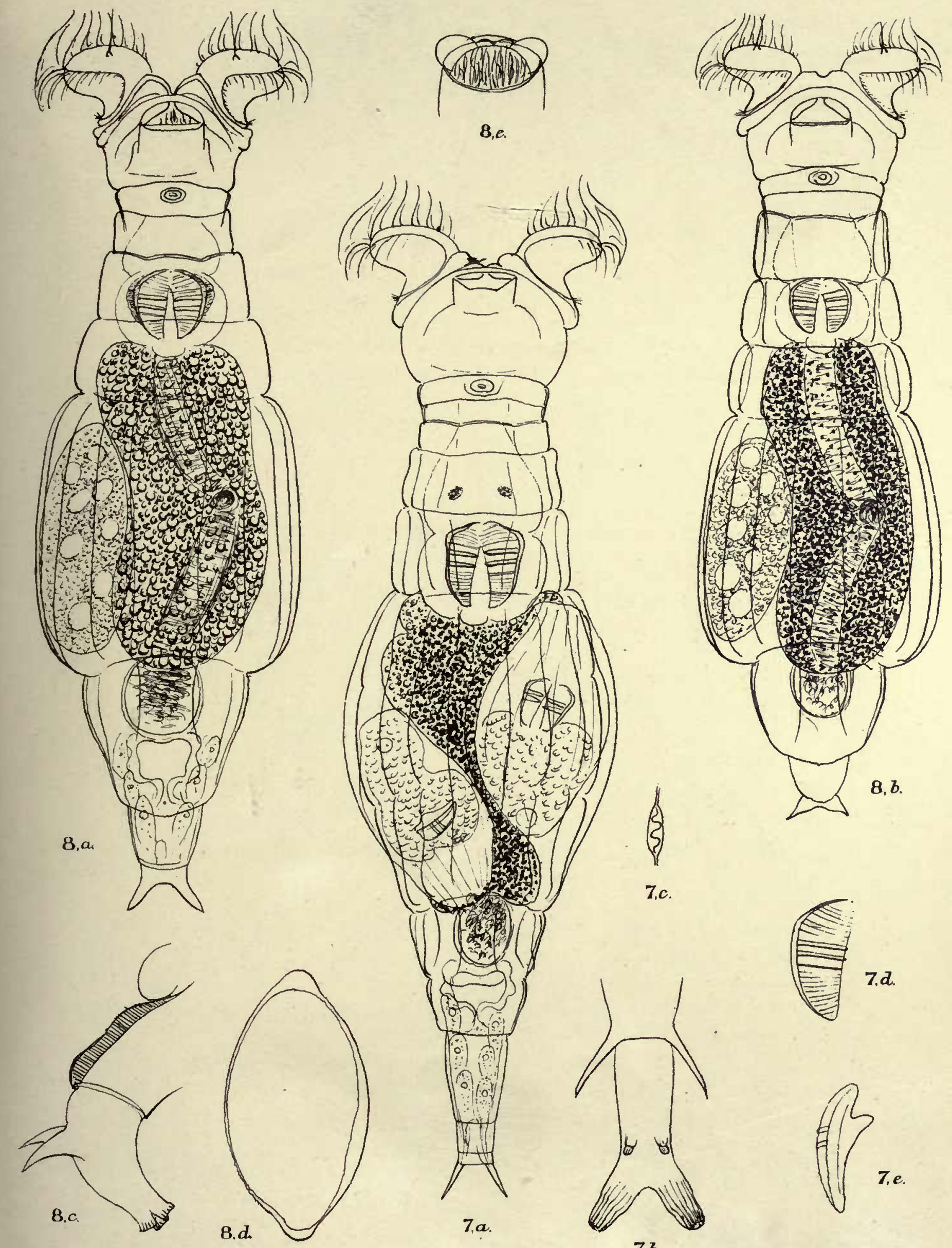

7. PHILOdINA GREgaRIA, sp.n.

8. Callidina habita Bryce.

Murray del ad nat. 



\section{PLATE XII}

BRIT. ANTARCT. EXPED. 1907-9. VOL. I. 


\section{PLATE XII}

Figure 9a.-Adineta barbata, Janson?

Figure 9b. - Egg of the same from Blue Lake; one pole is produced, and there are no other processes.

Figure 9c.-Egg from Deep Lake, Cape Barne, from which a similar Adineta was hatched on September 24, after the egg had been dry for about a year, and had been conveyed from Antarctica to Britain.

FIGURE 10a.-Adineta grandis, large stout example, showing six young, apparently all in an equally advanced state of development, and with the jaws well grown.

Figure 10b.-Head of the same, ventral surface, showing the lamellæ, brush of cilia and motile setæ, pectinate folds at posterior margin of corona, \&c.

FIGURE 10c.-Jaw of the same, showing the projection at back of ramus.

FIQURE 10d.-Yolk-mass of the same, dividing into six parts, each containing one nucleus. The number of nuclei is normally eight, as in most Bdelloids. In this instance the full number may be present, two of them hidden behind the centre of the mass.

FIGURE 11a.-Adineta longicornis? The rostral part is not of the same form as in the type, but allowing for a different angle of inclination it may be the same.

Figure 11b.-Spurs of the same. They are considerably shorter than in the type, but are still relatively much longer than in any other known species.

Figure 12a.-Callidina angularis, sp. n., dorsal view, showing angular outline and stippled surface.

Figure 12b.-Jaw of the same, with four principal teeth and many finer ones diminishing backwards.

Figures $12 c$ and $12 d$.-Eggs found associated with this species and with C. constricta.

Figure 13a.-Callidina constricta, Duj., dorsal view, illustrating the differences between this species and C. angularis; the outline is not angular and the skin is not stippled.

FIGURE 13b. - Part of one disc of the corona of C. constricta, showing the groups of cilia which give the appearance of toothed wheels to the philodinoid corona. Diagrams elucidating the motions of the cilia which cause the appearance of teeth have often been published. This is not a diagram, but a drawing from an example which had just been killed and fixed with osmic acid while in the act of feeding. Each group has cilia at every stage of the stroke, thus showing the course followed by each. The specimen was mounted in fluid and preserved. Unfortunately, as was only to be expected, the slight difference of density between the fluids within and without the body has resulted in making the disc turgid and opened out the groups of cilia into one uniform fringe. 


\section{Murray: Antarctic Rotifera.}
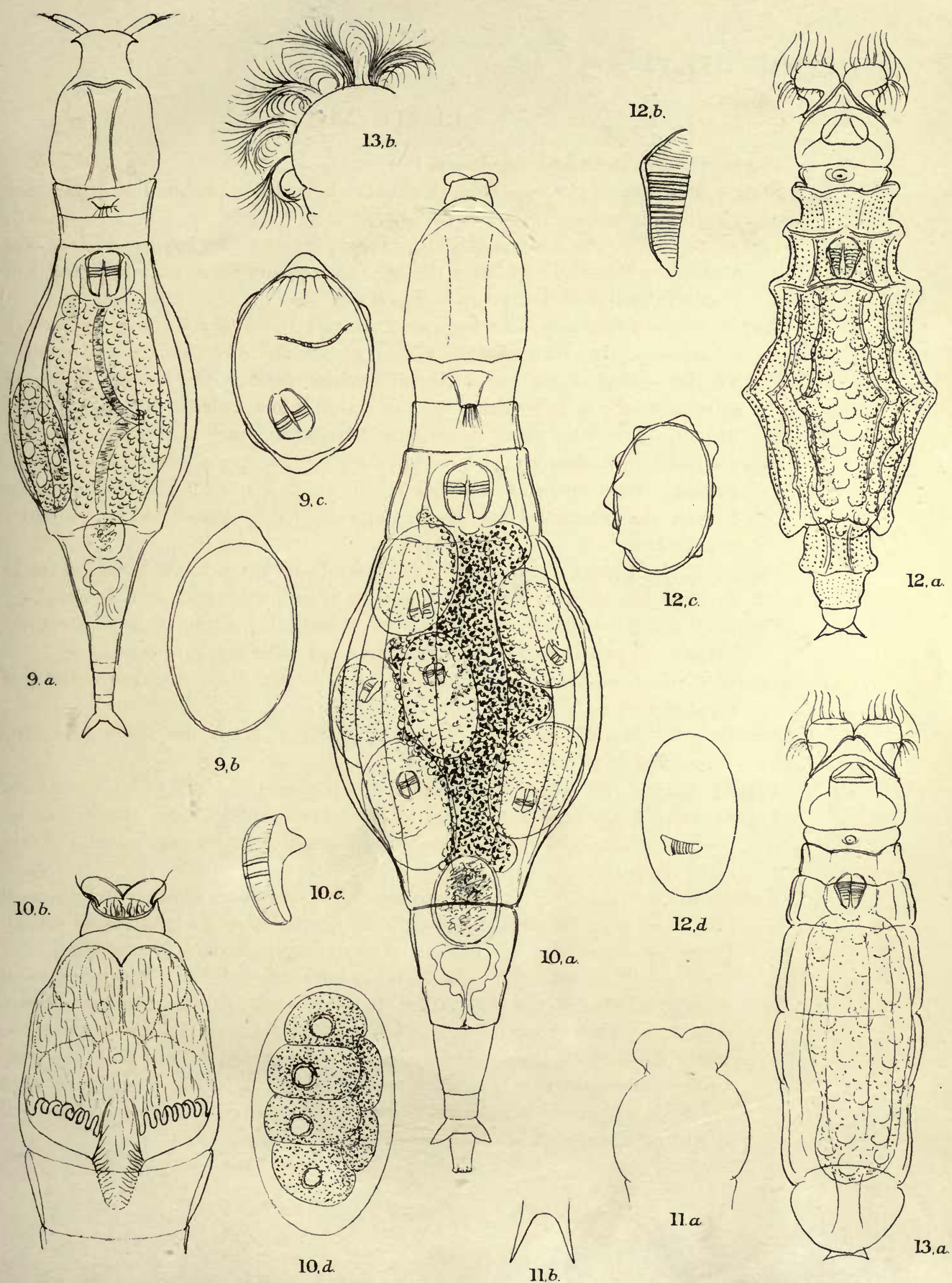

9. ADINETA BARBATA?

10, A GRANDIS, sp. n.

11. A LONGICORNIS

12. CALlidiNa ANGULARIs, sp. n. 13, C. CONSTRICTA. 

PLATE XIII 


\section{PLATE XIII}

Figure 14a.-Pleurotrocha, sp. A large active animal resembling $P$. grandis, but with longer spurs and some other differences.

Figure 14b.-Elliptical papillose egg of the same.

Figure 14c.-Jaws of the same, drawn from an example in the egg.

Figure 15.-Floscularia, sp., semi-contracted.

FIgure 16a.-Diaschiza tenuior, lateral view with the foot drawn well under the body.

Figure 16b.-The same, dorsal view.

Figure $16 c$ and 16d.-Dorsal and lateral views of a supposed male of the same, having rudimentary jaws.

Fiqure 16e.-Rough sketch of jaws of the female.

Frgure 16f-Thick-shelled egg containing jaws similar to those of the supposed male (Figs. $16 c$ and $16 d$ ). 
Murray: Antarctic Rotifera.

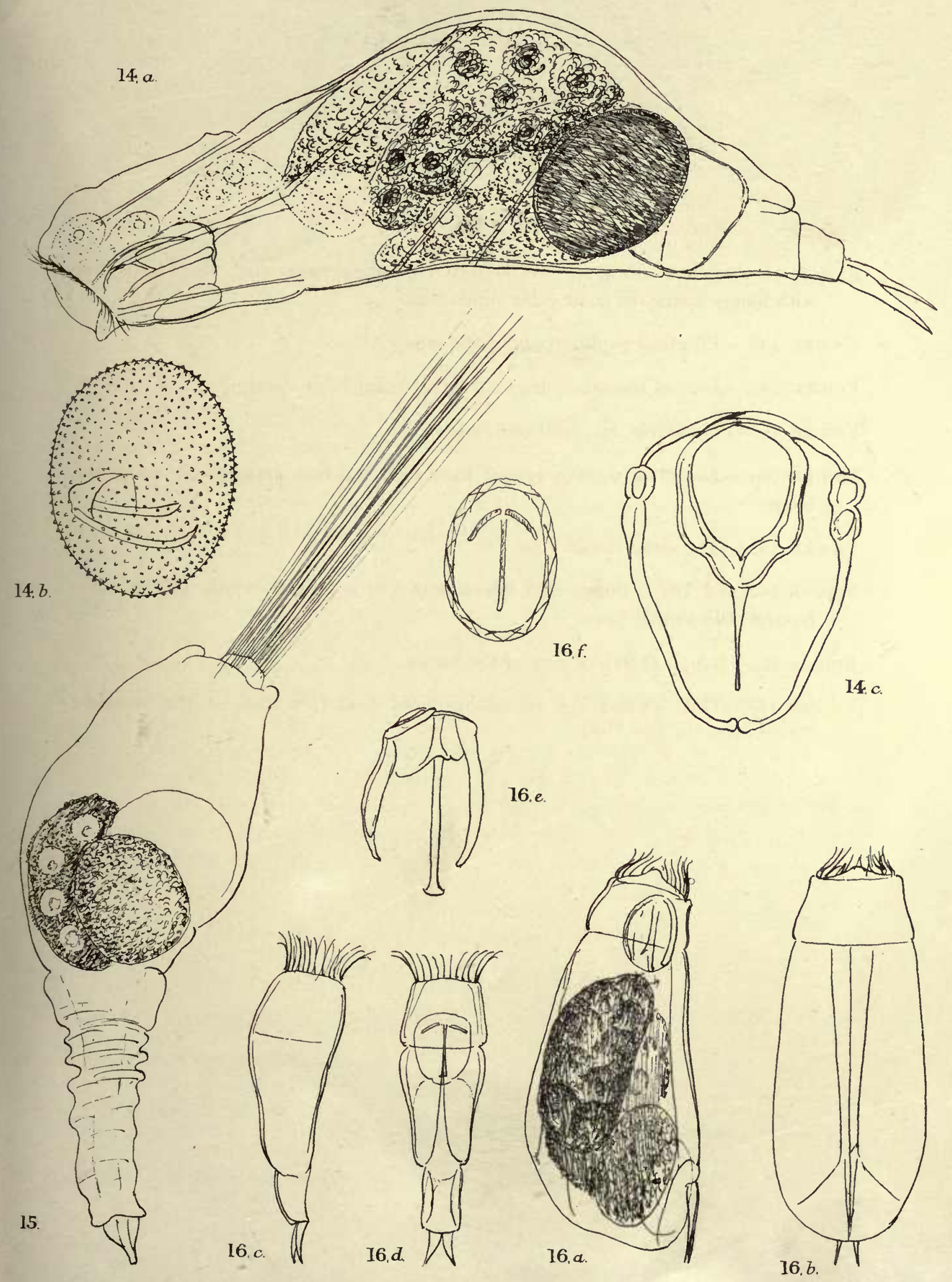

14. Pleurotrocha, sp.

15. Floscularia sp.

16. Diaschiza tenuior

IMurray del ad nat 



\section{PART IV \\ M U S C I}

Note SUR les Mousses rapportées Par L'EXPÉdition dU “Nimrod”

\section{PAR JULES CARDOT}

Les Mousses de l'expédition du Nimrod proviennent de la même région que celles rapportées antérieurement par le Discovery.* Elles consistent seulement en 4 espèces, déjà connues, mais dont l'une toutefois est nouvelle pour la flore antarctique. Les échantillons sont extrêmement rabougris, et tous donnent l'impression de plantes malades, luttant péniblement contre des conditions de milieu exceptionellement rudes.

Alors que nous ne connaissons encore que 8 mousses végétant misérablement sur les côtes inhospitalières de la Terre Victoria, M. Bryhn vient de publier $†$ une liste de 62 espèces de Muscinées ( 57 Mousses et 5 Hépatiques) rapportées par Peary de 3 localités de la Terre de Grant, par $81^{\circ}-82^{\circ}$ de latitude boréale-chiffre supérieur à celui des espèces actuellement connues dans tout le domaine antarctique au sud du $60^{\text {eme }}$ parallèle.

La seule comparaison du nombre des espèces connues d'une part à la Terre Victoria, par $77^{\circ}-78^{\circ}$ lat. sud, et d'uutre part à la Terre de Grant, sous une latitude sensiblement plus élevée, fait ressortir d'une façon frappante combien sont différentes les conditions climatériques auxquelles sont soumises les régions polaires dans les deux hémisphères.

\section{Dicranacee}

\section{Dicranella Hookeri}

Dicranella Hookeri (C. Müll.), Card. in Bull. Herb. Boissier, $2^{\circ}$ sér., vi., p. 4, et Fl. bryol. Terres Magell., etc., p. 60.

Angstramia Hookeri (C. Müll.), Syn. II. p. 607.

* Cf. National Antarctic Expedition, Nat. History, vol. ii., Musci.

$\dagger$ Ad cognitionem Bryophytorum arcticorum contributiones sparse (Christiania, Vidensk.-Selsk Fordhandl. for 1908, No. 5.).

BRIT. ANTARCT. EXPED. 1907-9. VOL. I. PART 4, ISSUED APRIL 1910 I 
Anisothecium Jamesoni, Mitt. Musci., austro-amer., p. 39, pro parte.

Dichodontium Jamesoni, Sch. Syn. Musc. Europ., éd. i., p. 66, et auct. plurim., pro parte.

Dicranella Jamesoni, Broth. in Nat. Pflanzenfam., Musci, p. 311, 1 ro parte.

"Cape Royds, 1908."

Echantillon en très mauvais état, d'un vert noirâtre. Les feuilles sont tantôt entières, comme dans la forme normale de l'espèce, tantôt denticulées vers l'extrémité. Il me paraît néanmoins certain que ce spécimen appartient bien au $D$. Hookeri, espèce connue dans le domaine magellanique, à la Géorgie du sud, ì Kerguelen et ì l'île Heard, et qui n'avait pas encore été signalée dans l'Antarctide.

Il y a quelques tiges de Bryum argenteum, L., en mélange.

\section{Pottiacex}

\section{Sarconeurum glaciale}

Sarconeurum glaciale (Hook. fils et Wils.), Card. et Bryhn, in Nat. Antarc. Exped., Musci, p. 3. Didymodon (?) glacialis (Hook. fils et Wils.), Fl. Antarc., ii. p. 408, t. 152, fig. 6. Sarconeurum antarcticum, Bryhn, in Nyt. Mag. f. Naturvidensk, B. 40, H. iii., p. 204, tab. i. et ii. Barbula, sp., Gepp, Report on the coll, voyage Southern Cross, XXI. Cryptog., Musci, p. 319.

"Hut Point, Ross Island, $77^{\circ}$ 50' S. lat., Coll. E. Joyce, Nov. 1908 ; Cape Irizar, S. Victoria Land, Coll. T.W.E. David, Nov. 1908; Cape Barne, Ross Island, Coll. J. Murray, Nov. 1908; High Moraines, Cape Royds, $77^{\circ} 30^{\prime}$ S. lat., Coll. J. Murray, Jan. 1909."

Les rhizoïdes forment une masse feutrée, compacte, mélangée de sable et de terre, épaisse d'un centimètre environ, et limitée inférienrement par une surface nette. Il est probable que cette surface indique le contact avec la partie du sol qui ne dégèle jarnais et qui arrête ainsi la pénétration des rhizoïdes.

\section{BRYACEA}

\section{Bryum argenteum}

Bryum argenterem, L., Sp. pl. p. 1120.

"High Moraines, Cape Royds, Ross Island, $77^{\circ} 30^{\prime}$ S. lat., Col. J. Murray, Jan. 1909."

Forme excessivement rabougrie, identique aux échantillons déjà rapportés de la même région par le Discovery

"Stranded Moraines, McMurdo Sound, S. Victoria Land, Coll. R. E. Priestley, 1908." 
Tiges émettant de nombreux rameaux très grêles, longs de 2 à 4 millimètres, garnis de très petites feuilles espacées, très concaves, orbiculaires, ou suborbiculaires, obtuses ou apiculées, rappelant beaucoup les feuilles du B. cephalozioides, Card., mais les feuilles inférieures sont normales.

\section{Bryum antarcticum}

Bryum antarcticum (Hook. fils et Wils.), Fl. Antarct. r r. p. 414, t. 153, fig. 6.

Webera antarctica, Jaeg. Ad. r. p. 599.

"Stranded Moraines, McMurdo Sound, S. Victoria Land, Coll. R. E. Priestley, 1908." 



\title{
BRITISH ANTARCTIC EXPEDITION 190\%-9
}

UNDER THE COMMAND OF SIR E. H. SHACKLETON, C.V.O.

\section{REPORTS ON THE SCIENTIFIC INVESTIGATIONS}

\section{VOL. I \\ BIOLOGY}

EDITOR - - JAMES MURRAY

\author{
PAR'T V \\ T A R D I GR A D A \\ BY JAMES MURRAY, F.R.S.E., F.Z.S.
}

(WITH EIGHT PLATES)

LONDON

PUBLISHED FOR THE EXPEDITION BY WILLIAM HEINEMANN 21 BEDFORD STREET, W.C.

1910

ISSUED SEPARATELY, DECEMBER 1910

Price Ten Shillings net 


\section{REPORTS ALREADY ISSUED}

VOL. I. PART I., ON COLLECTING AT CAPE ROYDS BY JAMES MURRAY

Price 1s. 6d.

VOL. I. PART II., ON MICROSCOPIC LIFE AT CAPE ROYDS BY JAMES MURRAY

Price 5s. Od.

VOL. I. PART III., ANTARCTIC ROTIFERA BY JAMES MURRAY

Price 5s. Od.

VOL. I. PART IV., MUSCI By JULES CARDOT

Price 1s. Od. 


\title{
PART V
}

\section{TARDIGRADA}

\author{
BY JAMES MURRAY
}

(With PLATES XIV.-XXI.)

\section{CONTENTS}

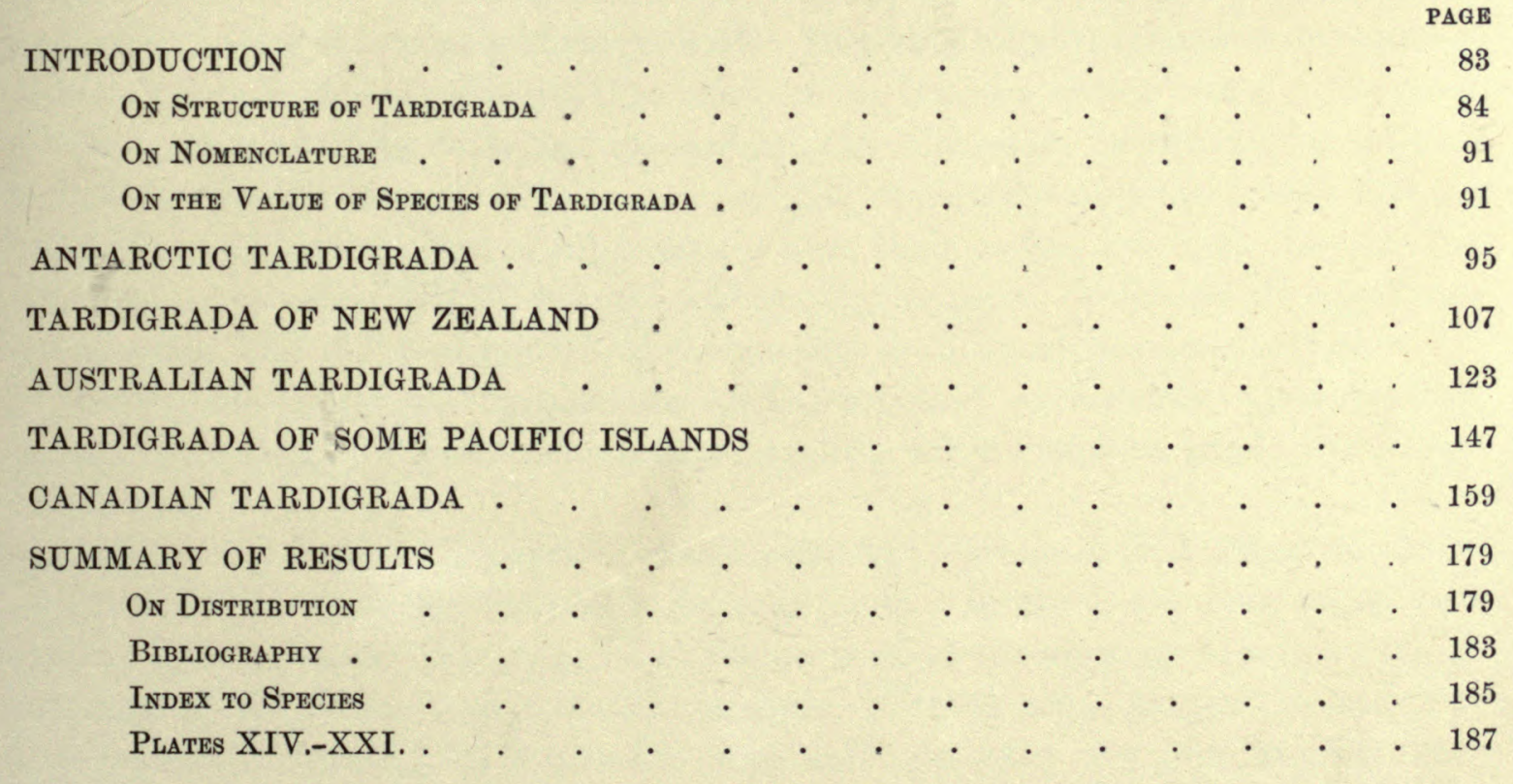

BRIT, ANTARCT, EXPED, 1907-9, vol. I. PART 5, ISSUed DeCEMber 1910 M 


\section{Y. TPLS \\ ACTA. TET)TISTAT}

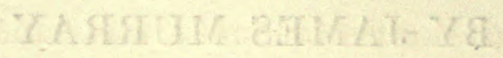

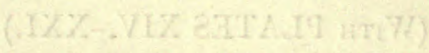

217.117.0?

720100790\%

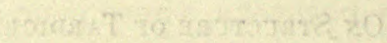

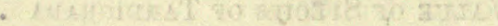

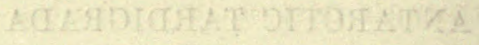

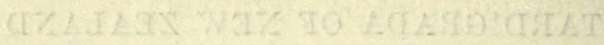

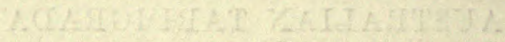

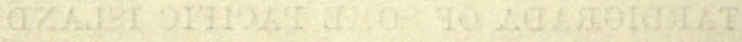

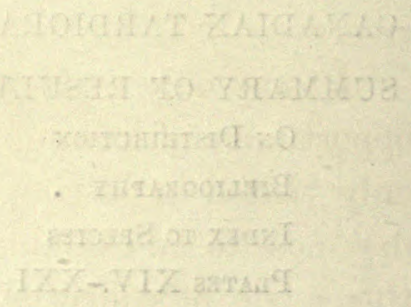

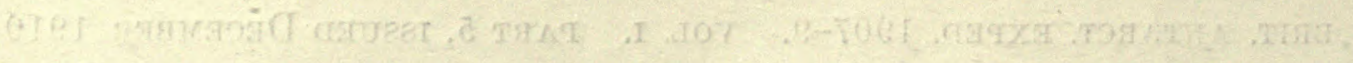




\section{IN'TRODUCTION}

TARDIGRADA were collected not only in the Antarctic, but in all other countries visited by the Expedition in the course of the voyage round the world. These were New Zealand, the Macquarie Islands, Australia, Fiji, Hawaii, and Canada. A brief visit was paid to South Africa, and some moss was collected on Table Mountain by Dr's. Mackay and Michell, but though animals of other sorts were plentiful enough, no Tardigrada were found.

The great majority of the Tardigrada obtained were of the kinds which live among moss. These everywhere over the world greatly exceed in numbers the true waterdwellers. All, of course, are aquatic animals, in the sense that they must have at least a film of water to support their active life, but the dwellers among moss have to endure frequent and often long-continued desiccation, while the others live in ponds and other waters of a more permanent sort. Though a number of species are common to both habitats, there is no doubt that most are confined to one or other. The mossdwellers are adapted to withstand desiccation, the others may be equally so, but they are rarely exposed to tests of their powers. By desiccation it is not meant that the animals can endure the loss of all moisture from their bodies, but that they can live when completely deprived of the external watery element. When so deprived they are dormant, and if any physiological change goes on, it must be excessively slow.

Only some half-dozen species are well recognised as habitual pond-dwellers, though in Scotland a good many others are frequently found in ponds, lakes, and rivers.

It was only in New Zealand, Australia, and the Antarctic that there was much opportunity of looking for the purely aquatic kinds. In those countries which were only visited in passing there was no available method of collecting except by taking dry moss to be examined afterwards at leisure. Nothing could exceed the facility of this mode of collecting. The moss is preferably gathered dry; the animals liave already become dormant in the natural course, and nothing is required for the examination afterwards, but to moisten the moss, when in half an hour or so the animals are found to be active. They will not live indefinitely, but for a year at least they can quickly be revived when wanted, and some have been kept for a number of years alive.

In this paper, after some introductory paragraphs dealing with structure, nomen- 
clature, and other matters, the Tardigrada of each country visited will be treated in a separate section, five altogether.

In the section dealing with each country there will be given first an account or how the collecting was done in that country, and a summary of previous knowledge of the Tardigrada. Then will follow the list of species and notes upon them, including descriptions of new species. The peculiarities of the Tardigrade fauna, and its relation to the rest of the world, will be briefly treated. General questions of geographical distribution, \&c., concerning the entire area over which work has been done, will be reserved for discussion in the general summary of results.

The information brought together about Tardigrada might have beeu exhibited in a more concise form by giving a complete list of all the species collected in all the countries, in one table, followerl by notes on the species, and a discussion of general questions of distribution. It seems to me, however, so important to the student to find all the information about each country collected together by itself, that I have adopted this form, even at the expense of a little repetition, and some redundancy in the tables illustrating the distribution.

The object has been to offer the information in accessible form, so that the student of one country may readily find what he wants. This has been attempted by a suitable classification of the facts under various headings, and for further assistance, there is a "Contents" page, and at the end an alphabetical index to the species, while the explanations of the plates have references to the pages of the text where the species figured are described.

We have thus what is practically a series of five papers, each complete in itself, with Introductory and Recapitulatory chapters, dealing with all of them collectively.

\section{Structure of Tardigrada}

The student is referred to other works for a general account of the structure of Tardigrada. Here there will be given only such details as are necessary to the understanding of the descriptions of the species.

Echiniscus.-In this genus the important points in description are : the number and texture of the plates; the processes on the body; the claws; and the skinfold (fringe) of the last legs. The plates vary in number. The minimum may be taken as nine and the maximum as twelve. There may often appear to be more than twelve plates, but I regard these as originating in the subdividing of the normal plates. The plates are either single or paired. The single plates are of two kinds: first, large, covering the back and sides; second, small, triangular, median plates. The pairs meet in the middle line, and go over the sides like the large single plates.

The number of segments of an Echiniscus have been variously estimated by different writers. Doyère gives four body-segments, without regarding the head, which he supposes to show traces of several segments. Schultze's E. beller- 
manni (43), has nine segments. What they mean by segments can only be ascertained by studying the figures which these writers have given. Richters' scheme is perhaps the most useful. It does not aim at accounting for all the morphological segments of some hypothetical primitive or typical Tardigrade, but is merely a division of the body for practical use to systematic naturalists.

He reckons six segments, and indicates them by roman numbers, I. to VI. These numbers are here adopted to distinguish the segments, and as there are two distinct types of segmentation I give two figures, one of each type, on which the segments are numbered, and other points of structure indicated (sce Plates XVIII. Fig. 34, and XVI. Fig. 14).

In one group of Echinisci the segments V. and VI. have coalesced so completely that there is no external mark of their separation (Plate XVI. Fig 14). 'This includes the great majority of the species. Segment I. is the head, II., III., and IV. the body segments bearing the first, second, and third pairs of legs, V. + VI. bears the fourth legs. The reckoning of $V$. as a segment is rather inconvenient, as there is in most species no visible trace of it.

In the other group, which includes only about a dozen species, segments $\mathrm{V}$. and VI. remain distinct (Plate XVIII. Fig. 34). When V. is separate it usually bears a pair of plates, like those of segments III. and IV., but it may be a half-ring, without trace of division in the middle, as in E. pulcher here figured.

All of the plates are liable in one species or another to be subdivided in various ways. This usually only affects the surface markings. The divisions may be merely lines separating different areas, or they may be broad bands devoid of markings. The median plates are often divided by a transverse line into two parts ( $E$. novoezeclandice, Plate XV. Fig. 5), or by median lines into pairs (E. pulcher, Plate XVIII. Fig. 34).

E. tessellatus (Plate XVI. Fig. 15) is an extreme case of the division of segments II. and V. + VI. by transverse and longitudinal bands. E. scrofa, Richters (26), is an example of subdivision of the median plates into many narrow bands.

The plates of the first and second pairs are commonly divided into two parts by a transverse plain band (E. duboisi, Plate XVII. Fig. 19, E. spinulosus, Plate XIX. Fig. 38). This band occupies a furrow. Sometimes the separation is a mere line, and the markings continue into the furrow. Occasionally there are two lines on each plute, separating narrow portions at the anterior and posterior borders, without any cessation of the markings (E. tessellatus, Plate XVI. Fig. 15).

The markings of the plates are of several kinds. As their true character is often in doubt they are named from their appearances. There are pellucid dots which do not appear to project from the general surface, actual projecting granules (E. granulatus, Doyère, very large in E. tessellatus, Plate XVI. Fig. 15), pits or apparent perforations, and reticulation of raised lines. The reticulation may be simply the borders of adjacent depressions (E. intermedius, Plate XVI. Fig. 17). Very peculiar are the close-set spicules of $E$. spiculifer, Schaudinn (41), and the reticulation of pearly dots 
of $E$. islandicus (18). A very few species are said to have no surface markings whatever on the plates.

The lumbar plate, which covers segment VI., or V. + VI. when these are joined, is nearly always divided by two lateral slits into a sort of trefoil. Often the middle and lateral flaps thus produced are bent downwards at an angle to the small mediau portion of the plate, which is then said to be faceted. The angle joining the two slits has caused it to be supposed that the posterior "tail-piece" thus separated is a distinct segment, and it has also been supposed that the portion in front of the slits is homologous with segment $\mathrm{V}$. This is undoubtedly not the case, as when $\mathrm{V}$. and VI. are separate, VI. is trefoliate in the usual way. A number of species have been figured without a trefoliate "lumbar plate" [E. spitsbergensis, Scourfield (45), and $E$. bisetosus, Heinis (7) ]. Personally I have only seen one species in which the lumbar plate is not trefoliate ( $E$. intermedius, described in this paper, see Plate XVI. Fig. 17, and Plate XX. Fig. 52). In other cases I do not take the evidence of figures, unless the authors refer to the character in their descriptions, as in certain positions the slits are hidden and may be overlooked.

The processes connected with the plates are either setce, longer or shorter spines, little spicules, or blunt cones or knobs. Certain processes often occur in definite situations, easily indicated in descriptions. Near the inouth there are four cirri and two palps, which are in most species of no distinctive value. In a few species they are conspicuously large, or slightly modified in form [considerably in $E$. cornutus (34)]. In one or two species they are stated to be lacking [E. imberbis (38)].

Of most regular occurrence are the five lateral processes and two dorsal processes, on each side. Richters distinguishes the lateral processes by the letters $a, b, c, d, e$, (Plate XVI. Fig. 14)* counting from the head backwards. $a$ is the head seta, the only process present in every known Echiniscus. It is situated at the base of the head, between I. and II. The pair commonly curve forward, and look very like cow's horns, but very thin, except in $E$. cornutus, where the resemblance is perfect.

At the base of seta $a$ there is generally (perhaps always) a little triangular or cylindrical palp or "Auricle" as it may be called. It is rarely distinctive but in a few species is of characteristic shape or large size.

In a few species there are other processes besides these most common ones. The most frequent are little spicules on the posterior borders of the plates of segments II., III., and IV. between the lateral and dorsal processes. In such cases there may be a similar spicule beside the slit in the lumbar plate, close to seta $e$, if that be present. There may be more than one spicule between the lateral and dorsal processes, especially on segment IV. (plates of the second pair), where there may be two or three [E. oihonno, Heinis (9)].

The dorsal processes usually spring from the postero-dorsal angle of the paired plates, that is, at the angle marking the limits of the space occupied by the median

* Seta $e$ is not present in the species figured. 
plates. Sometimes the dorsal processes are nearer the median line (E. borealis, \&c.), and when there are any processes on segment $V$. they are usually near the middle line (E. islandicus, E. novcrzeclandice).

In the group which has segments V. and VI. united there are usually only two median plates. A well-defined third median is rare, but there is often an area in the triangular space behind the second pair, dotted exactly like the plates, but without definite bounding lines.

In the group which has V. and VI. separate there are always three median plates, although they are often very obscurely separated from the pairs in front of them.

In the majority of species there is a serrate fold of skin on the fourth leg. The teeth or spines on this fold vary from short and blunt to slender and acute, and are useful for distinguishing species.

Near the base of the fourth leg, on the outer side, there is usually a blunt palp. On the first leg there is often a longer or shorter sharp spine. Rarely there are little spines on other legs (E. perarmatus).

The colour of Echiniscus is usually red, varying from pale pink to deep crimson or scarlet. A very few species are yellow (E. mutabilis, sylvarius, tessellatus), green (E. viridis) or colourless (E. intermedius).

The eggs are always smooth, shortly oval, and are laid in the cast skin. From one to nine have been seen in a single skin. As many as nine is quite exceptional, the usual number being three or four.

Oreella.-Like Echiniscus in every important detail of structure except that the body is not covered with plates. It is soft and flexible like Macrobiotus. The only trifling differences from Echiniscus are that the "Auricle" at the base of seta $\alpha$ is elongate and acute, and is elevated on a large papilla which bears the seta also; and that the anterior cirri at the mouth are replaced by narrowly conical processes.

The generic forms of land Tardigrada do not seem to be very numerous. Although work has been done in all regions of the globe now, no new genus has been found since Diphascon (Plate, 1888) till now.

Orcella has no eye-spots. The eggs are unknown.

Milnesium.-Though several species have been described, their differences are slight and inconstant, and only $M$. tardigradum is here admitted. It is a large animal with very wide gullet and elongate pear-shaped pharynx, in which there are no rods such as Macrobiotus has. There are six cylindrical palps round the mouth, and a pair farther back. A distinct genus, Acrophanes, of no value, was separated by Ehrenberg (5) apparently to receive a shrivelled skin of Milnesium.

The claws are very different from those of Macrobiotus. On each foot there are two claws, usually with two or three, or even four, branches. The three-branched claw appears to be homologous with a pair of Macrobiotus claws, including the supple. mentary point. On each foot there are also two very slender, bristle-like claws, each with a very fine supplementary point. 
The number of points on the branched claws has been used to distinguish species. Some examples have all these claws alike, and three-branched. In others they vary on the different legs. I find the commonest form to have fewer points on the front legs and more on the last. Thus, they will have only one point or two on the front legs; two or three on the second and third legs, and three on the fourth legs.

The colour in old animals is a very warm brown. The eggs are laid in the skin, and are often pretty numerous.

Macrobiotus. - In this genus the characters which lend themselves for descriptive purposes are: the organs of the mouth (teeth, gullet, and pharynx); the claws; the skin; the eyes; the fat-cells; and the egg. The teeth are slender or thick, more or less curved or bent abruptly, and have a larger or smaller furea where the bearer is attached, the bearer itself, though often mentioned in descriptions, having no specific importance. The gullet is slender or wide, and at the end in the pharynx may have merely a slightly enlarged run, or may be bent out into a flange. more or less wide. The pharynx may be nearly round, or somewhat elongated, The hard rods or nuts which surround the tube may be two, three, or four in each row. The last one in the row is often small and obscure, and is called from its shape the comma. There is often no comma. The more important rods (or nuts when they are so short that the name "rod "would be inappropilate) are never more than three in number. When there are three they are generally nearly equal in length: when there are only two, that nearer the gullet is longer, and often shows obvious traces of the two rods by the joining of which it may be supposed to have originated. Besides the rods there are apophyses attached to the end of the gullet. These are not in line with the rods, but alternate with them. When they are large, however, they may readily be mistaken for rods, and even recent descriptions have not always clearly distinguished the two structures.

The claws vary chiefly in their relative sizes, and in the degree of union of the pairs. They are always united in pairs, if only at the bases. Several types have been recognised, but they are connected by intermediate forms which are difficult to classify. The hufelandi type is commonest. The claws of each pair are united for some way above the base, usually for half their length or more. There is much variation within this type. Usually the claws of a pair are unequal, and the larger one has one or two supplementary points. Sometimes they are equal and placed side by side, but only one has the extra points. In some species they are very thick, and the supplementary point is very strong, and the whole thing makes a distinct approach to the branched claw of Milnesium.

The dispar type (or macronyx type) has the claws of each pair very unequal, the larger claw strongly curved and bearing a supplementary point, the smaller claw like a little barb from the base of the larger one. The two pairs are similar, and on the last legs the lesser claw is relatively larger.

The Diphascon type (found throughout the genus Diohascon, and in $M$. 
oberhäuseri and a few other Macrobioti) has the two pairs dissimilar. One pair has two claws, of which one is longer, united at the base; the other pair bas one very long claw (bristle-like in $M$. oberhïuseri), which is loosely attached to the middle of the back of a smaller claw.

The echinogenitus type has two similar pairs of claws which are united at the base only. The claws of each pair are equal or unequal. This type is not so distinct from the hufelandi type as it seems, and is connected with it by a series of forms having the claws united more or less above the base.* The typical form has the claws very widely divergent. Forms having the pairs unequal lead to the Diphascon type.

The skin varies in texture, \&c. It may be smooth and hyaline, papillose, or more or less pigmented. Often the young are transparent and colourless, and the older ones increasingly pigmented. The pigment is rarely of specific value, as most of the large old animals become brown, but in $M$. oberhüuser $i$ it is characteristic. A few species are papillose ( $M$. annulatus, $M$. nodosus, \&c.), and a few bear processes on the skin (M. ornatus, M. tuberculatus, M. sattleri, $M$. papillifer, and sometimes $M$. dispar).

The eyes are of doubtful specific value. They are usually dark brown or black, occasionally red. Though it is believed that the presence or absence of eye-spots is characteristic of each species, there is enough variation to make the character unreliable. It should, however, always be noted in descriptions.

The fat-cells are generally of no specific importance. In a few species $(M$. coronifer, M. islandicus, M. rubens, M. occidentalis, \&c.) they have a characteristic colour, red, yellow, orange, or brown.

The egg varies greatly. It is either smooth or covered with processes which are characteristic for each species. The smooth eggs are never quite spherical, but shortly oval, rarely narrowly oval. They are left in the skin at the moult. The ornamented eggs are spherical, with a very few exceptions (M. coronifer, M. pullari, \&c.). The form of the processes should be noted, the distance (if any) separating them, and the nature of the egg-shell where free from processes. In a number of forms the shell is areolate. It is thick, and composed of two layers, the space between which is divided into a number of equal chambers, showing on the surface as hexagons. From some of these the processes spring, at equal distances apart. The turgidity of the processes destroys the regularity of the hexagons, and additional septa in the chambers give rise to a variety of patterns in the "areolation."

The spiny eggs are laid free, not enclosed in the cast skin. An intermediate type of egg has the shell ornamented with rods, which are embedded in a hyaline substance, so that the surface is even (M. arcticus, \&c.). In $M$. hastatus these rods have tops shaped like fleurs-de-lis, which project above the general surface.

* Prof. Richters informs me, in a recent letter, that he has ascertained that M. echinogenitus and related species have the claws separate, but close together, in embryos in the egg, and that they join afterwards. The adult M. echinogenitus has claws of the hufelandi type, not V-shaped.

BRIT. ANTARCT, EXPED, 1907-9. VOL. I. 
Many species of Macrobiotus cannot be distinguished with certainty unless the egg is seen. The mere presence of eggs beside the adults is of no use, although there may be a presumptive relationship in such cases. The relation must be demonstrated, and this can be done in two ways: first, by finding in an egg the young so far advanced that the claws and pharynx can be recognised; second, by finding, in the adult, eggs so far advanced as to show the characteristic processes. The first way is the more generally useful. The second may be of greater use than the beginner would suspect. The eggs are soft till they are almost ready for laying, and the processes, when formed, are still so soft that they are squeezed flat against the shell by the enclosing membrane. If the membrane can be torn, and the eggs released, the processes often stand up and can be recognised.

All species of Macrobiotus, and probably other water-bears, may be found in what is called the "simplex" state. They are then devoid of teeth, of rods in the pharynx, sometimes of all the mouth parts. Plate founded the genus Doyeria on an animal in this condition. The simplex state is now explained as a part of the moult, though it does not occur simultaneously with the casting of the skin. Identification of an animal in the simplex condition is difficult, as one of the most important characters is lacking.

Many water-bears, perhaps all, encyst themselves. This appears to be a sort of hibernation, in which a quiescent period is passed in a special protective case. Some species, when encysted, undergo a simplification going far beyond the ordinary "simplex," for they lose all recognisable organs, teeth, pharynx, and claws, and afterwards acquire them anew.

Diphascon.-The genus differs from Macrobiotus solely in having the gullet elongated between the teeth and the pharynx. As specimens of Macrobiotus are sometimes found which have the gullet elongated, the value of the genus is very slight. Nevertheless, I believe Diphascon to be a natural group. All the species have claws of one type, known as the Diphascon type, which is also found, but rarely, in Macrobiotus. Many of the species have the pharynx very narrow, but others have it quite round. Most of the known species have no eye-spots.

In distinguishing species the chief points to attend to are the diameter of the gullet, which varies extremely, the proportions of the pharynx, and the number and sizes of the rods or nuts in it.

In outward form there is little variety. All are very similar except $D$. bullatum, which is short, nodose, and papillose, and $D$. augustatum, which has a heavy body, but tapers to a very narrow head.

As a rule the animals of the genus are small, but some very large forms inhabit the arctic regions.

The eggs are smooth, and are laid in the cast skin, as in Echiniscus and a large section of Macrobiotus. 


\section{NOMENClature}

The nomenclature of the Tardigrada is in need of revision. The validity of many of the accepted names, generic and specific, may be questioned, and some of them will certainly not hold. Professor Hay (6) has suggested a number of corrections which must be made. He has shown that the water-bears have no right to bear the name Tardigrada, which is preoccupied (for a suborder of Edentata).

The recognition by the earlier naturalists of species having two, three, and four claws may be explained as arising from different interpretations of the claws of Macrobiotus and Milnesium. Macrobiotus may be said to have two forked claws on each foot, or to have four claws united in pairs, just as you please. It is curious that so many good naturalists have recorded a water-bear with three claws, which nobody finds nowadays.

Milnesium is commonly supposed to be the same as Schrank's Arctiscon, in which case the earlier name must be used, unless it can be shown to be preoccupied. If Schultze's Macrobiotus hufelandii is accepted as the common water-bear, and the same as Müller's Acarus ursellus, Müller's specific name should be used for it. All these points would require a very careful revision of the whole literature of the group, and a comparison of all the early descriptions and figures.

The revision is so important that it should be made in a work of monographic character, or at any rate should comprehend the whole group. While, therefore, in perfect agreement with Professor Hay as to the necessary changes, I shall in this paper continue to use the familiar names. By this means the present report will be kept in line with a whole series of others dealing with the water-bears of various countries under the name "Tardigrada." This report has been announced in the earlier numbers of this publication under that title.

When changing the name it is desirable that the change should be final, if that be possible. It would require a careful examination of all writings on the subject prior to 1835 to satisfy ourselves that Perty's name Xenomorphidae (22) [which Professor Hay shows to have precedence of Schultze's Arctiscoida (44)] is really the earliest applied to the water-bears as a family.

The name Xenomorphida is a family name, and the group of the water-bears must be considered as of more than family value. Schultze's name Arctiscoida, although proposed as a family name, might be adopted as an ordinal name for the group, and Xenomorphidie for the only family as yet recognised.

\section{On the Value of Species of Tardigrada.}

In the course of this Expedition a great many diverse forms of Tardigrada were collected or observed. Some of these are described in the following papers as species, 
one even as of generic rank. Had the early practice been followed, whereby species of the genus Echiniscus were supposed to be sufficiently characterised if they differed by one pair of spines or setæ from the related species, or if even a seta were replaced by a spine or vice versa, a host of new species would have been added. I prefer a definition of species in that genus which excludes such forms, and requires species to show peculiarities in other points of structure than the spines (such as claws, or plates, or texture), or to have the spinous armature conspicuously different from that of the nearest relatives.

No definition of species can be made which will be universally applicable. In some groups it is necessary to distinguish species by characters so slight that they would not be admitted in other groups. Species corresponds to no entity in Natureit is a human convenience. We may seek to distinguish by it such races of any organism which have through some degree of isolation and the tendency to vary (under influences of which we are profoundly ignorant) acquired more or less distinct marks by which they may be distinguished from the related races of the same stock, and which we believe to be constant (in the sense that they continually recur, and that we believe the recurrence to indicate community of origin). The amount of distinctness considered necessary to constitute specific value gives an opportunity for the personal element in naturalists to assert itself, and has, incidentally, given occasion for much disputation.

Every species throws some light on the biological history of the world, and so we want to discover them all. Such cheap species as the ardent discoverer could so easily manufacture out of the myriad forms of Echiniscus would yield the minimum of light on biological problems. In so far as they are permanent, they are only fortuitous side eddies in the stream of evolution, if such a term can be permitted a popular application in science. I mean that the species having two spines and those having three, and not otherwise differing, are not instances of essential adaptation to the conditions of life of the animals, but that one is as good as the other. Further, the probability is that many of these slight forms are really not species in even the widest acceptation of the term, but merely individual peculiarities.

Among Echinisci there are forms known, such as E. granulatus and E. quadrispinosus, var. cribrosus, [see Murray (12) and (18)] which possess several good characteristics, besides their distinctive spines. In colonies of such species, which may be confidently identified by the concurrence of many characters, it continually happens that individuals occur in which one or more of the customary spines is lacking. That it is frequently only one spine of a pair which is absent indicates that these are inly error's or peculiarities in the development of the individual. Yet by the accepted practice one pair of spines or setre makes a species.

There is next to be considered the case where these slight peculiarities seem to be constant. Admittedly when example after example turns up, having all the trifling 
features identical, the idea of the value of the characters grows. This happens mast frequently in colonies got at one place and time. Now a whole brood, or even a whole colony, may possess some little peculiarity which would not be permanent in a race of animals having the sexes distinct, and where cross-fertilisation may occur. The case of the Bdelloid Rotifera, which will be discussed in a subsequent paper, is very different, as only females are known. The reproduction being parthenogenetic there seems to be no check to the multiplication of slightly marked species, and the study of certain groups of forms bears this out.

The group of Tardigrada has hitherto been fortunate in that it has not attracted the attention of any too-enthusiastic discoverer of species. Professor Richters has shown a commendable reserve in simply describing and figuring those doubtful Echinisci, without giving them names.

This appears to be the right course to take, in the present state of our knowledge, and yet these unnamed forms are a trouble to the student. There is nothing to get hold of, and the memory recognises them not-even reference to them is laborious. Since species are a human convenience one is sometimes tempted to wonder whether the convenience of naturalists is better served by describing unnamed forms than by lightly naming them in the good old way, with, however, its accompaniment of burdening the synonymy when we come to know better.

In the genus Macrobiotus the species difficulty takes another form. There is little external variability. As few of the species have superficial processes there is little difficulty of the sort we have in Echiniscus.

Variability is seen - in the coloration-the animal may be colourless when young, and highly pigmented when old; in the claws-the amount of union of the pairs may vary considerably; in the rods of the pharynx - the first rod, next the gullet, may be a long one, or divided into two shorter ones, and the "comma" may be present or absent; in the eyes, which may be present or absent. Some of these differences are known to be dependent upon age. The limits and value of others are not definitely known.

Two forms of Macroliotus may differ in two of the most important character's used in discriminating species (claws and pharynx for example), yet the range of variation of each of these characters, taken separately, is wide enough to embrace both forms. Whether it is likely that two or more characters would vary simultaneously, to the extreme extent, in animals which are of the same spécies, we cannot tell. If it were so specific distinctions in the genus would to a large extent break down, and we would have only a few species, representing the principal types of claws recognised (hufelandi, oberhïuseri, dispar), or of eggs (the hufelandi type, the hastatus type, and the smooth eggs).

Another difficulty with Macrobiotus is that series of species agree so closely in all the characters of the adult that they cannot be distinguished with certainty, and it is necessary to find the egg before a species can be identified. These series of closely 
related species only occur in the groups which lay spiny eggs, or at least the eggs are only of value in that group.

Now the eggs do not show the characteristic processes while they are in the body of the parent, and once they have been deposited there is nothing to indicate their relation to one animal or another. The actual act of deposition can rarely be observed.

While the eggs are still soft and their shape readily distorted by the pressure of the enclosing membrane, and of adjacent eggs, the processes are often already formed, and if the membrane be ruptured, the external pressure being removed, the turgidity of the egg causes it to assume its proper shape, and the processes then stand out. The opportunities for completing an identification in this way must be casual and uncertain, and it is oftener possible to find an egg in which the young is so well grown that it shows the distinctive characters of the adult.

While many species are only distinguishable by their eggs, the converse occurs. Quite distinct species have eggs exactly similar, or so nearly alike that identification cannot be certain.

These facts show the necessity there is for making an exhaustive study of each species whenever the opportunity offers, and the danger there is that species will be multiplied to no good purpose, if such study is neglected.

Bibliography.-Throughout the text references to the bibliographical list are made in heavy type enclosed in brackets.

Tables of Species. - In the lists of species given to illustrate distribution there was some difficulty in presenting the facts concisely. To classify the records of Tardigrada broadly the world was divided into nine great regions, one for each of the five continents, for Australasia, and for the Antarctic and Arctic Regions. As regards these eight divisions the classification is obvious and natural enough. The ninth division (Oceanic Islands) was introduced to receive a lot of scattered records, not otherwise provided for. This is not satisfactory, as the islands are so scattered. Those which lie near continents are included with them, the others are all slumped together. It is a makeshift which may serve for the moment. Greater accuracy is not called for till a more comprehensive survey of the distribution of all the Tardigrada is attempted.

I have given all the records I could find, but many may have been overlooked. Some discrepancies may be found between the number of species for any one region given in different tables. This is due to the fact that many records were added from time to time after the tables were first compiled, and it could hardly be hoped that no errors would occur in collating so many tables.

In dealing with each country the local distribution is treated with more detail, and in addition to the nine main divisions of the earth's surface there may be given a column for such adjacent regions as may be supposed likely to show some relationship. Thus with the Antarctic a sub-Antarctic area is distinguished. 


\section{ANTARCTIC TARDIGRADA}

On collecting Antarctic Tardigrada.-The methods employed in collecting the fresh-water organisms in general have been detailed in Part $\mathrm{I}$. of this volume, and need not be repeated here. The water-bears were collected among the vegetation in the lakes, and also among moss. They came next in importance after the Rotifers, but not on account of being numerous in species. They were conspicuous in the lakes from the great abundance of one species (Macrobiotus arcticus), which occurred in numbers comparable with those of the two Bdelloid Rotifers, Philodina gregaria and Adineta grandis.

Two species were got in the lakes. The same two occurred among moss, with two others.

Priestley collected moss on the west side of Macmurdo Sound, at the Stranded Moraines. It contained three species, one of which was not known at Cape Royds (M. polaris), and one species found on Ross Island (M. oberhäuseri) did not occur at the Stranded Moraines.

All the Tardigrada were collected between $77^{\circ} 30^{\prime}$ and $78^{\circ} \mathrm{S}$. lat. No Tardigrada were found among the mosses collected by Professor David about 2 degrees farther north.

Summary of previous knowledge.-'The water-bears are better known than any other group of Antarctic fresh-water animals. Half a dozen papers on the subject have appeared, most of them by Professor Richters. The first mention I can find of an Antarctic Tardigrade is by Richters, who in 1904 (31), in his preliminary report on the Antarctic Moss Fauna, described a species (Macrobiotus antarcticus) found by the German "Gauss" Expedition on the Gaussberg, a hill on the Antarctic continent, and just within the Antarctic Circle. This was the only truly Antarctic species recorded in that paper, the other ten species being from islands in the southern ocean.

In 1906 there appeared the report on the Tardigrada collected in the South Orkneys by Bruce's Scottish Expedition [Murray (15)]. These islands are truly polar in climate, although lying outside the Antarctic Circle and distant from the continent. Fifteen distinct species were found, but owing to the condition of the specimens it was only possible to name six of them, three of which were known and three were new.

Richters' full report on the Tardigrada of the Gauss Expedition appeared in 1907 (35). It made no addition to the list of Antarctic species, though it extended the list of species known from the islands of the southern ocean to seventeen. 
In 1907 (36) Richters published also a summary of all that was known of Antarctic Tardigrada, including the results of the work of the German, Scottish, and Swedish Expeditions (although the report on the last had not then appeared). $\mathrm{He}$ gives a list of twenty-three species recognised, and mentions fifteen others which had been imperfectly observed, but he does not in that paper discriminate between the Antarctic and the sub-Antarctic species.

The Tardigrada of the Swedish Expedition were described by Richters in 1908 (38). In a table at the end of this paper he enumerates ten species from the Antarctic Region proper. Adding one species collected by the Scottish Expedition and one by the German, we have a -total of twelve Antarctic species recognised and named, besides many insufficiently studied.

Lastly, in 1909 (40), in a short note in the Zoologischen Anzeiger, Richters noted three species found in moss collected by the National Antarctic Expedition, under Captain Scott, in S. Victoria Land. Only one of these was sufficiently studied, and was found to be a new species, and described as Macrobiotus meridionalis.

There were thus thirteen species recorded for the Antarctic. We collected only four species, but of these three were new to the Antarctic and one was new to science.

The full list of the Antarctic species, with their relation to sub-Antarctic and other regions, will be given in tabular form at the end of this paper.

\section{LIST OF SPECIES}

Macrobiotus arcticus, Murray.

Mr. oberhäuseri, Doyère.

$M$. polaris, sp.n., Murray.

Diphascon alpinum, Murray.

Diphascon or Macrobiotus(?).

\section{Notes on the SPECIES \\ Genus-Macrobiotus, Schultze (42)}

Macroliotus arcticus, Murray (19) (Plate XIV. Figs. 2a-2f)

Specific characters.-Large: young hyaline, adult pigmented. Teeth strongly curved; gullet narrow; pharynx shortly oval, with two short rods, the second shorter, and no comma. Claws large, of the Diphascon type, one pair with nearly equal claws, united for some way above the base, the other pair with a very long claw springing from the back of a shorter thick one. Egg oval or round, thickshelled, studded with short rods which are embedded in a hyaline substance. Dark eyes. 
As $M$. arcticus was originally described from an egg containing the young ready to hatch, and the adult had never been seen, it is here redescribed from adult examples. The principal differences are that the rods in the pharynx are longer in the adult (they are nearly round or quadrate in the young), and that it acquires a brown pigment like that of $M$. hufelandii.

Detailed description.--Length $500 \mu$ and upwards. The young is perfectly hyaline, and has the long claws as slender and bristle-like as those of $M$. oberhäuseri. The long claws become a little thicker in the adult. They are strongly curved towards the tip, which is not the case with oberhüuseri.

The gullet is narrow, and is expanded at the end in the pharynx into a prominent thickened flange. In the adult the rod nearest the gullet is between three and four times as long as broad-the second rod is a little shorter, three times as long as broad, or rather less than that.

The stomach is voluminous: about a dozen of its component cells are visible in dorsal view. They are filled with large granules of a brownish colour, and there are deeper brown patches. About the middle of August many were observed which had the stomach green or deep blue. Macrobiotus with blue stomach has been noticed in Scottish lochs and in the Arctic.

Four unripe eggs have been seen in the body at once. The eggs are spherical or very shortly oval, $96 \mu$ in diameter. The thickness of the shell is about 5 or $6 \mu$, but varies considerably. The eggs often appear to be viscous, and have much adherent material : some are quite clean and don't seem viscous. It may be that they are viscous when first laid, and become hard afterwards.

Habitat.-In nearly all the lakes about Cape Royds and Cape Barne, extremely abundant.

It was the first water-bear which we found. On March 15 we obtained it, and also eggs, among dried vegetation on the ground. This had doubtless originated in a lake. It was most abundant in Coast Lake, where we could always get great quantities.

In Blue Lake on July 17 it was found alive at the bottom, on a thin pellicle of vegetation under 15 feet of ice.

In the experiments made to test the vitality of rotifers, many water-bears of this species were present with the rotifers. They endured equally well exposure to the greatest Antarctic cold, and repeated freezing and thawing, at weekly intervals, for months. They were not subjected to lieat.

After being kept dry for a year, and conveyed on a voyage through the Tropics to England, no adult animals revived, but the eggs retained their vitality and some hatched out, and were exhibited at the Quekett Microscopical Club by Mr. Scourfield.

$M$. arcticus appeared to be a thorough pond-dweller, and was never found among mosses at Cape Royds. Nevertheless, in mosses which Priestley brought from the BRIT. ANTARCT. EXPED. 1907-9. VOL I 
Stranded Moraines, on the west side of Macmurdo Sound, they were plentiful, and there were many eggs.

These eggs differ from those got in the lakes, but not enough to cause us to regard it as a distinct species. They are smaller and much thinner-shelled. The shell is so thin that the rods which traverse it are scarcely longer than broad. They do not seem viscous. The animal does not differ at all. The thinner-shelled eggs may be summer eggs.

The distribution of $M$. arcticus is peculiar. As far as our meagre knowledge goes it is confined to the polar regions, but an egg of the thin-shelled form has been got in a Scottish loch, and a similar egg, but smaller, in tropical Africa. In various countries visited on the homeward voyage (New Zealand, Australia, Canada) an animal was found which is almost certainly this species, as it has all the characters of the adult, but as no eggs were found there is a certain doubt about the identification.

M. arcticus has only one near relative, M. hastatus, Murray (18), an inhabitant of peat-bogs. Several Macrobioti are now known which have claws of the Diphascon type, but only these two species have the peculiar eggs, studded with rods.

\section{Macrobiotus polaris, sp. n. (Plate XIV. Figs. 1c-1e)}

Specific characters.--Large, hyaline, or old examples somewhat pigmented. Gullet of intermediate width: teeth curved: pharynx shortly oval, with apophysis, and three short rods and comma in each row. Claws slender, of hufelandi type, very unequal, and united less than half-way. Eggs spherical: processes from polygonal bases, varying from round to acuminate, separated by polygons of equal size to their bases. Dark eyes.

Detailed description.--Length, up to $800 \mu$. The egg measures $75 \mu$ in diameter, exclusive of the processes, and about $85 \mu$ over the rounded processes, or $95 \mu$ over the pointed ones. A young one squeezed out of an egg was $250 \mu$ in length, which is a very large animal to come from such a small egg, but it may have been slightly elongated by pressure. The animal is somewhat narrow and elongated. The gullet is about $4 \mu$ wide, with parallel sides, and bent out to form a narrow flange at the end in the pharynx. The pharynx measures $36 \mu$ by $30 \mu$. The three rods are of nearly equal length and are rounded at the ends. They vary in length, according to age, from $1 \frac{1}{2}$ to $2 \frac{1}{2}$ times as long as broad. The stomach is narrowed at both ends, and consists of numerous cells, about twenty being in view at one time. The fat-cells are small, 5 or $6 \mu$ in diameter. The body-fluid in old animals is pale yellow, the stomach sienna-brown.

The claws are unusually slender for a large animal of the hufelandi group. The lesser claw of each pair is little more than half as long as the larger one. Only one supplementary point could be seen on the long claw. 
The egg is extremely variable. It is one of the "areolate" type (see $M$. areolatus, p. 167). The shell appears to be double, and the enclosed space is divided into a number of equal cells or chambers by septa which appear on the surface as a hexagonal reticulation. From certain hexagons, at equal distances apart, the processes spring. They are separated by one hexagon. They vary greatly in form. Some are rounded at the top and appear as semicircles in optical section: others are conical and acute: others again acuminate, with slender points. The turgidity of the processes causes pressure upon the surrounding hexagons, and thus interferes with the regularity of the reticulation. Sometimes the processes appear wrinkled or shrunken at their bases, when they may become smaller than the intervening polygons.

Habitat.-Among moss collected by R. E. Priestley at the Stranded Moraines on the west side of Macmurdo Sound, very abundant, eggs also numerous.

After being dry for more than a year, several adults were found alive when the moss was moistened on February 15, 1910. Some eggs were hatched, thus completing the life-history of the animal.

M. polaris has affinities with a great many species forming what may be called the hufelandi group. Most of the species are characterised by eggs having very distinctive characters, but it must be admitted that several of them could not be recognised with certainty, unless the egg were found, and its relation to the animal demonstrated by hatching or otherwise. It is not one of the species nearest to 11. hufelandii, which have very wide gullets. It is only necessary here to point out the characters in which it differs from those species which have somewhat similar eggs.

The nearest relative is perhaps $M$. meridionalis, Richters (40), with which I at first identified it. Professor Richters' figure does not give all the details necessary to separate the species, but he informs me in a letter that the processes of the egg are hemispheres with a small discoid projection on top, and that the surface is not reticulate in the manner described above. This form of egg I know as occurring on Scottish mountains, and it is quite different from M. polaris.

$M$. echinogenitus and $M$. areolatus have the claws joined near the base only: the former has not a reticulate shell, and the latter has a much larger egg and no comma in the pharynx.

M. montanus (see p. 116) has the processes hemispherical, almost touching at their bases, and the surface not reticulate. M. harmsworthi has the processes acuminate, and close together on the shell, which is not reticulate.

\section{Macrobiotus oberhäuseri, Doyère (2)}

As an Antarctic species this is only known from a single example, found in moss from the High Moraines at Cape Royds, January 1909. A photograph of the animal from life is shown in Part 2 of this volume, Plate III. Fig. 11. 
The animal is strongly pigmented, of the characteristic colour, and is smooth all over, not papillose as in many examples from tropical regions.

\section{Genus-Diphascon, Plate (23)}

\section{Diphascon alpinum, Murray (14) (Plate XIV. Fig. 3)}

It has been pointed out by Professor Richters that the southern representative of D. alpinum is not precisely like the type as found on Ben Lawers in Scotland. The Antarctic form has a comma in the pharynx, in addition to the three rods. The comma is not noticed in the original description or figure, but at that time I do not think the comma had begun to be taken notice of as a serious character.

In the Antarctic examples the three rods do not increase in size so much from first to third as in the type, and the claws appear to be relatively larger and more slender. All these differences do not justify the separation of a new species without fuller study.

At Cape Royds $D$. alpinum was much less common than $M$. arcticus. It was present in a good many of the lakes and ponds, but was never abundant, perhaps most so in Terraced Lake, Cape Barne.

It was first found in Blue Lake on March 27, 1908, and in that lake, on July 17, a skin with three smooth oval eggs, very probably of this species, was got at a depth of 15 feet, on a thin film of vegetation which covered the stones on the bottom.

One example measured $200 \mu$ in length, but that was undoubtedly a small one, though I have no measurements of any larger. The type was $250 \mu \mathrm{long}$, and some examples from the South Orkneys were $360 \mu$ in length.

At Cape Royds it was never found among moss, but at the Stranded Moraines it did occur. There also three eggs were found in a skin.

It is now recorded for Spitsbergen and Canada. There are no notes as to the "comma" in these countries.

\section{Diphascon (?), sp. (Plate XIV. Fig. 4)}

A small animal, of which only one example was found, is referred doubtfully to the genus Diphascon, to which it technically belongs, having a slightly elongated gullet, and claws of the Diphascon type.

The animal is smooth and hyaline. It measures $300 \mu$ in length. The teeth are small, and curved strongly outwards towards the furca. The gullet is of moderate width. It is about twice as long as the teeth. The pharynx is shortly oval and contains two rods in each row of thickenings. The end of the gullet in the pharynx is expauded into a broad flange, to which the apophyses are attached. The 
first rod (nearest the gullet) is about three times, the second about twice as long as broad. There is no "comma."

The claws are of the Diphascon type, but the longest claw is less in excess of the others than usual. The lesser pair has one claw considerably longer than the other.

The eggs are unknown; eyes were not seen; there are no notes about the stomach or fat-cells.

The animal is not sufficiently studied for identification. Although technically a Diphascon, there is some reason to think that it is a sport of a Macrobiotus. It will be noticed that, apart from the elongated gullet, the teeth and pharynx are very like those of $M$. arcticus (Fig. 2b).

As that species also has claws of the Diphascon type, there is little to separate the two. The elongation of the gullet is less than in any Diphascon except angustatum, and the portion between the bearers and the pharynx did not appear flexible.

A similar slightly elongated gullet is known in an animal having claws of the dispar type, and thercfore certainly no Diphascon.

Found among dried vegetation, probably of lake origin, which also contained M. arcticus and its eggs.

\section{Remarks on the Antarctic Tardigrade Fauna.}

The Antarctic is defined for the purposes of this paper as comprising the whole Antarctic Continent, not excepting the small part which lies outside the Antarctic Circle, and such islands lying off the coast as enjoy a similar frigid climate to that of the continent itself. It is a region where the summer temperature of the air is never very far above freezing-point. The sea is for the most part permanently of a temperature somewhere between the freezing-point of fresh and that of sea water. It is a desolate and inhospitable region, presenting a remarkable contrast to the North Polar region, which has a relatively genial climate in latitudes several degrees highel than any in which biological studies have been attempted in the south.

So far as known there is no life in the Antarctic except on or very near the coast. The remotest living thing recorded for the Antarctic is probably the Lichen obtained by Captain Scott at an altitude of 5000 feet in the Western Mountains. This is a remarkable occurrence. The summer climate there is like the winter polar climate on the coast. The occurrence of Penguins 80 miles from the sea is an altogether different case, as they could not live there. Like the men who saw them they were provisioned and clothed for a journey to a distance from their base. So hardy are the Lichens that one wonder's whether there may not be some on the bare rocks of Mount Hope or the Cloudmaker. If one had time on such journeys for such things, and if a keeneyed lichenologist were of the party, it is not unlikely that he would detect some stains which no one else would recognise for Lichens. 
Tardigrada we would not expect far inland. As far as moss could exist waterbears might be expected. At present none is known south of latitude $78^{\circ}$.

So few are the Tardigrada of Victoria Land that it is hardly worth while entering into any discussion of general questions concerning their origin and relationships.

Taken in conjunction with the Tardigrada of other parts of the Antarctic, altogether making the modest total of sixteen identified species, it may be better worth while to discuss such questions.

The whole circuit of the Antarctic Coast has only been touched (for purposes of biological study) at three points in its many thousands of miles : at Graham Land, at the Gaussberg, and at South Victoria Land. The Graham Land region, including the Islands, lies entirely outside the Antarctic Circle; the Gaussberg is almost on the Circle; Victoria Land is far to the scuth. The region round Graham Land is best known. Some half-dozen expeditions have visited it, but only the Scottish and Swedish have published reports on the Tardigrada.

It is hoped that Dr. Charcot's recent expedition will afford material for further study of the Tardigrada of this region.

There is undoubtedly a fairly rich Tardigrade fauna in the region lying south of Cape Horn. The other two points of the continent examined are very poor in Tardigrada. In Victoria Land, Ross Island is reckoned as part of the continent. Though technically an island, permanent ice or snow joins it with the mainland.

In the following table a list is given of all known Antarctic species, with their distribution in the three Antarctic localities, and their general distribution over the world.

The list includes sixteen species, but many other's are known to exist, at least in the islands. There are three species of Echiniscus, one of Mitnesinum, nine of Macrobiotus, and three of Diphascon.

Seven of these species are known to be widely distributed over the world : they are, E. arctomys (?), M. tardigradum, M. echinogenitus, M. oberhëuseri, D. chilenense, D. alpinum, and D. scoticum.

Three species are not yet known outside the Antarctic, but the adjacent lands are too little known to permit us to build anything on the restriction. The species are E. meridionalis, $M$. meridionalis, and M. polaris.

Two species are only known in the southern hemisphere. $M$. furciger is common in the Antarctic region south of Cape Horn, and in the adjacent sub-Antarctic localities of Tierra del Fuego and South Georgia. On the other side of the world it occurs in New Zealand, where it is found in both the principal islands, and in the North Island attains to a sub-tropical latitude. $M$. asper is only found in the Antarctic to the south of Cape Horn and in the neighbouring South Georgia.

Three species appear to have a bi-polar distribution. E. wendti is in both polar regions, and is also recorded for Germany and doubtfully for Scotland.* $M$. arcticus is in both polar regions, and is also doubtfully recorded for New Zealand, Australia,

* It has now been found (September 1910) on the summit of Snowdon, in Wales. 
Africa, Scotland, and Canada. M. antarcticus is in the South Polar region, and though not yet known in the Arctic, it comes pretty near to it in Sweden, where it has recently been found by Carlzon (1). The other six bi-polar species are cosmopolitan, or very widely distributed.

\section{Distribution: Local and General, of all Known ANTarctic 'Tardigrada.}

\begin{tabular}{|c|c|c|c|c|c|c|c|c|c|c|c|c|c|c|c|}
\hline \multicolumn{2}{|l|}{ mane } & 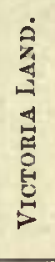 & 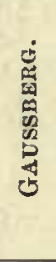 & 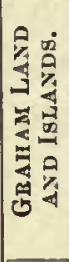 & 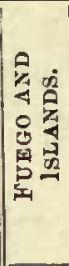 & 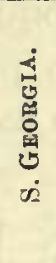 & 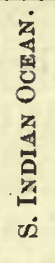 & 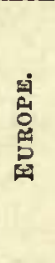 & $\frac{1}{4}$ & 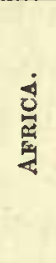 & 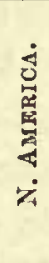 & 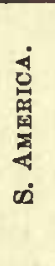 & 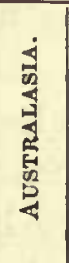 & 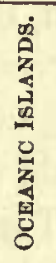 & 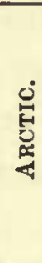 \\
\hline \multicolumn{2}{|c|}{ Echiniscres arctomys (?) (see p. 126) } & - & - & $x$ & - & - & $x$ & $x$ & $x$ & $x$ & - & - & $x$ & $x$ & \\
\hline E. wendti. & & $\dot{-}$ & - & $x$ & - & 一 & - & $x$ & - & - & 一 & - & - & - & $x$ \\
\hline E.meridionalis. . & . & - & - & $x$ & - & - & - & - & - & - & - & - & - & - & - \\
\hline MFilnesinm terdigradum & . & $\div$ & - & $x$ & - & $x$ & $x$ & $x$ & $x$ & $x$ & $x$ & $x$ & $x$ & $x$ & $x$ \\
\hline Nacrobiotus furciger. & . & - & - & $x$ & $x$ & $x$ & - & - & 一 & 一 & - & - & $x$ & - & - \\
\hline Mr. echinogenitus . & . & - & - & $x$ & - & - & $x$ & $x$ & $x$ & $x$ & $x$ & - & $x$ & $x$ & $x$ \\
\hline M. merillionalis. & . & $x$ & - & $=$ & - & - & - & - & - & - & - & - & - & - & 一 \\
\hline M. polaris. & . & $x$ & - & - & - & - & - & - & - & - & - & - & - & - & - \\
\hline Mr. obeshäuseri . & . & $x$ & - & - & $x$ & - & $x$ & $x$ & $x$ & $x$ & $x$ & $x$ & - & $x$ & $x$ \\
\hline M. arcticus . & & $x$ & - & - & 一 & - & - & $x$ & - & $x$ & $x$ & - & $x$ & - & $x$ \\
\hline 1r. asper . & . & - & 一 & $x$ & 一 & $x$ & - & - & 一 & 一 & 一 & - & - & 一 & - \\
\hline M. merrayi & . & - & - & $-1 x$ & - & $x$ & - & - & - & - & - & - & - & - & 一 \\
\hline M. antarcticns. & . & - & $x$ & - & - & - & - & $x$ & - & - & - & - & - & - & - \\
\hline Diphascon chilevense. & & - & - & $x$ & 一 & - & - & $x$ & $x$ & - & $x$ & $x$ & $x$ & - & $x$ \\
\hline D. alpinum . & - & $x$ & - & $x$ & - & - & - & $x$ & - & - & $x$ & - & $x$ & - & $x$ \\
\hline D. scaticum & . & - & - & $x$ & $x$ & - & $x$ & $x$ & - & - & $x$ & $x$ & $x$ & $x$ & $x$ \\
\hline
\end{tabular}

The local distribution within the Antarctic is very remarkable. In the three portions of the Antarctic from which Tardigrada are known the species are all different in each locality, with the single exception of $D$. alpinum, which occurs in both Victoria Land and the Graham Land region. From the uniformity of the conditions round the Antarctic coast it would be expected that the fauna would be uniformly distributed. It is true that there is a great difference in latitude, amounting to not far short of 1000 miles, between the regions studied in East and in West Antarctica. The climatic conditions do not correspond to this great difference of latitude, though the Graham Land region is somewhat warmer.

It might be suggested that the Tardigrada have peopled the different districts independently by migration from the nearest lands to the north. A glance at the map will show how improbable this is. Migration across those broad oceans must be excessively difficult for Tardigrada, even considering the few small islands which afford intermediate resting-places. Migration of such animals is involuntary, and 
can scarcely be effected by any other agency than the winds. The prevalent storm winds on the Antarctic coast are southerly. The Tardigradit of the different regions do not correspond more closely with the nearest northern lands than with other regions, except to some small extent to the south of Cape Horn, where access to the Antarctic from the north is easiest. In Victoria Land all the species of Tardigrada yet found are unknown in New Zealand, with the one exception of D. alpinum, and $M$. furciger, an Antarctic species found in New Zealand, is absent from Victoria Land.

Undoubtedly migration along the Antarctic coast is easier than migration to it from the north. In that case the birds, such as the Skua gulls, could assist in the process. If the Antarctic las been peopled from the north, the Cape Horn to Graham Land route is the likeliest to have been followed, and the numerous islands would make it easier.

There is little evidence that any species have been developed through long isolation in the Antarctic. $M$. furciger and $M$. asper might have originated thus and spread to the north, but it is quite as likely to have been the other way round. There are, of course, the three species peculiar to the Antarctic, but they may any day be found on the other side of the world, as happened with M. antarcticus.

Contrasting the Antarctic Tardigrada with the Rotifera of the same region, we arrive at the following considerations. In both groups there are about the same number of Antarctic species known. In the Tardigrada the few peculiar species are not very peculiar, and their modifications do not appear to render them better fitted for the conditions than other species. None of them is strikingly abundant in the region. If there is a dominant species in any region it is $M$. arcticus. The peculiar species of Bdelloid Rotifera are more peculiar, and their peculiarities seem more likely to have arisen through long isolation, in adaptation to the conditions, and the extraordinary abundance of some of them (e.g., Philodina gregaria and Adineta grandis) bear this out.

The different life-conditions of these two groups must, however, be borne in mind. The Bdelloids reproduce only parthenogenetically, so that there is no check by crossbreeding to variation. The Tardigrada are sexual, so that if fresh migrants arrived, even at long intervals, the development of new forms would be retarded.

One of the most curious features in the Antarctic Tardigrade fauna is the absence of the genus Echiniscus from the Antarctic Continent. No Echiniscus is yet known on the continent, or anywhere south of the Antarctic Circle. In the North Polar region there are at least a dozen species found within the Arctic Circle, and almost as many even in Spitsbergen and Franz-Josef Land, in latitude $80^{\circ}$ or higher. Is it that the Echinisci are less resistant to cold than the Macrobioti? In the Antarctic Islands, the South Orkneys and South Shetlands, \&c., there are many species of Echiniscus.

The relation of the Antarctic Tardigrade fauna to that of other regions of the 
earth is indicated in the Table by the following figures. Of the 16 species, 10 occur also in Europe, 9 in the Arctic, 8 in Australasia, 8 also in the sub-Antarctic islands, 7 in North America, 5 in Asia, Africa, and Oceanic Islands, and 4 in South America (excluding Tierra del Fuego, which is taken into the sub-Antaretic region).

These figures are of little value, on account of the paucity of our knowledge. As they stand, they indicate the closest affinity with Europe, and after that with the Arctic, the sub-Antarctic islands, and Australasia.

The Antarctic species which extend into Europe and the Arctic are identical in these two regions, with the addition of $M$. antarcticus to the European list.

Of the eight species in the sub-Antarctic region, and the eight in Australasia, there are five which are common to the two regions. 



\section{TARDIGRADA OF NEW ZEALAND}

Collecting in New Zealand.-Tardigrada were collected in a great number of localities -fairly representative of all the varied climates of the country-in both of the large islands: in the moist sub-tropical bush of the extreme North, beyond Auckland - in the volcanic district of Rotarua-in the cold lake district of the South Island-and among the Alpine ranges of Mount Cook.

New Zealand stretches from nearly $34^{\circ} \mathrm{S}$. latitude to nearly $47^{\circ} \mathrm{S}$., and Stewart Island passes the 47 th parallel by a few miles. The districts visited stretched between $36^{\circ}$ and $47^{\circ} \mathrm{S}$.

On the arrival of the Nimrod in the end of 1907 there was one month available for work in New Zealand. After a day or two spent in the neighbourhood of Christchurch a party set out for the Hermitage at Mount Cook. Dr. Mackay was bent on mountain-climbing: Dr. Michell assisted me in collecting.

From the railway terminus at Fairlie two days were occupied in getting to. the Hermitage. The first day's journey was made on foot, ending at a guest-house on the shore of Lake Tekapo, whose green, milky water made a strange outlandishlooking landscape. The chalky water was examined for pelagic animals, which were present but not abundant.

Next day we went by motor-coach to the Hermitage. The hostel stands at an elevation of more than 2000 feet above sea-level. The valley bottoms of the Tasman and Hooker Rivers had the aspect of Scottish Moorland, and abounded in similar mosses, peat-mosses and others, albeit the flowering plants were very different. No Scotch thistle is so formidable a foe as a New Zealand "Spaniard."

The home-like character of this moorland was only disturbed by the wide desolate beds of the glacial rivers, miles across at places, a vast stony waste, intersected, now when the rivers were low, by innumerable branching channels.

The moorlands of Mount Cook were not nearly so prolific in forns of microscopic life as similar places in Scotland would be, although this district yielded the greater part of our New Zealand species. The Sphagnum was particularly unproductive. This may be due to the fact that the mosses have to endure much greater heat, and are dried up for longer periods.

While I collected in the valley and at moderate elevations, my companions climbed some of the peaks in the neighbourhood, and they were always mindful to 
bring mosses from the highest points at which they grew. Together they climbed Mount Wakefield, over 6000 feet high, and got moss near the top. Dr. Michell ascended to a similar height on the Sealy Range.

Dr. Mackay made the first ascent of the hitherto maiden peak of the Nun's Veil, just under 9000 feet in height. From that trip we got the most interesting biological results of our whole work in New Zealand. Dr. Mackay got some moss at about 6000 feet, and some lichen near the top. The moss was a little scrap of a Dicranum, and I am told that it is a previously unknown species. In the axils of its leaves there were several species of water-bears, two of which are new to science and are the only peculiar species obtained in New Zealand.

Lake Wakatipu was next visited. The microfauna was much the same as in the Mount Cook district. The water of this lake was not milky, but beautifully clear and cold. In the plankton of the lake a species of the rotifer. Pedalion was found.

A journey was made by coach through the beautiful Otira Gorge to the west coast. As soon as we crossed the pass and got on to the western slope we found ourselves in a different world. The whole country was densely wooded, the tree-ferns giving a tropical and unfamiliar look to the bush. Everything was festooned with luxuriant moss. Incidentally, the torrential rains which promote the luxuriance of the vegetation poured upon us all the time that we stayed on the coast.

There was little opportunity for studying the moss fauna on the spot, though a light microscope was carried with ns. The fauna was poor, especially in Tardigrada, but one or two rotifers were got which are peculiar to New Zealand.

The available time being short, we set out on a coasting steamer for Wellington. At every port we visited, from Hokotika, to Nelson, we had a few hours ashore, and spent them in the bush, picking mosses from the trees. No attempt could now be made to examine them, and they were sent off from time to time by mail for future study.

Foggy weather delayed us, and when we reached the North Island our time was almost spent. In the few days remaining it was desired to get as far north as possible, so as to include in our study of the fauna as great a range in latitude as might be. We went to Auckland, and on the advice of $\mathrm{Mr}$. Cheeseman, of the Auckland Museum, proceeded to the Waitakerei Range, a short distance to the north-west of the town. Here we found the bush of similar character to that of the South Island at Hokotika, but if anything moister and still more abounding in ferns.

It was a happy hunting-ground for the student of mosses and moss faunas, but we were not permitted to linger hunting there. In our limited time we collected half a dozen kinds of water-bears, which bad all been previously obtained in the South Island.

When the Nimrod came back out of the south the first green-clothed land we came to was Stewart Island. We had a whole day ashore there. The bush in that uninhabited region was almost impenetrable, and after spending some hours and 
getting only a few hundred yards through it, without encountering any moss worth collecting, I came out on the shore again. There was a little islet with precipitous sides, cut off from the main island at high water. On the summit of the islet therc was only some scrubby bush and deep cushions of some large mosses. These were not of sorts usually favourable to microscopic life (they were large Dicrana, and Iylocomium and the like), and we did find them very unproductive, but among other things we got five kinds of Tardigrada.

No collecting was done in the South Island during the second visit, in 1909, but a. week was spent in the volcanic region of Rotorua, in the North Island. The country had the look of being habitually parched and dusty, and was not mossy, though there were mosses enough in shady nooks by springs and waterfalls. Hot springs and cold springs were examined, the lakes were netted, and the mosses were washed, but no water-bear of any genus appeared to reward our exertions.

Two members of the Expedition, Mawson and Mackintosh, fetched me moss from a considerable elevation on the slopes of the volcano Ngauruhoe, but this also was unproductive.

Summary of previous knowledge.-Scarcely anything is known of the Tardigrada of New Zealand. Captain Hutton's Index, 1904 (10), makes no mention of the group. 'The only paper I know on the subject is Professor Richters' "Moosfauna Australiens" (37), in which three species are noted from the North Island, and from Bare Island, a little islet near Napier, on the east coast. They are Echiniscus gladiator, $E$. novazcelandice and Macrobiotus hufelardii.

We found all these species again, but curiously enough we did not get the type of E. gladiator, but only the spineless variety exarmatus, hitherto unknown outside of Scotland.

In February 1907 Mr. D. J. Scourfield gave me some moss which he had received fiom Gisborne, N.Z. In this I found a single example of Macrobiotus nodosus, a species discovered shortly before in Africa. The species did not occur in our collections from New Zealand, but it was obtained by Captain Davis, when the $N i m r o d$ called at the Macquarie Islands on the homeward voyage.

\section{List of SPECIES Found}

Echiniscus mutabilis, Murray.

L. novcezeelandice, Richters.

E. gladiator, Murray.

E. velamimis, sp. n.

Ifilnesium tardigradum, Doyère

Macrobiotus hufelandii, Schultze.

ML. furciger, Murray.

Mr. echinogenitus, Richters.

M. harmsworthi, Murray.

M. montanus, sp. n.

$M$ intermedius, Plate.
M. dispar, Murray.

$M$. arcticus, Murray ?

$M$. nodosus, Murray.

M. sattleri, Richters.

M. papillifer, Murray.

$M$. ornatus, Richters.

M. annulatus, Murray.

Diphascon chilenense, Plate.

D. alpinum, Murray.

D. scoticum, Murray.

Four Species not identified (3 Echiniscus, 1 Macrobiohus). 


\section{NOTES ON THE SPECIES}

\section{Genus-Echiniscus, Schultze \\ A : Species having Segments V. and VI. Distinct \\ Echiniscus mutabilis, Murray}

The commonest Echiniscus in New Zealand, occurring in many localities in both of the large islands, but not in Stewart Island, the Aucklands, or the Macquaries.

I was formerly inclined, relying on second-hand descriptions of $E$. arctomys, Ehr., to believe that $E$. mutcubilis was closely related to that speciss. Reference to Ehrenberg's original figure (4) and description (3) shows that they have nothing in common. They even belong to different sections of the genus, which will probably become distinct genera eventually. E. arctomys has segments V. and VI. (Richters) completely fused, and E. mutabilis has these segments distinct. Any records which I have made of $E$. arctomys in previous papers are erroneous-they all refer to E. mutabilis (see p. 126, footnote).

\section{Echiniscus novøzeclandice, Richters (37) (Plate XV. Fig. 5)}

Specific characters.-Segments V. and VI. separate, V. a pair, obscurely divided, bearing two stout dorsal processes somewhat near the median line: first and second median plates divided by transverse line: all finely dotted: no fringe on the fourth legs.

Description.-Professor Richters contents himself with a lather brief diagnosis, so a fuller one is given here. The animal varies considerably, in size and other respects. It is the closest relative of $\boldsymbol{E}$. mutabilis, and it is doubtful if they could be distinguished, except by the characteristic spines on $V$. The colour varies from brick-red to yellow. The number of plates is difficult to state, on account of the obscure separation of some of them, and the sub-division of others. I prefer to regard those sub-divisions as not constituting distinct plates, and thus consider a typical animal in which V. and VI. are distinct as having twelve plates, of which three are median, and there are three pairs. There are species in which the plates of the third pair (segment V.) are completely fused.

Apart from the ten processes on the head, which appear to be common to all Echinisci, there are usually no processes on the body of E. novcracclandice except the two stout spines on $V$. These vary greatly in size, sometimes reaching almost as far as the posterior border of plate VI., sometimes reduced to short cones. In one example they measured $30 \mu$ in length.

These processes are often forked. There are often short cones at the posterolateral margins of the plates of the second pair ( $d$ Richtels). There may be rudi-

* Except only E. imberbis, which is said by Prof, Richters (38) to lack the six processes near the mouth 
ments of similar cones at the angles of the preceding segments ( $b$ and $c$ Richters). There is a slender spine on the first leg, and a blunt palp near the base of the fourth, as in many other species. Seta $a$ at the base of the head is generally nearly straight - the auricle at its base is fairly large. The legs are long. No barbs were detected on the inner claws of the fourth leg, but they would be readily overlooked if as small as in E. mutabilis.

It is usually a small species, but attains to a tength of $280 \mu$ or more, exclusive of the fourth legs. The eggs are two to four in number. Two have been seen in a skin which measured only $100 \mu$, so that the species evidently, like E. mutabilis, grows after attaining to maturity. The eggs measured $50 \mu$ in length.

The species was described by Richters (37) in the same year (1907) in which we collected it. It was only known in New Zealand till 1909, when I obtained it in Australia, and later a variety in Hawaii. This variety (see p. 151 and Plate XIX. Fig. 35) completely links $E$. novcezeclandice with $E$. mutabilis, as the dorsal processes on $\mathrm{V}$. are reduced to mere angles on the posterior margins of the plates.

The figure (Plate XV. Fig. 5) shows the forked process and little lateral cones $(d)$, although these peculiarities were not observed in New Zealand. The figure is from an Australian specimen.

Habitat.-North Island, Waitakerei Range, north-west of Auckland; South Island, Mount Cook district, elevation 2000 to 3000 feet; shore of Lake Wakatipu at Kingston.

There are only about a dozen species in that section of the genus which has segments V. and VI. separate. It is only necessary to compare $E$. novcezeelandia with those which have processes on the posterior border of $V$. (third pair). Of these there are three: $E$. islandicus and $E$. borealis have numerous spines and setæ, $E$. imberbis has a long seta at $d$, and a dorsal spicule over $c$.

A species from the Canary Islands, figured but not named by Heinis (8) has the spines of $\mathrm{V}$. precisely like those of $E$. novazeelandia, but it has setæ $c, d$, and $e$.

\section{-B : Species having Segments V. and VI. Coalesced}

\section{Echiniscus gladiator, Murray (12)}

We did not find the type of the species, but the variety exarmatus, Murray (18), was got in moss brought by Drs. Mackay and Michell from an elevation of about 5000 feet on Mount Wakefield, in the Mount Cook district of the South Island. This spineless variety was previously known only in the Shetland Islands.

Professor Richters got the type from Bare Island, close to the coast of the North Island.

There is one character, by which $E$. gladiator and its variety exarmatus may be distinguished from all other species, which has not been referred to in the descriptions 
or shown in the figures. The paired plates meet in the middle line only close to the anterior border, and gape behind. A pair of plates, showing the gap, is figured among Canadian Tardigrada below (Plate XX. Fig. 51).

\section{Echiniscus velaminis, sp. n. (Plate XV. Fig. 6)}

Specific characters.-Size moderate; plates nine, two pairs, two median, surface with fine irregular pits, very large on the last (lumbar) plate; $c, d$, and $e$ are setæ, $d$ shorter, $e$ very long; dorsal setæo over $c$ and $d$; fringe of few large blunt processes ; ciaws all without barbs.

General description.-Length $270 \mu$, seta $a 75 \mu, c 125 \mu, d 80 \mu, e 250 \mu$; setæ $d$ has sometimes a short curved spine at its base. None of the plates has the surface markings interrupted by lines or bands. The markings are fine on all the plates except the last, where they are very coarse. They are very unequal in size, and look like perforations. The teeth of the fringe are very few in number (5 or 6), and are large and very obtuse. There is a blunt palp at the base of the fourth leg.

Habitat.-Among mosses from the Nun's Veil Mountain, Mount Cook district, elevation about 6000 feet; collected by Dr. Mackay.

Remarks.-E. velaminis belongs to that group of species which have segments $\mathrm{V}$. and VI. (Richters) united, and which possess one or more long lateral setæ in addition to the one $(\alpha)$ at the base of the head, which is present in all known species. Though there are no species in that group so near as to require careful discrimination, it will be necessary to compare it with a considerable number of species, many of which are very insufficiently described. Several species have the same number of lateral setæ, but they are differently arranged, and there are other distinctions. $E$. testudo lias the setæ $a, b, c$, and $e$, the dorsal setæ over $c$ is lacking, and the "fringe" has many smaller teeth. E. blumi has" setæe $a, b, c$, and $d$, and the outer claws are barbed. $E$. crassus has setre $a, b, c$, and $d, e$ is a blunt process, the fringe has small blunt teeth, and the surface is coarsely granular. E. filamentosus has setre $a, b, c$, and $e$ (as in testudo), and on each side, according to Plate, two dorsal spines over the second and one over the third leg. E. muscicola has setæa also, $a, b, c$, and $e$, and there is a long dorsal seta over $c$, but none over $d$.

Several species have one lateral seta more than velaminis, besides other differences. E. creplini has small spines near the bases of setæ $b, c$, and $d ; E$. quadrispinosus and E. scrofa have some of the plates sub-divided, and the fringe with many sharp teeth.

A number of species have one seta less than velaminis, and differ in other respects. $E$. bellermanni has small spines at the postero-lateral angles of the segments; $E$. merokensis has the outer claws barbed; $E$. longispinosus lacks seta $e$, and has the fringe of slender spines; $E$. meridionalis has $d$ a spine, and a dorsal spine over it; $E$. granulatus has the dots real granules.

The forked or double seta of velaminis is reminiscent of $E$. aculeata (23), but 
according to Plate the forked process should be $c$, there are no lateral setæe except $a$, and there is no mention of fringe. I do not consider forked processes as of any specific importance. They occur as "sports" in various species, and very often only the process of one side is forked. The lateral processes, $c$ and $d$, are those most commonly forked.

\section{Echiniscus, sp. ? (Plate XV. Fig. 7)}

Size moderate, $220 \mu$ in length; plates nine, V. and VI. joined, two pairs, two median. Lateral processes, $a, c, d, e-a$ a seta $120 \mu$ long, $c$ a seta of $90 \mu, d$ and $e$ short curved spines of $20 \mu$. Dorsal processes, over $c$ a seta of $90 \mu$.

Lack of information about surface texture, fringe and claws, makes identification impossible.

Habitat.-Among the moss Thuidium at the Hermitage, Mount Cook.

No affinity with any known species can be suggested. There is no species which has $c$ a long seta, and $d$ and $e$ short spines.

\section{Echiniscus, sp. ? (Plate XV. Fig. 8)}

Very small, length $130 \mu$; plates nine, V. and VI. joined, two pairs, two median. Lateral processes, $\alpha, c, d, e-\alpha$ a curved seta, $50 \mu$ long, with a small blunt "auricle" at its base, $c$ and $d$ short curved spines of 10 and $15 \mu, e$ a curved seta of $70 \mu$. The fringe of the fourth legs has short blunt processes. The claws were not seen.

The surface markings were small and regular, but could not be definitely stated to be either pits or papillæ. The posterior borders of the second paired plates and of plate VI. between the slits, showed an undulation like that of E. perarmatus (20) so that in all likehood the dots are papillæ.

This little animal has a very distinctive form. The paired plates have an anterior narrow portion forming a distinct roll, which shows on the outline, and the posterior edge diverges widely laterally. No other species besides perarmatus shows the dots on the edge of some of the plates.

It is very probably a distinct species, but the small size indicates that it may be a larva, and as the claws were not seen the study cannot be completed.

Habitat.-Among New Zealand moss, note of the locality lost.

There is no close relationship to any known species. In this section of the genus there is none which has $a$ and $e$ long setæ, and $c$ and $d$ short spines.

\section{Echiniscus, sp. ? (Plate XV. Fig. 9)}

Small, length $180 \mu$; plates nine, V. and VI. united, two pairs, two median. Lateral processes, $a, c, d$, and ${ }^{\circ} c-\alpha$ a curved seta of $70 \mu, c$ a long slender spine of $50 \mu$ with bulbous base, $d$ a short curved spine of $25 \mu, e$ a seta of $65 \mu$. Dorsal 
processes-over $c$ a broad-based curved spine of $35 \mu$-over $d$ triangular process $12 \mu$ long and $6 \mu$ across the base.

There are no notes as to surface markings, fringe, or claws, and so the species cannot be identified.

Habitat.-Among moss from the hills at Lyttelton, South Island.

The animal has a certain resemblance to E. oihonno. The relative proportions of the processes $a, c, d$, and $e$ are similar, and the dorsal processes correspond. It differs in lacking process $b$ and the small spicules at the angles of the plates.

\section{Milnesium tardigradum, Doyère (2)}

Found in several localities in the three principal Islands (North, South and Stewart Island). The short claws of several examples which were studied had three points each, except those of the first legs, which had two points each. The cyst was found in Mount Cook district. It was of oblong form, with rounded ends, and measured $230 \mu$ in length. The gullet and pharynx were present, but no claws or other recognisable organs.

One specimen from the Lyttelton Hills had the thick claws of the first legs unbranched, those of the last legs three-pointed, and of the second and third legs some with two and some with three points.

Ascends to an altitude of 5000 feet on Mount Wakefield, Mount Cook district.

\section{Genus-Macrobiotus, Schultze (42)}

\section{A : Spectes which lay Rough Eggs, Free \\ Macrobiotus hufelandii, Schultze (42)}

The commonest species in New Zealand, as in most other countries. It occurred in all three islands.

Wherever I have recorded $M$. hufelandii it is on the authority of Professor Richters, who has established Schultze's name for the water-bear which is commonest in Europe, and apparently almost everywhere else.

Schultze's own description is insufficient to allow of the identification of the animal with any certainty.

The characteristic egg has been regarded as the best character for identifying Richters' hufelandii, but it is now known that other species have similar eggs (M. hufelandioides, see p. 138).

\section{Macrobiotus furciger, Murray (15)}

Habitat.-Near Auckland, Nortb Island; shores of Lake Wakatipu, South Island. Identified by the eggs. 
This is one of the most interesting species found in New Zealand. Its distribution is peculiar. So far as our knowledge goes it is solely a sonthern species. It is found in a number of islands in the Cape Horn region, from Tierra del Fuego to the Antarctic Continent at Graham Land (Richters, 38). It was discovered by the Scottish Expedition in the South Orkneys. New Zealand is the lowest latitude recorded for it. Its known range is from about $36.30^{\circ} \mathrm{S}$. (near Auckland, N.Z.) almost to the Antarctic Circle.

It has been considered as a southern representative of $M$. hufelandii. In most of the localities it is not associated with that species-it takes its place-only in New Zealand and Tierra del Fuego have the two species been found together. A peculiarity in its distribution is its absence from the Victoria Land region of the Antarctic, though it is so abundant on the other side of the continent.

\section{Macrobiotus echinogenitus, Richters (27)}

In the South Island only. As we learn more about Tardigrada it appears that there are several species which have stellate eggs, more or less resembling those of M. echinogenitus, some of them probably not to be distinguished from them unless they contain well-grown embryos. The separation of some of these (for example, M. areolatus and $M$. harmsworthi) makes it easier to understand $M$. echinogenitus itself, which formerly seemed to vary to such an extent that it was difficult to get a clear conception of it. M. areolatus, and some related species not yet described, have eggs the surface of which is reticulate. The shells are double-skinned and the space between is divided by septa into hexagonal chambers. From these hexagons the processes spring, at such distance apart that they are always separated by the width of one cell.

M. harmsworthi has the egg processes close together, and the claws united as in $M$. hufelandii (Richters). The true $M$. echinogenitus has the egg-shell without reticulation, the conical processes almost or quite close together, and the claws joined at the bases only. Further study is necessary to clear up the whole group satisfactorily (see p. 89 , footnote).

\section{Macrobiotus harmsworthi, Murray (19)}

South Island and Stewart Island. The egg cannot be distinguished from some forms of those of $M$. echinogenitus. In examples from the Mount Cook district the identity was established by finding eggs in the body, which, when freed from the enclosing membrane, showed the close-set acuminate processes. 


\section{Macroliotus montanus, sp. n. (Plate XV. Figs. 10a-10d)}

Specific characters.-Large, brown; gullet wide; pharynx with three short rods and a "comma"; claws of hufelandi type, united for half their length, those of each pair equal and placed side by side, but only one with a strong supplementary point; egg spherical, covered with hemispherical processes, which almost meet at their bases.

Detailed description. - Length about $500 \mu$ and upwards: diameter of egg, over the processes, 75 to $80 \mu$. Old examples are deeply coloured with a dull brown pigment similar to that of M. hufelandii. The clarvs are thick and strong, and are nearly equal: in most species of the hufelandi group they are more or less unequal, often markedly so. The gullet is wide, and the teeth strong and curved; the end of the gullet in the pharynx expands into a prominent flange, beyond which the apophyses are fixed. The three thickenings in the pharynx are just about equal in size; they are twice as long as broad, and are rounded at the ends; the "comma" is rather an obscure one.

Habitat.-Among moss gathered by Dr: Mackay on the Nun's Veil Mountain, in the Mount Cook district, South Island, at an elevation of about 6000 feet, on the occasion when that peak was ascended for the first time, December 1907.

Remarks.-M. montanus is one of a large group of species, closely related to M. hufelandii. All of them possess wide gullets and strong teeth. The pharynx has either three distinct rods, or the two next the gullet are united, usually showing traces of their component rods. The claws are united for a considerable distance, usually half-way or more, and one of each pair has one or two supplementary points. The eggs are spherical and are ornamented with processes of various form.

The majority of the species have eggs very different from those of $M$. montanus. It is only necessary to compare it critically with one or two species which approach it very closely. Those are $M$. meridionalis, Richters (40), and M. polaris, Murray (see the preceding section on Antarctic Tardigrada in this paper, p. 98).

According to Professor Richters, M. meridionalis has the processes on the egg nipple-shaped, which he explains in a letter as being a hemispherical base surmounted by a narrower portion. This form of egg I know from the Scottish mountains, though we did not find it in the Antarctic.

The egg of $M$. polaris differs markedly from both. The surface of the shell is reticulate, like that of $M$. areolatus (see Canadian Tardigrada, p. 167 of this paper). The double shell encloses a series of compartments, showing as polygons at the surface. From certain polygons arise the processes, at such distance apart that they are separated always by one polygon. The processes vary from round to acuminate. The polygons are relatively much smaller than in $M$. areolatus. $M$. polaris has moreover, much more slender and very unequal claws, and the gullet is relatively narrower. $M$. montanus was found to be alive after the moss containing it had been 
dry for two and a half years. Only a small proportion of the individuals revived when the moss was moistened. The relation of the egg to the animal was demonstrated by the presence in some of them of young in which the pharynx and claws could be seen.

Eggs of Macrobiotus having close-set processes, nearly or quite hemispherical, have been figured by Richters and myself. In his "Eier der Tardigraden" (32), Plate V. Fig. 4, Richters figures one such as apparently a variety of $\boldsymbol{M}$. echinogenitus. In "Scottish Alpine Tardigrada" (14), Plate IH. Fig. 10, I show an egg which in all probability is that of $M$. montanus. A similar egg occurred in Nova Zemblil, and is figured in "Arctic Tardigrada" (19), Plate XLV. Fig. 4.

According to Doyère (2), confirmed recently by Richters in a letter, $\boldsymbol{M}$. oberhïuseri has an egg of similar form, with rounded processes.

\section{Macrobiotus intermedius, Plate (23)}

In many localities in the South Island; Hills at Lyttelton, Otira Gorge, near Lake Wakatipu; Mount Cook district, at an altitude of 5000 feet on Mount Wakefield; near Auckland, North Island.

'The eggs were found near Lyttelton. They had not the typical top-shaped processes, expanded upwards. They were narrower at the top, like truncate cones, of a lieight equal to the breadth of base, and with a very slight indication of expansion at the top. The processes were separated by spaces rather greater in diameter than their bases. The exposed surface of the shell between the processes was finely papillose.

Professor Richters informs me in a letter that he knows a variety of $M$. intermedius which has processes very like those of $M$. hufelandii. This variety I have also seen (see Australian Tardigrada, p. 139, in this paper). The variety from Lyttelton is like it, but the processes are shorter, and not expanded into a disc above.

\section{Macrobiotus dispar, Murray (16)}

Habitat.-Many localities in the South Island; a pond on the Moraine of the Muiller Glacier; on the Vegetable Sheep (Haastia), Mount Wakefield, elevation about 5000 feet; on the Nun's Veil peak, elevation 6000 feet (collected by Dr. Mackay) ; among tree-moss fiom the moist bush of the west coast. The simplex condition also occurred.

It is curious that, though usually dwelling in ponds, the species occurred only once in a pond in New Zealand. In all other instances it was got among moss, or moss-like vegetation (Haastia).

The examples from the Nun's Veil had the two dorsal processes of the type, which are often lacking. 
B : Species which lay Thick-sirleled Eggs, witi Embedped Rons

Macrobiotus arcticus, Murray?

Habitat. - Mount Cook district, South Island.

In the absence of the egg there is some doubt about the identification. The claws are of the Diphascon type. Apart from M. oberhäuseri, which is easily distinguished by the colour and the pharynx, there are very few species having claws of this type, and $M$. arcticus is the commonest of them.

\section{C : Species which lay Smooth Eggs in the Cas' Skin}

Macrobiotus nodosus, Murray (20)

Habitat.-Near Gisborne, North Island; Macquarie Islands.

The species was collected by the expedition in the Macquaries, but it had been previously found in moss from Gisborne, given to me by Mr. D. J. Scourfield. Its distribution is peculiar. It is known in Africa, New Zealand, the Macquaries, and Fiji.

\section{Macrobiotus sattleri, Richters (26)}

Habitat.-Hills beside Lake Wakatipu, South Island.

\section{Macrobiotus papillifer, Murray (12)}

Habitat.-On Myriophyllum in a torrent fed by melting snow, Black Birch Creek, Mount Cook district, South Island.

\section{Macrobiotus ornatus, Richters (24)}

Habitat.-Among bog-mosses, near Birch Hill Creek, and Myriophyllum, Black Birch Creek, Mount Cook district. In the latter place a cyst was found.

\section{Macrobiotus annulatus, Murray (12)}

Habitat.-Birch Hill Creek, and in the bush of the west coast, near Westport, South Island. At Birch Hill Creek it was abundant, but it was never seen carrying the eggs in the characteristic way. The examples from Westport had the papillæ very small.

Macrobiotus, sp. ? (Plate XV. Fig. 12)

Macquarie Islands. A large species with claws of the Diphascon type. It could not be identified because it was in the condition known as simplex (i.e., it had no 
teeth and no rods in the pharynx). It is pretty certain that it is distinct from all known species. The position of the pharyngeal bulb indicates that it is a Macrobiotus, not a Diplascon. There are only a few species having claws of the Diphascon type, and none of them have such strong claws as this animal. They more resemble those of some of the larger northern species of Diphascon, such as D. spitzbergense (27). The length was $550 \mu$.

\section{Diphascon chilenense, Plate? (23) (Plate XV. Figs. 11a, 11b)}

This species is noted from the Mount Cook district and from Stewart Island. It is recorded as doubtfully $D$. chilenense on account of the characters of the claws, which appear to be intermediate between the true Diphascon and the hufelandi types. The two pairs are not very unequal in size, and the claws of each appear to be united for some distance above the base. As the animal was a very small one, and the claws relatively very small, it could not be satisfactorily determined whether the structure of the larger pair was essentially that of the Diphascon type, which is shown in Fig. 12 on the same plate.

The pharynx (Fig. 11a) has four round nuts in each row of thickenings, besides the apophyses on the end of the gullet. This seems to be one more than in any other Tardigrade, unless we regard the fourth nut as homologous with the "comma." Plate figures four nuts, but does not show the apophysis.

The example here figured was obtained by Dr. Mackay from a height of about 6000 feet on the Nun's Veil, a peak nearly 9000 feet high.

\section{Diphascon alpinum, Murray (14)}

South Island only (Otira Gorge). Though discovered in Scotland, the species is best known as a southern and Antarctic species. It occurs on both sides of the Antarctic, on the Continent at Graham Land, on the adjacent islands, and also in Victoria Land.

\section{Diphascon scoticum, Murray (11)}

In Stewart Island only. The species is found in both Polar Regions and in several places between. In the north it attains a high latitude in Spitsbergen and Franz-Josef Land. In the south Richter's has found it in Possession Island (recorded as $D$. crozetense), and in the South Shetlands. It is also in Australia, Hawaii, and Canada.

\section{Remarks on the Tardigrade Fauna of New Zealand}

Its composition.-For a country of such extent, so isolated, and offering such a variety in climate and conditions, the Tardigrade fauna appears poor in species, and 
remarkably deficient in peculiar forms. It cannot, of course, be supposed that our knowledge of the fauna is nearly adequate to permit of definite conclusions on such points, but it might be expected that in an examination extending over two months, during which a great variety of localities were visited, we would have detected signs of a rich fauna or of peculiar forms, if the fauna were rich or peculiar. Further work may yet bring such forms to light.

Altogether 25 species were observed, of which 21 were identified. These were 4 species of Echiniscus, 13 of Macrobiotus, 1 of Milnesium, and 3 of Diphascon. The unidentified species were 3 of Echiniscus and 1 Macrobiotus. Two species, an Echiniscus and a Macrobiotus, are described as new species.

About one-half of the species are common and widely distributed. The others are in varying degrees local, and several have a very peculiar distribution.

The accompanying table of local and general distribution, shows the relation of the Tardigrade fauna to that of other parts of the world.

Distribution : Local and General

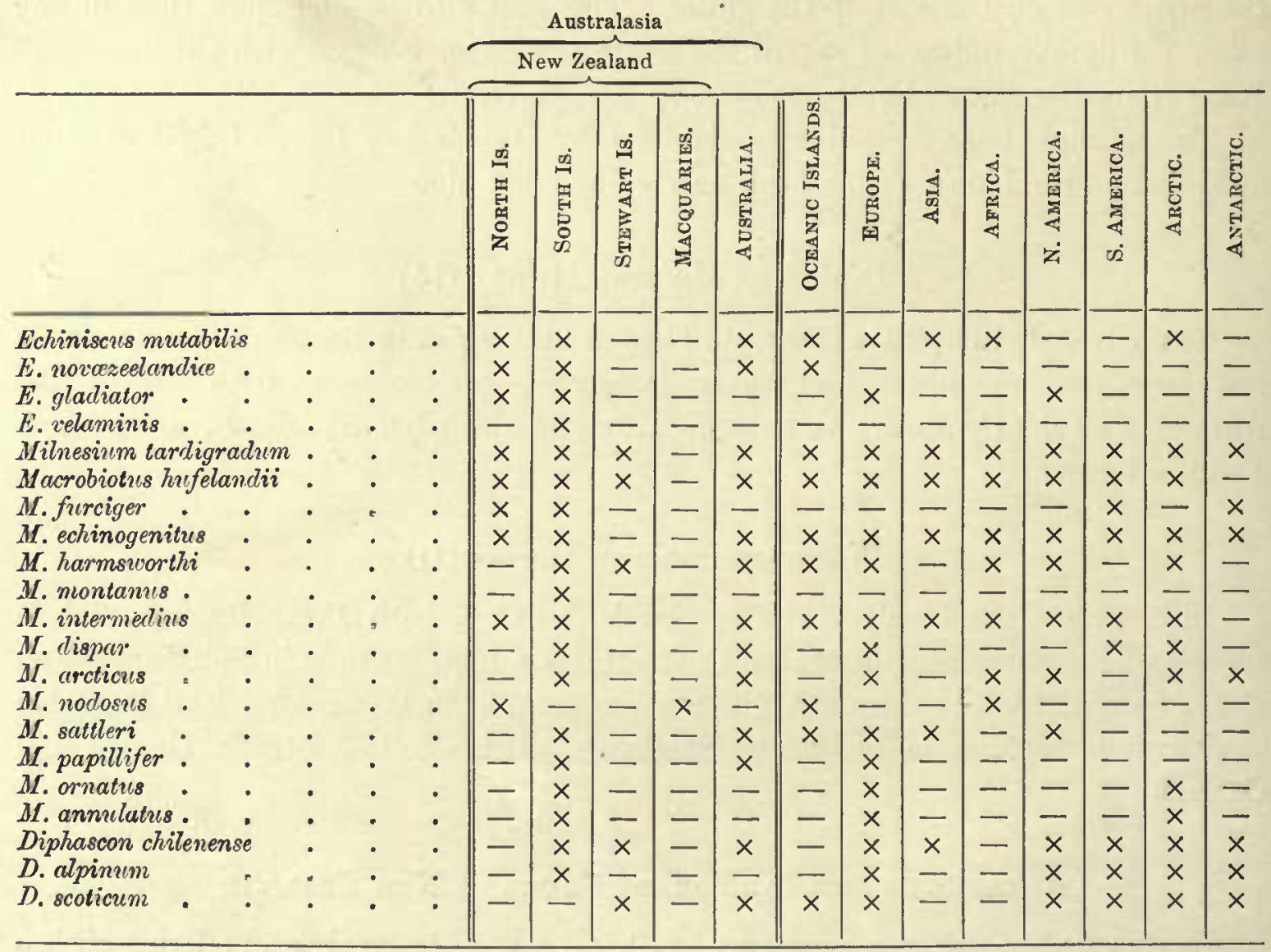


The foregoing table shows the distribution of the New Zealand species over the world. For this purpose the surface of the globe is divided into nine great areas, being one for each of the continents, for the Arctic and Antarctic regions, and for Australasia. The islands adjacent to the continents are included with them, New Zealand is included with Australia, but Oceanic Islands have a column to themselves. The group of the "Oceanic Islands" is unsatisfactory, as the only character which they have in common is their isolation. The group is formed to gather up some odds and ends of Tardigrade records from all over the world.

For the local distribution the Australasian column is subdivided into five subordinate columns.

In compiling the table I have used the published papers of Richters, Plate, and others, and for some regions (S. America, Africa) I have used unpublished notes of my own. Many records may have been overlooked, but in any case the whole aspect of the facts is liable to be changed at any moment by fresh work in any of the regions.

As our knowledge stands, it appears that of the 21 identified species 16 are also found in Europe, 13 in Australia and the Arctic Region, 11 in N.America, 9 in S. America, 10 in the Oceanic Islands, 8 in Africa, 7 in the Antarctic and Asia.

These proportions indicate probably rather the amount of work done in the different regions than actual facts in distribution. This is especially likely to be true in the case of Europe, where water-bears were first studied, and most of the species discovered.

Nevertheless, for what the facts are worth, the table shows that temperate New Zealand has a closer correspondence with temperate Europe than with any other country. In has as much affinity with the Arctic Region as with its nearest neighbour Australia. It has least in common with the adjacent Antarctic (which doubtless means that the Antarctic is poor in species) and with Asia (which is very little known).

All the species which are common to New Zealand and the Arctic are also found in Europe. Of the New Zealand species which are also in Australia and in the Arctic, there are 10 species which are common to these two regions.

The range of the various New Zealand species works out as follows. Milnesium and $M$. echinogenitus are in all 9 columns, $M$. hufelandii and $M$. intermedius in 8,D. chilenense and D. scoticum in $7, E$. mutabilis and $M$. arcticus in 6, M. harmsworthi, M. sattleri, and D. alpinum in 5. The others must be considered local.

E. novezzeelandice is known only in the three localities, New Zealand, Australia, and Hawaii, all widely separated. M. furciger is a southern species, occurring in New Zealand, S. America, and the Antarctic. Several others have no continuity in their range, as at present known. $M$. nodosus is in New Zealand, Fiji, and Africa; E. gladiator in New Zealand, Europe, and N. America; M. papillifer in BRIT. ANTARCT. EXPED. 1907-9. VOL. $\lambda$. 
New Zealand, Australia, and Europe; M. ornatus and $M$. annulatus in New Zealand, Europe, and the Arctic. Two species only, E. velaminis and M. montanus, are not known except in New Zealand.

Any considerations which might be offered as to the possible origin and history of the New Zealand Tardigrade fauna will be reserved for the paper on Geographical Distribution, in a later number of this publication. 


\section{AUSTRALIAN TARDIGRADA}

On collecting in Australia.-On the return of the Nimrod from the Antarctic in the spring of 1909 nearly a month was spent in Australia in the collection of various fresh-water microscopic animals, chiefly Rotifera and Tardigrada.

In this work I was greatly assisted by some good friends in Sydney, Mr. E. G. Goddard, Mr. S. Johnston and Mr. T. Whitelegge, who guided me on excursions to various likely collecting-grounds in the neighbourhood. Without this friendly assistance the time might have been to a large extent wasted, as in a country so generally parched is 'Australia seems to be, mosses are not so much in evidence as in moister countries like New Zealand.

Only two of the Australian States were visited, New South Wales and Queenslaud. The inmediate neighbourhood of Sydney was not very productive. There is usually very little moss in the Eucalyptus bush, and when some is found it often yields few microscopic animals, or none. Some water-bears were got in moss from the National Park, near Sydney, and in the ponds in the Botanic Gardens some of the purely aquatic species were collected.

It was only in the mountain ranges, where a moister climate prevails, and mosses are more abundant, that many Tardigrada were obtained. T'wo mountainous regions in New South Wales were visited-the Australian Alps near the Victorian border, and the Blue Mountains near Sydney.

On the journey to the Alps, the last stage of which was by coach, although the road ran at a considerable elevation, and the air was cool, the country still seemed arid. The hard baked earth showed everywhere among the gum-trees, and no moss was visible. At the guest-house of "the Creel," altitude about 3000 feet, on the Snowy River, there was scarcely any moss except on the banks of the river. This moss was as unproductive as that gathered near Sydney, probably because it is dried for too long at a time.

With Dr. Mackay an ascent was made to the Hospice, a government guest-house in course of erection on the road to Mount Kosciusko, at an altitude of about 5000 feet. As we ascended from 3000 to 5000 feet the climatic changes which we passed through were surprisingly great for such a small difference of level. The first part of the way, from 3000 to 4000 feet, was through bush, which was dry and barren, the pasturage for the few sheep which we saw consisting of little isolated tufts of grass, separated by yards of bare earth. 
The bush was cheerful with the whistling and chattering of parrots of many sorts and sizes, and of crows and magpies. Sometimes an isolated gum-tree would be seen loaded with white cockatoos, lonking at a distance like blossom. As we approacher the 5000 feet level the signs of a moister climate gradually increased. Mosses appeared, and became increasingly plentiful. As we topped the rise, at somewhat over 5000 feet, we came out on a stretch of moorland, apparently covered with heather and familiar heath-plants and mosses. Dr. Mackay ran down and gathered some of the seeming heather and other plants. They were all strange and foreign, as was only to be expected. The purple-tipped heather was not a plant in bloon at all, but was something like Vaccinium with the young leaves purplish brown. The peat-mosses (Sphagnum) were genuine and proved that we had reached a temperate clime, where a rich harvest of water-bears and other animals was to be looked for, and this anticipation was not disappointed.

Dr. Mackay went on and ascended Mount Kosciusko itself, but as the journey was made on horseback there was no chance to gather moss on the highest point of land on the Australian Continent. A great deal of moss was collected on lesser peaks, between 5000 and 6000 feet in height. The mosses afterwards yielded many water-bears, including two interesting species which are new to science (Echiniscus pulcher and Macrobiotus aculeatus).

On the trip to the Blue Mountains Mr. Goddard kindly accompanied me as guide. It was a hurried visit, as only two days could be given up to it. At Katoomba, where we stayed, at an elevation of something like 3000 feet, the air was invigorating, but the sun was hot, the earth was scorched, and no moss was to be seen. But $\mathrm{Mr}$. Goddard had good reason for selecting Katoomba. It lies close to the edge of the wonderful sunken valley, between 1000 and 2000 feet in depth, bounded by vertical precipices. Little gullies, leading to the valley bottom, have been utilised for the making of stairways, by which access is now easy. In these shady gullies there are trickles of water and plenty of moss, including even Sphagnum and Loucobryum (or a plant which looks like it).

On the day of our arrival we descended one of the stairways, some 2000 steps, and, after traversing a part of the bush in the valley, ascended near the Falls of Leura. The trees in the valley, as well as boulders and rocks, were often festooned with slender hanging branches of a pleurocarpous moss. Returning home, a first examination of the moss was made. On glancing at the field of the microscope there immediately met the eye a very remarkable Bdelloid rotifer (Callidina mirabilis, described in a subsequent number of this publication) and several other strange beasts were discovered on this cursory examination, including some water-bears. It was an index of what we were to expect from the Katoomba collections. We had reached our best collecting-ground in Australia. For long afterwards the moss continued to produce good things whenever examined, and it was a year afterwards that the best find of all was made, a new generic type of Tardigrade, which has been 
named Oreella. It is essentially an Echiniscus which lacks the armature of protective plates, and has a soft body like Macrobiotus.

In Queensland there was only one day available for collecting. By the advice of Mr. Bailey, the veteran botanist, it was spent in the bush at the quiet little station of Eumundi, some distance north of Brisbane. The weather was very hot, and the bush was very dry. The prickly wires of the Rattan, as they sawed lines in the face, sometimes several at one time, were rather dangerous to the eyes, and often required a pause of several minutes as they were carefully picked off, one by one, before progress could be resumed. But here and there pendent pleurocarpous mosses hung from the trees, and with these I filled my pockets. In some little gullies, where a few pools of water indicated the existence of a stream in rainy weather, there were tufts of various mosses.

These mosses afterwards proved fairly productive, both of water-bears and rotifers. The experience with these Queensland mosses illustrates how local water-bear's are in their distribution, and the capriciousness of the method of collecting from mosses. For a long time the mosses from Queensland gave very meagre results, and at last, a year after gathering, a tuft in no way different-looking from the rest, produced water-bear's enough to make up quite a fair list for Queensland, including two interesting new species of Echiniscus.

Since my return to England, Mr. S. Johnston of Sydney has been good enough to send me freshly gathered mosses, which have afforded an opportunity of continuing the study of the Australian water-bears and other animals.

The region examined in Australia extends over about 10 degrees of latitude, from $27^{\circ} \mathrm{S}$. in Queensland to $37^{\circ} \mathrm{S}$. on the borders of New South Wales and Victoria.

Previous knowledge of Australian Tardigrada.-There is very little known of Australian water-bears. Whitelegge's "Invertebrate Fauna," 1889 (46), has no reference to the group. The only record $I$ have been able to find is in Richters' "Moosfauna Australiens," 1908 (37), in which he mentions the ubiquitous M. hufelandii as found at Katoomba, in the Blue Mountains.

\section{List of the Species Collected}

Echiniscus mutabilis, Murray.

E. novcezelandice, Richters.

E. pulcher, sp. n.

E. arctomys, Ehrenberg.

E. kerguelensis, Richters.

E. tessellatus, sp. n.

$E$. intermedius, sp. n.

E. spiniger, Richters.

E. duboisi, Richters.

E. blumi, Richters.

E. oihonnce, Richters.

Oreella mollis, gen. n., sp. $\mathbf{n}$.
Milnesium tardigradum, Doyère.

Macrobiotus hafelandii, Schultze.

$M$. echinogenitus, Richters.

M. areolatus, Murray.

M. larnisworthi, Murray.

M. hufelandioides, sp. $\mathbf{n}$.

M. occidentalis, Murray.

M. intermedius, Plate.

Mr. crassidens, Murray.

$M$. aculeatus, sp. $\mathrm{n}$.

M. dispar, Murray.

$M$. curcticess, Murray. 
MI. sattleri, Richters.

M. papillifer, Murray.

Mr. rubens, Murray.

MI. augusti, Murray.
M1. virgatis, Murray.

Diphascon chilenense, Plate.

D. scoticum, Murray.

Seven species not identified (5 Echiniscus, 2 Macrobiotus).

\section{Notes on the SPECIES}

Genus-Echiniscus, Schultze (43)

\section{A: Species having Segments V. and VI. Distinct \\ Echiniscus mutabilis, Murray (12)}

Common in all the localities visited, both in New South Wales and Queensland.

It is desirable that a correction should be made in this place in regard to all records which I have made heretofore of $E$. arctomys in various countries. All these records must be taken as referring to $E$. mutabilis. The error arose from a misunderstanding of $E$. arctomys, Ehr. That species was supposed by Richters to have segments V. and VI. separate, but V. was described as being a half-ring, not a pair, and there were no spines on the inner claws. E. mutabilis has V. paired, and there are small barbs, easily overlooked, on the inner claws. The differences are slight, as the separation of the third pair (segment V.) of plates in E. mutabilis is very obscure. If it is conceded that these differences are not of specific value, then Richters' records of $E$. arctomys may also refer to $E$. mutabilis, Murray.*

The true E. arctomys, Ehr. ["Mikrogeologie," $1854(4)$ ], is quite a different animal. It has segments V. and VI. united (see p. 128).

If it is sought to identify $E$. mutabilis with any of Ehrenberg's species it must be with E. suillus. The figure of that species is only a profile, and therefore not very satisfactory for identification. It is not clear if the last line crossing the trunk is the separation of V. and VI. or only one slit of the ordinary trefoil. If it is supposed that V. and VI. are separate, there remains another difference. Ehrenberg figures on the near fourth leg one very large curved spine at the base of the claws. This may represent the barb of the inner claws, though if so it is incorrectly drawn. In any case it is different from anything in $E$. mutabilis. A skin of $150 \mu$ contained three eggs of $50 \mu$ by $42 \mu$.

\section{Echiniscus novazeelandice, Richters (37) (Plate XV. Fig. 5)}

Near Sydney and at Katoomba, in the Blue Mountains, pretty frequent.

The figure on Plate XV. is drawn from an Australian example, in order to show some peculiarities which are commoner in that country. These are-the forking of

* Prof, lichters informs me in a letter that all his records under the name E. arclomys should be E. suillus, Ehr. 'The relationship of $E$. mulabilis to $E$. suillus requires further investigation. 
the dorsal spine, and the presence of little conical processes at thep ostero-lateral angles of IV. Occasionally these little cones occur also at segments II. and III.

Examples of 175 and $140 \mu$ had eggs, which measured $56 \mu$ by $40 \mu$.

Echiniscus pulcher, sp. n. (Plate XVIII. Fig. 34)

Specific characters.-Large, red; V. and KI. separate; three median plates; V. a narrow half-ring; pairs obscurely divided; lateral processes- $a$ a seta, $b, c, d$, conical knobs, $e$ a long seta; no fringe on fourth legs, inner claws with small barbs.

General description.-Length $300 \mu$, seta $e 100 \mu$. The four cirri near the mouth have conspicuous conical bases, the palps beside them are very large; seta $\alpha$ measures about $75 \mu$, and has a palp or auricle at its base. The plates may be regarded as eleven in number (the normal number is twelve in that section of the genus which has V. and VI. separate), but many of the divisions are obscure. The head and shoulder plates, and V. and VI., are quite distinct. The three median have the posterior edge distinct and rounded. The second and third median are divided by a median line ; their anterior edge is faintly marked, and between it and the pairs there is an area which may be regarded as belonging to either. $V$. is a very narrow band, with no sign of being a pair, and sharply separated from the plates before and behind. VI. is not distinctly trefoliate, but there are obscure lines where the cut of the trefoil would be, and those of the opposite sides appear to be joined. Seta $e$ springs not from the very edge of the plate but a little way up on the dorsal surface.

The animal is much flattened dorso-ventrally. The plates are very finely dotted with pellucid dots. The claws are slender and the small barb is very near the base. The legs are short.

The larva is unusually large, measuring $175 \mu$. It has two claws, and differs in no other respect from the adult. Eggs up to the number of nine have been seen in the cast skin, by far the largest number I have seen in an Echiniscus.

Habitat.-Among moss from the summit of a mountain, Pretty Point, in the Australian Alps near Mount Kosciusko, 6000 feet, April 1909. Very abundant in the tufts of one kind of moss, which has not been identified. Not known elsewhere. The skins with eggs were common, and a number of larvæ were seen.

There are about a dozen species in the section of the genus to which E. pulcher belongs. They have segments V. and VI. distinct. None of these species come near enough to pulcher to cause any difficulty in discriminating them. Only two of them possess seta $e$ (E. borealis and E. islandicus) and they differ conspicuously, having numerous long spines, lateral and dorsal, on the body.

E. imberbis (38) is most like E. pulcher, but the long seta is $d$, and segment $V$. is a pair and bears two dorsal spines. E. pulcher is the only species known to me which has plate $V$. decidedly as a half-ring, and not paired. 


\section{B : Species having V. and VI. Fused}

Echiniscus arctomys, Ehrenberg (3)

On technical grounds I identify an Australian species as Ehrenberg's arctomys, although not quite sure that it is mature. Ehrenberg's very meagre description, as far as it goes, fits the Australian animal. There are nine coarsely punctate plates, the seta $\alpha$ is of moderate length, there are no other setæo or spines on the body, and no fringe on the last legs, or barbs on the claws.

The dots in our animal appear to be pits. The lumbar plate is strongly faceted, having a central panel, two lateral, and one posterior, the lateral and posterior facets being separated by the clefts which make the trefoil.

The length of the animal is about $230 \mu$, exclusive of the fourth legs; seta $a$ measures about $50 \mu$, and the claws 12 to $15 \mu$.

Habitat.-Katoomba, Blue Mountains ; fairly plentiful.

As already pointed out (pp. 110 and 126), all my previous records under the name of $E$. arctomys are erroneous, and really refer to a form of E. mutabilis. This is the first record I lave made of the true arctomys, agreeing with Ehrenberg's description and figure.

According to the records E. arctomys is one of the most cosmopolitan of Tardigrada, but it is doubtful whether many of them refer to the true arctomys of Ehrenberg.

\section{Echiniscus kerguelensis, Richters (31) (Plate XVI. Fig. 13)}

Professor Richters, unfortunately, gives no figure of this species. From his description it appears to be distinguished from $E$. arctomys by the presence of a fringe on the fourth leg, and by the weaker granulation.

As in the absence of a figure of the species the identity is not quite certain, I here figure and describe fully the Australian form.

Description.-Total length, exclusive of legs, $225 \mu$, seta $a$ about $80 \mu$ long (which is longer than that of the Australian arctomys, but shorter than that of wendti). Plates nine, coarsely punctate with apparent perforations. The auricles at the bases of setæe $a$ are prominent and somewhat elongate. The mouth cirri and palps are normal. The plates of the pairs are each divided into two parts by a line which cuts off a narrow zone parallel with the anterior border. There are two median plates. The lumbar plate is trefoliate and is not faceted. The fourth legs are fairly long, and each has a blunt palp near its base. The fringe consists of narrow sharp spines. The inner claws have decurved barbs. The colour is red.

Habitat.-The Australian Alps of New South Wales, near the Victorian border, altitude 5000 to 6000 feet.

The occurrence of this Kerguelen species in Australia, one of the nearest masses 
of continental land, is not at all surprising, and at the high elevation at which it lived the climatic conditions might approximate nearly to those of the bleak southern island.

\section{Echiniscus tessellatus, sp. n. (Plate XVI. Fig. 15)}

Specific charcacters.-Small, yellow, plates nine, V. and VI. joined, coarsely papillose. Seta $a$ at base of head, very long. Shoulder plate divided into ten papillose facets, separated by plain bands; lumbar plate divided into six similar facets; the paired plates divided into three portions each by lines merely; two pairs, lumbar plate trefoliate. The lateral-ventral margins of the principal plates with a non-granular band, which in empty skins forms a glassy clear zone round the whole animal like a nimbus. Last leg with a spiny fringe, claws without barbs.

General description.-Length $200 \mu$, seta $\alpha 150 \mu$. The form is short and broad, relatively broader in the empty skin. The plain lateral marginal band of the shoulder, paired, and lumbar plates appears to be free from the body, forming a kind of projecting flange, which can sometimes be seen in the living animal, but is more pronounced in the empty skin. The papillæ are large hemispherical knobs, the coarsest known in an Echiniscus. The subdivisions of the shoulder and lumbar plates are not to be regarded as distinct plates; they are panels ornamenting the surface. The lumbar plate is faceted, having four surfaces, which meet at an angle - a central one, two lateral, and one posterior.

The papillæe are seen on the posterior margins of most of the plates, showing that the skin is there bent over.

The two-clawed larva is known, and skins with one or two eggs have been seen.

Many species of Echiniscus have the plates more or less subdivided. The plates most commonly divided are the pairs, which are often crossed by one or two plain bands, separating the plates into two or three papillose portions. Sometimes the median plates are divided. There is no other species known which has such clear divisions of the shoulder and lumbar plates. This character alone distinguishes it from all other Echinisci. Other good characters are the hyaline margin to the plates, the very long head setæe, and the very coarse granules.

Habitat.-Among moss from trees in the bush at Eumundi, Queensland, May 1909. Abundant in one tuft of moss.

\section{Echiniscus intermedius, sp. n. (Plate XVI. Fig. 17)}

Specific characters. - Small, hyaline or greyish. Mouth cirri with large conical bases. Seta $\alpha$ long; no other processes on the body. Plates nine; V. and VI. united; two pairs; three median; each divided by transverse line into two portions; lumbar plate not trefoliate. Plates covered with very wide shallow depressions, the margins 
of which nake a regular reticulation. No fringe on the fourth leg: a blunt palp at the base of the fourth leg; no barbs on the claws.

Detailed description.-Length, exclusive of fourth legs and head, about $150 \mu$; seta $a 40 \mu$. There is no trace of the red colour so generally chiuracteristic of Echinisci. The plates are the usual nine. The first and second median plates are each divided into two portions, of which the anterior is larger and has a rounded posterior border. The third median has a similar appearance, but the second portion is so obscurely separated from the lumbar plate that it may be reckoned as part of it. Under pressure there is no trace of division of the lumbar plate into a trefoil. This is a very unusual character. Though a number of species are figured without the slits, it is suspected that they may have been sometimes overlooked. They are often not visible in a dorsal view when the body is drawn together. The eyes are red.

Habitat.-Eumundi, Queensland; two examples.

Very similar animals in Hawaii and Canada show an interesting series of changes in the markings of the plates. In the type the reticulation is relatively large, the hexagons measuring 5 or $6 \mu$ in diameter; in the Hawaiian variety they are only 2 or $3 \mu$ in diameter; in the Canadian form no depressions or reticulation can be detected, but the plates are marked by extremely fine pellucid dots. These differences are of some importance, and probably indicate that the three forms have been long isolated.

In Queensland neither eggs nor larvæ were found. It would have been impossible to decide whether the specimens were mature, and the very small size would have led to the supposition that they were young. The Canadian and Hawaiian examples supplied what was lacking in our knowledge. In Canada the species was plentiful. Though no eggs were found, there were a number of larvæ. These have a distinctive form, especially of the head and the lumbar plates, which are quite different from those of other species, but more easily understood from the figure than from descriptions (Plate XX. Fig. 52b). In Honolulu the eggs were found. Skins with eggs were even smaller than the Australian examples, so it may be supposed that these were full-grown.

The peculiar faceting of the lumbar plate, so well marked in Canada and Hawaii, was not observed in Australia, but the two specimens studied were not in favourable condition for abserving such characters.

The species may be easily distinguished from all others yet known by the small size, large seta $a$, divided median plates, lack of red colour, and of trefoil.

The name intermedius does not indicate that the animal is supposed to be truly intermediate between the two great divisions of the genus (those having V. and VI. fused, and those having them separate). It shares some of the characters of both, without being genetically intermediate.

$E$. intermedius belongs to a small group of species which have no dorsal or lateral processes after the seta $a$ at the base of the head. There are about a dozen forms in 
the group. All of them differ conspicuously and need not be compared in detail. It is enough to say that no one of them has the median plates transversely divided, except the variety excrmatus of $E$. gladiator. That has large barbs on the inner claws of the fourth leg, the paired plates gape behind, and there are other points of difference.

\section{Echiniscus spiniger, Richters (28) (Plate XVII. Fig. 24)}

Habitat. - Among moss from the bush at Eumundi, Queensland.

This Australian animal is identified with Richters' species, despite some small differences, which do not appear to be very important. Richters' type has the four lateral spines, $b, c, d$, and $e$, nearly equal, and from 30 to $36 \mu$ in length; the dorsal plocess orer $c$ is a seta of $51 \mu$, and that over $d$ a curved spine of $48 \mu$.

The Australian form has the spine $b$ shorter, of 8 to $10 \mu$ in length; $c, d$, and $e$ of about $30 \mu$; the dorsal spines over $c$ and $d$ are short, of only 10 to $15 \mu$. The dorsal processes vary greatly in size, and may be absent. Many species vary in the same respect.

The teeth or spines of the fringe on the fourth legs are obtuse. The barbs of the inner claws of the fourth legs are very strong, and are placed farther from the base than in most species, resembling those of $E$. gladiator. The plates are marked with very fine pellucid dots. Richters says nothing as to the granulation.

Unfortunately Richters gives no figure of his species, but his description is such that the positions of the spines and setre can be definitely known, and a diagram of the animal can be constructed from it.

\section{Echiniscus duboisi, Richters (25) (Plate XVII. Figs. 19-20)}

Two varieties of this species occurred in Australia, neither of them agreeing closely with the type. That has the four lateral spines, $b, c, d$, and $e$, short, nearly equal, and finely spinulose; the dorsal spines smooth.

Description of the Australian varieties. Variety 1 (Fig. 19).-Size moderate, length about $250 \mu$, exclusive of the legs. Seta $\alpha$ is $80 \mu$ in length, and the "auricle" at its base is elongate (about $15 \mu \mathrm{in}$ length). The four lateral spines are of different lengths $-b$ is $25 \mu$ long, $c 46 \mu, d 50 \mu$, and $e 40 \mu$, but they vary considerably in different individuals. The dorsal spine over $c$ is very short $(12 \mu)$, and is smooth. It is inserted nearer the median line of the body than the postero-dorsal angle of the plate. The spine over $d$ is $50 \mu$ long, flat, and serrate on both margins.

There are two median plates, and a dotted band behind the second pair, which may be reckoned as a plate or not. 'The dots on the plates, which Richters describes as coarse granules, seem in our specimens to be pits or perforations, irregular in size, and some very large. Each plate of the pairs is divided into two parts by a broad plain band, on which there are no dots. The spines of the fringe on the fourth leg 
are narrow, acute, curved, and are separated at their bases. There are no outer or inner barbs on the claws.

Variety 2.-Smaller, length $190 \mu$. Seta $a$ not seen (only dead skins were examined). The three lateral spines ( $b$ is absent) are nearly equal, of 30 to $40 \mu$. They are usually strongly curved, and they bear few (three or four) large spinules, which are also curved. The dorsal spines over $c$ and $d$ are of similar length to the lateral spines. They are broad and flat, and are irregularly serrate or merely erose on the margins. The dots on the plates are like those of variety 1 . There is no note of the crossing of the paired plates by a plain band. Fringe and claws were not seen.

The middle lobe of the trefoil of the lumbar plate seems marked off from the anterior portion by a narrow band, interrupting the granules. This may be merely optical, as it often happens, when this part of the plate forms a panel set at an angle to the rest of the plate, that the thickness of the plate is seen in optical section, marked by two parallel lines.

Habitat.-Variety 1 common in the Blue Mountains and in Queensland; variety 2 Queensland.

The Australian varieties differ from the type in having the dorsal processes also serrate. Variety 1 is nearer the type; variety 2 lacks spine $b$.

\section{Echiniscus blumi, Richters (27) (Plate XVI. Fig. 14)}

Habitat.-Australian Alps, several examples.

Agreeing in the main with Richters' figure, there are some small differences of no great importance. I saw no third median plate, but that may often be hidden by the pair in front. The dots, which appear to be granules, are smaller and closer. The lumbar plate is not divided right across, as in Richters' figure, but simply divided by two slits into a trefoil. In this respect I believe Professor Richters now agrees with my interpretation.

Some of the setæ in the example figured have little curved branches, which I have seen in no other species except an undescribed Antarctic one. The straight spines on the outer claws of the fourth legs vary fiom one to three in number, as I have previously observed in E. granulatus. The largest example measured $400 \mu$ in length, exclusive of the fourth legs.

\section{Echiniscus oihonnce, Richters ? (27) (Plate XVII. Fig. 21)}

There are several points of difference from Richters' type which render this identification more than doubtful. The lateral process $c$ is reduced to a long spine : the dor'sal process over $d$ is elongated into a sharp spine of moderate length; the spicules at the bases of $b, c, d$, and $e$, were not observed. In the aggregate these characters are of some weight, but the most important one (the lack of spicules) is 
very difficult to be sure about, and I do not feel justified in separating a new species on a mere difference in the relative proportions of two processes.

In a subsequent chapter in this paper, on Canadian Tardigrada (p. 163) another form is recorded doubtfully as E. oihonna. Its divergence from the type has taken quite another direction. On any estimate of specific values these two extreme forms (the Canadian and the Australian) cannot be regarded as one and the same species, but we must learn more about the extent and the limits of variation among Echinisci before we shall know what to make of them.

Description.-Length $250 \mu$, exclusive of legs; seta $a 130 \mu, b 36 \mu, c 50 \mu$, $d 60 \mu, c 150 \mu$. Mouth cirri long and palps large. Dorsal processes, over $c$ a seta of $120 \mu$, over $d$ one of $30 \mu$. Plates nine, two pairs, two median. The dots are of moderate size, and appear to be pits. They are uniform in size and regularly spaced. The lumbar plate is trefoliate and divided into four facets, of which the posterior one shows obscure subdivision into two. The spines of the fringe are triangular and acute. The claws are large (actual measurement not noted) and the inner ones have decurved spines (barbs) a little way above the base.

Habitat.-Among moss, Australian Alps near the southern border of New South Wales, altitude 5000 to 6000 feet.

\section{Echiniscus, sp. ? (Plate XVI. Fig. 18)}

A large red animal (the figure is drawn from a small individual) with no dorsal processes. Plates nine, V. and VI. united, two pairs, two median. Lateral processes four setæ, $a, c, d$, and $e$, each $100 \mu$ to $150 \mu$ or even more in length. Auricle at base of seta $a$ exceptionally long (about $15 \mu$ ), palp near mouth very large. The markings on the plates are larger and smaller dots, which look like perforations. Each of the paired plates is divided into two dotted areas, separated by a plain undotted band. The fourth legs have a fringe of sharp spines, and the inner claws have small decurved barbs.

The texture of the plates, and the interruption of the paired plates by a plain band, are exactly as in $E$. duboisi (Plate XVII. Fig. 19) and E. spinulosus (Plate XIX. Fig. 38). These characters may be common to many species of Echiniscus, but species have not usually been examined with sufficient attention to the markings of the plates. The absence of dorsal processes is probably not a constant character.

Habitat.-Australian Alps, New South Wales, altitude 5000 to 6000 feet.

The lateral setre are the same in number as in $E$. testudo and some related species, but they are $a, c, d, e$, instead of $a, b, c, e$. E. velaminis has exactly the same setæe (Plate XV. Fig. 6), but differs in having two dorsal setæe at each side, in not having the paired plates clivided into two dotted areas, in having the auricles small, and no barbs on any claws. 


\section{Echiniscus sp.? (Plate XVII. Fig. 25)}

A small animal resembling that figured on Plate XVI. Fig. 18, and having the same number of lateral processes, but having also one dorsal seta on each side. The lateral setæ are $a, c, d$, and $e$. They differ greatly in length. The seta $a$ is $50 \mu$ in length, $c$ is $30 \mu, d 150 \mu$ (equal to the whole length of the body), $e 70 \mu$. The dorsal seta is over $c$ and measures $50 \mu$.

The plates are marked with obscure dots, the nature of which could not be made out. The fourth legs have a fringe of sharp spines, and the inner claws have decurved barbs of moderate size, which are farther from the base than usual. Colour pink.

Habitat.-Australian Alps, New South Wales, altitude 5000 to 6000 feet.

This animal has some resemblance to $E$. oihonnee, but it lacks the process $b$, and it has $c$ a spine and $d$ a long seta, whereas oihonnce has $c$ the seta and $d$ the spine. It also lacks the lateral spicules of oihonna.

\section{Echiniscus, sp.? (Plate XVII. Fig. 22).}

A large animal with two very long setre on each side, in addition to seta $a$ on the head. There are nine plates, V. and VI. united, two pairs and two median. The dots are large circles of uniform size and close together. The lateral setæ are $a, b$, and $c$; $b$ and $c$ are about $170 \mu$ in length. Over $c$ there is a dorsal seta also of $170 \mu$; over $d$ there is a flat spine of $25 \mu$ in length by 6 to $9 \mu$ across the base. An empty skin measured $270 \mu$ in length by $140 \mu$ in breadth.

The fringe has six to eight blunt rounded processes. There are no barbs on any claws.

This animal may be compared with E. muscicola, Plate, and E. spitsbergensis, Scourfield. Plate's description (23) is very meagre, and takes no account of the fringe, the barbs of the claws, or the surface texture of the plates. The setee are $a, b, c$, and $e$, and over $c$ there is a long dorsal seta. Our animal lacks seta $e$, and has an additional spine over $d$.

Richters (35) adds to Plate's description, noting the nature of the granulation, and that the inner claws are barbed. His description of the granulation fits our animal. When you focus high on the dots they appear as circles with central points; when you focus deeper they become hexagons.

Scourfield's description of E. spitsbergensis (45) is better, and he gives a figure. It has four setre, $a, b, c$, and $d$; it has a flat triangular process over $d$; the inner claws are barbed, and there is a fringe of rounded processes.

This Australian animal stands near to both E. muscicole and E. spitsbergensis, from the litter of which it only differs by one pair of setre and the lack of barbs on the inner claws.

IIalritat.-Australian Alps, New South Wales, altitude 5000 to 6000 feet. 


\section{Echiniscus, sp.? (Plate XVI. Fig. 16)}

Small; plates nine, V. and VI. joined, two pairs, two median. Lateral processes-a a curved seta of $50 \mu ; d$, a strong curved spine of $50 \mu$. Dorsal processes-over $c$ a strong curved spine of $30 \mu$. Dots of moderate size, regularly spaced. Fringe dentate, with few small points. Inner claws with somewhat strong decurved barbs.

The length is $200 \mu$, exclusive of the legs. - The nature of the dots is not apparent, whether granules or pits. The colour is red.

Habitat.-Australian Alps, New South Wales, altitude 5000 to 6000 feet.

It is unlike any known species, but it is probably immature and might acquire other processes as it grows.

\section{Echiniscus, sp. ?-larva (Plate XVII. Fig. 23)}

Description -Small, length $120 \mu$, exclusive of legs. Plates 9, V. and VI. united, two pairs, two median. Dots of moderate size, very regular, and appearing to be granules.

Lateral processes- $a$ and $e, \alpha$ a seta of $36 \mu, e$ a curved spine of $18 \mu$. Dorsal process-a short curved spine of $8 \mu$ over $d$. There is a fringe of small triangular teeth, and the claws of the fourth legs have large decurved barbs.

Habitat.-Among moss from the bush at Eumundi, Queensland.

It is usually impossible to assign a larva of Echiniscus to the species to which it belongs, although when a species occuis abundantly, without admixture of other species, and larve are found with it, there is a presumption that they belong to it. Some larvæ of species having very distinct characters (such as $E$. gladiator and E. reticulatus) can be recognised without difficulty. In this case no suggestion can be made as to the species.

\section{Oreella, gen. nov. (Plate XVIII. Fig. 26)}

Generic characters.-Head with ten processes, as in Echiniscus; body soft, not protected on back and sides by plates; teeth, pharynx, and claws as in Echiniscus.

Oreella has the soft body of a Macroliotus, with the teeth, pharynx, claws, and processes on the head as in Echiniscus. Minor differences from typical Echiniscus may be of merely specific value, and will be noted in the description of the only species at present known.

\section{Oreella mollis, sp. n. (Plate XVIII. Fig. 26)}

Specific cliaracters.-Small, hyaline, back and sides papillose; setre at base of head long, springing from the summits of large narrow conical processes, which also bear a little below the summit long narrow palps; cirri near mouth with small conical bases; anterior pair of processes narrow cones; the palps reduced to small 
hemispherical papillæ; no eyes; trunk terminating posteriorly in little median process; legs long, obscurely three-jointed; without fringe; claws all similar, without barbs; stomach brownish.

General description.-Length, up to $230 \mu$; the teeth are very short, and the pharynx nearly as broad as long. The processes on the head and mouth correspond in number and position with those which characterise Echiniscus, but they differ in several respects. In Echiniscus each of the principal setæ (or horns) of the head has at its base a separate triangular or oblong palp (or auricle). In Oreella this palp is borne near the summit of the papilla from which the seta springs. In Echiniscus the four processes near the mouth are all alike cirri, with minute conical bases; in Oreella the anterior pair are not cirri, but narrow cones. The palps seen in dorsal view between the two pairs of cirri are here reduced to very small papillæ. The body papillæ are low and rounded. They might be regarded as the rudiments of the armour-plating, but they are not confined to definite areas, except that they do not extend on to the ventral surface. Each leg consists of three joints, of which the first and third are short, and the middle one longer. The feet are slightly webbed, a membrane joining the bases of the claws. Beneath the skin an obscure irregular areolation is seen. The stomach consists of a few large cells, which contain darker brown spots. No mature eggs have been seen, but in some examples there appear to be two very young eggs, with granular contents.

Though in all essential features except the armour-plates very close to Echiniscus, there are several little points in which it differs from all known species of that genus. These are, the modification of the anterior pair of processes near the mouth, the elevation of the auricle on the same papilla which bears the seta $\alpha$ at the base of the head, the absence of eyes, and the little median "tail" which terminates the body.

Its movements are very slow.

Habitat. - Katoomba, in the Blue Mountains of New South Wales, altitude about 3000 feet. It was found in moss which had been dry for about a year. When moistened about fifteen examples were found, of which only a few regained activity.

Most of the genera of Tardigrada are closely related to the genus Echiniscus. Though no other genus may have the elaborate armour-plating which protects Echiniscus, all of them but Macrobiotus and Diphascon possess some of the numerous palps and cirri which adorn the head of Echiniscus. Several genera (Halechiniscus, Battilipes, Oreella) have the armature of the head almost identical with that of Echiniscus. Other genera have the processes more or less modified, or reduced in number (Microlyda [=Lydella], Echiniscoides, Tetrakentron, Milnesium).

Milnesium, which departs furthest from Echiniscus, has eight palps on the head which may be regarded as homologous with eight of the ten processes of Echiniscus. In Echiniscus itself the processes may be reduced in number, though any departure from the normal number is very rare.

All the exclusively marine genera, five in number, are related to Echiniscus. All 
of these have some spines on the body which may be homologous with the lateral and dorsal processes, especially two at the posterior extremity which appear to be the most constant, and are probably homologous with seta $e$ of Echiniscus. Even in the genus Macrobiotus certain species (M. dispar, M. aculeatus, and perhaps the group of species related to $M$. tuberculatus) have dorsal processes in pairs, which may be homologous with those of Echiniscus.

Oreella is nearer to Echiniscus than any of the other genera. It has all the ten processes occupying the same positions, and only slightly modified in detail. The teeth, pharynx, and claws are all as in Echiniscus. The only important difference is the lack of the armour-plates.

\section{Genus-Milnesium, Doyère (2)}

Milnesium tardigradum, Doyère (2)

Common in all the districts visited, in New South Wales and Queensland.

Mitnesium is the most thoroughly cosmopolitan of all Tardigrada.

In the Australian Alps a skin was found which contained ten eggs, each measuring $104 \mu$ in length.

\section{Genus-Macrobiotus, Schultze (42)}

\section{A : Species which lay Rough Eggs, Free}

\section{Macrobiotus hufelandii, Schultze (42)}

The commonest Tardigrade here as in most other places. Found in all the localities visited; eggs equally common.

\section{Macrobiotus echinogenitus, Richters (27) (Plate XVIII. Fig. 30)}

At Katoomba in the Blue Mountains, elevation 2000 to 3000 feet.

\section{Macrobiotus areolatus, Murray (19)}

At Katoomba in the Blue Mountains; only eggs seen. This species, which was regarded as a variety of M. echniogenitus, is described as a species among the Canadian Tardigrada in this paper, as in Canada material was got for a study of the egg, the young, and the adult. It can be identified from the egg alone.

\section{Macrobiotus harmsworthi, Murray (19) (Plate XVIII. Fig. 31)}

In the Australian Alps, near Mount Kosciusko, altitude 5000 to 6000 feet. Not to be identified with certainty from the adult alone or from the egg alone. It is necessary to find an egg containing a well-grown young, or an adult with ripe eggs in the body. In this instance the young was found in the egg.

BRIT. ANTARCT. EXPED. 1907-9. VOL. I. 


\section{Macrobiotus hufelandioides, sp. n. (Plate XVIII. Figs. 29a-29c)}

Specific characters.-Small. Claws of hufelandi type, very thick, the larger one of each pair with two strong supplementary points. Teeth slender, curved or bent. Gullet slender. Pharynx shortly oval, with three short rods in each row of thickenings. Egg-processes conical with expanded discoid tops.

Detailed description.--Length, $350 \mu$ and upwards. No figures noted for larger examples. The teeth are slender, and taper very gradually. They are bent at a very obtuse angle just after emerging from the guides, and again more abruptly near the furca. The gullet is scarcely more than one-third of the relative width of that of hufelandii. The three rods in the pharynx are about twice as long as broad, and have rounded ends. They are of nearly equal size. The first one, though clearly distinguishable from the apophysis, is apparently closely attached to the end of the gullet. There is no comma, or a very small and obscure one.

The stomach is brown, with darker brown patches. The fat-cells are 8 to $10 \mu$ in diameter. There are two dark eyes. The claws are very stout and strong; the lesser one considerably shorter than the other.

Eggs were found in the body which, when squeezed out and fieed from the surrounding membrane, were found to have processes like those of the typical hufelandii egg. The processes taper from a broad base, which is surrounded by a circlet of dots, and are abruptly expanded at the summit into flat discs. No eggs were found which contained embryos, but the establishment of the relation of the egg to the animal was made in the more satisfactory way. If an embryo with a slender gullet were found in an egg, apparently of hufelandii, it might be supposed that the young of that species had the gullet more slender (although I believe this is not so). When the eggs are got in a mature adult, however, there is no such doubt. The species occurred in two localities in the same district, confirming the first observations.

Habitat.-Australian Alps, near the southern border of New South Wales; at the Creel, altitude about 3000 feet, and on the summit of a peak near the Hospice on the road to Mount Kosciusko, altitude 5000 to 6000 feet.

The combination of an egg exactly like, and claws sufficiently like, those of $M$. hufelandii, with slender teeth and gullet, distinguishes the species from all others. It is impossible to say whether it is really very close to M. hufelandii, or has acquired the characters in which it resembles it independently. All the closest relations of $M$. hufelandii have very wide gullets and thick powerful teeth. One form of $M$. intermedius, which is not at all closely related to $M$. hufelandii, has similar egg-processes.

It has been known that some forms of M. hufelandii could not be positively distinguished from allied species, and the egg had to be relied upon for their separation. It was supposed that the egg, with its disc-topped processes with their basal circlets of dots, was unmistakable. 
There must now be added this additional worry to the troubles ot the student of water-bears, that when he finds an egg of the hufelandi type, he must get an embryo in order to complete the identification.

\section{Macrobiotus occidentalis, Murray? (Plate XXI. Figs. 54a-54e) \\ (See Canadian Tardigrada, p. 169 in this paper)}

In the Australian Alps there occurred, at an elevation of between 5000 and 6000 feet, an animal closely related to that which is described under the above name in a later section of this paper, if it is not identical with it.

It is a large animal of yellow colour, with dotted skin. The skin is double, with a clear fluid circulating between the layers. In the type this fluid contains numerous thin, hyaline rectangular plates, which are absent from the Australian form. There is a comma in the pharynx.

The species was described among the Canadian Tardigrada, as the eggs were found there, and the study completed.

No eggs like the Canadian ones were found in Australia.

An identical water-bear was got in Hawaii (see p. 155 and Plate XIX. Fig. 39.)

The curious distribution will be discussed in the Canadian section of this paper.

\section{Macrobiotus intermedius, Plate (23)}

Habitat.-Eumundi, Queensland.

This species is one of a group of three, very closely related, and most readily distinguished by their eggs. M. intermedius has an egg with short blunt processes. In the typical form these are expanded from narrow bases, and are thus somewhat top-shaped. Another form of egg is like a miniature of that of M. hufelandii. The processes taper from the base and are surmounted by disc-shaped or saucer-shaped expansions.

The egg of $M$. crassidens has very long slender processes, that of $M$. aculeatus has somewhat similar, but thinner and more scattered, processes. That animal is distinguished by the dorsal processes.

Sometimes the processes of the variety having eggs of the hufelandi type are irregularly furcate at the tips, recalling those of $M$. furciger and $M$. orcadensis.

\section{Macrobiotus crassidens, Murray (20).}

At Katoomba in the Blue Mountains, New South Wales, altitude 2000 to 3000 feet.

Macrobiotus aculeatus, sp. n. (Plate XVIII. Figs. 27a-27e)

Specific characters.-Size moderate; old examples densely pigmented; skin bearing 2-6 soft white conical dorsal processes in pairs on the segments over the 
second, third, and fourth pairs of legs; teeth slender, curved, gullet narrow, expanded in the pharynx; pharynx nearly round, containing apophysis, three very broad nuts, and an obscure "comma" in each row. Claws of the liafelandi type, slender, unequal in each pair, and united for half the length of the longer one. ligg small, covered with very slender undulate or curved processes, which spring from small conical bases, and are separated by interspaces greater than their own diameter.

General description.-Considered as one of the smaller Macrobioti, though individuals occasionally attain to a very considerable size. Length of an ordinary example about $300 \mu$. Only the very large individuals are strongly pigmented; those of moderate size are generally nearly colourless except in the stomach. The pigment is not in bands. There are usually two small dark eyes, but they are sometimes absent. The nuts in the pharynx are often broader than long. The first appears to be closely united to the gullet, though distinct from the apophysis. The dorsal processes can be seen in the young squeezed out of the ripe egg.

$M$. aculeatus is very closely related to $M$. crassidens, Murray (20), and to $M$. intermedius, Plate (23). The spines distinguish it from these species. It las no close affinity with $M$. papillifer, Murray (12), and $M$. sattleri, Richters (26), which have somewhat similar spines. They belong to a different section of the genus. The close relationship to $M$. crassidens is further indicated by the similar egg. They are of almost identical size, but that of $M$. crassidens, which has been recently discovered in Africa, has spines with larger bases and no spaces between them.

Habitat.-Among moss; the type with six spines in the Australian Alps near Mount Kosciusko, at an elevation of 5000 to 6000 feet; a variety with only the last pair of spines (Fig. 27e) at Katoomba in the Blue Mountains of New South Wales.

\section{Macrobiotus dispar, Murray (16)}

Habitat.-Ponds in the Botanic Gardens, Sydney. One of the two aquatic species obtained, the other being $M$. curgusti.

\section{B: Eggs with Thick Shells, Enclosing Rods}

Macrobiotus arcticus, Murray? (19)

Habitat.-Katoomba, in the Blue Mountains.

Without the egg the identification of $M$. arcticus cannot be absolutely certain, but the animal agreed in all other characters with this species.

It measured $300 \mu$ in length, the claws were of the Diphascon type, the gullet was slender and expanded in the pharynx, which contained two rods of nearly equal length and about $2 \frac{1}{2}$ times as long as broad, and no "comma." 


\section{C: Smootit Eggs laid in the Cast Skin \\ Macrobiotus sattleri, Richters (26)}

Habitat.-Tree-moss, Eumundi, Queensland.

Professor Richters neither describes nor figures the pharynx of this species. He probably found it in the "simplex" condition. The structure of the skin is very distinctive, and taken in conjunction with the divergent claws there would seem to be little difficulty in recognising the species, without considering the pharynx. There is reason, however, to believe that more than one furm has skin like sattleri and also divergent claws. One of them is figured in Scottish Tardigrada (18) Plate IV. Fig. $26 b$.

The Australian form has a different pharynx. There are two rods-the one next the gullet about two and a half times as long as broad, and slightly constricted in the middle, making two equal lobes; the second about twice as long as broad. There is no "comma." The claws are unequal, and are joined at the bases only. They diverge at less than a right angle. The long claw of one pair is longer than that of the other, and has a small supplementary point. Eyes are present.

\section{Macroliotus papillifer, Murray (12)}

Habitat.-Among moss from the Australian Alps, altitude 5000 feet, New South Wales.

\section{Macrobiotus rubens, Murray (17)}

Habitat.-At Katoomba, in the Blue Mountains, altitude between 2000 and 3000 feet, abundant.

It was not seen alive. The fat-cells still retained the red colour. The largest example measured $450 \mu$ in length. No comma was seen in the pharynx, but it is often difficult to see in dead animals.

The distribution of the species, so far as known, is peculiar. Discovered in India (17) at an elevation of 6000 feet, Professor Richters afterwards found it in Ascension and Sumatra (39). It now reappears in Australia, where the eggs as well as the adults were found.

\section{Macrobiotus augusti, Murray (18)}

Itabitat.-Ponds in the public parks, Sydney 


\section{D : EgGs Unknown}

Macrobiotus virgatus, Murray? (Plate XVIII. Fig. 28)

See description in Canadian Tardigrada, p. 173, and figure (Plate XXI.

Figs. $55 \alpha \div 55 c)$.

The Australian form is not fully studied, but it agrees with the type in the important characters of the pharynx and claws. The teeth are straight for threequarter's of their length, then very abruptly bent outwards. There is some individual variation in this respect. The pharynx possesses a minute comma, which is not noted for the type. There are no eyes, while the type has eyes. There are no notes as to the colour of the Australian examples.

Habitat.-Katoomba, in the Blue Mountains, New South Wales.

\section{Macrobiotus, sp. ? (Plate XVIII. Figs. 32a-32c)}

Description.-Large, $450 \mu$ in length. Gullet slender; teeth slender, abruptly bent towards the furca. Pharynx shortly oval, with two rods in each row, and no comma. The first rod is twice as long as the second, and about four times as long as broad. The claws are V's, or more properly U's, united at the base only. The pairs are unequal, and one claw of each pair is longer. The longer claws have two fine supplementary points. Each foot has a prominent boss near the extremity. The skin is finely granular.

Habitat.-Katoomba, Blue Mountains, New South Wales.

This appears to be a very distinct species, but till more specimens are examined, and the eggs found, it is not desirable to name it. Plate figures such bosses on the legs of $M$. oberhïuseri.

\section{Macrobiotus, sp.? (Plate XVIII. Figs. 33a-33c)}

A small animal, resembling $M$. hufelandii in claws and pharynx, yet with several points of difference.

Description.-Very small ; the example studied measured only $120 \mu$ in length. The gullet is wide, and has a very prominent rim on the end in the pharynx. The teeth are strongly curved. The pharynx is shortly oval, and has two rods in each row and no "comma." The rod next the gullet is about three times as long as broad, the second rod about twice as long as broad. The claws are slender, and are united for rather more than half their length. The two claws of each pair are slightly unequal. Eyes are present.

Habitat.-Eumundi, Queensland.

Although very similar to $M$. hufelandii, the characters of the pharynx are or some value. It would be necessary to find the egg in order to settle the position of the animal. 
Genus-Diphascon, Plate (23)

Diphascon chilenense, Plate (23)

In the Australian Alps near the borders of New South Wales and Victoria, altitude 5000 to 6000 feet.

\section{Diphascon scoticum, Murray (11)}

Synonym.-D. crozetense, Richters (35).

At Katoomba, in the Blue Mountains, elevation 2000 to 3000 feet, frequent.

\section{Remarks on the Australian Tardigrade Fauna}

Its composition.-Thirty-one species have been recognised and named, but a good many others have been observed, though they could not be named. The list includes eleven species of Echiniscus, one of Milnesium, two of Diphascon, sixteen of Macrobiotus, and Oreella, a new genus.

This 'Tardigrade fauna shows many peculiarities. It is, of course, very imperfectly known, but taking the facts as they stand, the following are points of interest. Though much less carefully worked than New Zealand, the Australian list is longer than the New Zealand one.

It presents much greater peculiarity. Only about half the species are common or widely distributed. There is one interesting generic type, somewhat intermediate between Echiniscus and Macrobiotus, at present unknown elsewhere. There are six new species, of which five are as jet only known in Australia, and there are several the distribution of which is very restricted or very peculiar.

The list is the longest one compiled for any one country during the expedition. In Australia we got 38 species, of which 31 were identified. Canada comes next with 31 species (23 identified), then New Zealand with 25 species (21 identified).

The subjoined table shows the distribution of the Australian water-bears over the world, in 13 columns, 4 for the principal localities visited in Australia, and 9 for the rest of the world.

The local distribution is remarkable on account of the very little indication there is that the species are to any extent generally distributed in Australia. No fewer than twenty-three out of the thirty-one species occurred in only one of the four localities visited. Those localities certainly offer very different climatic conditions. 'The contrast between the cool moist mountain-tops of the Alpine region at elevations of from 5000 to 6000 feet above the sea, and the low-lying parched bush of subtropical Queensland, is very great. The Blue Mountain region is of intermediate character, and it was in it that the greater number of the species, and the most peculiar species, were obtained. 'That the distribution is very local, even in any one district, is clearly shown by our experience in washing the moss. For a long time 
Distribution: Local and General

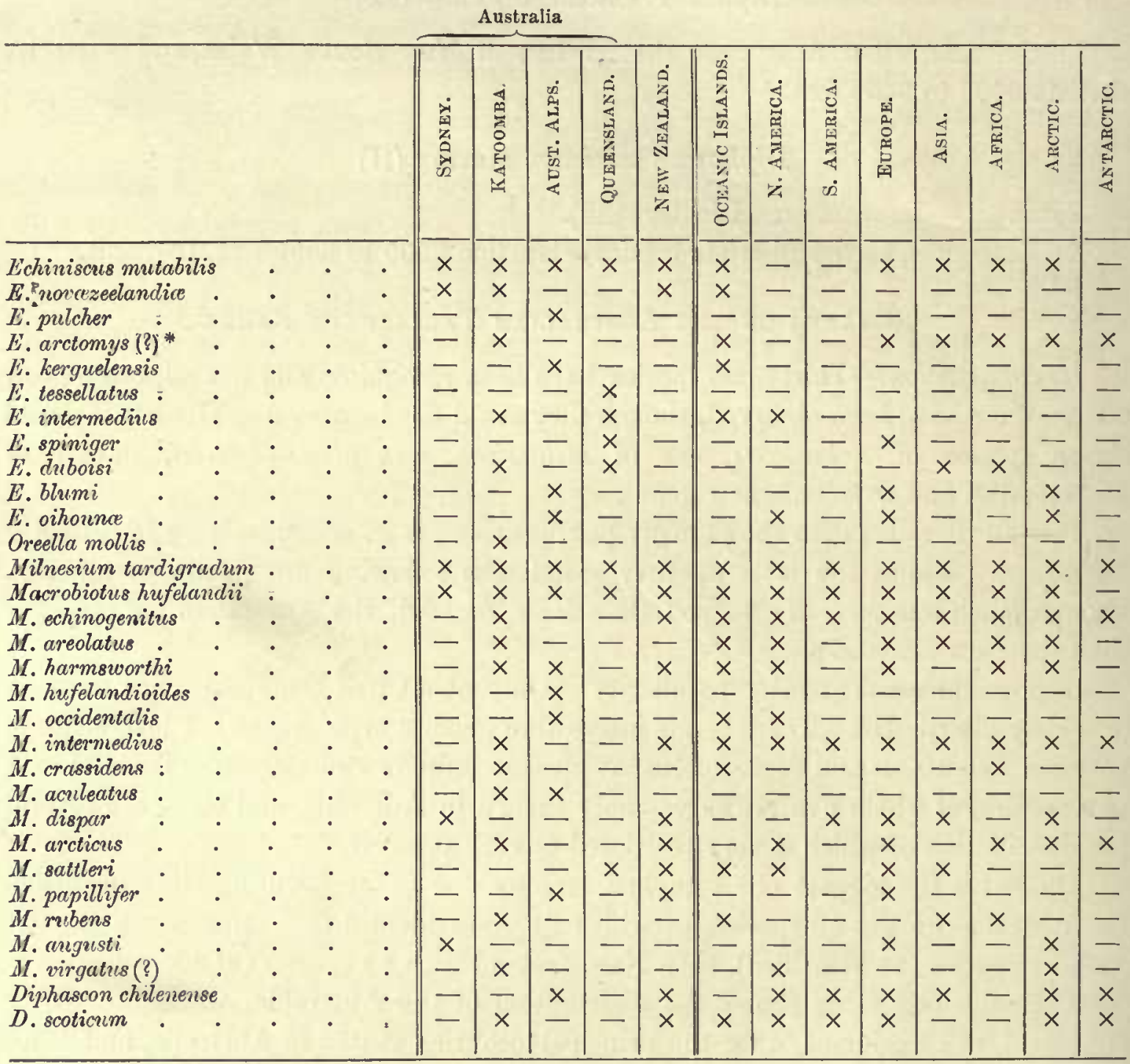

there was very little got in the Australian moss, and then, a year after gathering some little tufts proved very productive.

About a dozen of the species are widely distributed or cosmopolitan. These occur in six or more of the principal columns in the table. Some are more local, and a few have a very restricted range. E. novcezcelandice is at present only known from Australia, New Zealand, and Hawaii, E. kerguelensis occurs only in Australia and Kerguelen. 'Two species, E. intermedius and M. occidentalis, are on both sides of the Pacific, in Anstralia and British Columbia, and also on islands in mid-Pacific. E. blumi is found in Australia, Europe, and the Arctic, E. oilomna in the same three * All the records of li. arctomys are wrong, except for Austrulia (sce p. 126 and footnote). 
regions, and also in Canada. M. crassidens is only known in Australia, the Pacific Islands, and Africa; M. papillifer in Australia, New Zealand and Europe; M. virgatus in Australia and Canada; M. rubens in Australia, India, and some islands.

The list of Australian Tardigrada corresponds with those of other regions in the following proportions: Of the 31 species, 18 are known also in Europe, 16 in the Oceanic Islands, 15 in the Arctic, 14 in N. America, 13 in New Zealand, 12 in Asia and Africa, 7 in S. America and the Arctic.

That there is so nearly the same degree of correspondence with such diverse regions as New Zealand, Canada, Asia, and Africa, is an indication of how little proximity counts in determining relationship, and the number of rare species which are common to Australia and various distant countries gives some idea of the com. plexity of the problem of the origin of the Tardigrade fauna of any one land.

One-sixth of all the species are peculiar to Australia. This is a large proportion, but a greater number of species, and a much higher proportion of them, are peculiar to Canada. The degree of peculiarity is much higher in Australia than in Canada, as the list includes one new genus, and the species are more strongly marked ones. It is evident that at the present time we know far too little to come to any definite conclusions as to the origin of the Australian Tardigrada, and their interrelationships with those of other countries. 



\section{TARDIGRADA OF SOME PACIFIC ISLANDS}

\section{FIJI : ISLAND OF VITI LEVU}

On collecting in Fiji.-The collecting in Fiji was done under unfavourable conditions. The steamer stayed only for a few hours, and there was no time to get advice as to the most suitable localities in the neighbourhood of Suva. It was oppressively hot, and everything seemed burnt up by the sun. I first tried the shore road, skirting a mangrove swamp for some distance, but found no moss or similar plant. Then I made a short tour inland, passing through some banana plantations, and visiting the reservoir. No moss was found in all this round, although some patches of wood were examined. Then, returning disappointed by one of the main roads, I came on a little ditch and a small trickle of water connected with it. A few tufts of unpromising moss, silted up with gritty mud, were got alongside the ditch, and in some scrubby bush bordering the streamlet there were some mosses on fallen trees. This last was the only likely moss for the kind of animals I was seeking, and it was very little in quantity. The moss from the ditch was very different from the "dry" moss which is the happy hunting-ground of the student of "Moosbewohner" (moss-dwellers); it was likely to contain only those truly aquatic species which are not accustomed to being dried up periodically, and which were therefore unlikely to survive the long journey which had to be made before they could be examined. Nevertheless, when moistened and examined some months later, these unpromising mosses were found to harbour a considerable number of microscopic animals. These were chiefly Bdelloid Rotifera; of these were about as many species as we got in Hawaii. There were very few Tardigrada, only two species being identified.

The Fiji Islands are situated in the Tropics, $16^{\circ}$ south of the Equator, and due north of New Zealand, which is distant about 1200 miles. The nearest part of Australia is about 1500 miles distant. Though so far separated from these nearest considerable masses of land, there are numerous intervening islands which would assist rigration, so that some correspondence with the microfauna of Australia and New Zealand would not be surprising. The Tardigrada of Fiji are almost unknown. We identified only two species, the cosmopolitan $M$. areolatus (a doubtful identification), and M. nodosus, a species found in New Zealand.

Previous knowledge.-I can learn of no previous work on the Tardigrada of Fiji. 


\section{LIST OF SPECIES}

Macrobiotus areolatus, Murray?

M. nodosus, Murray.

Macrobiotus, sp. ?

Macrobiotus areolatus, Murray ? (19) (Plate XIX. Fig. 40)

See description of M. areolatus on p. 167 of this paper

The identification rests on the egg only, and as the egg is by no means typical there is much room for doubt as to the species. The egg is considerably smaller, measuring only about $70 \mu$ in diameter, exclusive of the spines. $M$. areolatus measures about $100 \mu$ without the spines. The processes also differ in form, being ovate and subobtuse, while those of areolatus type are conical and acuminate. They measure only about $12 \mu$, while those of the type attain to $50 \mu$ in length.

The surface of the shell, between the processes, is marked by chambers or areolie like those from which the type was named, but these are more rounded and scarcely polygonal at all. It is on this character that the provisional identification is made. It is more probable that the egg belongs to a related species not yet recognised, perhaps to that found assuciated with it, and described below (figured on Plate XIX. Fig. '43).

\section{Macrobiotus nodosus, Murray (20)}

The only abundant species in the collection from Fiji. Young and old were seen, and skins containing the reddish brown eggs. One of these, containing three eggs, measured $400 \mu$, the eggs $68 \mu$. The largest animals were as large as African specimens (500 $\mu$ and upwards). The claws were $30 \mu$ in length.

The newly hatched young of $160 \mu$ in length were hyaline and colourless, or very faintly yellow. The characteristic kuobs were not developed, and the papilla were wide but very obscure. The phargnx has the thickenings much shorter than in the adult. They are as broad as long, and somewhat quadrate.

'The empty skins lose the papillæ, but show their position by a regular reticulation. Seven eggs were seen in one skin.

The occurrence of $M$. nodosus in mid-Pacific is very interesting. The species is at present known in Africa, New Zealand, and the Macquarie Islands.

\section{Macrobiotus, sp. ? (Plate XIX. Figs. 43a, 43b)}

A fairly large animal, nearly $500 \mu$ in length. It is pigmented with a dull brown colour like that of $M$. hufelandii. The teeth are stout and the gullet wide. The pharynx is shortly oval, and contains, besides the apophyses, three short thick rods in each row, and a large comma. The middle rod is a little shorter than the two 
others. The claws are in pairs, united at the bases only. One claw of each pair is larger. No supplementary points were seen. There are no eye-spots.

The pharynx is $40 \mu$ long by $30 \mu$ wide. Having points of affinity with several species (M. echinogenitus, $M$. areolatus, \&c.), the recognition of the egg is necessary for its identification. The strong comma distinguishes it from areolatus, but, as Richters has pointed out, we are not yet sure of the constancy of the "comma." The slight shortening of the middle rod may show some degree of relationship to $M$. virgatus, a Canadian species (see p. 173 and Plate XXI. Fig. 55).

\section{HAWAII : ISLAND OF OAHU}

Collecting in Hawaii.-At Honolulu we remained for twenty-four hours, so that there was a much better opportunity for collecting than we had in Fiji. As, however, we arrived at 5 P.Mr. it was impossible to get clear of the town before sunset, and serious collecting had to be deferred till next day. The remaining daylight of the first evening was occupied in making a journey by street-car to the Aquarium. On the way some irrigation ditches were seen, and these were visited, and a net thrown in to collect the aquatic rotifers, with lively hopes of getting Trochosphara, and who knows what else? A few sweeps of the net filled it with a delightful green slime, of endless possibilities, but alas! in drawing it out it caught on some spiny twig and was torn, and the contents lost.

Next day a start was made in the cool of the morning, before sunrise. Even at that early hour ( 5 A.M.) a café was found open, and by the time breakfast was over the street-cars were running. Knowing nothing of the gengraphy of the country, an electric tram was boarded, which, as luck would have it, conveyed me five miles out, to the foot of a valley on the east of the city. For a mile or two the road ran through the level valley, among farms. A very little stream ran in this valley. It would be only two or three feet across and a few inches deep. None of the water was wasted, each farm or garden using it for irrigation, and letting the overflow pass on to the next. No mosses were seen in this valley till the last of the houses was left behind, when some tufts growing on clay were got on the banks of the stream.

The stream was now left and I began to climb up a long spur rising gradually towards a ridge which formed the watershed at the head of the valley. The country was open, with deep grass and occasional bushes. Here, at some little elevation, moss of a likely kind began to appear, first on stones, then on the stems of trees and bushes. Everything was dry and scorched by the sun:

As I advanced the bushes became denser and rather troublesome. The moss also became quite abundant and my pockets were bulging with it. There were many kinds of it, but one was dominant. It formed large sheets of a vivid green, with rich autumnal browns in the withered parts. It had all the habit of a pleurocarpous 
moss, but the hairy calyptra of the capsules showed it to be a relative of the Orthotricum family.

It was my intention to go on to the top of the ridge, which seemed but a little way in front, and to descend into the Pali road, which I knew was only a little way down on the other side. Nature did not permit this. As I advanced the bushes became very dense and I got into it zone of ferns. The spur had become high and narrow, with very steep sides and scarcely walking room on the summit.

Though there were few prickly bushes the long trailing branches of some of them were very tough and difficult to negotiate. The fern got so dense that it was difficult to part it. This innocent-looking fern appears to be a bracken, not unlike the British kind, which can be obstructive enough on a hill-side. It was all dry and withered, and the pinnules were mostly broken off, leaving only about an eighth of an inch of the base. These fragments of pinnules were strong and hard, and with their ragged edges they caught and tore the clothing as Smilax prickles would do.

At last, not many hundreds of yards from the ridge towards which I was making, the fern was so dense that I never set foot to ground at all, but walked on the entangled fern, a yard or more above ground. It was evident that, at the rate at which I was progressing, if I held on till I gained the Pali road I would miss the steamer, so I turned back by the way I had come. On descending from the spur I struck the stream at a point farther up the valley than where I had left it, and crossed some boggy places where there were plenty of bog IIypna and even Sphagnum. Had it been possible to examine these while fresh there would doubtless have been interesting additions to the list of species.

The trip was successful, judging by the quantity of moss collected, and for more than a year afterwards it continued to yield plenty of microscopic animals. Among them there were more than a dozen species of 'T'ardigrada.

The Sandwich Islands are situated in the Tropics, Honolulu, on the Island of Oahu, being $22^{\circ}$ north of the Equator. It is the most isolated land visited. The nearest land mass is $\mathrm{N}$. America, the nearest point being 2000 miles distant. Although the numberless islands of Polynesia lie to the southward, there are few islands near the Hawaiian group which could facilitate migration. The microfauna of the group may thus be expected to be of great interest.

Previous knowledge of Hawaiian Tardigrada.-The only reference to Hawaiian Tardigrada with which I am acquainted is in Richters' "Moosfauna Australiens" (37). In moss from Oahu and Hawaii, collected by Professor Schauinsland in 1896-7, Richters found $E$. arctomys and $M$. hufelandii, both in Oahu, the latter also in Hawaii. We found the Macrobiotus again, but not $E$. arctomys, unless the record of that species refers to the same aninal which I identify as $E$. mutatilis. The matter requires clearing up. 


\section{LIST OF SPECIES}

Echiniscus mutabilis, Murray.

F. novcezeelandice, Richters.

$E$. intermedius, sp. n.

E. viridis, sp. $\mathrm{n}$.

E. spinulosus, Doyère.

E. perasmatus, Murray.

Milnesium tardigradum, Doyère.
Macrobiotus hrefelandii, Schultze.

$M$. occidentalis (?), sp. $\mathrm{n}$.

$M$. intermedius, Plate.

$M$. crassidens, Murray.

$M$. oberhïuseri, Doyère.

Diphascon scoticum, Murray.

Three species not identified (1 Echiniscus, 2 Mracrobiotus)

\section{Genus-Echiniscus}

\section{A : Segments V. and VI. Separate \\ Echiniscus mutabilis, Murray (12)}

The commonest species in Hawaii. The form of Echiniscus recorded below as E. novazeelandice has the characteristic dorsal processes so reduced in size that it may be questioned whether it should not rather be regarded as a form of $\boldsymbol{E}$. mutabilis. At any rate it is a transitional form from the one species to the other, and indicates how closely related they are, although their types differ so conspicuously.

\section{Echiniscus novazeelandia, Richters (37) (Plate XIX.) Fig. 35}

The form of this species which occurred in Hawaii differs from the typical examples found in New Zealand and Australia in the extreme reduction of the dorsal processes on the third pair of plates. They are mere knobs or sometimes only angles of these plates.

Only a few examples were seen. They measured about $240 \mu$ in length, exclusive of the legs. The setæ $\alpha$ were more widely spreading than usual, and were $60 \mu$ long.

\section{B : SEgments V. AND VI. UnIted}

Echiniscus intermedius, Murray (Plate XIX. Figs. 36c, 36d)

See description in Australian Tardigrada, p. 129 of this volume, also in Canadian

Tardigrada, p. 161

This most interesting little species occurs in Hawaii as a peculiar variety. The type as found in Queensland and the variety found in Canada differ so much that they would be considered as distinct species, were it not for the Hawaiian variety, which is intermediate between them. The type has the plates marked with large but rery faint hexagons, the Canadian variety has very fine pellucid dots; the Hawaiian form has markings of intermediate size, but they are depressions like those of the 
type. It is a question whether all three are not distinct species. There is no other Echiniscus which shows such a range of variation of the surface texture.

Description.-Small, length about 190 to $220 \mu$. Plates ten, two pairs, three median. All the median divided by transverse lines into two nearly equal portions. Both parts of the first median are dotted. In the second and third median only the fiont portion was seen to be dotted. The posterior half of the third median is only separated by a faint line from the lumbar plate. The plates of the pairs are each traversed by a transverse furrow, separating anterior and posterior convex portions. It is uncertain if the dots cease in the furrow. The lumbar plate is not trefoliate. It is faceted, having a median and two lateral panels.

The surface of the plates is marked with a fine reticulation, regularly hexagonal. This is formed by the margins of contiguous shallow pits, as in $E$. reticulatus. These are much smaller than in the Australian form of the species. It must be understood that these pits are extremely difficult to observe. To show them by lines in the drawing exaggerates their apparent importance.

The seta $\alpha$, at the base of the head, is relatively long. The smallest example observed, $190 \mu$ in length, contained two nearly round eggs $40 \mu$ in diameter. An example of $210 \mu$ contained one narrow egg of $50 \mu$ by $32 \mu$.

\section{Echiniscus viridis, sp. n. (Plate XIX. Figs. 36a, 36b)}

Specific characters. - Large, stout; plates ten, three median, two pairs, V. and VI. joined; colour of plates olive-green, dots darker green, regularly spaced, largest in the centre of the body, and diminishing to the sides; seta $\alpha$ very short, springing from large conical papilla ; fringe of small teeth; claws very large, inner with small barbs ; small spine on first leg.

General description.-Length, $250 \mu$, exclusive of the large stout legs, claws $25 \mu$ long. The plates are very distinct, with clearly marked edges. Only the plates are coloured green; the interior of the body is of the usual Echiniscus red. The colour does not affect the bands of skin connecting the plates, but it does extend into the fourth leg as far as the fringe; beyond that is clear. The dots do not appear as either pits or papillæ, but simply as darker patches. They are very regularly spaced, and are separated by spaces of about the same diameter as themselves.

None of the plates is distinctly subdivided, but each plate of the pairs is divided into three bands, the anterior and posterior darker, and the one between lighter, with smaller dots. The first median is far separated from the shoulder plate, and near the first pair. The third nedian is somewhat obscure, being little more than a dotted area with obscure margins, close to the second pair.

The claws are unusually large, being about one-tenth of the length of the body, but there are species in which they are still longer (relatively). There is a palp near the base of the fourth leg, and a very short spine on the first leg. 
E. viridis has been known for many years. The first specimens seen were empty skins, and it was considered unsafe to put any importance on the colour of the dead animals. The colour alone could not be considered of specific value, as it might be due to disease, and could only be regarded as having any weight if the animal showed other peculiarities. These we find in the nature of the dots, the rery short head setæ, and the very large claws.

The animal was first found alive in Hawaii, and it was seen that the plates had the distinctive colour in life, and possessed the other peculiarities which had been noticed in the green skins previously observed.

It appears, then, to be a good species, and the olive colour seems to be constant and characteristic. Disregarding the green colour there is no species with which it could be united. There are but few species having V. and VI. joined, and no processes after seta $a$. E. wendti and $E$. reticulatus have the seta $a$ very long, and the latter has the surface reticulate and the spine on the front leg very long. $E$. arctomys has no fringe. $E$. kerguelensis and $E$. sylvanus have very fine dots on the plates. E. macronyx (38), which has similar large claws, has the surface finely punctate, and there are no barbs on the claws. The other species of the group differ conspicuously, and need not be compared.

IIabitat.-Among moss from the bush near the City of Honolulu, Island of Oahu, Sandwich Islands. Previously found at the margins of two Scottish lochs (Ness and Morar).

The dots on the plates vary somewhat in size, though always large; the figure shows them of the largest size.

\section{Echiniscus spinulosus, Doyère (2) (Plate XIX. Fig. 38)}

Although differing from Doyère's species in one important point, viz., that the two dorsal processes, over $c$ and $d$, are small spicules instead of long spines, I do not feel justified in making this Hawaiian form a distinct species. The dorsal processes vary more than any others in relative size. In a large series of specimens of E. dulvoisi, a species closely related to this one, and like it having only spines on the body, I have seen the dorsal processes vary from spicules to long spines. As the Hawaiian examples have some distinct character's, not noticed in Doyère's description, a full description is here given. These are in the surface texture of the plates, and have been insufficiently attended to in descriptions of species.

Description.--Size moderate, length $250 \mu$ exclusive of the legs. Plates nine, two pairs, two median. The surface texture is very striking. The dots appear very distinctly as perforations, some large and some small, with irregular wide spaces between. On each plate of the pairs the dots are confined to two areas, separated by a plain band on which there are no dots. The anterior area, along the border of the plate, is narrow, the posterior area occupies more than half the plate.

BRIT. ANTARCT, EXPED. 1907-9, VOL. I. 
In front of the second median plate, from which it is separated by a plain band, and close to the edge of the first pair, there is a narrow dotted band. There is a similar band behind the second pair of plates, which I have not considered as a median plate. These bands, and the separate dotted areas on the paired plates, recall the intercalary plates of Richters' E. scrofo and E. quadrispinosa (26) and are doubtless of similar value.

The lumbar plate is trefoliate and faceted, having four principal panels of which the posterior one is obscurely divided in two. The spines of the fringe on the fourth leg are short triangles. The decurved spine of the inner claws is somewhat large and far from the base of the claw.

The oval eggs are about $80 \mu$ long, by $60 \mu$ wide. Two or three are laid in the skin.

Australian varieties of $E$. duboisi have precisely the same surface texture, and the same subdivision of the dotted area of the paired plates. This confirms the close affinity of the two species. Such peculiarities of surface texture must not be given too much weight in separating new forms from old, as there can be little doubt that they have been generally overlooked.

\section{Echiniscus perarmatus, Murray? (20)}

Identified from a mutilated skin, having none of the spines or setæ. The plates with dots of two kinds, the broad plain band at the posterior margin of the paired plates, and the papillæ showing on the very edge of the lumbar and median plates, are all character's unknown in any other species, or at any rate not combined in any species.

\section{Echiniscus, sp.? (Plate XIX. Fig. 37)}

A small animal, probably immature, which could not be identified. Several examples were seen.

Description.-Length $125 \mu$, exclusive of the legs. Plates nine, two pairs, $t w o$ median; dots fine, regular, nature doubtful. Lateral processes $-\alpha$ and $e, \alpha$ a seta of $50, e$ a curved spine of $12 \mu$, sometimes lacking. Dorsal process-over $d$ a short curved spine of $6 \mu$. On fourth leg a fringe of small blunt teeth. All claws withont barbs. Lumbar plate trefoliate.

It is needless to make any comparison with other species, as the animal appears to be young and incompletely developed.

$$
\text { Genus-Milnesium, Doyère (2) }
$$

Milnesium tardigradum, Doyère (2)

The branched claws had, some three, some two points. 
Genus-Macrobiotus, Schultze (42)

\section{A : Species having Rovgh EgGs}

Macrobiotus intermedius, Plate (23)

Identified from an egg which contained a well-developed young. The egg had the typical top-shaped processes. It was, however, not spherical but shortly oval, measuring 60 by $50 \mu$ over the spines. The pharnyx contained three quadrate nuts in each row, the first apparently united to the gullet, but distinct from the apophysis.

Another elliptical spiny egg occurred in Hawaii (Plate XIX. Fig. 416).

\section{Macroliotus crassidens, Murray (20)}

As the egg was not found there is some little doubt about this record. It is distiuguished from the preceding by the greater relative breadth of the nuts in the pharynx, which are even broader than long.

\section{Macrobiotus oberhäuseri, Doyère (2)}

The Hawaiian form of this species was papillose all over, as in Central African examples, but the papillæ were smaller. The bands of colour were faint. The pharynx contained two nuts in each row.

It is likely that this all-papillose species will prove to be distinct from Doyère's type. The eggs of the various forms of this species are not yet sufficiently known.

\section{Macrobiotus occidentalis (?), Murray (Plate XIX. Figs. 39a-39c)}

This Macrobiotus, differing in some respects from the type of M. occidentalis, and probably a distinct insular race or species, cannot be assigned its final place till the egg is known.

Description.-Small, hyaline or very pale yellow. Length $300 \mu$. Skin thin, dotted. In all the examples seen there was never the double skin, enclosing a clear fluid filled with thin hyaline rectangular plates, as in the type. Teeth small, not widely spreading, abruptly bent outwards beyond the middle. Gullet narrow; pharynx with apophysis and two short rods in each row, the first (next the gullet) more than twice as long as the second, which is shortly oval; a small comma. Small black eyes. Fat-cells very large, 10 to $15 \mu$ in diameter, hyaline.

A large (old) example measured $450 \mu$ in length, and was pigmented like M. hufelandii. The claws are slender, and united less than half-way.

The points of difference from the type are : the smaller size, lack of colour in the fat-cells, lack of double skin, abruptlyobent teeth, and comma in the pharynx. These are points of unequal value, in the aggregate of considerable importance. The pale 
colour might be associated with youth, but even the eggs of the type have dull reddish contents. The double skin, with enclosed fluid and plates, is not regarded as a specific character, although all the Canadian examples had it. It is possibly pathological. The comma is also of uncertain value, though I believe generally constant in a species. It remains for the discovery of the egg to decide the position of the form. Although pretty abundant no eggs were found which might belong to it.

An almost identical form was found in Australia.

\section{Macrobiotus, sp.? (Plate XIX. Figs. 41a, 41b)}

An elliptical egg, with processes of the hufelandi type, and containing a young with well-grown pharynx. The egg measures $90 \mu$ by $65 \mu$ over the processes, which are about $6 \mu$ in length. The processes are of the typical hufelandi form, but many of them are divided at the ends, as in furcigir, orcadensis, and a variety of intermedius.

Teeth slender, curved outwards about the middle; gullet of moderate width; pharynx shortly oval, with apophysis and two rods in each row, the first twice as long as the second. The claws were not seen.

\section{B: EGGS UNKNOWN.}

Macrobiotus, sp.? (Plate XIX. Figs. $42(a, 42 b)$.

A hyaline form, of which the egg is unknown. The claws are of the hufelandi type, but they are only joined for a short way above the base, and one of each pair is much shorter than the other.

The gullet is narrower than in hufelandii and has a prominent rim at its end in the pharynx. The pharynx is shortly oval and has two rods and a comma in each row of thickenings. The first rod is more than twice as long as the second, and has a rounded projection near its base. The comma is very small. The apophysis was not observed. Eyes present. Length $350 \mu$.

Without the egg the species cannot be identified. It has some affinity with hufelandii, but has the claws united for a shorter distance, narrower gullet, and weaker teeth. The form of the first rod seems distinctive.

$$
\text { Macrobiotus, sp.? (Plate XIX. Figs 43a, 43b). }
$$

Pharynx like that of $M$. virgatus (p. 173), but with a comma. Claws different, united at base only, unequal.

\section{Remarks on the Tardigrade Fauna of the Pacific Islands}

The interest of the Tardigrade fauna of these islands is chiefly geographical. They have not yet yielded any peculiar insular forms in this group, although in some cases varieties may indicate peculiar insular races. 
Our knowledge is as yet far too scanty to permit of any useful discussion even of geographical distribution. All the collections have been hurriedly made in the most unlikely localities, viz., in the immediate neighbourhood of the various ports of call. The entire interior of the islands, with all their variety of climate and physical features, is untonched.

No doubt the right kind of work would result in greatly extending the number of species. The great apparent difference in the productiveness of Fiji and Hawaii is doubtless due to nothing else than the fact that there was no suitable collectingground within reach at Fiji.

All that can at present be done is to indicate the general distribution of the few species yet collected.

In the following table I have included Professor Richters' records for Samoa and the Hawaiian group (37). These include one species (M. samoctmus) which we did not get, and the only species which is not known anywhere else than in the Pacific Islands. It exhibits the distribution in four columns for the islands, and nine for the rest of the world.

\section{Distribution : Local and General}

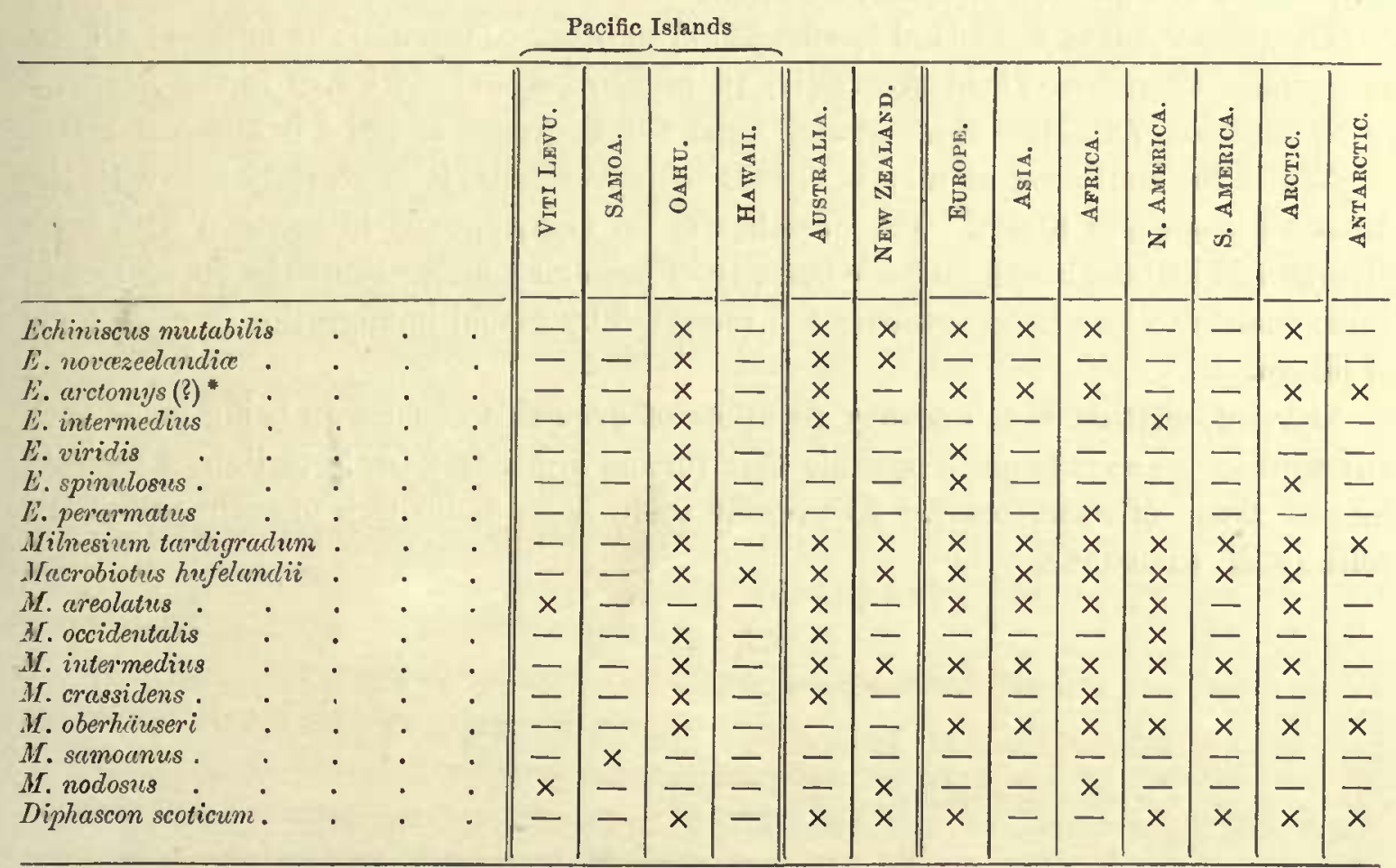

Nineteen species were collected in the islands, 3 in Fiji and 16 in the Hawaiian group (Sandwich Isles), but only 15 were identified. Adding $M$. samocmus,

* All these records, except the Australian one, are wrong; the animals recorded as $L$. arctomys are either E. mutabilis or L. suillus (see p. 126 and footnote). 
discovered by Richters in Samoa, and L. arctomys, recorded by him for Oahu, we have 17 species known from the Pacific Islands.

The only instance of a species known to be common to two islands is M. hufelundii in Oahu and Hawaii. This fact is of no importance, as only Oahu is at all well known.

There are 7 species of Echiniscus (besides 1 not identified) all from Oahu. No Echiniscus is known in the other islands. There are 8 identified species of Macrobiotus, 5 from Oahu, 2 from Fiji, and 1 from Samoa, the ubiquitous Milnesium, and Diphascon scoticum.

There are eight of the species which are almost cosmopolitan in distribution, and which are therefore of little importance in the study of island faunas. They indicate that migration to these remote islands is not difficult.

The other nine species are of very restricted range. None of them is known in more than three of the regions, though only $M$. samoanus is confined to the islands. E. novezeelandice occurs in Oahu, Australia, and New Zealand; E. intermedius in Oahu, Australia, and Canada ; E. viridis in Oahu and Scotland; E. spinulosus in Oahu, Europe, and the Aretic; E. perarmatus in Oahu and Africa; M. occidentalis in Oahu, Australia, and Canada; M. crassidens in Oahu, Australia, and Africa; M. nodosus in Fiji, New Zealand, and Africa.

The proportion of the island species found in other countries is as follows: Of the 17 species, there are 11 in Australia, 10 in Europe and Africa, 9 in the Arctic, 8 in N. America, 7 in New Zealand and Asia, 5 in S. America, and 4 in the Antarctic.

While the indicated affinity is closest with Australia, it is scarcely less with the distant Europe and Africa. The presence of so many species in common with such diverse and distant lands, and the scarcity of peculiar species, show the population of these islands to be a heterogeneous lot, recruited by casual immigration from all sorts of places.

Our information is too scanty to allow of even this conclusion being made with any confidence, as it is quite possible that further work may bring to light a peculiar insular fanna of water-bears. At present there is no indication of such, except the solitary M. samounus. 


\section{CANADIAN TARDIGRADA}

Collecting in Canada.-The only opportunities which offered for collecting in Canada were the pauses in a hurried journey across the continent. At Victoria, British Columbia, where the steamer called for a few hours, plenty of moss was found on the sea-shore, close by the wharf. This proved afterwards to be the most productive got in Canada. At Vancouver a whole day was spent, but the time available was not sufficient to go farther afield than the Stanley Public Park. This park, in its half-wild state, and everywhere clothed in moss, was very suitable for the collection of microscopic animals.

Thereafter, right across the continent, there was nothing to be looked for but chance collecting at any stations where the train stopped for more than a few minutes. Through the Selkirks and the Rockies, at all the stations where the train stopped long enough to allow time for meals, I generally managed to get my pockets filled with moss.

Accident assisted science. Twice on the journey the train was held up for some time. At Sicamous, floods had destroyed a little bridge, and a heavy engine had got overturned. While a new loop of railway was being built round the obstruction there were two days available for collecting. It was a beautiful spot, on the shore of a lake, and moss was abundant, but somehow it proved very unproductive. We were afraid to make long excursions up the neighbouring hills, as we did not know when the train might go on.

A few days later, after crossing the Prairies and just after passing the Lake of the Woods, there was a train-wreck in front of us, on a high bank between two lakes. This delayed us for several hours. The microscope was again got out, the dry moss was washed in the lake, and the sediment examined. This time we were luckier, and got many interesting things.

Half a day was spent in Ottawa, and much moss was collected in the public parks and roadsides. This also proved good.

The only records of Canadian Tardigrada with which I am acquainted are in Richters' "Moosfauna Australiens, \&c.," 1908 (37). He records three species from Vancouver: Echiniscus gladiator, Milnesium tardigradum, and Macrobiotus hufelandii. For the whole North American continent I only know one other record, Packard's insufficiently described Macrobiotus americanus (21). Some half-dozen species are recorded for South America. 


\section{List of Species Collected}

Echiniscus gladiator, Murray.

E. sylvanus, sp. n.

$\boldsymbol{E}$. intermedius, Murray.

E. cancudensis, sp. $\mathbf{n}$.

E. oihonno, Richters?

E. bisetosus, Heinis?

Milnesium tardigradum, Doyère.

Macrobiotus hufelandii, Schultze.

M. echinogenitus, Richters.

$M$. areolatus, sp. $\mathrm{n}$.

M. harmsworthi, Murray.

1K. occidentalis, sp. n.
M. oberhäuseri, Doyc̀re

M. intermedius, Plate.

MI. articus, Murray?

M. sattleri, Richter's.

M. tuberculatus, Platc.

M. canadensis, sp. $\mathrm{n}$.

II. virgatus, sp. $\mathrm{n}$.

Diphascon chilenense, Plate.

D. alpinum, Murray.

D. scoticum, Murray.

D. canadense, sp. $\mathrm{n}$.

Eight species not identified (3 Echiniscus, 5 Macrobiotus).

\section{Notes on the SPECIES}

\section{Genus-Echiniscus, Schultze (43)}

The eight species collected all belong to that section of the genus in which segments V. and VI. are completely fused into one plate. It is rire to find a district possessing so many species without including one in which V. and VI. are separate. E. mutabilis is the commonest species in that section, but it is not yet recorded from either North or South America.

\section{Echiniscus gladiator, Murray (12) (Plate XX. Fig. 51)}

Stanley Park, Vancouver, British Columbia. Professor Richters had previously found it in moss from Vancouver (37).

The British Columbian form differs from the type in that the plates are covered by wide but very low bosses. The figure, in which these bosses are indicated by black lines, inevitably exaggerates their prominence, but it shows their size in relation to the plates.

The paired plates of $E$. gladiator and its variety exarmatus differ from those of all other known Echinisci in that they only touch in the middle line for a short distance near the anterior border, and diverge behind, as shown in Fig. 51. This character has not been indicated in previous figures.

\section{Echiniscus sylvanus, sp. n. (Plate XX. Fig. 49)}

Specific characters.-Size moderate; colour yellow; plates nine, two pairs, two median; V. and VI. joined; seta $\alpha$ thick, short; no other doreal or lateral processes, other than those on the head; dots of moderate size, and seeming to be perforations; each plate of the pairs divided in two by lines; lumbar plate faceted and trefoliate; fringe on fourth legs; inner claws barbed.

Detciled description. - Length $275 \mu$, exclusive of fourth legs. The palps at the 
mouth are prominent and the cirri short. Seta $\alpha$ measures about $50 \mu$ in length. It is thicker than in any known species except $E$. cornutus, Richters, but it scarcely tapers at all, and has a blunt rounded end. The "auricle" at its base is large and of triangular form. The first median plate is separated from the plate in front of it by a broad space. The second median is divided into two dotted portions by a transverse plain band. Each plate of the pairs is divided into two unequal parts by a line which runs parallel with its anterior border, the narrow part in front forming a prominent roll which continues round the side and shows in the outline. The granulation is of the sort which makes the plates seem cribrose. The dots seem to perforate the plate; they are unequal in size and are separated by irregular spaces. The lumbar plate has four facets, the posterior one obscurely divided into two.

The processes of the fringe are few (about eight to ten); they are narrow and acute, and are separated by small spaces. The claws are large, about $25 \mu$ in length. The inner claws of the fourth legs have small decurved barbs near their bases.

Habitat.-Among dry moss from the woods on the shore of the Lake of the Woods, Ontario.

$E$. sylvanus belongs to a group of species of which $E$. arctomys may be taken as the type. These have nine or ten plates, segments V. and VI. have completely coalesced, and there are no processes, dorsal or lateral, on the body, after seta $\alpha$. This section of the genus includes ten forms previously known, and three others, in addition to E. sylvanus, are described in this paper. Two of these forms (macromastix and exarmatus) were described merely as varieties.

Most of these species differ in conspicuous characters from E. sylvanus. The thick seta $a$ alone separates it from all of them. Other distinguishing points are here given briefly. Four species have seta $\alpha$ extremely long (macromastix, vendti, reticulatus, tessellatus), four species have no fringe (elegans, intermedius, arctomys, exarmatus), two species have totally different surface markings (spiculifer, Jigranulatus). There remain three species which bear a closer resemblance to E. sylvanus. $E$. viridis and $E$. macronyx have, like E. sylvanus, very large claws. E. viridis has the surface dots very large, and seta $\alpha$ very short and fine. $E$. macronyx has extremely fine and close dots, no barbs on any claws, and only the fourth legs have large claws.

$E$. herguelensis is nearest to E. sylvamus. It has shorter claws and seta $c$ is slender. It is also considerably smaller ( $165 \mu$, according to Richters, but Australian examples larger, $225 \mu$; sylvanus, $275 \mu$ ).

\section{Echiniscus intermertius, Murray (Plate XX. Figs. 52a, 52b)}

Characters of Canadian variety.-Small, hyaline or greyish. Mouth cirri with large conical bases; seta $a$ long, no other processes on body. Three median plates, first and second divided into two equal portions by transverse lines. Plates finely BRIT. ANTARCT. EXPED. 1:907-9. VOL. I. 
dotted with p sllusid d sts. Lumbar plate not trefoliate, faceted in three panels, the lines separating the lateral from the median panels going right up to the third median plate. No fringe on fourth legs, or barbs on claws. Red eyes. Larva with two claws, otherwise like the adult.

General description.-Length $175 \mu$, exclusive of the legs, larva $100 \mu$, seta $a$ (of adult) $60 \mu$. The anterior portion of the head is rounded, and more like a head of Macrobiotus than Echiniscus, lacking the lateral knobs and the beak usual in the genus. The base of the hexd is wider than the front of the next segment, so that there is a slight neck, rather more pronounced in the larva. The first and second median plates are each divided into two portions, as is common in that section of the genus which has V. and VI. separate. The third median often appears to be divided in exactly the same manner, but the second portion is closely joined to the lumbar plate. Both parts of the divided median plates are dotted. The plates of each pair appear to be divided into two by a broad band, which is, however, dotted.

$E$. intermedius is a very distinct species. It has V. and VI. united, yet has the median plates transversely divided, which is only usual in species having V. and VI. separate. It appears to consistently lack the normal red colour of Echiniscus, though that is not a safe character. The faceting of the lumbar plate is unusual in that the angle of junction of the three facets continues to the anterior edge of the plate. The absence of a trefoil on the lumbar plate is very unusual. I know of no other species where this character is so distinctly marked. Some have been figured without the cuts which make the trefoil, but unless the authors emphasise the absence it is likely that they have been overlooked.

The eggs have only been seen in a form, probably of specific value, from Hawaii (see p. 151).

Habitat.-Among moss from the sea-shore at Victoria, British Columbia, June 1909, abundant.

This variety, with fine pellucid dots, is not known anywhere else, but in Queensland there occurs the type in which the plates have a broad reticulation instead of the pellucid dots (see p. 129). Curiously enough, there is a form linking these extremes in Hawaii. It is reticulate, like the Queensland form, but the reticulation is smaller, and is formed by the edges of shallow pits (see p. 151).

\section{Echiniscus canadensis, sp. n. (Plate XX. Fig. 47)}

Specific charcicters. - Large, red; plates nine, two pairs, two median, V. and VI. fused, dots round, regular, close; no lateral processes except seta $a$; dorsal processes - a long setæ over $c$, sometimes a shorter seta over $d$; fringe of sharp spines on the fourth leg; inner claws with decurved, outer with straight, spines near the base.

Detailed description.-Length $300 \mu$ and upwards, exclusive of the fourth legs; 
seta $a$ about $75 \mu$, dorsal seta over $c$ about 100 to $150 \mu$. Body very thick dorso-ventrally. The dots on the plates are of moderate size. They are circles which touch at their edges, and which often show a central dot. They look like very flat granules. The paired plates are each divided by a furrow into two parts. It could not be seen whether the dots ceased in this furrow. Most of the specimens, even very large ones, had no processes on the body except the dorsal seta over $c$; only a few had the smaller one over $d$. The lumbar plate is obscurely trefoliate. The spines of the fringe are triangular, and are usually separated a little at their bases. The two-clawed larva has been seen, and from two to four shortly oval eggs in the cast skin. The barbs of the inner claws are fairly large and high up on the claw. The outer claws have not been seen with more than one straight spine near the base.

Habitat.-Among moss growing on the sea-shore, but little above the high-water mark, Victoria, British Columbia. Very abundant in some pieces of the moss.

It is not necessary to compare $E$. canadensis with very many species in order to discriminate it. There are very few species known which have straight barbs on the outer claws. Among them there are none which are destitute of lateral processes (other than a). Indeed it is very rare for any species to have dorsal and no lateral processes.

The Echinisci with straight barbs on the outer claws are four in number$E$. granulatus, E. blumi, E. oihonna, and E. merokensis. The types of $E$. granulatus and $E$. oihonna are not described as having outer barbs, but the barbs have been observed in Scottish examples. All of these species have from two to four lateral processes (exclusive of seta $\alpha$ ), while $E$. canadensis has none. The dots of $E$. granulatus are distinct papillæ. E. merokensis and E. blumi have, according to Richters' figures, much coarser dots. $E$. oihonne has four lateral spicules, over $b, c$, $d$, and $e$, in addition to the larger spines and setæe.

\section{Echiniscus oihonna, Richters ? (27) (Plate XX. Fig. 48)}

This is a very doubtful identification, and the Canadian animal is only provisionally united with oihonno because we know so little as to the limits to the variation in the length of the setre and spines. There are points of striking resemblance to oihonnce, as well as important differences.

This form differs from oihonnce in lacking seta $b$, and in the great elongation of process $d$ (which is a spine in oihonna). It resembles it in having all the corresponding processes except seta $b$, in having the dorsal process over $d$ a broad triangle, and in the little spicules near the bases of the lateral setæ.

Description.-Of large size; length $300 \mu$ exclusive of head and foot. Plates nine, two pairs, two median. Surface punctate with large dots, which appear to be perforations, and are separatcd by spaces wider than themselves. The three lateral 
setæe $c, d$, and $e$ are nearly equal to one another and about $200 \mu$ in length. The dorsal seta over $c$ is about $120 \mu$ long. The fringe on the fourth leg consists of short triangular teeth. The claws measure $30 \mu$ in length. The inner ones have small decurved barbs, which are placed very high, little below the middle of the claw.

Habitat.-Stanley Park, Vancouver, British Columbia.

In Scottish examples of oihonna, which are typical in all other respects, the outer claws of the fourth legs bear straight spines near their bases, although Professor Richters makes the absence of such spines one of his specific characters. Although the presence of these spines may be of some positive value, since they are possessed by very few species, their absence cannot be relied upon as a specific character. In $E$. gramulatus (or the animal which I identify as that species) the young which have passed the two-clawed stage have no outer barbs, which are acquired at later moults, and increase in number to three in large examples. The same progressive development of the outer barbs occurs in $E$. blumi, which may also have as many as three of them on one claw.

The character is thus shown to be a mark of age, but as the great majority of the species do not have them at any age, when present they make a good confirmatory character.

The Canadian examples, though of large size, had no barbs on the outer claws, in this respect conforming to Richters' type. It differs mainly in lacking seta $b$, and in the equalisation of the lateral processes $c, d$, and $e$.

\section{Echiniscus bisetosus, Heinis ? (7) (Plate XX. Fig. 50)}

This is a somewhat doubtful identification, though the animal is certainly very near Heinis's species. The differences are not very serious, and as our animal was small, and therefore probably immature, the processes which it lacks might be acquired later.

Description.-Colour red; length $175 \mu$, exclusive of legs. Plates nine, two pairs, two median, dots obscure. Lateral process one, the seta $a, 50 \mu$ in length. Dorsal processes-over $c$ a seta of $60 \mu$, over $d$ a small curved spine of $8 \mu$. Fringe of small triangular teeth on fourth leg. No barbs seen on any claws.

Habitat.-Among moss from the sea-shore at Victoria, British Columbia, one example only.

According to Heinis, $E$. bisetosus has also a short spine $c$, and decurved barbs on the inner claws. His figure shows a minute lateral spicule $d$, of which $I$ find no mention in the text.

It might be suggested that this small animal could be a young example of $E$. canadensis (Fig. 47) which was found abundantly at the same place. That species has, however, at all ages conspicuous barbs. 


\section{Echiniscus, sp.? (Plate XX. Fig. 44)}

Description.-Large, red; length $300 \mu$, exclusive of legs. Plates ten, V. and VI. united, two pairs, three median. Lateral processes four- $a$ a seta of $80 \mu, c$ a seta of $120 \mu, d$ a seta of $70 \mu, e$ a seta of $90 \mu$. Dorsal processes-over $c$ a curved spine of variable length, 10 to $25 \mu$ and upwards-over $d$ a small spicule. The mouth palps are large and stout, and the cirri short. The auricle at the base of $\alpha$ is small and rounded. The fringe on the fourth leg is crenate. The inner claws of the fourth leg have decurved barbs of moderate size. The dots on the plates are very fine, and appear to be granules. An example of $210 \mu$ in length had claws of nearly $25 \mu$.

Skins with two eggs have been found. 'The larva with two claws, found associated with this animal, had only the setæ $a$ and $c$. All the dorsal processes may be lacking.

IIabitat.-Among moss from the sea-shore at Victoria, British Columbia, several examples, larva, and eggs.

It rarely happens that an Echiniscus with V. and VI. united has three distinct median plates. Sometimes the skin between IV. and V. is dotted, but there are no lines marking the boundaries of a plate. In this animal, and another figured on the sarne plate (Fig. 46), the third median is distinct.

The lateral setre are the same in number as in E. testudo, E. muscicola, E. filamentosus, \&c., but they are differently arranged. E. velaminis has the same number of setæ, and their positions are the same, but it has the dots of a totally different character, no barbs on the claws, and much larger processes on the fringe.

Although the finding of eggs shows that the animal is mature, it cannot be positively identified with any known species, nor yet accepted as distinct. The variability of the dorsal processes confirms what has been already stated as to the unreliability of that character. It is a good example of those forms which may be regarded as distinct species, but which lack sufficiently good characters, other than the arrangement of the spines and setæ.

\section{Echiniscus, sp. ? (Plate XX. Fig. 46)}

Description._-Small, red; length $180 \mu$, exclusive of legs. Plates nine, V. and VI. united, two pairs, three median. Lateral processes four- $a$ a seta of $80 \mu, b$ a seta of $40 \mu, c$ a seta of $100 \mu, d$ a seta of $100 \mu$. Dorsal processes-over $c$ a seta of $40 \mu$, over $d$ a spine of $15 \mu$. Mouth palps relatively large, and cirri long. Lumbar plate trefoliate. Fringe of few large blunt processes. A blunt palp at the base of the fourth leg. The inner claws of the last legs with small decurved barbs. Dots on the plates small and uniform, apparently granules.

Habitat. - Stanley Park, Vancouver, British Columbia.

In the number and the surface texture of the plates this animal resembles that 
figured on the same plate (Fig. 44). It has the same number of lateral setæe, but they are $a, b, c$, and $d$, instead of $a, e, d, e$.

It has a close resemblance to E. blumi, Richters (27.) The lateral setre are the same in position and relative sizes. The differences are-the lack of barbs on the outer claws, the finer granulation, and the blunt processes of the fringe. The absence of barbs on the outer claws is of little importance as a negative character, since it varies with age. There is no indication that our animal is mature. Richters figures $E$. blumi with very coarse granulation, and with the fringe of sharp spines. Many examples had no dorsal processes.

\section{Echiniscus, sp.? (Plate XX. Fig. 45)}

Description.-Size moderate; length $212 \mu$. Plates nine, V. and VI. united, two pairs, two median. Dots small, some appearing as perforations, irregular, of two sorts, a larger dark, a smaller pellucid. Lateral processes four- $a$ a curved seta of $70 \mu$; $c, d$, and $e$ long, broad spines of 50,50 , and $80 \mu$ respectively. Dorsal processesover $c$, a flat spine of $40 \mu$-between this spine and the lateral one a spicule. The lateral and dorsal spines are all rough. There is a fringe of obtuse processes on the fourth leg. It was not ascertained if there were barbs on any claws.

Habitat.-Among moss from the sea-shore of Victoria, British Columbia, one example only.

This appears to be a distinct species, but it is not sufficiently known, as only one example was observed, and that might not be mature. There is no species known with similar roughened spines. In E. duboisi they are spinulose, not rough, and the animal is otherwise very different.

\section{Genus-Milnesium, Doyère (2)}

\section{Milnesium tardigradum; Doyère (2)}

This, the most generally distributed of all water-bears, was only observed in Ontario, where it occurred in two localities, near the Lake of the Woods and in Ottawa. Length, up to $800 \mu$. Four eggs seen in the body.

\section{Genus-Macrobiotus, Schultze (42)}

\section{A : Species having Rough Eggs}

\section{Macrobiotus hufelandii, Schultze (42)}

Abundant in all the Canadian localities visited; eggs also plentiful. In the Rocky Mountains it attained a length of $1200 \mu$, being the largest water-bear I have measured. 


\section{Macrobiotus echinogenitus, Richters? (27)}

This identification, being made from the egg alone, is somewhat uncertain. The egg (Plate XXI. Fig. 58) is like that of M. areolatus (Fig. 53d), but is smaller, and the spines are not separated by any space.

Habitat.-British Columbia and Ottawa.

For a discussion of the affinities of this species with $M$. areolatus and other related species, see below, under M. areolatus.

\section{Macrobiotus areolatus, sp. n. (Plate XXI. Figs. 53a-53e)}

Synonym: M. echinogenitus, Richters, var. areolatus, Murray (19)

Specific characters. - Large, dark brown; gullet wide; teeth strong, bent near the furca ; pharynx shortly oval, with apophyses, three narrow equal rods, and no comma; egg large, bearing very large conical processes, which are separated at their bases, the surface between marked with irregular polygons which form a symmetrical pattern.

General description.-The largest example measured was $700 \mu$ in length. The egg measures about $100 \mu$ without the spines, $200 \mu$ over the spines, which, however, vary considerably in length. Old individuals, as in most large species of the genus, are strongly pigmented with a dingy brown colour, which is not disposed in such regular bands as in $M$. oberhïuseri, but which still falls into obscure bands, probably caused by the disposition of the muscles and other structures in the skin. The young are colourless and transparent. The gullet is somewhat constricted towards the mouth and enlarged towards the pharynx, and bears the usual apophyses on its end. The three linear rods are slightly curved and are nearly equal in length. The stomach consists of few large cells. There is a pair of dark eyes. The claws are in two similar pairs, which are united at the bases only, and diverge widely. One claw of each pair is longer, and has supplementary points.

Four unripe eggs have been seen in the body together. The shell of the egg is thick, and of two layers. The reticulation which appears on the surface is produced by the edges of septa which cross the space between the two layers. The areolation appears to be originally regular hexagons, of which alternate ones bear processes, The intermediate hexagons are each divided by a transverse septum, producing two irregular pentagons. The turgidity of the processes further distorts and obscures the regularity of the original hexagons.

The areolation varies considerably. In one variety (Fig. 53e) the intermediate hexagons are undivided and equal the processes in basal area. Some forms have all the areolæ rounded, and circular or elliptical.

Owing to imperfect understanding of M. echinogenitus this species was at first 
united to it as a variety. Subsequent experience of the animal in many parts of the world established confidence in the constancy of its peculiarities. The absence of a "comma" in the pharynx cannot be considered an important specific character, but when we find it constantly associated with an areolated egg, while $M$. echinogenitus has a conspicuous comma, and non-areolated egg, the character adds weight to the other specific distinctions.

Habitat.-Among moss; Rocky Mountains, British Columbia, and Ottawa, June 1909. Widely distributed over the world-recorded from Spitsbergen, Scotland, India, Tropical and South Africa, Australia, New Zealand, \&c. Richters (39) has recorded it from Ascension and Comoro.

Arctic examples have attained to a larger size, but the Canadian eggs are the largest yet seen.

The rods in the pharynx are relatively shorter and broader in the young (Fig. 53 is drawn from a young hyaline example). In the adult they are linear and curved.

The character's of the egg sufficiently distinguish the species from all others hitherto described. There are some species, not yet described, which have the surface areolate in the same manner, but the processes of different form.

If the egg is not found, the identification is less certain. The presence of three equal linear rods, without a comma, and of divergent claws, united at the base only, differentiates it from the typical forms of hufelandii, harmsworthi, and other related species. According to Richters, however, M. hufelandii may have three equal rods, and the claws may be joined at the base only. The other species probably vary in the same manner.

Since Richters' original diagnosis of $M$. echinogenitus was evidently too comprehensive, and included several forms which we are now, after extended experience, enabled to separate, it will be well to take a review here of the group of related species.

Richters, in lis description, recognised two forms which he distinguished as $u$ and $b$, but he did not bestow separate names on them; $a$ has three "bacilla" and a "comma" in the pharynx, $b$ has two equal bacilla, and a comma. Both have $\mathrm{V}$-shaped claws and the eggs are exactly similar in form, but that of $a$ is much larger.

M. harmsworthi was at first separated from echinogenitus on account of the form of the claws alone, which were joined for about half of their length, as in $M$. hufelandi. Richters considers that the claws vary in the amount of union, just as thase of hufelandi do, but assents to the separation of $M$. harmsworthi, which he supposes to be his echinogenitus $a$, ${ }^{*}$ on the characters of the pharynx.

M. areolatus is also supposed by Richters to be included in echinogenitus $a$, but

"See Richters' "Tardigraden aus den Karpathen," Zool. Anzeiy., Bd. 36, July 1910, p. 7. This paper appeared after our Bibliographical List was completed, so could not be included in its proper place. 
that has a "comma" in the pharynx, and the egg is figured with the processes close together at their bases, so that there is no room for the "areolation."

There remains $M$. echinogenitus $b$, which, with the separation of $a$, becomes the type of the species. It has the two bacilla equal, a not very common arrangement, and the claws united at the base or for a short way above the base; the surface of the egg is not "areolate." A great many of the records of this species must be regarded as doubtful. Many of these were made before the related species areolatus and harmsworthi were discriminated, so that unless details of the pharynx are given it cannot be known to which form a record refers. It was till recently supposed that the eggs of echinogenitus and harmsworthi could be distinguished. The original specimens of the eggs of harmsworthi had processes much more shortly acuminate than those of the typical echinogenitus, but some have recently been seen with points almost as long. Records of echinogenitus have been commonly made (at any rate in my papers) on the strength of finding the egg alone. Although the eggs with short points may be usually harmsworthi and those with long points echinogenitus, there will always be doubt about these records unless the eggs are so ripe as to show pharynx and claws (see p. 89, footnote).

M. polaris has the surface of the egg "areolate" in the same manner as in one form of areolatus (Fig. 53e), and the processes may be of the same form. It is, nevertheless, a totally different egg, being much smaller, and with the polygons relatively much smaller, and therefore more numerous.

\section{Macrobiotus harmsworthi, Murray (19)}

Habitat.-Near the Lake of the Woods, and in the public parks, Ottawa.

The identification was made from eggs which contained young in which the pharynx and claws could be seen. The egg measured $60 \mu$ without the processes, and $80 \mu$ over the processes. These were even shorter than in the type, being considerably broader than long. The claws of a pair were unequal, and united for about half the length of the larger one.

A very similar egg, but of larger size, was got in Ottawa. It measured $80 \mu$, without the spines, and $120 \mu$ over the spines. The pharynx and claws were not seen.

\section{Macrobiotus occidentalis, sp. n. (Plate XXI. Figs. 54a-54e)}

Specific characters.-Large, orange-red; stomach and eggs darker red; skin hyaline, dotted; gullet narrow; teeth moderately sleoder, curved; pharynx shortly oval, with apophyses and two rods, the second shorter, and no "comma." Claws of hufelandi type, united half-way. Egg spherical, covered with slender tapering curved processes, which are separated at their bases.

General description.-Total length up to $800 \mu$, pharynx of small example, BRIT. ANTARCT. EXPED, 1907-9. VOL. I. 
$42 \mu$ long, claws $20 \mu$. Eyes dark. The dots on the skin are irregularly placed, but at very nearly equal spaces. They are not pigment spots, but appear to be minute elliptical pieces of the same nature as the skin, set into it like buttons in a cushion, and looking dark from the different refraction of the light. The reddish colour is confined within the body fluid, and is resident chiefly in the fat-cells, though the fluid is also more or less coloured. There are two layers of skin, between which there is enclosed a colourless fluid, in which float numerous thin hyaline oblong plates. This may be a pathological condition, but it is noteworthy that it occurred in all the individuals examined, old and young, and in none of the other species present.

The claws are like those of hufelandii, but more slender. Those of each pair are unequal in length, and are united for half the length of the larger one, which bears the usual two supplementary points.

The basal ridge, which in $M$. coronifer bears the "corona" of little spines, is in this species irregularly dentate.

The processes of the egg are separated by interspaces grcater than their own diameter at the base. They have narrow conical bases, and taper to slender points which are curred over.

The gullet is about $4 \mu$ in width, but is rather narrower below and expanded towards the pharynx. The rod next the gullet is about three times as long as broad, the second about twice as long as broad.

Habitat.-Among moss from the sea-shore, little above high-water level, at Victoria, British Columbia ; very abundant, eggs also abundant.

$M$. occidentalis appears to have its closest affinities with that group of northern species of which $M$. coronifer may be regarded as the type. Sereral of these species have a spinose ridge in front of the claws, most distinct on the fourth legs. In $M$. coronifer and $M$. granulatus the ridge bears spines-in $M$. crenulatus it is wrinkled-in $M$. harmsworthi it is crenate or plain. In large examples of $M$. occidentalis the ridge is dentate (Fig. 54d).

Several of the northern species have distinctive colouring, resident in the fat-cells. $M$. coronifer and $M$. islandicus are bright yellow. The colour of $M$. occidentalis is more inclined to red. As in $M$. coronifer, the colour is present even in the egg. In the egg it is darker, and more distinctly red. It cannot then be resident in the fat-cells. The body fluid itself is in old animals of a yellowish colour.

The processes of the egg have some resemblance to those of $M$. coronifer and M. islandicus. The egg of coronifer is elliptical, and the spines are straight; that of islandicus is round, but it has two sorts of processes, spines like those of coronifer and processes like those of granulatus. M. occidentalis hás longer and more slender spines than either, and they are variously bent and turned over at the ends.

The pharynx is quite like those of coronifer and islandicus. On the whole the 
species is nearest to islandicus, from which it is distinguished by the ridge without spines, by the different egg-spines, and by the dotted skin.

In Australia and Hawaii there is a form, apparently belonging to this species, agrceing with it in most characters, but not yet fully studied. The colour is a paler yellow. The skin is dotted as in the type, but the specimens lacked the clear fluid circulating between two layers of skin, and containing numerous hyaline plates. The eggs were not seen in these countries.

\section{Macrobiotus intermedius, Plate (23)}

Habitat.-Near the Lake of the Woods, Ontario.

The egg had the typical top-shaped processes. It measured $50 \mu$ without the processes, $58 \mu$ over them. The young squeezed out of the egg was $120 \mu$ in length, and the round pharynx was $15 \mu$ in diameter. The processes of the egg were separated by spaces greater than their own diameter, and the surface between them was covered with regular pellucid dots.

\section{Macrobiotus oberhäuseri, Doyère (2)}

IIcbitat.-Vancouver, British Columbia.

American examples were not papillose, as is so often the case in Africa.

\section{B : Species having Thick-shelled Eggs with Embedded Rods}

\section{Macrobiotus arcticus, Murray? (19)}

IIclitat.-Vancouver, Rocky Mountains, Lake of the Woods.

No eggs were found in Canada, and without them there is some doubt about the identification. The animal found in three of the localities visited agrees with M. arcticus in having a narrow gullet, two short "bacilla" in the pharynx, and claws of the Diphascon type.

The only other species known which has similar eggs is H. hastatus, Murray (18), which was not observed in Canada.

\section{C : Species having Smooth Eggs}

\section{Macrobiotus canadensis, sp. n. (Plate XXI. Figs. $61 a-61 d$ )}

Specific characters.-Small, hyaline; gullet slender; teeth abruptly enlarged about the middle; pharynx nearly round, with three short nuts, increasing in size from first to third, comma very obscure or none; claws widely divergent, but approaching the Diphascon type; one claw of each pair is longer and thinner than the other, and that of one pair is very long and slender; eggs narrowly oblong, smooth, laid in the skin at the moult.

General description.-Length $225 \mu$. A pair of small dark eyes. The teeth are 
straight for somewhat more than half their length from the points. They are then enlarged and curved outwards to the furca. The pharynx is a little longer than broad. The end of the gullet bears the apophyses. The nut next the gullet is scarcely longer than broad; the second is a little longer, and the third a little longer still. The first is nearest the middle line, and the second and third diverge successively farther from it.

The stomach is oblong and very slightly coloured. Its separate cells are not conspicuous.

One egg measured $70 \mu$ by $36 \mu$, but others were rather shorter. The newly hatched young was $100 \mu$ in length.

There are few species with which it is necessary to compare $M$. canadensis very carefully. The Macrobioti which lay smooth eggs are not so numerous as those which lay rough eggs. There are two principal groups of them, one comprising species which have warts or spines or distinct papillæ on the body, the other species which are smooth or very finely papillose. In the former group there are several which have three short nuts in the pharynx; in the second group, to which $M$. canadensis belongs, there are only two which have the pharynx of this type.

M. tetradactyloides, Richters (35), and $M$. schaudinni, Richters, ${ }^{*}$ are very similar to $M$. canadensis. Both are, however, much larger and more robust animals. Richters himself considers the size important in distinguishing $M$. tetradactyloides from $M$. tetradactylus. $M$. schaudinni is nearly twice as long as $M$. canadensis, and $M$. tetradactyloides is larger still. It is pretty certain that $M$. canadensis is really a small animal, although some water-bears vary greatly in size. It was very common in some parts of Canada, and yet it was uniformly small. The largest measured was only $225 \mu$ in length, and many mature-looking animals, with eggs in the body, were less than $200 \mu$.

$M$. canadensis may be distinguished from $M$. tetradactyloides by the unequal pairs of claws and by the greater inequality of the claws of each pair. It is more difficult to separate from $M$. schaudinni, which has the pairs unequal. Richters figures his species with much robuster claws.

In $M$. canadensis the claws are intermediate between the Diphascon type and the $\mathrm{V}$ type. The long claw of each pair is very slender, and that of the larger pair is almost bristle-like, as in $M$. oberhüuseri. The bristle-like claw is set on to the lesser claw of the same pair in the same manner as in Diphascon, but nearer to the base. The two claws diverge very widely.

While usually smooth, it sometimes happens that the body is finely papillose on the posterior half, or more than half, though never all over.

The nuts of the pharynx are only slightly rounded at the ends, not enough to destroy their quadrate character.

Habitat.-Victoria, British Columbia, and the Rocky Mountains, abundant.

" "Tardigraden-Studien," Ber. Senckbg. Naturf. Ges., 1909, p. 32. 


\section{Macrobiotus tuberculatus, Plate (23)}

Habitat.-Victoria, British Columbia.

The examples were rather larger than the average, but not so large as $M$. nodosus. They were colourless, and the knobs did not show on the outline in dorsal view.

\section{Macrobiotus sattleri, Richters (26)}

Habitat.-Rocky Mountains.

M. sattleri is either variable in the characters of the pharynx, or there are several forms which have the same peculiar skin-markings.

One form has three short rods in the pharynx. The Australian form (sce p. 141) has two unequal rods. The Canadian form has two equal rods, each about four times as long as broad. No comma was seen. The pairs of claws are unequal, and the claws of the larger pair are united for a short distance above the base.

\section{Macrobiotus, sp. ?}

Four eggs in a skin of $200 \mu$ in length. Eggs smooth, of about $60 \mu$ by $45 \mu$. Claws V's, equal pairs of equal claws, joined at the base only.

Without knowledge of the pharynx identification is not possible. It is certainly different from any of the species recognised. The claws prove that it is not a Diphascon.

\section{D : EGGS UNRNOWN}

Macrobiotus virgatus, sp. n. (Plate XXI. Figs. 55a-55c)

Specific characters.-Large and robust; pigmented with a warm brown colour arranged in longitudinal bands; gullet very wide, and teeth strong; pharynx shortly oval, with apophysis, and two rods and a nut in each row, the nut between the two rods; dark eyes; claws very thick, of the hifelandi type, very unequal, united for half the length of the longer one, which bears two thick supplementary points.

Detailed description.-Length, up to $750 \mu$. The colour is a warm brown, not unlike that of $M$. oberhïuseri, but less inclined to purple. It is arranged in three principal longitudinal bands, one median and two lateral. These latter may be subdivided into narrower bands, and there are some thin transverse bands.

The gullet is as much as 9 or $10 \mu$ in diameter. The teeth penetrate its wall at about the middle of its length. The end of the gullet in the pharynx has a slight projecting rim. The rods are of unusual proportions-the first and third are about four times as long as broad, the second varies from little longer than broad to twice as long as broad. 
The claws are quite like those of hufelandii, but they are more unequal and even thicker. The egg is unknown.

Habitat.-Victoria, British Columbia ; Ottawa, Australia (?), Franz-Josef Land (?).

The records for Australia and Franz-Josef Land are very uncertain, as they depend on the characters of the pharynx only. There were claws on the only specimen from Franz-Josef Land, but as they were only seen in profile, little can be said about them. They do not appear to be so thick or so far united as in M. virgatus.

If the Franz-Josef Land specimen is M. virgatus, then the eggs are smooth and are laid in the skin. Judging from the characters of the teeth, gullet, and claws, it might be expected that the animal would prove to belong to the hufelandi group, with rough eggs. There are very few species which combine the characters of smooth eggs and hufelandi claws. M. rubens is the best instance known to me.

The peculiar proportions of the "bacilla" in the pharynx, one short between two long, distinguish $M$. virgatus from all related species. Only $M$. augusti, which is not closely related, has a rather shorter middle rod.

It is rarely permissible to describe a Macrobiotus of which the egg is unknown. In this case the association of so many distinct characters-the colour, the pharynx, the claws-seemed to justify a breach of the rule. When the eggs are found there should be no difficulty in demonstrating their connection with this species.

\section{Macrobiotus sp. ? (Plate XXI. Fig. 60)}

Description. - Size moderate, length $300 \mu$. Colour grey; no eyes. Gullet of moderate width. Teeth strongly curved, with large furca. Pharynx shortly oval, with conspicuous apophysis, and two "bacilla" in each row. The first, next the gullet, is three times as long as broad. It is divided by a constriction into two equal parts. The second is not quite twice as long as broad. There is no comma.

The claws resemble exactly those of $M$. canadensis (Fig. 61c). The pairs are unequal and diverge widely. Each pair has one claw longer than the other, and the long claw of the larger pair is very slender, almost bristle-like. The long claw is attached to the shorter claw near its base, showing a slight approach to the Diphascon type.

The association of several distinct characters marks this as a distinct species, but as only one example was seen, and the egg is unknown, it is left in the meantime unnamed.

Habitat.-Rocky Mountains 


\section{E: Unidentified EGGS.}

Macrobiotus, sp. ? (Plate XXI. Fig. 57)

A large egg, measuring $105 \mu$ over the processes, which are low cones, rounded at the ends, and papillose all over. The processes stand close together, without any interspaces.

This closely resembles an egg figured by Richters in the "Moosrasen des Gaussbergs" (35), Plate XX. Fig. 7, as probably related to $M$. echinogenitus. It is probably a distinct species.

\section{Macroliotus, sp.? (Plate XXI. Fig. 56)}

A large egg, measuring $100 \mu$ over the processes, $80 \mu$ without the processes. These are narrow conical pegs, rounded at the ends. They are separated by spaces about equal to the diameter of the pegs at the base.

A similar egg is figured in "Tardigrada of the South Orkneys" (15), Plate IV. Fig. 14, as perhaps a form of $M$. echinogenitus. Another somewhat like it is figured in "Arctic Tardigrada" (19) Plate XLV. Fig. 2, as perhaps M. islandicus, Richters. The processes are not rounded, but many are a little expanded at the tip, showing an approach to hufelandii.

The Canadian egg is probably a distinct species.

\section{Macroliotus, sp. ? (Plate XXI. Fig. 59)}

A small egg, $80 \mu$ over the spines, $68 \mu$ without them. The processes are small cones, slightly acuminate, acute. They are separated by spaces rather less than the diameter of the processes at the base. The surface exposed between the processes is marked by regular pellucid dots.

Several species have eggs like this, and they cannot be distinguished with any certainty unless they are found containing young.

$M$. dispar has such an egg, but rather larger; that of $M$. pullari is somewhat smaller. The egg of $M$. ascensionis is considerably smaller, and has the processes more closely set.

Genus-Diphascon, Plate (23)

Diphascon chilenense, Plate (23)

Habitat.-Rocky Mountains.

Diphascon alpinum, Murray (14)

Habitat.-Rocky Mountains : near the Lake of the Woods, Ontario. 


\section{Diphascon scoticum, Murray (11)}

Habitat.-Stanley Park, Vancouver : Rocky Mountains.

\section{Diphascon canadense, sp. n. (Plate XXI. Figs. $62 \alpha-62 c$ )}

Specific characters.-Small, without eyes, hyaline. Gullet long, slender. Pharynx round, with apophysis, two rods and a "comma" in each row, the first about twice as long as broad, the second about as long as broad. Claws typical for the genus.

Detailed description.-Length up to $250 \mu$. Form narrow and elongate. Pharynx $25 \mu$ in diameter. Gullet 50 to $60 \mu$ in length, very slender, little over $1 \mu$ in diameter. The largest pair of claws is about 12 to $15 \mu$ in length. The long claw is very slender, the short one somewhat thick. Both claws of the smaller pair are slender-they are unequal and joined at the base only. The eggs were not seen.

Habitat.-Moss from the sea-shore at Victoria, British Columbia, fairly abundant.

Among species having the gullet slender and the pharynx short it is only necessary to compare $D$. canadensis with $D$. oculatum (13), to which it is closely related. It was at first supposed to be a blind form of oculatum, till other slight differences were noticed.

$D$. oculatum is larger, and has a pair of dark eyes. The pharynx is not so nearly round, and the two thickenings in each row are equal, and scarcely longer than broad. The claws of the shorter pair are shorter and thicker.

The eye-spots are not considered to be trustworthy as specific characters, though I know of no variation in the genus Diphascon. When, however, we consider the slight but constant differences in the pharynx and claws, the species appears sufficiently distinguished from $D$. oculatum.

\section{Remarks on the Canadian Tardigrade Fauna}

Its composition.-Of the 31 species studied 23 were identified-the other 8 require further study. There are 9 species of Echiniscus, 17 of Macrobiotus, 4 of Diphascon, and 1 Milnesium. Seven species are considered to be new to science (2 Echiniscus, 4 Macrobiotus, and 1 Diphascon).

The list is such a one as might be expected as the result of a very limited amount of work on any continental area. The different genera are represented in about the average proportions, and there are no very peculiar forms. The most curious fact in the composition of the list is the total absence from it of species of Echiniscus of that section of the genus which has plates V. and VI. quite separate. As E. mutcebilis is one of the most cosmopolitan water-bears the absence from our collections must be considered as accidental. 
In the accompanying table the distribution of the Canadian species, both in Canada and over the world, is shown in thirteeu columns.

\section{Distribution : Local and General}

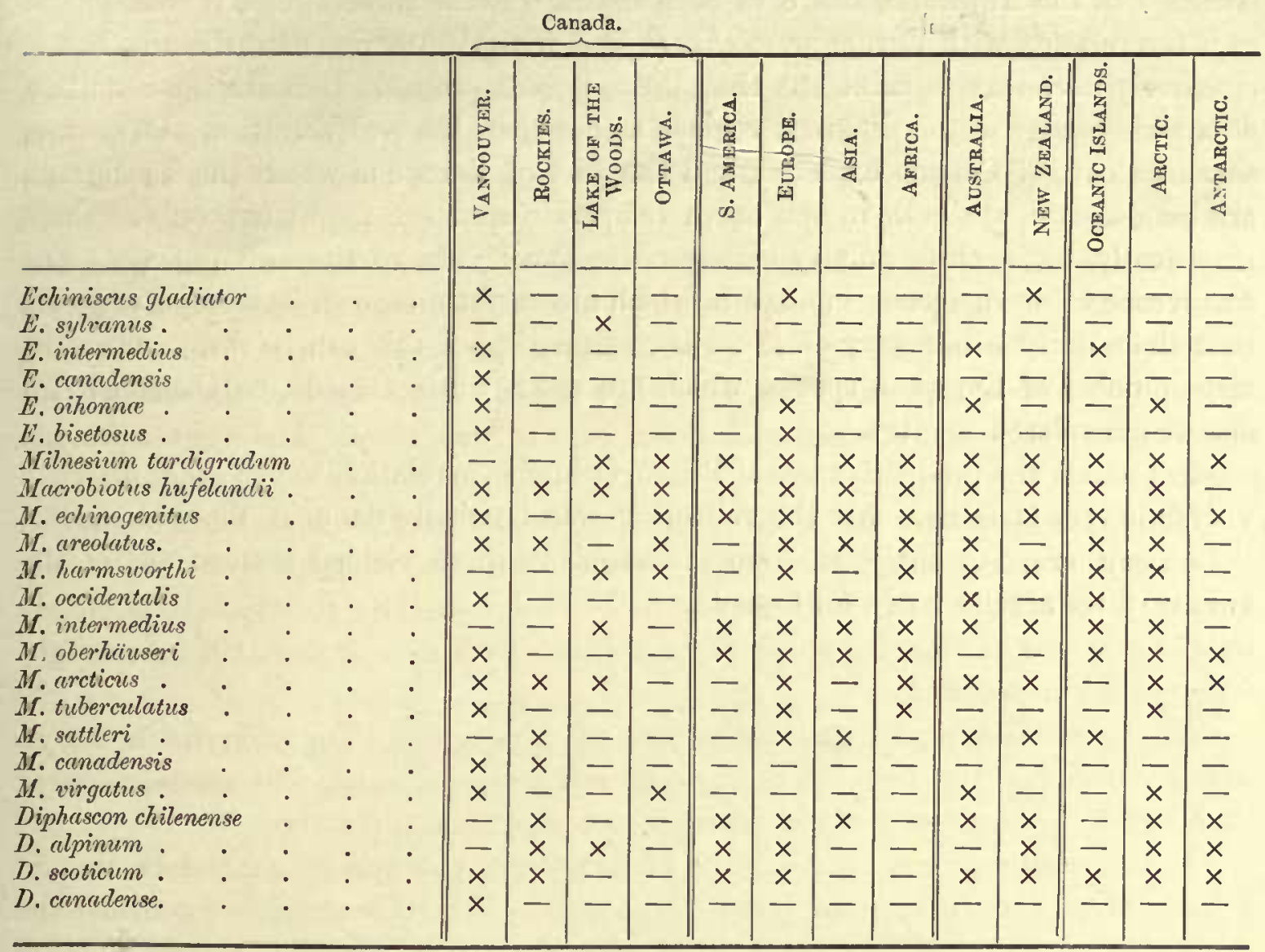

The table brings out some interesting facts in distribution. About nine of the species are cosmopolitan, or very widely distributed. These are Milnesium, $M$. hufelandii, $M$. echinogenitus, $M$. areolatus, $M$. intermedius, $M$. oberhäuseri, $M$. creticus, $D$. chilenense, and $D$. alpinum. These occur in six or more of the nine great regions into which the surface of the earth has been divided for the purpose of this comparison.

The others are more restricted in their range. The seven new species described in this paper are not all confined to Canada; three of them are already known elsewhere. $M$. areolatus (which was described some years ago as a variety of $M$. echinogenitus) is even among the cosmopolitan species. M. occidentalis, though discovered and fully studied in Canada, appears to have a "Pacific" distribution, as it has since been found in Honolulu and Australia. Another species having the identical range is Echiniscus intermedius, first discovered in Australia, and subsequently in Honolulu and Canada. In this case the species appears under a slightly different form in all three localities.

BRIT. ANTARCT. EXPED, 1907-9. VOL. I. 
The relation of the Canadian Tardigrade Fauna to that of other regions is shown in the following figures. Canada has 16 species which occur also in Europe, 14 in Australia, 14 in the Arctic, 8 in the Pacific Islands, New Zealand, and Asia, 9 in Africa, 7 in the Antarctic, and 6 in S. America. From these figures it would seem as if the relation with Europe were closest, and with S. America most distant, but it is scarcely necessary to point out that these figures probably indicate the condition of our knowledge of the different regions rather than the real affinities. Of course, since the part of Canada explored, and the part of Europe of which the Tardigrada are best known, are both in the north temperate zone, we might expect, and there may really be, a close affinity between the Tardigrada of the two regions. The occurrence of seven species in Canada which are as yet unknown in Europe suggests that the affinity is not very close. No confirmation of this can be drawn from the large number of European species which are unknown in Canada, as Canada is an almost unexplored country.

In Canada the productiveness of British Columbia in relation to the other districts visited is very striking. All the collecting was hurriedly done, in Victoria no less than elsewhere, yet the moss from the sea-shore there yielded sixteen out of the twenty-three species noted for Canada. 


\section{SUMMARY OF RESULTS}

The work of the Expedition on Tardigrada has resulted in the enumeration of fifty species, distributed in five genera. This may seem a small number, considering how many countries were visited, and the great range of climatic conditions which they present, from tropical heat to polar cold.

These fifty species are, however, about half of the known Tardigrada, and considerably more than half of the land and fresh-water species. And in addition to the fifty species identified, a considerable number more (something like twenty-three species) were observed and described, which, while not sufficiently known to be identified or pronounced to be new, are recognised as distinct from any of the species in the list.

It must be remembered, too, that it is only within the last few years that naturalists have begun to discriminate the species of Tardigrada carefully, and to realise that they are fairly numerous. For half a century after the discovery of the first water-bear by Göze in 1773 naturalists supposed that there was only one, or at most two, species. From Schultze's time (1834), when Tardigrada began to be more carefully looked at, for another half-century, scarcely a dozen species were distinguished. Even in 1888 Plate's monograph (23) admitted only twenty-five species, in six genera. Eight of the species and two of the genera were Plate's own discoveries. One of his genera, and at least four of his species, would now be disallowed.

Only with the arrival of Richters in the beginning of the present century were the Tardigrada looked at with sufficient care, and satisfactory diagnoses inaugurated. About the same period it began to be appreciated what great facilities were afforded by mosses for the collection and study of microfaunas, and in consequence the Tardigrada and other microscopic animals of distant countries became known.

Among the Tardigrada collected by the Expedition there are seventeen species recognised as new to science, and one new generic type was found in Australia.

In the accompanying table is given a list of all the species collected, and their distribution is shown in all the countries visited, and also the distribution over the world.

Distritution.-An analysis of the list brings out some interesting facts. There were observed in all 73 species, of which 33 were identified as known species, 17 are 
Distribution of all Species collected by the Expedition.

Echiniscus mutabilis, Murray K. novoezeelandice, Richters

E. pulcher, sp. n.

E. arctomys, Ehrenberg? *

E. kerguelensis, Richters

k. sylvanus, sp. n.

E. viridis, sp. $\mathrm{n}$.

E. tessellatus, sp. n.

L. gladiator, Murray

E. intermedius, sp. n.

L. canadensis, sp. n.

E. bisetosus, Heinis .

E. spinulosus, Doyère

E. spiniger, Richters

E. duboisi, Richters

h. perarmatus, Muriay

E. blumi, Richters

L. velaminis, sp. $\mathrm{n}$.

E. oihonno, Richters

Oreella mollis, gen. n., sp. n.

- Milnesium tardigradum, Doyère

Macrobiotus hufelandii, Schultze

M. furciger, Murray .

-M. echinogenitus, Richters

M. areolatus, sp. $\mathrm{n}$.

M. harmsworthi, Murray

M. montunus, sp. n. .

Mr. polaris, sp. $\mathrm{n}$.

Mr. hufelandioides, sp. n.

$M$. occidentalis, sp. $n$.

Mr. intermedius, Plate

M. crassidens, Murray

M. aculeatus, sp. n. .

M. oberhäuseri, Doyère

NI. dispar, Murray

MI. arcticus, Murray.

11. tuberculatus, Plate

MI. nodosus, Murray .

Mr. sattleri, Richters .

M. papillifer, Murriy

II. ornatus, Richters

MI. vubens, Murray .

M. connulatus, Murray

M. canadensis, sp. n.

M. aregusti, Murray .

M. virgatess, sp. n.

Diphascon chilenense, Plate

D. alpinum, Murray.

D. scoticum, Murray.

D. canadense, sp. n.

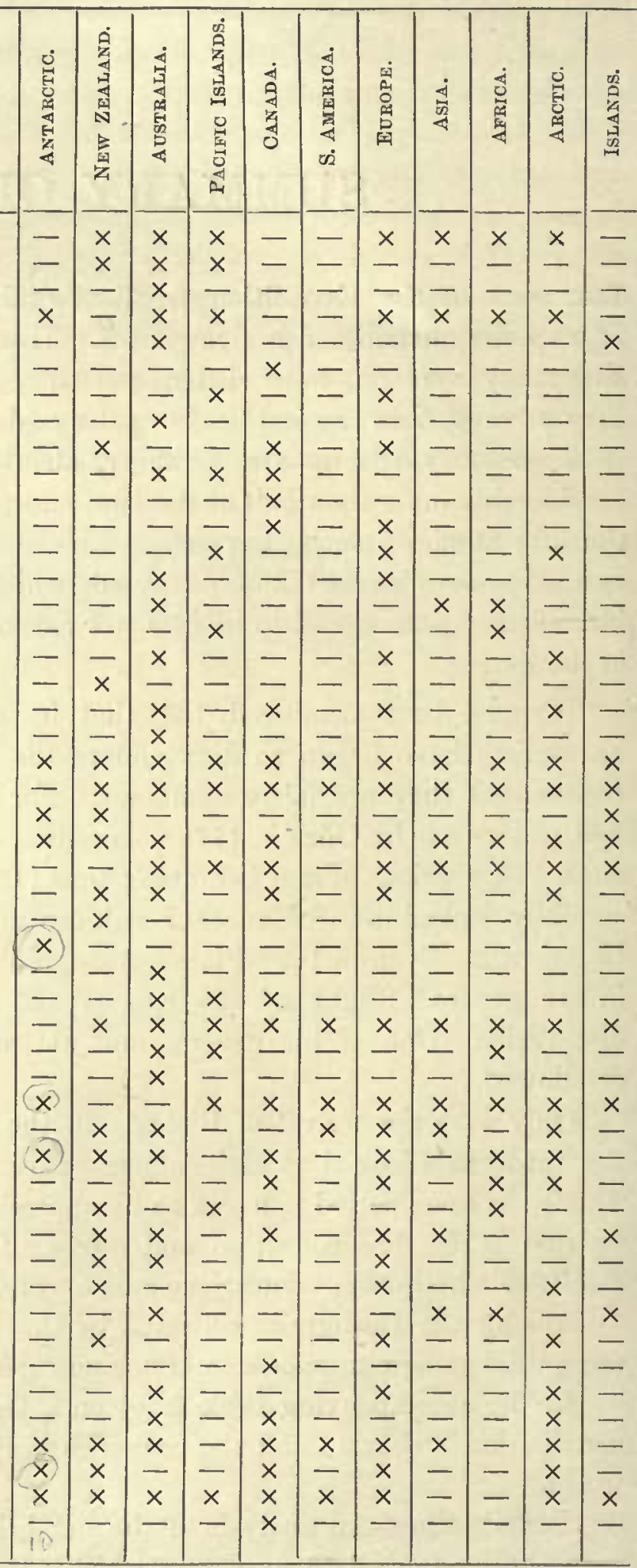

Twenty-three species not identifiod-12 of Lchiniscus, 10 of Mracrobiotus, and 1 doubtful, Macrobintus or Diphuscon. Total, 73 species.

* All these records of $E$. curctomys, except for Australia, are wrong (see p. 126 and footnote). 
described as new species, and 23 could not be identified. Of the 50 named species 26 were got in one only of the countries visited; 14 of these 26 are known in other parts of the world, while 12 are as yet unknown except in the one locality for each here recorded. These last are, of course, among the new species collected by the Expedition. Five of the new species were found in more than one country, or were previously kuown elsewhere, though they had not been described.

Australia has most species, viz., 38 (31 identified), Canada comes next with 31 (23 identified), New Zealand has 25 (21 identified), the Pacific Islands 18 (15 identified), and the Antarctic 5 (4 identified).

Canada has 7 of the new species, Australia 6 (and 1 new genus), New Zealand 2, the Pacific Islands 1, and the Antarctic 1.

It is noticeable how much richer the continental areas are than the islands, both in the number of species and the proportion of peculiar species. The isolation of New Zealand, Fiji, and Hawaii does not appear to have led to the development of many new forms.

As the Tardigrada of Europe are much more fully known than those of any other part of the world, the list of European species may be used as a standard, and it may be instructive to compare the lists of species from the various countries with it, and to note how much they have in common. Canada has 16 species in common with Europe, Australia 17 species, New Zealand 16 species, Pacific Islands 9 species, and Antarctic 3 species. Taking the ratios of these numbers to the totals for each country, it appears that subtropical Australia has in its Tardigrade Fauna nearly as much correspondence with that of Europe as has temperate Canada, where the climatic conditions are so similar to those of northern Europe. New Zealand and the Antarctic have more correspondence than either. For what those figures are worth, New Zealand is most like Europe, the Antarctic comes next, then Canada, Australia, and last of all the Pacific Islands. But there is little to choose between them, and the figures are not worth much, as they would be liable to change whenever further work is done in these countries.

The peculiarity of the Australian Tardigrade Fauna is greater than we would suppose from a mere consideration of the number of peculiar species. Not only is there a distinct generic type (Oreella), but most of the species (E. pulcher, E. tessellatus, $E$. intermedius), are conspicuously different from their nearest relatives. Even $M$. aculeatus, though differing from the African $M$. crassidens mainly by one external character, is of great interest. The six spines, occupying definite positions as they do on the segments which bear the second, third, and fourth pairs of legs, may possibly be the homologues of the dorsal processes of Echiniscus. If this were the case the occurrence of this species, and of the genus Oreella, would be of great importance in elucidating the affinities of the genera Macrobiotus and Echiniscus.

The existence of these various peculiar forms in Australia scrves to indicate that the Australian native Tardigrada are partly at least of very ancient origin, although, 
on account of the comparative facility of immigration, such facts have less weight in this group than in the Vertebrata.

The further study of the Tardigrada of continental and insular areas, in which cognisance would be taken of all known species, is alluring, but beyond the scope of this work.

Natural History.-There is in this paper, unfortunately, too little study of pure biology, or the natural history of the water-bear's, except in the wide sense that the form of every organism is a manifestation of life. In this sense, every trifling variation of form could throw some light on the nature of the living force which produces it, although we may be unable to trace its meaning.

The conditions under which the work was done prevented much attention being given to the study of living animals. Nearly all of the species were seen alive, so that the material for the investigation of life-histories was available, yet we know nothing as to such points as the duration of life, the time taken to grow up, the changes that occur during growth, the relations of the sexes, the time required for the eggs to hatch, and a host of others.

The observation of the living animals so closely as to elucidate any of these points, while fascinating to the naturalist, is too tedious, or if not tedious yet takes far too long, to be compatible with the compilation of a series of reports on the collections of an expedition.

There is no suggestion made as to the meaning of the peculiarities of species in their relation to their surroundings. The value of specific peculiarities to their possessors is generally very obscure, so much so that in an earlier chapter dealing with the Value of Species (p. 92) I have suggested that many of the specific characters are "fortuitous." Fortuitous in the ordinary sense they cannot be, but they may be so described in the restricted sense that they are of no definite use to the species. They may have beeu produced by the interaction of the conditions and the living force, without leading to more complete adaptation to the conditions. This must be understood as applying only to certain characters, since constant adaptation must have gone on as well.

We can understand or guess at the reasons why it is advantageous to some species to deposit smooth eggs in the skin at the moult, while others lay rough eggs without the protection of the skin-we can imagine benefits from the strange simplification and encystment of water-bears. These things are obviously important, whether we fully understand them or not.

There are, however, many little peculiarities of outward form, those things which supply the specific characters generally, in which it is difficult to see any advantage. They may, of course, have a value which is hidden from our eyes. Such are the spines and setæ of Echiniscus. It seems a reasonable supposition that such spines are protective : they may deter an enemy from making a meal of their possessor. But there are species with the processes quite soft and weak, such as the acicular 
spines of E. cfricanus, and these cannot be protective; while the commonest of all species have no spines.

In one direction the study of the variations of form among the Tardigrada is important, although we may not see the causes of the variation or its value to the animals. Through the various forms we can learn the affinities of the species, and we may thus gain some knowledge of the history of the development of the group. Thus the Tardigrada are brought into geological history, although their remains may be scarcely known in the strata of the earth.

It is an interesting fact in itself that so many Tardigrada have been obtained alive from dried mosses. Although a few were studied while the mosses were fresh, the great majority of the fifty species were got fiom mosses which had been dried for a longer or shorter period, varying from a month or two to nearly three years. This brings out strongly the power possessed by habitual moss-dwellers of surviving long periods of drought. After being kept for a year perfectly dry the number of animals which revive on being moistened seems no less than when the moss has only been a short time dry. After a year the vitality rapidly diminishesafter three years a very small proportion of the animals survive. The duration of their vitality is greatly affected by conditions. If there is a suspicion of moisture, if enough to produce mildew, or even merely to cause a musty smell, they will not live long.

In the Antarctic some experiments were made in order to test the limits to the vitality of water-bears. These are detailed briefly under the account of Macrobiotus creticus.

\section{BIBLIOGRAPHICAL LIST OF WORKS REFERRED TO IN THE TEX'T}

Several others, which came too late to be inserted in their proper places, will be found in footnotes. In the text the references to this list are made in figures in heavy type, enclosed in parentheses.

1. Carlzox, C., "Schwedische Tardigraden," Zool. Anzeig., Bd. 34, 1909, p. 137.

2. Doyìre, M. T., "MLémoire sur les Tardigrades," Ann. des sci. nat., Sér. 2, Tom. 14, 1840, p. 269.

3. EnrenberG, C. G., "Diagnoses novarum formarum," Verh. K. Akad. Wiss. Berl., 1853, p. 530.

4. " " "Mikrogeologie," Atlas, Taf. 35в, 1854.

5. " " "Mikroscopischen Lebens in bis 20,000 Fuss Alpenhöhe," Abhand. K. Akad. Wiss Berl. (aus dem Jahre 1858), 1859, p. 429.

6. Hay, W. P., "A Bear-Animal renamed," Proc. Biol. Soc. Washington, xix., 1907, p. 46.

7. Heinis, Fr., "Tardigraden der Schweiz," Zool. Anzeig., Bd. 32, 1908, p. 633.

8. " " "Moosfauna der kanarischen Inseln," Zool. Anzeig., Bd. 33, 1908, p. 711.

9. " " "Moosbewohnenden Rhizopoden, Rotatorien, und Tardigraden," Arch. fïr Ilydrobiol. und Planktonkunde, Bd, 5, 1910.

10. Hutrox, F. W., "Index Faunæ Novæ Zealandiæ," London, 1904.

11. Murray, J., "Tardigrada of the Forth Valley," Ann. Scot. Nat. Hist. 1905, p. 160.

12. " " "The Tardigrada of the Scottish Lochs," Trans. Roy. Soc. Edin., vol. xli., 1905, p. 677.

13. " "Tardigrada of the Forth Valley," 2nd paper, Ann. Scot. Nat. Hist., 1906, p. 214.

14. " "Scottish Alpine Tardigrada," Ann. Scol. Nut. Hist., 1906, p. 25.

15. " " "Tardigrada of the South Orkneys," Trans. Roy. Soc. Edin., vol. xlv., 1906, p. 323. 
16. Murray, J. "The Encystment of Macrobiotus," The Zoologist, 1907, p. 1.

17. " "Some Tardigrada of the Sikkim Himalaya," Journ. Roy. Micr. Soc., 1907, p. 269.

18. " " "Scottish Tardigrada, collected by the Iake Survey," Truns. Roy. Soc. Edin., vol. xlv., 1907, p. 641.

19. " " "Arctic Tardigrada, collected by Wm. S. Bruce," Trans. Roy. Soc. Edin., vol. xlv., 1907 , p. 669.

20. " "Some South African Tardigrada," Journ. Roy. Micr. Soc., 1907, p. 515.

21. Packard, A. S., "Discovery of a Tardigrade," Aner. Naturclist, vol. vii., 1873, p. 740.

22. Perty, M., "Die Familie Xenomorphidæ," Okens Isis (Jahr'g. 1834), p. 1241, 1835.

23. Puate, L. H., "Naturgeschichte der Tardigraden," Zool. Jahrb., Abt. f. Anat. Bd. 3, 1888, p. 487.

24. Ricuters, F., "Fauna der Umgegend von Frankfurt-a.-M.," Ber. Senckbg. Naterf. Ges., 1900.

25. " " "Neue Moosbewohner," Ber. Senckbg. Nuturf. Ges., 1902.

26. " " " "Fauna der Umgebung von Frankfurt-a.-M.," Ber. Senckbg. Naturf. Ges., 1902.

27. " " "Nordische Tardigraden," Zool. Arezeig., Bd. 27, 1903, p. 168.

28. " " "Verbreitung der Tardigrader," Zool. Anzeig., Bd. 28, 1904, p. 317.

29. " " "Echiniscus conifer," Ber. Senckbg. Naturf. Ges., 1904, p. 73.

30. " " "Islandische Tardigraden," Zool. Anveig., Bd. 28, 1904, p. 373.

31. " " "Antarktische Moosfauna," Verh. dertsch. Zool. Ges., 1904, p. 236.

32. " " "Die Eier der Tardigraden," Ber. Senckbg. Naturf. Ges., 1904, p. 59.

33. " " "Arktische Tardigraden," Farna Arctica, Bd. 3, Jena 1904, p. 495.

34. " " "Zwei neue Echiniscus-Arten," Zool. Anzeig., Bd. 31, 1907, p. 197.

35. " " "Fauna der Moosrasen des Ganssbergs, dec.," Dert. Sïllpol. Exped., 1001-3, Bd. 9 Zool. 1907, p. 261:

36. " " "Antarktische Tardigraden," Zool. Anzeig., Bd. 31, 1907, p. 915.

37. " " "Moosfauna Australiens, \&c.," Zool. Jahrb., Bd. 26, Abt. für Syst. 1908, p. 196.

38. " " " "Moosbewohner," Wiss. Ergebn. Schwed. südpol. Exped., 1901-3, 1908.

39. " " "Moosfauna-Studien," Ber. Senckbg. Naturf. Ges., 1908, p. 14.

40. " " "Tardigraden unter $77^{\circ}$ S. Br." Zool. Anz eig., Bd."34, 1909, p. 604.

41. Schaudinn, F., "Die Tardigraden," Fauna Arctica, Bd. 2, 1901, p. 187.

42. Schultze, C. A. S., "Macrobiotns hufelandii," Okens Isis., 1834, p. 708.

43. " " "Echiniscus bellermanni," Berlin, 1840.

44. " " "Echiniscus creplini," Gryphiæ, 1861.

45. Scourfield, D. J., "Non-Marine Fauna of Spitsbergen." Part I.-Rhizopoda, Tardigrada Entomostraca, \&c., Proc. Zool. Soc. London, 1897, p. 790.

46. Whrtelegaz, T., "Invertebrate Fauna of Port Jackson and neighbourhood," Journ, and Proc. Roy. Soc. N.S.W., 1889, p. 163. 


\section{INDEX TO SPECIES}

Diphascon alpinum, Murray, 100, 119, 175

D. concudense, sp. n., 176

D. chilenense, Plate, $119,143,175$

D. scoticune, Murray, 119, 143, 176

Echiniscus arctomys, Ehrenberg, 128

$E$. bisetosus, Heinis, 164

E. blumi, Richters, 132

E. canadensis, sp. n., 162

E. duboisi, Richters, 131

E. gladiator, Murray, 111, 160

E. intermedius, sp. n., 129, 151, 161

E. kerguelensis, Richters, 128

E. mutabilis, Murray, 110, 126, 151

E. norreaelandice, lichters, 110, 126, 151

E. oilonne, Richters, 132, 163

E. percurmatus, Murray, 154

E. pulcher, sp. n., 127

E. spiniger, Richters, 131

E. spinzlosus, Doyère, 153

k. sylvanus, sp. n., 160

E. tessellatus, sp. n., 129

E. veluminis, sp. n., 112

E. viridis, sp. n., 152

Macrobiotus aculeatus, sp. n., 139

M. connelaters, Murray, 118
M. arcticus, Murray, 96, 118, 140, 171

M. areolatus, sp. n., 137, 148, 167

M. augusti Murray, 141

MI. canadensis, sp. n., 171

H. crassidens, Murray, 139, 155

$M$-dispar, Murray, 117, 140

M. echinogenitus, Richters, 115, 137, 167

Mr. furciger, Murray, 114

MI. harmsworthi, Murray, 115, 137, 169

Mf. hufelandii, Schultze, 114, 137, 166

M. Inefelandioides, sp. n., 138

M. intermedins, Plate, 117, 139, 155, 171

M. montanus, sp. n., 116

M. nodlosus, Murray, 118, 148

MI. oberhïuseri, Doyère, 99, 155, 171

M. occidentelis, sp. n., 139, 155, 169

M. ornetus, Richters, 118

M. papillifer, Murray, 118, 141

31. polaris, sp. n., 98

Mr. rubens, Murray, 141

M. sattleri, Richters, 118, 141, 173

M. tuberculaters, Plate, 173

M. virgatus, sp. n., 142, 173

Milnesium tardiyradum, Doyère, 114, 137, 154,166

Oreella mollis, gen. n.; sp. n, 135 

PLATE XIV 


\section{PLATE XIV}

\section{ANTARCTIC TARDIGRADA}

FigURE 1a.-Macrobiotus polaris, sp. n., adult . . . . $\times 300$

Figure 1b.-The same, teeth and pharynx

Figure 1c.-The same, young emerging from the egg . . . $\times 300$

Figure $1 d$.-The same, variety of the egg . . . . . $\times 300$

Figure 1e.-The same, claws

Figure 2a.-Macrobiotus arcticus, Murray, adult . . . . $\times 300$

Figure 2b.-The same, teeth and pharynx of adult

Figure 2c.-The same, thick-shelled egg . . . . . $\quad \times 300$

Figure 2d.-The same, claws of adult

Figure 2e.-The same, young just hatched . . . . . $\times 300$

Figure $2 f$.-The same, teeth and pharynx of young

Figure 3.-Diphascon alpinum, Murray, Antarctic variety . . $\times 300100$

Figure 4.--Diphascon or Macrobiotus (?). A doubtful intermediate 100 form. Teeth and pharynx, showing shortly elongated gullet. The claws are like Fig. $2 d$ on this plate. 


\section{Murray: ANtarctic TARdigrada.}
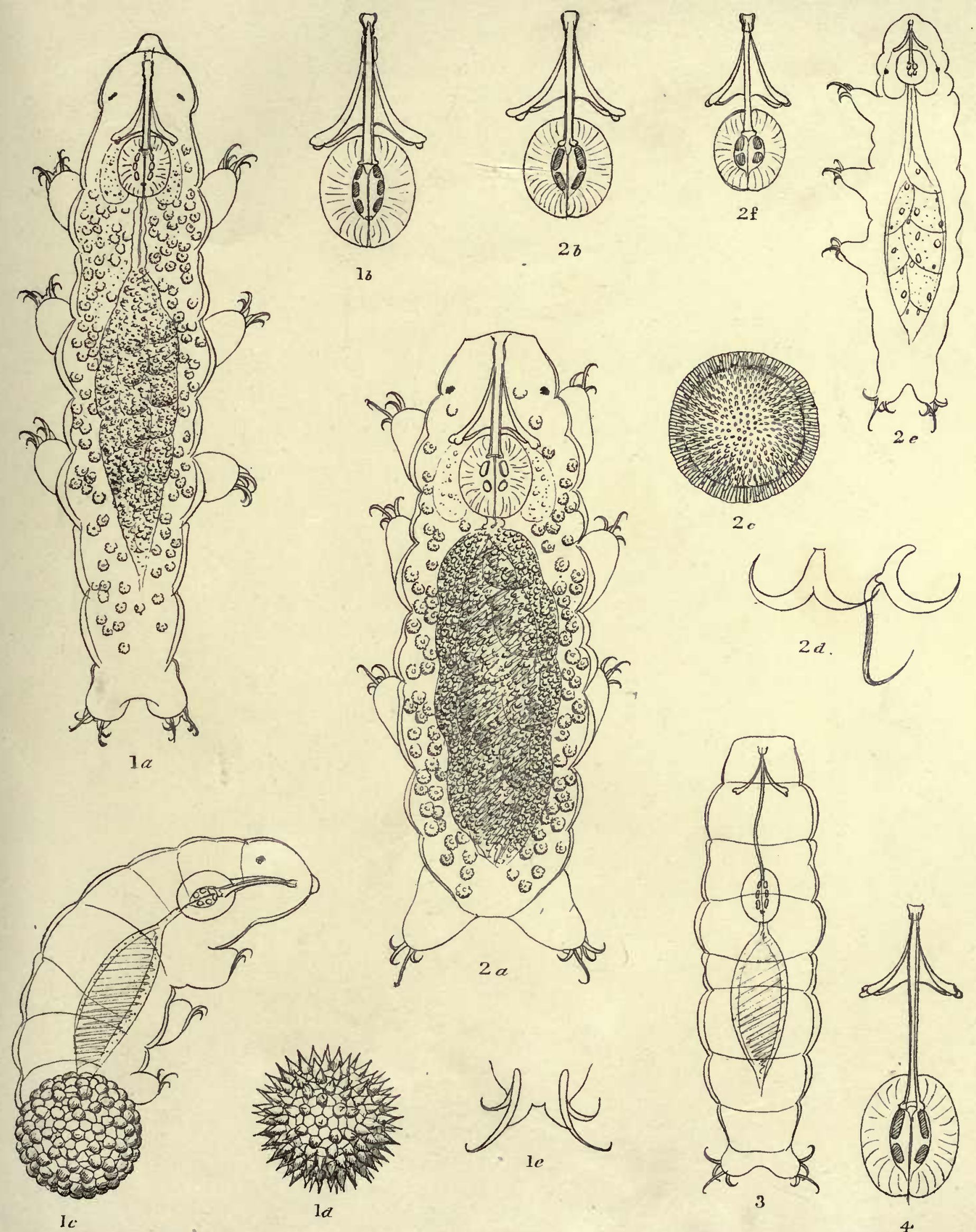

$2 c$
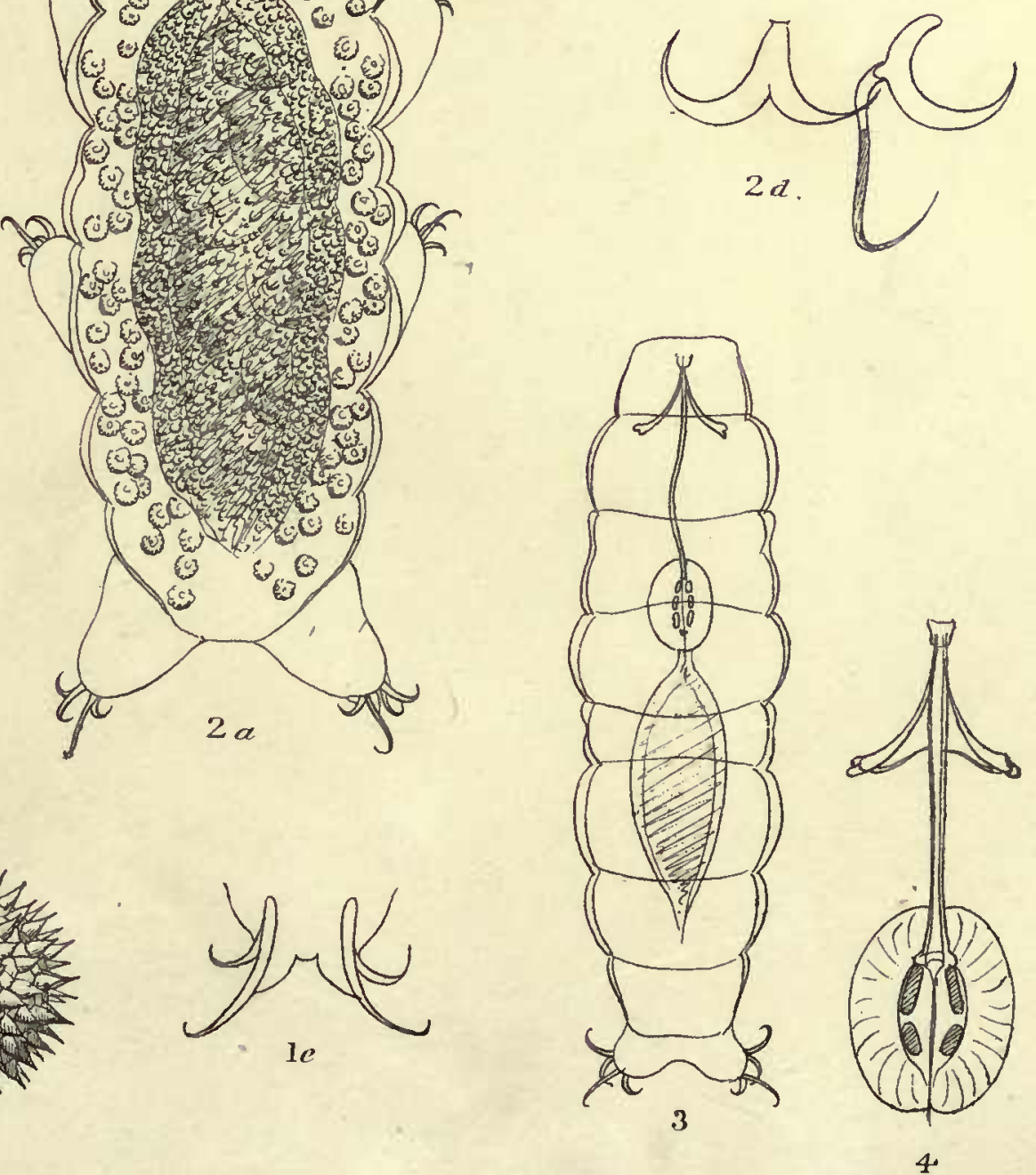

-1.Macrobiotus polaris.sp.n. 2. M.arcticus Murray. 3.Diphasc on alpinum Murray. 4. Diphascon or Macrobiotus. 


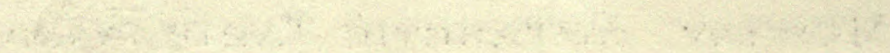


PLATE XV 


\section{PLATE XV}

\section{TARDIGRADA OF NEW ZEALAND}

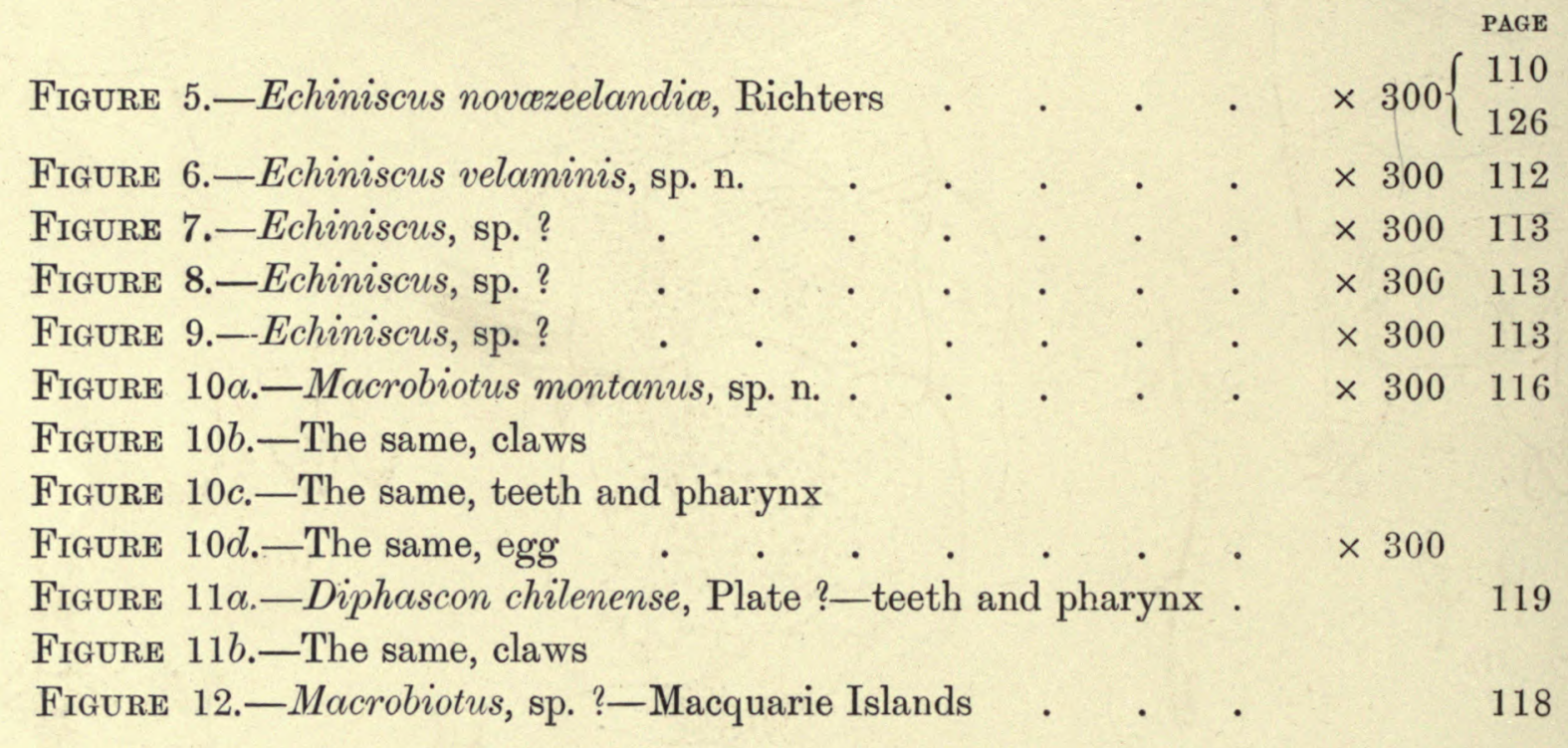


Murray: Tardigrada of New Zealand
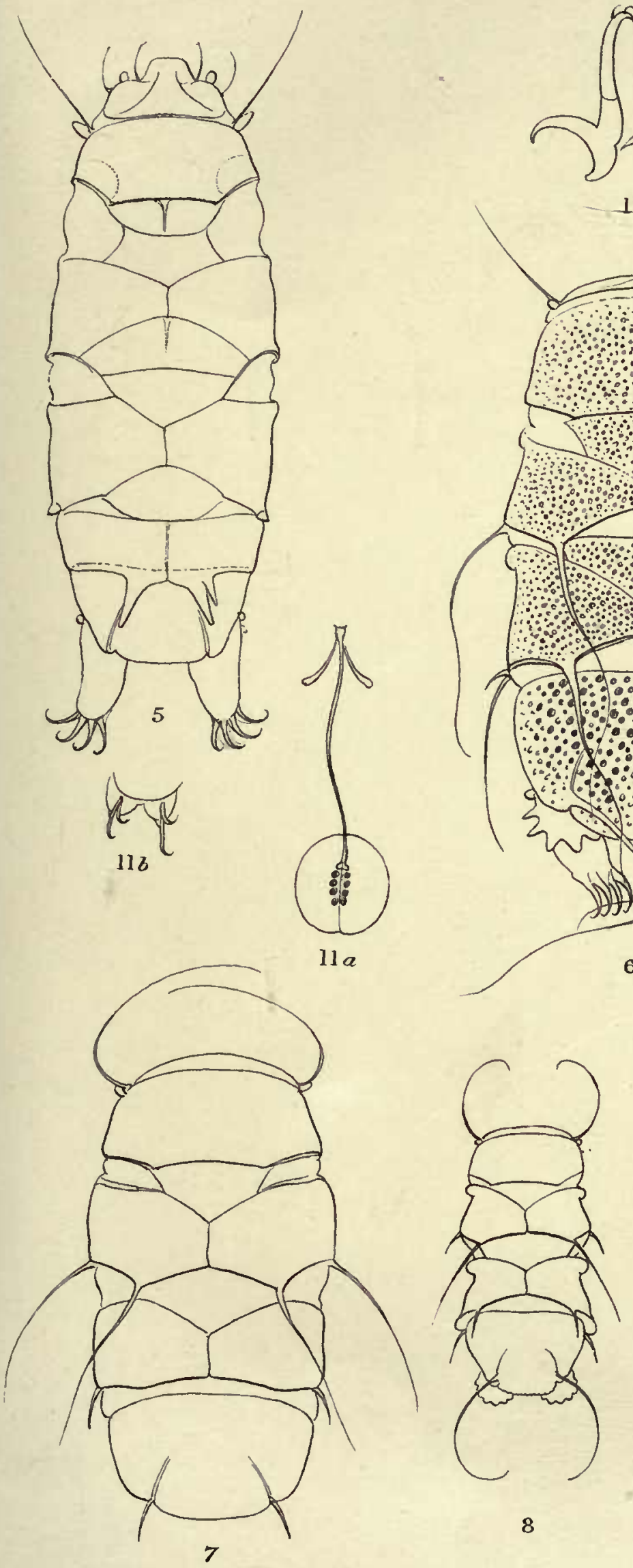

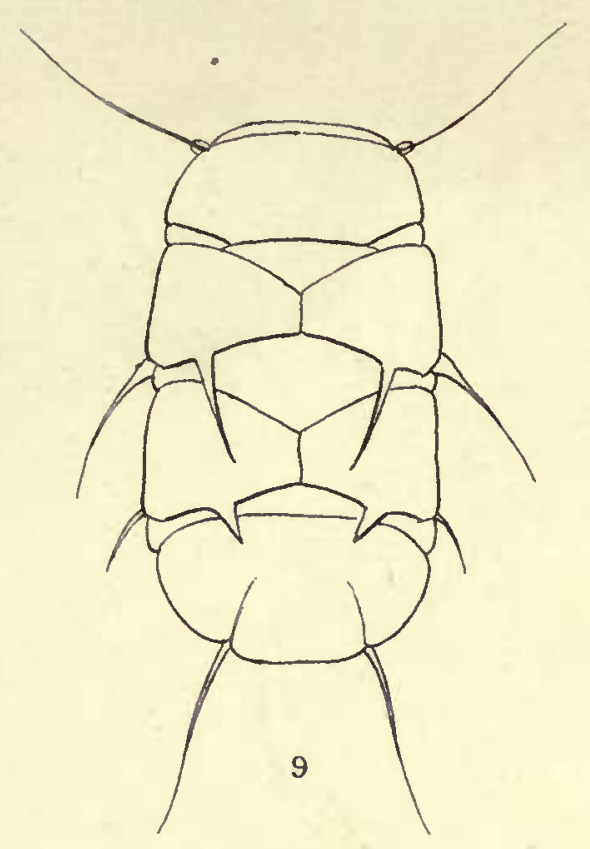

vive

106

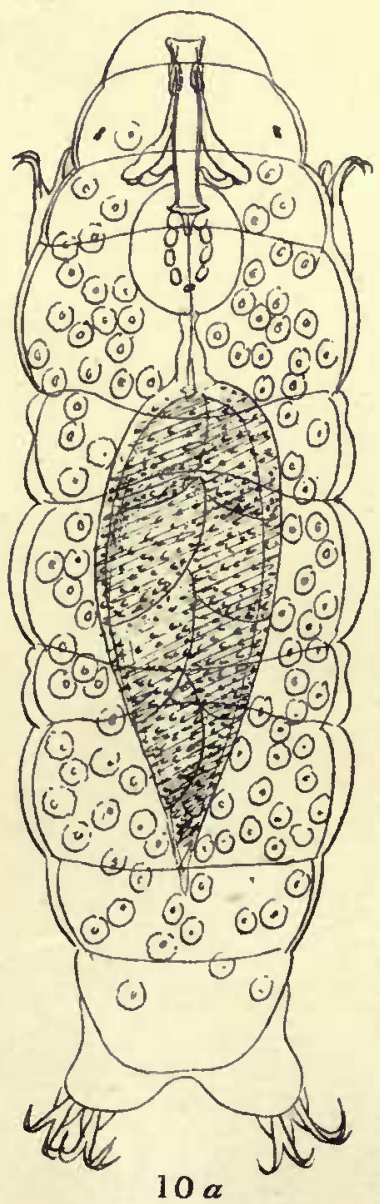

5. ECHINISCUS NOVAEZEELANDIAE RICHTERS. 6. E. VELAMTNIS sp.n

T. 8 \& 9 . ECHINISCUS SPECIES?

10. Machobiotus montanus sp.n. 12. Macrobiotus SPECIES?

11. DiPHASCON CHILENENSE PLATE

I Murray del. ad nat 


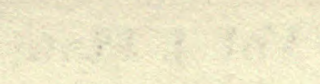

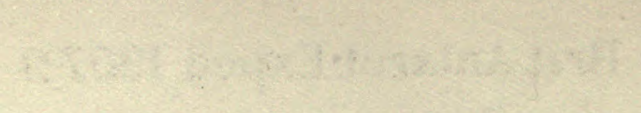


PLATE XVI 


\section{PLATE XVI}

\section{AUSTRALIAN TARDIGRADA}

PAGE

Figure 13.-Echiniscus kerguelensis, Richters . . . . $\quad \times 300128$

Figure 14.-Echiniscus blumi, Richters . . . . . . $\quad \times 300132$

Figure 15.-Echiniscus tessellatus, sp. n. . . . . . . $\quad . \quad \times 300129$

FIGURE 16.-Echiniscus, sp. ? . . . . . . . . $\quad \times 300135$

FIGURE 17.-Echiniscus intermedius, sp. n., type with reticulate surface . . . . . . . . . . $\quad . \quad \times 300 \quad 129$

Figure 18.-Echiniscus, sp. ? . . . . . . . . . $\times 300133$

FIG. 14.-E. blumi is marked to indicate the segments I. to VI. (Richters), and the lateral processes $a, b, c$, and $d$. Those four processes are setæ, but $e$ is lacking in this species. At the base of $a$ is the "auricle." Segments V. and VI. having completely coalesced, the single segment resulting is referred to as V.+VI. The figure shows also a little sharp spine on the first leg, a blunt palp at the base of the fourth leg, the "fringe" of sharp teeth, and the "barbs" of the outer and inner claws. 
MURray: AUstralian Tardigrada.
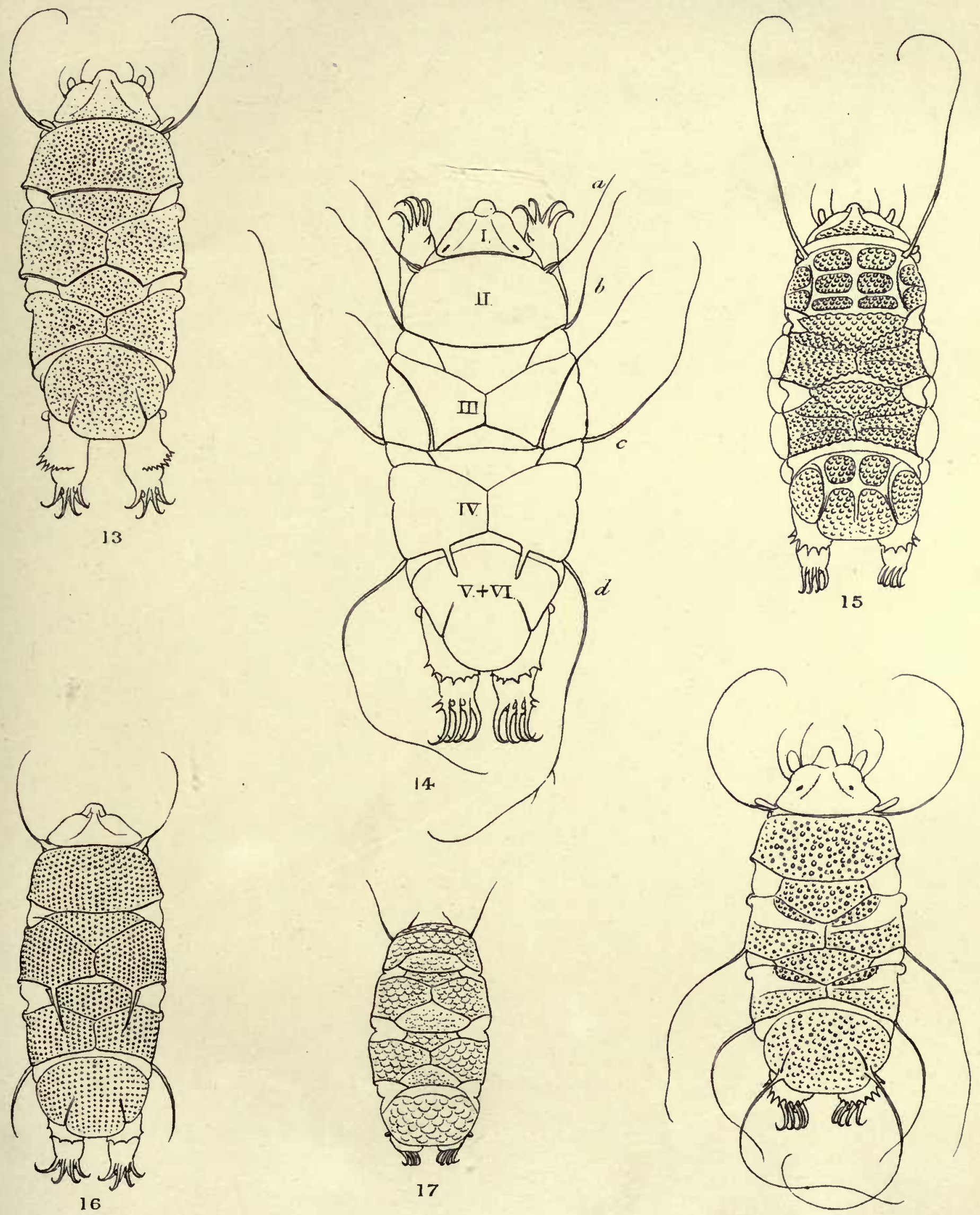

18

13.ECHINISCUS KERGUELENSIS RICHTER.S. 14. E.BLUMI RICHTERS. 15. E. TESSELLATUS, sp n J.Murray del ad nat.

\author{
17. E INTERMEDIUS sp.n 16. \& 18. ECHINISCUS. SPECIES.?
}





\section{PLATE XVII}

BRIT. ANTARCT. EXPED, 1907-9. VOL. I. 


\section{PLATE XVII}

\section{AUSTRALIAN TARDIGRADA}

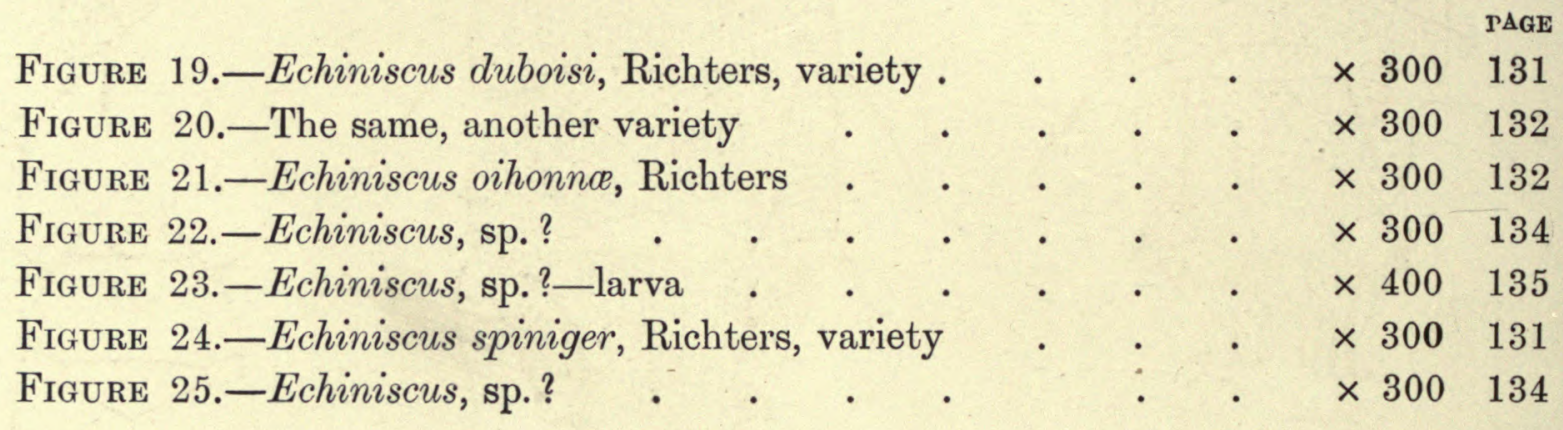




\section{MURRAY: AUstralian Tardigrada.}
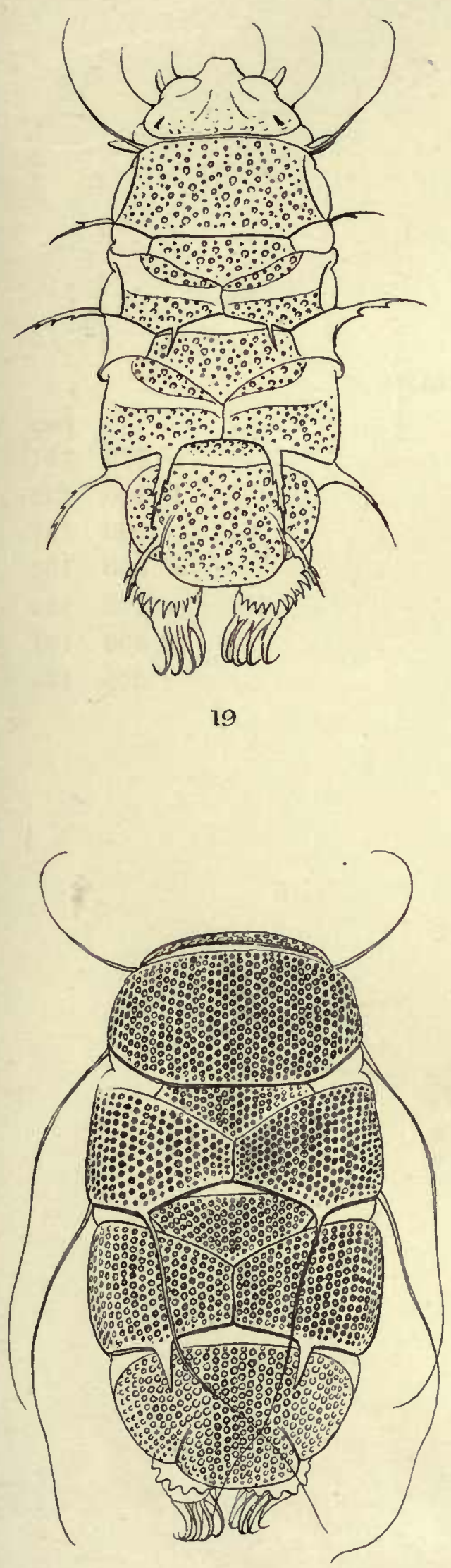

22.
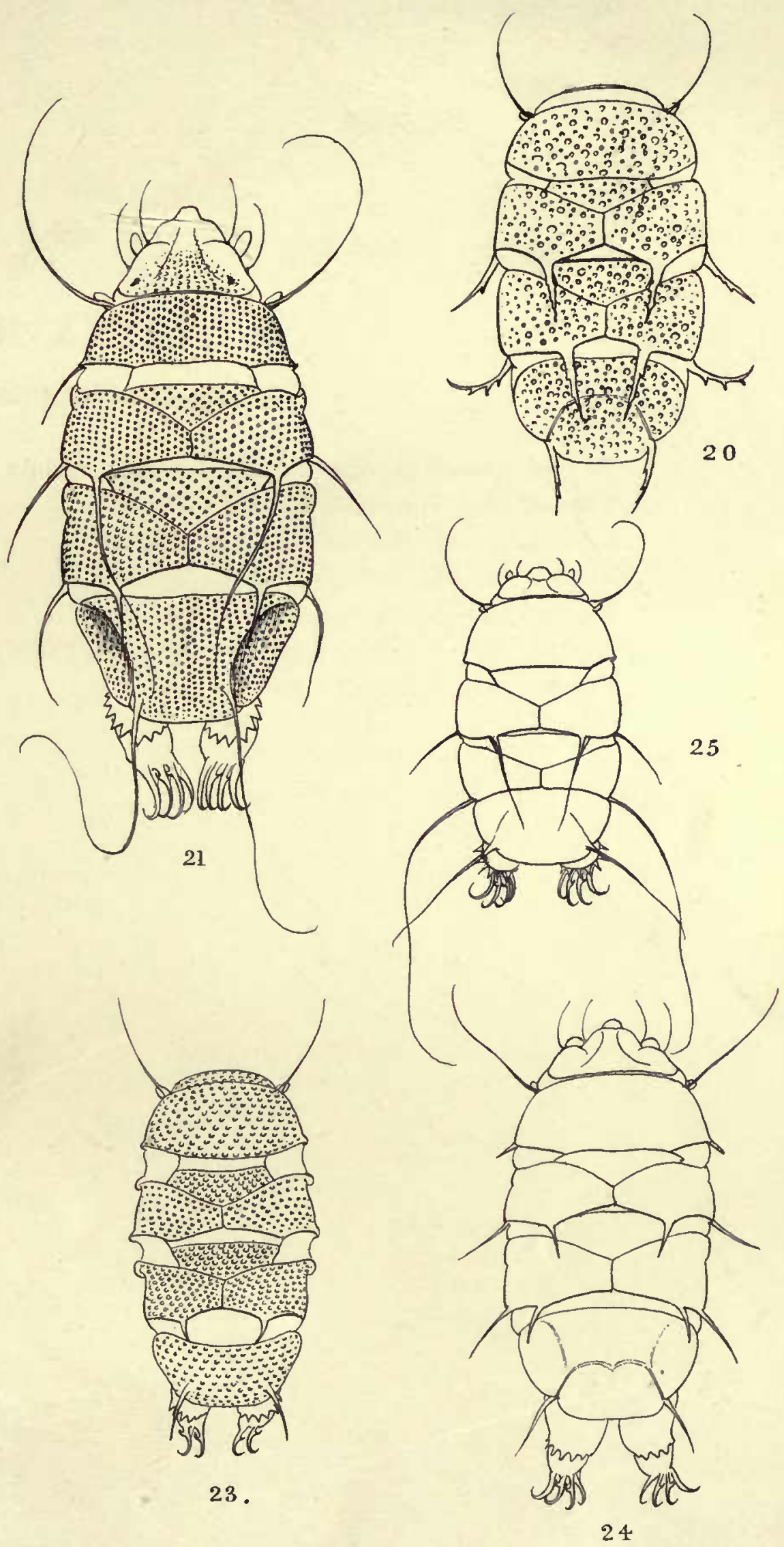

19. 2 20. ECHINISCUS DUbOISI RICHTERS. 21. E.OIHONNAE RicHTERs. 24. E. SPINIGERRICHTERS 

PLATE XVIII 


\section{PLATE XVIII}

\section{AUSTRALIAN TARDIGRADA}

Frgure 26.-Oreella, gen. n., mollis, sp. n. . . . . . $\quad \times 300135$

Figure 27a.-Macrobiotus aculeatus, sp. n. . . . . . . $\quad \times 300139$

Figure 27b.-The same, teeth and pharynx

Figure 27c.-The same, egg . . . . . . . $\times 300$

Figure 27d.-The same, claws

Figure 27e.-The same, variety with only two spines . . . $\quad \times 300$

Figure 28.-Macrobiotus virgatus (?) . . . . . . . . 142

Figure 29a.-Macroliotus hufelandioides, sp. n. . . . . . 138

FIGURE 29b. - The same, three processes of the egg

Figure 29c.-The same, claws

Figure 30.-Macrobiotus echinogenitus (?)-egg . . . . . $\quad \times 300137$

Figune 31.-Macroliotus harmsworthi (?)—egg . . . . . $\quad \times 300137$

Figure 32a.-Macrobiotus, sp. ?-foot, showing knob . . . . 142

Figure 32b.-The same, claws

Figure 32c.-The same, teeth and pharynx

Figure $33 \alpha$. -Macrobiotus, sp. ? . . . . . . . . . $\quad \times 300142$

Figure $33 b$. -The same, claws

Figure 33c.-The same, teeth and pharynx

FIGURE 34.-Echiniscus pulcher, sp. n. . • . • • . $\quad \times 300127$

This figure is marked to indicate the segments I. to VI. (Richters), and the lateral processes $a, b, c, d$, and $e$. In this species $a$ and $e$ are setæ and $b, c, d$ are little cones. At the base of $\alpha$ is the "auricle." Segments V. and VI. are separate. 
Brit Antarct Exped 1907-9.

Murray: Austratian Tardigrada.

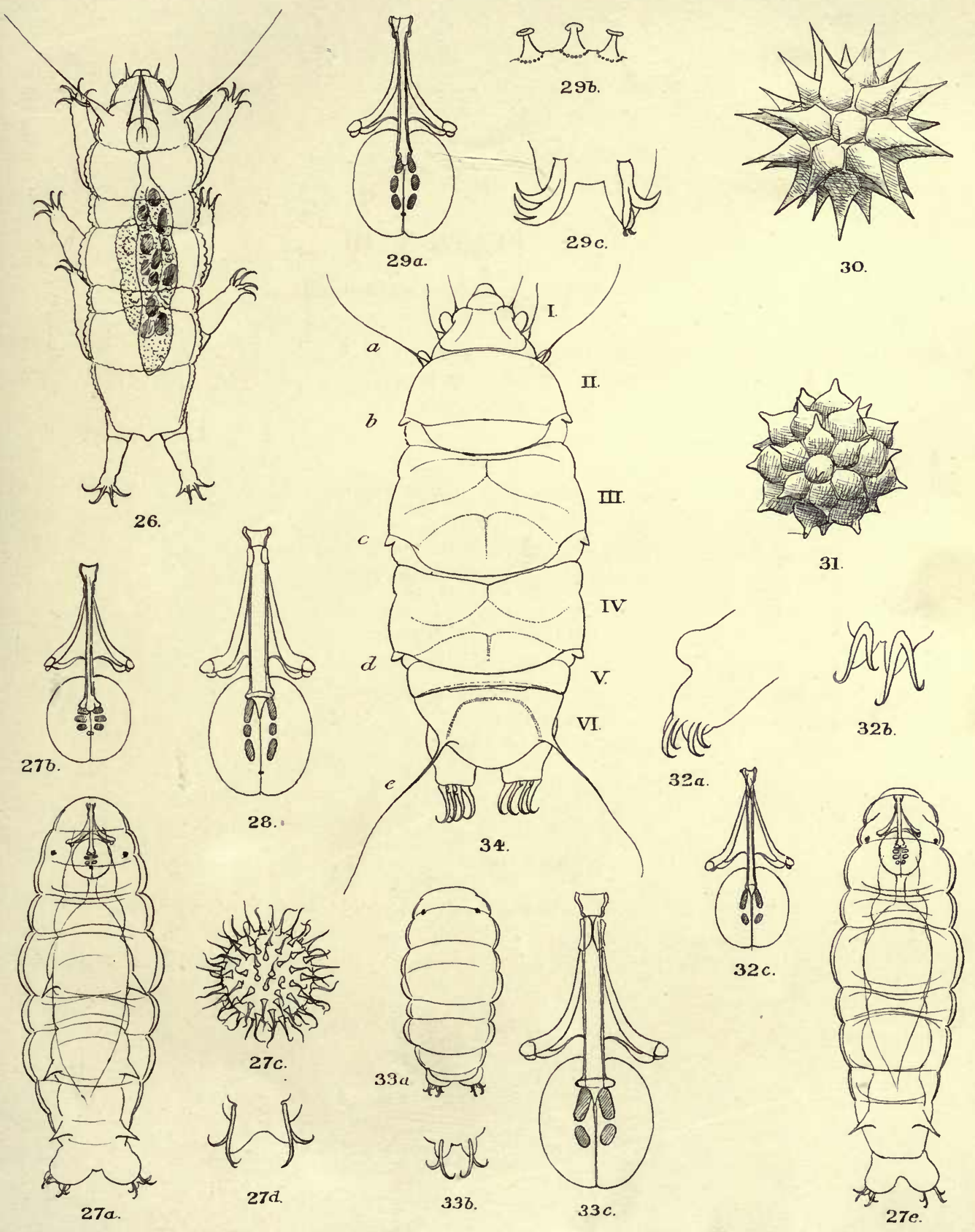

26.0REFiLLA ngen MOLLIS n.sp. 27MACROBIOTUS ACULEATUS spn 28M. VIRCATUS MURRAY? 29. M. HUPLLANDIOIDES sp.n 30. MECHINOGENITUS RICHTERS. 31.M. HARMSWORTHI MURRAY. 34.ECHINISCUS PULCHER.sp n J. Murray del. ad nat. 



\section{PLA'TE XIX}




\section{PLATE XIX}

\section{TARDIGRADA OF PACIFIC ISLANDS}

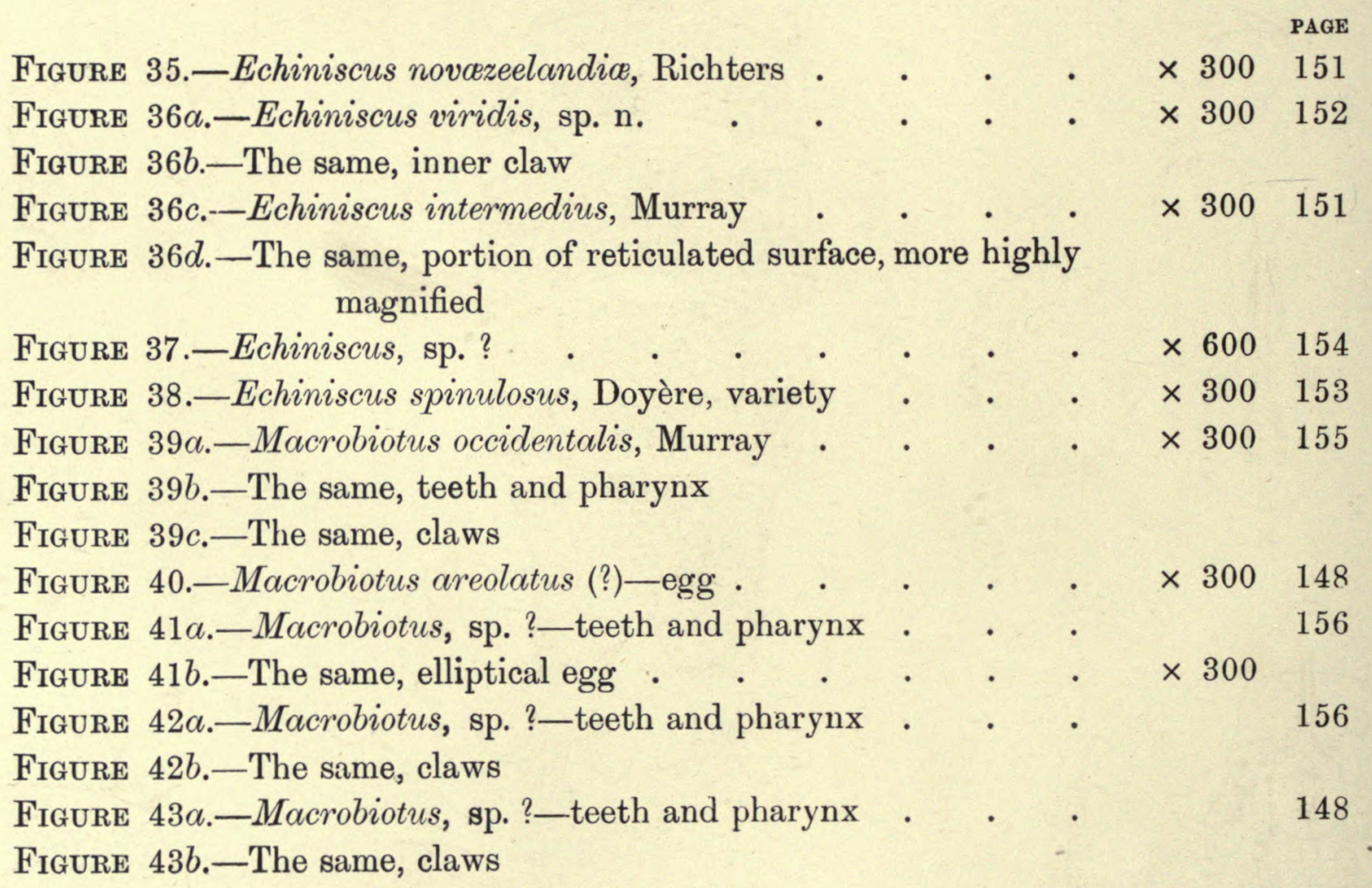


Brit Antarct Exped. 1907-9.

Vol. I. Plate XIX.

\section{Murray: Tardigrada of Pacific Islands.}

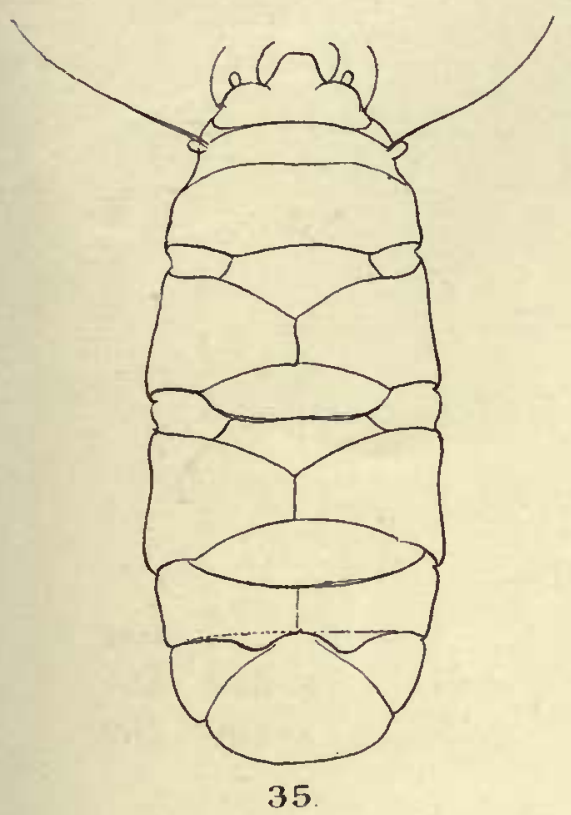

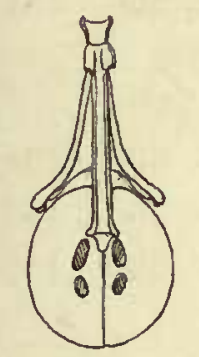

4Ia
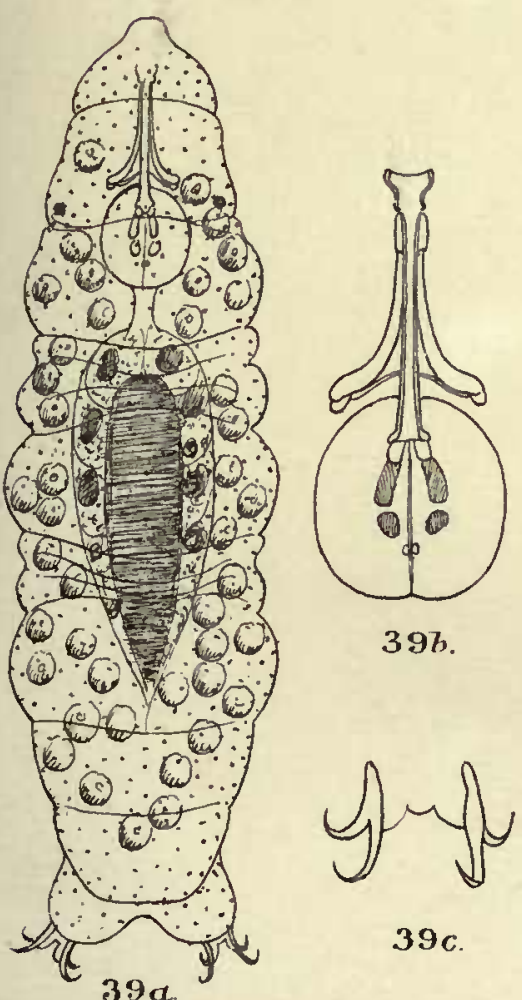

givg

$39 c$.
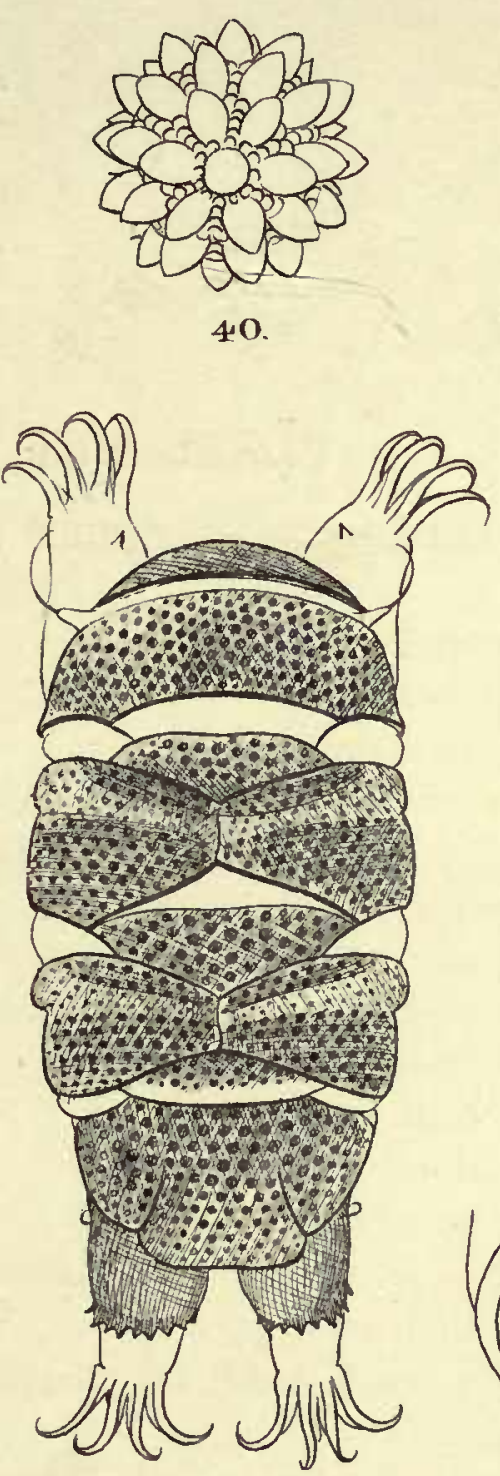

$36 a$.
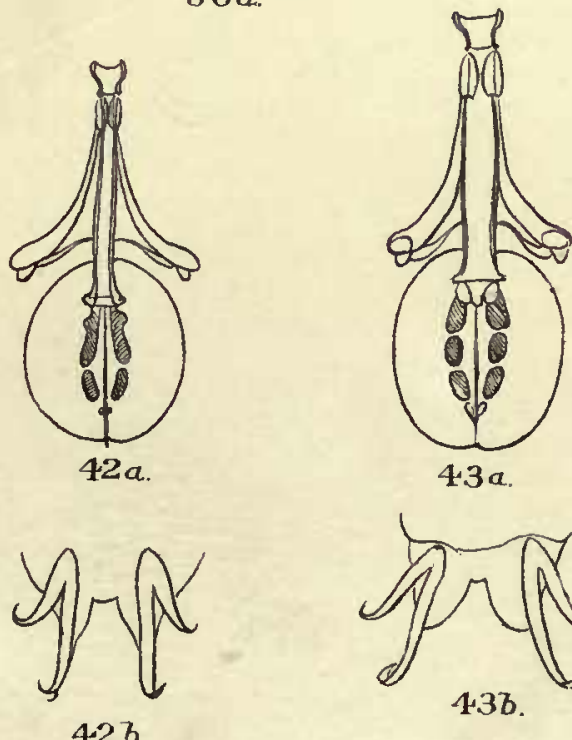

436 .
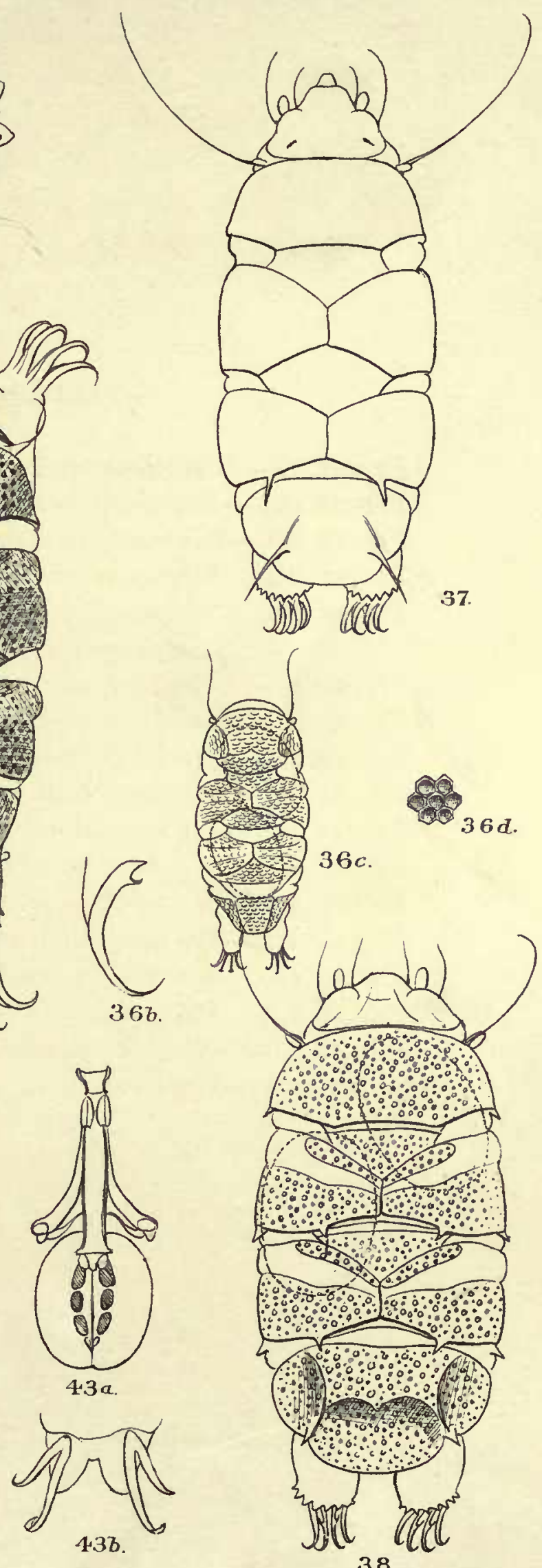
38 .

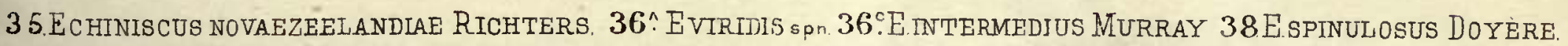
37. ECHINISCUS sp? 39.MaCROBIOTUS OCCIDENTALIS MURR.AY 40.TO43MaCrobiotus sp? 

PLATE XX 


\section{PLATE XX \\ CANADIAN TARDIGRADA}

FIGURE 44.-Echiniscus, sp. ? . . . . . . . . $\times 260165$

Figure 45.-Echiniscus, sp. ? . . . . . . . . $\quad \times 260166$

Figure 46-Echiniscus, sp. ? . . . . . . . $\times 260165$

FIGURE 47.-Echiniscus canadensis, sp. n. . . . . . . $\quad \times 260162$

FigURE 48.-Echiniscus oihonnce, Richters?. . . . . . $\quad \times 260163$

FIGURe 49.-Echiniscus sylvanus, sp. n. . . . . . . $\quad \times 260160$

Figure 50.-Echiniscus bisetosus, Heinis? . . . . . $\times 260164$

Figure 51.-Echiniscus gladiator, Murray, one pair of plates . 160

Figure 52a.-Echiniscus intermedius, Murray, American variety. $\quad \times 260161$

Figure 52b.-The same, larva with two claws . . . . $\times 260$ 


\section{Murray: Canadlan Tardigrada.}
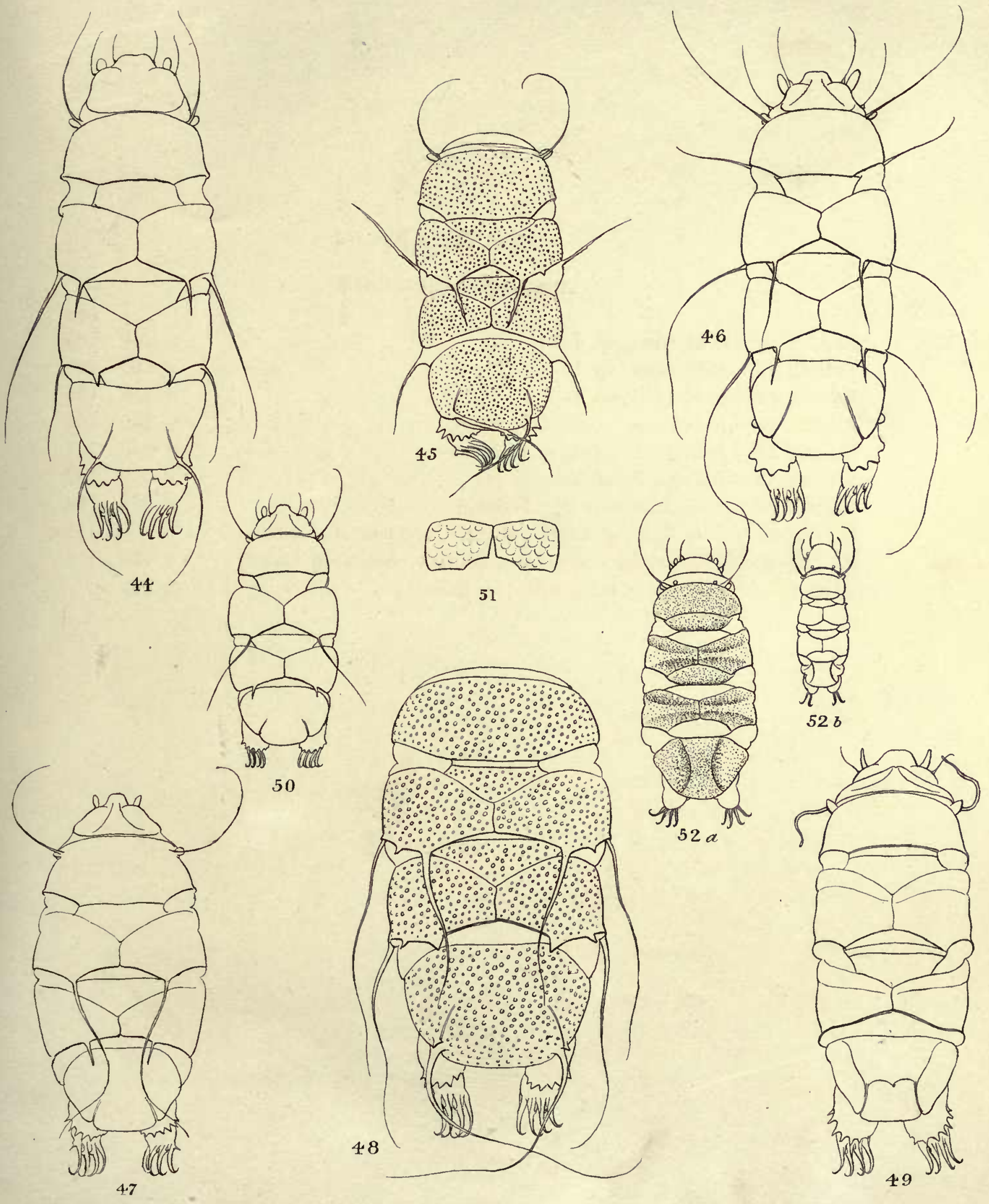

47 ECHINISCUS CANADENSIS. sp. n. 48. E. OIHONNAE RICHTERS? 49. E. SYLVANUS.sp. n. 50. E. BISETOSUS HEINIS.?

5I. E. GLADIATOR MURRAY.
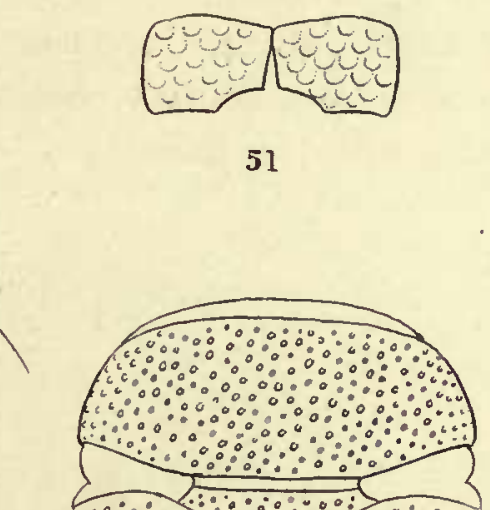

51

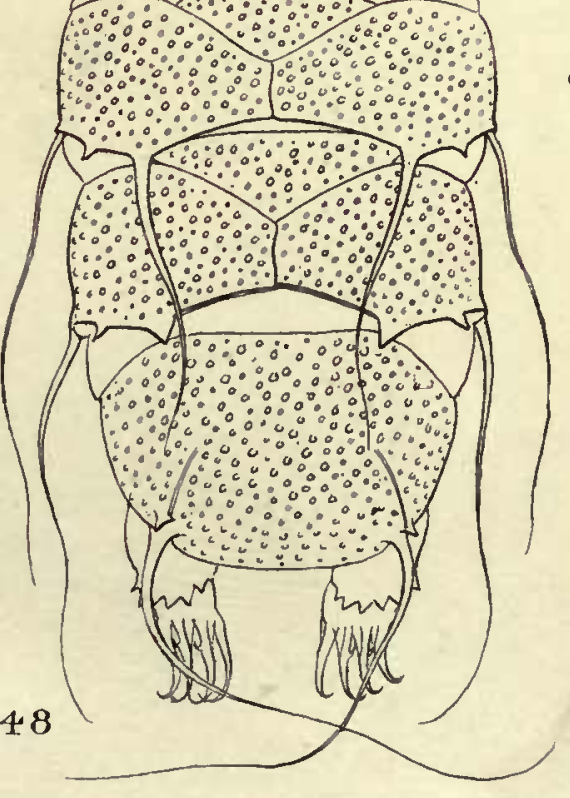

52. E.INTERMEDIUS MURRAY. 44. TO 46. ECHINISCUS SPECIES.? 



\section{PLATE XXI}

BRIT. ANTARCT. EXPED. 1907-9. VOL. I. 


\section{PLATE XXI}

\section{CANADIAN TARDIGRADA}

Figure 53a.-Macroliotus areolatus, Murray .

PAGE

Frgure 53b.-The same, teeth and pharynx

Figure $53 c$-The same, claws

Figure 53d.-The same, egg . . . . . . $\times 260$

Figure 53e.-The same, variety of egg ? . $\quad$ • . . . $\quad$. $\times 260$

Frgure 54c.-Macroliotus occidentalis, sp. n. . . . . . $\times 260$ 169

Frgure 54b.-The same, teeth and pharynx

Frgure 54c.-The same, egg .

$\times 260$

Figure 54d.--The same, claws

Figure 54e.-The same, double skin with dots and plates

Figure 55a.-Macroliotus virgatus, sp. n.

$\times 260173$

Figure 55b.-The same, teeth and pharynx

Figure 55c.-The same, claws

Figure 56.-Egg of unknown Macrobiotus . . . . . . $\quad \times 260175$

Figure 57.-Egg of unknown Macrobiotus . $\quad$ • . . . $\quad$ • $\quad \times 260175$

Figure 58.-Egg of $M$. echinogenitus, variety - . . . . $\quad \times \quad \times 260167$

Figure 59.-Egg like that of M. dispar, \&c. ․ . . . $\quad \times 260175$

Frgure 60.-Macrobiotus, sp. ?--teeth and pharynx . . . 174

FIgURe 61a-Macroliotus canadensis, sp. n. . . . . $\times 260171$

Figure 61b.- The same, teeth and pharynx

Figure 61c.-The same, claws

Frgure $61 d$.-The same, egg . . . . . . . $\times 260$

Figure 62a.-Diphascon canadense, sp. n. . . . . . $\quad \times 260 \div 176$

Frgure 62b.-The same, teeth, gullet, and pharnyx

Figure 62c.-The same, claws 


\section{MURRAY: CANAdian TARdigrada.}

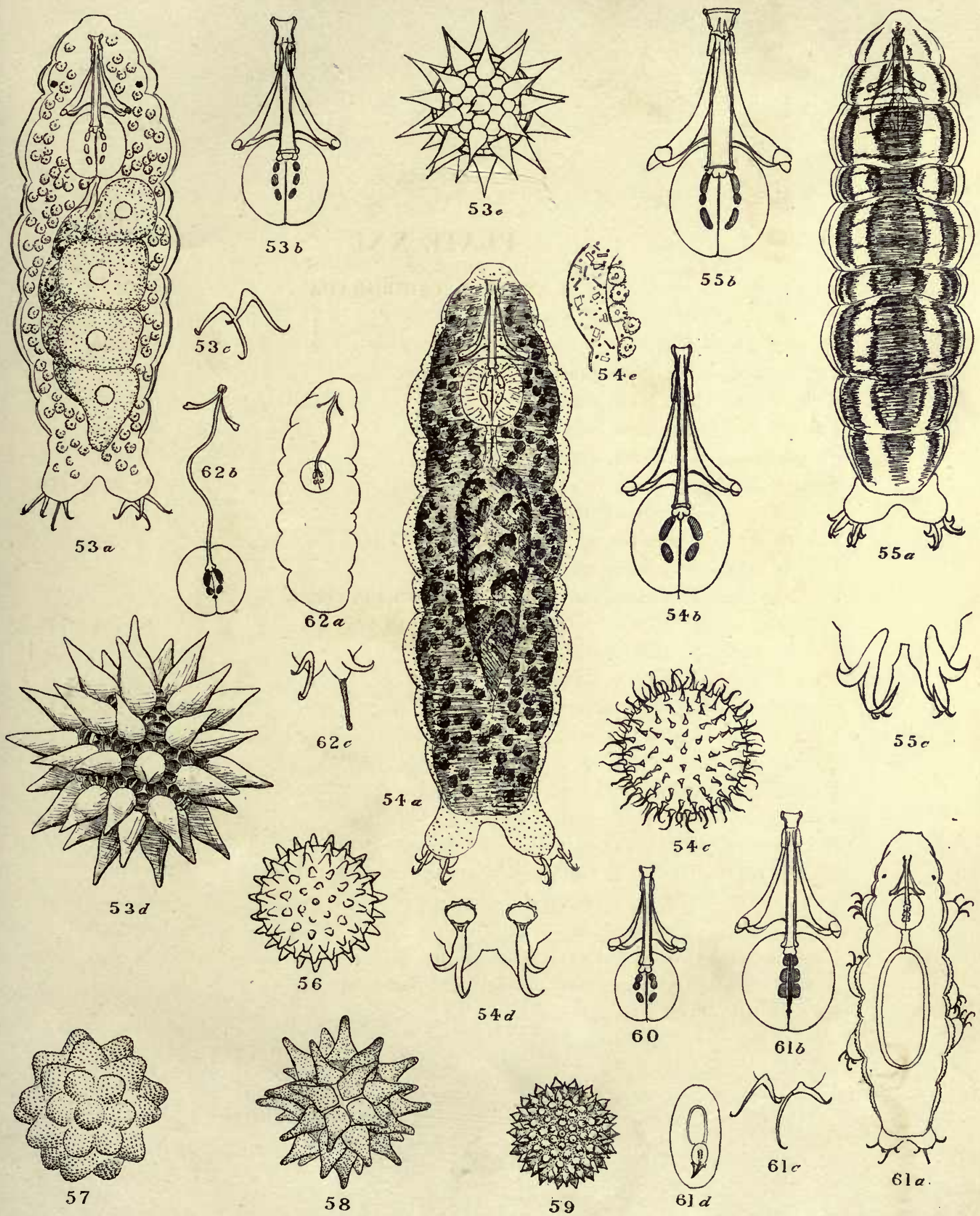

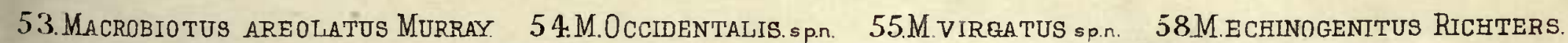
61.M. CANADENSIS.spn. 62DIPHASCON CANADENSIS. 56.57.59. \&60. MACROBIOTUS. SPECIES.? 



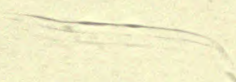





\title{
BRITISH ANTARCTIC EXPEDITION 190\%-9
}

\author{
UNDER THE COMMAND OF SIR E. H. SHACKLETON, C.V.O.
}

\section{REPORTS ON THE SCIENTIFIC INVESTIGA'IIONS}

\section{VOL. I \\ BIOLOGY}

EDITOR - - JAMES MURRAY

\section{PART VI \\ RHIZOPODES D'EAU DOUCE}

BY EUGÈNE PLNARD, DR. ìs SCIENCES

(WITH TWO PLATES)

LONDON

PUBLISHED FOR THE EXPEDITION BY WILILIAM HEINEMANN

21 BEDFORD STREET, W.C.

1911

ISSUED SEPARATELY, JANUARY 1911

Price Three Shillings Net 


\section{REPORTS ALREADY ISSUED}

VOL. I. PART I., ON COLLECTING AT CAPE ROYDS BY JAMES MURRAY

Price 1s, 6d.

VOL. I. PART II., ON MICROSCOPIC LIFE AT CAPE ROYDS BY JAMES MURRAY

Price 5s. Od.

VOL. I. PART III., ANTARCTIC ROTIFERA BY JAMES MURRAY

Price 5s. Od.

VOL. I. PART IV., MUSCI BY JULES CARDOT

Price 1s. 0d.

VOL. I. PART V., TARDIGRADA

BY JAMES MURRAY

Price 10s. Od. 


\section{PAR'T VI \\ SARCODINA}

RIIIZOPODES D'EAU DOUCE

\section{Par EUGÈne PENARD, Dr. ìs Sciences}

(AVEC LES PLANCHES XXII., XXIII.)

LFs collections que Mr. J. Murray a bien voulu m'envoyer, pour l'examen des Rhizopodes d'eau douce rapportés par l'Expédition antarctique du Nimrod, me sont parrenues sous la forme soit de paquets de mousses ou autres végétaux à l'état sec, soit de sédiments conservés dans la formaline.

En rendant compte aujourd'hui du résultat de mes recherches, il me semble utile d'envisager ces collections comme formant deux groupes spéciaux, et nécessitant par là une distinction en deux chapitres nettement séparés.

Le premier groupe, représenté dans les collections par six flacons de résidu ì la formaline et cinq petits paquets de mousses rases, minuscules, feutrées, fragmentaires et réduites pour ainsi dire à leur plus simple expression, concerne les terres antarctiques proprement dites, l'île Ross arec le Cap Royds et ses petits lacs, Hut Point où dans une expédition précédente hiverna la Discovery, et les Moraines échouées du contilent.

Avec le second groupe, nous aurons à nous occuper des Rhizopodes recueillis lors du voyage de retour, et qui me sont arrivés sous la forme de dix-neuf paquets de mousses sèches et de quinze flacons renfermant du sédiment.

Mais ce second chapitre, à son tour, comporte un certain nombre de subdivisions: Iles méridionales du Pacifique, Nouvelle Zélande, Australie, Iles du Pacifique en général, Vancouver et le Canada.

Un tablean général des espèces rencontrées aura son utilité, en permettant un coup d'œil d'ensemble sur la distribution des espèces. Ces dernières, enfin, seront reprises une à une et donneront lieu à quelques observations d'intérêt général.

BRIT. ANTARCT. EXPED, 1907-9. VOL. I. PART 6, ISSUED SEPARA'TELY 1911 


\section{CHAPITRE . I}

\section{Antarctique}

\section{Cape Royds, mare à sec (dried tarn)}

Le matériel récolté dans cette localité, en Avril 1908, par Mr. J. Murray, consistait exclusivement en fragments jaunâtres de "weed," de cette matière organique que les explorateurs ont trouvée en abondance dans les environs du Cap Royds, et sur la nature de laquelle on n'est pas encore au clair.

Aucun rhizopode ne s'est montré dans cette "herbe," sauf peut-être une Corycia, genre auquel paraissaient devoir se rapporter deux enveloppes vides et en manvais état.

\section{Cape Royds, mousses récoltées par J. Murray, le 26 Janv. 1909}

Ces quelques petits fragments d'une mousse courte et feutrée se sont trourés renfermer, avec une abondance relative, la Corycia flava de Gresfr, représentée ici par une forme un peu spéciale, de faible taille, et dont l'enveloppe, d'une teinte claire et d'une transparence toute particulière, a permis des observations biologiques qui n'avaient pu être faites auparavant. ${ }^{1}$ Ces rhizopodes, en effet, étaient vivants, et se sont montrés tels après un temps relativement très court, une heure ou deux d'immersion; il m'a été possible de les conserver plus de huit jours.

Outre cette espèce, les mousses du Cap Royds ont fourni :

Euglypha laevis, plusieurs exemplaires, coquilles vides.

Assulina muscorum, une seule enveloppe vide.

Centropyxis aculeata, une petite enveloppe vide, de $95 \mu$ de diamètre, et qui se rapportait à cette forme décrite par CAsII comme var, spinosa, particulière aux sphagnum et aux mousses.

Arcella arenaria, une enveloppe vide.

Heleopera petricola, une coquille vide, très vieille et en mauvais état, mais qui montrait bien les caractères de l'espèce, et revêtait encore cette teinte légèrement violette que l'on observe fréquemment dans cet organisme.

Daus cette station du Cap Royds, se trouvait enfin certainement Trinema enchelys, à en juger d'après un croquis que Mr. Murray m'a enroyé, et qui ne peut laisser ancun doute sur l'espèce.

1 Ces observations trouveront leur place dans un mémoire qui sera publié prochainement, dans la Revue Suisse de Zoologie ('Tome 19, 1911). 
3. Substance organique, remplissant des poches (Vegetation in pockets, Murray) souterraines, Cape Royds, 12 Mars 1908

Encore la même "végétation" problématique, feuilletée, ici d'un blanc sale et sans éléments figurés clairement reconnaissables. Aucun rhizopode ne s'y est rencontré.

\section{Coast Lake, Janvier 1909}

(a) ̀̀ sec

(b) sédiment dans la formaline

A part deux exemplaires de Corycia penardi, en mauvais état mais nettement reconuaissables encore, et dans lesquels il fut possible de colorer le noyau, le seul Rhizopode que parût renfermer ce petit lac a été la Quadrula irregularis, Archer, une très petite forme, arrondie, et qui n'était relativement pas très rare. Elle s'est rencontrée aussi bien dans le sédiment conservé au formol que dans les "herbes" à sec, où, là aussi, on ne la voyait qu'ì l'état de coquilles vides.

Mr. Murray avait, du reste, pu examiner sur place ce Rhizopode ì l'état vivant, comme le montre une microphotographie qu'il a bien voulu m'envoyer.

Cette espèce, très-cosmopolite, aquatique en général mais qui se rencontre également parfois dans les mousses, varie passablement d'une localité à une autre, sous le rapport de la compression de l'enveloppe. 'Tantôt fortement aplatie, tantôt presque ronde en section transversale, elle se montre ou discoïde ou globuleuse; c'est sous cette deruière forme, par exemple, qu'on la trouve au fond des lacs suisses (var. globulosa Penard) ; et c'est comme telle également qu'on la rencontrait au Cap Royds ; beaucoup plus petite cependant, la forme de Coast Lake mesurant $23 \mu$, en regard de 30-40 $\mu$ qu'elle atteint dans le lac de Genève. Au Spitzberg, dans les mousses, on en a trouvé une variété très peu comprimée également.

C'est dans ce même Coast-Lake que Mr. Murray a constaté la présence d'un héliozoaire, Acanthocystis spec., qu'il figure à la Pl. VIII. du fascicule "on microscopic life at Cape Royds," mais que malgré toutes mes recherches je n'ai pas réussi ̀̀ retrouver. D'après Murray, cette espèce était abondante en Avril 1908; la récolte que j’ai examinée était de Janvier 1909.

\section{Clear Lake, Février 1908}

Malgré la présence d'une abondante végétation microscopique (conferves, algues, diatomées minuscules), comme aussi de rotifères et de quelques infusoires, aucun rhizopode ne s'est rencontré dans cette récolte. 


\section{Blue Lake}

(a) végétation à sec

(b) sédiment dans la formaline

Récolte de J. Murray, en Septembre 1908, à 3 pieds de profondeur, dans la partie resserrée (narrows) du lac.

La Quadrula irregularis s'est retrouvée ici, plus abondante même qu'à Coast Lake, et peut-être avec une taille légèrement supérieure; d'ailleurs parfaitement typique, et, elle aussi, presque ronde en section transversale.

Dans ce même petit lac se trouvait Corycia flava (un seul individu), et Amoeba terricola. Mais pour cette dernière, je ne puis certifier d'une identification absolue; les deux on trois organismes qui, d'après leur apparence générale et leur noyau ovoïde, m'ont paru pouvoir se rapporter à cette espèce, étaient enkystés, entourés d'une enveloppe spéciale, membraneuse, souple et relativement épaisse, telle qu'on ne la connaît pas dans cette espèce, laquelle d'ailleurs, en Europe, n'a jamais montré de phénomènes véritables d'enkystement.

Probablement est-ce dans ce Blue Lake que Murray a trouvé la Nebela vas, cette espèce si largement répandue dans l'hémisphère austral, et qui parviendrait ainsi jusqu'à l'extrême sud. Mais elle $\mathrm{y}$ serait en tout cas très rare, car il m'a été impossible d'en retrouver le moindre vestige.

\section{Terraced Lake, Cape Barne}

\section{Récolte de J. Murray, 27 Septembre 1908}

Dans les sédiments provenant de ce lac, il ne s'est montré, en fait de Rhizopodes, qu'une enveloppe vide de Corycia, en trop mauvais ćtat pour qu'il fût possible de la déterminer avec certitude, mais qui m'a paru pourtant devoir se rapporter à $C$. penaidi.

Ces mêmes sédiments, pour le dire en passant, étaient rendus intéressants par la présence de nombreux fragments d'obsidienne, poussières volcaniques lancées sans doute par l'Erebus; puis de fibres végétales, appartenant à des plantes phanérogames (même une fois à un conifère), et qui sans doute avaient été apportées de bien loin par les vents.

\section{Moraines échouées (stranded moraines)}

Récolte de R. Priestley, Novembre 1908

Les quelques petits fragments de mousses, récoltés par Mr. Priestley dans les "moraines échouées," sur la côte du Continent et à quelque 30 kilomètres au sud du Cap Royds, ont fourni l'une des meilleurs récoltes de rhizopodes qui aient été faites dans l'Antarctique. 
Outre la petite Arcelle des mousses, Arcella arenaria, relativement assez commune, et la Diffugia lucida qui n'était pas très rare, on trouvait là un représentant du genre Diplochlamys, $D$. timida, nettement caractéristique, ${ }^{1}$ puis Euglypha compressa, représentée, à l'état de coques vides, par deux ou trois individus de très faible taille; enfin Corycia flava. Comme toujours et partout, cette dernière espèce n'a exigé que quelques instants, une fois les mousses humectées, pour reprendre vie.

\section{Hut Point}

Récolte de R. Priestley, Novembre 1908

Dans cette récolte, et en dépit d'un examen poussé très ì fond, pas un rhizopode ne s'est montré. Les seuls organismes observés ont été quelques rotifères enkystés. Des spicules de spongiaires, nombreuses, attestaient le voisinage de la mer.

\section{RÉcapitulation Générale}

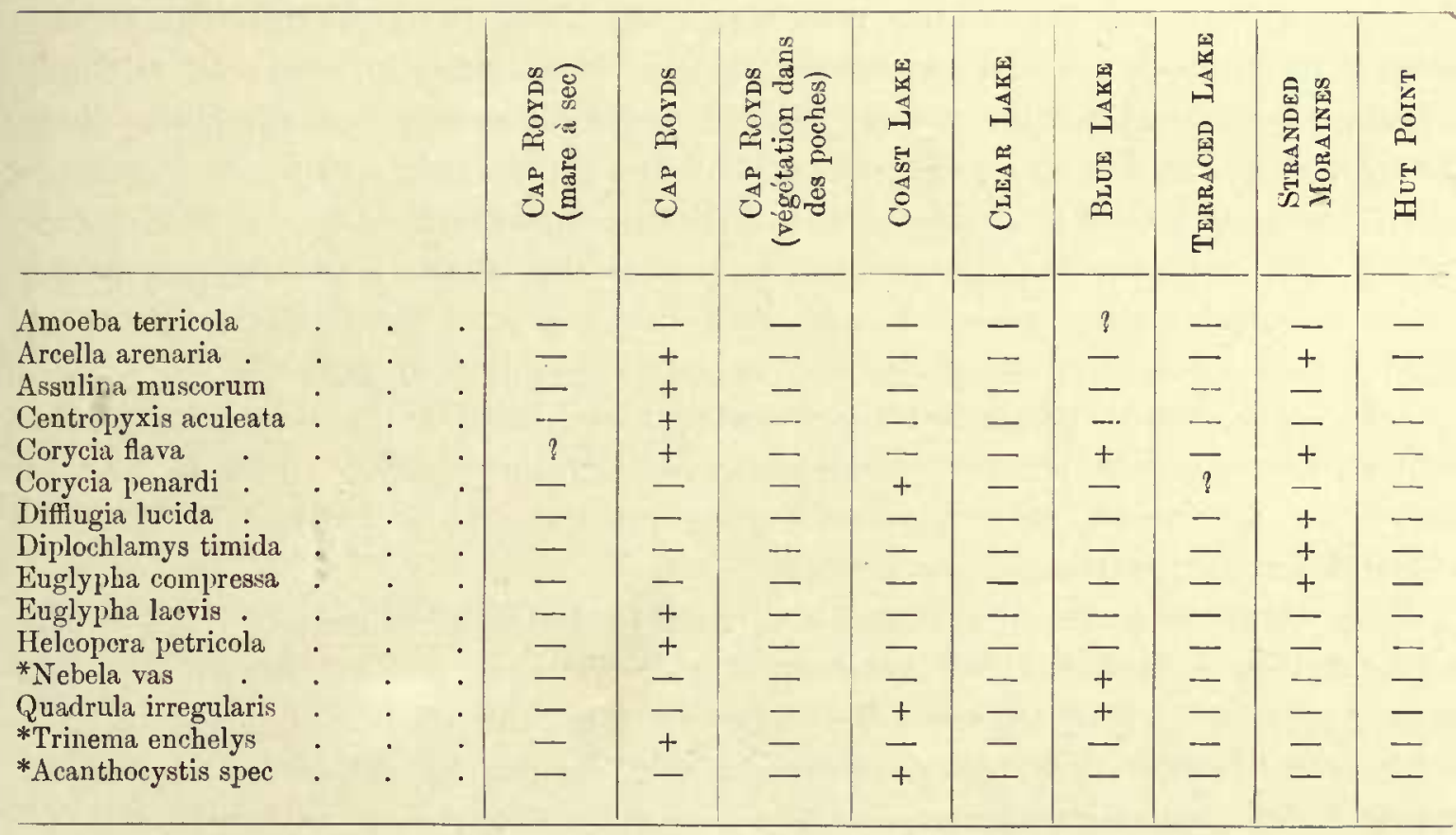

Les espèces marquées * n'ont été trouvées que par Mr. Murray.

Le tableau qui vient de récapituler les paragraphes précédents, ne sera pas sans doute dépourvu de quelque intérêt, en permettant d'envisager d'un coup d'œil les résultats obtenus.

1 Très probablement, la $D$. fragilis se trouvait également représentée; mais les quelques spécimens rencontrés étaient en si mauvais état que le fait ne peut être donné comme certain. 
Dans cette liste générale, j'ai cru devoir faire entrer, aussi bien que les autres, les stations qui se sont montrées vierges de tout Sarcodiné. Peut-être ces colonnes vides seront-elles tout aussi significatives, en faisant ressortir, par le fait même qu'elles n'ont rien à montrer, la pauvreté vraiment extraordinaire des terres antarctiques en rhizopodes d'eau douce.

Ces parages sont très pauvres en effet. Peut-être, au premier coup-d'œil jeté sur ces quinze noms d'espèces énumérés les uns au-dessous des autres, sera-t-on tenté de trouver à redire à cette qualification de "pauvres," de considérer même le nombre obtenu comme un résultat auquel on n'anrait guère pu s'attendre, alors que sous les mêmes latitudes on n'avait signalé jusqu'ici que trois Rhizopodes, Amoeba terricola et Corycia flava, trouvés par Richters dans les mousses du Ganssberg, ${ }^{1}$ puis Arcella urenaria, observés par le même anteur dans des mousses du Victoria-Land. ${ }^{2}$

Mais ce que la liste ne pouvait pas dire, c'est que cette pénurie d'organismes réside non pas tant dans le nombre des espèces que dans celui des individus.

Pour qui a quelque expérience dans la recherche de ces Sarcodinés bryophiles, les mousses de l'Antarctique sont en effet un étonnement. Si l'on excepte la Corycia flava, qui dans deux localités (Cape Royds et Stranded moraines) se montrait avec une proportion d'individus ì peu près comparable ì ce qu'on pourrait s'attendre à trouver en Europe, tout est extrêmement rare. Même Arcella arenaria, Difflugia lucida, que j'indique comme relativement communes, ne se rencontraient que de temps ì autre; et quand aux autres espèces, on peut dire, j'en suis sûr, que si les précédents observateurs ne les ont pas trouvées, c'est qu'il fallait pour cela un spécialiste disposant, de tout son temps, habitué à la patience, et surtout bien décidé à ne s'attaquer qu'aux seuls Rhizopodes pour laisser de côté tout le reste, et à ne considérer Rotifères, 'Tardigrades, Acariens et Nématodes que comme des quantités négligeables.

La plus grande partie, en effet, des espèces citées, se sont montrées représentées par quelques individus seulement, péniblement obtenus après de longues heures de recherches, et eux-mêmes en manvais état, sous la forme de coquilles vides, déformées, et quelquefois brisées.

On serait même en droit, semble-t-il, de se demander si ces individus appartenaient bien à la faune de l'Antarctique, s'ils n'avaient pas été apportés lì déjà sans vie, et au même titre que les fibres de végétaux phanérogamiques qu'on a rencontrés dans les lacs, par les vents du nord ou par les pattes des oiseaux au retour de leurs quartiers d'hiver.

Mais il ne faut pas nous arrêter longtemps à cette idée. 'Tout en admettant que chaque espèce ait à l'origine été introduite, et cela dans un passé plus ou moins reculé, il faut reconnaître que ces Rhizopodes faisaient, au moment de la récolte, partie intégrante de la faune locale. L'aspect spécial des enveloppes, les débris que les animaux avaient pu y incorporer, tout cela le montrait déjà claire-

1 Deutsche Siidpol. Exped. 1901-3. Vol. 9. Zool.

2 Zool. Anzciger, Juillet 1909, p. 604. 
ment; et puis, toute cette faune (ì l'exception de Quadrula ivregularis, qui se trouve, elle, bien et dûment établie dans les lacs) est une faune spéciale, caractéristique des mousses, et l'on ne peut concevoir que les vents ou les oiseaux aient fait un choix, et n'aient pas su apporter des coquilles ce difflugies, d'arcelles, et tant d'autres, qu'ils eussent tont aussi bien pu trouver.

A mon avis, c'est avant tout dans les conditions climatériques qu'il faut chercher l'explication de cette pénurie de Sarcodinés; dans le climat, et aussi, si l'on veut, dans les mousses elles-mêmes. Ces dernières, en effet, n'arrivent qu'ì grand peine, dans ces régions du Cap Royds, à traîner leur maigre existence; bien loin d'égaler en vigueur les mousses du Spitzberg, où l'on pent les récolter en touffes splendides, ce ne sont plus ici qui des végétaux rabougris, dont les tiges serrées ne forment qu'un feutre mince et dur; et dans des conditions semblables, an Pôle antarctique comme sur les rochers des hautes Alpes, la faune microscopique est toujours pauvre.

Cependant, e'est le climat par lui-même qui doit ici jouer le rôle le plus direct; il est décidément trop rude; s’il ne l'était, il y aurait place encore, dans ces mousses si courtes soient-elles, pour une faune rhizopodique bien plus abondante qu'elle ne l'est en réalité. Dans les laes, également, si riches en Algues, en Rotifères, Tardigrades, Nématodes et même Infusoires, on ne trouve-à part de temps ì autre une Corycia qui semble s'être égarée lì-que la Quadrula irrégularis.

Dans une lettre qu'il m'écrivait tout dernièrement, Mr. Murray disait: "Of all the moss-dwellers, I find the Rhizopods least willing to come alive after being for a long time dried." La conclusion du biologiste du Nimrod est celle-là même ì laquelle mes études m'avaient depuis longtemps amené, et que les récoltes de la dernière expédition antarctique viennent une fois de plus confirmer. Partout les mêmes faits se répètent: Acariens, Nématodes, 'lardigrades et Rotifères recommencent ì courir alors que les Rhizopodes gardent encore un repos absolu, ou reprennent vie alors que ces derniers ne le pouront jamais plus.

Les Rhizopodes, d'une manière générale, sont moins résistants que les organismes qui vienuent d'être cités; mais il ne faudrait pas envisager cette donnée comme absolument générale. Parmi les Sarcodinés des mousses, il en est quelques-uns qui constituent une exception bien nette ì la règle; je citcrai par exemple Diffugia arcula, puis Bullinula indica, qui rivalisent sous ce rapport avec les Rotifères les plus endurants (et pourtant manquaient au Cap Royds, pour des raisons spéciales sans doute); puis surtout la Corycie, Corycia flava, qui, elle, est d'une résistance incroyable, et dans cet ordre de faits tient pent-être le record dans toute la série des organismes animaux.

En résumé, les collections rapportées de l'Antarctique, et qui ont donné à Mr. J. Murray de si intéressants résultats pour les groupes qu'il a étudiés, en ont fourni de quelque valeur également pour les Sarcodinés. Elles ont montré que ces organismes se trouvent, en fait, représentés là-bas par les mêmes espèces que 
partout ailleurs; que ces espèces y sont, mais représentées par une très petite quantité d'individus.

Toute cette faune est arrivée, sans doute, tout près de la limite au-delà de laquelle la vie lui reste fermée au sud; mais cette limite, l'homme l'a dépassée, Shakleton et ses compagnons, pour aller planter à deux pas du Pôle le pavillon du Royaume Uni. 


\section{CHAPI'TRE II}

COLLECTIONS RECUEILLIES PENDANT LE VOYAGE DE RETOUR

A. Iles du Pacifique sud

1. Ile Macquarie

Récolte effectuée par Capt. J. K. Davis à Lusitania Bay, près d'un marécage. Mai 1909

(a) Une touffe d'une mousse longue et serrée, et un paquet de conferves.

(b) Sédiment dans la formaline.

\section{ESPÈCES RÉCOLTÉES.}

Amoeba terricola.

Arcella arenaria.

" vulgaris.

Assulina muscorum.

Bullinula indica.

Corythion dubium.

Difflugia arcula.

" constricta.

Euglypha alveolata.

$"$ ciliata.

" compressa.

" laevis.
Heleopera petricola.
" $\quad$ sphagni.
Nebela caudata.
" dentistoma.
" lageniformis.
" martiali.
" vas.

Phryganella hemisphaerica. Sphenoderia dentata. Trinema enchelys.

\section{Iles Auckland}

Fragment de mousse récoltée par le Dr. Cockayne, botaniste du Gouvernement de la N Nle Zélande. 1907

Cette mousse tapissait le tronc d'un "Rata," Metrosideros lucida

Assulina muscorum.

Difflugia arcula.

$$
\text { " constricta. }
$$

BRIT. ANTARCT. EXPED. 1907-9 VOL. I.
Euglypha compressa.

Hyalosphonia cockayni.

Nebela tincta. 


\section{B. Nouvelle Zélande}

\section{Ile Stewart}

Récolte de J. Murray, au sommet d'un petit îlot. Mar's 1909

(a) Mousses sèches, en petite quantité.

(b) Sédiment dans la formaline.

Amoeba terricola.

Arcella arenaria.

Assulina muscorum.

"seminulum.

Bullinula indica.

Centropyxis horrida.

Corythion dubium.

Difflugia arcula.

" constricta.
Diplochlamys fragilis.

Euglypha ciliata.

" compressa.

" laevis.

Heleopera sylvatica.

Nebela lageniformis.

Phryganella hemisphaerica.

Plagiopy xis callida.

Trinema enchelys.

\section{District du Mont Cook, lle du Sud}

* Récoltes de J. Murray, sur différents points, de 3000 à 6000 pieds d'altitude, et sur un espace de plusieurs milles. Décembre 1907

(a) Mousses diverses, avec une belle touffe de sphagnum.

(b) Sédiment dans la formaline.

Amoeba sphieronucleolus.

$״$ terricola.

Amphizonella violacea.

Arcella arenaria.

Assulina muscorum.

" seminulum.

Bullinula indica.

Centropyxis aculeata.

Corycia penardi.

Corythion dubium.

Cyphoderia ampulla.

Difflugia arcula.

" constricta.

, lucida.

„ manicata.

" pyriformis, var. bryophila.

Diplochlamys timida.

Euglypha alveolata.

ciliata.
Euglypha compressa.

Heleopera petricola. sphagni.

Hyalosphenia cockayni.

Nebela collaris.

„ dentistoma.

" lageniformis.

" longicollis.

" tincta.

" vas.

Phryganclla hemisphaerica.

$" \quad$ nidulus.

Pontigulasia bryophila.

Sphenoderia dentata. compressa.

Trinema enchelys.

$$
\text { fissirostris. }
$$

" lineare. 
** Récolte du Dr. Mackay, sur un seul point, à Nun's Veil, 5000 pieds. Décembre 1907

Arcella arenaria.

Bullinula indica.

Difflugia arcula.

Euglypha ciliata.

Euglypha laevis.

Nebela lageniformis.

" vas.

Phryganella hemisphaerica.

3. Waiata-Rua, Côte occidentale, Ile du Nord

Récolte de J. Murray, dans le "bush," près des chutes du Nihotupo.

Mousses diverses, en petite quantité. Décembre 1907

Amoeba terricola.

Assulina muscorum.

seminulum.

Bullinula indica.

Corythion dubium.

Difflugia arcula.

$"$ constricta.

" lucida.

Diplochlarnys fragilis.

Euglypha ciliata.

compressa.
Euglypha strigosa.

Heleopera sphagni.

Nebela collaris.

" lageniformis.

" longicollis.

" tincta.

" vas.

Phryganella hemisphaerica.

Plagiopyxis callida.

Pontigulasia compressa.

Trinema enchelys.

4. Ngauruhoe, volcan, Ile du Nord

Récolte du Dr. Mawson, dans une seule région, à 4-5000 pieds d'altitude. Avril 1909

(a) Mousses diverses, à sec.

(b) Sédiment dans la formaline.

Assulina muscorum. seminulum.

Bullinula indica.

Centropyxis laevigata.

Corythion dubium.

Difflugia arcula.

" constricta.

, lucida.

Euglypha ciliata.

, compressa.
Heleopera sphagni.

Nebela caudata.

" collaris.

" lageniformis.

") martiali.

" militaris.

" vas.

Phryganella hemisphaerica.

Trinema enchelys. 


\section{Rotorua, Ile du Nord}

Récolte de J. Murray, dans le "bush." Avril 1909. Mousses diverses

Amoeba terricola.

Arcella arenaria.

Bullinula indica.

Centropyxis laevigata.
Difflugia constricta.

Euglypha ciliata.

Nebela lageniformis.

Phryganella hemisphacrica.

\section{Australie}

\section{Sydney, Nouvelle Galles du Sud}

Mousses diverses, récoltées par J. Murray, au National Park, puis dans les environs de Sydney. Avril 1909

Amoeba muralis.

$$
\text { " radiosa. }
$$

Assulina muscorum.

$$
\text { , seminulum. }
$$

Bullinula indica.

Corycia flava.

Corythion dubium.

Difflugia arcula.

$$
\text { " constricta. }
$$

, fallax.

Euglypha ciliata.

$$
\begin{array}{ll} 
& \text { compressa. } \\
& \text { laevis. }
\end{array}
$$

Heleopera petricola.
Heleopera sordida.

$$
\text { " sylvatica. }
$$

Hyalosphenia cockayni.

Nebela certesi.

, collaris.

" lageniformis.

" martiali.

" tincta.

" vas.

Parmulina cyathus.

Phryganella hemisphacrica.

Plagiopyxis callida.

$$
\text { " labiata. }
$$

Trincma complanatum. " enchelys.

\section{Alpes australiennes, Nouvelle Galles dı Sud}

\section{Récoltes de J. Murray. Avril 1909}

(a) Région tourbeuse près de l'Hospice, 5000 pieds ; mousses et sphagnum.

(b) "The Creel," 3000 pieds, mousses, belles et longues.

(c) Sédiment dans la formalinc.

Amoeba terricola.

Amphizonella violacea.

Arcella arenaria.
Assulina muscorum.

Bullinula indica.

Corycia flava. 
Corythion dubium.

Difflugia arcula. constricta.

, fallax.

Diplochlamys fragilis.

Euglypha alveolata. ciliata. compressa. filifera. laevis. strigosa.

Helcopera petricola. sylvatica.
Lieberkühnia wageneri.

Nebela caudata.

" lageniformis.

" martiali.

"vas.

Phryganella hemisphaerica.

Plagiopyxis callida.

labiata.

Quadrula symmetrica.

Sphenoderia dentata.

Trinema coinplanatum.

" lineare.

\section{Katoomba, Montagnes bleues, $\mathbf{N}^{\text {lle }}$ Galles du Sud}

Récoltes de J. Murray, dans trois petites gorges (gullies) qui mènent à la "Sunken Valley," et sur un territoire de 2 milles. Mai 1909

(a) Mousses diverses, avec une touffe de sphagnum.

(b) Sédiment dans la formaline.

A moeba sphaeronucleolus. "terricola.

Amphitrema stenostoma.

Amphizonella violacen.

Arcella arenaria.

Assulina muscorum.

" seminulum.

Bullinula indica.

Centropyxis horrida.

Corycia flava. laevigata.

Corythion dubium.

Diftugia arcula.

" constricta.

" lucida.

Diplochlamys fragilis. n vestita.

Euglypha compressa.
Euglypha cristata.

$"$ laevis.

" strigosa.

Heleopera sylvatica.

Nebela certesi.

" collaris.

" griseola.

" lageniformis.

" longicollis.

" martiali.

"militaris.

" tincta.

" vas.

Phryganella hemisphaerica.

Plagiopyxis callida.

T'rinema complanatum.

" enchelys.

" lincare. 


\section{Eumundi Station, Queensland}

Récolte de J. Murray, dans le "bush," sur un territoire de deux milles carrés environ. Mai 1909

(a) Paquet de mousses, sans sphagnum.

(b) Beau paquet de mousses variées, quelquefois sur écorce, avec un petit fragment de sphagnum.

(c) Sédiment dans la formaline.

Amoeba sphaeronucleolus.

" terricola.

Arcella arenaria.

Assulina muscorum.

Bullinula indica.

Centropyxis aculeata.

Corycia flava. delicatula.

Corythion dubium.

Difflugia arcula.

" constricta.

" lucida. "

" pyriformis, var. bryophila.
Diplochlamys timida.

Euglypha ciliata.

" compressa.

" laevis.

Heleopera sphagni.

Hyalosphenia subflava.

Nebela caudata.

" collaris.

" lageniformis.

Phryganella hemisphaerica.

Plagiopyxis callida.

Trincma complanatum. enchelys.

\section{Iles du PaCifique}

\section{Suva, Fiji}

Récolte de J. Murray, près du rivage, au bord d'un marécage à palétuviers, puis dans l'intérieur, à un mille ou deux de la côte, dans les fossés au bord de la route. Mai 1909

(a) Mousses très-courtes, avec beaucoup de terre.

(b) Sédiment dans la formaline.

Amoeba terricola.

Bullinula indica.

Centropyxis delicatula.

Corycia aculeata.

" penardi.

Difflugia arcula.

" constricta.

" lucida.
Difflugia pyriformis, var. bryophila.

Euglypha laevis.

Heleopera petricola.

Nebela vas.

Phryganella hemisphaerica.

Quadrula irregularis.

Trinema lineare. 


\section{Oahu, Hawaii}

Récolte de J. Murray, aux environs d'Honolulu, dans une vallée où le "bush" devint rapidement impraticable à cause de la densité de la végétation, les fougères (Pteris) couvrant si bien le sol que la marche s'effectuait à un ou deux yards au-dessus du sol. Mai 1909

(a) Belles mousses, l'une d'elles très-claire, longue et soyeuse.

(b) Sédiment dans la formaline.

Amoeba terricola.

Assulina seminulum.

Bullinula indica.

Centropyxis aculeata.

Corycia flava.

Corythion dubium.

Cyphoderia ampulla.

Difflugia arcula.

" constricta.

Diplochlanys gruberi.

" timida.
Euglypha ciliata.

" compressa.

"laevis.

Heleopera sylvatica.

Nebela collaris.

" lageniformis.

" militaris.

" minor.

Phryganella hemisphaerica.

Sphenoderia dentata.

Trinema enchelys.

\section{E. Colombie Brimannique et Canada}

1. Victoria, B.C.

Récolte de J. Murray, parmi les plantes du rivage (Sedum, \&c.), puis dans un petit bois, non loin du rivage également. Juin 1909

Amoeba terricola.

Arcella arenaria.

Assulina muscorum.

Bullinula indica.

Corythion dubium.

Difflugia constricta.

Euglypha ciliata.
Euglypha laevis.

" strigosa.

Nebela bigibbosa.

" caudata.

Phryganella hemisphaerica.

Plagiopyxis labiata.

Trinema enchelys. 


\section{1*. Vancouver, B.C.}

Récolte de J. Murray, Stanley Park. Juin 1909

(a) Mousses, avec une touffe de sphagnum.

(b) Sédiment dans la formaline.

Arcella arenaria.

Assulina muscorum. seminulum.

Centropyxis aculeata.

Corycia flava.

" penardi.

Cyphoderia ampulla.

Difflugia arcula.

" bacillifera.

" constricta.

" lueida.

" pyriformis, var. bryophila.

Diplochlamys vestita.

Euglypha alveolata.

" brachiata.

" ciliata.

" compressa.

" strigosa.

Heleopera petricola.

" sordida.
Lesqucreusia ......

Lieberkïhnia wageneri.

Nebela bigibbosa.

" candata.

" collaris.

" dentistoma.

" flabellulıur.

" lageniformis.

" tincta.

" tubulosa.

"vas.

Phryganella hemisphaerica.

Placocysta jurassica.

" spinosa.

Plagiopyxis callida.

Pontigulasia bryophila.

Quadrula symmetrica.

Trinema complanatum.

" linearc.

\section{Monts Selkirk, B.C., et Montagnes Rocheuses, Canada}

Récoltes de J. Murray, à des altitudes de 3000 à 6000 pieds, auprès des diverses stations de la ligne où le train s'arrêtait plus de 5 minutes de temps. Juin 1909

(a) Mousses diverses.

(b) Sédiment dans la formaline.

Amoeba sphacronucleolus. " terricola.

Arcella arenaria.

Bullinula indica.

Corycia flava.

Difllugia arcula.

constricta.
Euglypha ciliata. " compressa.

Nebela collaris. " lageniformis.

Phryganella hemisphaerica.

Plagiopyxis callida. 


\section{Province d'Ontario, Canada}

+ Lake of the Woods

Récolte de J. Murray, dans le fourré, au bord du lac, pendant un arrêt du train. Juin 1909

(a) Mousses diverses.

(b) Sédiment dans la formaline.

Amoeba sphaeronucleolus.

"terricola.

Arcella arenaria.

Assulina muscorum. seminulum.

Bullinula indica.

Corythion dubium.

Difflugia constricta.
Euglypha ciliata.

" compressa.

" laevis.

Nebela lageniformis.

"tincta.

Phryganella hemisphaerica.

Trinema cnchelys.

" lincare.

$$
++ \text { Ottauce }
$$

Récolte de J. Murray, dans le "Public Park," et tout auprès sur le bord du chemin. Juin 1909

(a) Mousses sèches.

(b) Sédiment dans la formaline.

Amoeba terricola.

Arcella arenaria.

Awerinzewia cyclostoma.

Corycia flava.

" penardi.

Difflugia constricta.

$" \quad$ lucida.

Diplochlamys fragilis.
Diplochlamys timida.

Euglypha ciliata. laevis.

Nebela ininor.

Parmulina cyathus.

Phryganella hemisphaerica.

Trineina complanatum.

lineare. 


\section{RÉCAPITULATION}

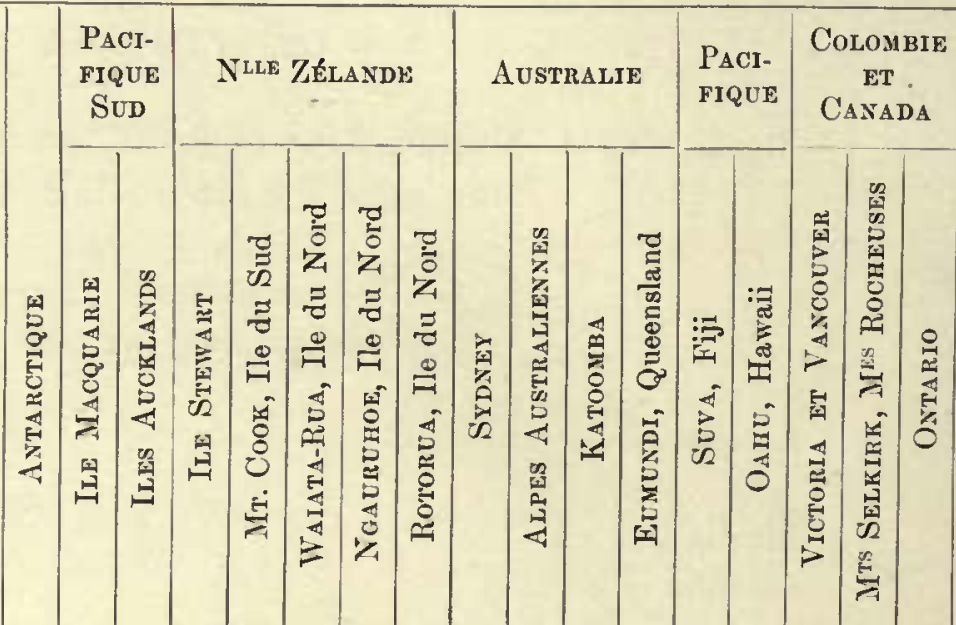

Amoeba muralis

radiosa.

sphaeronucleolus terricola

Amphitrema stenostoma

Anphizonella violacea

Arcella arenaria

, vulgaris .

Assulina muscorum

, seminulum.

Awerinzewia cyclostoma

Bullinula indica

Centrolyyxis aculeata.

delicatula

Corycia acnleata

,$\quad$ delicatula

" flava

" penardi.

Corythion dubium

Cyphoderia anpulla

Difflugia arcnla.

, bacillifera

, constricta

" fallax

" lucida

" manicata

, pyriformis, var. bryophila

Diplochlamys fragilis .

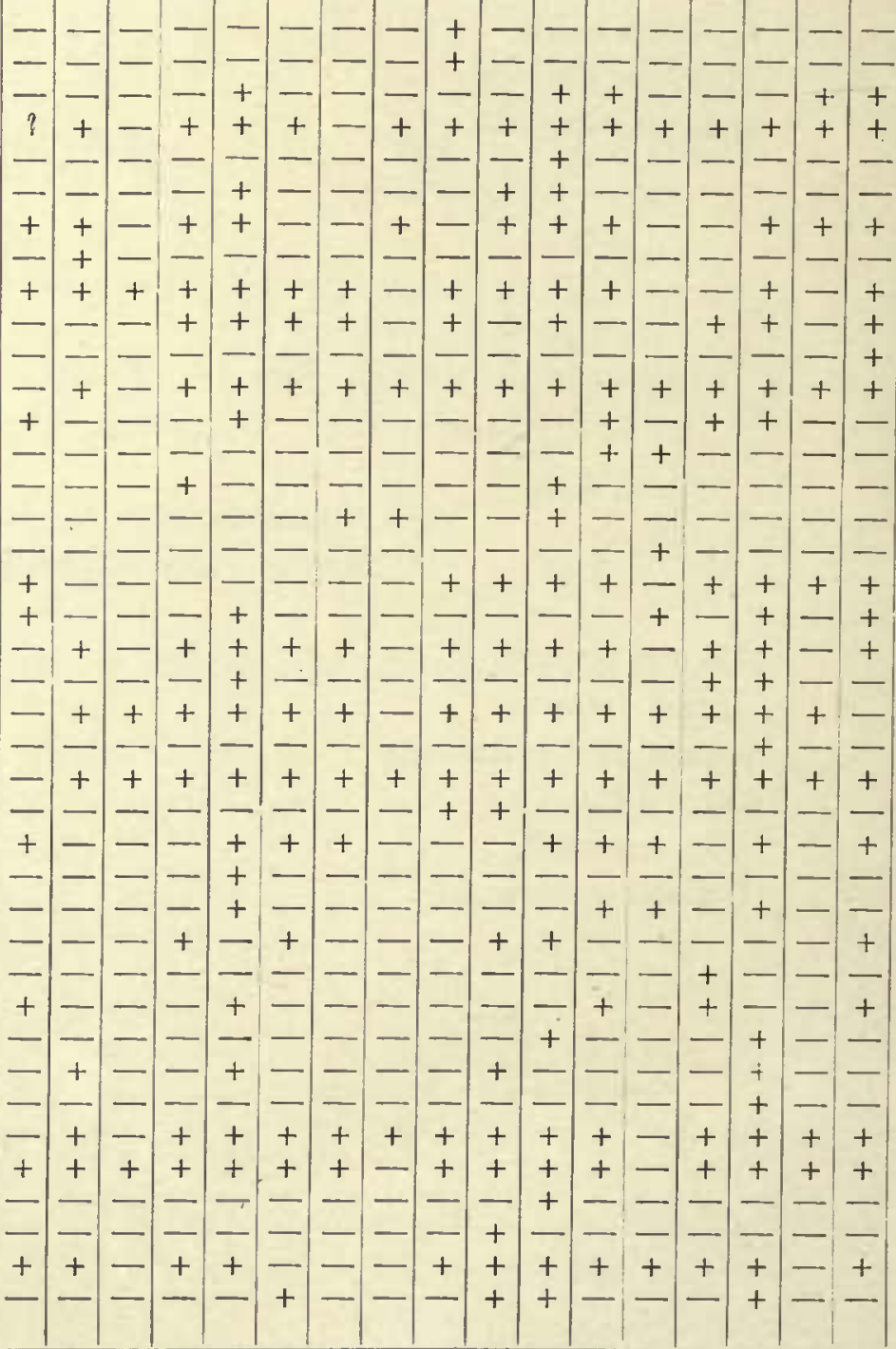

Englypha alveolata

$$
\begin{aligned}
& \text { gruberi . } \\
& \text { timida . } \\
& \text { vestita. } \\
& \text { eolata . }
\end{aligned}
$$$$
\text { brachiata }
$$$$
\text { ciliata }
$$$$
\text { compressa. }
$$$$
\text { cristata }
$$$$
\text { filifera }
$$$$
\text { laevis . }
$$$$
\text { strigosa }
$$

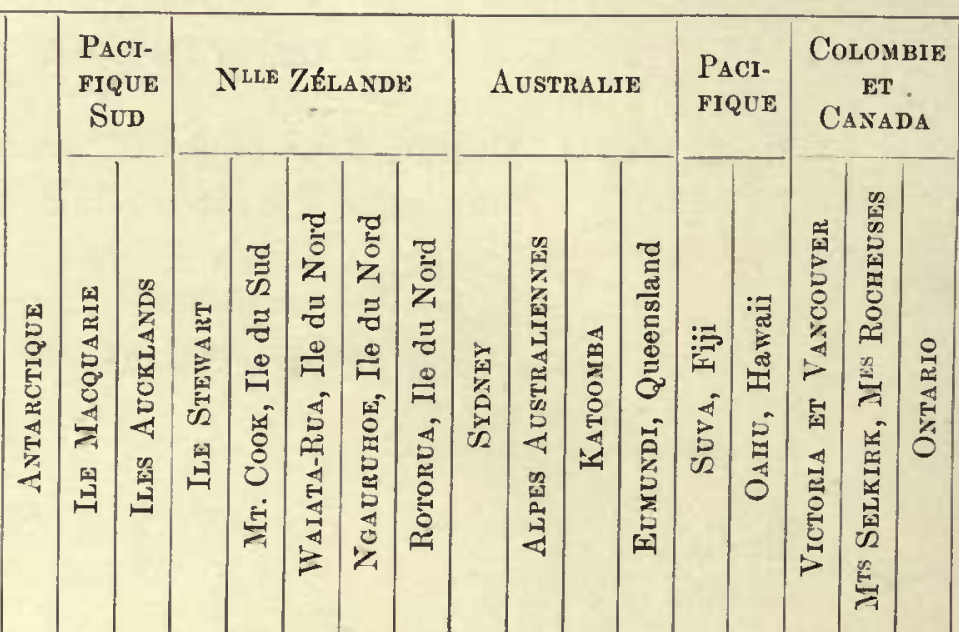


Récapitulation (suite)

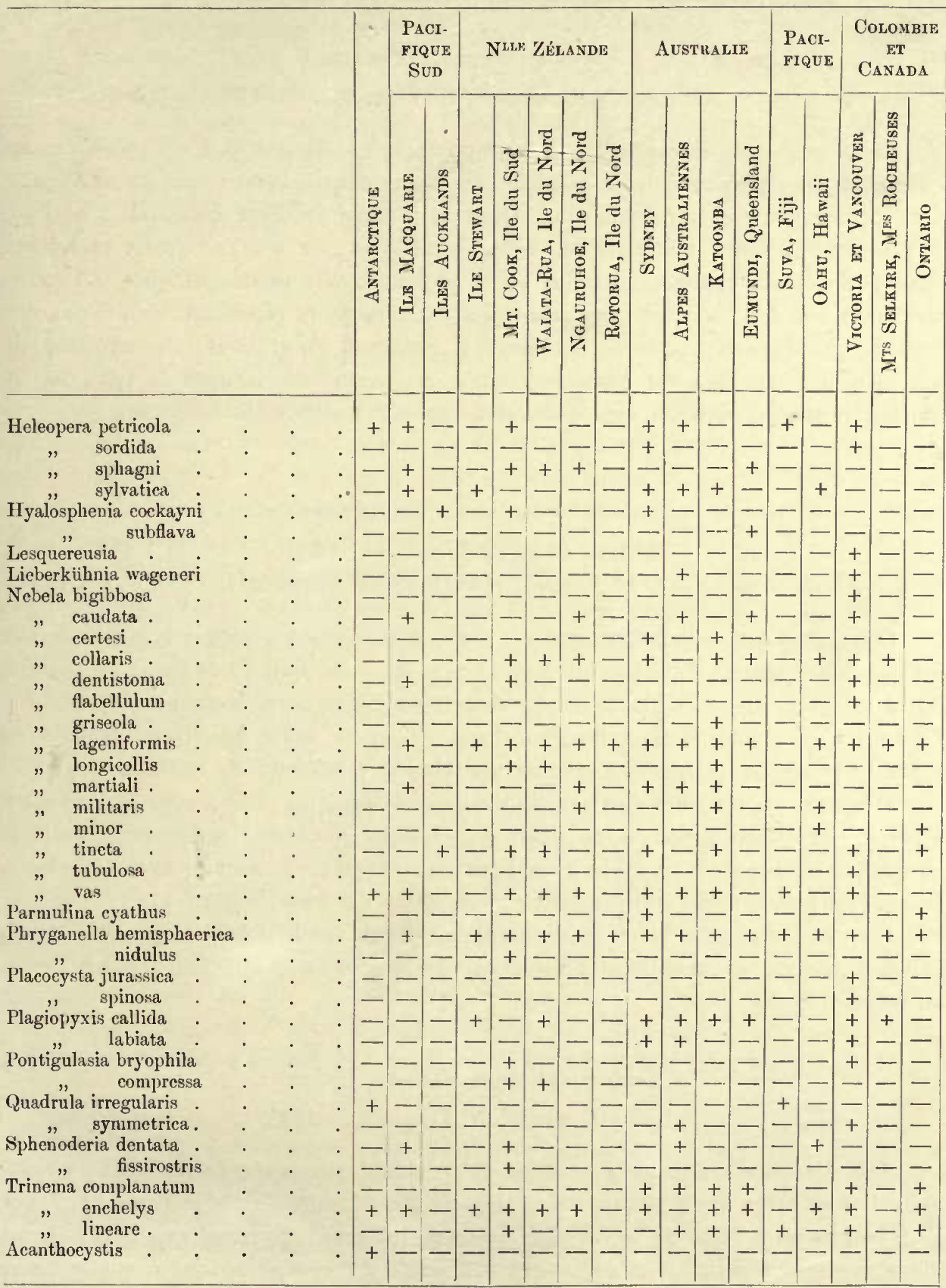




\section{CONSIDÉRATIONS GÉNÉRALES SUR LES ESPÈCES RENCONTRÉES}

\section{Amoeba muralis. Penard}

Arch, für Protistenkunde, $B^{11} 17$, p. 267. 1909

Cette amibe, de faible taille, et peu apparente en elle-même, a dû probablement se trouver dans plusieurs des récoltes; mais ce n'est qu'à l'état vivant et actif qu'on peut espérer pouvoir la reconnaître. Dans la mousse du Parc National, à Sydney, il s'en est rencontré un individu, bien vivant, qui par ses principaux caractères, plasma très-dense, opalescent sur les bords, prolongements pseudopodiques très-courts rayonnant sur les côtés, noyaux très-petits et nombreux, répondait bien à ce que nous savons de cette espèce. Les noyaux, pourtant, montraient une structure un peu spéciale; au lieu du nucléole central et unique décrit dans le type, on en trouvait plusieurs, répartis sans ordre dans un suc nucléaire très-compact.

\section{Amoeba radiosa. Ehrenberg}

Abh. K. Akad., Berlin, p. 39.1830

Podostoma fligerum. Clap. ex Lachm. Mém. Inst. Nat. Genevois, vol. 6, p. 441.1859

Cette amibe n'est apparue qu'une seule fois, dans les mousses récoltées aux environs de Sydney. Elle y était représentée par cette forme très-petite, ì pseudopodes droits et très-fins, d'une longueur extraordinaire, pour laquelle Claparède et Lachmann ont créé le nom de Podostoma filigerum, mais que l'on s'accorde en général aujourd'hui à regarder comme une simple variété de $A$. radiosa.

Il n'en a été trouvé qu'un seul individu, mais typique, vivant, actif et largement déployé. Peut-être scrait-on en droit de supposer que cette amibe se trouvait là en qualité d'étrangère, apportée avec l'eau dans laquelle la récolte avait été lavée. Je crois la chose ì peine vraisemblable; mais le fait est possible pourtant.

C'est ici du reste, pour le dire en passant, la seule fois que je croie devoir indiquer comme douteuse la provenance des organismes qui font l'objet de ce mémoire.

\section{Amoeba sphaeronucleolus. GreEFF}

Biolog. Centralbl ${ }^{\mathrm{t}}, \mathrm{B}^{\mathrm{d}}$ 11, p. 639. 1891

Les Amoebiens nus ne sont guère déterminables autrement que sur le vivant; mais il faut faire une exception pour les amibes terrestres, ou "pelliculeuses," qui, déjà mortes ou à l'état de vie latente, plissées, informes, montrent cependant encore d'une manière très-nette les caractères distinctifs du groupe spécial auquel elles se 
rattachent. Mais quant aux caractères de l'espèce, ils restent beaucoup moins distincts, et dans les diverses récoltes où se sont trouvées des amibes à pellicule, j'ai dû me contenter, pour la diagnose "sphaeronucleolus," de constater les signes distinctifs suivants : taille faible, noyau unique et arrondi.

Dans les mousses des Montagnes Rocheuses, les individus se sont parfois montrés vivants, mais jamais actifs; ils étaient enkystés, on plutôt, ils revêtaient l'état spécial qui dans ce groupe représente l'enkystement; plasma rétracté, arrondi, sous la protection de la membrane propre ou pellicule caractéristique, qui, en fait, a la valeur d'une enveloppe véritable.

\section{Amoeba terricola. GReEFF}

Arch. für Mikrosk. Anat., B ${ }^{\mathrm{l}} 2$, p. 300.1866

Beaucoup plus nettement reconnaissable que la précédente, l'Amoeba terricola s'est rencontrée dans un grand nombre de stations, souvent morte, ou bien aussi sous cette forme rétractée qui dans cette espèce représente l'enkystement; plus rarement elle était vivante (Montagnes Rocheuses, Victoria), mais alors, malades en apparence, les animaux n'ont jamais montré les signes d'un réveil certain.

Dans un individu, qui semblait vouloir sortir de son état de repos et montrait déjà quelques petites vésicules contractiles, le noyau renfermait, disséminés parmi les nucléoles caractéristiques, un certain nombre de grains d'excrétion brillants. C'est là un fait que j’avais constaté quelquefois déjà, ì Genève, sur des individus qui avaient été soumis à un jeûne prolongé. ${ }^{1}$

\section{Amphitrema stenostoma. NÜssLIN}

Zeitsch. für Wiss. Zool., Bd 40 , p. 717. 1884

Cette espèce, caractéristique des tourbières à sphagnum, est assez rare en général ; mais quand on la rencontre, c'est presque toujours en grandes quantités. Tel était bien le cas à Katoomba, ò̀ ce rhizopode ne s'est montré que dans une petite touffe de sphagnum jointe aux mousse ordinaires. Les individus étaient nombreux, encore verts et pourvus des zoochlorelles caractéristiques de cette espèce, morts cependant, on peut-être seulement enkystés. Aucun d'eux, en tout cas, n'est revenu à la vie active. ${ }^{2}$

1 Je crois avoir aussi, à deux reprises, rencontré Anoela alba, qui se distingue de la précédénte par sa forte tailie et par la présence de noyaux très petits et en nombre considérable. Mais il ne m'a pas été possible d'arriver à des conclusions certaines.

2 Pendant les quelques semaines qu'a duré mon examen de ces récoltes, il a fait très-chaud, et les rhizopodes, ou bien revenaient $a$ la vie dans les quaraute-huit heures, ou bien n'y revenaient pas du tout. De plus, ceux-là même qui reprenaient vic inouraient très-rapidement. A cette règle, il y a eu cependant des exceptions. 


\section{Amphizonella violacea. GREeFF}

Arch. fuir Mikr. Anat., B $B^{\mathbb{d}}$, p. 323.1866

Cette espèce s'est montrée dans trois stations, au Mont Cook, dans les Alpes australiennes, à Katoomba. Les individus, partout rares, étaient morts, reconnaissables pourtant à des traits certains; mais pâles, jaunâtres, et presque entièrement dépourvus de la teinte violette qui caractérise cet organisme.

\section{Arcella arenaria. GREeFF}

Arch. für Mikr. Anat., B ${ }^{\mathrm{d}}$ 2, p. 330. 1866

C'est là un des rhizopodes les plus caractéristiques des mousses, dans lesquelles il est bien rare de ne pas le trouver. Il manque pourtant dans quelques-unes des récoltes; peut-être y existe-t-il en fait, et a-t-il passé inaperçu; mais en tout cas, il y serait fort rare, car, lors de la confection de mon tableau général, étonné de ne pas avoir ì l'indiquer, j'ai tenu à contrôler le fait en examinaut ce qui me restait de mousses, mais sans rien trouver de nouveau.

Presque partout ce rhizopode se trouvait à l'état de coquilles vides. Dans les Alpes australiennes, beaucoup d'individus vivaient, mais aucun n'a déployé de pseudopodes. A l'île Macquarie, cette espèce se trouvait représentée par une variété plus claire et plus grande que le type habituel.

\section{Arcella vulgaris. Eurenbera}

Abh. Kais. Akad. Wiss., Berlin, p. 40.1830

Cette espèce n'habite pas les mousses, où elle est normalement remplacée par l'Arcella arenaria. Aussi bien n'est-ce pas dans les mousses qu'elle a été recontrée, mais dans un paquet de Conferves prises dans un marécage, et qui se trouvaient jointes aux mousses de la même station (Ile Macquarie).

L'Arcella vulgaris est connue par un grand nombre de variétés; ì l'île Macquarie, c'était une petite forme, de $75 \mu$ de diamètre, dont l'enveloppe, très-claire, couverte de dessins alvéolaires bien nets et réguliers, était relativement peu renflée, se rapprochant par lì de l'Arcella discoides, qui, elle aussi, fait le désespoir des naturalistes par ses nombreuses variétés.

Les individus, qui se trouvaient lì en grand nombre, étaient toujours ì l'état de coquilles vides. 
Assulina muscorum. GREwF

Sitzungsber., Marburg, p. 117.1888

Cette petite espèce, caractéristique avant tout des mousses, où elle ne manque presque jamais, s'est en effet rencontrée un peu partont dans les récoltes, presque toujours à l'ćtat de coquilles vides et souvent décolorées.

\section{Assulina seminulum. (Ehrenberg), Leidy}

Diflugia seminulum. EHrig. Monatsberichte K. Akad. Wiss., Berlin, p. 379. 1848

Assulina seminulum. LEIDY. Freshw. Rhiz. N.A., p. 225. 1879

Ce rhizopode est surtout caractéristique des Sphagnum, mais on le trouve anssi, fréquemment, dans les mousses belles et bien fommies des forêts. Sa taille normale est, le plus souvent, de $80 \mu$ environ, mais il arrive à dépasser quelqnefois de beaucoup cette mesure. A Ngauruhoe, par exemple, c'était une grande forme, d'un brun-ronge vif, et qui mesurait jusqu'à $115 \mu$ en longneur; à Vancouver, dans les mousses, la forme et la taille étaient normales, mais dans les Sphagnum, on y trouvait cette belle et grande variété discoïde, de 110 à $115 \mu$, et à dessins particulièrement bien marqués, que dans le temps j'avais cru devoir considérer comme une espèce spéciale (A. scandinarica).

\section{Awerinzewia cyclostoma. (Penard), Scioutedex}

Hclcopera cyclostoma. Penard. Faune Rhizopodique Léman, p. 390.1902

Awerinzewic cyclostoma. Schoutedes. Ann. biol. lacustre, t. i. p. 357.1906

Quelques individus seulement, à l'état de coquilles vides, revêtues encore de leur teinte caractéristique d'un violet noirâtre, se sont montrés dans la récolte de Ottawa.

\section{Bullinula indica. Penard (emend)}

Bulinclla indica. Penard. Journ. R. Mier. Soc., p. 274. 1907

La première mention de ce Rhizopode, l'un des plus intéressants parmi cenx des mousses, et le prototype de tout un grompe spécial voisin du genre Diplochlamys, ne date que de trois années ì peine, et son histoire est assez curieuse en elle-même.

'Irouvé en 1906 par J. Murray, dans des mousses qui provenaient de l'Himalaya, puis décrit par moi-même en 1907, sur la demande de Mr. Murray, ce rhizopode semblait devoir rester très-rare; mais à peine l'espèce venait-elle d'être publiée, que Mr. Murray la retrouvait dans les Sphagnun de l'Ecosse, puis dans des mousses venant 
de l'Ouganda. En 1909, je la récoltais enfin moi-même, en grande abondance, dans une tourbière du Jura suisse (La Pile), et alors dans un état de vie et de fraîcheur qui me permettait d'en faire une étude biologique qui n'avait pas été possible jusque la. ${ }^{1}$

Au retour de l'Antarctique, Mr. Murray a récolté cette espèce dans toutes les localités visitées; elle ne manque, en fait, qu'aux îles Auckland, lesquelles d'ailleurs n'étaient représentées dans les récoltes que par quelques fragments d'écorce revêtus d'une mousse rase.

Partout la Bullinula revêtait son apparence caractéristique, mais cependant elle se montrait quelque peu différente suivant la nature des particules (paillettes siliceuses plus ou moins nombreuses, petits grains de quartz, fibres de mousses, diatomées) qui recouvraient l'enveloppe, comme aussi sous le rapport de la taille, qui dans cette espèce varie daus une mesure assez forte.

Mais à cet égard, il est un détail sur lequel il me faut insister un instant, et sur lequel Mr. Murray, en 1909, et à propos des mousses de l'Ouganda, attirait déjà mon attention: A côté de la forme normale, grande et relativement allongée, ellipsoïdale, de 190 ̀̀ $200 \mu$ en genéral, et qui arrive jusqu'à $250 \mu$ dans des cas exceptionnels, on en trouve parfois une autre, presque ou même quelquefois tout- $\dot{a}$-fait ronde, ct beaucoup plus petite, de 130 à $170 \mu$ de diamètre (Fig. 1).

C'est bien lì également ce que montraient les récoltes qui font l'objet du mémoirc actuel; la petite forme ronde s'est retrouvée dans unc grande partie des collections; à Katoomba, à Rotorua, ̀̀ Oahu, à l'île Macquarie, elle était seule, et la grande forme manquait; à l'île Stewart, dans les Alpes anstraliennes, à Sydney, les deux formes sc trouvaient mélangées; au Quecnsland, à Ngauruhoc, à Victoria, dans les Montagnes Rocheuses, seule la grande forme était représentéc.

Il faut voir, semble-t-il, dans cette petite forme ronde une variété spéciale; mais entre cettc variété et le type, on trouve, dans les stations où elles vivent ensemble, les transitions les plus diverses, de sorte qu'on pent se demander s'il n'y aurait pas là une espèce unique, mais assez variablc, et qui tendrait à sc fixer sous deux formes extrêmes.

La promic̀re description de ce Rhizopode date de Juin 1907; mais d'après ce que Mr. Murray m'apprend aujourd'hui, il paraît que cc nom de Bullinella a été déjà appliqué ì un genre de mollusques.

Il faut donc nous hâtcr, pendant que cet organisme reste encore peu connu, d'apporter la rectification nécessaire; ct peut-être la dénomination générique de Buhlinula au lien de Bulinella suffira-t-elle pour contenter les zoologistes.

1 Cette étude fera l'objet d'un chapitre dans un des prochains numéros de la Revue Suisse de Zoologie (Notes sur quelques Sarcodinés, $3^{\circ}$ partie, vol. 19, 1911). 


\section{Centropyxis aculeata. STEIN}

Sitzungsber. Böhm. Akad. Wiss., B $B^{d}$ 10, p. 43.1857

Cette espèce est toujours rare dans les monsses, et il n'en a été trouvé que quelques exemplaires dans quclques-nnes des collections. A Vancouver (Sphagnum) elle était représentée par cette petite forme très-plate, claire, transparente et membraneuse, dont CASII a fait une variété spéciale, var. spinosa (British Freshw. Rhizop., Vol. I. p. 135, 1905). A Oalnu, c'était également une petite forme, très-rapprochée de la même variété.

\section{Centropyxis delicatula. Penard}

Faune Rhizopodique Léman, p. 308. 1902

Quclques exemplaires senlement, ì l'état de coquilles vides, an Qucensland et à Fijji.

\section{Centropyxis horrida, spec. nova}

Fig. $2, a$ et $b$

En même temps qu'il m'envoyait ses récoltes, Mr. Murray attirait mon attention sur me Centropyxis de lîle Stewart, qui lui paraissait nonvelle, et qui en effet me semble certainement devoir être décrite comme une espèce à part.

L'enveloppe elle-même, dans son ensemble, n'a rien qui doive la faire distinguer de la Cent. aculeata, connue d'ailleurs par de nombreuses variétés. Aplatie sur son axe dorso-ventral, et plus fortement à sa partie antérieure où se trouve l'ouverture buccale excentrique et infère, elle est jaunâtre, formée d'une chitine relativement très-claire dans laquelle sont empâtées des paillettes siliceuses, minces, très peu distinctes, puis sonvent aussi des particules de nature organique, et des filaments brunâtres arrachés aux mousses.

Mais ce qui distingue cette forme de toutes les autrés du même genre, c'est l'existence, non pas de cornes véritables, mais d'une sorte d'aile ou de carène, plate, déchiquetée, creusée de lacunes que parfois viennent combler des fragments siliceux, et qui borde toute la périphérie de l'enveloppe, à l'exception toutefois de la partie antérieure, qui reste lisse aux environs de la bouche.

De distance en distance, alors, cette carène lamcllaire est munie de prolongements, tantôt arrondis ì leur sommet, sinueux, lobós, capricieux dans leur forme, tantôt (et BRIT. ANTARCT. EXPED. 1907-9. VOL. I. 
le plus souvent) étirés en longues épines acérées, droites ou recourbées; plus rarement enfin, les épines sont remplacées par de simples expansions anguleuses (Fig. 2b).

'Toute cette structure donne l'impression d'une exsudation, qui se serait figée après avoir coulé; il semble que la coquille a été collée à quelque chose, anx feuilles des mousses, d'où la pluie ne pourrait alors plus la détacher; et peut-être cette impression première correspond-elle ì la réalité ; ce qui contribuerait ì le faire croire, c'est que les longues épines latérales, au lien d'être normalement dirigées par leur pointe vers la partie postérieure de la coquille, comme c'est le cas dans les autres Centropyxis et dans les Rhizopodes en général, montrent des directions quelconques, et même semblent se recourber de préférence vers l'avant; c'est là en tout cas un fait anormal, peu en rapport avec les besoins de l'animal ì l'état actif.

La Centropyxis horrida était abondante à l'île Stewart. La seule station où elle se soit retrouvée à été Katoomba, dans les Montagnes blenes, oì trois individus seulement se sont montrés.

\section{Centropyxis lacvigata. Penard}

Faune Rhizopodique Léman, p. 306. 1902

Cette espèce est rare; il n'en a été vı qu'un nombre très-restreint d'individus, à Rotorua, à Ngauruhoe, et à Katoomba.

\section{Corycia aculeata. GreEFF}

Pseudochlamys aculeata. GreEfF. Sitzungsber., Marburg, p. 332. 1888

Deux exemplaires seulement, nettement reconnaissables, à dents relativement courtes, ont été trouvés à l'île de Suva, Fiji.

\section{Corycia flava. GREeFF}

Amphizonella flava. GREEFF. Arch. f. Mikr. Anat., Bd 2, p. 329.1866

Cette espèce, en général commune, surtont sur les vieux murs ou dans les mousses rases qui garnissent les troncs des arbres, s'est rencontrée dans un grand nombre de stations, toujours typique dans ses caractères, mais assez variable de taille suivant les localités. Dans cette espèce, l'enveloppe mesure de 80 a $100 \mu$ en général; mais à Katoomba, elle arrivait à $145 \mu$, et jusqu'ł $150 \mu$ dans les Montagnes Rocheuses.

Partout les animaux étaient vivants, mais aucun d'eux n'a montré de pseudopodes; dans le genre Corycia, d'ailleurs, on ne les voit presque jamais. 


\section{Corycia penardi. Penard, Awerinzew}

Cor. Coronata, var. simplex. Penard. Faune Rhizop. Léman, p. 179. 1902

Cor. Penardi. Awerinzew. Trudui Petersb. Ob., tom. 36, p. 143. 1906

Cette espèce, peu commune en général, ne s'est montrée que dans peu de stations, et toujours représentée par quelques individưs sełlement, 3 à Vanconver, 1 à Suva, 1 au Mont Cook. A Ottawa, elle était pourtant moins rare.

\section{Corythion dubium. 'IARANEK}

Abhand. Kön. Böhm. Gesellschaft (6), B 2.1882

Ce petit Rhizopode n'est pas rare en général dans les mousses et les Sphagnum; mais on ne le reconnaît que difficilement, par suite de sa ressemblance presque parfaite avec une variété bryophile de Trinema enchelys. Dans le Corythion, la coquille est formée d'écailles toutes petites, de 3 à $4 \mu$ seulement de longueur, elliptiques ou vaguement rectangulaires avec angles arrondis, et disposées sans beaucoup d'ordre les unes à côté des autres; dans le Trinema, les écailles sont beaucoup plus grandes, rondes, et imbriquées daus un ordre géométriquement régulier; mais comme, daus ces deux formes, les éléments siliceux ne sont que très-difficilement visibles un à un, la distinction n'est pas tonjours aisée.

A l'île Macquarie, comme aussi au Mont Cook, cette espèce revêtait une forme spéciale (Fig. 3 $\alpha$ ), très-large, arrondie en un cercle presque parfait, et la taille, de 62 à $63 \mu$ de longueur, était de beancoup supériemre à celle dn type habituel, laquelle ne mesure guère que 35 à $40 \mu$.

A Ngauruhoe, à l'île Stewart, ̀̀ Oalıu, au Queensland, on tronvait une variété plus curieuse encore (Fig. 3b); l'enveloppe, de 40 à $50 \mu$ de longueur, très-large, à forte ouverture buccale, se montrait revêtue sur tout son pourtour (sauf à la bouche) d'une rangée régulière d'aiguillons acérés. Ces aiguilles, du reste, n'étaient pas silicenses au même titre que les écailles de la coquille; elles étaient composées de cette même matière chitinoïde, incolore, qui cimente les écailles entre elles, et se dissolvaient immédiatement dans l'acide sulfurique concentré bouillant.

C'est là, me semble-t-il, une variété fixée, et que l'on pourrait appeler var. spicata.

\section{Cyphoderia ampulla. Ehrenberg}

Monatsberichte K. Akad., Berlin, p. 199. 1840

Cette espèce n'est pas muscicole, mais on la rencontre quelquefois dans les Sphagnum. Au Mont Cook, il s'en est trouvé deux exemplaires, typiques, et à dessins 
aréolaires relativement très-grands, $3 \mu$ environ; puis à Vancouver, une seule coquille vide; dans ces deux récoltes, il faut le remarquer, il y avait du Sphagnum. A Oahu, par contre, où s'est également montrée une coquille vide, le splagnum manquait; mais on y voyait de belles mousses bien fournies, l'une d'elles très-claire, longue et soyeuse, et dans ces conditions-là les mousses renferment quelquefois des organismes sphagnophiles en général.

\section{Difflugia arcula. LEIDY}

Freshw. Rhiz. N. America, p. 116.1879

Cette difflugie, - qui n'est pas une difflugie en réalité, mais un Rhizopode très-voisin des genres Bullinula et Diplochlamys, ${ }^{1}$ - est l'une des espèces les plus caractéristiques des Sphagnum et des mousses, et s'est rencontrée dans la plupart des récoltes de Mr. Murray. Tout en restant toujours bien typique dans son apparence générale, elle varie passablement, d'une localité à une autre et souvent aussi dans une même localité, sous le rapport de la taille, de la hauteur comparée à la largeur, des éléments qui recouvrent l'enveloppe. Quelquefois aussi, dans une même station, on trouve deux formes l'une à côté de l'autre, une grande et une petite, que ne relie ancune transition. 'I'el a été le cas à Oahu, à l'île Macquarie, comme anssi au Queensland.

Dans plusieurs des récoltes, les animaux se sont montrés vivants. Ce rhizopode, en effet, est doué d'une résistance tout-à-fait remarquable; mais jamais aucun individu n'a déployé de pseudopode. Le contraire, du reste, eût été très-étonnant, car dans cette espèce, les pseudopodes, quelquefois mentionnés par suite d'une confusion avec un autre organisme (Centropyxis laevigata), n'ont jamais été vus en réalité, et paraissent décidément manquer.

\section{Difflugia bacillifera. Penard}

Mém. Soc. Phys. Hist. Nat., Genève, vol. 31, p. 146. 1890

Seulement trois coquilles vides, à Vancouver. Cette espèce est très-rare, et peu caractéristique; peut-être eût-il mieux valu, dès l'origine, l'envisager simplement comme une variété de Diff. pyriformis.

1 Voir un des prochains numéros de la Revue Suisse de Zoologie, tome 19, 1911. 


\section{Difflugia constricta. EhrenberG}

Abh. Kön. Akad. Wiss., Berlin, p. 410. 1841

C'est là le rhizopode le plus constant dans les mousses, et qui, en fait, s'est montré dans toutes les stations (il manque dans l'Antarctique proprement dit, ce qui n'est pas sans étonner). Il est tonjours et partout représenté par de nombreuses variétés, petites ou grandes, longues ou larges, plus ou moins comprimées, etc., et tout cela s'est trouvé dans les récoltes de Mr. Murray.

\section{Difflugia fallax. Penard}

Mém. Soc. Phys. Hist. Nat., Genève, vol. 31, p. 144. 1890

Cette petite espèce n'a été rencontrée que dans les Alpes australiennes, puis à Sydney, sous la forme de rares coquilles vicles. Elle est toujours difficile à déterminer, et vu le mauvais état des exemplaires examinés, peut-être faudrait-il ne l'indiquer ici que suivie d'un point d'interrogation.

\section{Diffugia lucida. Penard}

Mém. Soc. Phys. Hist. Nat., Genève, vol. 31, p. 145. 1890

Ce rhizopode est de faible taille, pen apparent, et passe facilement inaperçu; mais grâce ì sa forme spéciale et à l'aplatissement considérable de la coquille, on le reconnait facilement. Dans la plupart des récoltes, il s'est montré rare, représenté par quelques coquilles vides seulement; à Katoomba, dans la mousse comme aussi dans le sphagnum, les exemplaires en étaient plus nombreux, et souvent vivants, mais alors enkystés.

\section{Difflugia manicata. PEnsRD}

Faune Rhizopodique Léman, p. 226. 1902

Quelques individus seulement, dans le Sphagnum du Mont Cook; ovoïdes, de $90 \mu$ de longuenr, peu typiques de forme; mais grâce à leur couronne de grosses particules quartzeuses en arrière du péristome, on pouvait les identifier sans difficulté. 
Diffugia pyriformis. Perty, var. bryophila. Penard

PERTy. Zur Kenntniss Kleinster Lebensformen, p. 187. 1851

Penakd. Faune Rhizop. Léman, p. 221. 1902

La Diff. pyriformis, le plus conmun pent-être de tous les rhizopodes d'ean douce en général, manque, à l'état typique, dans les mousses (sauf, bien entendu, dans les mousses submergées, qui peuvent héberger toute la faune habituelle des étangs); elle y est remplacée, cependant, par une variété plus petite, var. bryophila, pas très commune en général, et qui ne s'est rencontrée que dans quelques-unes des récoltes.

\section{Diplochlamys fragilis. Penard}

Areh. für Protistenkunde, $B^{d}$ 17, p. 272. 1909

Parmi les différentes espèces qui composent le genre Diplochlamys, il en est deux, $D$. fragilis et $D$. Leidyi, qui sont fort rapprochées l'une de l'autre, et ne peuvent guère être distinguées autrement qu'à l'état vivant; dans les récoltes de Mr. Murray, les rares individus rencontrés étaient on morts, ou enkystés, et si la détermination du genve est certaine, peut-être faudrait-il mettre un point d'interrogation à côté du nom de l'espèce.

\section{(?) Diplochlamys gruberi. Penard}

Arch. für Protistenk., $B^{\text {d }} 17$, p. 282.1909

Les restrictions qui viennent d'être faites à propos de la Diplochlamys fragilis sont peut-être plus̉ nécessaires encore dans le cas actuel. Un représentant de ce genre, qui semblait ne pouvoir être autre chose que $D$. gruberi, s'est montré dans plusieurs des récoltes, mais c'est seulement dans les mousses d'Oahu que j'ai cru pouvoir m'assurer d'une détermination à peu près certaine.

\section{Diplochlamys timida. Penard}

Arch. für Protistenk., B ${ }^{d}$ 17, p. 275. 1909

Cette espèce, de taille plus faible que les précédentes, et qui s'en distingue en outre par des caractères assez précis (noyau, enveloppe interne, revêtement externe), a pu, au contraire de ces deux dernières, être déterminée avec certitude.

A Ottawa, au Queensland, on la trouvait vivante, mais rétractée dans son enveloppe. 


\section{Diplochlamys vestita. Penard}

Amoeba vestita. Penard. Mém. Soc. Phys. Hist. Nat., Genève, vol. 31.1890

Diploeh. vestita. Penard. Arch. für Protistenk., B ${ }^{\mathrm{d}}$ 17, p. 279.1909

Beaucoup plus grande que toutes les espèces précédentes, dont elle diffère également par la nature de son enveloppe et par la présence de noyaux très nombreux et très-petits, la Dipl. vestita s'est montrée à Vancouver et à Katoomba. Dans cette dernière localité, cependant, le seul exemplaire rencontré était en trop mauvais état pour qu'il fût possible de l'identifier avec certitude.

\section{Euglypha alveolata. Dujardin}

Hist. Nat. Zooph. infusoires, p. 252. 1841

L'Euglypha alveolata ne se rencontre guère dans les mousses, mais par contre elle est assez fréquente dans les Sphagnum. C'est bien dans le sphagnum aussi qu'elle a été trouvée, au Mont Cook, à Vancouver, dans les Alpes australiennes; à l'île Macquarie, par contre, le sphagnum manquait, mais on y voyait une touffe d'une mousse claire, longue et très fournie, laquelle, comme nous l'avons déjà vu, a fourni plusieurs organismes sphagnicoles en général.

Dans les trois premières de ces stations, l'espèce était représentée par cette variété, normalement prolongée en arrière de quatre longues épines, que Leidy, par exemple, figure dans la Pl. 35 (Fig. 15 à 17) de son grand ouvrage, et qui ì l'heure actuelle est généralement indiquée comme Euglypha brachiata (voir page suivante, remarques à propos de cette espèce). Mais cette forme elle-même est assez variable quant au nombre des épines qui la caractérisent. Dans les Alpes australiennes, comme aussi au Mont Cook, la plus grande partie des coquilles, reconnaissables pourtant (grâce à leur forme, aux denticulations buccales, etc.) comme devant se rattacher à cette variété spéciale, étaient lisses, sans épines. A Vanconver, on trouvait une seule aiguille, sur le côté, ou bien deux, ou trois, ou bien encore l'une des aiguilles était terminale, prolongeant d'une longue épine le fond de la coque.

Quant à l'Euglypha alveolata de l'île Macquarie, c'était une variété spéciale, de 75 à $105 \mu$ de longueur, à coquille légèrement comprimée (à section transversale elliptique), ornée de dessins aréolaires largement marqués, et munie à la bouche d'écailles pourvues en avant d'une ligne de denticulations très-petites et serrées.

\section{Euglypha brachiata. LEIDY}

E. brachiata. Leidy. Freshw. Rhiz. N. Amer., p. 220.1879

non Penard. Faune Rhizopodique Léman, p. 504. 1902

Peu de Rhizopodes sont aussi variables-en apparence au moins-que ceux qui se rapportent au genre Euglypha; et pour cette raison même, il est peu de genres dans 
lesquels on ait réuni sous une même dénomination spécifique une aussi grande quantité de formes différentes, et dont plusieurs, sans aucun doute, représentent en réalité des espèces bien autonomes.

Mais il est aussi, dans ce genre Euglypha, des espèces bien nettement distinctes, faciles à caractériser, et avant toutes les autres on peut citer sous ce rapport l'Euglypha brachiato, sous sa forme typique, celle que Leidy figure à la $\mathrm{Pl}$. 37 de son grand ouvrage (Fig. 5 à 10). Et pourtant, elle aussi reste encore méconnue; sous le nom spécifique de brachiata, on s'accorde en général aujourd'hui à réunir toutes les formes dont les épines, au lieu de constitner chacme nn élément distinct en soi, ne sont que le prolongement effilé d'une des écailles ordinaires et régulièrement imbriquées qui constituent l'ensemble de la coquille.

Cette généralisation, compréhensible dans l'état actuel de nos connaissances, est regrettable; et quant à l'Euglypha brachirata, il y a lì une grave erreur à réparer. Parmi les naturalistes qui ont cité cette espèce, bien peu, en réalité, me semblent avoir eu sous les yeux la forme type de LeIdy ; aucun même pent-être, à la senle exception de G. S. West, ${ }^{1}$ qui, lui, l'a évidemment trouvée (Capel Curig, N. Wales, et small lakes East of Recess, W. Ireland), et qui dit it cette occasion: "This is another rare species of the genus, which I have only obtained twice, and in both instances from submerged sphagnum." Pour mon compte, ce n'est que tout récemment, dans les sphagnum de Vancouver, que j'ai pu voir cette espèce telle qu'il faut la comprendre aujourd'hui; il s'en est tont-à-coup montré un exemplaire, une coquille vide en parfait état, puis, après bien des recherches, j'ai fini par en trouver un second.

Comme la description de LEIDY, bien que parfaitement exacte, est un peu écourtée, il ne sera pas inutile de donner ici quelques renscignements supplémentaires sur cette Euglypha, peut-être la plus élégante dans ses formes de toutes celles que l'on connaît actuellement (Fig. 4, $a$ et $b$ ).

La coquille, allongée, légèrement pointne en arrière, s'élargit de là graduellement pour acquérir son plus grand diamètre un peu en arrière du milieu de la longueur, puis s'infléchit vers l'avant, en décrivant une légère courbe rentrante, et vient se terminer en une bouche relativement étroite, formée de 7 écailles ( 7 en tont cas dans l'individu particulièrement examiné).

Comme toujours dans le genre Euglypha, ces écailles de la bouche sont denticulées en avant, et ici, la disposition de ces dents est assez curieuse: une large dent médiane, presque triangulaire, puis de cliaque côté une dent plus petite, allongée en forme de dé à condre, puis une plus petite encore, et enfin l'ébauche d'une troisième.

En arrière de cette première rangée buccale, la seconde ligne d'écailles porte encore des denticulations, puis viennent les écailles lisses, ovales, très-belles, qui se continuent sur toute la coque, et, en rapport avec la forme même de cette dernière, plus grandes sur les parties reuflées, plus petites sur les parties étroites, même rondes au fond de la coquille, de manière à ue jamais violenter la belle imbrication régulière.

1 Linnæan Society's Journal, Zool., vol. 28, p. 328, 1901. 
Quant aux longs “bras” caractéristiques de cette espèce, et que LeIDY indique comme étant au nombre de 2 ou de 4, plus rarement de 6, l'un des individus que j’ai pu examiner en portait 2, l'autre 4. Ce ne sont lì pas autre chose que des écailles, très-fortement modifiées; par leur base, elles s'insèrent entre les écailles ordinaires, et font partie du revêtement général; puis elles s'élancent au dehors, et par une large courbe elles vont s'épanouir en arrière, comme deux ailes ou deux longs bois de renne.

Vus de côté, ces appendices se présentent comme-de simples aiguilles recourbées en alène; mais si l'on s'arrange ì les voir d'en haut, par exemple, on constate que ce sont des lames, larges, minces, et, comme j'ai pu m'en assurer sur un “bras" cassé, creusées en gonttière ${ }^{1}$ (Fig. 46 ).

Ces longs appendices fonctionnant comme des ancres, doivent être d'une réelle utilité pour retenir l'animal entre les feuilles des Sphagnum; peut-être même est-ce pour cette raison que dans les localités où on le trouve on a peine à en obtenir quelques rares individus; mais dans d'autres circonstances, ces ramures doivent gêner considérablement l'animal, et l'on peut se demander si cette espèce si peu répandue n'est pas en train de disparaître, comme ont disparu d'autres animaux plus élevés en organisation, par suite d'une trop grande complication de leurs organes ì l'origine protecteurs.

\section{Euglypha ciliata. Emrenbera}

Monatsber. K. Akad. Wiss., Berlin, p. 379. 1848

Cette espèce est toujours commune dans les mousses, et de fait, elle a été vue un peu partout. A Ngauruhoe, à l'île Macquarie, daus les Alpes australiennes, on en trouvait une variété très-hirsute, ì épines fortes et nombreuses, disposées en désordre les unes dans les autres.

\section{Euglypha compressa. CARTER}

Ann. Mag. Nat. Hist., vol. 13, p. 32. 1864

Commune en général dans les mousses et surtont dans les Sphagnum, cette espèce n'a manqué nulle part, sauf à Fiji, oì les circonstances, nous l'avons vu, étaient un peu particulières. Dans plusieurs des récoltes (Ile Stewart, $\mathrm{M}^{\mathrm{t}}$ Cook, Sydney), on la rencontrait sous deux formes, une grande et une petite, sans qu'il apparût de transitions. A l'île Stewart, presque tous les exemplaires se rattachant a la grande forme étaient dépourvus d'aiguilles; an Mont Cook, la grande forme, très-belle, rappelait d'assez près la Placocysta spinosa, avec laquelle du reste cette espèce a été souvent confondue. A Sydney (National Park), l'on trouvait une variété superbe, de $145 \mu$ de longueur.

1 Lemy éerit à ce snjet: "Rarely, I have seen them straight, with thickened ends and oar-like, as seen in Fig. 7."

BRIT, ANTARCT. EXPED, 1907-9. VOL. I 


\section{Euglypha cristata. Lerdy}

Proc. Acad. Nat. Sci., Philad., p. 226. 1874

non Awerinzew. R hizopodienstudien, Ann. de Biol. Lacustre, tom. 1, p. 323. 1906

Cette jolie petite espèce, toujours facile à reconnaître, ne s'est rencontrée que dans une seule des récoltes, dans les Sphagnum de Katoomba, $\mathrm{M}^{\mathrm{es}}$ Bleues, et cela sous la forme d'une seule coquille vide, parfaitement typique d'ailleurs.

\section{Euglypha filifera. Pexard}

Mém. Soc. Phys. Hist. Nat., Genève, vol. 31, p. 179.1890

Ce petit rhizopode, caractérisé surtout par ses aiguilles fines, longues et trèsdroites, peu nombreuses, disposées de distance en distance sur l'arête de la coquille, s'est montré dans la seule station de Creel, Alpes australiennes.

\section{Euylypha laevis. PERTY}

Mittheil. Naturf. Ges., Bern., p. 163. 1849

On rencontre pour ainsi dire toujours, daus les mousses, toute unc série d'Euglypha très-petites, lisses, à dessins alvéolaires à peine reconnaissables, et quc, faute de mieux, on s'accorde généralement à considérer comme représentant l'Euglyplıa laevis de Perty.

Tel a été le cas dans les récoltes de Mr. Murray. Dans plusieurs stations, on voyait également, à côté de la forme habituelle, cette variété extrêmement petite $(36 \mu)$ que j'avais décrite en $1890^{1}$ comme var. minor.

\section{Euglypha strigosa. LeIdY}

Proc. Acad. Nat. Sci., Philad., p. 172.1878

Difficile à distinguer de l'Euglypha ciliata dont elle diffère par un revêtement d'aiguilles très-courtes et très-serrées, comme aussi par sa forme un peu spéciale et la structure particulière du péristome, ${ }^{2}$ l'Euglypha strigosa s'est montrée dans quelques-unes seulement des récoltes. Dans les Alpes australiennes, la coquille était pourvue d'aiguilles relativement très-fortes ct très-serrées. A Vanconver, dans la mousse lavée depuis trois jours, il s'en est rencontré un individu vivant, qui courait gaiement au milieu des débris, avec pseudopodes déployés.

1 Mém. Soc. Phys. Hist. Nat., Genève, vol. 31, p. 182.

2 Penard, Faune Rhizopodique Léman, p. 503. 


\section{Heleopera petricola. LEIDY}

Freshw. Rhiz. North Am, p. 165. 1879

Cette espèce s'est rencontrée dans un nombre relativement restreint de stations, sous la forme de coquilles vides ou d'individus enkystés, et souvent (Australian Alps, Mt. Cook, Vancouver) avec cette teinte rosée que-prend volontiers la coquille. A Suva (Fiji) comme aussi à Sydney (National Park), c'était une petite variété incolore, qui peut-être aurait droit à une dénomination spécifique particulière.

\section{Heleopera sordida. Penard}

Revue Suisse de Zoologie, tom. 18, fasc. 3. 1910

Cette Heleopera, à coquille petite, large et renflée, d'un jaune sale, et dout la description toute récente a été donnée d'après des échantillons récoltés en 1909 dans les tourbières du Jura suisse, où les individus ont été étudiés vivants et en état d'activité, s'est rencontrée dans les Sphagnum de Vancouver, puis au Parc National de Sydney, mais toujours à l'état de coquilles vides.

\section{Heleopera sphagni. LeIDY}

Difflugia (Nebela) sphagni. Leidy. Proc. Acad. Nat. Sci., Philad., p. 157. 1874

Heleopera picta. Leidy. Freshw. Rhiz. N. Amer., p. 162.1879

Heleopera sphagni. CASH et Hopkinson. Brit. Freshw. Rhiz., p. 143. 1909

Cette grande et belle espèce s'est montrée dans cinq des récoltes, toutes, il faut le remarquer, de l'hémisphère sud. Elle était partout bien reconnaissable, mais partout aussi un peu différente du type figuré par LEIDY, et tel que, pour mon compte, je l'ai également trouvé en Europe.

La coquille, jaunâtre pâle, relativement très-élargie, portait ici des dessins aréolaires extrêmement petits, tels qu'on n'est guère habitué à les voir. Elle variait, suivant les exemplaires, entre 92 et $110 \mu$. A l'île Macquarie, c'était une forme très-belle, de 130 à $140 \mu$ en longueur; souvent les individus se trouvaient à l'état enkysté, et l'on pouvait reconnaître an plasma une teinte verdâtre qui semblait montrer que là aussi la symbiose est un phénomène ordinaire.

\section{Heleopera sylvatica. Penard}

Mém. Soc. Phys. Hist. Nat., Gen., vol. 31, p. 168.1890

Caractéristique des mousses proprement dites, ce rhizopode manque le plus souvent dans le Sphagnum. Distinct des autres espèces du genre par sa taille très- 
faible (60 $\mu$ en général), par sa transparence, l’imbrication de ses écailles, comme par d'autres caractères moins évidents, il s'est montré bien normal dans les différentes stations où il a été recueilli. A Oahu, cependant, la taille était relativement très-faible.

Cet organisme résiste bien ì la dessication, et s'enkyste volontiers; c'est sous cette forme vivante, mais cnkystée, qu'il a été souvent trouvé.

\section{Hyalospheria cockuyni, spec. nova}

Fig. $5, a$ et $b$

En m'envoyant quelques petits fragments de mousses recucillis par le Dr. Cockayne, botaniste du Gouv. de Nlle. Zélande, sur le tronc d'un arbre aux îles Aucklind, Mr. Murray attirait mon attention sur un Rhizopode qu'il croyait nouveau. Ce devait être là, pensait-il, une Nebela; mais ì mon avis, cet organisme doit plutôt rentrer dans le genre Hyalosphenia, dont il serait même un représentant assez typique.

Entre ces deux genres, du reste, il n'existe pas de différences bien sensibles; on s'accorde ì considérer comme Hyalosphenia les formes dont la coquille est ou paraît être lisse, réservant le nom de Nebcla pour celles dont l'enveloppe est revêtue d'écailles ou de plaques. Mais dans le fait, cette distinction est assez subtile, et dans la plupart des Hyalosphenia, on distingue souvent, chez certains individus ou dans certaines localités, des réticulations dues ì la présence d'éléments siliceux fort petits, noyés dans l'épaisseur de l'enveloppe. ${ }^{1}$

Daus la $I$. cockayni l'enveloppe, d'un jaune chamois très-clair, transparente, comprimée, ì peu pròs pyriforme d'apparence, et une fois et demi aussi longue que large, se montre tout d'abord lisse et unie; mais en l'examinant avec attention, on finit par y reconnaître, dans tous les inclividus mais sur les uns plus distinctement que sur les antres, la présence d'éléments siliceux, généralement très-petits (quelques $\mu$ ), ronds ou plus souvent ovales, et se toucliant les uns les autres sur toute la surface de l'enveloppe. Jans plusieurs cxemplaires, j'ai trouvé quelques-uns de ces éléments silicenx qui n'étaient pas autre chose que les écailles bucales d'une Euylypha, et même, grâce ì la structure et à la disposition des denticulations caractéristiques, on reconnaissait $E$. compressc. ${ }^{2}$

La structure de notre $H$. cockayni est donc à peu près identique ì celle de H. papitio; mais la forme est toute différente: les bords latéraux de la coquille, au

1 Daus II. tincta (Nelela tincta, Awerinzew), on peut trouver des stations oì tous les individns montreront une enveloppe parfaitement lisse à première apparence, tandis que dans d'antres localitís, plus nombreuses, cette enveloppe se verra tout entic̀re recouverte d'écailles bien nettement définies.

${ }^{2}$ C'est pour cette raison, même, que j'ai porté sur la liste des espèces récoltées cette ḱuglypha qui en réalité n'y a pas été trouvée en tant qu'individu; mais il fallait bien qu'elle existât, puisque notre Hyalosphenia en avait amassé les écailles. 
lieu d'aller tout droit et d'une seule venue jusqu'd̀ l'extrémité, se creusent brusquement, ‘̀ ganche et à droite, et vers le tiers antérieur de l'enveloppe, d'une encoche, d'un arc rentrant, et ces deux encoches droite et gauche donnent à toute cette enveloppe une apparence assez élégante, qui rappellerait celle d'un violon.

En avant, l'onverture buccale, plus étroite que dans $I I$. papilio, est un peu renflée en lèvre, arquée sur la face large, crensée sur la face étroite.

Sur les côtés de cette partic antérieure rétréeie, qu'on pourrait appeler le tube buccal, on voit souvent une ou même deux perforations ou pores, mais qui n'existent pas nécessairement. En arrière, on ne distingue aucun pore, rien d'analogue à ce qui existe chez $H$. papilio.

'Tous les exemplaires rencontrés l'ont été soit à l'état de coquilles vides, soit enkystés, le plasma figurant une masse ovoïde. D'après la couleur et l'apparence de ce plasma, il semblerait qu'à l'état de vie active on trouve, ici aussi, normalement des plićnomènes de symbiose.

C'est, comme nous venons de le voir, anx îles Auckland que cette espèce a été découvertc tont d'abord; plus tard, elle s'est retrouvée dans les Sphagnum du Mont Cook, représentée par une seule coquille vide, très-grande, de $115 \mu$; enfin, dans les environs de Sydney, clle s'est revue encore, pas très-rare; les exemplaires mesuraient $100 \mu$ environ.

Aux îles Auckland, la longnenr variait entre 89 et $100 \mu$, pour un largeur de 45 à $55 \mu$. L'enveloppe est assez fortement comprimée, et son épaisseur arrive à peine à la moitié de sa largeur.

\section{Hyalosphenia subflava. CAsI}

Brit. Freshw. Rhiz. and Helioz., vol. 2, p. 87. 1909

Fig. $6, a, b$, et $c$

Dans les mousses provenant d'Eumundi, Queensland, et plus spécialement dans la touffe de sphagnum qui s'y trouvait jointe, s'est rencontrée, avec une abondance relative, cette petite Hyalosphenia, décrite tout dernièrcment, comme provenant soit des tourbières d'Irlam Moss près de Manchester, soit des monts Pentland (Mr. Evans) en Ficosse.

Bien que le Rhizopode trouvé au Queensland puisse être assimilé sans trop de peine à celui des Iles Britanniques, il n'en est pas moins vrai que l'on y constatait des différences de détail assez sensibles. L'enveloppe, plus petite (59 $\mu$ au maximum, et généralement $53 \mu$, en regard de 65 ̀े $70 \mu$ qu'indique $\mathrm{CASH}$ ), relativement plus large, un peu moins comprimée, était terminée par une ouverture buccale assez petite, ovale ou presque ronde, pourvue d'une sorte de bordure ou lèvre très courte et à peine indiquée, qu'entourait à son tour uu petit cercle de grains faiblement marqués; cette lèvre ne portait pas trace d'encoche sur les côtés, et aucun exemplaire n'a montré le pore terminal postéricur dont parle CAsH (mais qu'il ne figure pas). 
L'enveloppe, jaunâtre, semblait parfaitement lisse à première apparence, mais un examen attentif y décelait la présence de granulations serrées, ou éléments silicenx très-petits noyés dans la masse chitineuse.

Presque tous les exemplaires n'ont été trouvés qu'à l'état d'enveloppes vides; quelquefois, un reste de plasma, inerte et en manvais état, laissait supposer qu'il y avait peut-être eu lì des zoochlorelles symbiotiques.

\section{Lesquereusia ... spec.}

Les éléments siliceux qui forment la coquille dans les Lesquereusia sont tellement caractéristiques, que je n'ai aucune hésitation ì indiquer la présence de ce genre dans le sphagnum de Vanconver, bien qu'il n'ait été trouvé qu'un tout petit fragment de coquille. Même, d'après la forme trapue et courte des quelques écailles siliceuses vermiculaires qui constituaient ce fragment, je croirais volontiers que c'était la Lesquereusia epistomium, PeNard. Mais ce serait là en tout cas une identification un peu aventureuse.

\section{Limberkiihnia wageneri. ClaP. ET Lachmans}

Mém. Inst. Nat., Genève, vol. 6, p. 465. 1859

Après avoir observé, ̀̀ Vancouver comme dans les Alpes australiennes, des organismes inertes et peu reconnaissables que je croyais pourtant devoir rapporter à cette espèce, j’ai fini par constater sur quelques individus la présence de ce long "pédoncule" interne, caractéristique dn genre, et qui ne peut montrer autre chose qu'une Lieberkiihnia. La taille, la présence de petits globules en grand nombre qui sans doute représentaient les noyaux, indiquaient la Liel. wageneri, et non pas L. paludosa qui ne possède qu'un seul noyau très-gros, ou bien quelquefois en renferme plusieurs, mais encore volumineux et en nombre très-restreint.

\section{Nebela bigiblosa. Penard}

Mém. Soc. Phys. Hist. Nat., Genève, vol. 31, p. 161. 1890

Cette curieuse Nebela, si typique avec ses deux brides latérales invaginées, et qui fut trouvée pour la première fois anx environs de Wiesbaden en 1890, puis en 1902 dans les mousses du Spitzberg, en 1903 dans les forêts du Valais, enfin en 1909 ̀̀ la montagne des Voirons près de Genève, s'est encore revue dans les collections Murray, à Vancouver et à Victoria; rare d'ailleurs et représentée par des coquilles vides, mais bien nettement caractérisées. 


\section{Nebela caudata. LEIDY}

Proc. Acad. Nat. Sci., Philad., p. 58. 1876

Cette espèce rare, découverte par Leidy en 1876 dans les tourbières du New Jersey, et qui, à ma connaissance n'a été trouvée en Lurope qu'une seule fois, dans le Loch Ness en Ecosse, ${ }^{1}$ semble être beancoup plus commune dans l'hémisphère sud. ${ }^{2}$

Les récoltes de Mr. Murray l'ont montrée dans une demi-douzaine de localités, soit à l'état de coquilles vides, soit enkystée, le plasma figurant une masse sphérique protégée par un épiphragme.

Ce qu'il y a de plus caractéristique dans cette espèce, ce sont ses cornes, ou prolongements crenx, au nombre de $3,4,5$, qui terminent la coquille en arrière. Mais ces cornes sont bien sonvent rudimentaires, à moitié formées, ou bien manquent en partie, quelquefois même tout-ì-fait.

$\mathrm{Au}$ Queensland, la forme était normale, et presque toujours les individns portaient les prolongements caractéristiques, le plus souvent au nombre de 4 ou 5. A Ngauruhoe, les individus montraient le plus généralement nne ou deux cornes seulement, et plus ou moins rndimentaires; ì l'île Macquarie, on trouvait toutes les transitions possibles entre un simple rudiment d'une seule corne et des prolongements normaux. A Victoria, B.C., à Vancouver, presque tous les individus étaient lisses, dépourvns de prolongements quelconques, et personne, à première vue, n'aurait hésité à considérer ces coquilles comme autre chose que ce qu'elles étaient vraiment; il y avait lì, en apparence, une simple variété de Nebela dentistoma.

\section{Nebela certesi. Certes, spec. nova}

Neb. collaris. Cerrtes. Var. Cap Horn, $a$ et $b$. Mission scientif. Cap Horn, tom. 6, Zool., p. 14

Fig. $7, a$ et $b$

En même temps qu'il décrivait sa curiense Nebela martiali, Certes désiguait sous les noms de Neb. collaris, var. a Cap Horn et Neb. collaris, var. $b$ Cap Horn, deux rhizopodes d'une forme et d'une apparence spéciale, et caractérisés par la présence d'un “sillon” qui “part de l'onverture et va en s'atténuant jusqu’à la moitié de la longueur du col, orné de perles irrégulièrement disposées de chaque côté dù sillon au nombre de 3 à 7 et même plus." La variété $b$ se distinguait en ontre par la présence de "quatre ouvertures triangnlaires symétriqnement disposćes," et situées ì la base du col.

1 J Murray, in Proc. Roy. Soc., Edinburgh, 1904-5, vol. 25, 1. 614.

${ }^{2}$ Elle s'est retrouvée dans les mousses rapportées par le Dr. Bruce de Gough Island, Océan atlantique Sud, au cours du voyage de la Scotia. 
Il n'est pas difficile de reconnaître lì une Nebela qui s'est rencontrée d'abord à Katoomba (Montagnes Bleues), puis aux environs de Sydney, partout très-rare et représentée par des enveloppes vides et souvent en mauvais état, mais suffisantes pour une détermination exacte.

Il est étrange, à vrai dire, que Certes n'ait cru devoir considérer ce Rhizopode que comme une variété de Nebela collaris, dont il s'éloigne en réalité de très-loin; mais, si j'en puis juger d'après quelques-unes des figures domnées par l'observateur français, il est probable que certaines coquilles malformées et en manvais état lui auront paru constituer des formes de transition qui l'auront induit en erreur.

En même temps, ces deux variétés $a$ et $b$ de CERTEs ne concement bien certainement qu'un même organisme, car les quatre "ouvertures triangulaires" existent toujours en principe, mais souvent si rudimentaires et si indécises à la vue qu'on a peine ì les trouver.

Pour moi, c'est là une espèce tout-à-fait caractéristique, et qui, me semble-t-il, doit porter le nom du consciencieux savant français.

La Nebelce certesi est une espèce d'assez grande taille, ou plutôt, faudrait-il dire, d'une taille asse\% allongée, mesurant 145 ¿ $150 \mu$ en général; mais la coquille, fine, mince, étroite et délicate, en fait un organisme assez chétif en apparence, et qui passe facilement inaperęu.

Elle a la forme d'une bouteille, étroite, au col allongé, et, assez fortement comprimée, elle présente une face large et une face étroite. Cette enveloppe est jaunâtre, très-claire, formée d'une matiòre chitinoïde dans laquelle sont empâtés des éléments siliceux ovales ou arrondis, très-petits, ou mêlés de plus gros. La bouche est bordée d'un épaississement, ou lève saillante et arquée en avant sur la face large, creusée d'une faible gonttière sur la face étroite. Mais ce qu'il 'y a de 'plus curieux dans cette espèce, c'est la présence d'un étroit sillon, qui, partant du péristome et au milieu de chacune des lèves, descend tout droit le long du col, pour disparaître ì la moitié de la longueur de ce col.

C'est là un véritable canal, creusé dans l'épaisseur de la paroi, et bordé par contre, sur l'un de ses côtés, d'un épaississement qui simule un bâtonnet; aussi, sur des coqnilles brisćes, trouve-t-on quelquefois que la déclirure s'est faite juste le long du sillon, c.a.d. sur la ligne de moindre résistance.

A droite et à gauche du canal, on remarque également toujours deux ou plusieurs lignes de petites perles brillantes."

Plus bas, en arrière du col, on voit, à gauche et à droite, et sur chacune des faces, une petite ouverture, irrégulière de contour, mais si faible qu'elle ne se distingue guère que sur des coquilles et bon état. Ce ne sont pas là, du reste, de simples perforations, mais l'indice d'une sorte de tube, plus ou moins rudimentaire, qui traverse la coquille de part en part.

1 Dans le baume du Canada, ces perles ne sc distinguent presque plus, et le sillon buecal lui-même devient peu visible. 
Aucun des individus rencontrés ne l'a été autrement qu'à l'état de coquille vide; ou bien aussi l'on trourait quelques restes de plasma mort, ì l'abri d'un diaphragme épais et feuilletć, tel qu'on le connaît dans les Nébélides en général.

\section{Nebela collaris. EIIREnBERG}

Diffugia collaris. EhrbG. Monatsb. Akad. Wiss., Berlin, p. 218.1848 Nebcla collaris. Leidy. Proc. Acad. Sci., Philad., p. 162. 1879

Cette espèce est fort variable, et souvent difficile à determiner. En général, on ne la trouve guère représentée dans les mousses proprement dites que par de petites formes, dont certaines (Neb. minor, parvula) ont été élevées au rang d'espèces; et dans les récoltes de Mr. Murray, la forme type s'est montrée très-rare; on ne la trouvait guère qu'au Mont Cook. Dans les Montagnes Rocheuses, comme au Queensland, c'étaient de petites variétés; ̀̀ Ngaurulıoe, à Vancouver, la taille était forte, et la forme rappelait plutôt la Neb. bohemica de Taranek, dont les caractères ne sont peut-être ni assez précis ni assez constants pour autoriser une séparation d'avec le type. A Waïata-Rua, une variété très-petite montrait ce même type bohemica, tandis qu'à Oahu l'on avait affaire ̀̀ une forme très-large, discoïde, qu'on eut pu sans trop de difficulté rapporter à Nebela tincta.

\section{Nebelı dentistoma. Penard}

Mém. Soc. Phys. Hist. Nat., Genève, vol. 31, p. 162. 1890

Nebela crenulata. CAsh. Tran. Manch. Micr. Soc., p. 50. 1891 (1892)

Assez peu répandue en général, cette Nebela ne s'est guère trouvée qu'au Mont Cook et à Vancouver, dans les Sphagnum; puis à l'île Macquarie, où, nous l'avons déjì vu, dans une grande mousse claire et serrée, plusieurs espèces se sont rencontrées qui sont sphagnicoles en général. ${ }^{1}$

\section{Nebela flabellulum. Leidy}

Proc. Acad. Nat. Sci., Philad., p. 157. 1874

Cette espèce sera tonjour's difficile à déterminer exactement, par le fait que plusieurs Nébélides (Nebela collaris, galeata, tincta, \&c.) ont une tendance à

1 L'histoire de cette espèce est assez curieuse : décrite en 1890 sous le nom de $N$. dentistoma, elle devint en $1893 \mathrm{Ne}$. crenulata; j'avais eru en effet devoir opérer cette réforme, pour obéir aux lois de la nomenclature qui, paraît-il, repoussent tout adjectif formé d'un nom grec et d'un nom latin à la fois. Mais en adoptant ce terme de crenulata, j'ignorais totalement qu'il existait déjà, en fait, une Nebela crenulata, créée par CasH eu 1892, et qui, bien plus, par une curieuse coïncidence, se trouvait être justement cette unême espèce que je venais de débaptiser. Aujourd'hui, il faut paraît-il en revenir au premier nom spécifique de Neb. Clentistoma (ainsi nommée déjà dans le volume de Cash \& Hopkinson, 1909); un auteur n'a plus le droit de clıanger un nom d'espèce, même formé contre toutes les règles.

BRIT. ANTARCT. EXPED. 1907-9. VOL. I. 
revêtir la forme très-large qui constitue le caractère spécial de $N$. flabellulum, et dans certaines stations ne se trouvent même plus guère que sous cette forme-là.

L'espèce typique, telle qu'elle est indiquée et figurée p.e. par Casi et Hopкinson

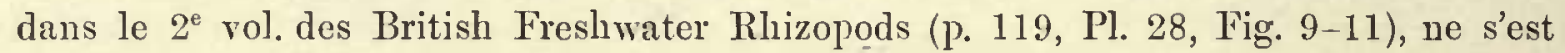
rencontrée que dans les.Sphagnum de Vancouver.

\section{Nebela griseola, spec. nova}

Fig. $8, a$ et $b$

Dans le sphagnum de Katoomba s'est montré, en exemplaires assez nombreux, un petit Rhizopode que l'on croirait à première vue devoir rapporter au genre Diffugia, mais qui, grâce à la nature particulière de son enveloppe, doit être attribué au genre Nebela.

La coquille, grisâtre, très-peu transparente, de 70 à $75 \mu$ en longueur, et qui rappellerait celle de certaines variétés de Difflugia pyriformis, est faite d'une matière chitinoïde, une pellicule sur laquelle sont collés, serrés les uns contre les autres, des éléments siliceux, arrondis, ovales, droits (diatomées modifiées), ou bien quelque peu recourbés, vermiformes; le tout, enfin, formant un revêtement qui tient à la fois du genre Nebela et du genre Lesquereusia.

Elle est pyriforme, ̀̀ peu près deux fois aussi longue que large, et peut être indiquée comme comprimée, car elle présente une face large et une face étroite; mais cette compression est si faible que, dans certains individus examinés en section transversale, on se demande s'il y a une différence quelconque entre les deux axes de la figure elliptique que l'on a sous les yeux; plus souvent, cependant, la différence est nettement seusible, le grand axe étant au petit comme 6 est ì 5, ou même quelquefois comme 5 est à 4 .

A la bouche, l'enveloppe s'évase légèrement, figurant un bourrelet plus ou moins prononeé, et qui dans certains cas m'a paru résulter d'un reploiement sur elle-même de la membrane garnie encore de ses éléments de recouvrement.

L'ouverture buccale est petite, elliptique dans son contour, ou même, trèssouvent, parfaitement circulaire.

La Nebela griseola ne s'est montrée, dans les récoltes de Mr. Murray, qu'à l'état d'enveloppes vides; mais pourtant, je puis ajouter ici quelques renseignements concernant le plasma.

Si cette espèce, en effet, est aujourd'hui décrite pour la première fois, elle n'est pas absolument nouvelle, en ce sens qu'elle a été récoltée, par moi-même, le 30 Juillet 1909, dans les mousses de Glendarary Ho., au promontoire d'Achill, côte occidentale de l'Irlande; mais les résultats de mes recherches ne devant être publiés que dans un avenir peut-être encore assez éloigné, la station des Montagnes Bleues vient, de fait, première en date. 
L'enveloppe renferme alors un plasma clair, limpide, dans le sein duquel on trouve des grains d'amidon, des éléments de réserve pour la coufection d'une nouvelle coquille, puis une, on deux, vésicules contractiles, et enfin le noyau; ce dernier, sphérique, relativement petit $(12 \mu)$, consiste en unc masse d'un blen tendre, renfermant un amas̄ central, irrégulier, de nucléoles pâles et très-petits.

'Très-timides, les animanx n'ont jamais déployé de pseudopodes; ils se collent souvent au substratum, par leur péristome un peu glutineux.

En Irlande, la coquille était identique à celle de Katoomba, mais plus grande, en général, de 80 à $85 \mu$ au lieu de 70 à $75 \mu$ qu'elle avait en Australie.

\section{Nebela lageniformis. Penard}

Mém. Soc. Phys. Hist. Nat., Genève, vol, 31, p. 159.1890

La Nebela lageniformis est l'un des représentants les plus caractéristiques des mousses, anssi les récoltes de Mr. Murray l'ont-elles montrée à peu près partout. Cependant cette espèce, qui jusqu'ici était connue pour posséder des caractères de forme très-nets et pen sujets à de sérieuses variations, s'est montrée, dans tout l'hémisphère sud, extrêmement variable, et cette variabilité affectait uniquement la partie antérieure de la coquille, le col, qui dans le type figure une sorte de tube aplati, posé directement sur la partie renflée et arrondie de l'enveloppe.

Au Mont Cook, on trouvait tontes les transitions entre la forme normale et une autre à col très-élargi à sa base; d̀ Waïata-Rua, il en était encore de même, et les extrêmes arrivaient si loin qu'à certains exemplaires on ne trouvait plus de col du tout, et qu'on aurait cru à une espèce spéciale, ou à une variété de Neb. collaris. A l'île Stewart, le col était toujours très-large à sa base, un simple rétrécissement graduel de la partie antérieure de la coquille; à l'île Macquarie, avec la forme typique mais variable, on en trouvait une autre, à col étroit, droit, nettement indiqué; à Ngauruhoe, enfin, c'était une grande forme, de 140 à $160 \mu$, ̀̀ col tubulaire, étroit, prolongeant tout droit la coquille large et arrondie.

On constatait également d'assez grandes variations sons le rapport de la taille; tandis que dans la règle, la coquille mesure de 120 丸̀ $125 \mu$, on trouvait 140 aे $160 \mu$ à Ngauruhoe; et par contre, à Katoomba, une petite variété, mêlée à la forme type, n'arrivait qu’à $85 \mu$.

\section{Nebela longicollis. Penard}

Mém. Soc. Phys. Hist. Nat., Genève, vol. 31, p. 158.1890

En 1890, j'avais décrit sous le nom de Neb. longicollis un Rhizopode à coquille très-allongée, presque tubulaire, très peu comprimée; mais plus tard, j’avais cru devoir rattacher cette espèce à la Neb. americana de TARANEk. Or, à ce qu'il me semble anjourd'hui, la Neb. americana de Taraxek n'est pas autre chose que la Neb. 
lageniformis, PENARD; senlement, la chose n'est pas certaine, car 'Taranek indique la coquille comme non comprimée, ronde en section transversale; mais ... je serais porté à croire que cette détermination de "drehrund" repose sur une erreur d'observation.

Reste maintenant la $N e b$. barbata de Leidy, à laquelle on rapporte quelquefois la Neb. longicollis; mais, on le sait enfin aujourd'hui, la Neb. barbata existe, espèce bien autonome, avec sa forme spéciale, son recouvrement de cils.

Il me faut alors reprendre aujourd'hui l'espèce abandonnée, pour distinguer sous le nom de $\mathrm{Neb}$. longicollis une forme incolore, claire et transparente, en forme de bouteille très-allongée, presque tubuleuse, faiblement comprimée, à écailles fortes et nettes, qui dessinent des aréoles très-marqués. A la bouche, les écailles font parfois saillie, ou bien elles y sont noyées dans un bourrelet jaunâtre, souvent un peu creusé sur la face étroite.

Mais, il faut l'avouer, cette espèce est extrêmement polymorphe; tantôt droite, tantôt recourbée en virgule, l'enveloppe est quelquefois si courte, que s'il n'existait pas toutes les transitions possible (par ex. au Mont Cook), on croirait devoir la rapporter à la Nebela vitraea.

Au Mont Cook, dans le sphagnum, cette espèce v'était pas très-rare; à WaïataRua, à Katoomba, il ne s'en est rencontré que quelques exemplaires.

\section{Nebela martiali. Certes}

Mission seient. du Cap Horn, tom. 6, Protoz., p. 14. 1889

Fig. $9, a$ et $b$

Certes a donné, en 1889, une bonne description de cette curieuse espèce, qu'il avait reçue du Cap Horn, et qui n'a pas été revue depuis.

Comme dans la $N e b$. certesi dont il a été question plus haut, nous trouvons sur le col un certain nombre d'ornements en forme de perles, très-petites, disposées ici comme un collier, en plusieur's rangées et juste en arrière de la bouche.

Certes indique, comme traits caractéristiques, "six ouvertures ou pores disposés symétriquement deux à deux; la première paire à moitié du col, les deux autres perpendiculaires à la première, à la base du col."

Mais les choses sont un peu différentes en réalité: la première paire dont parle Certis, se rapporte en effet ì deux perforations, très-faibles et souvent même invisibles, sur les deux côtés du col; mais les deux autres paires représentent chacune un tube, qui traverse la coquille de part en part, et dont les deux ouvertures ont été prises par Certis chacune pour une simple perforation. Ces tubes, dont les orifices se trouvent eux-mêmes au fond d'un lèger étranglement de l'enveloppe, s'ouvrent au dehors en une large lumière, et figurent ì la vue deux grands yeux enfoncés; la coquille, vue la tête en bas, semble être un animal fantastique, une sorte de chouette, qui regarde fixement. 
Cette enveloppe, jaunatre, est couverte de petites plaques serrées, pen apparentes, généralement elliptiques, quelquefois entremêlées de plus grandes, qui semblent avoir été volćes aux Trinema.

A l'île Macquarie, les exemplaires, très-rares, mesuraient $125 \mu$; à Ngauruhoe, une seule coquille vide a été trouvée; dans les Alpes australiennes, cette nébélide était commune, très-belle, mais toujours à l'état de coquilles vides, lesquelles, beaucoup plus grandes qu’à Macquarie, mesuraient de 165 à $180 \mu$.

CERtes indique pour cette espèce une longueur de $550 \mu$, une largeur de $290 \mu$; il doit y avoir là un simple lapsus calami.

\section{Nebela militaris. PenaRD}

Mém. Soc. Phys. Hist. Nat., Genève, tom. 31, p. $164.1890^{\circ}$

Cette jolie petite espèce, très-délicate, et toujours assez rare, s'est rencontrée à Katoomba, à Ngauruhoe, à Oahu. Dans cette dernière station, la taille était très-faible, $51 \mu$ en longueur.

Nebela minor. PenaRd

Arch. Sci. Phys. Nat., Genève (3), vol. 29, p. 181. 1893

Cette petite Nebela, à coquille très-claire et très-transparente, converte en général de plaques rondes bien régnlières, et qui pent être considérée comme un diminutif de la Neb. collaris, mais semble pourtant avoir droit au titre d'espèce, était abondante dans une mousse claire et bien fournie provenant de Oahu. Elle s'est retrouvée, beaucoup plus rare, à Ottawa.

\section{Nebela tincta. LEIDY}

Iyalosphenia tincta. LeIdy. Freshw. Rhiz. N.A., p. 138. 1879

Nebela tincta. Awerinzew. Trudui, S. Petersb., vol. 36, p. 354.1906

Cettc espèce, qui sous sa forme typique, avec euveloppe fortement comprimée, régulic̀rement arrondie, transparente et lisse, représente nettement une Hyalosphenia, est assez variable pourtant, et dans beancoup de stations se montre couverte de dessins qui l'ont fait réunir (ì tort, peut-être) au genre Nebela. Elle s'est rencontrée dans un assez grand nombre des récoltes.

\section{Nebela tubulosa. Penard}

Mém. Soc. Phys. Hist. Nat., Genève, vol. 31, p. 159. 1890

Cettc grande espècc, assez rare, n'est apparue que dans la seule station de Vanconver, bien typique, avec ses écailles très-petites, sa teinte spéciale d'un brun chocolat clair, et sa taille de 205 à $225 \mu$ en général. 


\section{Nebela vas. Cerwes}

Mission scientifique du Cap Horn, tom. 6, Zoolog., p. 15. 1889. Fig. 10

Cette belle espèce, inconnue jusqu'ici en Europe comme aussi aux Etats-Unis, mais qui semble être très-répandue sur tout le territoire du Pacifique et probablement dans l'hémisphère sud tout entier, a été décrite, avec une bonne figure, par CERTEs en 1889, d'après des exemplaires provenant du Cap Horn.

Comme forme, elle rappelle à s'y méprendre l'une des variétés de la Diffugia (Pontigulasia) vas de Leidy, et plus particulièrement celle qui, élevée au rang d'espèce, est connue comme Pontigulasia spectabilis, PENard. Mais ce n'est lì qu'une conformité d'apparence, et, comme Certes l'a déjà remarqué, "ce n'est pas la première fois que l'on rencontre des espèces différentes construisant chacune leur coquille sur le même type." L'enveloppe, ici bien plus fortement comprimée, revêt la structure typique des Nebela. Le plasma, le noyau, le mode d'enkystement, le diaphragme qui ferme le col lors de l'enkystement, tout cela est d'une Nebela.

La Nebela vas s'est trouvée dans la plupart des récoltes de Mr. Murray, toujours bien caractéristique, mais variable dans ses dimensions, suivant la localité. Dans plusieurs stations (Mont Cook, île Macquarie), outre la forme normale qui généralement mesure de 160 à $165 \mu$ de longueur, on en trouvait une autre, plus claire, plus délicate, et beaucoup plus petite; à Waïata-Rua, cette petite forme, de $95 \mu$ seulement, existait seule; il semble y avoir là une variété spéciale, qu'aucune transition ne relie au type.

La coquille est jaunâtre, et formée dans la règle de plaquettes arrondies bien nettes. Mais il y a sous ce rapport un fait intéressant à noter: dans cette espèce, l'animal semble montrer une prédilection toute particulière pour les écailles des Euglypha; il les capture, les incorpore à la masse de ses "plaques de réserve," et les emploie en aussi grand nombre que possible. Mais, ce qu'il y a de curieux, c'est que toutes les écailles qui dans l'Euglypha avaient été buccales, c'est-à-dire que l'on trouve munies des ornements et denticulations caractéristiques; se voient sur le col de la Nebela, et jamais sur le corps même de la coquille. En outre, presque toujours, les denticulations de ces écailles parsemées un peu partout sur le col, sont dirigées en avant; il y a donc eu un choix, tant dans le placement des écailles que dans leur orientation.

Mais ce n'est pas tout: s'il y a, dans cette capture des écailles d'Euglypha, en quelque sorte une habitude acquise par la Nebela, cette habitude peut faire défaut dans certains cas ; par exemple, tandis qu'à Ngauruhoe, à Vancouver, la plupart des coquilles portaient de ces écailles spéciales, et que dans les autres stations beaucoup d'individus n'en montraient pas, elles manquaient tonjours ì l'île Macquarie, au Mont Cook, ̀̀ Waïata-Rua, bien que les Euglypha (E. ciliata, E. compressa) y fussent aussi nombreuses qu'ailleurs. 
La plupart des représentants de cette espèce ont été trouvés ì l'état de coquilles vides, ou bien aussi le plasma, encore vivant, se voyait enkysté; mais aucun individu n'est revenu à la vie active. Dans un exemplaire provenant de Ngauruhoe, cependant, et gardé pendant 5 jours dans un verre de montre, j'ai pu examiner le plasma, qui se trouvait rempli de petits grains d'amidon, puis renfermait encore de grosses sphérules jaunâtres, d'aspect cireux (résidus de nourriture?), et un beau noyau, de $28 \mu$ de diamètre, du type habituel aux Nebela, c'est-à-dire-renfermant un certain nombre de nucléoles disséminés sans ordre dans une masse (suc nucléaire) grisâtre, pâteuse, pleine de granulations très-petites.

\section{Parmulina cyathus. Pexard}

Faune Rhizopodique Léman, p. 207. 1902

Ce petit organisme, très-peu apparent de sa nature, et qui lorsqu'il n'est pas en très-bon état de forme reste facilement inaperçu, ne s'est rencontré d'une manière évidente qu'd̀ Sydney (National Park) et à Ottawa. Dans ces deux stations, l'animal était vivant, mais enkysté, c'est-à-dire simplement rétracté en boule sous la protection de son enveloppe.

\section{Phrygunella hemisphaerica. PEnARD}

Pseudodifflugia hemisphaerica. Penard. Mérn. Soe. Phys. Hist. Nat., Genève, tom. 31 , p. 169.1890

Phryganella hemisphaeriea. Faune Rhizop. Léman, p. 421. 1902

Le plus commun peut-être de tous les Rhizopodes des mousses, et qui en effet n'a manqué nulle part, sauf aux îles Auckland, d'où il n'a été rapporté qu'un simple fragment d'écorce garni d'une petite mousse rase.

On la rencontre presque toujours et partout à l'état de coquilles vides; et presque toujours aussi, on y reconnaît deux formes, l'une petite, très-variable d'ailleurs, et qui semble se rapporter a ces divers petits rhizopodes que sous le nom de Difflugia globulosa, LEIDY, représente à la Pl. XVI. de son grand ouvrages (Fig. 11 à 20); puis une plus grande $(40$ à $50 \mu)$, que dans cette même planche de Leidy on trouve représentée par les Fig. 23 et $24 . \mathrm{C}_{A S H}$ identifie cette espèce, peut-être avec raison, à Difflugia aeropodia, Hertwig ET LESSER.

A l'île Macquarie, une très-grande variété arrivait ì $100 \mu$.

\section{Phryganella nidulus. PeNard}

Frune Rhizopodique Léman, p. 419. 1902

Cette grande espèce est apparue dans la récolte du Mont Cook; mais encore faut-il faire des réserves sur l'exactitude de la détermination. En effet, la seule coquille ren- 
contrée, vide, présentait des caractères partieuliers ; de $190 \mu$ de diamètre, hémisphérique, pourvue d'une ouverture plutôt petite et déchiquetée, elle était munie sur tout son pourtour, ì la face ventrale, d'une sorte de rebord ou d'aile circulaire, qui peut-être n'avait d'autre signification que celle d'un mucilage durei, destiné à souder la coquille sur le substratum.

\section{Placocysta jurassica. Penard}

Revue Suisse Zool., vol. 13, p. 611.1905

Ce Rhizopode, qui jusqu'ici n'avait, ì ma connaissance, été indiqué que dans une tourbière du Jura suisse (la Pile), a refait cette année son apparition, dans le spliagnum de Vancouver, où il n'était pas rare; parfaitement typique d'ailleurs, et avee la taille normale de 70 ì $75 \mu$ en moyenne, mais pourvu d'aiguilles plus longues et plus serrées que celles des exemplaires dı Jura.

\section{Placocysta spinosa. LEIDY}

Proc. Acad. Nat. Sci., Philad., p. 226. 1874

Dans ce même sphagnum de Vancouver s'est également montrée, beaucoup moins abondante que la précédente, la Placocysta spinosa, bien typique, mais revêtue d'une profusion tout-ì-fait anormale d'aiguilles, qui poussaient serrées, souvent en faisceaux, tout le long de l'arête latérale. Ces aiguilles, également, étaient moins larges, moins aplaties que dans le type ordinaire, et leur extrémité se voyait tronquée ì angle droit.

Les exemplaires rencontrés montraient entre eux de grandes différences sous le rapport de la longueur, et variaient de 104 à $140 \mu$. Il est rare que dans l'espèce type on ait trouvé jusqu'ici moins de $130 \mu$.

\section{Plagiopyxis callida. Penard}

Revue Suisse de Zoologie, tome 18, fasc. 3. 1910

Cette espèce, décrite tout récemment d'après des exemplaires tronvés aux environs de Genève, rappelle à première vue une des nombreuses variétés de Difflugia constricta; mais c'est là en réalité un type tout différent, uu organisme qui par la structure toute particulière de son plasma, lequel s'épaissit à sa surface de manière à constituer une véritable enveloppe interne, se rapproche de très-près des genres Diplochlamys et Bullinula.

Elle s'est renccutrée dans plusieurs récoltes, mais rare partout sauf ì l'île Stewart, où elle atteignait jusqu’à $135 \mu$, une taille relativement très forte. Celle dı type mesure rarement plus de $120 \mu$. 
A Sydney, les individus étaient vivants, et j'ai pu m'assurer que le plasma était le même qu'à Genève, avec ses myriades de petits grains pâles, ses particules nutritives jaunâtres où l'on reconnaît des parcelles arrachées aux mousses, et son noyau caractéristique.

\section{Plagiopyxis labiata, spec. nova}

Fig. 11

Dans les mousses des environs de Sydney, de Creel, de Victoria (B.C.), s'est montré, toujours très-rare, un petit rhizopode qui à première vue pouvait être pris pour une des nombreuses formes de Difflugia constricta, mais qui en réalité doit rentrer dans le genre Plagiopyxis.

Plus petite que dans l'espèce précédente, la coquille, de 80 à $88 \mu$ de diamètre, brunâtre, chitinoïde avec pierres de recouvrement, hémisphérique avec face dorsale surélevée, est pourvue d'un orifice allongé en fente, ventral, excentrique, très-rapproché du bord antérieur. Le péristome, alors, simplement arrondi sur l'nn de ses bords (bord antérieur), est prolongé sur l'autre bord d'une lèvre plus ou moins proéminente, une sorte de languette vaguement triangulaire, qui plonge en avant vers l'intérieur de la coquille, et tient lieu ici de ce plancher caractéristique qui dans la Plagiopyxis callida s'enfonce jusque bien bas dans l'intérieur.

Le plasma, qu'il ne m'a été possible d'examiner que sur un seul individu, est conforme à celui de l'espèce précédente, complétement bourré de grains pâles extraordinairement petits, puis renfermant des parcelles de noumiture jaunâtres, et un noyau sphérique, pourvu à son intérieur d'un gros nucléole gramnlé. Il n'a pas été tronvé de vésicule contractile, laquelle ne s'observe d'ailleurs que très-rarement dans ce genre. Quant aux pseudopodes, il en est probablement ici de même que dans la Plag. callida, où l'on peut examiner bien des centaines d'animaux pleins de vie sans les voir se développer.

\section{Pontigulasia bryophila. Penard}

Faune Rhizopodique Léman, p. 324. 1902

Ce rhizopode, qui rappelle Diffugia pyriformis dont il se distingue avant tout par l'étranglement caractéristique du col, ne s'est montré qu'au Mont Cook et à Vancouver, sous la forme de quelques coquilles vides.

\section{Pontigulasia compressa. Carter}

Diflugia compressa. CArter. Ann. Mag. Nat. Hist. (3), vol. 13, p. 22.1864

Pontig. compressa. Cash et Hopkinson. Brit. Freshw. Rhiz., vol. 2, p. 62.1909

Cette espèce s'est rencontrée à Waïata-Rua, puis au Mont Cook, toujours en individus isolés, qui revêtaient la forme typique, et atteignaient jusqu'ì $190 \mu$ en longueur. 
Cette Pontigulasia a été signalée dans ces dernières années par différents auteurs comme étant identique ì Pontig. bigibbosa, Perard, laquelle habite les lacs profonds. A différentes reprises, en 1909 et 1910 , je l'ai moi-même trouvée dans les Sphagnum de la Suisse, et en effet, je n'y trouve pas de diffćrence importante avec Pont. bigibbos $x$. Il est donc regrettable que cette dernière ait, par suite de l'ignorance de ce qu'était en réalité la Difflugia compressa de CarTER, été élevée au rang d'espèce distincte. Mais il n'en reste pas moins vrai qu'entre la Pont. compressa, CArtir, et la grande forme lacustre, la différence est trèsgrande; dans le Léman, les individus atteignent facilement $250 \mu$ en longueur, avec une largeur si considérable qu'elle égale très-souvent la longueur, et dans des cas exceptionnels va même jusqu'à la dépasser.

\section{Quadrula irregularis. ARciner}

Quart. Journ. Micr. Sci., vol. 17, p. 103.1877

Cette espèce est assez rare dans les mousses; aussi ne s'est-elle trouvée représentée dans les collections de Mr. Murray que dans une senle station, Suva dans l'archipel des Fiji (nous l'avons pourtant déjà rencontrée, on se le rappelle, dans les petits lacs du Cape Royds). Mais ì Suva, les conditions étaient un peu spéciales; les mousses avaient été récoltées au bord d'un marécage, puis dans les fossés près de la route ; aussi cette espèce n'était-elle peut-être pas là bryophile. ${ }^{1}$

\section{Quadrula symmetrica. F. E. SclluL\%E}

Arch. f. Mikr., Anat., B 11 p. 329. 1875

C'est dans les Sphagnum, ì Vancouver et dans les Alpes australiennes, que s'est rencontrée cette espèce, laquelle n'habite pas les mousses proprement dites.

Il ne s'en est montré qu'un nombre extrêmenent restreint d'individus; mais j'ai pn faire, cependant, à deux reprises et sur des coquilles provenant de Vancouver, certaines expériences qui ne seront pas hors de place ici :

On sait que Lageruein (Geol. Fören. Förhand, tom. 24) a fait en 1902 la curieuse constatation que les plaques caractéristiques de la Quadrula irregularis étaient, non pas siliceuses, mais formées d'une combination de calcinm. En 1893, puis plus tard encore, je confirmais de mon côté les observations de Lagerheni, en montrant qu'en tout cas ces plaques étaient solubles dans l'acide sulfurique concentré ì chand. Awerinzew, en 1907 (Zool. Anzeiger, B ${ }^{\mathrm{l}}$ 31, No. 8', confirme à son tour la chose, et se demande en même temps si, malgré la grande analogie qui existe dans la structure de la coquille, il ne faudrait pas voir dans Qucud.

1 Voir pages suivantes pour les observations sur la nature des plaques daus cette esjecee 
irregularis et Quad. symmetrica deux rhizopodes très-éloignés l'un de l'autre, et appartenant en réalité à des genres différents.

Cette hypothèse est très-naturelle en elle-même, et pour mon compte, c'est ainsi que, depuis 1893, je m'expliquais la chose; mais encore fallait-il connaître d'une manière certaine la composition des plaques dans la Quad. symmetrica. Depuis longtemps j'avais pu m'assurer, sur une coquille appartenant à une grande variété spéciale provenant des Montagnes Rocheuses, que les plaques étaient siliceuses; mais c'était là, après tout, une variété; il fallait faire des expériences sur le type.

Or, ell expérimentant sur la Quad. symmetrica de Vancouver, qui représente bien le type normal, j'ai pu constater que les plaques sont purement siliceuses; l'acide sulfurique bouillant les laisse parfaitement indemnes, et on les retrouve bien nettes également après l'action du chalumeau. Je serais donc assez disposé à adopter l'opinion d'AwERIszew, qui suppose une simple convergence dans deux orgauismes génériquement différents. ${ }^{1}$

Pent-être me sera-t-il permis, ì ce propos, d'ajouter quelques mots à propos d'expériences de même nature faites sur la Quadrula irregularis:

Dans cette espèce, l'acide sulfurique concentré froid dissout à peine, trèsdifficilement, les plaques; ì chaud, il les dissout de suite; l'acide chlorhydrique dissout les plaques, mais laisse intacte la pellicule fondamentale, sur laquelle on voit encore, nettement imprimées, les marques des plaques disparues; l'acide acétique, par contre, n'a aucune action; il laisse les plaques absolument indemnes. Pour dissoudre les plaques dans cette espèce, il faut donc en tout cas un acide fort, et ce n'est pas lì, sans doute, un simple carbonate de chaux.

\section{Sphenoderia fissirostris. Penard}

Mém. Soc. Phys. Hist. Nat., Genève, vol. 31, p. 187. 1890

Une seule coquille vide, au Mont Cook.

\section{Trinema complanatum. PENARD}

Mém. Soc. Phys. Hist. Nat., Genève, vol. 31, p. 187. 1890

Cette petite espèce, très-fréquente en général dans les mousses, s'est rencontrée dans quelques-unes des récoltes.

1 Awerinzew se fonde d'ailleurs, et à juste titre, non pas seulement sur la composition des plaques, mais encore sur la forme de louverture buceale, ainsi que sur la structure différente du plasma. 


\section{Trinema enchelys. DUJARDIN}

Trinème, Duj. Ann. Sci. Nat., p. 205. 1836

Très-fréquente dans les mousses, la Trinema enchelys s'est montrée dans un grand nombre de stations, très-variable comme toujours, et offrant surtout deux formes bien accusées, l'une d'elles belle, grande, à fortes écailles (la forme typique de Leidy, Fig. 1, 2, 3, 4, de sa Pl. 39); l'autre, particulière aux mousses, toute différente en réalité de la première (Penard, Faune Rhizop. Léman, p. 527, Fig. 5), et qui rappelle de fort près, à première vue, le Corythion dubium de Taranek.

\section{Trinema lineare. Penard}

Mém. Soc. Phys. Hist. Nat., Genève, vol. 31, p. 187

Cette espèce, toute petite, chétive et qui passe facilement inaperçue, a été notée dans bon nombre de stations, soit enkystée, soit à l'état de coquilles vides. 


\section{CONCLUSIONS}

LES Rhizopodes d'eau donce rapportés par le biologiste du Nimrod forment aujourd'hni la liste assez respectable de 79 espèces; assez respectable en effet, car, ì une ou deux exceptions près, les collections étaient représentées par des mousses, et seule la faune des mousses s'y est trouvée, presque au complet. Les Sphagnum, également, se sont montrés représentés dans quelques-unes des récoltes, et là comme partout, ont permis d'étudier quelques espèces particulières, qui manquent alx mousses proprement dites.

Il est bien évident que les marécages, les étangs, les flaques d'eau douce, auraient fourni un supplément considérable d'informations; on eût tronvé des Arcelles, des Difflugies, et bien d'autres choses encore; mais dans les circonstances où opérait Mr. Murray, il ne faliait guère songer à ce genre de récoltes; et d'áilleurs, on peut se demander si l'absence, dans ces collections, de Rhizopodes purement aquatiques est vraiment ì regretter.

Tels qu'ils sont, en effet, les résultats acquis montrent une homogénéité peutêtre encore plus significative que s'ils enssent été fournis par différents milieux.

Cette faune spéciale et pourtant si riche encore, apporte avec elle certains renseignements, quelque confirmation ì ce que nous savions déjà comme la faune aquatique, elle est cosmopolite; mais comme elle aussi, elle ne l'est pas d'une manière absolue; certaines espèces sont localisées, et leur rencontre peut donner lieu ì des conclusions d'un intérêt spécial.

La Nebela vas, par exemple, décrite il y a longtemps déjà comme provenant du Cap Horn, et que le Prof. Richters a retrouvée dans toute une série de localités: Australie, $\mathrm{N}^{\text {1le }}$ Zélande, Hawaii, Java, Iles Chatham, Staaten Isl ${ }^{\mathrm{d}}$, Falklands, Kerguelen, St. Paul, etc. etc., s'est montrée commune danș l'hémisphère austral et sur le territoire du Pacifique tout entier; on la tronve encore ì Vancouver, mais elle ne semble pas pénétrer dans l'intérieur du continent américain. Les Nebela certesi, Nebela marticali, ces formes si curieuses, que Certes avait également observées au Cap Horn, et qui n'avaient pas été vues depuis, ont refait leur apparition, et se sont montrées, dans le Pacifique, avec leurs caractères nettement inarqués; Hyalosphenia cockayni semble dans le Pacifique sud tenir la place de l'Hyalosph. papilio en Europe et aux Etats-Unis; et la Centropyxis horrida possède une aire de dispersion peut-être plus localisée encore.

Toutes ces données, sans doute, n'apportent pas avec elles une bieu grande

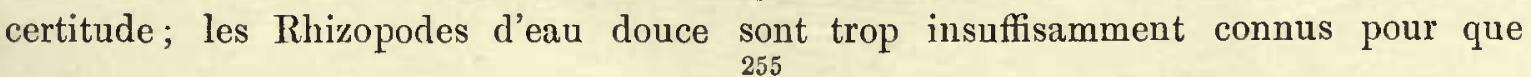


l'on soit en droit de tirer de leur présence des conclusions évidentes; mais ils ont pourtant leur mot ì dire, eux aussi, dans les questions de géographie zoologique.

On les a trop négligés jusqu'iei, et, il faut bien le dire, il est peu de naturalistes qui semblent se rendre compte de l'importance générale qu'ils pourraient bien avoir en effet. Certains de ces organismes, il est vrai, se montrent sous des aspects si divers, ou sous la forme de variétés si nombreuses, qu'ils semblent n'être là que pour déeoncerter l'observateur; mais beaucoup d'autres, les plus nombreux même, sont parfaitement nets et fixés dans leurs caractères; tout au moins ne varient-ils que dans une faible mesure, souvent beaucoup moins, même, que tant d'êtres plus élevés en organisation, Entomostracés, Insectes, Lépidoptères, qui pourtant sont considérés comme ayant une certaine importance dans les questions de faunistique générale.

Dans le compte-rendu donné tout dernièrement dans "Nature" 1 du volume de $\mathrm{C}_{A \mathrm{SH}}$ et Hopkinsun sur les Rhizopodes d'eau douce, on trouve exprimée dans les termes suivants l'opinion qui, me semble-t-il, est à peu près celle de la majorité des naturalistes: "To the working microscopist who is anxions to find names for the varieties he discovers in the fresh-waters that he visits, the book will doubtless be of some value, for it gives liim .. . \&c. Mais tout cela n'est pas tout-ì-fait juste; pour les Rhizopodes, il est vrai, et plus pour eux peut-être que pour tout autre groupe animal, les études systématiques sont nécessaires, et le seront longtemps encore; mais non pas pour collectionner des noms; c'est pour arriver a des faits qu'il faut cataloguer; quand la systématique sera mieux fixéc, on reconnaîtra à ces organismes une importance plus grande qu'on ne l'a soupçonnée jusqu'iei.

Et alors, si cette importance était reconnue, si dans chaque expédition aux pays nouveaux le naturaliste décidait de songer à ces organismes un peu plus qu'on ne l'a fait jusqu'ì ce jour, si les monsses et les sphagnum étaient considérés comme devant avoir leur juste part dans la répartition entre botanistes et zoologistes, quoi de plus aisé que de les récolter? quelques petits paquets de végétaux secs, et vous aurez toute une faune, Rotifères, Tardigrades, Nématodes, Rhizopodes et d'autres choses encore, que souvent vous pourrez rapporter vivants, et qui se trouveront avoir leur importance dans les résultats biologiques obtenus.

Sons ce rapport aussi, me semblc-t-il, les collections recueillies par Mr. Murray renferment un enseignement. Pour moi, j’ai pris à cette étude un intérêt tont particulier, et en rendant compte du résultat de mes recherehes, c'est avec autant de plaisir que de reconnaissance que je remercierai Sir Ernest Shackleton et Mr. James Murray d'avoir bien voulu me confier ces collections.

1 No. 2118, vol. 83, June 2, 1910. 


\section{LISTE BIBLIOGRAPHIQUE}

Casi, J., And Hopkisson, J., "The British Freshwater Rhizopoda and Heliozoa." Printed for the Ray Society. Vol, ii. 1909.

Certes, A., "Mission scientifique du Cap Horn," tom. vi., Zoologie, 1889.

LEIDy, J., "Freshwater Rhizopods of North America," Report of the United States Geol. Survey, vol. xii., 1879.

Lennexfeli), R. V., "Australian Freshwater Rhizopods," Proceed. Linnocan Soc. of New Soutl Wales, vol. $x_{.}, 1885$, p. 724 .

Murray, James, "On Collecting at Cape Royds," British Antarctic Expecl., 1907-9. Biology, vol. i. part i.

" "On Microscopic Life at Cape Royds," British Antarctic Expecl., 1907-9. Biology, vol. i. part ii.

Penary, E., "On Some Rhizopods from the Sikkim Himalaya," Journ. Roy. Microsc. Soc., 1907, pp. 274-78.

" "Faune Rhizopodique du Bassin du Léman," Genève, 1902.

Richrers, F., "Fauna der Moosrasen des Gaussbergs und einiger südlichen Inseln," Deutsche Südpolar Exped., 1901-3, Bd. 9, Zool.

" "Moosbewohner," Schuedische Sïdpolar Exped., 1901-3, Bd. 6, 1908.

" "Moosfauna Australiens, ete.,"Zool. Jahrbrïch. : Alt. für Syst., Bd. 26, 1908, p. 196.

" "Moosfauna-Studien," Ber. der Senclilg. Natf. Ges. Frankfurt-a-M., 1908, p. 22.

Schewiakoff, W., "Ueber die geographische Verbreitung der Süssw. Protozoen," Mém. Acad. Sci., Petersbourg, vii. Sér., tom. xli. No. 8.

Wintelegae, T., "Invertebrate Fauna of Port Jackson and Neighbourhood," Journ. and Proceed. Roy. Soc. New South Wales, vol. 23, 1899, p. 296.

"List of the Freshwater Rhizopods of New South Wales," Proceed. of the Linnwan Soc. of Nevo South Wales, Ser. 2, vol. i., 1886, p. 497. 

PLATE XXII 


\section{EXPLICATION DE LA PLANCHE XXII}

Figure 1.-Bullinula indica, petite variété ronde.

Figure 2.-Centropyxis horrida. (a) Forme type; (b) forme dépourvue d'épines.

Figure 3.-Corythion dubium. (a) Variété orbiculaire; (b) variété spicatum.

Figure 4.-Euglypha brachiata. (a) Aspect général de la coquille; (b) la même vue d'en haut, pour montrer l'aplatissement des " bras."

Figure 5.-Hyalosphenia cockayni. (a) Vue par le côté large: sur le col on remarque deux écailles buccales d'une Euglypha; $(b)$ vue par le côté étroit. 


\section{PENARD : RHIZOPODES}
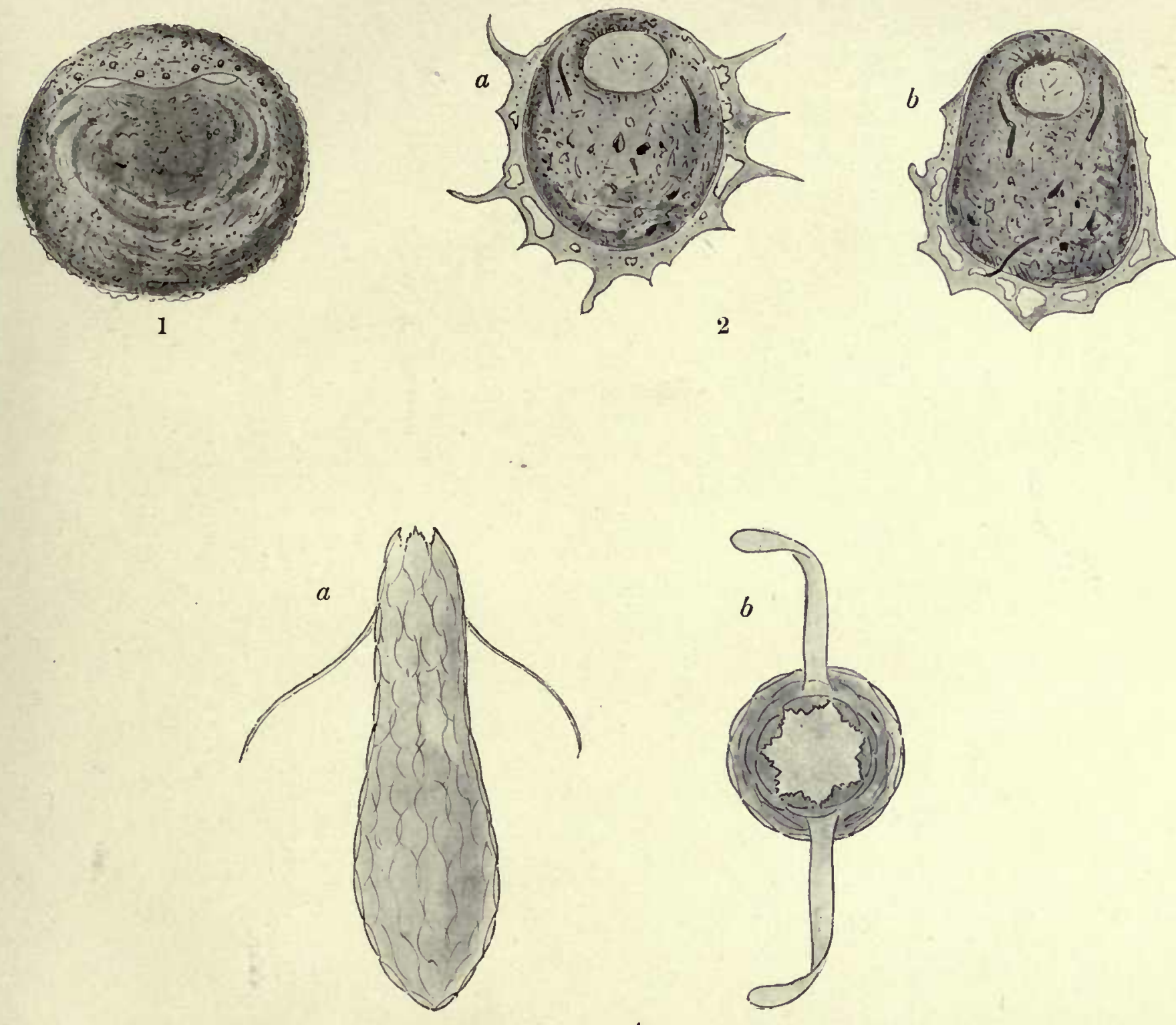

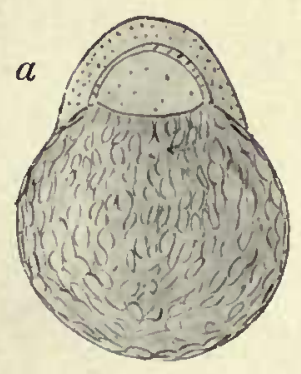

E. Penard del.
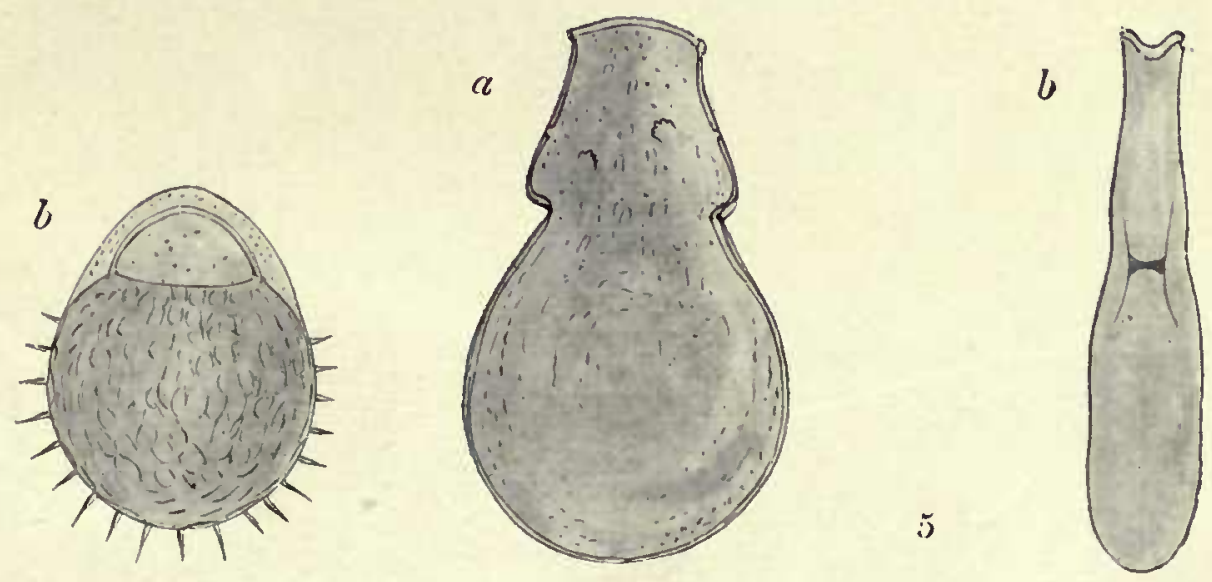



\section{PLATE XXIII}




\section{EXPLICATION DE LA PLANCHE XXIII}

Figure 6.-Hyalosphenia subflava. (a) Vue par le côté large ; (b) côté étroit ; $(c)$ la coquille vue d'en haut par l'orifice buccal.

Figure 7.-Nebela certesi. (a) Côté large ; $(b)$ côté étroit.

Figure 8.-Nebela griseola. ( $a$ ) Coquille vide; $(b)$ une autre, vue d'en haut.

Figure 9.-Nebela martiali. (a) Côté large ; $(b)$ côté étroit.

Figure 10.-Nebela vas. Sur le col, ou voit trois écailles buccales d'Euglypha.

Figure 11.-Plagiopyxis labiata. La coquille vue par la face ventrale. 


\section{PENARD : RHIZOPODES}
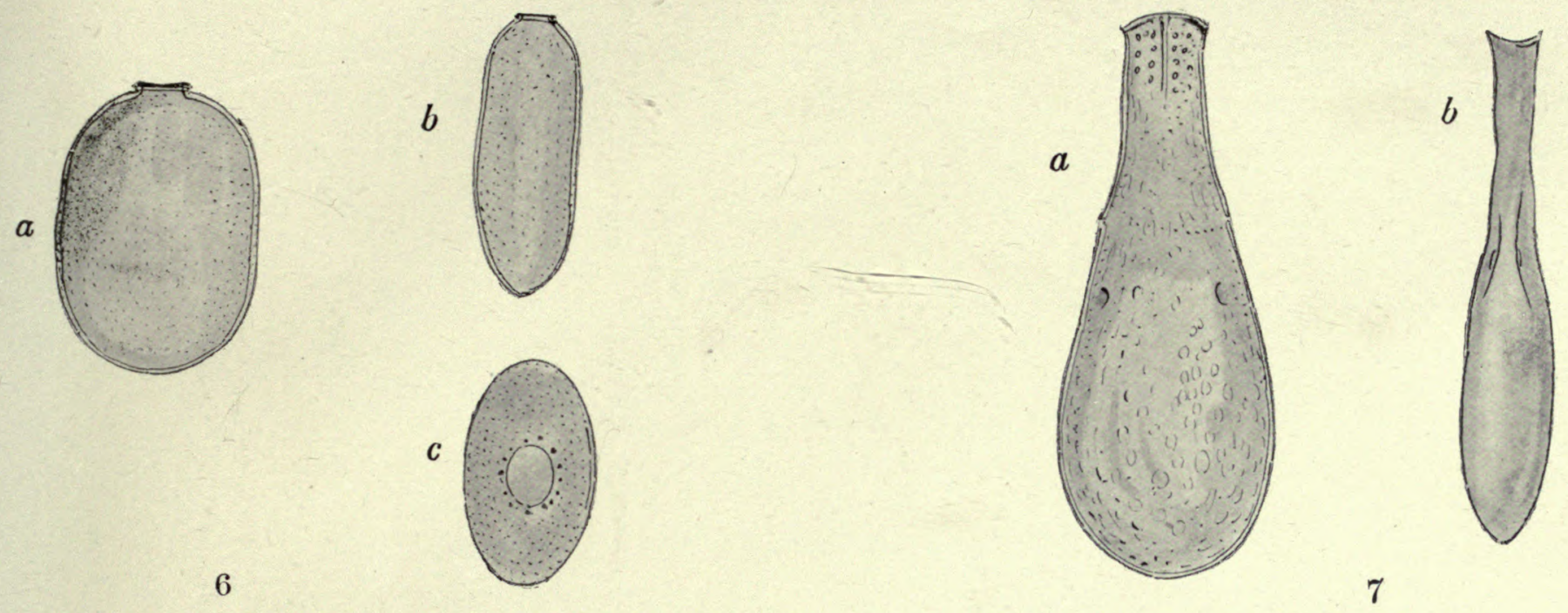

6
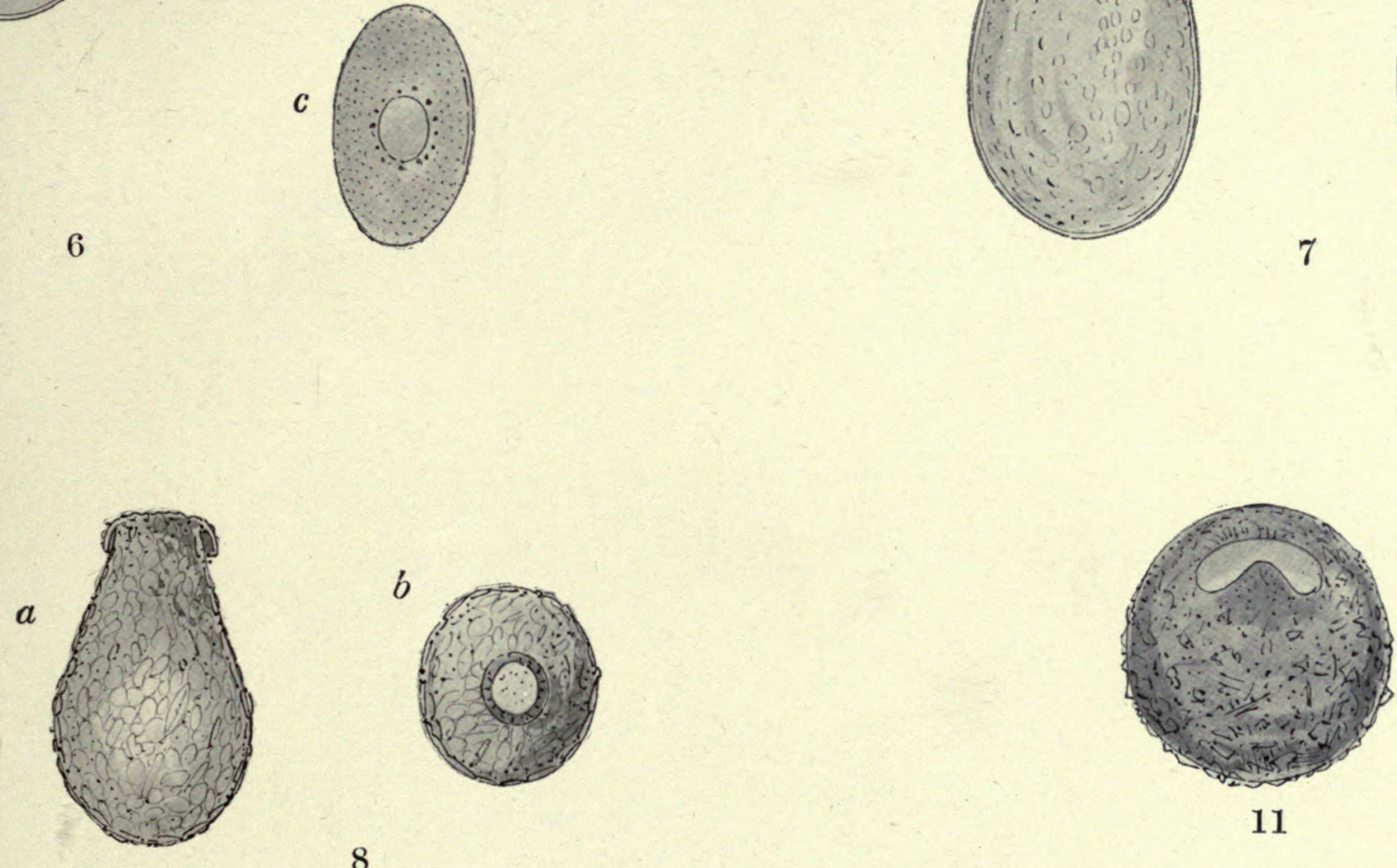

11

8
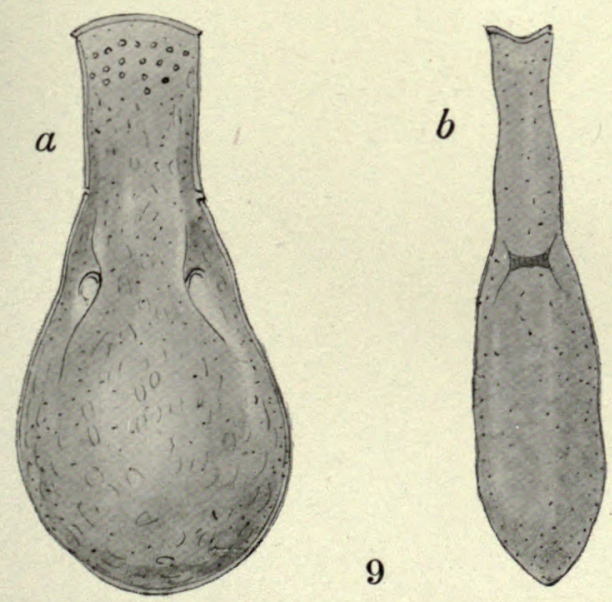

10

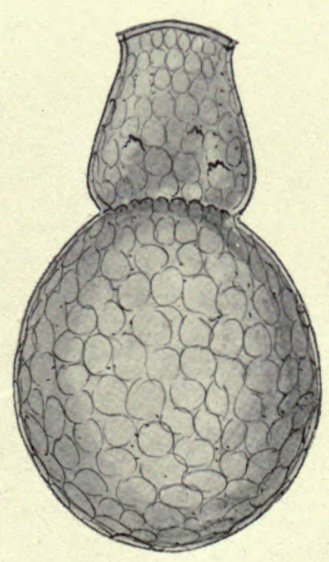

E. Penard del. 



\title{
BRITISH ANTARCTIC EXPEDITION 190\%-9
}

UNDER THE COMMAND OF SIR E. H. SHACKLETON, C.V.O.

\section{REPORTS ON THE SCIENTIFIC INVESTIGATIONS}

\author{
VOL. I \\ BIOLOGY \\ EDITOR - - JAMES MURRAY \\ PART VII

\section{FRESHWATER ALGA}

BY W. WEST, F.L.S., AND G. S. WEST, M.A., D.Sc., F.L.S.

(WITH THREE PLATES)

LONDON

PUBLISHED FOR THE EXPEDITION BY WILIIAM HEINEMANN

21 BEDFORD STREET, W.C.

1911

ISSUED SEPARATELY, DECEMBER 1911

Price Three Shillings Net 


\section{REPORTS ALREADY ISSUED}

VOL. I. PART I., ON COLLECTING AT CAPE ROYDS BY JAMES MURRAY

Price 1s, 6d. NET

VOL. I. PART II., ON MICROSCOPIC LIFE AT CAPE ROYYS BY JAMES MURRAY

Price 5s. Od. NeT

VOL. I. PART III., ANTARCTIC ROTIFERA BY JAMES MURRAY

Price 5s, Od. Net

VOL. I. PART IV., MUSCI BY JULES CARDOT

Price 1s. Od. Net

VOL. I. PART V., TARDIGRADA BY JAMES MURRAY

VOL. I. PART VI., RHIZOPODES D'EAU DOUCE BY EUGENE PENARD 


\title{
PART VII \\ FRESHW ATER ALGA
}

\author{
By W. WEST, F.L.S., AND G. S. WEST, M.A., D.Sc., F.L.S. \\ With Plates XXIV to XXVI
}

\section{INTRODUCTORY REMARKS}

UP to the present our knowledge of Antarctic Freshwater Algæ is very scanty. The first records were by Hooker and Harvey* of certain forms collected during the voyage of H.M. shins Erebus and Terror from 1839 to 1843 . Wildeman $\dagger$ has given a brief account of the Algæ collected by Racovitza on the Antarctic expedition of the s.y. Belgica, and Van Heurck $\ddagger$ has worked out the diatoms of this expedition very fully. Wille $\$$ has also recorded two Algæ from Cape Adare, South Victoria Land (rather more than $71^{\circ} \mathrm{S}$. lat.), collected on the Borchgrevink Antarctic Expedition. Other papers dealing more or less with Antarctic freshwater algæ are those of Reinsch on Algæ collected in Kerguelen Land $\|$ and in South Georgia.** These islands, however, do not extend beyond $55^{\circ} \mathrm{S}$. lat., and they possess an Alga-flora which cannot be regarded as of an Antarctic type.

The algal material collected by the different members of the expedition, but mostly by Mr. James Murray, is probably fairly representative of the Alga-flora of the Antarctic continent in the vicinity of Ross Island. The Algæ were found on the ground, on stones, and in the lakes, and owing to the severity of the weather conditions they are completely frozen for at least nine months of the year. In some cases it appears that the lake does not become free from ice for several years, and the Algæ have thus to retain their vitality in a frozen state for an extended period. Many of

* J. D. Hooker and W. H. Harvey, "Algæ in J. D. Hooker's Botany of the Antarctio Voyage," Flora Antarctica, Part I., London, 1847.

† E. de Wildeman, "Note préliminaire sur les Algues rapportées par M. E. Racovitza, naturaliste de l'expédition antarctique belge," Bull. Acad. Roy. Belgique, 1900.

‡ Van Heurck, "Diatomées in Résult. Voyage du в.y. Belgica cn 1897-99," Anvers, 1909, pp. 1-128, Pls. I.-XIII.

$\S \mathrm{N}$. Wille, "Antarktische Algen in Mittheilungen über einige von C. E. Borchgrevink auf dem antarctischen Festlande gesammelte Pflanzen," Nyt Mag. f. Naturvidenskab, Bd. 40, Heft III. 1902.

|| P. F. Reinsch, "Species ac. gener. Nov. Algarum aq. dulc. Expedit. Vener. transit. hieme 1874-75 in insul. Kerguelensi a cl. Eaton collectis," Journ. Linn. Soc. bot., Xv., 1876.

** P. F. Reinsch, "Spec. et gen. nov. Algarum ex insul. Georgia Austr.," Ber. Deutsch. botan. Ges., vi., 1888.

BRIT. ANTARCT. EXPED. 1907-9. VOL I. PART 7, ISSUED DECEMBER 1911 
them were actually collected by being thawed out of the ice, in which they could be seen embedded. Others were obtained from under the ice of the lakes, and from the lake-bottom, by digging throngh a great thickness of ice, in one case as much as 15 feet. Yet others were exposed on the surface of the ice as the latter was removed by ablation during the blizzards.

The smaller ponds completely thawed in the brief summer period, but they did not contain so many A lgæ as the more or less frozen lakes.

It is evident from the foregoing remarks that the Antarctic Freshwater Algæ have a very severe struggle for existence, and evidences of this can be seen in many ways. Both slowness of growth and interrupted growth are noticeable in the Prasiolas, and the frustules of the more delicate diatoms, such as Tropidoneis loevissima, exhibit considerable deformity.

The Algæ observed in the collections were as follows:

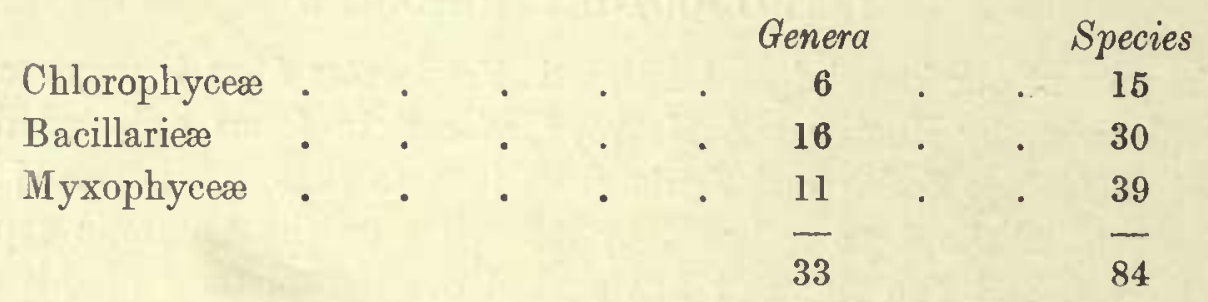

Thus the Chlorophyceæ were but feebly represented, and it should be remarked that no Conjugatæ were observed. The Myxophycex (or Blue-green Algæ) were the most frequent, although the diatoms were very numerous in some of the lakes. Many representatives of both these groups were mixed up in the sediment of the ponds and lakes, and on the surface of the latter, often embedded in the ice, were very extensive sheets of Myxophyceæ. These sheets were often of a brilliant blue-green colour, but were frequently bleached, owing most probably to the intensity of the light, and were usually of a warm brown colour.

There was a conspicuous absence of red or yellow snow in the region visited by the expedition. A small amount of yellow snow was observed by Mr. R. E. Priestley, of the Western Geological Party, but the collection was lost with much of the rest of the impedimenta on that memorable escape of the members of this party from a drifting ice-floe.

Special attention is directed to the great salinity of the water of Green Lake, from which locality quite a large percentage of the species recorded in this paper were obtained. These species, which included a number of Algæ generally regarded as freshwater types, were certainly living in water in which there was a much greater degree of concentration of salts than in ordinary sea-water. A number of typical marine diatoms occurred in this lake, but other species which were here plentiful also occurred in other lakes and ponds in which the water was not strongly saline. We have not, however, as yet any information as to the degree of salinity of Green Lake in summer, when the ice is all melted. 
Compared with the Alga-flora of Arctic land-areas in a similar latitude, that of the Antarctic continent is distinctly poor. The Green Algæ are relatively fewer, and there is a lack of diversity among the species of diatoms. Both of these facts may be directly due to the undoubted salinity of most of the lakes near the coast. Such a condition would be prejudicial to the growth of most Green Algæ, and the majority of freshwater species of diatoms would be excluded for the same reason. The most truly freshwater of the diatoms observed were those from the ponds on the lower slopes of Mt. Erebus. The comparative poorness of the Antaretic Alga-flora may also-be in part due to the greater severity of the climate combined with the remoteness of the Antarctic continent from other continental areas.

\section{BRIEF ACCOUNT OF THE COLLECTIONS}

Most of the collections were made by Mr. James Murray in the near vicinity of the winter quarters of the Expedition at Cape Royds on Ross Island. One was made by the leader of the Expedition at Hut Point, Ross Island, and two others on the mainland of South Victoria Land. The following data will include brief statements as to the habitats and the principal Algæ found in each collection.

\section{Ross Island}

The camp at Cape Royds was at $77^{\circ} 32^{\prime} \mathrm{S}$. lat. and $166^{\circ} 12^{\prime} \mathrm{E}$. long. All the collections were made within a few miles of this, except the one at Hut Point, lat. $77^{\circ} 50^{\prime} \mathrm{S}$. The numerous ponds and lakes near the camp yielded quite a number of interesting Algæ, and special attention should be drawn to the numerous Blue-greer. Algæ, some of which occurred in extersive sheet-like expansions.

\section{Pony Lake, Cape Royds}

A pril 22, 1908, and January 4, 1909 ; coll. J. Murray. Close to winter quarters. Never clear of ice except in small parts between November 28, 1908, and the end of January 1909. Temperature of water never much above freezing-point, the highost record being $35^{\circ} \mathrm{F}$. on December $4,1908$.

In January the material was distinctly green, and consisted of quantities of Chlamydomonas subcaudata and C. intermedia forma antarctica among the numerous trichomes of Phormidium autumnale.

In April the material (obtained from under the ice) was darker in colour and contained fewer Algø.

In both months filaments of the curiously contorted Phormidium anturcticum were common, also Pleurococcus frigidus.

\section{Ponds, Cape Royds}

A number of small ponds in which the temperature about the end of December rose to $60^{\circ} \mathrm{F}$. Coll. J. Murray. 
(a) December 1908. Great quantity of Nostoc antarctica with many diatoms.

(b) December 1908. Large quantity of Nostoc antarctica with several Green Algæ.

(c) January 26, 1909. Half a mile from camp. Mostly Ulothrix subtilis var. rariabilis, with several blue-green filamentous forms, including Oscillatoria terebriformis forma tenuis, and O. amphibia var. robusta.

\section{Green Lake, Cape Royds}

Half a mile from camp. Coll. J. Murray. Three collections were made:

(a) November 29, 1908. Some open water on the lake.

(b) January 3,1909 . Temperature of open water $36^{\circ} \mathrm{F}$.

(c) February 2, 1909. Temperature of open water $35^{\circ} \mathrm{F}$. On this day the lake became frozen over again.

The water of this lake is very saline, and there is always a little water under the ice. Owing to its remarkable salinity, the fluid obtained from under the ice at the time when it was thickest did not freeze until the temperature was reduced to $-7^{\circ} \mathrm{F}$. On June 26 the temperature under the ice was $21^{\circ} \mathrm{F}$., and on August 6, 1908, it was $8^{\circ} \mathrm{F}$.

The lake contained twenty-six species of Algæ, among which the Myxophyceæ predominated. These Blue-green Algæ were free-floating in the briny liquid, no extensive sheets being developed. The Green Algæ occurred mostly in February. Eleven species of diatoms were observed, almost all of which were marine forms. Two of them, however, Navicula muticopsis and $N$. (Pinnularia) globiceps, occurred plentifully in other situations which were not so saline in character.

We append a complete list of the species of Algæ which lived in association under the conditions of great salinity prevailing in this lake:

Ulothrix tenerrima Kütz. forma antarctica.

$U$. aqualis Kütz. forma.

Pleurococcus angulosus Lagerh. forma.

$P l$. antarcticus sp. $\mathrm{n}$.

$P l$. dissectus (Kütz.) Näg.

Trochiscia aspera (Reinsch) Hansg.

Coscinodiscus lentiginosus Jan.

Hemiaulus ambiguus Jan. var.

Triceratium arcticum Btw.

Fragilaria obliquecostata V. Heurck. " $\quad$ " forma maxima V. Heurck.

Navicula muticopsis V. Heurck.

N. (Pinnularia) globiceps Greg.

Trachyneis aspera (Ehrenb.) Cleve.

Tropidoneis lavissima sp. $\mathrm{n}$. 
Cocconeis litigiosa V. Heurck.

Lyngbya limnetica Lemm.

L. murrayi sp. n.

Phormidium fragile (Menegh.) Gomont.

Oscillatoria deflexa sp. n.

O. chlorina Kütz.

O limosa Ag.

Chroococcus cohcerens (Bréb.) Näg.

Chr. minutus (Kütz.) Näg.

Chr. minor (Kütz.) Näg. forma minima West.

Microcystis chroococcoidea sp. n.

Asterocystis antarctica sp. n.

\section{Penguin Rookery, Cape Royds}

February 3, 1909. On the sloping ground below the rookery, largely permeated by the drainage from this nesting-place, were masses of the Hormidium-stage of Prasiola crispa. Amongst the filaments were vast numbers of Navicula muticopsis.

A small pond in the rookery, which was never observed with water in it, contained quantities of Prasiola crispa forma aspera.

\section{Small, almost dried-up lake, Cape Royds}

Not far from the Penguin Rookery. [No further data.] Material consisted of a great quantity of Ulothrix aqualis, amongst which were Phormidium retzii and large numbers of Navicula muticopsis.

\section{Moraines near camp, Cape Royds}

March 12, 1908; coll. J. Murray. Material collected in underground pockets, believed to have formed part of an old lake-bottom. No Algœ of any kind were observed in this collection.

\section{Recent geological deposit containing subfossil diatoms}

Coll. J. Murray. Material obtained from the summit of a small hill about 200 feet high, near Cape Royds. Believed by the geologists to be the bottom of an old tarn.

Contained four species of interesting diatoms, three of which were found in the ponds and lakes, the remaining one being new. The species were: Navicula muticopsis V. Heurck, N. globiceps Greg., N. peraustralis sp. n., and Stauroneis anceps Ehrenb. var. amphicephala Kütz.

\section{Blue Lake, Cape Royds}

December 10, 1908 ; coll. J. Murray. This was the largest lake of the district, situated half a mile east of the camp. It was never even partially melted. The 
material was obtained from under fifteen feet of ice in one place and from one to three feet in another. The ice of this lake yielded water of such purity that it could be used in place of distilled water in chemical experiments.

The material consisted of thin, tough sheets of Myxophycex, of a deep blue-green colour and $0.5-1 \mathrm{~mm}$. in thickness. The greater part of the material consisted of Phormidium glaciale, with smaller quantities of Phormidium inundatum and Lyngbya martensiana. A species of Calothrix was also present in small quantity. Among the blue-green sheets were Pleurococcus antarcticus forma robusta and Chlamydomonas nivalis (in the resting state).

No diatoms were observed in the lake.

On the ground not far away from the margins of the lake was an abundance of Prasiola crispa in the Schizogonium-stage and with quantities of the earlier Pleurococcus-like stages. Amongst it were large numbers of Navicula muticopsis.

\section{Coast Lake, Cape Royds}

One mile from the camp. Some open water on November 28, 1908, and all clear of ice early in January 1909 ; completely frozen over again early in February. Temperature of water at the edge of lake: December 4, 1908, $47^{\circ} \mathrm{F}$.; January 2, 1909, $40^{\circ} \mathrm{F}$. ; January $18,1909,45^{\circ} \mathrm{F}$. This was the best lake for animal life.

(a) September 2, 1908. Expanded sheets of a deep blue-green colour, often bleached and about $1 \mathrm{~mm}$. in thickness, consisting of two species of Phormidium, more especially Ph. glaciale.

(b) January 1909 ; coll. J. Murray. Algæ were all Myxophyceæ, but all freefloating. No sheet-like expansions observed. No diatoms. Mostly species of Oscillatoria, such as $O$. deflexa, O. cortiana, O. formosa, O. tenuis, O. subproboscidea, and O. limosa, with small quantities of Lyngbya kützingii, Microcystis stagnalis, and Chroococcus minutus var. obliteratus.

\section{Clear Lake, Cape Royds}

April 1908; coll. J. Murray. This lake was one mile north of the camp, and was never seen clear of ice. The temperature of the water was just above freezingpoint, the highest reading being $35^{\circ} \mathrm{F}$. under nine feet of ice.

(a) Material obtained from the bottom of the lake at a depth of 17 feet. It was black and smelt offensively, but contained many species of ciatoms. Also small quantities of Pleurococcus antarcticus, the cells of which contained one or two small globules of a fatty oil.

(b) Material melted from the ice and consisting of layers of Algæ. Some were sheets of Phormidium glaciale with a slight admixture of Oscillatoria cortiana; others were compactly interwoven layers of Ulothrix cqualis.

\section{Deep Lake, Cape Royds}

October 1908; coll. J. Murray. Two miles south of camp, lying in a decp 
gully, and of unknown depth. The lake was never seen clear of ice, but round the stones at the margin a little water was found in which Algæ occurred. The temperature of the water was just over freezing-point. The material consisted of thin papery shects of Phormidium angustissimum, densely studded with colonies of Pleurococcus dissectus.

\section{Ponds on the slopes of Mt. Erebus}

There were a number of these ponds from whieh two collections were obtained.

(a) March 28, 1908 ; coll. D. Mawson, from ponds rather near the camp. The material consisted of extensive cartilaginous patches of Lyngbya erebi, some 3 to $5 \mathrm{~mm}$. in thickness. Enclosed in this tough stratum were also threads of Lyngbya kützingii and Oscillatoria limosa, together with colonies of Pleurococcus dissectus and a few specimens of Tabellaria flocculosa, Cocconema pusilla, Navicula radiosa, and Melosira varians.

(b) December 31, 1908; coll. J. Murray, from ponds about two miles from the camp. The great mass of material consisted of grey papery patches of considerable extent and of $0.5 \mathrm{~mm}$. in thickness, the nature of which was difficult to determine. It is probable that most of it consisted of Leptothrix or other allied filamentous bacteria. Amongst these colourless threads were various sparsely scattered Myxophycer, including Phormidium autumnale and Oscillatoria producta. Colonies of Pleurococcus dissectus occurred on both sides of the grey expanded sheets.

One tube contained a quantity of Nostoc antarctica.*

\section{High moraines on Mt. Erebus}

Altitude from 300 to 400 feet, and situated about three miles from the camp. Coll. J. Murray.

(a) December 1908. Ulothrix implexa, with large numbers of Diatoms, especially Navicula muticopsis.

(b) January 1909. Quantities of Prasiola antarctica attached to the stones. Amongst it were Glococapsa shuttiworthiana and Aphanocapsa montana, the latter covering quite large areas of the stones.

\section{Pond at Cape Barne}

December 12, 1908 ; coll. J. Murray. Two miles south of the camp. Temperature of water $54^{\circ} \mathrm{F}$. The pond was covered from side to side (from 20 to 30 yards) with an unbroken sheet of Myxophyceæ about $12 \mathrm{~mm}$. in thickness. The mass was lept floating by oxygen bubbles generated by the activity of the Algæ.

This stratum, which was of a totally different character from the blue-green sheets in Blue Lake, Coast Lake, or Deep Lake, consisted of Oscillatoria sancta and Phormidium autumnale.

* Attached to some half-decayed thalli of this Nostoc were a few small colonies of the fungus Sporodinia aspergillus Schroet. Tho specimons, which were carefully compared with British ones, were found to be typical in all respects. This is probably the farthest south reoord for any member of the Mucorinæ. 


\section{Lake at Hut Point}

Coll. Sir E. Shackleton. Not seen clear of ice. The material was in yellowbrown or greenish-brown sheets, and consisted mostly of a Leptothrix, in which matrix were Phormidium inundatum, Lyngbya-shackletoni, and Calothrix epiphytica.

\section{South VICTORIA LAND}

Only two collections were brought from this part of the mainland of the Antarctic continent.

\section{Lake on west side of McMurdo Sound}

January 1909 ; coll. R. E. Priestley. This lake was close to the "Stranded Moraines" and twenty-five miles from the camp at Cape Royds. Lat. $77^{\circ} 45^{\prime} \mathrm{S}$. It is said to be a large lake, but there were no data as to the temperature of the water or how long clear of ice. Water swarming with red Rotifers. Yellowish snow on shores, believed to be caused by Rotifers, but specimen lost.

The main mass of the material consisted of Oscillatoria priestleyi, amongst which were scattered trichomes of Phormidium autumnale and Oscillatoria deflexa. Also two species of Chroococcus. Numerous diatoms occurred, of a very similar nature to those found in the lakes of Ross Island.

\section{Five and a half miles south of Cape Irizar}

On the western side of the Ross Sea. October 23, 1908; coll. Prof. T. W. E. David. Lat. $75^{\circ} 40^{\prime} \mathrm{S}$. Situated 120 miles from the camp at Cape Royds.

The material consisted of Prasiola crispa, mostly in the Hormidium- and Schizogonium-stages. 


\title{
SYSTEMATIC ACCOUNT OF SPECIES OBSERVED CHLOROPHYCE $A$
}

\author{
ULOTRICHACE $\mathbb{E}$ \\ Genus-Ulothrix Kütz. \\ 1 Ulothrix subtilis Küitz.
}

Phyc. Germ. 1845, p. 197; Tab. Phycol. II, 1852, t. 85, f. 1 ; Rabenh. Flor. Europ. Alg. III., 1868, p. 365.

Var. variabilis (Kütz.) Kirchner, Alg. Schles. 1878, p. 77. U. variabilis Kütz. Spec. Alg. 1849, p. 346

Crass. fil. $6-7 \mu$; cellulis diametro $1 \frac{1}{4}-2$-plo longioribus.

$H a b$. In pond, Cape Royds.

The specimens were a trifle thicker than the average for this plant, but they are referable to no other species of the genus. Some of the more elongated cells had formed "thin-walled aplanospores," which were germinating while still within the original mother-cell. It is possible that this may have been the germination of incompletely formed zoogonidia, a plenomenon which occurs not infrequently in $U$. zonata, but the material did not admit of a determination of this point.

2 Ulothrix tenerrima Kütz.

Phyc. gen. 1843, p. 253, t. 9, f. 1 ; Phyc. Germ. 1845, p. 197 ; Spec. Alg. 1849, p. 346 ; Rabenh. Flor. Europ. Alg. III, 1868, p. 366. U. tenuis Kütz. Spec. Alg. 1849 , p. 346.

Forma antarctica. (Pl. XXIV, Figs. 5-7)

Forma filis brevissimis, flexuosis vel subcontortis, libere natantibus inter algas varias Myxophycearum; cellulis plerumque brevibus, diametro $\frac{1}{2}-1$-plo longioribus.

Crass. fil. $7-8 \mu$.

$H a b$. Green Lake.

The extreme shortness of the filaments and their bent character are the distinguishing features of this form. It should be emphasised that this form was growing in very saline water, with a much greater concentration of salts than in sea-water.

\section{Ulothrix implexa Kütz.}

Spec. Alg. 1849, p. 349 ; Tab. Phycol. II, 1852, t. 94, f. 2 ; Hazen in Mem. Torr. Bot. Club, xi, No. 2, 1902, p. 153, t. 21, f. 1, 2.

Crass. fil. 11.5-12.5 $\mu$; cellulis plerumque paullo inflatis, diametro $\frac{3}{4}-1$-plo longioribus.

Hab. High moraines, Mt. Erebus. BRIT. ANTARCT. EXPED. 1907-9. VOL. I. 
This is normally a submarine species, and although in its present habitat there would doubtless be a substratum containing a considcrable percentage of saline constituents, yet this locality was the least saline of any from which species of Ulothrix were obtained. Some of the diatoms amongst the mass of Ulothrix were typically submarine.

\section{Ulothrix cqualis Kütz.}

Phye.Germ. 1845, p. 197 ; Spec. Alg. 1849, p. 347 ; Tab. Phycol. II, 1852, t. 89, f. 1. Hormiscia aqualis Rabenh. Flor. Europ. Alg. III, 1868, p. 363.

$\mathrm{U}$. filis exacte cylindricis, subrectis vel leviter flexuosis, cellulis diametro 0.7-1.3-plo longioribus; chromatophora parietali subparva, sublobata, plerumque unilateraliter disposita, pyrenoidibus nullis.

Diam. cell. 14-20 $\mu$; long. cell. 10-25 $\mu$. (Pl. XXIV, Figs. 1, 2)

Hab. Dried-up Lake, Cape Royds.

As the characters of Ulothrix oqualis are still somewhat obscure, we have given a concise description and figures of the Antarctic specimens. We attach no importance to the absence of pyrenoids from the chloroplasts, as this condition is frequent throughout the genus when the chloroplasts are small and only occupy about half the cell.

Both Ulothrix oqqualis and $U$. tenerrima have been found in the snow-flora of Spitzbergen. Cf. Lagerheim in Nuova Notarisia, ser. vi, 1895, p. 6 (sep.).

Forma filis paullo tenuioribus, chromatophora majori cum pyrenoide singulo vel rare pyrenoidibus binis.

Diam. cell. 13-16 $\mu$; long. cell. 11.5-18 $\mu$. (Pl. XXIV, Figs. 3, 4)

Hab. Green Lake.

This form was not uncommon among various Myxophyceæ.

\section{PRASIOLACE无 \\ Genus-Prastola Ag. \\ 5 Prasiola crispa (Lightf.) Menegh.}

Kütz. Phye. gener. 1843, p. 295; Gay, Recherches sur la développement et la classif. Alg. Vertes, Paris, 1891, p. 86.

$H a b$. On the ground and in a small pond, Cape Royds; also covering a considerable area of the ground below the Penguin Rookery. Near Blue Lake, on the ground. Also on the ground $5 \frac{1}{2}$ miles south of Cape Irizar.

Nearly all the specimens of the genus Prasiola examined from the Antarctic region were without doubt forms of $P$. crispa.

In the vicinity of Cape Royds the Hormidium- and Schizogonium-stages were squent. The cells measured 9-12 $\mu$ in diameter, and the filaments were mostly rather short. In the Penguin Rookery, where the necessary couditions for the growth of this Alga were fully realised, it occurred in great abundance. The filaments showed 
every sign of being subjected to very rigorous conditions. The small amount of growth from one of the old cells of a preceding season could be well seen in most of the specimens. (Vide Pl. XXIV, Figs. 12-14)

Among the filaments in the Hormidium-stage which formed a felty covering over the ground near Blue Lake on December 11, 1908, were all the early stages of development which so much resemble both small and large colonies of Pleurococcus. They have, however, several distinguishing features, one of which is in the form and disposition of the chloroplast.

The expanded thalli were abundant from several places near Cape Royds and from $5 \frac{1}{2}$ miles south of Cape Irizar, South Victoria Land. All stages in the development were frequent, and were very similar to those figured by Wille (in Nyt Mag $\mathrm{f}$. Naturvidenskab, Bd. 40, Heft III, 1902, t. 3) from another Antarctic region. The spacing of the cells was exactly as in P. crispa. (Pl. XXIV, Figs. 8, 9)

It would appear that the great mass of the Antarctic Prasiola differs in no way from the northern $P$. crispa. The fully expanded and plicate thalli attained a breadth of $13 \mathrm{~mm}$, the cells varying from 6 to $9 \mu$ in diameter.

Var. aspera var. n. (Pl. XXIV, Figs. 15-18)

Filis in statu Hormidio modo visis; membrana exteriori cellularum incrassata et lamellosa, marginibus valde et irregulariter asperis; cellulis sæpe brevissimis.

Crass. fil. 12-18 $\mu$; diam. cell. 9-11 $\mu$; long. cell. 1.4-7.5 $\mu$.

Hab. In small pond, Cape Royds.

This peculiarly rough variety certainly does not agree with the published descriptions and figures of Prasiola crenulata. (Kütz.) Gay (= Hormidium crenulatum Kütz. Phyc. Germ. 1845, p. 193 ; Ulothrix crenulata Kütz. Tab. Phycol. II, t. 97, f. 2).

\section{Prasiola antarctica Kütz.}

Spec. Alg. 1849, p. 473 ; Tab. Phycolog. V, t. 40, f. 4 ; Rabenh. Flor. Europ. Alg. III, 1868, p. 311.

Long. thall. 2-4 mm.; lat. thall. 1.5-3 $\mu$; diam. cell. 4-7 $\mu_{\text {. }}$ (Pl. XXIV, Figs. $10,11)$

Hab. High moraines on Mt. Erebus, attached to stones.

Although most of the Prasiolas examined from this Antarctic region were without doubt forms of $P$. crispa the one on the " high moraines" of Mt. Erebus was different in the growth of its thalli and in the spacing of the cells. The spaces between the cell-groups were wider and the cells themselves were not so closely aggregated. This Prasiola agrees in all essential particulars with that described and figured by Kützing as $P$. antarctica; and, moreover, the habitat on the moist stones of Mt. Erebus is precisely like that given by Kützing (" in rupibus madidis ") for this species, whereas $P$. crispa was only observed on the ground or submerged.

Under the circumstances we are compelled to regard the Mt. Erebus specimens as Prasiola antarctica, and to disagree with Wille's assertion, based on a single Antarctic 
sample from Cape Adare, that there is no difference between $P$. antarctica and $P$. crispa. Wille's figures show that the specimens he examined were ordinary forms of $P$. crispa, but we fail to see how that in any way affeets the specific distinctness of $P$. antarctica.

\section{VOLVOCACEA}

Genus-Chlamydomonas Ehrenb.

7 Chlamydomonas nivalis (Bauer) Wille

"Alg. Notizen XI," Nyt Magazin f. Naturvidenskab, Bd. 41, Heft 1, 1903, pp. 147-149, t. 3, f. 44, 45 ; t. 4, f. 25 . Spharella nivalis (Bauer) Sommerfeld, 1824.

Diam. cell. 19-23.5 $\mu$.

Hab. Blue Lake and Deep Lake.

Only the resting stage of this Alga was observed. The brillant red cells, full of fatty-oil reserve, occurred in small groups among Pleurococcus antarcticus forma robusta in the stratum of Phormidium glaciale.

\section{Chlamydomonas subcaudata Wille}

l.c. p. 118 , t. 3, f. $12-18$.

Long. cell. 31-34 $\mu$; lat. 16.5-18 $\mu$. (Pl. XXIV, Figs. 25-29)

Hab. Pony Lake.

This rather large species of the genus was fairly common amongst Chlamydomonas intermedia forma antarctica. It possesses very distinetive characters, and the Antarctic form scarcely differs in any way from that originally described by Wille from Aalesund. The protoplast fully occupied the middle portion of the cell, but both in front and behind it did not extend close up to the cell-wall. The posterior extension of the cell-wall was generally acute, but no specimens were seen in which it was subcaudate as in Wille's Fig. 12. Nearly all the cells were very slightly asymmetrical about the longitudinal axis.

The chloroplast is massive, with a very large pyrenoid in its hinder half. The pyrenoid is in the median line and immediately in front of it is the nucleus. The nucleus is thus slightly nearer the centre of the cell than in Wille's specimens. (Cf. Wille's Figs. 12-15.) In all the specimens seen the chloroplast appeared to be finely pitted, giving rise to flattened tooth-like marginal projections such as those figured by Wille in his end view of the cell (Wille, Fig. 16), but in the Antarctic specimens it was not possible to ascribe this appearance to longitndinal grooves. We would prefer, however, not to press this point, as it is often difficult to clearly make out the finer details of a chloroplast in preserved material.

Many examples were in the process of formation of daughter-cells, four of which were produced in the mother-cell. The division was evidently by two oblique planes crossing each other almost at right angles. (Vide Pl. XXIV, Figs. 28, 29) 


\section{Chlamydomonas intermedia Chodat}

In Bull. de l'Herb. Boiss. tom. ii, p. 590, t. 22, 23 ; Wille, l.c. p. 142, t. 4, f. 15. Forma antarctica. (Pl. XXIV, Figs. 19-24)

Forma minor, stigmata juxta pyrenoidem.

Isong. cell. 12-15 $\mu$; lat. 8-10 $\mu$.

$H a b$. Pony Lake.

Very well-preserved specimens of this species-were abundant among Phormidium autumnale. The cells were ellipsoid, or ovoid-ellipsoid, and somewhat smaller than in the form described by Chodat, but otherwise they were very similar. The protoplast completely occupied the confines of the delicate cell-wall, and the chloroplast was large and cup-shaped, with a prominent pyrenoid situated in the median line toward the hinder end of the cell. The pigment spot (stigma) was of variable shape, generally elongated and somewhat curved, and was disposed towards one side of the cell, either near the pyrenoid or half way between the pyrenoid and the insertion of the cilia. Two daughter-cells evidently arose by longitudinal division of the mothercell. (Figs. 23, 24.)

One cell was observed with two pyrenoids (Fig. 24). This individual was without doubt active when fixed in formalin, but it is possible that the division of the pyrenoid had occurred as an antecedent to cell-division.

\section{PLEUROCOCCACE $Æ$}

Genus-Pleurococcus Menegh.

10 Pleurococcus pachydermus Lagerh.

In Wittr. et Nordst. Alg. Exsic. No. 447 ; in Botaniska Notiser, 1882, p. 55.

Forma cellulis plerumque globosis sed hinc inde anguloso-globosis e mutua pressione; crass. membr. cell. $2 \mu$; diam. cell. matur. 17.5-19.5 $\mu$, cell. juv. (gonid.) $8-8.5$ ․ (Pl. XXIV, Figs. 45, 46)

$H a b$. Green Lake.

All these cells contained a single parietal chloroplast of considerable extent, furnished with a single pyrenoid. Iodine solution stained this pyrenoid deeply, and also brought out the cell-nucleus. The latter stained well after treatment with osmic acid, and is seen to be situated internal to the chloroplast and rather to one side of the cell.

Forma stipitata. (Pl. XXIV, Figs. 47, 48)

Cellulis solitariis, libere natantibus, "stipitatis."

Diam. cell. 18-20 $\mu$; long. stip. 7.5-26 $\mu$; lat. stip. 1.8-3.1 $\mu$.

Hab. In pond, Cape Royds.

The cells of this curious form possessed a cylindrical and more or less elongated appendage at one side. This appendage was generally curved and quite solid, and 
had more the appearance of a short stalk than anything else, although the cells were quite free and unattached.

\section{Pleurococcus frigidus sp. 11. (Pl. XXIV, Figs. 40-44)}

Cellulis globosis, 20-24 $\mu$ latis, singulis vel plerumque aggregatis, intra stratum Myxophycearum nidulantibus; membrana cellularum $1.4 \mu$ crassa; ehromatophora singula magna, indistincte limitata, cum grannlis amylaceis numerosis vel pyrenoidibus conspicuis 2-3. Propagatio gonidiis globosis 2 vel 3 intra cellulas maternas ortis; diam. gonid. 10-14 $\mu$.

$H a b$. Pony Lake.

This species was more or less abundant in a matrix consisting mostly of Phormidium autumnale and other Blue-green Algæ. It appears to belong to that section of Pleurococcus for which Klebs founded the special genus Chlorosphara, but so far as could be ascertained from the preserved material multiplication takes place by the division of the contents of the mother-cell into two or three portions, which then become rounded non-motile gonidia. As these grow in size they gradually throw off the old wall of the mother-cell. Each cell possesses a single nucleus, placed in a rather excentric position.

In the specimens collected in A pril 1908 the massive chloroplast contained numerous minute granules of starch. In those obtained from the same locality in January 1909 the chloroplast possessed either 2 or 3 distinct pyrenoids and no scattered starch granules.

The cells are considerably larger than those of Pleurococcus angulosus Menegh., and the chloroplast is not reticulated.

\section{Pleurococcus antarcticus sp. n. (Pl. XXIV, Figs. 49-51)}

Cellulis globosis, 20-37 (plerumque 32) $\mu$ latis, singulis vel in familiis parvis aggregatis inter algas Myxophycearum libere natantibus, membrana cellularum usque ad $2.2 \mu$ crassa, homogenea vel nonnunquam indistincte lamellosa; chromatophora magna parietali, indistincte limitata, sæpe cum globulis oleariis conspicuis. Propagatio ignota.

$H a b$. Green Lake and Clear Lake.

This is a large species, and, like the preceding, probably belongs to the section "Chlorosphara (Klebs) Hansg." Nothing was scen which in any way gave a clue as to its methods of propagation. The chloroplast is massive, but its limitations could not be definitely made out from the available material. It was generally partly contracted from the wall at one side of the cell, and this space frequently contained one, or more rarely two, globules of a fatty oil, such as occurs in Pleurococcus rufescens.

Forma robusta. (Pl. XXIV, Figs. 52-54)

Cellulis majoribus, diam. 35-78 $\mu$, intra stratum Myxophycearum nidulantibus, sæpe dense aggregatis; membr. cell. 2.5-6 $\mu$ crassa et lamellosa; chromatophora sæpe distincte parietali, globulis oleariis nullis. 
Hab. Blue Lake.

These are the largest Pleurococcus cells we have yet seen.

13 Pleurococcus dissectus (Kütz.) Näg.

Gatt. einzell. Alg. 1849, p. 65, t. 4, f. 3 ; Protococcus dissectus Kütz. Spec. Alg. 1849, p. $199 ;$ Tab. Phyc. p. 4, t. 3.

Diam. cell. 4.5-9 $\mu$ (usque ad $16 \mu$ in cellulis solitarus). (Pl. XXIV, Figs. 30-39)

$H a b$. Ponds on Mt. Erebus, attached to the tough sheets of Lyngbya Erebi. Green Lake, among Ulothrix aqualis forma. Blue Lake and Deep Lake, attached to the sheets of Myxophyceæ.

The specimens agreed well with forms of this species, and especially with the figures given by Suringar (Observ. Phyc. in Flor. Batav., Leovardice, 1857, p. 56, t. 4, f.D) of "Protococcus dissectus $\beta$ cuneata." They were, however, submerged (though frozen), whereas the usual habitat of $P l$. dissectus is a subaerial one. The division of the cells, partly radial, partly tangential, and partly oblique, is very characteristic.

This species often forms a one-layered stratım, in which the cells remain angular by compression. This condition is almost a definite state of the plant. (Vide Pl. XXIV, Fig. 39).

Genus-Trochiscia Kütz.

14 Trochiscia aspera (Reinsch) Hansg.

In Hedwigia, 1888, p. 128 ; G. S. West, Treatise Brit. Freshw. Alg. 1904, p. 303, c. figs. 82 A-F. Acanthococcus aspera Reinsch, 1886.

Diam. cell. 15.5-22 $\mu$.

$H a b$. Green Lake.

\section{PALMELLACEA.}

Genus-GLGocystis Näg.

15 Glooocystis sp.

Diam. cell. 5-12 $\mu$, c. integ. gelat. 14-30 $\mu$.

$H a b$. In pond, Cape Royds.

From the available material it is not possible to exactly identify this Alga. Wille has recently accepted certain views of Gerneck, and stated that the various Algæ included in Nägeli's genus Gloocystis are merely developmental stages of other green Algæ (cf. Wille in Engler and Prantl, Natürlich. Pfanzenfam. Chlorophyceo, 1909, p. 31). This view we do not entirely accept, as there is no positive proof that all these Algæ are states of species belonging to other genera, and Gerneck's experience is much too limited to warrant such a wide statement. This is the more emphasised when one finds that some of Gerneck's recently proposed genera can scarcely be regarded as specifically distinct, let alone as valid generic types.

The greatest suspicion always attaches itself to Algæ found only in culture vessels. Such forms may il many cases be mere states of other Algæ which remain 
for a longer or shorter period in a profoundly modified condition owing to the unnatural and generally abnormal conditions of the culture.

It is very probable that several species of Glococystis, including G. gigas (Kütz.) Lagerh., to which the Antarctic plant nearly approaches, are independent organisms with a life-history of their own.

\section{BACILLARIEAE}

C O S C I N O D I S C A CE $\mathrm{E}$

Genus-Melosira Ag.

16 Melosira distans (Ehrenb.) Kütz.

A. Schmidt, Atlas Diat. t. 182, f. 4; O. Müller in Engler's Botan. Jahrbuch. xxxiv, 1904. p. 271.

Diam. cell. $9.4-10 \mu$.

Hab. In pond, Cape Royds.

17 Melosira varians Ag.

W. Sm. Brit. Diat. II, p. 57, t. 51, f. 332 ; V. Heurck, Synops. Diat. Belg. t. 85, f. $10,11,14,15$.

Diam. valv. 17-19 $\mu$.

Hab. Ponds on Mt. Erebus.

\section{Genus-Coscinodiscus Ehrenb. \\ 18 Coscinodiscus lentiginosus Jan.}

A. Schmidt, Atlas Diat. t. 58, f. 11.

Diam. valv. $120 \mu$.

$H a b$. Green Lake, not uncommon.

This interesting species has been found to be fairly frequent in soundings made by the s.y. Belgica from $62^{\circ} 11^{\prime}$ to $70^{\circ} 53^{\prime}$ S. lat.

\section{Genus-Triceratium Ehronb.}

\section{Triceratium arcticum Brightw.}

Diam. valv. $230-258 \mu$.

Hah. Green Lake.

The specimens were typical, agreeing exactly with the figures in A. Schmidt's Atlas Diut. t. 79 , f. 12 and $12 a$, and also with examples mounted and named by J. Tempère. 
Genus-Hemiaulus Ehrenb.

20 Hemiaulus ambiguus Janisch

Var. V. Heurck, Diatomées, Result. Voyage du s.y. "Belgica," Anvers, 1909, t. 8, f. 110 .

Diam. valv. $60 \mu$.

Hab. Green Lake.

Dr. Van Heurck was apparently somewhat doubtful concerning the exact determination of his specimen (l.c. p. 36). Those observed from the above locality were in exact agreement with his figure.

\section{TABELLARIACE $\mathrm{E}$}

Genus-Tabellaria Ehrenb.

21 Tabellaria focculosa (Roth.) Kütz.

W. Sm. Brit. Diat. II, p. 45, t. 43, f. 316 . V. Heurck, Synops. Diat. Belg. t. 52, f. 10-12.

Long. valv. 26-27 $\mu$; lat. max. ad med. 9.5-10 $\mu$.

Hab. Ponds on slopes of Mt. Erebus.

In his Synopsis of Naviculoid Diatoms, Part I., 1894, p. 12, Cleve states that " of Tabellaria flocculosa, one of the most frequent diatoms of Europe, not a trace has been found either in S. America from Ecuador to Argentina, or in Australia or New Zealand." Recently, however (G. S. West, "Alg. Yan Yean Reservoir," Journ. Linn. Soc. bot. xxxix, 1909, p. 30), this cosmopolitan species has been shown to be abundant in at least one district of Victoria, and the examples from Mt. Erebus were in every way typical. Moreover, the specimens were in no way fragmentary, but had been fixed in the living state, although the colonies were not observed to consist of more than two cells, possibly owing to the rigorous conditions of existence.

\section{FRAGILARIACE $刃$ \\ Genus--Fragilaria Lyngb.}

22 Fragilaria tenuicollis Heib. var. antarctica var. n. (Pl. XXVI, Fig. 128) $10 \mu$.

Var. polis valva valde productis et leviter subcapitatis; striis non radiatis, 16 in

Long. valv. $37 \mu$; lat. $3 \mu$.

Hab. Clear Lake.

In outward form the valves were very similar to $F$. tenuicollis var intermedic (Grun.) V. Heurck [ = F. intermedia Grun.; V. Heurck, Synops. Diat. Belg. t. 45, f. 9], but they did not possess the median unilateral central area which is characteristic of that viriety.

BliIT. ANTARCT. EXPED, 1907-9. VOI, I. 


\section{Fragilaria virescens $\mathrm{Ralfs}$}

V. Heurck, l.c. t. 44 , f. 1 .

Long. valv. $40 \mu$; lat. $8.5 \mu$.

Hab. Ponds on Mt. Erebus.

\section{Fragilaria obliquecostata V. Heurck}

Diatomées, Result. Voyage du s.y. "Belgica," Anvers, 1909, p. 25, t. 3, f. 38.

Long. valv. $47 \mu$; lat. $8 \mu$; costis 6 in $10 \mu$.

$H a b$. Green Lake, frequent.

Forma maxima V. Heurck, l.c. f. 40.

Long. valv. $75 \mu$; lat. med. $8.5 \mu$, costis $5 \frac{1}{2}$ in $10 \mu$.

$H a b$. Green Lake, rare.

The valves were not so large as those described and figured by Van Heurck, but they possessed the same slightly tumid median portion.

\section{ACHNANTHACE}

\section{Genus-AchNanthes Bory.}

25 Achnanthes brevipes Ag. var. intermedia (Kütz.) Cleve

Synops. Navic. Diat. II., 1895, p. 193 ; A. subsessilis Kütz., 1833.

Long. valv. 31-33 $\mu$; lat. 8.8-9.3 $\mu$. (Pl. XXVI, Figs. 126, 127)

Hab. Moraines near camp, Cape Royds. Clear Lake.

In outward form the valves were similar in form to those of $A$. brevipes var. intermedia, although not quite so elliptic, and occasionally there was a faint indication of a median constriction. The markings agreed well with the general disposition of the punctate costæ of this most variable species. We figure the upper and lower valves for future comparison with other Antarctic forms.

Striations on lower valve 13 in $10 \mu$, strongly radiate; on upper valve 12 in $10 \mu$, transverse in the middle of the valve, but rather irregularly bent towards the poles.

\section{COCCONEIDACE E \\ Genus-Cocconeis Ehrenb. \\ 26 Cocconeis litigiosa V. Heurck}

Diatomées, Result. Voyage du s.y. "Belgica," Anvers, 1909, p. 18, t. 2, f. 28.

Long. valv. $79 \mu$; lat. $54 \mu$; striis 9 in $10 \mu$.

$H a b$. Green Lake, rare.

Only the inferior valves were seen, and although a little smaller than Van Hcurck's original specimen, they possessed precisely the same striation. Moreover, they 
possessed a similar transversely expanded, asymmetrical central area, and the lunate terminal areas. The latter feature is also possessed by $C$. pellucida Hantzsch (cf. A. Schmidt's Atlas Diat. t. 195, f. 1-6.)

\section{NAVICULACE $\mathbb{E}$ \\ Genus-Tropidoneis Cleve.}

27 Tropidoneis lavissima sp. n. (Pl. XXVI, Figs. 115-120)

T. parva, delicatissima et lævissima; valvis oblongo-linearis, diametro 8-11-plo longioribus, in parte mediana marginibus parallelibus, apices versus leviter et gradatim angustioribus, polis obtuse rotundatis, raphe recta sed juxta polos levissime curvata nodulo centrali in staurum transversum producto, stauro angustissimo plerumqu valvæ margines versus paullulo dilatato, alis (vel carinis) carentibus, striis non visis Cellula in aspectu cingulato anguste oblongo-rectangulari, medio constricta, lateribus convexis et angulis rotundatis.

Long. valv. 49-98 $\mu$; lat. med. 8-9.5 $\mu$.

Hab. Clear Lake, Green Lake, and lake on west side of McMurdo Sound.

This diatom was one of the most abundant species in the Antarctic collections occurring in great quantity in several of the lakes, both freshwater and strongly saline

It belongs to the section Orthotropis of the genus Tropidoneis, having a raphe which is practically straight. The valves are very convex (consult Fig. 120), with a slight thickening along the central axis, but they are entirely destitute of wings (or keels). The great convexity of the valves, the slight indication of the bending of the raphe near the poles, and the form of the girdle-view are all characters which place the diatom in the genus Tropidoneis. The markings, if any are present, must be exceedingly fine. Carefully prepared valves were examined most minutely with a Leitz oil-immersion lens giving a magnification of 2000 diameters, but no trace of striations could be discovered.

The central stauros is very narrow and reaches to the edges of the valve, where it is slightly dilated. The general character of this stauros is very similar to that of the pelagic Navicula (Stauroneis) Biblos Cleve (Le Diatomiste, Mar. 1892, p. 77, t. 12, f. 9, 10), but the other characters of the diatom are very different. A stauros of a similar kind is found in several species of Stauroneis, and there is a slight resemblance between Tropidoneis lavissima and Stauroneis spicula Dickie (vide Van Heurck, Synops. Diat. Belg. t. 4, f. 9), but the valves are not so attenuated and the striations (if present) are not nearly so strong. 
Genus-Stauroneis Ehrenb.

28 Stauroneis anceps Ehrenb.

W. Sm. Brit. Diat. I, t. 19, f. 190 ; V. Heurck, Synops. Diat. Belg. t. 4, f. 4, 5.

Var. amphicephala Kütz.

Long. $37-43 \mu$; lat. $8-10 \mu$; striis 22 in $10 \mu$.

Hab. Recent geological deposit containing subfossil diatoms. Also lake on west side of McMurdo Sound.

The specimens seen were rather small, but otherwise typical.

\section{Genus-Trachyneis Cleve.}

29 Trachyneis aspera (Ehrenb.) Cleve.

Synops. Navic. Diat. I, 1894, p. 191.

Long. $254 \mu$; lat. $48 \mu$.

Hab. Green Lake.

This handsome diatom was seen very sparingly, and we have not placed it definitely under one of the numerous described varieties synopsised by Cleve. In outward form the valves would agree with var. genuina Cleve, but in general appearance of markings it agrees best with var. oblonga (Bail.) Cleve [vide figure of Stauroptera oblonga Bail. in A. Schmidt's Atlas Diat. t. 48, f. 16], which is known from Australia, South America, and the Island of Kerguelen. The alveolate striæ were closer together ( 7 in $10 \mu$ ) near the poles of the valves than they were in the median part $(6$ in $10 \mu)$.

\section{Genus-Navicura Bory.}

30 Navicula perlepida Grun.

"Diatom. Franz Josefs-]and," in Denk. Akad. Wiss. Wien, xlviii, 1884, p. 104, t. 1, f. 44 .

Long. 16-18 $\mu$; lat. med. valv. 2.6-2.7 $\mu$.

Hab. Clear Lake.

This minute diatom agrees with Grunow's description of Navicula perlepida, and also with his Fig. $44 a$. His dimensions are long. 20-34 $\mu$; lat. 2-3.3 $\mu$, so that the Antarctic specimens, although of the same breadth, are scarcely so long as the Arctic ones.

In general form and size the valves of this diatom are very similar to species of Achnanthes of the section Microneis.

31 Navicula glaberrima sp. n. (Pl. XXVI, Fig. 125)

N. minutissima et lævissima; valvis rhomboideis vel rhomboideo-ellipticis cum lateribus pæne rectis, polis levissime rotundatis, raphe rectissima, nodulis terminalibus conspicuis; striis non visis. 
Long. valv. $19 \mu$; lat. $5.1 \mu$.

$H a b$. Lake on west side of McMurdo Sound.

This minute Navicula was rather scarce amongst quantities of other diatoms, especially Hantzschia elongata, Tropidoneis losvissima, and Navicula muticopsis. Careful examination of the valves with a one-twelfth-inch oil-immersion lens revealed no trace of striations. Other examples of apparently smooth species of Navicula are N. perlepida Grun., N. lineola Grun., and N. nuda Pantoesek.

$N$. glaberrima should be compared with $N$. palpebralis var. minor (Greg.) V. Heurck (Synops. Diat. Belg. t. 11, f. 11; = N. minor Greg.), from which it differs in being smaller and more angular, and in having no striations.

\section{Navicula rhynchocephala Kütz. forma}

Long. $51 \mu$; lat. $10 \mu$; striis 12 in $10 \mu$.

Hab. In pond, Cape Royds.

The form noticed was apparently one of the intermediate states between the more typical form (with subcapitate poles) and the var. amphiceros (Kütz.) Cleve, Synops. Navic. Diat. II, 1895, p. 15. The poles were slightly swollen and more obtuse than the figure of var. amphiceros given by O. Müller in Engler's Bot. Jahrbuch. xlv, 1910, t. 2 , f. 20. The form was very similar in outline to " $N$. rhynchocephala var." in Cleve et Grun. Beitr. Arctisch. Diat. 1880, t. 2, f. 33.

\section{Navicula muticopsis V. Heurck}

Diatomées, Result. Voyage du s.y. "Belgica," Anvers, 1909, p. 12, t. 2, f. 181.

Long. 14.6-23 $\mu$; lat. 8-9.1 $\mu$; striis 13-14 in $10 \mu$. (Pl. XXVI, Figs. 121-124)

$H a b$. In ponds, and on the ground in the Penguin Rookery, Cape Royds. Also in recent geological deposit containing diatoms. Clear Lake, Green Lake, Pony Lake, and near Blue Lake. Lake on west side of McMurdo Sound.

This was the most abundant of all the Antarctic diatoms collected by the Expedition. It occurred in nearly all the ponds and lakes, often in quantity, but was most abundant in the Penguin Rookery at Cape Royds.

Considerable range of variation was exhibited by the valves, mostly in the character of the poles, which were sometimes decidedly subcapitate, whereas at other times they were merely "produced." The actual polar margin was frequently subtruncate, but more often much more rounded. The central area was of variable form, from a transverse stauros to a rounded area of considerable size. The striations in all the specimens examined were 13 or 14 in $10 \mu$, and consisted of 3-5 puncta each, except in the median part of the valve and at the poles. A solitary unilateral punctum was present in the central area of some specimens, but no trace of it existed in others.

In all cases the median portion of the valve possessed subparallel sides.

The two following forms may be distinguished:

Forma evoluta. Cellulæ paullo elongatæ, infra polum unumquemque distincte sed leviter constrictæ; striis 13-14 in $10 \mu$. 
Forma reducta. Cellulæ breviores, polis minus productis et distincte truncatis; striis 13 in $10 \mu$.

Both of these forms were common over the whole area in which collections were made.

\section{Navicula muticopsiforme sp. n. (Pl. XXVI, Fig. 131)}

N. minutissima, valvis subellipticis, diametro circiter duplo longioribus, parte mediana parva cum marginibus parallelis, polis longe cuneiformibus et obtuse rotundatis, platea centrali magna et transverse dilatata, platea axiali lata, striis 17 utrobique (16 in $10 \mu)$, punctatis, in parte mediana (adversus plateam centralem) striis tribus brevibus e puncto singulo elliptico formatis, ceteris radiatis o punctis duobus formatis.

Long. $11.3 \mu$; lat. $5.3 \mu$.

Hab. Clear Lake.

This minute species has a slight resemblance to the more reduced forms of $N$. muticopsis V. Heurck, but differs in the cuneate poles of the valves and in its strix. There is a relatively large central area, caused by the shortening of three striæ on each side. These striæ are reduced to a single elliptical punctum. The remaining striæ, which are somewhat divergent, are disposed in seven pairs in each half of the valve. They leave a rather wide axial area, and each striation consists of two somewhat elongated puncta.

The species should be compared with $N$. mutica Kütz. and $N$. seminulum Grun., from both of which it differs in outward form and in the striation of the valves.

\section{Navicula peraustralis sp. n. (Pl. XXVI, Fig. 132)}

N. parva, valvis anguste lineari-lanceolatis, diametro circiter $4 \frac{1}{3}$-plo longioribus, lateribus triundulatis inflatione mediana majori, polis inflato-capitatis et levissima angularibus, platea centrali parva et elliptica, platea axiali angusta, striis validis 18 in $10 \mu$, leviter radiatis, a plateis lateralibus duobus interruptis.

Long. $47.7 \mu$; lat. $11.1 \mu$.

Hab. Recent geological deposit containing subfossil diatoms.

This species is similar to those of the $N$. mesolepta group, but does not agree with any of them. The two lateral areas interrupting the striations are also very characteristic. In general outline it is not unlike $N$. semicruciata Ehrenb., as figured in A. Schmidt's Atlas Diat. t. 44, f. 45.

\section{Navicula (Pinnularia) globiceps Greg.}

Cleve, Synops. Navic. Diat. II, 1895, p. 77.

Long. $23-25 \mu$; lat. $9-9.5 \mu$; striis 18 in $10 \mu$. (Pl. XXVI, Fig. 135)

$H a b$. Green Lake and Clear Lake. Recent geological deposit containing diatoms.

In one half of the central area was a single isolated punctum. The striations in the median part of the valve were interrupted by two longitudinal lines, and in the region of the capitate poles by one longitudinal line. 
37 Navicula (Pinnularia) murrayi sp. n. (Pl. XXVI, Fig. 129)

N. parva, valvis lineari-ellipticis, diametro circiter 4-plo longioribus, polis obtusis lovissime dilatatis, platea centrali transverse expansa, marginem utrinque pæne attingente, cum puncta solitaria asymmetrica, platea axiali angusta, striis 14 in $10 \mu$, punctulatis, in toto radiatis, in parte mediana 4 (circ.) utrobique multe brevioribus.

Long. $45 \mu$; lat. $11.5 \mu$.

$H a b$. In pond, and moraines near the camp, Cape Royds.

This spccies stands nearest to $N$. reinhardtii Grun. (cf. V. Heurck, Synops. Diat. Belg. p. 86 , t. 7 , f. 5,$6 ;=N$. vernalis Donkin), but differs in the form of the central area, with its solitary unilateral puncta, in the shorter striæ bordering the central area, and in the much closer striations (which are 14 in $10 \mu$ as compared with 9 in $10 \mu)$. The striations are also radiate throughout, and never transverse at the poles, which are very slightly dilated.

Var. elegans var. n. (Pl. XXVI, Fig. 130)

Var. minor, polis valvæ angustioribus, productis et subcapitatis; striis 15 in $10 \mu$. Long. $31 \mu$; lat. $8.1 \mu$.

Hab. Pond, Cape Royds.

This variety should be compared with $N$. salinarum Grun. (in Cleve et Grun. "Beitr. Arctisch. Diat.," Kongl. Sv. Vet.-Akad. Handl. Bd. 17, No. 2, 1880, p. 33, t. 2, f. 34), from which it differs in many respects, although the spacing of the striæ is the same.

38 Navicula (Pinnularia) cymatopleura sp. n. (Pl. XXVI, Figs. 133, 134)

N. minutissima, valvis sublinearis, diametro $4 \frac{1}{4}-5 \frac{2}{5}$-plo longioribus, lateribus triundulatis, undulo mediana levissime majori, polis subcapitatis, platea centrali magna et longitudinaliter elliptica, platea axiali lata, striis brevibus et lævibus, 20-21 in $10 \mu$, leviter radiatis, in parte mediana (adversus plateam centralem) brevioribus.

Long. $17-27 \mu$; lat. $4-5 \mu$.

Hab. Clear Lake. Lake on west side of McMurdo Sound.

This minute species occurred abundantly in the above-mentioned lakes. It is one of the $N$. mesolepta group, but the poles are much too wide for any form of $N$. mesolepta, and the striations are too fine. The undulate sides are not quite parallel, as there is a gradual and almost imperceptible attenuation. N. rupestris Hantzsch is of a similar shape, and there is a similar reduction of the striations in the middle of the valve (vide A. Schmidt's Atlas Diat. t. 45, f. 45-48), but the striations of $N$. cymatopleura are finer and shorter than in any of these forms.

It should be carefully compared with Pinnularia gracillima Grog., $P$. appendiculata Ag., and P. undulata Greg. The latter is figured in Cleve's " Diatoms of Finland," Acta Soc. pro fauna et flora Fennica, VIII, No. 2, 1891, t. 2, f. 8, and is at once seen to be quite a different diatom. 
39 Navicula (Pinnularia) shackletoni sp. n. (Pl. XXVI, Figs. 136-138)

N. minuta, valvis anguste elliptico-lanceolatis cum polis valde productis levissime subcapitatis et obtusis, platea centrali minuta, platea axiali angustissima, striis 10-12 in $10 \mu$, leviter radiatis, validis et non-punctulatis, in medio striis duobus utrobique adversus plateam centralem delicatissimis et valde indistinctis. Cellula in aspectu cingulato anguste lineari-oblonga.

Long. 25-29 $\mu$; lat. 4-5 $\mu$.

Hab. Clear Lake, abundant.

This minute species should be compared with $N$. lanceolata Kütz. var. tenella (A. Schm.) Cleve [ = N. tenella A. Schmidt, Atlas Diat. 1876, t. 47, f. 45], from which it is distinguished by its distinctly produced poles, its more distant and less radiate striæ, and by the two faint median striæ on each side of the central area.

$N$. cryptocephala Kütz. is also a similar species, but the lateral margins of the valves are more ventricose and the poles more distinctly demarcated from the elliptic body of the valve than in $N$. shackletoni. Moreover, the striæ are as a rule much finer.

In general outline $N$. shackletoni is not unlike $N . E l \quad K a b$ forma lanceolata O. Müller (in Hedwigia, xxxviii, 1899, p. 311, t. 12, f. 19), but the striation is much coarser and differently disposed.

Var. pellucida var. n. (Pl. XXVI, Figs. 139-141)

Var. platea centrali majori, leviter transverse dilatata, striis minus robustis, in medio duobus utrobique brevioribus. Cellula in aspectu cingulato conspicue latiori.

Long. $25-29 \mu$; lat. $4.5-4.8 \mu$.

$H a b$. In pond, Cape Royds, common.

This appears to be a well-marked variety, but the distinctions are hardly such as to warrant specific separation. The much greater width in the girdle view was a constant and noteworthy feature.

40 Navicula radiosa Kütz.

V. Heurck, Synops. Diat. Belg. p. 83, t. 7, f. 20. Pinnularia radiosa W. Sm. Brit. Diat. p. 56, t. 18, f. 171. P. acuta W. Sm.

Long. $74 \mu$; lat. $13 \mu$; striis $11-12$ in $10 \mu$.

$H a b$. Ponds on Mt. Erebus.

The specimens were not altogether typical as the apices were as acute as those of the var. tenella (Bréb.) Cleve, Navic. Diat. II, 1895, p. 17, but the striations were rather coarser than in that variety. 


\section{COCCONEMACE $A$}

Genus-Cocconema Ehrenb.

41 Cocconema pusilla (Grun.) nob.

Cymbella pusilla Grun., 1875 ; Cleve, Synops. Navic. Diat. I, 1894, p. 162. Long. valv. $31 \mu$; lat. $5.2 \mu$; striis 17 in $10 \mu$.

$H a b$. In ponds, Mt. Erebus.

\section{NITZSCHIACE E \\ Genus-Nitzschia Hassall \\ 42 Nitzschia subtilis (Kütz.) Grun. var.}

Long. $39.2 \mu$; lat. $3.1 \mu$; punctis 16 vel 17 in $10 \mu$.

Hab. Clear Lake.

This Nitzschia seems undoubtedly to belong to $N$. subtilis, and resembles very much the var. glacialis Grun. ("Diat. Franz Josefs-land," Denk. Akad. Wiss. Wien. xlviii, 1884, p. 107 , t. 1, f. 64). It is, however, very slightly more attenuated and the carinal puncta are further apart. It should also be compared with $N$. subtilis var. paleacea Grun. (cf. V. Heurck, Synops. Diat. Belg. t. 68, f. 9, the right-hand figure).

\section{Genus-Hantzschia Grun.}

43 Hantzschia amphioxys (Ehrenb.) Grun.

Long. $56 \mu$; lat. $8.6 \mu$.

Hah. Lake on west side of MeMurdo Sound.

Var. capitellata Grum. in Cleve et Grun. "Arctisch. Diat.," K. S!". Vet.-Akad. Handl. Bd. 17, No. 2, 1880, p. 103.

Long. $72 \mu$; lat. $13 \mu$.

Hab. In pond, Cape Royds.

\section{Hantzschia elongata (Hantzsch) Grunow}

H. Amphioxys var. elongata Grun. in V. Heurck, Synops. Diat. Belg. t. 26, f. 21-24. Long. 168-190 $\mu$; lat. 9.5-11 $\mu$; earin. punct. $7-8$ in $10 \mu$.

Hab. Clear Lake. Lake on west side of McMurdo Sound, very common.

\section{SURIRELLACE $A$ \\ Genus-Surirella Turpin. \\ 45 Surirella angusta Kütz.}

Long. $29 \mu$; lat. $9.3 \mu$; $\operatorname{costax} 6$ in $10 \mu$.

Hab. In pond, Cape Royds.

BRIT. ANTARCT. EXPED. 1907-9. VOL. I. 
This diatom was seen very sparingly, but the specimens were quite typical, and agreed exactly both in the poles and the costæ with those in A. Schmidt's Atlas Diat. t. 23, f. 40 .

\section{MYXOPHYCEA}

\section{NOSTOCACE $A$ \\ Genus-Nostoc Vaucher}

\section{Nostoc antarctica sp. 11. (Pl. XXV, Figs. 58-67)}

Thallo initio globoso, parvo, pallide ærugineo, demum irregulariter expanso, fuscescente, tenuissimo et membranaceo, crispato, usque ad $4.5 \mathrm{cms}$. lato, brunneo; trichomatibus in thallo membranaceo densissime contorto-intricatis, confertissimis; cellulis parvis, globosis vel nonnunquam ellipsoideis, confertissimis tanquam parenchymaticis; heterocystis subglobosis, diametro trichomatis duplo latioribus, rare solitariis sed plerumque $2-5$ seriatis ; sporis ellipsoideo-globosis, episporio glabro.

Diam. cell. veget. 2.5-3 $\mu$; diam. heterocyst. $6-7 \mu$; diam. spor. 6.5-7 $\mu$.

Hab. In ponds, Cape Royds. Also in ponds, Mt. Erebus.

This is the most extraordinary Nostoc we have yet examined. Except for its brown colour, the adult thallus presents all the appearance of a Monostroma. It is exceedingly thin, with a crisped or pleated margin, and the trichomes are so densely intricate as to give rise to an apparent parenchyma. In fact, we know of no species of the genus with anything like this density of interlaced trichomes. The heterocysts are rarely single, but more often $2-5$ seriate, a character in common with $N$. commune Vauch.

$N$. antarcticum is perhaps nearest to $N$. minutum Desmaz. (vide Born. et Flah. "Revis. Nostoch. Hétér." Ann. Sci. Nat. $7^{\mathrm{e}}$ série, Bot. vii, 1888, p. 209), from which it differs in the much greater dimensions of the adult thallus, the much denser disposition of the trichomes, the spherical cells, and the greater diameter and seriate character of the heterocysts.

Note.-A species of Nostoc was observed from Blue Lake, forming rounded colonies up to $800 \mu$ diameter. Diam. cells $4 \mu$. The material was only fragmentary and insufficient for accurate identification.

\section{OSCILLATORIACE $Æ$}

\section{Genus-Plectonema Thuret.}

\section{Plectonema notatum Schmidle}

In Allg. bot. Zeitschr. 1901 Nos. 3 and 4, p. 4, Figs. 8, 9 on p. 2.

Crass. fil. 3-3.8 $\mu$, trich. 1.6-2 $\mu$.

Hab. In ponds, Mt. Erebus.

The specimens observed from the Antarctic were more in agreement with 
Plectonema notatum than with any of the other small species of the genus. The false branches were rare and solitary, and the cells were sometimes twice as long as broad.

$$
\text { Genus-Lyngaya C. Ag. }
$$

48 Lyngbya shackletoni sp. n. (Pl. XXV, Figs. 68, 69)

L. filis sparsis inter stratum algarum Myxophycearum, subrectis; vaginis firmis achrois distincte lamellosis; trichomatibus læte ærugineo-ceruleis, inter cellulas non constrictis, massa intercellulari inflato-torulosa et refringenti crebro interruptis, apicibus rectis; cellulis diametro trichomatis quadruplo brevioribus, cytioplasmate minute granulato; cellula apicali elongato-conica et pallidissime æruginea.

Crass. fil. 12-12.5 $\mu$, trich. 8.5-9.5 $\mu$; long. cell. 2-2.4 $\mu$.

$H a b$. Lake at Hut Point.

This species should be carefully compared with $L$. nigra Ag., which is the only species with which it might be confused. The sheaths of $L$. shackletoni are much thicker than those of $L$. nigra and are evidently lamellose; the trichomes are also frequently interrupted by lens-shaped masses of brightly coloured, highly refractive material, and the apical cell, although markedly conical, has no calyptra. Moreover, the end of the trichome is never capitate.

49 Lyngbya martensiana Menegh.

1837; Gomont "Monogr. des Oscillar.," Ann. Sci. Nat. $7^{\circ}$ série, Bot. xvi., 1892 , p. 165 , t. 3 , f. 17.

Crass. fil. 8-9 $\mu$, trich. $6-7 \mu$.

Hab. Blue Lake.

50 Lyngbya arugineo-coerulea (Kütz.) Gomont,

l.c. p. 166 , t. 4 , f. $1-3$.

Crass. fil. $7 \mu$, trich. 5.7.

$H a b$. Ponds on Mt. Erebus.

\section{Lyngbya murrayi sp. n. (Pl. XXV, Figs. 70, 71)}

L. filis inter algas varias Myxophycearum libere natantibus, stratum non formatis, flexuosis; vaginis tenuibus arctissimis et achrois; trichomatibus læte ærugineocœruleis, inter cellulas non constrictis, apicibus rectis, non attenuatis, obtusis vel rotundato-truncatis; cellulis diametro trichomatis $1 \frac{1}{2}-1 \frac{3}{4}$-plo longioribus, cytioplasmate homogeneo cum granulis magnis 1 vel 2 prope dissepimenta utrobique aggregatis.

Crass. fil. 3.1-3.3 $\mu$; long. cell. 5-6 $\mu$.

Hab. Green Lake.

This species probably stands nearest to $L$. versicolor (Wartm.) Gomont, but is distinguished by its free-floating habit, its much thinner sheaths, which are not agglutinated, and by the coarsely granulate dissepiments. 
52 Lyngbyc Kützingii Schmidle

in Allg. bot. Zeitschr. 1896, iii, p. 58; Lemm. Alg. Brandenburg, 1907, p. 136. Leibleinia martensiana Kütz.

Crass. fil. $2-3 \mu$.

Hab. In ponds on Mt. Erebus. Coast Lake. Blue Lake.

Var. distincta (Nordst.) Lemm. in Engler's Botan. Jahrbüch. xxxv, 1905, p. 620. L. martensiana var. distincta Nordst. Alg. aq. dulc. et Char. Sandvic. 1878, p. 4. L. distincta (Nordst.) Schmidle, 1896. L. subtilis West in Journ. Roy. Micr. Soc. 1892 , p. 29 , t. 10 , f. 58 .

Crass. fil. $1.5 \mu$.

$H a b$. In pond, Cape Royds.

In his "Sylloge Myxophycearum" Dr. Achille Forti places L. subtitis as a distinct species, owing perhaps to an error in his description. His "articulis diam. ad 2-plo longioribus" should be "articulis diam. ad 2-plo brevioribus."

\section{Lyngbya limnetica Lemm.}

in Botan. Centralbl. Bd. 76, 1898, p. 154; Alg. Brandenburg, 1907, p. 135 et p. 102 , f. 8 .

Crass. fil. $1 \mu$; long. cell. 1-1.4 $\mu$.

Hab. In pond, Cape Royds. Green Lake.

54 Lyngbya erebi sp. n. (Pl. XXV, Figs. 72a-72d)

L. strato valde expanso, cartilagineo, 3-5 mm. crasso, obscule ærugineo vel vix colorato; filis flexuosis, densissime tortuoso-intricatis; vaginis tenuibus arctis, validis et achrois, crebro vacuis; trichomatibus angustissimis pallide ærugineis, inter cellulas non constrictis, apicibus rectis, obtusis et non attenuatis; cellulis diametro trichomatis paullo brevioribus, contentu homogeneo.

Crass. fil. et trich $0.9 \mu$; long. cell. $0.6-0.8 \mu$.

Hab. In pond on Mt. Erebus.

This narrow Lyngbya formed a thick and very tough cartilagiuous stratum, almost destitute of colour, owing to a great extent to the enormous number of empty sheaths of which it was composed. The sheaths themselves, although so thin, are both strong and persistent, and form a densely contorted mass difficult to tease out. The trichomes are very pale æruginous green, and show no signs of granulation.

In size $L$. erebi compares with the smallest of the plankton-Lyngbyas, but is entirely different from them in habit.

It should be compared with Phormidium glaciale, from which it is distinguished by the nature of its stratum and its strong persistent sheaths, both of which characters give an entirely different aspect to the plant. 


\section{Genus-Phormidium Kütz.}

\section{Phormidium autumnale (Ag.) Gomont}

l.c. 1892 , p. 187 , t. 5 , f. 23,24 ; Johs. Schmidt, "Danmarks blaagroenne Alger," Bot. Tidsskrift, Bd. 22, Heft 3, 1899, p. 348. Ph. uncinatum (Ag.) Gomont, l.c. p. 204, t. 5, f. $21,23$.

Crass. trich. 4.6-7 $\mu$. (Pl. XXV, Figs. 77-85)

Hab. Pony Lake. Coast Lake. Ponds on Hft. Erebus.

This Alga appears to be frequent in the Antarctic regions, and was recorded from the Falkland Islands by Hooker and Harvey as long ago as 1847. It occurred in great abundance in Pony Lake, and the ends of the trichomes were furnished with precisely similar small clusters of Bacteria as one so constantly observes in European specimens.

It not only occurred in pure masses, but was frequent in the strata of other species of Phormidium.

As pointed out by Johs. Schmidt, there is no question of the identity of $P h$. autumnale and $P h$. uncinatum. There are no characters by which it is possible to discriminate between them.

\section{Phormidium retzii (Ag.) Gomont}

l.c. p. 195 , t. 5 , f. $6-9$.

Crass. trich. $6-6.5 \mu$.

Hab. Dried-up lake, Cape Royds, among Ulothrix coqualis Kütz.

57 Phormidium inundatum Kütz.

Spec. Alg. 1849, p. 251 ; Tab. Phycol. I, p. 32, t. 45, f. iii; Gomont, l.c. p. 192, t. 4, f. 31,32 .

Crass. trich. 3.5-4.1 $\mu$.

Hab. Among Calothrix sp. in lake at Hut Point. In pond at Cape Barne, abundant among Oscillatoria sancta.

A slightly thicker form (crass. trich. 4.6-5 $\mu$ ), but well within the limits of size for this species, also occurred in Blue Lake.

58 Phormidium fragile (Menegh.) Gomont

l.c. p. 183 , t. 4 , f. $13-15$.

Crass. trich. 1.2-1.6 $\mu$.

Hab. Pony Lake, Green Lake, and Coast Lake.

Forma tenuis. (Pl. XXV, Fig. 76)

Crass. trich. 0.9-1 $\mu$.

$H a b$. Coast Lake.

59 Phormidium glaciale sp. n. (Pl. XXV, Figs. 73a-73d)

$\mathrm{Ph}$. strato valde expanso, læte æruginoso vel æruginoso-coeruleo, usque ad $2 \mathrm{~mm}$. crasso ; filis flexuosis densissime tortuoso-intricatis, vaginis in muco hyalino diffluen- 
tibus; trichomatibus angustissimis, læte æruginosis, inter cellulas plus minusve constrictis, apicibus rectis non attenuatis nec capitatis; cellulis tam longis quam latis vel paullo longioribus, contentu homogeneo.

Crass. trich. 0.8-0.9 $\mu$; long. cell. 0.8-1.1 $\mu$.

Hab. Blue Lake, Coast Lake, and Clear Lake; in great abundance and forming extensive sheets.

This species was one of the most abundant of the Blue-green Algæ which occurred in certain of the frozen lakes. Most of the specimens were obtained by melting the blue-green sheets from the ice, where they must remain frozen sometimes for several years. It is allied to $P$. angustissimum, but forms a thicker stratum, has slightly thicker and more contorted trichomes, and has shorter cells.

\section{Phormidium angustissimum W. \& G. S. West}

"Welw. Afric. Freshw. Algæ," Journ. Bot. Aitg. 1897, p. 72.

Crass. trich. $0.6-0.7 \mu$; long. cell. $2-4 \mu$.

Hab. Deep Lake, forming thin papery sheets of considerable cxtent and abont $0.1-0.2 \mathrm{~mm}$. in thickness.

This specics was only observed from this one lake, forming extensive sheets similar to those formed by $\mathrm{Ph}$. glaciale, but much thinner. The trichomes are densely intricate and flexuose, but are not so contorted as those of $P h$. glaciale, and the cells are much longer than in that species.

\section{Phormidium antarcticum sp. n. (P1. XXV, Figs. 74, 75a-75g)}

$\mathrm{Ph}$. filis non in strato associatis, sed inter algas varias Myxophycearum libere natantibus, brevibus; vaginis indistinctis, plerumque diffluentibus; trichomatibus brevibus vel brevissimis, pallide ærugineis, valde et subirregulariter spiraliter contortis, apicibus obtusis et non attenuatis; cellulis diametro trichomatis 1-2-plo longioribus, contentu homogeneo.

Crass. trich. $0.6 \mu$; long. cell. 0.6-1.2 $\mu$.

Hab. Pony Lake.

This minute and much-twisted Phormidium was present in quantity in the sediment obtained from under the ice of Pony Lake both in April 1908 and in January 1909. It was not observed in any of the other collcctions, and occurred mixed with various Green and Blue-green Algæ. The trichomes are very short and invariably twisted into some form of spiral, althongh they exhibit great irregularity.

It need not be confused with any of the spirally twisted prankton species of Lyngbya. It has no definite sheath, and is smaller and narrower than any of them. Some specimens showed slight indications of a sheatl which had become diffluent, otherwise the Alga might be regarded as an irregular species of the genus Arthrospira. 
Genuis-Oscillatoria Vaucher

62 Oscillatoria limosa Ag.

1812; Gomont, l.c. p. 230, t. 6, f. 13.

Crass. trich. $14-17 \mu$.

Hab. Pony Lake, Coast Lake, and Green Lake. Also ponds on Mt. Erebus.

This species was abundant in the above-mentioned localities, and in most cases was remarkable for the shortness of its filaments, many of which were only $40-60 \mu$ in length.

63 Oscillatoria sancta Kütz.

Tab. Phycol. I, p. 30, t. 42, f. 7 ; Spec. Alg. 1849, p. 246 ; Gomont, l.c. p. 229, t. 6, f. 12 .

Crass. trich. 12.5-15 $\mu$.

Hab. Pond, Cape Barne.

64 Oscillatoria subproboscidea sp. n. (Pl. XXV, Figs. 91-94)

O. trichomatibus inter varias Oscillatorias libere natantibus, olivaceo-ærugineis, elongatis, rectis vel leviter flexuosis, juxta apicem attenuatis et plerumque subuncinatis, inter cellulas non constrictis; cellulis diametro trichomatis circiter $2 \frac{1}{2}$-plo brevioribus, non elongatis apicem versus; cytioplasmate minutissime granulatis, dissepimenta non granulata; cellula apicali brevi et convexo-obtusa, membranam convexam leviter incrassatam præbens.

Crass. trich. 8.2-9 $\mu$; long. cell. $3-4 \mu$.

Hab. Coast Lake.

This species was frequent in the sediment under the ice of Coast Lake, mixed with O. tenuis and others. It is perhaps nearest to O. proboscidea Gomont, but is considerably narrower, with straight trichomes and rather longer cells. The apex is also different, as although it is somewhat suddenly attenuated and frequently uncinate, it is never capitate.

In thickness $O$. subproboscidea is similar to $O$. chalybea, but there are no constrictions between the cells as in the latter species, and the trichomes are only attenuated close to the apex. The apical cell is also short and possesses a calyptra.

65 Oscillatoria tenuis Ag.

1813 ; Gomont, l.c. p. 240, t. 7, f. 2,3 .

Crass. trich. $7-10 \mu$.

Hab. Coast Lake.

This species was frequent amongst $O$. subproboscidea and a small quantity of o. limosa Ag. The trichomes were typical in all respects, and varied considerably in thickness. 


\section{Oscillatoria producta sp. n. (Pl. XXV, Figs. 86-90)}

O. trichomatibus sparsis inter alias algas Myxophycearum natantibus, ærugineis, subrectis, inter cellulas leviter constrictis, apices versus et juxta leviter attenuatis; cellulis diametro trichomatis 3-4-plo brevioribus; cytioplasmate granulata, dissepimenta non granulata; cellula apicali in processum mamillatum vel digitatum nonnunquam uncinatum, p'us minusve producta, usque diametro $2 \frac{1}{2}$-plo longiori, pellucida, sæpe calyptra convexo-conica ornata.

Crass. trich. 5.3-6.8 $\mu$; long. cell. 1.4-1.8 $\mu$.

Hab. Pond on Mt. Erebus.

Perhaps the nearest species to 0 . producta is the one described as $O$. lloydiana by Gomont (in Bull. Soc. botan. France, xlvi, 1899. p. 39, t. 1, f. 17), from which it is distinguished by its narrower trichomes, the absence of granules at the dissepiments, the differently attenuated apex, and the presence of a calyptra.

It might also be compared with $O$. janthophora Gomont, O. cortiana Menegh., and O. okeni $\mathrm{Ag}$, from all of which it is easily distinguished.

\section{Oscillatoria cortiana Menegh.}

1837 ; Gomont in Ann. Sci. Nat. $7^{\text {e }}$ série, Bot. xvi, 1892, p. 251, t. 7, f. 17.

Forma cellulis paullo brevioribus; crass. trich. 5.8-6.9 $\mu$; long. coll. 4-5.5 $\mu$; crass. apic. trich. $2.8-3.3 \mu$; long. cell. apic. $7.5-10 \mu$.

Hab. Clear Lake, rather scarce among the sheets of Phormidium glaciale.

\section{Oscillatoria priestleyi sp. n. (Pl. XXVI, Figs. 99-101)}

O. trichomatibus libere natantibus, densissime aggregatis, pallide ærugineis, elongatis et subrectis, apicem versus longe attenuatis, apicibus curvatis et sæpc recurvatis, interdum irregulariter flexuosis, obtusis, inter cellulas non constrictis, hinc inde massa intercellulari inflato-torulosa et refringenti interruptis; cellulis subquadratis vel plerumque paullo brevioribus, interdum paullo tumidulis, non elongatis apicem versus; cytioplasmate minutissime granulatis et interdum cum granulo magno subrefringenti ornato; cellula apicali obtusa, nunquam capitata ; calyptra nulla.

Crass. trich. 5-5.9 $\mu$; crass. apic. trich. 2.3-3.2 $\mu$; long. cell. $3-5 \mu$.

Hab. Lake on west side of McMurdo Sound.

The only species related to Oscillatoria priestleyi are $O$. subuliformis Kütz., O. cortiana Menegh., and O. tanganyika G. S. West, with the first of which it should be very carefully compared.

O. priestleyi differs from 0 . subuliformis in the entire absence of undulation from the straight or gently flexuose filaments, in the much more irregular curvature of their attenuated apices, in the relatively shorter cells, which remain short to the very apex of the filament, and in the presence of numerous refractive lens-shaped masses of deeply coloured and deeply staining intercellular substance. The trichomes are 
of the same thickness as the marine $O$. subuliformis, and the gradual attenuation towards the apex is a very similar character.

\section{Oscillatoria formosa Bory}

1827 ; Kütz. Tab. Phycol. I, t. 41, f. 8 ; Gomont, l.c. p. 250, t. 7, f. 16.

Crass. trich. $4.8 \mu$.

Hab. Coast Lake, scarce among O. tenuis, O. subproboscidea, and O. limosa.

\section{Oscillatoria chlorina Kütz.}

Phyc. gener. 1853, p. 185 ; Spec. Alg. 1849, p. 239 ; Tab. Phycol. I, p. 28, t. 39, f. iii ; Gomont, 1.c. p. 243.

Crass. trich. 3.5-4 $\mu$; long. coll. 3.8-5.5 $\mu$.

$H a b$. Green Lake. In pond, Cape Royds.

71 Oscillatoria terebriformis $\mathrm{Ag}$.

1827 ; Gomont, l.c. p. 254, t. 7. f. 24.

Forma tenuis. (Pl. XXVI, Fig. 98)

Forma trichomatibus $3 \mu$ crassis, cellulis subquadratis; dissepimenta granulata; cellula apicali subtruncata.

Hab. In pond, Cape Royds.

72 Oscillatoria amphibia Ag.

1827 ; Gomont, l.c. p. 241, t. 7, f. 4, 5.

Crass. trich. 2-2.1 $\mu$.

Hab. Coast Lake, infrequent among various Myxophyceæ.

Var. robusta var. n. (Pl. XXVI, Fig. 102)

Var. trichomatibus crassioribus; dissepimenta granulos plures pulcherrime coeruleas utrobique præbens.

Crass. trich. $3.5 \mu$.

Hab. In pond, Cape Royds.

\section{Oscillatoria deflexa sp. n. (Pl. XXV, Figs. 95-97)}

O. trichomatibus sparsis et nonnunquam in cæspitibus parvis subspiraliter contortis inter alias Myxophycearum natantibus, rectis, ærugineis, apices versus gradatim attenuatis et juxta apicem subiter deflexis; inter cellulas non constriotis, dissepimenta non granulata; cellulis diametro trichomatis $2-2 \frac{1}{2}$-plo longioribus, cytioplasmate homogeneo; cellula apicali attenuata obtusa, calyptra nulla.

Crass. trich. 0.9-1 $\mu$; long. cell. 2.4-2.9 $\mu$; long. part. deflex. apic. 4.2-4.8 $\mu_{\text {。 }}$

$H a b$. Green Lake. Coast Lake.

This species should be compared with $O$. subtilissima Kütz., O. Kützingiana Näg., and $O$. angustissima W. \& G. S. West, from all of which it differs in the apex of the trichomes and other points. O. minuta Hansg. may also be an allied species. 


\section{CHROOCOCCACE 2 \\ Genus-Asterocystis Gobi}

74 Asterocystis antarctica sp. n. (Pl. XXVI, Figs. 103-106)

A. minuta, inter varias algas libere natantes; filis brevibus, vaginatis, vix ramosis, valde contortis, e serie singula cellularum formatis; vaginis aretis, achrois et gelatinosis; cellulis ante divisionem ellipsoideis, post divisionem subhemisphæricis vel elongato-hemisphæricis, tam longis quam latis vel brevioribus; cytioplasmate ærugineo et granuloso (verisimiliter ut in Chroococco minuto).

Long. cell. 4.5-8 $\mu$; lat. $6-8 \mu$; crass vag. 9-10 $\mu$.

$H a b$. Green Lake.

Asterocystis antarctica is of about the same size as $A$. africana G. S. West (in Journ. Linn. Soc. bot. xxxviii, 1907, p. 196), but is of a different habit and has cells of a different form. The short, contorted filaments, almost without any trace of branches, distinguish it at once from all the other species of the genus.

\section{Genus-Microcystis Kütz.}

75 Microcystis chroococcoidea sp. n. (Pl. XXVI, Figs. 107-114)

M. coloniis parvis, libere natantibus, e cellulis paucis $(6-24)$ compositis, tegumento gelatinoso et achroo, vix conspicuo; cellulis confertis sed irregulariter aggregatis, iis periphericis interdum paullo minoribus, contentu pallide flavo-æruginoso, subtiliter granuloso cum granulis conspicuis majoribus 2-4.

Diam. cell. 4-7 $\mu$; diam. colon. 14-33 $\mu$.

$H a b$. Green Lake.

This member of the Chroococcacer was not uncommon in the strongly saline water of Green Lake. The colonies are very small, free-floating, and often do not consist of more than a dozen cells. The cells are closely aggregated to form a somewhat irregular colony, in which the peripheral cells are sometimes slightly smaller than the others. The cells do not possess an independent envelope, but are all enclosed in a very thin and almost invisible mucous integument. The alga forms a connecting link between the genera Microcystis and Chroococcus, and might equally well be named "Chroococcus microcystoidea."

\section{Genus-GLgocapsa Kütz.}

\section{Glococapsa. shuttleworthiana Kütz.}

Phyc. gener. 1843, p. 175; Tab. Phycol. I, p. 18, t. 23, f. 1 ; Forti, Syll. Myxophy. 1907, p. 37.

Diam. cell. 2.5-3.5 $\mu$, c. integ. prim. 7-8 $\mu$; tegumentis internis intense aurantio-rubris.

Hab. On stones, High Moraines, Mt. Erebus. Also fragmentary in pond, Cape Royds. 


\section{Genus-APhanocaPsa Näg. \\ 77 Aphanocapsa montana Cramer}

Rabenh. Flor. Europ. Alg. II, 1865, p. 50; Forti, Syll. Myxophy. 1907, p. 72. Diam. cell. 2-2.4 $\mu$.

Hab. On stones, High Moraines, Mt. Erebus.

The cells were fairly crowded, and formed yellow-green, gelatinous colonies from 800 to $1300 \mu$ in extent, closely adherent to the stones, and amongst the thalli of Prasiola antarctica Kütz.

\section{Genus-Chroococcus Näg.}

78 Chroococcus minutus (Kütz.) Näg.

Gatt. einzell. Alg. 1849, p. 46; Forti, Syll. Myxophy. 1907, p. 14.

Dianı. cell. $8-11 \mu$; colon. usque ad $60 \mu$ diam.

$H a b$. Green Lake. Pond on Mt. Erebus.

Var. obliteratus (Richter) Hansg. Prodr. Algenfl. Böhm. II. p. 162. Chr. obliteratus Richter in Hauck \& Richter, Phyk. Univ. No. 41 ; Notarisia, 1886, p. 97.

Diam. cell. 6-8 $\mu$; diam. colon. 23-29 $\mu$.

Hab. Coast Lake.

\section{Chroococcus minor (Kütz.) Näg.}

Gatt. einzell. Alg. 1849, p. 47, t. 1A ; Rabenh. Flor. Europ. Alg. II, 1865, p. 30

Diam. cell. $4 \mu$; diam. colon. 18-20 $\mu$.

Hab. In pond, Cape Royds.

Forma minima West in Journ. Linn. Soc. bot. 1894, p. 275, t. 16, f. 18. Chr. minutus var. minimus v. Keissler in Verhandl. der zool.-bot. Ges. Wein, 1901, p. 394, f. 1, 2. Chr. minimus (v. Keissler) Lemm. in Archiv. für Botan. utgifv. af K. Sv. Vet.Akad. Bd. 2, No. 2, 1904, p. 102.

Diam. cell. 1.9-2.2 $\mu$; diam. colon. 22-31 $\mu$.

Hab. Green Lake. Lake on west side of McMurdo Sound.

\section{Chroococcus pallidus Näg.}

Gatt. einzell. Alg. 1849, p. 46, t. I, f. A2; Rabenh. Flor. Europ. Alg. II, 1865, p. 33. Diam. cell. 6-7 $\mu$; diam. colon. 16-21 $\mu$.

$H a b$. Lake on west side of McMurdo Sound.

The colonies were rather irregular and consisted of four or eight almost globose cells. The cell-contents were pale yellow-green and granulose.

\section{Chroococcus cohoerens (Bréb.) Näg.}

Gatt. einzell. Alg. 1849, p. 46 ; Rabenh. Flor. Europ. Alg. II, 1865, p. 30.

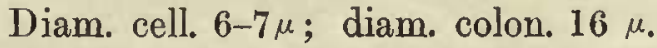

Hab. Green Lake. 
Colonies small and compact, consisting of eight or sixteen regularly arranged cells. Cell-contents of a brilliant blue-green colour and granulose.

Genus-Microcystis Kütz.

82 Microcystis stagnalis Lemm.

in Forschungsber Biol. Stat. Plön. X., p. 150. Polycystis pallida Lemm. P. elongata W. \& G. S. West.

Diam. cell. 1.7-1.8 $\mu$.

$H a b$. Coast Lake.

\section{RIVULARIACE 被 \\ Genus-CaLothrix Ag.}

83 Calothrix epiphytica W. \& G. S. West

"Welw. Afric. Freshw. Alg.", Journ. Bot. 1897, p. 240.

Crass. fil. ad bas. 7.5-8 $\mu$; crass. trich. ad bas. 5.4-5.8 $\mu$.

Hab. Lake at Hut Point.

\section{Calothrix sp. (Pl. XXV, Figs. 55-57)}

C. strato tenui submembranaceo ærugineo-cœruleo; filis subbrevibus dense intricatis et contortis, paullo attenuatis sed non in pilum productis; trichomatibus cœeruleis, gradatim attenuatis, cellula terminali obtusa ; cellulis subtorulosis, rotundatorectangularibus, diametro trichomatis paullo brevioribus vel nonnunquam duplo brevioribus; heterocystis basilaribus singulis et inflato-hemisphæricis.

Crass. fil. ad. bas. 10-12 $\mu$; crass. trich. ad bas. 8-9.6 $\mu$.

$H a b$. Blue Lake.

It is highly probable that this is as yet an unnamed species of Calothrix, but we do not feel justified in expressing a definite opinion until more material has been examined. It occurred in very small thin patches, of a most intense blue-grcen colour, among the tough sheets of Phormidium glaciale. The filaments were much contorted, densely intricate, and quite without any definite arrangement in the stratum. 'The attenuation was slight, and none of the plants showed any signs of hair-like apices. The subtorulose cells are also a feature of the trichomes. 
PLATE XXIV 


\section{PLA'TE XXIV}

FiguRes 1-2. Ulothrix aqualis Kütz. $\times 500$.

Figures 3-4. Ulothrix aqualis Kiitz. forma. $\times 500$.

Figures 5-7. Ulothrix tenerrima Kütz. forma antarctica. 5 and $6, \times 500 ; 7$, $\times$ 1000. py, pyrenoid.

Figures 8-9. Prasiola crispa (Lightf.) Menegh. 8, thallus, natural size; 9, cells of small portion of thallus, $\times 500$.

Figures 10-11. Prasiola antarctica Kütz. 10, thalli, natural size; 11, cells of smali portion of thallus, $\times 500$.

Figures 12-14. Prasiola crispa (Lightf.) Menegh. Hormidium-stage, from vicinity of Cape Royds. $\times 500$.

Figures 15-18. Prasiola crispa var. aspera var. n. $\times 500$.

Figures 19-24. Chlamydomonas intermedia Chodat forma antarctica. $\times 500 . \quad p y$, pyrenoid; st, pigment spot. 23 and 24 show stages of division.

Figures 25-29. Chlamydomonas subcaudata Wille. $\times 500 \quad n$, nuclens; py, pyrenoid; st, pigment spot. 28 and 29 show stages of division.

Figures 30-39. Pleurococcus dissectus (Kütz.) Näg. $\times 500$.

Figures 40-44. Pleurococcus frigidus sp. n. $\times 500 n$, nucleus; py, pyrenoid; $s$, small granules of starch.

Figures 45-46. Pleurococcus pachydermus Lagerh. $\times 500 . \quad n$, nucleus; py, pyrenoid. 46 shows escape of eight daughter-cells (gonidia) from old mother-cell.

Figures 47-48. Pleurococcus pachydermus forma stipitata. $\times 500$.

Figures 49-51. Pleurococcus antarclicus sp. $11 . \times 500$. ol, globules of fatty oil.

Figures 52-54. Pleurococcus antarcticus forma robusta. $\times 500$. 
Brit. Antarct. Exped. 1907-9.

Vol. 1. Plate XXIV.

W. \& G. S. WEST: FRESHWATER ALGA.

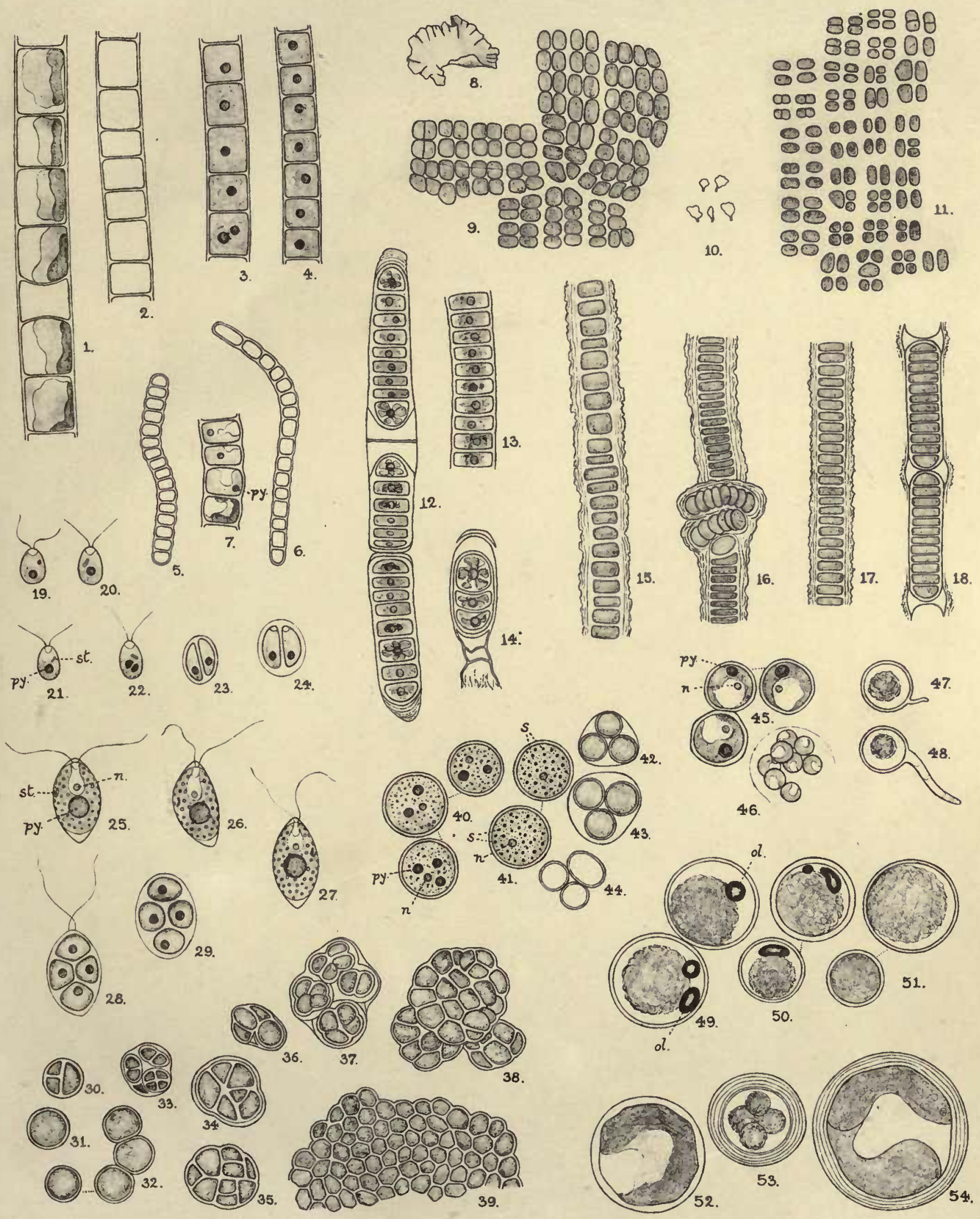

G. S. WEST. ad. nat. del. 

PLATE XXV 


\section{PLATE XXV}

Figures 55-57. Calothrix sp. $\times 500$.

FIgURES 58-67. Nostoc antarctica sp. n. 58, young thalli, nat. size; 59, fully grown thalli, nat. size; 60, margin of adult thallus showing the dense crowding of the trichomes, $\times 500 ; 61-65$, portions of isolated trichomes showing seriate heterocysts, $\times 500 ; 66$, very young thallus, $\times 500 ; 67$, portion of trichome with five spores (sp.), $\times 500$.

Figures 68-69. Lyngbya shackletoni sp. n. $\quad \times 500$.

Figures 70-71. Lyngbya murrayi sp. n. 70, $\times 500 ; 71, \times 1000$.

Figure 72. Lyngbya erebi sp. n. $\times 1000$.

Figure 73. Phormidium glaciale sp. n. $\times 1000$.

Figures 74-75. Phormidium antarcticum sp. n. $\quad \times 1000$.

Figure 76. Phormidium fragile (Menegh.) Gom. forma tenuis. $\quad \times 1000$.

Figures 77-85. Phormidium autumnale (Ag.) Gomont. Various forms, $\times 500$.

Figures 86-90. Oscillatoria producta sp. n. 86, $\times 500 ; 87-90, \times 1000$.

Figures 91-94. Oscillatoria subproboscidea sp. n. $\times 500$.

Figures 95-97. Oscillatoria deflexa sp. n. 95, twisted bundle of trichomes, $\times 100$; 96 and 97 , single trichomes, $\times 1000$. 
Brit. Antarct. Exped. 1907-9.

Vol. 1. Plate XXV.

W. \& G. S. WEST: FRESHWATER ALGAE.
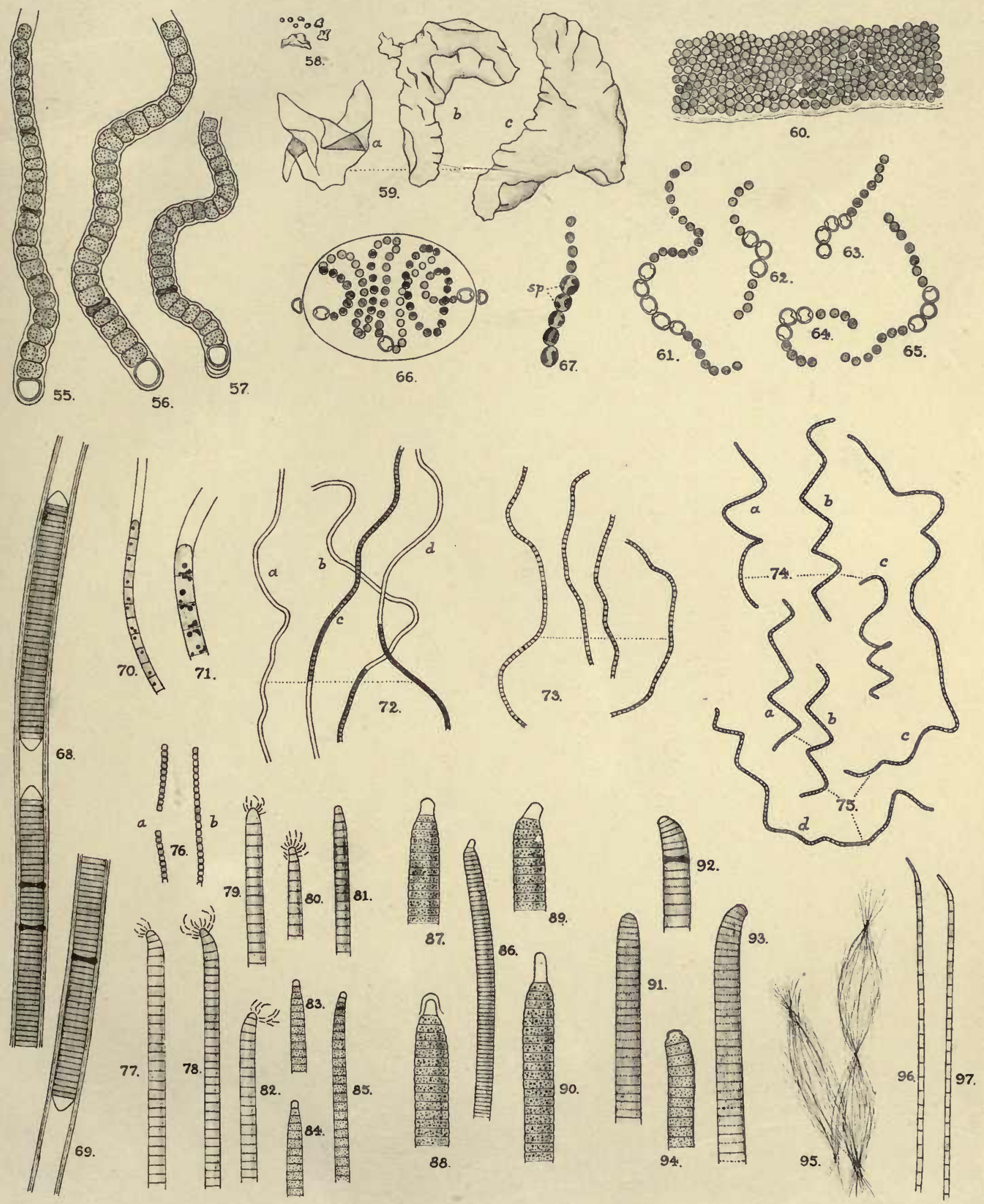

PLATE XXVI

BRIT, ANTARCT, EXPED, 1907-9. VOL.I. 


\section{PLATE XXVI}

Figure 98. Oscillatoria terebriformis Ag. forma tenuis. $\times 500$.

Figures 99-101. Oscillatoria priestleyi sp. n. 99, $\times 500 ; 100$ and $101, \times 1000$.

Figure 102. Oscillatoria amphibia Ag. var. robusta var. n. $a, \times 500 ; b, \times 1000$. Figures 103-106. Asterocystis antarctica sp. n. 103-105, $\times 500 ; 106, \times 1000$.

Figures 107-114. Microcystis chroococcoidea sp. n. $\times 500$.

Figures 115-120. Tropidoneis lavissima sp. n. 115-118 and 120, $\times 500 ; 119$, $\times$ 1000. Fig. 117 is one of the deformed valves not infrequent in Clear Iarke.

Fig. 115 is the girdle view, and Fig. 120 the end view of a frustule.

Figures 121-124. Navicula muticopsis V. Heurck. $\times 1500$.

Figure 125. Navicula glaberrima sp. n. $\times 1000$.

Figures 126-127. Achnanthes brevipes Ag. var. intermedia (Kütz.) Cleve. $\times 1500$.

Figure 128. Fragilaria tenuicollis Heib. var. antarctica var. n. $\quad \times 1500$.

Figure 129. Navicula murrayi sp. n. $\times 1500$.

Figure 130. Navicula murrayi var. elegans var. $n . \quad \times 1500$.

Figure 131. Navicula muticopsiforme sp. n. $\times 1500$.

FigURE 132. Navicula peraustralis sp. n. $\times 1800$.

Figures 133-134. Navicula cymatopleura sp. n. $\times 1500$.

Figure 135. Navicula globiceps Greg. $\times 1500$.

Figures 136-138. Navicula shackletoni sp. n. $\times 1500$.

Figures 139-141. Navicula shackletoni var, pellucida var. n. $\times 1500$. 
Brit. Antarct. Exped. 1907-9.

Vol. 1. Plate XXVI.

W. 8 G. S. WEST: FRESHWATER ALGAE.

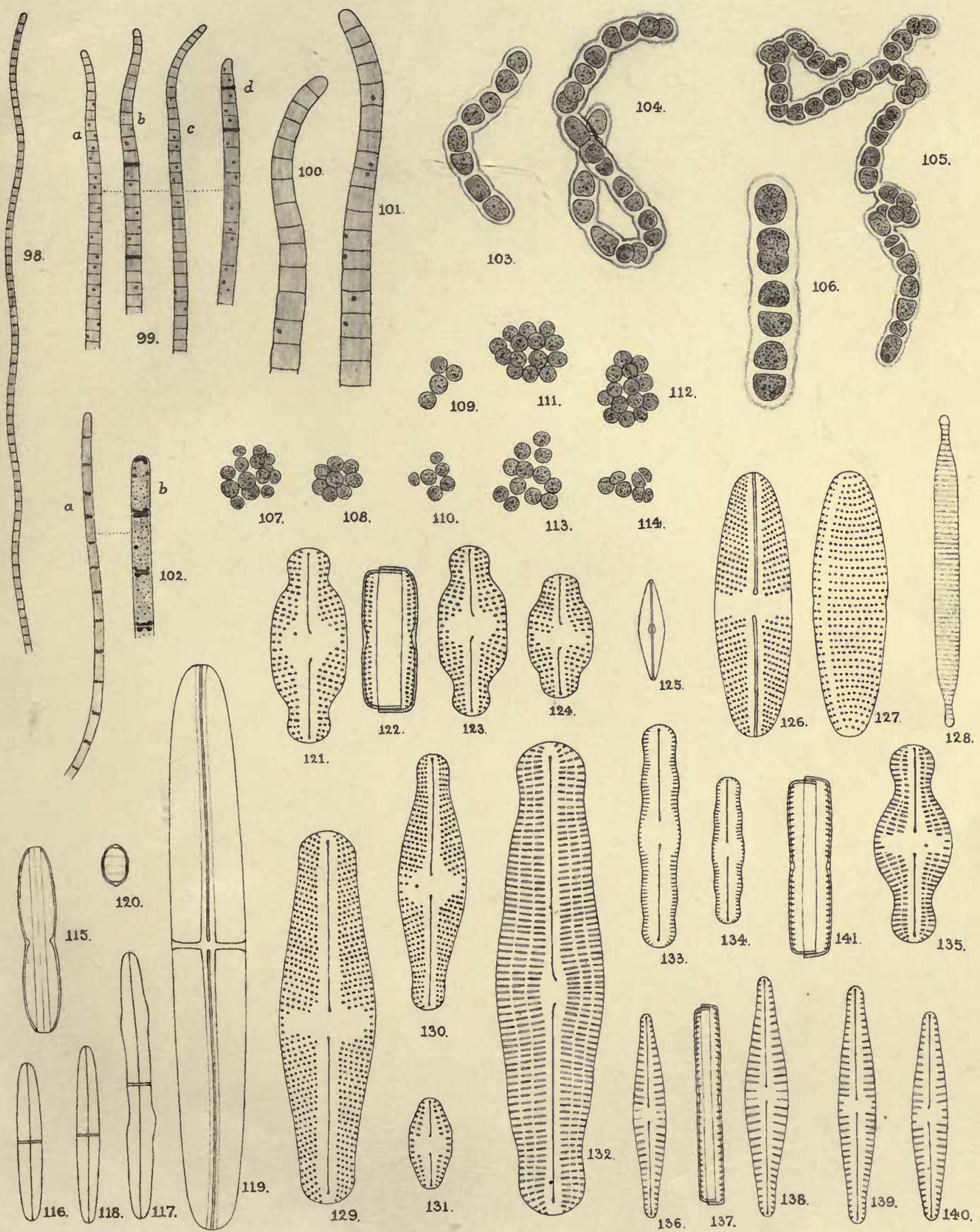

G. S. WEST. ad. nat. del. 




\title{
BRITISH ANTARCTIC EXPEDITION 190\%-9
}

UNDER THE COMMAND OF SIR E. H. SHACKLETON, C.V.O.

\section{REPORTS ON THE SCIENTIFIC INVESTIGATIONS}

\author{
VOL. II \\ BIOLOGY
}

EDITOR - - JAMES MURRAY

\author{
PART I \\ MOLLUSCA \\ BY CHAS. HEDLEY \\ (AUSTRALIAN MUSEUM, SYDNEY)
}

(WITH ONE PLATE)

LONDON

PUBLISHED FOR THE EXPEDITION BY WILIIIAM HEINEMANN

21 BEDFORD STREET, W.C.

1911

ISSUED SEPARATELY, APRIL, 1911

Price $1 s .6 d$. Net 


\section{REPORTS ALREADY ISSUED}

VOL. I. PART I., ON COLLECTING AT CAPE ROYDS BY JAMES MURRAY

Price 1s. 6d. NeT

VOL. I. PART II., ON MICROSCOPIC LIFE AT CAPE ROYDS BY JAMES MURRAY

Price 5s. Od. NET

VOL. I. PART III., ANTARCIIC ROTLFERA BY JAMES MURRAY

Price 5s. Od. Net

VOL. I. PART IV., MUSCI BY JULES CARDOT

Price 1s. Od. NeT

VOL. I. PART V., TARDIGRADA BV JAMES MURRAY

Price 10s. Od. NET

VOL. I. PART VI., RHIZOPODES D'EAU DUUCE BY EUGẼNE PENARD

Price 3s, Od. NeT 


\section{PAR'T I}

\section{MOTLUSCA}

\section{BY CHARLES HEDLEY}

(Prepared by permission of the Trustees of the Australian Museum, Sydney)

(With Plate I.)

Edrorial Note. Mr. Hedley has asked me to preface lis report with field notes on the species. The Mollusca were collected in two localities, within a short distance of one another at Cape Royds, yet of totally diflerent character. The "Bay" is a very small shallow inlet, lying to the east of our camp, between Cape Royds and Cape Barne. It appears to be little affected by currents, or even by storms, for the ice forms early there and stays late. Wherever it has been examined at depths of more than two fathoms, the bottom resembles the bed of a lake in being covered with a fine tenacious black silt. In consequence of the early formation of the winter ice in the Bay we were able to dredge there as early as A pril, and frequently afterwards till July. Then this dredging-ground was lost, and no more work was done in the Bay till February, when the ice had gone ont of part of the Bay. The Bay is only free from ice for a few weeks in summer, perhaps in cold seasons not at all. The dredging was done at depths of between seven and twenty fathouns.

The "Sound" is a situation of very different claracter. The part where most of the dredging was done is at the moutl of the Bay, where the bottom begins to slope down iuto decper water. A strong current prevails there, as indicated by Brocklehurst's Current Indicator; and by the effect on our dledging lines. 'The bottom is fice from und, even in shallow water close by the clifls of Cape Royds. At a depth of less than twenty-five fathoms there are many pebbles and boulders of kenyte and other rocks. At greater depths no pebbles are found, the dredge bringing up only living or dead organisms, which apparently grow so densely crowded together that the dredge nevel touches the bed of the sea, of whatever materials composed.

The molluscan fauna of these two localities differs greatly. In the Bay the dominant forms are Neobuccinem, Anatina, I'ecten, and Yoldia. The delicate Trophon is not rare, and there are many small and even microscopic molluses, both Gastropods and Lamellibranchs.

Yeobuccinum eatoni appears to surpass all the other large species in abundance, but this may be due to its activity and voracity. It comes readily to any bait which is put down for even a short time. No trap or dredge is needed to get them. They hold tiglit on to the bait and come up with it. They must have keen senses, of whatever sort, as the crowds which sometimes covered the bait must have collected from some little distance around. The sliells of Pecten colbecki are very abundant, but the animal was rarely found alive. The first living example was got on June 17, between seven and twelve fathoms. On account of the delicacy of its valves it was removed from the bucket and placed on the ice for safety. The temperature was low, and it showed its disapproval of its first experience of a temperature $\left(-10^{\circ} \mathrm{F}\right.$.) forty degrees below that to wlich it was accustomed by snapping angrily for some time. When replaced in the bucket and conveyed to the house it seemed none the worse, and again snapped when exposerl to the air. It lived for many hours, under the influence of a weak narcotic (Eucaine), thus showing a tenacity of life unusual among Antarctic marine animals, and unexpected in this delicate P'ecten. A very small specimen was dredged on a stony bottom, at a depth of only two fathoms, close to the shore.

The shells of Anatina are very abundant and of large size, but only very small examples were got alive. BRIT. ANTARCT. EXPED. 1907-9. VOL TI. PART 1, ISSUED A PRIL 1911 
It may be that the living molluses are too firmly embedded in the mud to be detached by the dredge. The mud which has been stirred up by the dredging, when allowed to settle in the bucket, is so tenacious that it is with difficulty that a half-buried Anatina shell can be pulled out.

'The living Yoldie, as well as shells, are very plentiful.

In the Sound the large molluses are entirely different. The conspicuous forms of the mudily bottom are absent, except for an occasional empty shell of Anatina or Yoldia, and instead we find Lima, Tritoniella, Philobrya, Natica, and others.

Only the Lima and Philobrya are at all abundant; the other conspicuous forms are rather rare. The Lima is constantly present at depths of twenty-five to eighty fathoms. Very commonly the animal is embedded in a sponge, usually in one of the softer horny kinds.

Some sorts of Opisthobranchs (Tectibranchs) were obtained both in the Bay and the Sound, but the best specimens were got in the mouths of the Big-head Fishes (Trematomus).

A comparison of our collection with that of the Discovery Expedition is instructive for the light it throws on local distribution in the Ross Ser area.

Leaving out of account the Opisthobranchs, which are not yet fully worked out for our Expedition (although Mr. Hedley records a few species), our collection includes ten Lamellibranchs and twenty Gastropods, agaiust fourteen Lamellibranchs and twenty-five Gastropods obtained by the Discovery. Of these, seven Lamellibranchs and twelve Gastropods are common to the two collections. The Discovery had thus twenty species (seven Lamellibranchs and thirteen Gastropods) which were not in our collection, and we had eleven species (three Lamellibranchis and eight Gastropods) which were not in the Discovery collection.

This amount of difference between collections made at stations only twenty miles apart is very considerable. It is more important that one of our most abundant shallow-water species (Yoldia eightsi) did not occur at all at Hut Point (the Discovery winter quarters).

Of the species which occurred in our collection and not in that of the Discovery, one Gastropod and one Lamellibranch were got by the Southern Cross far to the north of our position, and one Gastropod was collected by the Belgica.

Seven of our species (two Lamellibranchs and five Gastropods) are described by Mr. Hedley as new to science.

J. M.

Sir Ernest Shackleton has done me the honour to hand me for report the collection of mollusca accumulated by the British Antarctic Expedition of 1908 under his command. This consists chiefly of specimens dredged by Mr. James Murray through holes and cracks in the ice around Cape Royds. In this neighbourhood the slope of Mount Erebus continues under the sea, so that shallow and deep stations lie near together.

For several feet below the surface all life is destroyed by the floating ice, but below its influence a fauna flourishes which, for the latitude, may be considered luxuriant. The bottom in shoaler depths is described by Mr. Murray as carpeted with a matted growth of weed and sponge, beyond which was an area of soft black inud.

Salient characters of the collection, which strike an observer accustomed to tropical and temperate faunas, are the great chemical erosion which the shells have suffered, and against which some, Yoldix for instance, have dereloped a dense epidermis. A large proportion are frail and thin.

No great number of novelties could be anticipated from this collection, for the Expedition's field of examination had alrcady been exploited by the Discovery; 
while the area searched by the Southern Cross was sufficiently near to infringe upon their prospects. But viewing this collection as a control upon its predecessors and as an intenser study of the fauna of McMurdo Sound, we gain from it a better idea of the distribution of the Antarctic marine fauna.

\section{LAMELLIBRA NCHIATA}

Yoldia eightsi, Couthouy

Smith, Report Collect. Southern Cross, 1902, p. 211. Alive, abundant, from five to thirty fathoms.

\section{Adacnarca nitens, Pelseneer}

Smith, Report Nat. Antarctic Exped., Lamell., 1907, p. 5, Plate LII., Figs. 6-6c. Alive, twelve specimens from eighteen to twenty fathoms.

\section{Philobrya limoides, Smith}

Smith, Report Nat. Antarctic Exped., Lamell., 1907, p. 4, Plate III., Figs. 2-2b. Alive, abundant from ten to eighty fathoms.

\section{Pecten colbecki, Smith}

Snith, Report Nat. Antarctic Exped., Lamell., 1907, p. 6, Plate III., Figs. 9-9a. Several living specimens, largest about $83 \times 79 \mathrm{~mm}$., from two to twelve fathoms. Several double and many single and broken valves from ten to twelve fathoms.

\section{Lima hodgsoni, Smith}

Sınith, Report Nat. Autarctic Exped., Lamell., 1907, p. 6, Plate III., Figs. 8-8b. Alive, abundaut from ten to eighty fathoms.

\section{Aratina elliptica, King and Broderip}

Smith, Report Nat. Antarctic Exped., Lamell., 1907, p. 1. Alive, abundant from seven to thirty fathoms.

\section{Thracia meridionalis, Smith}

Smith, Report Nat. Antarctic Exped., Lamell., 1907, p. 1.

Alive, a few specimens, mostly broken, from ten to eighty fathoms.

\section{Cardita astartoides, Martens}

Smith, Report Nat. Antarctic Exped., Lamell., 1907, p. 2. A couple of broken valves from ten to twenty fathoms. 


\section{Kellia nimrodiana, sp. nov. (Plate I., Figs. 1-4)}

Shell, subrhomboidal, slightly inequilateral, thin, inflated, glossy, white. Sculpture: fine irregular concentric growth lines without radials. Hinge line rather straight, umbo tumid, prodissoconch conspicuous. Ligament internal, right valve with a prominent cardinal knob, left valve with a feeble ridge, no laterals. Length, $3 \cdot 8$; height, $4 \cdot 25$; depth of conjoined valves, $3.1 \mathrm{~mm}$.

Fifteen specimens alive from ten to twenty fathoms off Cape Royds.

\section{Solecardia antarctica, sp. nov. (Plate I., Fig. 5)}

Shell small obloug compressed, semi-transparent, gaping at each end, polished, with a few radial striic. Length, 1.25 ; height, $0.8 \mathrm{~mm}$.

Five specimens alive from ten to twenty fathoms off Cape Royds.

\section{Gastropoda}

\section{Lepete antarctica, Smith}

Smith, Riep. Nit. Antarctic Exped., Gast., 1907, 1. 12, Plate 1I., Figs. 11-11\%. 'I'wo specimens alive from eighteen to eighty fathoms.

\section{Valvatella refulgens, Smith}

Smith, Rep. Nat. Antarctic Exped., Gast., 1907, p. 11, Plate II., Fig. 7. Abumdant alive from eighteen to eighty fathoms.

\section{Valvatella crebrilivulatu, Smith}

Smith, Rep. Nat. Antarctic Exped., Gast., 1907, p. 11, Plate II., Fig. 9. Abundant alive from ten to twenty fathoms.

\section{Lacuna macmurdensis, sp. nov. (Plate I., Fig. 6)}

Shell small, turbinate, thin, and loosely coiled. Colour, pale buff. Sculpture: three strong peripheral keels, beneath which are two smaller threads. Base flattened, angled at the margin of a rather wide spiral umbilicus. Major diam., $3.5 \mathrm{~mm}$.

A single broken specimen from ten to twenty fathoms off' Cape Royds.

This appears to represent L.notoreculensis, Melvill and Standen, * from the opposite coast of Antarctica. It differs by having the shoulder of the whorl sloping instead of flat, fewer and more prominent keels, and a broad smooth area between the lowest keel and the umbilical margin.

" Melvill and Standen, Trans. Roy. Soc. Edinburgh, xlvi., 1907, p. 131, Plate, Figs. 3-3a. 


\section{Rissoce adarensis, Smith}

Smith, Rep. Nat. Antarctic Exped., Gast., 1907, p. 8, Plate II., Fig. 2. Six shells from ten to twenty fathouns.

\section{Rissoa fraudulenta, Smith}

Smith, Rep. Nat. Antarctic Exped., Gast., 1907, p. 9, Plate II., Fig. 3. One shell from ten to twenty fathoms.

\section{Rissoa gelida, Smith}

Snith, Rep. Nat. Autarctic Exped., Gast., 1907, p. 9, Plate II., Figr. 5. Alive, twenty specimens from ten to twenty fathoms.

\section{Rissoa glacialis, Smith}

Smith, Rep. Nat. Antarctic Exped., Gast., 1907, p. 9, Plate II., Fig. 4. 'Two shells from ten to twenty fathoms.

\section{Capulus subcompressus, Pelseneer}

Pelseneer, Result voy. Belgica, Moll., 1903, p. 20, Plate V., Figs. 52-54.

One alive from "Bay, 2/09." This is an addition to the fauna of this quadrant of Antarctica.

\section{Lovenella antarctica, Smith}

Smith, Rep. Nat. Antarctic Exped., Gast., 1907, p. 10, Plate 1I., Figs. 6-6ce. A single shell. (Loc. Sound, twenty-five to fifty fathoms, "6/7/08")

\section{Lovenella austrina, sp. nov. (Plate I., Fig. 7)}

Shell small elongate-conical, thin and semi-transparent. Colour pale buff. Whorls ten, inclucling a smooth helicoid protoconch of a whorl and a half. Sculpture: three slender spiral keels on each whorl, of which one margins the lower suture, one is peripheral, and one intermediate; on the last whorl an incipient thread appears above the periphery and another on the base. 'These are beaded by the passage of fine numerous perpendicular irregular riblets which also cancellate the interspaces. Aperture subcircular, angled above, notched below by a very short perpendicular canal, columella thickened, arched, outer lip thin. Length, 8; breadth, $2 \cdot 5 \mathrm{~mm}$.

Twenty specimens alive from ten to twenty fathoms off Cape Royds, June 1908.

In size and shape closely resembling $L$. contarctica, but differing by fewer more delicate spirals and thinner shell. Cerithium charcoti, Lamy,* from Booth Wandel

\footnotetext{
* Lamy, Exped. Charcot, Moll., 1906, p. 1, Plate I., Fig. 1.
} 
Island, seems to be related, but is broader and has an extra keel on the shoulder of the whorl.

\section{Thestire innocens, Smith}

Smith, Rep. Nat. Antarctic Exped., Gast., 1907, p. 4, Plate I., Figs. 1-1b.

A single shell, Sound, twenty-five to fifty fathoms.

\section{Vermicularia murayi, sp. nov. (Plate I., Fig. 8)}

Shell solitary, small, solid, compactly coiled in about three discoidal whorls, the last rising free for almost a third of a revolution. Sculpture: on the upper surface three prominent equidistant spiral ridges parted by deep interstices. Aperture circular, slightly lobed. Diameter of coil, $4 \cdot 25$; diameter of aperture, $1 \cdot 65 \mathrm{~mm}$.

Several specimens, mostly young and fragmentary, from sixty to eighty fathous off Cape Royds.

This species is closely related to V. waitei, Hedley, ${ }^{*}$ from off Sydney, but is larger, more solid, has the spirals closer, and does not seem to develop variceal rings. It is named in honour of Mr. James Murray, the Biologist of the Expedition.

\section{Octostomiopsis major, sp. nov. (Plate I., Figs. 9-10)}

Shell ovate-conical, subperforate, very thin. Whorls four and a half, rounded, parted by deep sutures. Colour, white. Sculpture : on the second whorl half a dozen spiral punctate lines, the remainder smooth, save for microscopic incremental threads. Aperture roundly pyriform, outer lip thin, effuse anteriorly. Columella flattened, expanded over the axial perforation and then sharply bent. Length, 6 ; breadth, $4 \mathrm{~mm}$.

Type labelled "Bay, July, 1908 "; another specimen eighteen to twenty fathoms, and two more from sixty to eighty fathoms off Cape Royds. All alive.

The genus Odostomiopsis was proposed by Thiele $\dagger$ for the reception of two species from Kerguelen. To this genus should probably be referred Admete (?) limnaceformis, Smith, + also from Kerguelen. The appearance of the species suggests to me that possibly it may be, like Stilifer, a parasite upon Echinoderms.

\section{Neobuccinum eatoni, Smith (Plate I., Figs. 11-12)}

Smith, Rep. Nat. Antarctic Exped., Gast., 1907, p. 1.

Alive, abundunt from five to sixty fathoms. The expeditions led by Dr. Bruce $\S$ and Dr: Charcot respectively have recently extended the range of this species to

* Hedley, Mem. Austr. Mus., IV., 1908, p. 846, Fig. 72.

$\dagger$ Thiele, in Martens Gast. d. deut. Tiefsee Exped., 1898-1899, p. 68 (1903); not Odostomopsis, Blanckenhorn, Beitr. z. Geol. Syriens, 1890.

‡ Smith, Phil. Trans. Roy. Soc. Lond, clxviii, 1879, p. 17 , , Plate IX., Fig. 4.

§ Wilton, Zoological Log, Scotia, 1908, p. 2, Plate XXIV., Fig. 74. 
the opposite coast of the continent. The radula has lately been redescribed by Professor Thiele.*

All the adult specimens have the apex eroded, but the youngest examples show it (Fig. 11) to be dome-shaped and paucispiral.

The collection contains a quantity of molluscan ova labelled "7-20 fath., June 1908," occurring singly or plastered together in masses. From its size and abundance these can with some confidence be aseribed to $N$. eatoni. Each capsule (Fig. 12) is a hemispherical orange boss about a third of an inch in diameter and surrounded by a marginal membrane. The ova of Cominella densisculpta, Martens, $\uparrow$ seem to be similar.

\section{Amcenopsis rossiana, Smith}

Smith, Rep. Nat. Antarctic Exped., Gast., 1907, p. 5, Plate I., Figs. 6-6a.

Three dead and broken shells fiom five to twenty fathoms.

\section{Natica grisea, von Martens}

Watson, Rep. Chall., Zool., XV., 1886, p. 432., Plate XXVIII., Fig. 5 ; Thiele, Deut. Tiefsee Exped., VII., p. 64, Plate VIII., Fig. 44.

Two dead shells from ten to twenty fathoms.

\section{Lamellaria mollis, Smith}

Smith, Report Coll. Southern Cross, 1902, p. 205, Plate XXIV., Figs. 19-21.

Two small specimens from ten to eighty fathoms.

\section{Trophon sheckletoni, sp. nov. (Plate I., Fig. 13)}

Shell biconical, large, and thin. Colour dead white. Whorls five, and a subulate smooth protoconch, turreted, rather rapidly increasing. Sculpture: broad imbricate thin lamellæ, spreading from the base upwards, produced above in hollow curled spouts which crown the whorl, thence continuing to the suture in a low oblique limb. On the last whorl there are from twelve to fourteen lamellæ, which continue in a diminishing series up the spire. Interlamellar spaces are scored by fine spiral strix and more conspicuous scratches in the line of growth. Aperture ample, ovate. Canal rather short, screwed to the left, externally with imbricating hoods formed by bases of successive lamellæ. Specimen figured, $26 \mathrm{~mm}$. long, $18 \mathrm{~mm}$. broad. A larger example is $33 \mathrm{~mm}$. long and $23 \mathrm{~mm}$. broad.

Ten specimens, several alive, from seven to twenty fathoms off Cape Royds.

This appears to be closely related to $T$. coutmanensis, Smith, $\ddagger$ from which it

* Thiele, Deut. Tiefsee Exped., VII., p. 168, Plate IX., Fig. 57.

$\uparrow$ Martens and Pfeffer, Jahrb. Hamb. wiss. Anstal. III., 1886, p. 78, Plate I., Fig. 3.

¥ Smith, Discovery, Moll., p. 2, Plate I., Figs, 4-4b. 
differs by greater size, broader shape, more compact spire, shorter and more bent canal. Seeing the variability of the genus, I distinguish this as new with some diffidence, but the series before me is quite uniform, and $T$. combmanensis is reported from much deeper water, viz., 100 fathons. As the handsomest novelty in the collection, it is dedicited to the intrepid leader of the Expedition.

The apex is of the pattern figured for 'T. coulmanensis. In aged specimens several of the spire whorls are usually destroyed by erosion. The interlamellar spaces of the last whorl are usually packed with sponges and diatoms, thus providing the shell with an additional overcoat, a possible defence against chemical erosion.

\section{Tropleon longstaffi, Smith}

Smith, Rep. Nat. Antarctic Exped., Gast., 1907, p. 3, Plate I., Figs. 3-3d (Plate I., Fig. 14).

Three specimens alive from twenty to eighty fithoms.

As Mr. Smith observed, the upper whorls are more closely ribbed than the last. This causes much dissimilarity between younger and older shells. An immature shell $25 \mathrm{~mm}$. in length is here figured.

\section{Pliline apertissima, Smith}

Smith, Rep. Coll. Southern Cross, 1902, p. 208, Plate XXIV., Fig. 23.

Twenty living specimens from ten to twenty fathoms.

\section{Plitine centarcticr, Smith}

Sunith, Rep. Coll. Sonthern Cross, 1902, p. 208, Plate XXIV., Fig. 1.

Six living specimens from ten to twenty fithoms. Others from stomach of fish (Big-head, Trematomus).

\section{Clione antarctica, Smith}

Smith, Rep. Coll. Southern Cross, 1902, p. 210, Plate XXV., Figs. 7-8. Two specimens from surface near Cape Royds.

\section{Limacina antarctica, Woorward}

Smith, Rep. Coll. Southern Cross, 1902, p. 209.

A few specimens from surface near Cape Royds. Their shells were dissolved by the formol in which they were placed.

\section{Tritoniella belli, Eliot}

Eliot, Rep. Nat. Antarctic Exped., Nudibr., 1907, p. 6, Figs. A, B.

Several specimens from twenty to fifty fathoms off Cape Royds. Some coils of molluscan ora marked " $15-25$ fath., $7 / 08$ " probably belong to this species. 
PLATE I

BRIT. ANTAROY. EXPED. 1907-9. VOL. II. 


\section{PLATE I}

Figures 1-4.-Kellia nimrodiana, Hedley . • . 4

Figure 5.-Solecardia antarctica, Hedley . . . . . 4

Figure 6.-Lacuna macmurdensis, Hedley . . . . . 4

Figure 7.-Lovenella austrina, Hedley . . . . 5

Figure 8.-Vermicularia murrayi, Hedley _ . . 6

Figures 9-10.-Odostomiopsis major, Hedley . . . . 6

Figure 11.-Apex of Neobuccinum eatoni, Smith a . 6

Figure 12.-Eggs of Neobuccinum eatoni, Smith 7

Figure 13.-Trophon shackletoni, Hedley . . . . . 7

Figure 14.-Trophon longstaffi, Smith. . . . : : 8 
HEDLEY : MOLLUSCA
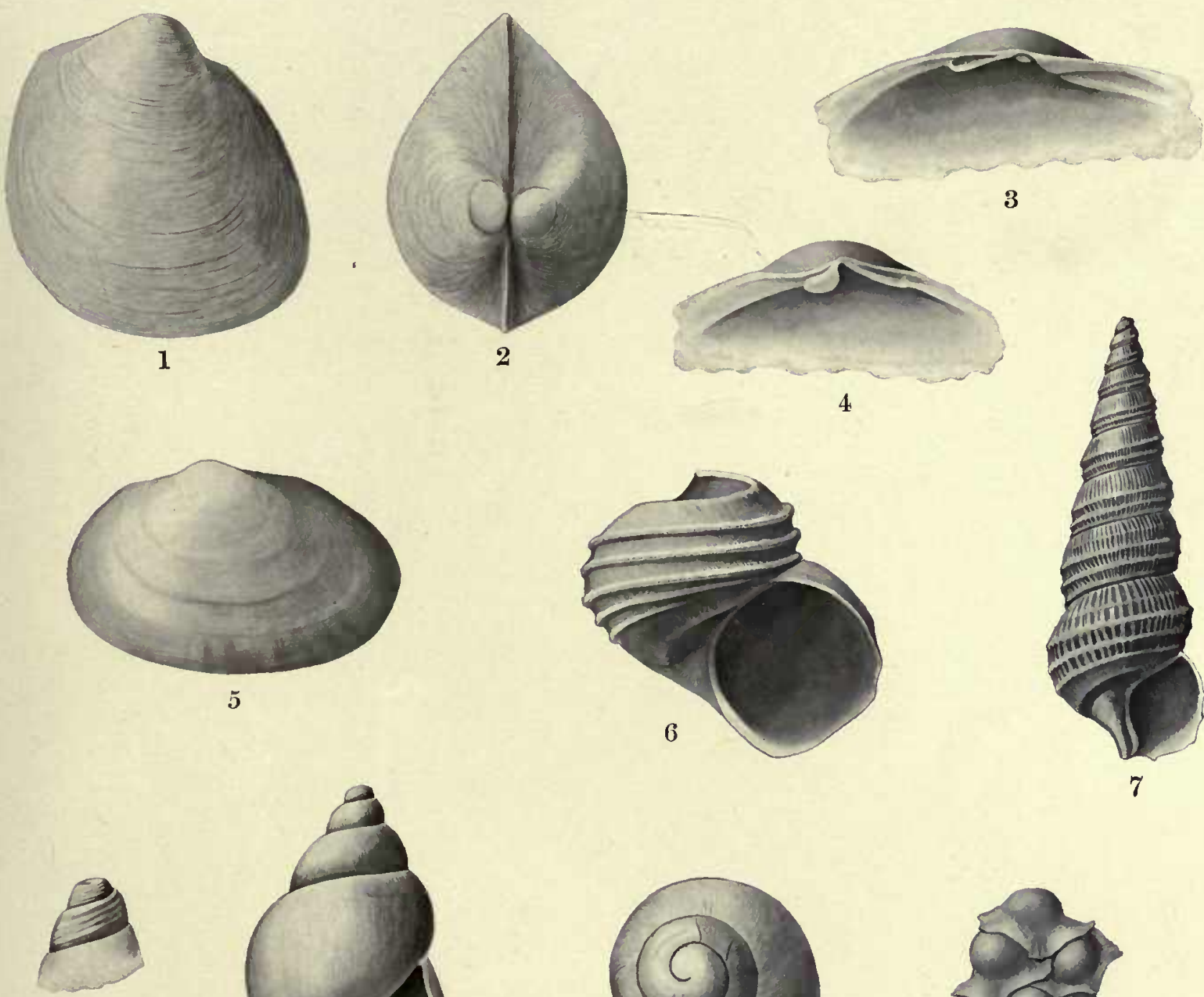

10
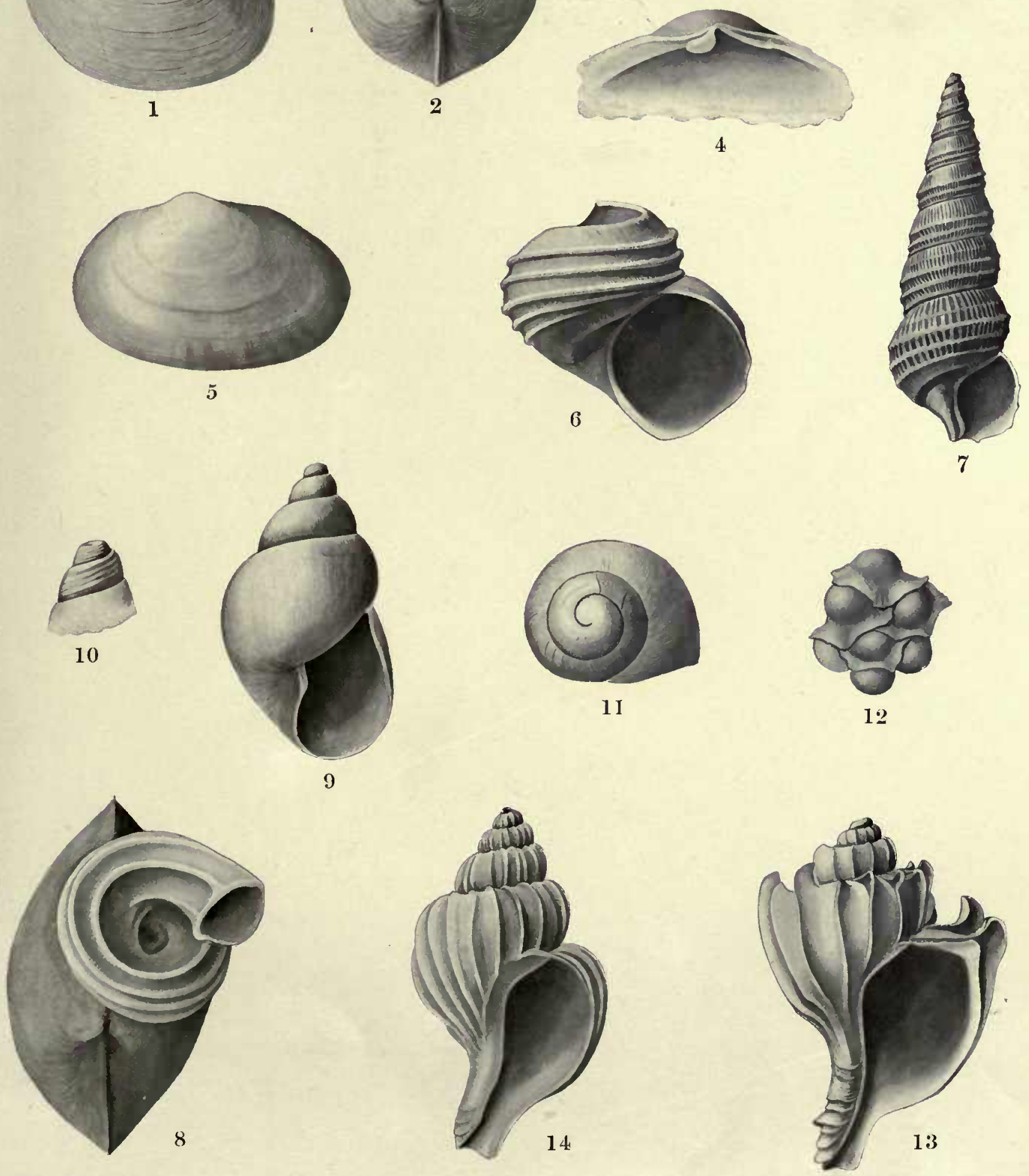

Miss West del. 




\title{
BRITISH ANTARCTIC EXPEDITION 190\%-9
}

UNDER THE COMMAND OF SIR E. H. SHACKLETON, C.V.O.

REPORTS ON THE SCIENTIFIC INVESTIGATIONS

\author{
VOL. II \\ BIOLOGY
}

EDITOR - - JAMES MURRAY

PART II

ANTARCTIC FISHES

BY EDGAR R. WAITE, F.L.S.

(WIT'H ONE PLATE)

LONDON

PUBLISHED FOR THE EXPEDITION BY WILIIAM HEINEMANN

21 BEDFORD STREET, W.C.

1911

ISSUED SEPARATELY, APRIL, 1911

Price $1 s .6 d$. Net 


\section{REPORTS ALREADY ISSUED}

VOL. I. PART I., ON COLLECTING AT CAPE ROYDS BY JAMES MURRAY Price 1s. 6d. NeT

VOL. I. PART II., ON MICROSCOPIC LIFE AT CAPE ROYDS By JAMES MURRAY Price 5s. Od. NeT

VOL. I. PART III., ANTARCTIC ROTIFERA BY JAMES MURRAY

Price 5s. Od. NeT

IOL. I. PART IV., MUSCI BY JULES CARDOT

Price 1s. Od. NeT

VOL. I. PART V., TARDIGRADA BV JAMES MURRAY

Price 10s. Od. NET

VOL. I PART VI., RHIZOPODES D'EAU DOUCE BY EUGENE PENARD

Price 3s. Od. NET

VUL. II. PART I., MOLLUSCA

BY CHARLES HEDLEY

Price 1s. 6d. NET 


\title{
PART II \\ PISCES \\ A NTARCTIC FISHES
}

\author{
BY EDGAR R. WAITE, F.L.S.
}

Curator, Canterbury Museum, New Zealand

(With Plate II.)

THE collection of fishes placed in my hands for report by Sir Ernest Shackleton is quite a small one, comprising five species only.

Of these, four were described by Dr. Boulenger from the proceeds of the Southern Cross Expedition.* When examining this latter collection, Boulenger separated off, on an osteological character, certain Nototheniids under the name Trematomus: four species were referred to this genus, namely, $T$. newnesi, T. borchgrevinki, T. hansoni, and T. bernacchii, all from the Antarctic, and new, whilst fifteen were retained as Notothenia, two only of which were taken in Antarctica, namely, $N$. nicholai and $N$. coriiceps.

Reporting on the fishes of the National Antarctic Expedition, 1901-1904, taken on the voyage of the Discovery, Boulenger $t$ records three of the four known species of Trematomus, that is, T. borchgrevinki, T. hansoni, and T. bernacchii, and four species of Notothenia, two of which were new, namely, $N$. scotti and $N$. hodgsoni.

Among the collection obtained by the Expédition Antarctique Française, 19031905, Professor Vaillant $\ddagger$ found eight species of Notothenia, but not a single species of Trematomus.

In the absence of the reports by Dollo on the fishes of the Belgica Expedition, and by Lönnberg on those of the Swedish South Polar Expedition, I cannot make further comparison, and the want of the latter paper makes it impossible for me to specifically determine, at present, the single example of the genus Artedidraco taken on the Expedition.

Lönnberg has described two species of this genus, namely, Artedidraco mirus and

* Boulenger, Southern Cross Exped. Report, 1902, Pisces, p. 174.

+ Boulenger, Zoology, Nat. Antarct. Exped., Fishes, 1907.

‡ Vaillant, Expéd. Antarct. Franç., 1906, Poissons.

BRIT. ANTARCT. EXPED. 1907-9. VOL. II. PART 2, ISSUED APRIL 1911 
A. skottsbergi, but their distinguishing characters are not at present known to me.

The four species of fishes which have been identified are :

Trematomus bernacchii, Boulenger.

Trematomus hansoni, Boulenger.

Trematomus newnesi, Boulenger.

Pleuragramma antarcticum, Boulenger.

The gill cavities of the two first named yielded small crustaceans, while parasitic forms were found upon T. bernacchii. All were submitted to Dr. Charles Chilton, and he has kindly identified them as follows:

Euphausiacea.

A single damaged specimen, not identifiable.

Isopoda.

Antarcturus franklinii, Hodgson, one imperfect specimen.

Amphipoda.

Orchomenopsis rossii, Walker, several specimens.

Orchomonella pinguides, Walker, several specimens.

Harpinia obtusifrons, Stebbing, one specimen.

Leptamphosus nova-zealandia, G. M. Thomson (=Oradarea longimana, Walker), one specimen.

Copepoda.

Calanus, sp., one specimen.

Parasitic Copepod, several specimens from T. bernacchii.

Trematomus, Boulenger, 1902

Trematomus bernacchii, Boulenger

Report Southern Cross Collections, 1902, p. 181, Plate XIV.

This species is characterised by the narrow interorbital space, which is also devoid of scales, with the exception of a few disposed in a single median longitudinal row.

In most of the examples preserved the upper half of the first dorsal fin is black or blackish, as described, though in some there is no trace of such; the other fins bear no markings. In addition to the coloration described by Boulenger, a few specimens possess a black blotch on the upper part of the opercle. The ground colour in preservative is reddish brown, but the red tint is probably more pronounced in life, for Mr. Murray has recorded the colour of some examples as "strongly ruddy," "light ruddy," \&c.

Specimens examined were in full ripe roe when taken on August 25, 1908; the ova are bright yellow in colour and very large, measuring $3.8 \mathrm{~mm}$. in diameter. 
Eighteen specimens were preserved, of which the largest measures $239 \mathrm{~mm}$. in length; they were localised as follows:

Nos. 1-3.-The Bay, Cape Royds, taken in trap 18 fathoms, May 20, 1908.

No. 4. -The Bay, Cape Royds, collected by Mawson, May 11, 1908.

Nos. 5-7.-Cape Royds, 30-80 fathoms, August 1908.

Nos. 8-13.-Bay, 10-20 fathoms, June 1908.

No. 14.-The Bay, Cape Royds, dredge 10-20 fathoms, May 12, 1908.

Nos. 15-18. - Sound, 10 fathoms, July 7, 1908.

I found small examples of Trematomus newnesi in the digestive tracts of some of the specimens, and the gills of most of the fishes submitted harboured many crustaceans; these have been submitted to Dr. Charles Chilton, who furnished the accompanying report. A Copepod (Calanus, sp.) was found to be parasitic on this fish.

\section{Trematomus hansoni, Boulenger}

Report Southern Cross Collections, 1902, p. 180, Plate XIII.

The narrow scaly interorbital space and the strongly barred fins are characteristic of this species, the markings in the specimens preserved being much more pronounced and better defined than portrayed by Boulenger: this feature was recognised as distinctive by Mr. Murray, who wrote: "Big-heads with black fins and markings." One example has the edge of the preopercle white, continued as a band across the occiput.

Though the ground colour in preservative is brownish, Mr. Murray renders the tint in fresh specimens as "dark greenish," "light grey," \&c.

Of six examples submitted the largest measures $249 \mathrm{~mm}$. in length.

The following are the localities of the specimens:

Nos. 1-2.-In fish-trap, Cape Royds, 25 fathoms, September 1, 1908.

No. 3 (cut in two).-Found on ice beside seal-hole in the Bay, Cape Royds, May 1908.

Nos. 4-6.-In fish-trap, Cape Royds, 25 fathoms, August 25, 1908.

Dr. Charles Chilton has examined the crustaceans found in the gill cavities of these fishes, and his report is printed herewith.

\section{Trematomus newnesi, Boulenger}

Report Southern Cross Collections, 1902, p. 177, Plate XI.

With two exceptions all the examples referred to this species are small. The largest measures $137 \mathrm{~mm}$. in length; most of the others are much smaller.

The relatively wide space between the eyes is a character common also to $T$. borchgrevinki, Boul., but $T$. newnesi is distinguishable from that species by the strongly marked and tubular lateral lines.

The specimens placed in my hands agree generally with the description of this 
species, but the tail is truncate and not rounded, the principal outer rays being as long as the inner ones. The pores on the upper surface of the head are, on the whole, as illustrated, but the median pore is placed more forward than shown, so that the five interorbital pores form a cross, the median pore being nearly in the axis.

Young examples have much the appearance of Notothenia hodysoni, Boul.,* and were so tentatively named by Mr. Murray. I have, however, examined the scapular arch, and find them to possess the distinguishing character of Trematomus; moreover, the vertebræ number fifty-four, which is the number given by Boulenger for T. newnesi.

The localities of the eleven specimens submitted are as follows:

Nos. 1-6.-Backdoor Bay (Priestley), 5-10 fathoms, February 6, 1909.

No. 7.-The Bay, Cape Royds, 5-10 fathoms, May 8, 1908.

No. 8. - "In mouth of Big-head," taken in fish-trap, Cape Royds, 25 fathoms, September 1908.

Nos. 9-11.--The Sound, Cape Royds, 10-25 fathoms, July 1908.

Pleuragramma, Boulenger, 1902

Pleuragramma antarcticum, Boulenger

Report Southern Cross Collections, 1902, p. 187, Plate XVIII.

The larger of the two specimens preserved was contained in a bottle with examples of Trematomus newnesi, labelled "Backdoor Bay, Priestley, five to ten fathoms, February 6, 1909"; the smaller "one was with specimens of T. hansoni, August 25, 1908.

The appearance of the fishes suggests that they were taken from the stomachs of a larger fish, or of a seal, all the fins having been more or less digested away.

The type specimens were also in poor condition, but were sufficiently complete to enable an accurate description and figure to be made, as confirmed by Vaillant, $\uparrow$ who had two excellent examples from the "Française" Expedition. He was enabled to give a greater range in the number of fin rays, and shows that a rudimentary lateral line exists on the hinder part of the body, whereas Boulenger did not find trace of such. Vaillant gives detailed descriptions and figures of the scales. The scales, though thin, are very adherent, and many of them still remain on our fishes, though, as above stated, the digestive process has proceeded to a considerable extent, and in the case of the larger example has removed the whole of the hinder part of the body.

One of our fishes appears to have been larger than any previously obtained, though its length, except by analogy, cannot be measured; in its mutilated state it measures $178 \mathrm{~mm}$. The head, exclusive of the projecting lower jaw, is $55 \mathrm{~mm}$. in length,

* Boulenger, Nat. Ant. Exped., II., 1907, Fishes, p. 2, Plate II. (I. in text), Fig. 2.

† Vaillant, Expéd. Ant. Française, 1906, Poissons, p. 48, Figs. 3 and 4. 
and this, contained three and a half times in the length of the body (the proportion approximately rendered by Boulenger and Vaillant), would yield a length of $193 \mathrm{~mm}$.

\section{ARTEDIDRACo, Lönnberg, 1908}

Since writing the foregoing I have received the account of the fishes of the Swedish South Polar Expedition by Lönnberg. *

The genus Artedidraco is therein diagnosed, and is represented by two speciesA. mirus and A. skottsbergi.

The specimen previously referred to as a member of this genus, but which, owing to the want of Lönnberg's paper, could not be specifically determined, proves to be a species distinct from either of the two previously described forms. It will be known as

Artedidraco shackletoni, sp. nov. (Plate II.)

$$
\text { B. V. ; D. V. } 27 \text {; A. } 20 \text {; V. I. } 5 \text {; P. } 15 \text {; C. } 12 \text {; L. lat. } 19+19 .
$$

Head broad, depressed; body rounded anteriorly, compressed behind. Length of head, 2.8 ; height of body, 4.2 ; length of caudal, 3.7 in the total ; diameter of eye, $3 \cdot 7$; interorbital space, $10 \cdot 2$; and length of snout, $4 \cdot 1$ in the head.

Mouth large and horizontal; the maxilla extends to below the middle of the eye, and the upper jaw is the longer; mental barb simple, its length equal to the diameter of the eye. The eye is large and prominent and cuts the upper profile; the nostril is in a long tube, placed a little nearer to the eye than to the margin of the preorbital. There are a number of large pores with raised rims on the head placed as shown in the figure. Opercular spine as in A. mirus.

The teeth are confined to the jaws and form a narrow band in each; the edges of the lips and the frenum behind the teeth are studded with minute papillæ.

The two anterior spines of the dorsal are abruptly bent near their tips, possibly an individual malformation; the second is the longest, its length being 2.5 in that of the head; the last spine does not quite reach to the second fin. The latter is high; the longest rays are the seventh to tenth, which are subequal, and a little more than one-half the length of the head; the last few rays are rapidly shortened and extend to the base of the caudal rays. The anal rays are much shorter than those of the dorsal and have their tips free. Anal papilla prominent. The ventrals are widely separated and are set quite horizontally; the fourth ray, which is the longest, is less than half the length of the head. The pectoral has a broad base and is rounded; it does not quite reach the origin of the anal. The caudal is feebly rounded, its peduncle is much compressed, and its least depth is less than the diameter of the eye.

The whole fish is scaleless, but is covered with mucus; the lateral line is formed of nineteen pores, which are a continuation of the post-orbital row of pores, and form 
a low ridge which extends to below the base of the eighth-ninth dorsal rays; the pores reappear faintly in the mid line above the fifth anal ray, are nineteen in number, and do not quite reach the base of the caudal rays.

Colours.-The single specimen preserved is almost colourless, but bears traces of darker markings across the back, and spots on the outer caudal rays.

Length of specimen, $146 \mathrm{~mm}$. It was taken in company with examples of Trematomus bernacchii in August 1908, off Cape Royds, at a depth of thirty to eighty fathoms.

The most apparent difference between A. shackletoni and the other members of the genus is in the larger number of spines and rays in the dorsal and anal fins, the dorsal spines in the other species being but three in number; some systematists would probably regard the distinction as of generic import.

In other respects the three species are very similar, $A$. shackletoni being in some characters intermediate. By comparison with Lönnberg's figures, ${ }^{*}$ it is found to resemble $A$. skottsbergi in general form, but otherwise more nearly approaches A. mirus, agreeing in the protuberant eye, the high second dorsal fin, and possibly also the coloration.

The comparative proportions of the three species are shown below :

\begin{tabular}{l|c|c|c|}
\hline & A. MIRUS & A. SEOTTSBERGI & A. SHACKLETONI \\
\cline { 2 - 4 } Dorsal spines and rays & III. $23-24$ & III. 25 & V.27 \\
Anal rays & 17 & 19 & 20 \\
Head in length & $2 \cdot 6$ & $2 \cdot 8$ & $2 \cdot 8$ \\
Height in length & $3 \cdot 8$ & $4 \cdot 7$ & $1 \cdot 2$ \\
Eye in head & $3 \cdot 9$ & $3 \cdot 2$ & $3 \cdot 8$ \\
Interorbital space in head & $3 \cdot 7$ & $3 \cdot 0$ & $10 \cdot 1$ \\
Snout in head & $4 \cdot 2$ & $3 \cdot 3$ & $3 \cdot 7$ \\
Caudal in length & & & \\
\hline
\end{tabular}

* Lönnberg, loc. cit., Plate IV,, Figs, 14 ]A. mirus) and 15 (A. skottsbergi). 
Plate II 


\section{PLATE II}

Artedidraco shackletoni, Waite, page 15.

Natural size. 


\section{WAITE : PISCES}

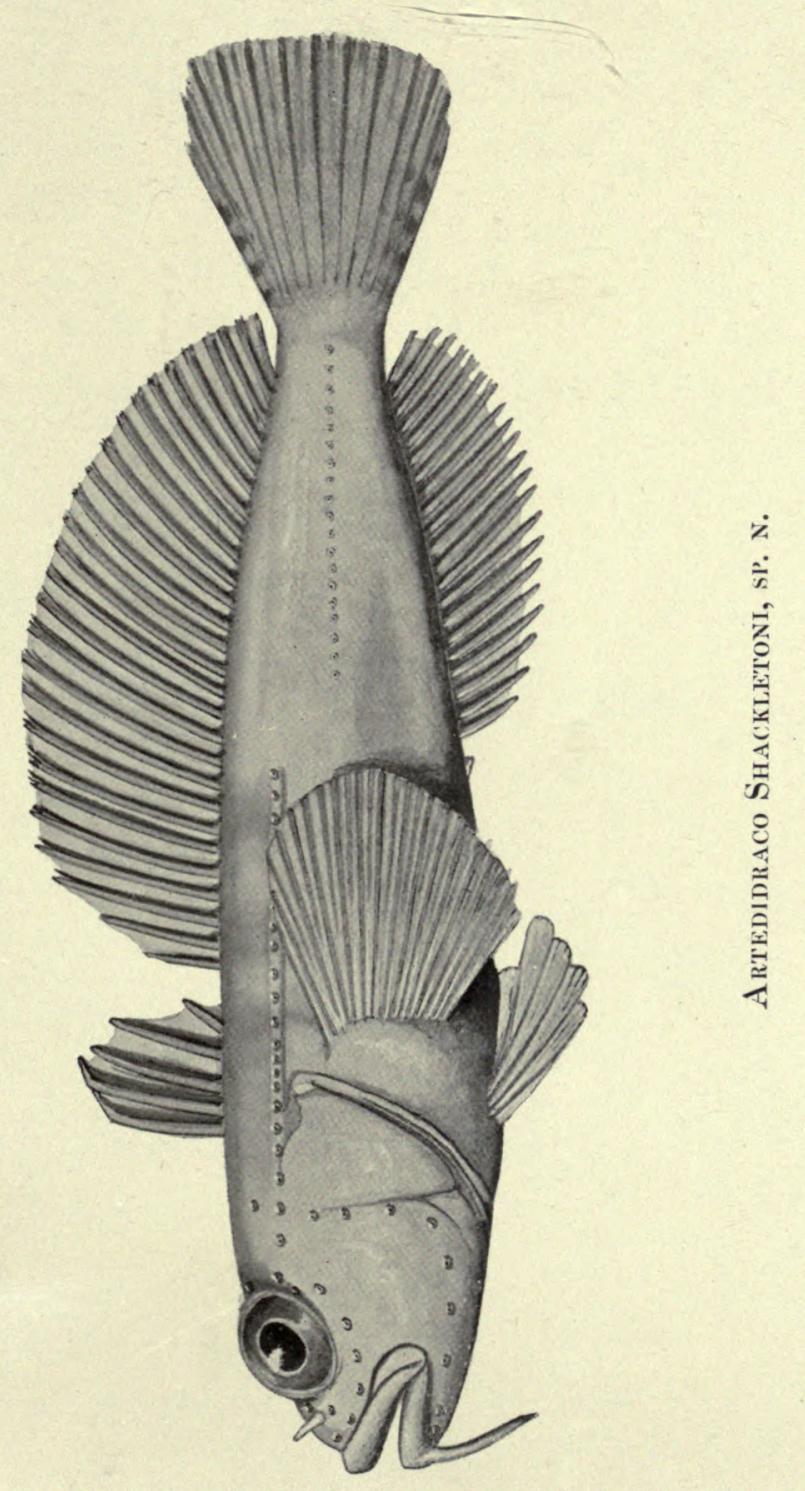

E. R. Waite del. 



\title{
BRITISH ANTARCTIC EXPEDITION 190\%-9
}

UNDER THE COMMAND OF SIR E. H. SHACKLETON, C.V.O.

REPORTS ON THE SCIENTIFIC INVESTIGATIONS

\author{
VOL. II \\ BIOLOGY
}

EDITOR - - JAMES MURRAY

\author{
PAR'T III \\ MALLOPHAGES \\ BY PROF. L. G. NEUMANN \\ (TOULOUSE)
}

(WITH ONE PLATE)

LONDON

PUBLISHED FOR THE EXPEDITION BY IVILI.IAM HEINEMANN

21 BEDFORD STREET, W.C.

1911

ISSUED SEPARATELY, APRIL, 1911

Price Is. 6d. Net 


\section{REPORTS ALREADY ISSUED}

VOL. I. PART I., ON COLLECTING AT CAPE ROYDS BY JAMES MURRAY

PRICE 1s. 6d. NeT

VOL. I. PART II., ON MICROSCOPIC LIFE AT CAPE ROYDS BY JAMES MURRAY

Price 5s. Od. NET

VOL. I. PART III., ANTARCTIC ROTIFERA BY JAMES MURRAY

Price 5s. Od. NET

VOL. I. PART IV., MUSCI BY JULES CARDOT

Price 1s. Od. NET

VOL. I. PART V., TARDIGRADA BV JAMES MURRAY

Price 10s. Od. NeT

VOL. I. PART VI., RHIZOPODES D'EAU DOUCE BY EUGÈNE PENARD

Price 3s. Od. Net

VOL. II. PART I., MOLLUSCA

BY CHARLES HEDLEY

Price 1s. 6d. NET

VOL. II. PART II., ANTARCTIC FISHES

BY EDGAR R. WAITE, F.L.S.

Price 1s. 6d. NeT 


\section{PART III \\ M A L L O P H A G A \\ PAR PROF. L. G. NEUMANN, Toulouse}

(Avec la Planche III)

Editorial Note. - The collection of Bird-lice is a very small one, and with a single exception was not obtained in the Antarctic region, but on the Albatrosses of the Southern Ocean.

The one exception, a variety of Philopterus lari, is interesting as the first species found on Maccormick's Skua, and also for its occurrence for the first time in the Antarctic.

As these parasites appear to be extremely rare in the Antarctic it is worth noting that one was observed alive on an Emperor Penguin, though unfortunately the specimen was lost among the down. The rarity appears to be real, as we carefully examined many penguins of both species, Skua Gulls, and Giant and Antarctic Petrels, and never saw any Bird-lice except these three, two on the Skua and one on the Emperor,

J. M.

\section{Mallophages}

La collection comprend 54 exemplaires, provenant de 6 oiseaux, dont 3 Diomedea exulans, 2 Thalassogeron culminatus, et 1 Megalestris maccormicki, ce dernier seul étant réellement antarctique.

Tous ces Mallophages représentent les espèces suivantes:

$1^{\circ}$. Phibopterus lari maynus (Piaget), sur Megalestris maccormicki.

$2^{\circ}$. Lipeurus concinnus Kellogg et Chapman, sur 1 Thalassigeron culminatus.

$3^{\circ}$. Lipeurus ferox Giebel, sur 1 Diomedea exulans.

$4^{\circ}$. Lipeurus hyalinus $\mathrm{n}$. sp., sur 2 Diomedea exulans:

$5^{\circ}$. Taschenbergius brevis (Dufour), sur les 3 Diomedea exulans et 1 Thalassigeron culminatus.

\section{$1^{\circ}$. Phitopterus lari (O. Fabricius) (Pl. III., figs. 2 à 4)}

1780. Pediculus lari, O. Fabricius, Fauna groenlandica, p. 219.

1842. Docophorus lari, H. Denny, Monographia Anoplurorum Britanniae, p. 89, Pl. V., fig. 9.

1844. Philopterus lari, P. Gervais, Histoire naturelle des Insectes : Aptères, iii., p. 337.

BRIT. ANTARCT. EXPED. 1907-9. VOL. II. PART 3, ISSUEd SEPARATELY APRIL 1911 
1871. Docophorus gonothorax, C. G. Giebel, Zeitschrift f. ges. Naturwiss., xxxvii. p. 450 .

1874. Docophorus congener, C. G. Giebel, Insecta Epizoa, p. 111.

1880. Docophorus lari v. magna, E. Piaget, Les Pédiculines, p. 112.

2 f, sur Megalestris maccormicki Saunders, au Cap Royds, par $77^{\circ} 32^{\prime}$ lat. S. et $166^{\circ} 12^{\prime}$ long. E., le $1^{\text {er }}$ janvier 1909.

Philopterus lari est une espèce commune sur nombre d'espèces de Larus. Elle est indiquée aussi sur Sula alba, Rissa tridactyla policäris, et Creagrus furcatus.

Les spécimens recueillis sur Megalestris maccormicki, les premiers Mallophages fournis par cet Oiseau, correspondent à la sous-espèce de Piaget, $P$. $l$. magnus : dimensions plus fortes que dans le type $(1 \mathrm{~mm} .7$ à $1 \mathrm{~mm} .8$ pour le $\hat{\delta})$, clypéus un peu plus allongé et échancré. Les spécimens de Piaget provenaient d'un Larus atricilla.

\section{$2^{\circ}$. Lipeurus concinnus Kellogg et Chapman}

1899. Lipeurus concinnus, V. L. Kellogg et B. L. Chapman, Occasional Papers of the California Academy of Sciences, vi., p. 97, PI. VII., fig. 2.

1 ㅇ, sur Thalassogeron culminatus (Gould), au S. de l'Océan Indien, par $43^{\circ}$ lat. S. et $91^{\circ} 30^{\prime}$ long. $\mathrm{E}$.

L'espèce a été décrite par Kellogg et Chapman d'après des individus pris sur Diomedea albatrus en Californie.

\section{$3^{\circ}$. Lipeurus ferox Giebel}

1834. Philopterus diomedea, L. Dufour, Ann. de la Soc. entomol. de France, iv., p. 669, Pl. XXI., figs. 1 et 2. (Non Pediculus diomedece Fabricius, Entomologia systematica, iv., 1794, p. 421).

1834. ? Philopterus pederiformis L. Dufour, Ann. de la Soc. entomol. de France, iv., p. 676, Pl. xxi., fig. 4.

1864. Lipeurus diomedex H. Giglioli, Quart. Journal of Microsc. Science (N.S.), iv., p. 19, Pl. I., figs. 1 et 2 .

1867. Lipeurus ferox C. G. Giebel, Zeitschrift f. ges. Naturwiss., xxix., p. 195.

1 ㅇ, sur Diomedea exulans I., dans l'Ocćan Indien S., au S. de la Tasmanie (avec Lipeurus hyalinus Nn., et Taschenbergius brevis (Dufour).

Kellogg donne pour hôtes à cette espèce : Diomedea melanophrys, D. brachyura, D. nigripes (Océan Pacifique N.), D. albatrus (Californic), et $D$. exulans.

L. ferox a été établi par Giebel d'après un individu đ̊ provenant de $D$. melanophrys. En en reprenant l'étude, Taschenberg a décrit comme $q$ une forme que Kellogg regarde comme étant probablement le ô de L. densus Kellogg. La q réelle de $L$. ferox a étć décrite et figurée par Kellogg (1896). La q de la collection antarctique est conforme à la description et à la figure de Kellogg. 


\section{$4^{\circ}$. Lipeurus hyalinus, n. sp. (Pl. III., figs. $1 a$ à $\left.1 d\right)$}

Cette espèce est représentée par deux lots, recueillis sur Diomedea exulans L., savoir:

5 f̊ et 3 o, dans l'Océan Indien S., par $40^{\circ}$ lat. S. et $47^{\circ}$ long. E. ; 4 fo, dans l'Océan Indien S., au S. de la Tasmanie.

Description.-Mâle. Longueur $4 \mathrm{~mm}$. 05, largeư $1 \mathrm{~mm}$. Corps large, avec des bandes incolores, transparentes et quelques petites taches noires.

Tête subtriangulaire, longue de $0 \mathrm{~mm} .9$, plus large $(0 \mathrm{~mm} .87)$ en arrière des yeux, parabolique et incolore en avant; un long poil à la suture, suivi de 4 autres plus courts, le dernier étant pré-antennal et très court; les 2 poils suturaux réunis par une ligne concave, suivie d'une ligne anguleuse qui aboutit aux bandes antennales; celles-ci incolores, à bord interne sinueux. Fosse antennale peu profonde à son bord dorsal. Antennes fortes, incolores, sauf le sommet du $3^{\mathrm{e}}$ article, qui est brunâtre. $\mathbf{1}^{\mathrm{er}}$ article long, renflé, ovoïde, une fois et demie anssi long que les 4 autres réunis; $2^{\mathrm{e}}$ ovoïde et presque aussi long que les 3 suivants réunis; le $3^{e}$ conique, recourbé en avant, plus long et plus gros que chacun des 2 suivants; $4^{\mathrm{e}}$ et $5^{\mathrm{e}}$ égaux, cylindriques, le $4^{\mathrm{e}}$ inséré sur la concavité du $3^{\text {e }}$. Yeux saillants, au sommet d'une tache noire trapézoïdale. Bord temporal d'abord convexe et saillant, puis droit et dirigé en dedans et en arrière; un long poil à l'angle temporal. Bord occipital concave. Couleur générale blanchâtre; bandes incolores, les occipitales réduites à un espace triangulaire.

Thorax long de 0 mm. 9. Prothorax court, rectangulaire, près de 2 fois aussi large que long, le bord postérieur un peu convexe, une épine à chaque angle postérieur ; blanchâtre avec bande latérale incolore et recourbée un peu sur le bord postérieur. Métathorax un peu plus large que long, le plus large en arrière, à bords latéraux et postérieur concaves; dans chaque angle postérieur 3 longs poils colorés et insérés sur une même saillie petite et conique; une bande latérale courte, claire et saillante en dedans ; 3 sternites incolores (présternite linéaire, mésosternite en hexagone allongé transversalement, métasternite subcirculaire. Couleur générale blanchâtre. Pattes incolores, sauf les tarses, qui sont brun châtain.

Abdomen long de $2 \mathrm{~mm}$. 3, plus large au $4^{\mathrm{e}}$ segment. Segments à peu près de même longueur. A chaque angle postérieur, 2 longs poils au $1^{\text {er }}$ segment; 3 aux $2^{\mathrm{e}}, 3^{\mathrm{e}}$ et $4^{\mathrm{e}} ; 4$ aux $5^{\mathrm{e}}$ et $6^{\mathrm{e}} ; 6$ au $7^{\mathrm{e}} ; 5$ all $8^{\mathrm{e}}$; le $9^{\mathrm{e}}$ étroit, émarginé à son extrémité, dont chaque lobe porte un poil court et un poil long. Couleur générale blanchâtre. Sur chaque segment, une bande latérale très étroite, élargie en 111 prolongement transversal au bord antérieur et en un autre plus court en avant de l'angle postérieur; au $7^{\circ}$ segment les deux élargissements ont la même importance; un seul au $8^{\circ}$. Sur les segments 2 à 6 une petite tache noire dans l'angle antérieur; une semblable an $8^{e}$, suivie d'une tache marron; chaque lobe du $9^{\circ}$ presque couvert par une tache marron ; l'extrémité de l'appareil copulateur est un peu colorée. Stigmates petits, situés sur le milieu de la longueur du segment, leur écartement égal à la noitié de sa largeur. 
Femelle.-Corps long de $4 \mathrm{~mm}$. 2, large de $1 \mathrm{~mm}$. Fosse antennale à angle antérieur formant une pointe aiguë. Antennes grêles; $1^{\text {er }}$ article renflé, plus gros et presque aussi long que le $2^{\mathrm{e}} ; 1^{\text {er }}$ et $2^{\mathrm{e}}$ formant plus de la moitié de la longueur de l'antenne ; $3^{\text {e }}$ et $5^{\text {e }}$ de même longueur et plus longs que le $4^{\text {e}}$. Abdomen long de 2 min. 4 ; poils plus longs que chez le $\hat{\delta}$; bandes latérales ayant, sur chacun des segments 1 à 7 , deux élargissenents égaux. Pas de tache noire antérieure au $2^{\mathrm{e}}$ segment, une au $7^{\mathrm{e}} ; 8^{\mathrm{e}}$ segment plus étroit que chez le ô ; $9^{\circ}$ à fente plus étroite.

Cette espèce est voisine de $L$. tricolor Piaget, et de $L$. confidens Kellogg. Elle rappelle aussi Nirmus giganticola Kellogg.

\section{$5^{\circ}$. Taschenbergius brevis Dufour}

1834. Philopterus brevis, L. Dufour, Ann. de la Soc. entomol. de France, iv., p. 674, Pl. XXI., fig. 3.

1838. Philopterus (Docophorus?) taurus Nitzsch; H. Burmeister, Handbuch der Entomologie, ii., p. 433.

1864. Docophoroides brevis, H. Giglioli, Quart. Journal of Microsc. Science (N.S.), iv., p. 21, Pl. I., figs. 3 et 4.

1866. Lipeurus taurus, C. G. Giebel, Zeitschrift f. ges. Naturwiss., xxviii., p. 385.

1882. Eurymetopus taurus, O. Taschenberg, Nova Acta der Ksl. Leop.-Carol.-Deutschen Akademie der Naturforscher, xliv., p. 183, Pl. V., figs. 8 et $8 a$.

1906. Taschenbergius brevis L. G. Neumann, Bull. de la Soc. Zoolog. de France, xx., p. 60.

1 i et 1 \%, sur Diomedea exulans L., au S. de l'Atlantique, par $35^{\circ}$ lat. S. et $30^{\circ} 27^{\prime}$ long. O.; 15 f et 10 \&, sur Diomedea exulans, au S. de l'Océan Indien, par $40^{\circ}$ lat. S. et $47^{\circ}$ long. E. (avec Lipeurus hyalinus Nn.); 3 fo et 7 i , sur D. exulans, dans l'Océan Indien, au S. de la Tasmanie (avec Lipeurus ferox Giebel, et $L$. hyalinus Nn.); 1 ô sur Thalassogeron culminatus Gould, au S. de l'Océan Indien, par $41^{\circ}$ lat. S. et $53^{\circ} 24^{\prime}$ long. E.

T. brevis a encore pour hôtes connus: Diomedea albatrus, D. nigripes, D. regia, Fulmarus glacialis, Puffinus opisthomelas, Arenaria interpres. 
PLATE III 


\section{PLANCHE III}

FIgURE 1.-Lipeurus hyalinus, n. sp. . . . . . . . . . 21

, a.-o Face dorsale . . . . . . . . . . . $\times 20$

„b.-Abdomen de la + . . . . . . . . . . . $\times 20$

" c.-Antennes fot + e. . . . . . . . . . $\times 45$

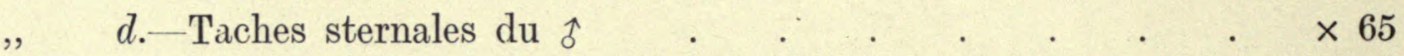

Figure 2.-Philopterus lari, $\hat{\delta}$, face dorsale . . . . . . . . . 19

Figure 3.--Philopterus lari, 今, tête et thorax (face ventrale)

Figure 4.-Philopterus lari, 合, taches ventrales 


\section{NEUMANN : MALLOPHAGA}

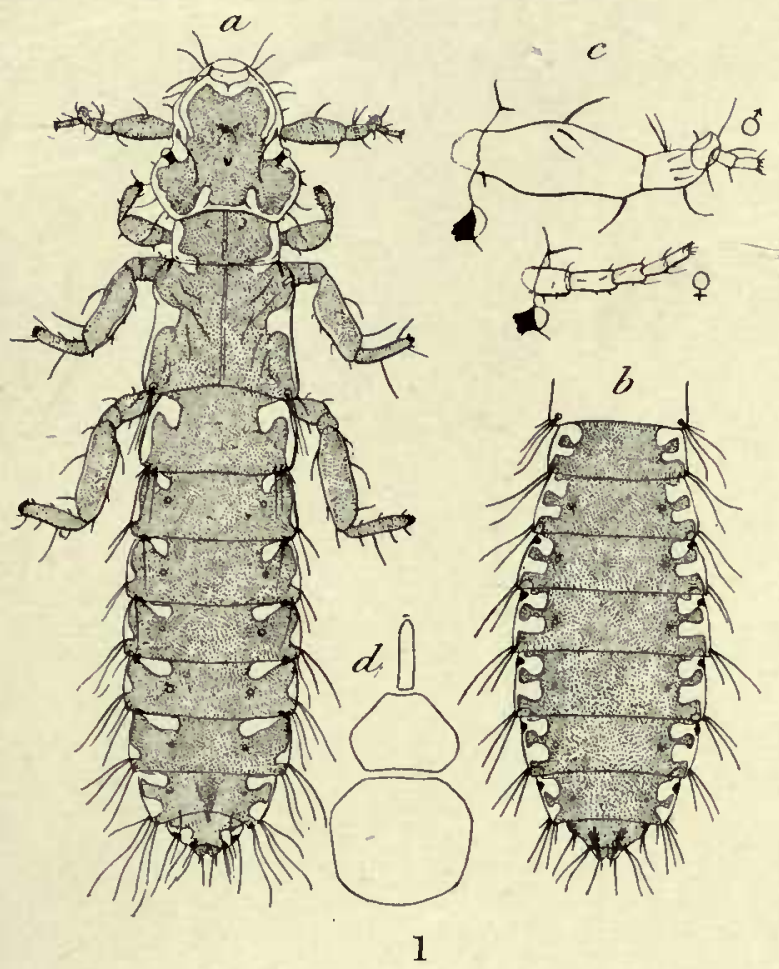

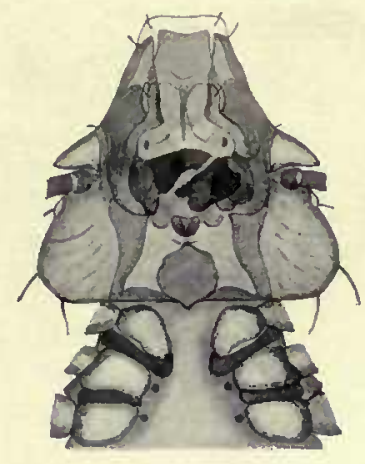

3

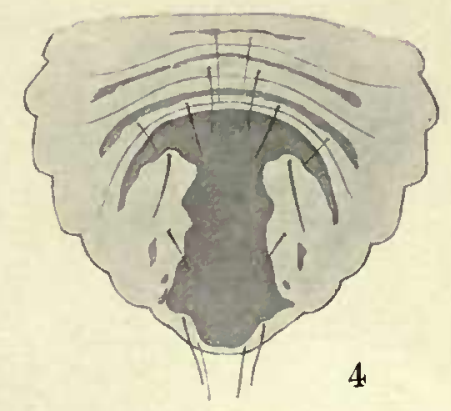

1. Lipeurus hyalinus, sp. N.

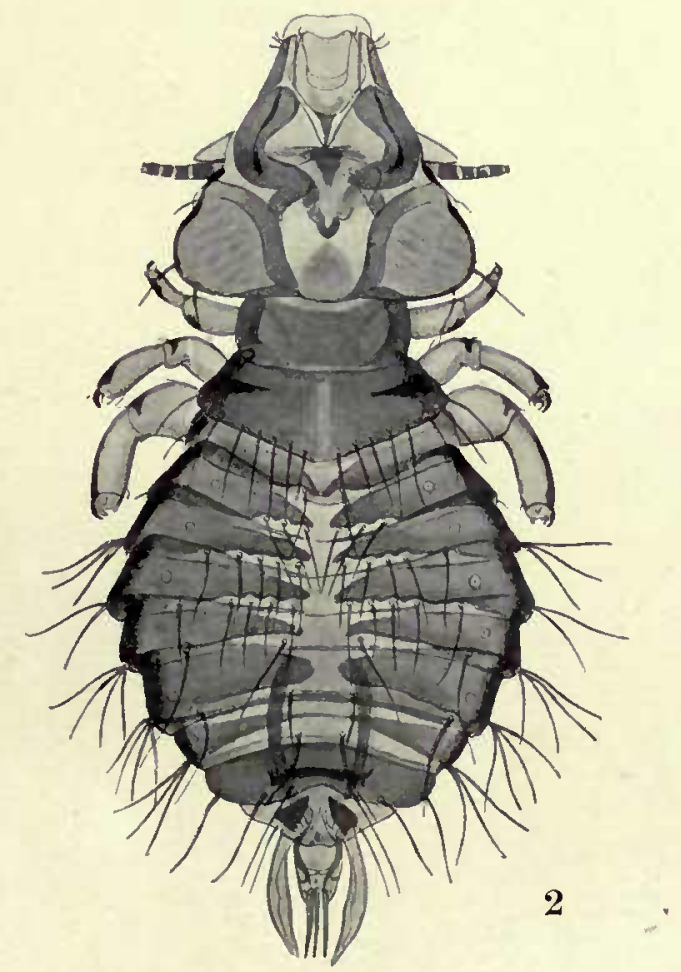

2-4. Philoptenus lari.

G. Neumann del. 





\section{BRITISH ANTARCTIC EXPEDITION 190\%-9}

UNDER THE COMMAND OF SIR E. H. SHACKLETON, C.V.O.

REPORTS ON THE SCIENTIFIC INVESTIGATIONS

$$
\text { BIOLOGY }
$$

EDITOR - - JAMES MURRAY

\section{PAR'T IV \\ ASTÉRIES, OPHIURES, ET ÉCHINIDES \\ BY R. KOEHLER \\ (LYONS)}

(WITH FIVE PLATES)

LONDON

PUBLISHED FOR 'THE EXPEDITION BY WILI.LAM HEINEMANN

21 BEDFORD STREET, W.C.

1911

ISSUED SEPARATELY, JUNE, 1911

Price 5s. Net 


\section{REPORTS ALREADY ISSUED}

VOL. I. PART I., ON COLLECTING AT CAPE ROYDS BY JAMES MURRAY

Price 1s. 6d. NET

VOL. I. PART II., ON MICROSCOPIC LIFE AT CAPE ROYDS BY JAMES MURRAY

Price 5s. Od. NET

VOL. I. PART III., ANTARCTIC ROTIFERA BY JAMES MURRAY

Price 5s. Od. Net

VOL. I. PART IV., MUSCI BY JULES CARDOT

Price 1s. Od. NET

VOL. I. PART V., TARDIGRADA

BV JAMES MURRAY

Price 10s. Od. NET

VOL. I. PART VI., RHIZOPODES D'EAU DOUCE BY EUGENE PENARD

Price 3s. Od. Net

VOL. II. PART I., MOLLUSCA BY CHARLES HEDLEY

Price 1s. 6d. NET

VOL. II. PART II., ANTARCTIC FISHES By EDGAR R. WAITE, F.L.S.

Price 1s. 6d. NeT

VOL. II. PART III., MALLOPHAGES

By Prof. L. G. NEumanN (Toulouse) Price 1s. 6d. net 


\title{
PART IV
}

\section{ECHINODERMA}

\section{ASTERRIES, OPHIURES, ET ÉCHINIDES \\ DE L'EXPÉDITION ANTARCTIQUE ANGLAISE DE 1907-1909}

\author{
PAR R. KGEHLER \\ Professeur à l'Université do Lyon \\ (Avec les Planches IV à VIII)
}

M. James Murray a bien voulu m'offrir d'étudier les Astéries, Ophiures et Échinides recueillis par le Nimrod, commandant E. Shackleton, à la Terre Victoria du Sud, en 1907-1909. Je suis heureux de le remercier ici de la confiance qu'il a bien voulu me témoigner.

Les Échinodermes recueillis proviennent tous du Cap Royds, qui représente la pointe la plus occidentale de l'île Ross, dans la Terre Victoria du Sud, par $77^{\circ} 32^{\prime}$ lat. S. et $166^{\circ} 12^{\prime}$ long. $\mathrm{E}$. La Terre Victoria et les régions avoisinantes ont déjà été explorées au point de vue zoologique; la Southern Cross et la Discovery en ont rapporté des collections qui ont été étudiées et plusieurs espèces d'Échinodermes y sont connues. Aussi pouvait-on supposer que les Échinodermes du Nimrod n'offriraient pas un très grand intérêt et ne renfermeraient que des représentants d'une faune déjà connue. Ces prévisions n'ont pas été réalisées, heureusement : la collection qui m'a été remise, bien qu'elle ne soit pas très importante, est au contraire très intéressante, non pas seulement à cause des espèces nouvelles que j'y ai trouvées, mais aussi en raison des renseignements qu'elle fournit sur la répartition géographique de certaines espèces.

Les explorations zoologiques de l'Antarctique ont surtout été faites dans deux directions différentes et presque opposées; les unes, qui avaient pour point de départ le détroit de Magellan, ont eu pour objet l'étude des régions situées au Sud de la pointe méridionale de l'Amérique du Sud; les Oreades et les Shetland du Sud, les terres de Graham, de Danco, etc., e'est-à-dire entre les $50^{\circ}$ et $70^{\circ}$ long. W.; les autres, qui avaient pour point de départ l'Australie ou la Nouvelle-Zélande, nous ont fait connaître des régions telles que la Terre Victoria du Sud, situées vers le $170^{\circ}$ long. E. Il reste entre ces deux points extrêmes un territoire à peine connu quoique la Belgica se soit avancée jusque vers le $100^{\circ}$ long. W., et le Français jusqu'au $126^{\circ}$ long. W.

BRtT. ANTARCT. EXPED. 1907-9. vol. II. PART 4, ISSUEd JUNE 1911 E 
Les Échinodermes recueillis par le Nimrod comprennent six Astéries, quatre Ophiures, et trois Échinides, soit en tout treize espèces dont huit sont nouvelles et trois représentent des genres nouveaux. En voici l'énumération :

\section{ASTÉRIES}

Odontaster validus Kœhler. Cryaster antarcticus Kœhler. Porania antaretica Smith.

Ophioglypha resistens, n. sp. Ophioglypha flexibilis, n. sp.
Coscinasterius brucei Kœhler.

Coscinasterias victorice, n. $\mathrm{sp}$.

Notasterias armata, n. gen. 11. sp.

\section{OPHIURES}

A mphizura celgilla, n. sp.

Ophiodiplax disjuncta, n. gen. n. sp.

\section{ÉCHINIDES}

Sterechinus neumayeri Meissner. Abatus shackletoni, n. sp.
Pseudabatus nimrodi, n. gen. n. sp.

Il est assez intéressant de constater, qu'à part une seule et unique exception, aucune des espèces ci-dessus n'a été rapportée par la Discovery de la Terre Victoria du Sud; la faune échinologique rencontrée par ce bâtiment a une composition toute différente d'après le rapport de J. Bell (08).* Il me paraît utile de rappeler ici les espèces signalées par ce naturaliste:

Asterias brandti Bell.

Asterias longstaffi Bell.

Heuresaster hodgsoni Bell.

Pentagonaster incertus Bell.

Leptoptychaster kerguelensis Smith.

Cycethra vermicosa Philippi.

Henricia ornata Perrier.

Solaster octoradiatus Ludwig.

Ophioglypha kœhleri Bell.

Ophiozona inermis Bell.

Ophiosteira antarctica Bell.
Ophionotus victorice Bell.

Ophiacantha imago Lyman.

Ophiacantha vivipara Ljungmann.

Ophiacantha cosmica Lyman.

Aphioconis antarctica Lyman.

Amphiura belgice Kœhler.

A strotoma aycessizii Iıyman.

Jeune Ophiure.

Austrocidaris canaliculata Agassiz.

Sterechinus margaritaceus Lamarck.

Abatus cavernosus Philippi.

La seule espèce de cette liste que j'ai retrouvée parmi les Échinodernes du Nimrod est la "jeune Ophiure" que J. Bell s'est contenté de figurer sans la décrire; nous verrons plus loin que cette forme, que le savant naturaliste anglais considérait comme un jeune, a tous les caractères d'un adulte.

Les espèces déjà connues que l'Expédition Antarctique Anglaise a rapportées sont au nombre de cinq; elles n'avaient pas encore été signalées à la Terre Victoria. Deux d'entre elles sont plus ou moins communes dans le domaine antarctique; ce sont la Porania antarctica et le Sterechinus neumayeri. La première espèce est très répandue dans les régions antarctiques et subantarctiques; le Nimrod l'a rencontrée à une latitude très élevée $\left(77^{\circ} \cdot 32^{\prime} \mathrm{S}\right.$.), alors que sa station la plus australe notée par la Belgica était située par $71^{\circ} 18^{\prime}$. Le Sterechinus neumayeri présente aussi une répartition

- Les chiffres en caractères gras renvoient à la liste des ouvrages cités qui se trouve à la fin du mémoire. 
géographique assez vaste: on le connaît au détroit de Magellan, à la Géorgie du Sud, aux Orcades du Sud, à la Terre de Graham, etc.; Mortensen nous apprend (10, p. 68) qu'il a été trouvé en plusieurs stations par l'Expédition Sud-polaire Suédoise et il estime qu'il doit être circumpolaire; sa répartition tient évidemment à ce qu'il possède une larve pélagique. Il n'y a donc rien d'étonnant à ce qu'il ait été capturé au Cap Royds.

Les trois autres espèces avaieut jusqu'à présent un habitat beaucoup plus restreint. La Coscinasterias brucei u'était connue qu'aux Orcades du Sud où la Scotia l'a découverte, et le Cryaster antarcticus a été trouvé par le Français vers le $65^{\circ}$ lat. S.

Enfin l'Odontaster validus a été rencontré par le Français vers les Terres de Graham et de Danco, et par la Scotia aux Orcades du Sud. Ces localités, comprises entre le $50^{\circ}$ et le $70^{\circ}$ long. W., sont, on le voit, très éloignées du Cap Royds.

J'ai dit plus haut que les Échinodermes proviennent tous du Cap Royds. D'après les renseignements qui m'ont été communiqués, les échantillons capturés à une profondeur de 10 à 20 brasses ont été recueillis dans une petite baie dont le fond renfermait une vase noire très adhérente; ceux qui proviennent de 40 à 80 brasses ont été dragués sur un fond de couleur claire dont la faune était très riche.

\section{ASTÉRIES}

\section{OdONTASTER VALIDUS Kœhler}

\section{Odontaster validus, Kœhler (06), p. 6}

Cap Royds. Juin 1908. Profondeur, 7-20 brasses. Quelques échantillons.

L'un des exemplaires est de très grande taille: $R=68$ millim., $r=30$ millim.; il est très robuste et l'épaisseur au centre du disque dépasse 20 millim. Cinq autres individus sont plus petits et $R$ varie entre 38 et 25 millim.; enfin d'autres individus, beaucoup plus petits et chez lesquels $R$ est compris entre 15 et 8 millim., se trouvent dans la collection.

\section{Porania ANTarctica Smith}

Voir pour la bibliograplie:

Perrier (91), p. 107 et 163.

Leitpold (95), p. 588.

Ludwig (03), p. 22.

Ludwig (05), p. 51.

Cap Royds. 20 a oût 1908. Profondeur, 60-80 brasses. Deux échantillons.

Les exemplaires sont très jeunes tous deux et ils ont la même taille: $R=20$ et $r=8$ millim., nıais dans l'un d'eux le disque est plus petit tandis que les bras sont plus grêles et plus longs que dans l'autre.

Les auteurs s'accordent à considérer comne devant rentrer dans la même espèce les $P$. antarctica Smith, magellanica Studer, glaber Sladen, et spinulata Sladen. Les Porania antarctiques varient en effet beaucoup dans leurs caractères et Perrier 
a mème fait remarquer que certaines formes arrivaient à se rapprocher de la $P$. pulvillus des mers du Nord.

Les deux individus que j'ai sous les yeux m'offrent un nouvel exemple de cette variation. L'un d'eux, qui a les bras plus courts et plus larges et le disque comparativement grand, offre, sur la face dorsale du disque, des tubercules coniques et bien apparents, au nombre d'une douzaine; sur les bras, ces tubercules sont beallcoup plus petits, mais assez nombreux et rapprochés. L'exemplaire correspond donc, par ses caractères, à la $P$. antarctica. Dans l'autre, dont les bras sont minces et allongés, il n'y a pas la moindre trace de tubercules ou de saillies sur la face dorsale: il rappellerait donc la forme décrite par Sladen sous le nom de $P$. glaber.

En raison des variations qui ont été notées par différents auteurs sur les Porania des diverses régions antarctiques explorées, il ne semble pas qu'on puisse établir une distinction entre les formes des îles Kergnelen et celles de l'extrémité méridionale de l'Amérique du Sud.

La $P$. antarctica paraît avoir une aire de répartition assez vaste dans les régions antarctiques. La Belgica l'a rencontrée à $71^{\circ} 18^{\prime}$ lat. S.: on voit qu'elle peut remonter encore davantage vers le pôle puisque l'Epédition Anglaise l'a capturée à $77^{\circ} 32^{\prime}$ lat. S.

\section{Cryaster antarcticus Køhler (Pl. IV, fig. 1 et 2)}

Cryaster antarcticus, Kœhler (06), p. 24, Pl. I, fig. 1, et Pl. II, fig. 10

Baie de Backdoor. 6 février 1907. Profondeur, 6-13 brasses. Un échantillon.

L'exemplaire est en excellent état de conservation. Au premier abord, il semble assez différent du type du $C$. antarcticus que j'ai décrit d'après les individus rapportés par la première Expédition du Dr. Charcot: tandis que chez ces derniers les faces dorsale et ventrale du corps offrent des petits piquants nombreux et serrés, l'échantillon de l'Expédition Antarctique Anglaise parait tout à fait inerme: de fait, ces piquants font à peu près complètement défaut et l'on ne trouve, en général, que la gaine tégumentaire des piquants, ceux-ci ayant disparu. Mais j'ai heureusement rencontré dans les collections recueillies récemment, au cours de la deuxième Expédition du Dr. Charcot, et qui viennent de m'être confiés, des exemplaires de $C$. antarcticus chez lesquels les piquants sont beaucoup moins développés que dans le type et peuvent rester complètement cachés dans leur enveloppe tégumentaire, de telle sorte que l'individu de la Terre Victoria apparaît comme le dernier terme d'une série dont je possède les principaux stades. Il n'y a donc aucune raison pour ne point le rapporter au $C$. antarcticus.

Les bras, au nombre de cinq, sont subégaux, mais, comme ils sont plus ou moins contournés et relevés vers la face dorsale, il est difficile de mesurer leur longueur exacte : sur les plus grands bras, $R$ varie de 120 à 130 millim.; $r=49$ millim.

Le disque est très épais, sa hauteur maxima atteignant $47 \mathrm{millim}$. ; il a la forme d'un cône surbaissé, à sommet très émoussé et il se continue largement avec les bras. 
On remarque, le long de chaque interradius, une dépression assez large et qui s'accentue à mesure qu'on se rapproche de la périphérie du disque; la base des bras se trouve ainsi nettement délimitée. Cette base est très large : elle mesure 48 millim. sur le bras le plus large et 38 sur le plus étroit. Les bras se rétrécissent très rapidement sur leur première moitié, et ensuite d'une manière plus lente, en s'amincissant progressivement jusqu'à l'extrémité qui est étroite et obtuse.

Malgré l'absence de dépôts calcaires dans les téguments de la face dorsale, celle-ci est très résistante et indéformable et le tégument qui la recouvre est épais et dur. Tout l'ensemble de l'animal est très robuste. La couche superficielle de ce tégument, dont l'épaisseur atteint au moins un millimètre, est constituée par dés saillies de forme très irrégulière et inégales, qui sont très serrées les unes contre les autres et séparées par des sillons très fins. Ces saillies ont la surface tantôt lisse, tantôt plissée; elles rappellent, par leur ensemble, les pustules que l'on observe sur la face dorsale de certaines Anasterias, mais elles sont beaucoup plus petites que dans ce dernier genre, car les plus grandes n'atteignent pas un centimètre de largeur.

Les petits piquants que j'ai signalés en 1906 chez les $C$. antarcticus provenant de la première Expédition Charcot, émergeaient de saillies analogues et leur base restait plongée, sur une longueur plus ou moins grande, dans le tissu mou qui lui formait ainsi une collerette. Ici le piquant fait complètement défaut et la collerette du piquant existe seule. J'ai examiné au microscope un grand nombre de ces pustules sans pouvoir y découvrir la moindre indication de piquants ou de dépôts calcaires; sur un certain nombre d'entre elles, on voit s'élever une petite protubérance centrale, conique, à pointe obtuse, mais celle-ci ne renferme pas non plus la moindre trace de piquant. On ne peut pas admettre que les piquants aient été dissous par les réactifs conservateurs, car j'en observe sur la face ventrale ainsi que je le dirai plus loin.

L'aspect de la face dorsale de cet individu est tout à fait identique à celui que j'observe chez certains individus provenant de la deuxième Expédition Charcot et chez lesquels cette face n'offre aucun piquant apparent; mais l'examen microscopique des collerettes ou pustules de ces individus montre que chacune d'elles renferme un petit piquant interne.

Vers le centre du disque, les petites pustules s'aplatissent progressivement et elles disparaissent sur un espace mesurant 15 millim. de diamètre environ, qui est occupé par un tégument lisse sur lequel on aperçoit cependant un fin réseau polygonal représentant sans doute l'impression de pustules disparues. Il semble que cette région ait subi des pressions ou des frottements qui ont comprimé ou enlevé les parties superficielles du tégument. Au centre de cette région se trouve un très petit pore qui correspond peut-être à l'anus.

Parmi les pustules, se trouvent de très nombreuses papules allongées et dont la longueur atteint 2 à 3 millim.; leurs parois, très molles, sont minces, transparentes et incolores et elles tranchent sur les autres parties des téguments dont la couleur est brun-clair. 
La couche ainsi constituée par les enveloppes des piquants avortés et les papules, atteint une épaisseur d'au moins 1 millim.; en dessous d'elle se trouve une paroi conjonctive résistante, de couleur blanchâtre, forméc d'un tissu très dense offrant des orifices circulaires par où passent les papules. La couche superficielle des téguments donne, à la main, la sensation du velours.

La plaque madréporique, très grande et allongée dans le sens interradial, mesure 10 millim. sur $7 \cdot 5$, et elle est située plus près du centre que du bord; sa surface est grossièrement granulcuse et les sillons ne sont pas apparents.

Dans les aires interradiaires ventrales, les sillons qui séparent les saillies tégımentaires se disposent d'une manière régulière, et parallèlement les uns aux autres, en allant du sillon anzbulacraire aux bords du disque et des bras. Les saillies tégumentaires elles-mêmes s'alignent ainsi en files transversales qui se continuent sur les bords du disque et des bras et passent aux pustules de la face dorsale. Ces saillies sont en général plus accentuées et plus grosses que celles de la face dorsale. Certaines d'entrc elles, surtout au voisinage de la bouche, renferment un petit piquant que l'on reconnait soit à l'examen microscopique, soit en tâtant l'expansion à l'aide d'une aiguille, mais aucun de ces piquants ne fait saillie au dehors. Sur les côtés des bras, mais dans la partie terminale seulement, j'observe aussi quelques saillies coniques renfermant chacune un piquant interne.

Les sillons ambulacraires sont étroits et les tubes sont placés sans ordrc, très serrés les uns contre les autres. Les piquants adambulacraires sont disposés sur trois rangs comme je l'ai décrit; ils sont très courts, épais et entourés d'une forte enveloppe tégumentaire.

\section{Coscinasterias bRUcei Kohler (Pl. V, fig. 5)}

\section{Stolasterias brucei Kohler (08), p. 41, Pl. V, fig. 46 et 47}

Cap Royds. 27 juillet 1908. Profondeur, 10-18 brasses. Quatre échantillons.

Les quatre exemplaires sont très jeunes et ils ont tous à peu près la même taille : $R$ ne mesure pas plus de 27 millim. Ils n'ont pas encore acquis leur forme définitive, mais ils possèdent tous les caractères principaux de la $C$. brucei et je ne crois pas me tromper en les rapportant à cette espèce que j'ai décrite d'après les échantillons recueillis par la Scotia aux Orcades du Sud, à une profondeur de 10 brasses. Pour les raisons que j'indiquerai plus loin, il me paraît plus correct de ranger cette Astérie dans le genre Coscinasterias plutôt que dans le genre Stolasterias auquel je l'avais d'abord rapportée.

Les quatre individus présentent les mêmes caractères: j'ai représenté, Pl. V, fig. 5, la face dorsale de l'un d'eux que j'ai desséché pour rendre ses caractères plus apparents. Le disque offre un cercle externe de piquants très courts et obtus, entourés chacun d'une collerette à pédicellaires croisés, peu nombreux, et, au centre, un petit piquant ou un groupe de deux ou trois piquants; dans l'espace intermédiaire, on n'observe que quelques piquants épars. La ligne carinale est marquée par une rangéc de piquants qui offre, comme chez le type de l'espèce, des sinuosités plus ou moins 
accentuées. Entre cette ligne et la rangée marginale dorsale, on n'observe que quelques piquants isolés, toujours entourés de leurs collerettes, mais la plus grande partie des côtés des bras reste nue. Les piquants sont cylindriques et ils se terminent par une extrémité arrondie offrant des denticulations très fines et pointues. Les piquants des rangées marginales dorsales et ventrales sont aplatis et un peu plus gros que les précédents; leur extrémité est souvent un peu élargie et elle porte aussi de très fines spinules. La rangée marginale ventrale est très rapprochée des piquants adambulacraires dont elle est simplement séparée par un intervalle étroit, sans la moindre trace de piquants. Ce caractère est bien conforme à ce qui existe chez la $C$. brucei, tandis qu'il existe une rangée ventrale de piquants chez la $C$. victorice que je décrirai ci-dessous.

Aux quatre échantillons que je viens de mentionner étaient joints une douzaine d'individus extrêmement jeunes chez lesquels $R$ est compris entre 12 et 4 millim. Ils appartiennent très vraisemblablement aussi à la $C$. brucei.

En rapportant primitivement la $C$. brucei au genre Stolasterias, j'avais donné à ce dernier genre la signification assez large indiquée par Sladen et non l'acception restreinte qui lui a été ensuite attribuée par Perrier. Les différentes coupures qui ont été établies par ce dernier savant dans l'ancien genre Stolasterias de Sladen ne sont peut-être pas très nécessaires, et, d'autre part, les limites mêmes assignées par Perrier au genre Stolasterias ne sont pas bien précises. Ainsi ce naturaliste établit en 1896 (Stellérides des Campagnes de l'Hirondelle, p. 34), une distinction entre le genre Stolasterias et un nouveau genre Distolasterias qu'il crée, et qui est fondé sur le fait que le premier a les piquants adambulacraires isolés, tandis que le second en a deux par plaque. Or, trois pages plus loin (p. 37), il décrit, sous le nom de Stolasterias neglecta, une nouvelle espèce qui possède deux rangées de piquants adambulacraires; je ne puis comprendre pourquoi l'auteur ne la rapporte pas à son genre Distolasterias plutôt qu'au genre Stolasterias qu'il caractérise, entre autres, par la rangée unique de piquants adambulacraires.

D'autre part, W. K. Fisher a montré (06, p. 1104) que le genre Stolasterias correspondait exactement au genre Coscinasterias, établi par Verrill pour la C. muricata (qui est synonyme de C. calamaria Gray); le terme Coscinasterias se trouve donc antérieur au terme Stolasterias puisqu'il date de 1869 , et le naturaliste américain estime que, logiquement, le premier doit être substitué au second. Ce genre Coscinasterias, pris dans son sens le plus large, comprend les formes principales suivantes: calamaria, tenuispina, gemmifera, volsellata, stichantha, eustyla, glacialis, etc.

Sans se prononcer d'une manière formelle sur la nécessité de subdiviser le genre Coscinasterias, W. K. Fisher propose de substituer aux genres établis par Perrier les coupures suivantes:

Coscinasterias Verrill, 1869 ; type, calamaria.

Stolasterias Sladen, 1889 (= Polyasterias Perrier); type, tenuispina. 


\section{Marthasterias Jullien, 1878; type, glacialis.}

Distolasterias Perrier, 1896 ; type, stichantha.

Il est bon de remarquer, à propos de ces quatre sous-genres, que le dernier n'a pas été utilisé par son créateur dans le travail même où il l'avait établi, et que l'avantdemier a été fondé sur un exemplaire mal conservé et n'offrant aucune valeur. D'autre part, l'un des principaux caractères sur lesquels on s'appuie pour séparer des autres le genre Coscinasterias (comme aussi le genre Polyasterias de Perrier), est la multiplicité des bras. Dans ces conditions, il n'apparaît pas d'une manière bien évidente qu'il soit nécessaire de subdiviser l'ancien genre Coscinasterias de Verrill; aussi j'ai cru devoir conserver ce terme en lui donnant sa signification la plus large sous laquelle il devient exactement synonyme du genre Stolasterias de Sladen.

\section{Coscinasterias victorie, nov. sp. (Pl. V, fig. 3 et 4)}

Cap Royds. 20 août 1908. Profondeur, 50-80 brasses. Un échantillon.

Cap Royds. 30 août 1908. Profondeur, 25 brasses. Un échantillon.

L'exemplaire du 20 août est en bon état, bien qu'il ait été légèrement altẹré par un séjour dans le formol. Les bras, au nombre de cinq, sont un peu inégaux: dans le plus petit, $R=68$ millim.; chez d'autres, $R$ varie de 75 à 82 nillim.; $r=15$ millim. Les bras sont très légèrement rétrécis à la base et leur largeur maxima varie entre 18 et 20 millim.; ils se rétrécissent progressivement jusqu'à l'extrémité qui est amincie et pointue. C'est cet individu qui me servira de type pour la description de l'espèce; il est représenté $\mathrm{Pl}$. V, fig. 3 et 4 .

L'individu capturé le 30 août n'est pas très bien conservé; il est quelque peu macéré et ses tissus sont un peu ramollis; le corps est aplati et il a dû subir une certaine compression. Mesuré sur le bras le plus grand, $R$ dépasse 130 millim.; les bras atteignent 27 millim. de largeur à la base et ils s'amincissent progressivement jusqu'à l'extrémité qui est pointue; $r=20$ millim.

Le disque est de taille moyenne: son diamètre, mesuré entre deux espaces interbrachiaux non consécutifs, oscille autour de 30 millim. La face dorsale des bras est convexe, légèrement carénée sur la ligne médiane; les faces latérales, comprises entre les rangées de plaques marginales dorsales et ventrales, sont étroites. Le squelette des bras est assez résistant et l'ensemble de l'animal est assez rigide.

La face dorsale du disque et des bras offre des piquants peu développés qui émergent d'une collerette ressemblant plutôt à une pustule d'Anasterias; ces collerettes sont accolées les unes contre les autres, et, entre elles, se montrent de nombreuses papules saillantes, de telle sorte que le squelette sous-jacent est absolument invisible. Les collerettes, avec les piquants qu'elles enveloppent, sout beaucoup moins distiuctes que dans la $C$. brucei et l'on recounait moins nettement que dans cette dernière espèce les rangées qu'elles forment.

La région centrale du disque, sur un dianètre de 14 millim., est occupée par un 
premier cercle de piquants entourés de leurs collerettes qui sont contiguës, inégales et peu distinctes: ces piquants font à peine saillie hors de la collerette et leur cxtrémité se termine en pointe émoussée. En dedans, on reconnait un deuxième cercle de piquants moins apparents, et dont les collerettes sont encore plus petites et moins distinctes que les précédentes. Lc reste de l'espace circulaire est occupé par des collerettes dépourvues de piquants, sauf au centre où il existe un piquant un peu plus fort que les antres. Entre les collerettes se montrent de nombreuses papules.

La ligne carinale des bras offre une rangée de piquants qui partent du cercle extérieur signalé ci-dessus et qui dépassent à peine la collerette entourant leur base. Ces collerettes sont serrées les unes contre les autres et leurs limites ne sont pas très apparentes en général. Elles forment une ligne irrégulièrement sinueuse, et, si leurs contours ne sont pas très distincts, la rangée qu'elles constituent sur chaque bras est, dans son ensemble, assez reconnaissable en général; sur la photographie, ces rangées ne sont pas très apparentes. Les dimensions de ces collerettes décroissent très lentement, mais elles deviennent très petites dans le dernier quart des bras, et, par conséquent, elles s'y montrent très nonbreuses; leur piquant central reste distinct jusqu'à l'extrémité du bras. Je compte plus de soixante collerettes dans cette rangéc carinale : elles sont, comme on le voit, plus petites, plus nombreuses, et plus serrées que chez la $C$. brucei où leur nombre ne dépasse pas quarante-cinq dans un exemplaire de même taille. On peut constater, en comparant la photographie que je donne ici (Pl. V, fig. 3) de la C. victorice au dessin que j'ai publié de la C. brucei (08, Pl. V, fig. 46), que, dans cette dernière, les collerettes conservent les mêmes dimensions sur presque toute la longueur des bras et qu'elles sont à peine plus rapprochées et plus petites vers l'extrémité, tandis qu'ici il en est tout autrement. Les sinuosités sont plus accentuées chez la $C$. victorice, mais la ligne elle-même est, dans son ensemble, moins distincte que chez la $C$. brucei. L'espace, très large, compris entre la rangée carinale et la rangée marginale dorsale, est occupé par des collerettes confluentes dont les contours sont presque toujours nial indiqués, et qui sont un peu plus petites et moins développées que celles de la rangée carinale; on reconnaît, par endroits, un arrangement en rangées longitudinales au nombre de deux ou trois de chaque côté. Du centre de chaque collerette, s'élève habituellement un petit piquant très court et obtus. Enfin, entre les collerettes, se montrent de nombreuses papules.

Sur le grand exemplaire, les contours des collerettes sont mieux marqués: elles sont arrondies ou irrégulièrement polygonales par pression réciproque. Celles de la ligne carinale ne sont pas beaucoup plus grandes que les autres et elles mesurent environ 2.5 millim. de largeur; elles sont disposées suivant une ligne beaucoup moins sinuense que sur le premier individu, mais plus distincte en revanche. Le piquant central reste toujours peu saillant. Les collerettes latérales forment trois ou quatre rangées longitudinales assez régulières et elles constituent également des rangées transversales légèrement obliques plus ou moins apparentes, dans chacune desquelles elles sont le plus souvent au nombre de quatre. La forme de ces collerettes est 
irrégulièrement polygonale, et leur largeur atteint 2 millim. Elles sont bien séparées les unes des autres, aussi distinctes et presque aussi grosses que celles de la rangée carinale et leurs limites sont beaucoup mieux marquées que dans l'autre exemplaire. Chacune d'elles porte un piquant central, court et émoussé. Les papules sont toujours abondantes et elles sont surtont nombreuses vers les bords des bras où elles forment de petits groupes réguliers entre les collerettes successives.

Le bord dorsal des bras est occupé par une rangée de gros piquants aplatis, courts, à extrémité tronquée et légèrement élargie, qui s'élèvent chacun du centre d'une collerette; leur région libre mesure environ 1.5 millim. de hauteur. La surface de ces piquants est légèrement canaliculée. Les collerettes, de forme rectangulaire, sont un peu plus grosses que celles de la face dorsale des bras. Vers l'extrémité des bras, les piquants sont plus petits et plus serrés; ils deviennent alors très nombreux, ainsi que cela arrive pour la rangée carinale.

Les piquants de la rangée marginale ventrale correspondent à ceux de la rangée marginale dorsale, mais ils sont plus épais et plus forts, tout en conservant la même forme générale. Les collerettes qui en entourent la base sont identiques à celles de la rangée dorsale. Entre ces deux rangées de piquants marginaux, les faces latérales des bras, très étroites, sont occupées par des papules très serrées et même tout à fait contiguës, formant une bande dont la largeur, à la base des bras, ne dépasse pas deux millimètres.

La face ventrale des bras présente une rangée de piquants qui correspondent à peu près exactement à ceux de la rangée marginale ventrale, mais qui sont un peu moins développés qu'eux. Ils deviennent plus petits dans la seconde moitié des bras, et, dans le dernier quart, ils ne se montrent qu'à des intervalles assez espacés. Cette rangée est tout à fait contiguë aux piquants adambulacraires et à ceux de la rangée marginale ventrale sur l'exemplaire qui me sert de type; sur le plus grand, elle est séparée des premiers par un espace étroit mais cependant bien apparent: malheureusement la face ventrale de ce dernier individu est en si mauvais état qu'elle ne se prête pas à l'étude.

Les sillons ambulacraires sont très larges et les tubes forment quatre rangées irrégulières. Les piquants adambulacraires sont disposés sur deux rangs: ils sont assez courts, mais fortement aplatis dans le sens transversal ; leur extrémité est tronquée et arrondie; les deux rangées sont à peu près identiques. Cinq piquants de la rangée externe correspondent à peu près à deux piquants de la rangée marginale ventrale.

Tous ces piquants, comme d'ailleurs ceux des rangées ventrales et marginales ventrales, sont enveloppés d'une enveloppe tégumentaire assez épaisse qui les recouvre complètement.

Les dents portent, à leur pointe proximale, chacune deux piquants cylindriques, terminés par une extrémité arrondie et plus minces que les adambulacraires; sur leur face ventrale, on rencontre un piquant plus fort, avec l'extrémité tronquée et rappelant davantage les piquants adambulacraires dont il diffère cependant par sa forme cylindrique. 
Il existe, comme d'habitude, des pédicellaires croisés assez nombreux dans le tissu des collerettes, et des pédicellaires droits qui se montrent, de distance en distance, sur les parois du sillon ambulacraire. Malheureusement le tissu calcaire de ces petits organes a été quelque peu attaqué par le formol et l'on ne peut en reconnaître la structure.

Rapports et différences. - La C. victorice est très voisine de la $C$. brucei; elle s'en distingue par ses bras plus amincis et comparativement plus longs, par le nombre des piquants carinaux, beaucoup plus élevé parce que ces piquants deviennent très petits et serrés dans la partie terminale des bras, par les piquants plus nombreux sur la face dorsale des bras où ils forment même plusieurs rangées longitudinales assez reconnaissables dans le grand exemplaire et enfin par la présence d'une rangée distincte de piquants sur la face ventrale, entre les piquants adambulacraires externes et la rangée marginale ventrale. Les piquants des deux rangées adambulacraires, ainsi que ceux des rangées ventrales et marginales ventrales, sont enveloppés d'une enveloppe tégumentaire qui les recouvre complètement, disposition que je n'ai pas observée chez la C. brucei.

\section{Notasterias, nov. gen.}

Le squelette des bras comprend cinq rangées régulières de plaques, une carinale, deux marginales dorsales et deux marginales ventrales, ainsi que cela est la règle dans le genre Coscinasterias et les genres voisins. Il existe en outre un commencement de rangée ventrale. Chaque plaque porte un piquant unique assez développé, mais dépourvu de collerettes à pédicellaires croisés. Les piquants de la rangée carinale offrent, à leur base, chacun un pédicellaire à valves croisées mais appartenant à un type particulier, et dont les dimensions sont vraiment considérables puisque leur longueur peut atteindre et même dépasser 2 millim. Ces pédicellaires sont toujours isolés à la base du piquant; ils ont les mêmes caractères que ceux que j'ai décrits chez l'Asterias pedicellaris recueilli par la Scotia (08, p. 49); leur structure diffère de celle des pédicellaires forcipiformes ordinaires et je propose de leur donner le nom de macrocéplrales; je reviendrai plus loin sur leurs caractères. A la base des piquants portés par les plaques marginales dorsales et ventrales, on rencontre aussi un et parfois deux pédicellaires macrocéphales, mais ces pédicellaires sont beaucoup plus petits que ceux qui accompagnent les piquants carinaux. Certains de ces piquants marginaux portent en outre des pédicellaires croisés ordinaires, au nombre d'un ou de deux au plus, et s'insérant sur le piquant lui-même entre sa base et son milieu. Ces pédicellaires forcipiformes sont toujours plus petits que les plus petits pédicellaires macrocéphales voisins : ils mesurent en effet 0.4 millin. de longueur environ, tandis que les plus petits pédicellaires macrocéphales atteignent près du double.

Dans la seule espèce connue, qui est de taille plutôt petite, il n'y a pas de rangée de plaques dorso-latérales. Les papules sont isolées et bien distinctes, arrondies et 
relativement assez grandes; elles sont espacées et forment une première rangée entre les carinales et les marginales dorsales, puis une deuxième, plus régulière, entre les marginales dorsales et ventrales. Les piquants adambulacraires sont disposés suivant quatre rangées irrégulières. Il existe des pédicellaires droits qui se montrent de distance en distance sur les parois des sillons ambulacraires. Les tubes ambulacraires forment plusieurs séries irrégulières.

Il me paraît utile de revenir sur les caractères des pédicellaires macrocéphales que j'ai pu étudier sur les deux échantillons de l'Expédition Anglaise, ainsi que sur un troisième exemplaire provenant de la deuxième Expédition Charcot, d'une manière plus complète que chez l'Asterias pedicellaris où ces gros pédicellaires étaient assez rares. Cette étude m'a convaincu que les différences entre ces pédicellaires et les pédicellaires forcipiformes sont assez marquées pour que l'on doive considérer les premiers comme représentant une forme à part; c'est pourquoi j'ai cru devoir leur appliquer un nom particulier.

Extérieurement, les pédicellaires macrocéphales se reconnaissent non seulement à leur taille, mais aussi à leur forme qui est conique, les deux valves qui constituent chacun d'eux allant en se rétrécissant jusqu'à l'extrémité, al lieu de former une lame convexe dont le bord libre est large, arrondi et muni d'une série de fines denticulations. En outre, l'extrémité de chaque valve est recourbée et se termine par un crochet plus ou moins développé qui se croise avec son congénère de telle sorte qu'on pourtait dire que ces pédicellaires sont doublement croisés : en effet, leurs valves se croisent d'abord au niveau de leur articulation sur la pièce basilaire, puis, une deuxième fois, vers leur extrémité. On peut voir, en comparant les dessins que je donne ici des pédicellaires macrocéphales (Pl. V, fig. 6 à 11 ; Pl. VI, fig. 4 à 8 ) aux figures de pédicellaires forcipiformes qui ont été publiées, soit autrefois par Perrier, soit plus récemment par Ludwig (03, Pl. VII, fig. 66 à 68), combien les deux formes sont diffèrentes. Dans les gros pédicellaires d'Asterias pedicellaris, le crochet terminal n'était pas très développé, mais il était toujours très fort et très apparent sur les petits (voir Kœhler, 08, Pl. VIII, fig. 75).

Ainsi que je l'ai dit en 1908, les valves de nos pédicellaires sont creuses: elles ont la forme d'un cornet dont une partie du bord libre se continue en une "queue" qui sert à l'articulation avec la pièce basilaire. En d'autres termes, la lame calcaire qui constitue la valve, s'enroule sur elle-même sur la moitié de sa longueur environ, et les deux bords de la partie euroulée s'adossent l'un à l'autre suivant une ligne droite qui porte des dents coniques et pointues (Pl. V, fig. 8, 9 et 11 ; Pl. VI, fig. 5 et 6). Ces dents sont moins nombreuses et moins fortes sur les gros pédicellaires que sur les petits, et elles ne se montrent que sur la partie proximale de la ligne suturale, de telle sorte que toute la région qui précède le crochet est dépourvue de dents. Sur les petits pédicellaires, les dents sont plus nombreuses et elles se montrent sur une plus grande longueur le long de la ligne suturale; chez l'A. pedicellaris, elles peuvent même s'avancer jusqu'au voisinage du crochet. Elles s'engrènent avec leurs congénères de 
la valve opposée. Le crochet termiual est pointu, plus ou moins allongé, tantôt droit, tantôt légèrement recourbé.

La queue de la valve, assez longue, est élargie, concave et elle se termine par un bord arrondi.

La lame calcaire qui forme chaque valve est constituée par un tissu aréolé, avec des perforations petites et très serrées, et la même structure s'observe sur toute l'étendue de la queue qui n'est pas constituée par du tissu compact. Seul le crochet qui termine les valves est formé par un tissu compact et transparent.

On voit donc que les valves des pédicellaires macrocéphales, avec leur forme de cône ou de cornet, leur crochet terminal, leurs denticulations disposées le long de la ligne- suturale qui correspond à l'une des génératrices du cône, et la queue formée de tissu calcaire aréolé, sont bien différentes de celles des pédicellaires croisés ou forcipiformes. La pièce basilaire sur laquelle les valves s'articulent, offre au contraire une composition peu différente de celle que l'on connaît chez ces derniers (Pl. V, fig. 10, et Pl. VI, fig. 7). Son corps représente une lame aplatie, allongée dans le genre Notasterias, plus courte chez l'Asterias pedicellaris, et qui se termine par un bord fortement convexe: celle-ci se présente par sa tranche quand on regarde le pédicellaire de profil comme celui qui est représenté Pl. V, fig. 6 et 7 , tandis que lorsque le pédicellaire est vu de face (Pl. VI, fig. 4 et 8), la lame se montre à plat. Les perforations, petites et nombreuses, sont disposées en rangées linéaires, légèrement divergentes et extrêmement serrées. La base de cette lame s'épaissit sur ses côtés de manière à former deux bords arrondis qui s'étendent presque perpendiculairement à son plan et se continuent chacun en avant et en arrière par une sorte d'apophyse conique et arrondie ; ces apophyses correspondent respectivement aux apophyses régulières et irrégulières de Perrier. On remarque que l'une des apophyses d'un côté est plus forte que l'autre du même côté, mais il n'y a pas, dans le développement et la direction, une inégalité comparable à celle que l'on connaît chez les pédicellaires forcipiformes. Dans les petits pédicellaires macrocéphales, les apophyses sont plus pointues et plus allongées et la lame est au contraire plus courte ; aussi, quand on regarde la pièce basilaire par le côté, on voit sur le plan supérieur les deux apophyses d'un côté et sur le plan inférieur les deux autres apophyses, tandis que la pièce basilaire ne représente qu'une saillie peu marquée. C'est l'aspect que j'ai figuré chez l'A. pedicellaris $(08, \mathrm{Pl}$. VII, fig. 67): la lame, moins développée que dans le genre Notasterias, était tout à fait invisible.

Les muscles adducteurs des valves sont extrêmement développés ; on les aperçoit par transparence sur des pédicellaires montés en entier et ils se prolongent assez haut dans l'intérieur des valves (Pl. V, fig. 7, et Pl. VI, fig. 4).

Les pédicellaires macrocéphales sont toujours isolés; ils ne sont jamais réunis en collerettes à la base des piquants comme l'on observe dans les Asterias et les genres voisins. Leurs valves sont entourées par un tissu conjonctif transparent qui se continue, à la base du pédicellaire, par un pédicule extrêmement court et mince, à l'aide duquel le 
pédicellaire se rattache au tégument de l'Astérie. Il n'y a pas de cordon fibreux s'insérant sur la pièce basilaire comme dans les pédicellaires forcipiformes.

La présence d'une forme particulière de pédicellaires chez une Astérie m'a paru suffisante pour justifier la création d'un genre nouveau, d'autant plus que les pédicellaires droits ou croisés conservent chez toutes les Asteriadées une structure très uniforme. Je propose d'appliquer le nom de Notasterias à l'Astérie découverte par l'Expédition Antarctique Anglaise.

Ainsi que j'ai eu l'occasion de le rappeler plus haut, j'ai rencontré les mêmes pédicellaires macrocéphales chez un Astérie recueillie par l'Expédition Antaretique Écossaise, à une profondeur de 1410 brasses, et que j'ai décrite sous le nom d'Asterias pedicellaris, mais cette dernière ne saurait rentrer dans le genre Notasterias : elle en diffère, en effet, par la constitution de son squelette, par la répartition irrégulière des pédicellaires macrocéphales, par l'absence de pédicellaires forcipiformes et par les piquants adambulacraires ne formant qu'une seule rangée. Je crois qu'il est nécessaire d'enlever cette espèce au genre Asterias et je serais disposé à en faire le type d'un nouveau genre qu'on pourrait appeler Autasterias. Les caractères distinctifs do ces deux genres antarctiques peuvent se résumer de la façon suivante :

Notasterias.-Le squelette des bras est formé par cinq rangées longitudinales de plaques assez grandes et unies de manière à former un squelette compact ne laissant que des orifices petits pour le passage des papules qui sont isolées. Chaque plaque porte un piquant dépourvu de collerettes à pédicellaires forcipiformes. Les piquants carinaux offrent, à leur base, chacun un gros pédicellaire macrocéphale unique; des pédicellaires analogues, mais plus petits, peuvent se rencontrer à la base des piquants marginaux dorsaux et ventraux, et ces piquants peuvent en outre porter quelques pédicellaires forcipiformes. Les piquants adambulacraires sont disposés sur deux rangées.

Une seule espèce, antarctique et littorale.

Autasterias.-Le squelette des bras est formé de cinq rangées longitudinales de plaques petites, portant chacune un piquant et reliées par des travées qui laissent entre elles de très larges mailles. Sur le réseau calcaire de la face dorsale, mais non spécialement à la base de chaque piquant, se trouvent disséminés quelques gros pédicellaires macrocéphales. Il n'y a pas de pédicellaires à la base des piquants portés par les plaques carinales et marginales dorsales, mais, à la base de chaque piquant marginal ventral, il existe un groupe de quelques petits macrocéphales; les pédicellaires forcipiformes font complètement défaut. Les piquants adambulacraires ne forment qu'une seule rangée.

Une seule espèce, antarctique et abyssale. 
Notasterias armata, nov. sp. (Pl. V, fig. 6 à 11 ; Pl. VI, fig. 1 à 8)

Baie du Cap Royds. 2 juillet 1908. Profondeur, 10-18 brasses.

Deux échantillons.

Les bras sont un peu inégaux. Dans le plus grand individu, $R=25$ à 28 millim., $r=5.5$ millim. Dans le second, $R=17$ à $20, r=4$ millim.

Le tégument est assez épais et il cache complètement les contours des plaques sous-jacentes; afin de pouvoir étudier ces dernières, j’ai desséché le plus petit échantillon chez lequel les contours des plaques sont devenus bien apparents. Je représente ici le plus grand individu (Pl. VI, fig. 1 et 2).

Le disque est petit; les bras en sont bien distincts, mais ils ne sont pas rétrécis à la base. Leur largeur est de 6.5 millim. en moyenne ; elle ne diminue guère que dans le dernier quart et l'extrémité est amincie.

La face dorsale du disque offre, à sa périphérie, un cercle de plaques au nombre de dix dans le petit exemplaire, cinq radiales et cinq interradiales; la disposition paraît être la même dans le grand exemplaire. Le centre est occupé par une plaque plus grande qui se relie à celles de la périphérie par des ossicules rayonnants. Chaque plaque porte un piquant assez fort, mesurant 2.5 à 3 millim. de longueur, assez élargi à la base et devenant ensuite cylindrique ; l'extrémité, obtuse, offre des rugosités ou de fines denticulations; de même que les piquants des bras, ceux-ci sont recouverts d'une mince enveloppe tégumentaire. A la base de chaque piquant se trouve un gros pédicellaire macrocéphale identique à ceux que nous retrouverons sur les bras, mais un peu plus petit en général que ces derniers, sauf celui qui se trouve à la base du piquant central. La plaque madréparique est petite, allongée dans le sens interradial et placée à peu près à égale distance du centre et des bords; ses sillons sont peu marqués.

Les bras présentent cinq rangées longitudinales de plaques: une carinale, deux marginales dorsales et deux marginales ventrales. La rangée carinale est bien saillante, de telle sorte que les bras sont assez fortement carénés; la rangée marginale dorsale est aussi très accusée. La rangée marginale ventrale est assez éloignée de la précédente et séparée d'elle par une face verticale; la coupe du bras se rapproche ainsi d'un polygone presque régulier, et dont la base seule est un peu plus grande que les autres côtés. Les plaques carinales, fortes et saillantes, ont une forme trifoliée, due à la présence de trois lobes arrondis, le lobe proximal recouvrant la région médiane de la plaque précédente et les lobes latéraux se reliant par de petites rangées aux plaques marginales dorsales. Les trois ou quatre premières plaques de chaque rangée portent chacune un piquant, mais les suivantes ne le possèdent pas toujours et parfois on ne le rencontre qu'une fois sur deux. Il y a une dizaine de piquants sur chaque bras dans le grand exemplaire et huit en moyenne dans le petit. I Les plaques qui portent un piquant sont plus fortes que les autres. Ces piquants ont les mêmes caractères que ceux du disque; ils sont seulement un peu plus longs et leur longueur 
atteint généralement 3 millim. Ils sont absolument dépourvus de collerettes à pédicellaires, mais, à la base de cnacun d'eux, se trouve un gros pédicellaire macrocéphale dont la longueur peut atteindre près de 3 millim. En raison de ses dimensions, ce pédicellaire rejette souvent le piquant, soit d'un côté, soit de l'autre; comme, d'autre part, la taille de ces pédicellaires varie, il en résulte que la rangée carinale de piquants parait plus ou moins irrégulière.

Les plaques marginales dorsales ont la même forme et la même disposition que les carinales, mais elles sont un peu plus saillantes que ces dernières; leurs lobes latéraux internes ne se réunissent directement à ceux des plaques marginales correspondantes qu'à l'extrémité des bras, mais, sur le reste de la longueur des bras, on remarque deux ou trois petites plaques intercalaires. La plupart des marginales dorsales portent un piquant rappelant ceux des carinales, mais un peu plus petit, et ces piquants paraissent plus fréquents que sur ces dernières plaques. En principe, les plaques marginales dorsales correspondent aux carinales, mais la correspondance est parfois troublée en raison de la présence ou de l'absence de piquants sur les plaques considérées. Certains piquants du commencement des bras offrent, à leur base, un pédicellaire macrocéphale constitué comme ceux de la série carinale, mais un peu plus petit; ces pédicellaires macrocéphales ne sont pas très nombreux sur les deux échantillons de l'Expédition Anglaise; j'aurai l'oceasion de faire remarquer plus loin que dans un exemplaire de Notasterias armata, recueilli par la deuxième Expédition Charcot, ces pédicellaires macrocéphales sont assez nombreux sur la série marginale dorsale. Ici, ces pédicellaires ne se montrent que sur les premiers piquants de la rangée marginale dorsale et les suivants portent, en général, chacun un ou deux pédicellaires forcipiformes ordinaires, qui s'insèrent, non plus à la base du piquant, mais à une hauteur variable sur sa première moitié, comme on l'observe chez diverses Asterias. Quand il y a deux pédicellaires croisés sur le même piquant, ceux-ci s'insèrent au même niveau; ils peuvent d'ailleurs coexister avec un pédicellaire macrocéplıale placé à la base du piquant. Ainsi que je l'ai dit plus haut, ces pédicellaires croisés sont toujours plus petits que les plus petits pédicellaires macrocéphales.

Les plaques marginales ventrales sont eucore plus saillantes que les marginales dorsales et elles forment, par leur ensemble, un bord tranchant qui sépare la face ventrale du reste du corps. Elles correspondent exactement aux marginales dorsales dont elles sont assez éloignées et, anxquelles elles sont réunies par des arceaux très réguliers, disposés parallèlement et comprenant chacun quelques petites plaques: ainsi se trouvent déterminées les faces latérales qui sont verticales. Chaque plaque porte un piquant analogue à ceux des marginales dorsales, mais un peu plus petit, légèrement aplati, avec l'extrémité arrondie et munie de fines aspérités. La plupart de ces piquants présentent, à leur base, un pédicellaire macrocéplale plus petit que ceux de la rangée carinale, et, plus haut, un ou deux petits pédicellaires croisés ordinaires s'insérant sur le piquant lui-même.

Entre les petits arceaux de plaques qui relient les carinales aux marginales dorsales, 
on remarque une ligne régulière de papules arrondies, absolument isolées et assez grandes; on peut même observer, à la base des bras, le commencement d'une deuxième rangée. Sur les côtés verticaux des bras, entre les plaques marginales dorsales et ventrales, il existe une autre rnngée, très régulière, de papules analogues.

Les sillons ambulacraires sont larges et renferment quatre séries irrégulières de tubes serrés.

Les piquants adambulacraires sont disposés suivant deux rangées très régulières : ces piquants sont cylindriques ou aplatis par suite de leur pression réciproque, et leur extrémité est arrondie; ils sont couverts d'une mince enveloppe tégumentaire qui les fait paraître lisses, mais, quand ils sont desséchés, on constate qu'ils sont couverts d'aspérités extrêmement fines et rapprochées.

Sur les parois du sillon, on reconnaît, de distance en distance, des pédicellaires droits qui ne présentent rien de particulier, et dont la longueur moyenne est d'un millimètre (Pl. VI, fig. 3).

Sur le grand exemplaire, il existe à la base des bras, entre les piquants adambulacraires et la rangée des piquants marginaux ventraux, une rangée intercalaire de piquants plus petits que ces derniers et qui leur correspondent assez exactement. Cette rangée ventrale atteint un développement variable : tantôt elle disparaît avant le milieu du bras, tantôt elle s'étend un peu plus loin. Ces piquants sont en général dépourvus de pédicellaires : j'observe cependant un pédicellaire croisé sur deux d'entre eux. Dans le petit exemplaire, cette rangée de piquants fait à peu près complètement défaut: on en retrouve cependant quelques vestiges à la base des bras.

Parmi les Échinodermes qui ont été recueillis par la deuxième Expédition Antarctique Française du Dr. Charcot, et qui viennent de m'être confiés, se trouve un exemplaire de Notasterias armata qui porte à trois le nombre des individus actuellement connus de cette espèce. Les dimensions sont voisines de celles des deux échantillons de la Terre Victoria : $R=20$ à 25 millim. Les deux rangées de plaques marginales dorsales sont un peu plus rapprochées de la rangée carinale et les gros pédicellaires macrocéphales sont un peu plus abondants: ils se montrent d'une manière assez constante à la base des piquants de la rangée marginale dorsale et j'en retrouve même à la base d'un certain nombre de piquants marginaux ventraux, mais ils sont alors beaucoup plus petits. En revanche, les pédicellaires croisés ordinaires sont très rares : j'en observe cependant quelques-uns sur les piquants des plaques marginales ventrales. 


\section{OPHIURES}

OphioglyPHA RESISTENS, nov. sp. (Pl. VIJ, fig. 9 à 12)

Cap Royds. Profondeur 10-20 brasses. $1^{\text {er }}$ juillet 1908. Plusieurs échantillons.

Dans le plus grand exemplaire, le diamètre du disque est de 12 millim. et les bras n'ont que 21 à 22 millim. de longueur: en général, les bras sont un peu plus longs et dans un échantillon chez lequel le diamètre du disque est de 10 millim. seulement, leur longueur atteint 28 millin. L'ensemble est très robuste: le disque est épais; les bras sont forts, épais et carénés sur la ligne médiane dorsale.

Le disque est arrondi ou subpentagonal. La face dorsale est couverte de plaques assez nombreuses, très inégales, épaisses et séparées par de larges sillons. On distingue généralement une centro-dorsale, grande et arrondie, et, en dehors, un cercle de cinq radiales un peu plus petites qu'elle et élargies transversalement: ces plaques sont séparées les unes des autres par une rangée de deux petites plaques arrondies; elles sont également séparées de la centro-dorsale par un cercle de plaques plus petites, entre lesquelles se montrent d'autres plaques très réduites. En dehors de cette partie centrale, viennent d'autres plaques parmi lesquelles on remarque, dans les espaces radiaux, une assez grande plaque arrondie, située à la base de chaque paire de boucliers radiaux et à laquelle fait suite une rangée de deux ou trois petites plaques séparant ces boucliers radiaux l'un de l'autre. Dans chaque espace interradial, on observe deux plaques successives principales, dont la plus exteme est située vers la périphérie du disque, avec d'autres plaques beaucoup plus petites. Les boucliers radiaux, de moyenne grosseur, sont triangulaires avec les angles arrondis, et un peu plus longs que larges: leur longueur ne dépasse guère le quart du rayon du disque; ils sont légèrement divergents et séparés sur toute leur longueur par la série de plaques signalée plus haut. On trouve, sur leur bord libre, une rangée de papilles, petites, arrondies, peu développées et formant une bordure régulière dans les individus de taille moyenne; dans les plus grands, ces papilles sont plus nombreuses, et elles sont disposées en deux ou même en trois rangées d'ailleurs très irrégulières: elles s'y montrent du reste moins développées que dans les individus moyens.

On remarque, sur les grands exemplaires, que les boucliers radiaux offrent, dans leur région centrale, une dépression plus ou moins accentuée, tandis qu'ils se relèvent vers leur bord externe en une ou deux proéminences arrondies. Cette disposition est analogue à celle que j'ai signalée chez l'O. anceps, mais elle est moins accentuée. De plus, la plupart des plaques de la face dorsale du disque, surtout celles qui sont voisines des bords, ont une tendance à se soulever en une ou deux protubérances centrales: au moins sont-elles toujours plus ou moins convexes; leur surface est rugueuse.

La face ventrale du disque offre, vers la périphérie, une assez grosse plaque médiane 
arrondie, généralement plus large que longue, avec quelques autres plaques plus petites. Les plaques génitales sont allongées et elles portent, sur leur bord libre, une rangée de papilles courtes et peu développées. Les fentes génitales sont étroites, mais elles s'étendent depuis l'extrémité des plaques adorales jusqu'à la périphérie du disque.

Les boucliers buccaux sont assez grands, piriformes ou pentagonaux, relativement plus gros dans les individus de taille moyenne que dans les grands: dans ces derniers, ils sont piriformes avec le bord externe convexe; dans les moyens, ils sont plutôt pentagonaux et offrent un angle proximal aigu limité par deux côtés droits et deux bords latéraux droits se reliant par des angles arrondis au côté distal convexe; ils sont un peu plus longs que larges. Les plaques adorales sont allongées et étroites, avec les bords parallèles, beaucoup plus longues que larges. Les plaques orales sont également allongées et plus longues que larges, mais elles sont plus petites et un peu plus étroites que les précédentes. Les papilles buccales sont au nombre de quatre de chaque côté; elles sont petites, basses, rectangulaires et subégales. La papille terminale impaire est petite et elle ne dépasse guère la taille des précédentes.

Les plaques brachiales dorsales sont assez grandes, quadrangulaires, avec un côté proximal étroit, un côté distal très large et fortement convexe et des bords latéraux divergents et droits; elles sont toutes contiguës. Les premières sont un peu plus larges que longues, puis elles deviennent aussi longues que larges et finalement plus longues que larges. Elles sont carémées, et, de plus, elles portent, un peu en arrière du bord distal, chacune un gros tubercule arrondi d'autant plus saillant et plus marqué que les exemplaires sont plus gros; ces tubercules rendent la carène des bras encore plus apparente.

La première plaque brachiale ventrale est assez grande, triangulaire, avec l'angle proximal arrondi et le bord distal un peu convexe; elle est aussi large que longue ou un peu plus large que longue. Les suivantes sont assez grandes, triangulaires, avec un angle proximal plutôt aigu, limité par des côtés droits et un bord distal légèrement convexe; elles sont plus larges que longues. Les premières sont contiguës, mais elles se séparent au delà du disque.

Les plaques latérales, peu proéminentes, portent, à la base des bras, quatre petits piquants papilliformes; ce chiffre tombe à trois à une certaine distance de la base des bras, et cela d'autant plus vite que l'échantillon est plus petit. Les deux piquants ventraux sont très rapprochés l'un de l'autre et le suivant est un peu éloigné du précédent; le dernier est tout à fait dorsal et placé à une certaine distance du troisième.

Lés pores tentaculaires sont peu développés. Ceux de la première paire ne s'ouvrent pas dans la bouche: ils offrent, sur leur bord externe, trois papilles basses, et, sur leur bord interne, deux ou trois papilles moins développées que les précédentes, plus étroites et formant une bordure très mince dans laquelle il est difficile de distinguer les limites des papilles. Les pores de la deuxième paire sont très petits et ils portent deux petites écailles papilliformes; on distingue encore les pores de la troisième paire qui sont très réduits et n’ont que deux écailles rudimentaires, mais, au delà, les pores cessent d'exister. 
Rapports et différcnces.-L'O. resistens rappelle beaucoup l'O. anceps que j'ai décrite d'après les exemplaires découverts par la Scotia, par $71^{\circ}$ lat. S. et $16^{\circ}$ long. W., à une profondeur de 1410 brasses, mais elle s'endistingue nettement par les fentes génitales plus allongées et par la présence de trois paires de pores tentaculaires : bien que les deux dernières paires soient peu développées, elles sont cependant bien visibles, tandis que l'O. anceps n'en possède pas plus de deux paires en tout. Les plaques dorsales du disque sont moins épaisses dans l'O. resistens que dans l'O. anceps et si leur région centrale est déprimée, elles n'offrent pas, comme dans cette dernière espèce, cet épaississement périphérique que j’ai indiqué; enfin les piquants brachiaux sont au nombre de quatre à la base du bras.

L'O. resistens s'éloigne de l'O. martensi Studer, par les pores tentaculaires et par la forme des plaques brachiales ventrales.

Ophioglypha flexibilis, nov. sp. (Pl. V, fig. 1 et 2 )

Cap Royds. Profondeur, 60-80 brasses. 20 août 1908. Quelques échantillons.

Dans les plus grands individus, le diamètre du disque égale 8 millim. et les bras ont de 20 à 25 millim. de longueur; dans les autres, qui sont les plus nombreux, le diamètre du disque varie entre 3 et 6 millim.

Le disque est arrondi ou subpentagonal; la face dorsale est fortement convexe et la face ventrale est plane: il est épais, tandis que les bras sont au contraire très grèles, minces et flexibles.

La face dorsale du disque est couverte de plaques très inégales, à linites nettenent indiquées. On distingue une grande centro-dorsale arrondie, et cinq radiales primaires également arrondies et de même taille que la centro-dorsale; les radiales sont séparées les unes des autres par une rangée de petites plaques et le cercle qu'elles forment est aussi séparé de la centro-dorsale par une rangée de plaques inégales, celles qui correspondent à l'intervalle des radiales étant beaucoup plus grandes que les autres. En dehors de ces plaques, on reconnaît dans les espaces radiaux une plaque triangulaire, plus grande que les voisines et qui sépare les régions proximales des boucliers radiaux de chaque paire; dans les espaces interradiaux, on remarque, vers la périphérie du disque, deux plaques très grandes, arrondies, dont la dernière occupe le bord du disque. Les autres plaques sont beaucoup plus petites, inégales et irrégulièrement arrondies. Les boucliers radiaux sont petits et leur taille est inférieure à celle des grandes plaques du disque : ils sont triangulaires, divergents, séparés sur toute leur longueur par deux plaques, la distale très petite, la proximale graude et triangulaire; ils sont raprochés l'un de l'autre an nivean de leur angle externe, mais non contigus sur les plus grands exemplaires. Ils sont à peine plus longs que larges et leur longueur ne dépassse pas le quart du rayon du disque. En dehors de chaque bonclier, on observe une rangée de papilles assez basses, rectangulaires, obtuses ou légèrement amincies à l'extrémité. 
La face ventrale n'offre, en dehors des grands boucliers buccaux, que quelques plaques peu nombreuses: on distingue une grande plaque médiane faisant suite au bonclier buccal et quelques autres plaques plus petites. Les plaques génitales sont étroites et elles portent sur leur bord libre une rangée de papilles basses. Les fentes génitales sont très apparentes.

Les boucliers buccaux sont grands, de forme pentagonale, aussi larges que longs: l'angle proximal, obtus, est limité par deux côtés droits et les bords latéraux se relient par denx angles arrondis au côté distal qui est convexe. Les plaques adorales sont assez petites, étroites, deux fois plus longues que larges. Les plaques orales sont petites et triangulaires. Les papilles buccales latérales ne dépassent généralement pas le nombre de trois, elles sont rectangulaires, assez petites et elles font suite directement aux papilles internes $d u$ pore tentaculaire buccal; la papille terminale impaire est un peu plus grande que les autres.

Les plaques brachiales dorsales sont assez grandes. Les premières sont rectangulaires et plus larges que longues, avec un côté proximal très étroit, deux bords latéraux divergents et un côté distal très large et fortement convexe qui se décompose ordinairement en trois côtés distincts se réunissant par des angles obtus. Le côté proximal ne tarde pas à disparaître sur les plaques suivantes qui deviennent alors triangulaires en même temps qu'elles se montrent un peu plus longues que larges. Elles sont contiguës sur le premier tiers des bras, puis elles se séparent par un intervalle étroit et elles deviennent bientôt un peu plus longues que larges.

La première plaque brachiale ventrale est triangulaire, un peu plus large que longue, avec l'angle proximal légèrenent tronqué; le bord distal, très convexe et offrant en son milieu un lobe assez large plus ou moins apparent, se décompose parfois en trois petits côtés distincts. La deuxième plaque est rectangulaire, un peu plus longue que large, avec un côté proximal plus étroit, un côté distal large et convexe et des bords latéraux divergents. Les suivantes sont pentagonales avec un angle proximal aigu, et un bord distal large et convexe offrant en son milieu un petit lobe plus ou moins accusé; ces plaques se séparent à partir de la troisième.

Les plaques latérales, peu proéminentes, portent chacune quatre piquants courts, assez larges, coniques et pointus, s'insérant le long du bord distal de la plaque à des intervalles égaux.

Les pores tentaculaires ne sont pas très développés. Ceux de la première paire, qui s'ouvrent dans la bouche, portent sur chacun de leurs bords trois écailles rectangulaires et obtuses, les internes plus fortes que les externes. Les pores de la denxième paire portent trois écailles proximales et externes, épaisses, coniques, pointues, et deux écailles distales et internes très petites, basses et peu développées; ceux de la troisième paire ont trois écailles proximales et une ou deux distales; ceux de la quatrième paire ont deux on trois écailles proximales et ume senle distalc; enfin les pores de la einquième paire ont deux écailles proximales et une distale. Au delà, il n'existe qu'ıne seule écaille proximale. 
Dans les jeunes exemplaires, le nombre des plaques dorsales du disque est beaucoup moins élevé: les six plaques primaires, avec les deux grandes plaques de chaque interradius, suffisent pour recouvrir la plus grande partie de la face dorsale du disque. Les boncliers radiaux sont rapprochés en dehors et parfois même contigus sur une certaine partie de leur longueur.

Rapports et différences.-L'O. flexibilis se rapproche de l'O. mimaria que j'ai décrite d'après des exemplaires recueillis par la Scotia, à une profondeur de 1410 brasses, par $71^{\circ} 22^{\prime}$ lat. S. et $16^{\circ} 34^{\prime}$ long. W. ; elle en diffère par ses plaques brachiales ventrales qui deviennent rapidement plus longues que larges, tandis que chez l'O. mimaria elles restent tonjours beancoup plus larges que longues, par la face ventrale du disque offrant une grande plaque médiane faisant suite au bouclier buccal et en dehors de laquelle il n'existe qu'un petit nombre de plaques seulement, enfin par les piquants brachiaux qui ne sont qu'au nombre de quatre.

Elle s'écarte de l'O. martensi Studer, de la Géorgie du Sud, par une forme complètement différente des plaques brachiales dorsales et ventrales, ainsi que par les pores tentaculaires, et par la présence de quatre piquants brachiaux.

Amphiura algida, nov. sp. (Pl. VII, fig. 14 et 15)

Cap Royds. Profondeur, 10-20 brasses. Deux échantillons.

Cap Royds. Profondeur, 50-80 brasses. Un échantillon.

Dans le plus grand individu, le diamètre du disque est de 4.5 millim.; dans les deux autres, il ne dépasse pas 3 millim. Les bras sont tous cassés et ils ne devaient pas avoir plus de 15 millim. de longueur.

Le disque est pentagonal avec les angles arrondis. La face dorsale est couverte de plaques grandes et inégales, en forme d'écailles aplaties, imbriquées, dont le bord libre offre une très mince bordure, sorte de liseré finement strié et transparent. Ces plaques sont très grandes dans la région centrale du disque: elles deviennent plus petites vers la périphérie et vers les boucliers radiaux; il n'y a pas la moindre indication de plaques primaires. Les boucliers radiaux sont petits et peu développés: ils sont à pcine deux fois et demie plus longs que larges et leur longueur est inférieure au quart du rayon du disque; ils sont assez rapprochés l'un de l'autre, peu divergents et séparés par une rangée étroite de plaques.

$\mathrm{La}$ face ventrale du disque est recouverte de plaques identiques à celles de la face dorsale, mais plus petites et égales. Les fentes génitales sont étroites.

Les boucliers buccaux sont triangulaires avec des côtés convexes et un angle proximal arrondi; le côté distal est fortement convexe et il offre même en son milieu un lobe qui n'est pas très proéminent dans le grand exenplaire où le bouclier est à peu près aussi long que large; dans les deux petits, ce lobe est au contraire très proéninent et les boucliers sont plus longs que larges. Les plaques adorales sont triangulaires, avec 
le bord oral légèrement incurvé ; elles sont fortement amincies en dedans et à peine contiguës sur la ligne médiane : parfois même elles restent séparées de leurs congénères par l'angle proximal du bouclier buccal ; leur région externe est au contraire fortement développée et arrive même à toucher la région correspondante de la plaque opposée en comprimant la première plaque brachiale ventrale. Les plaques orales sont étroites et assez hautes. Les papilles buccales comprennent d'abord deux papilles placées sur le même plan que les autres pièces buccales: l'interne est épaisse et arrondie, l'externe est allongée, proéminente, assez épaisse et son extrémité est obtuse ; il existe en outre, sur un plan supérieur, une petite papille conique et pointue s'insérant entre les deux précédentes.

Les plaques brachiales dorsales sont grandes et triangulaires avee les côtés légèrement convexes et un angle proximal arrondi; elles sont un peu plus larges que longues et toutes contiguës.

La première plaque brachiale ventrale est très petite et triangulaire, avec un angle distal aigu qui est limité de chaque côté par les plaques adorales. Quand ces dernières plaques sont très rapprochées ou contiguës, l'angle de la plaque, resserré entre elles, est très pointu ; quand les plaques adorales sont un peu écartées, l'angle devient tronqué. Les plaques suivantes sont pentagonales, avec un angle proximal: sur les premières plaques, qui sont à peu près aussi longues que larges, cet angle est d'abord très obtus ; il se montre plus aigu sur les plaques suivantes qui deviennent sensiblement plus longues que larges. Le bord distal s'échanere légèrement au-delà du disque. Toutes ces plaques sont contiguës.

Les plaques latérales portent quatre piquants subégaux et dont la longueur égale celle de l'article; ces piquants, assez épais, s'amincissent progressivement jusqu'à l'extrémité qui forme une pointe obtuse.

L'écaille tentaculaire, unique, est bien développée; elle offre deux côtés parallèles et une extrémité obtuse: elle est presque rectangulaire et près de deux fois aussi longue que large.

Rapports et différences.-L'A. algida se distingue facilement de toutes les Amphiura s. str. connues possédant des écailles sur les deux faces du disque et une seule écaille tentaculaire. L'A. profecta, que j'ai décrite d'après un exemplaire de l'île Campbell, a l'écaille tentaculaire remarquablement grande et plus forte que chez l' $A$. algida; les plaques primaires sont très apparentes, la papille buecale externe est squamiforme et la face ventrale du disque est couverte d'écailles très petites. L'A. pusilla Farquhar, de la Nouvelle-Zélande, a six piquants brachiaux et son écaille tentaculaire, arrondie, est assez petite. L'A. magellanica, avec son premier piquant ventral allongé, est bien différente de l'A. algida.

Notre espèce se rapproche surtout de l'A. angularis Lyman, mais, chez cette dernière, la face ventrale du disque est nue ou garnie d'écailles rudimentaires; de plus, la papille buccale externe est conique et pointue, l'écaille tentaculaire est arrondie et les boucliers buccaux sont presque circulaires. 


\section{OPHIODIPLAX, nov. gen.}

Ce genre rappelle les Ophiacantha et les genres voisins.

La face dorsale du disque est recouverte d'un tégument qui cache complètement les plaques sous-jacentes, y compris les boucliers radiaux, et qui porte de petits bâtonnets; ce tégument se continue sur les premières plaques brachiales dorsales. Celles-ci sont divisées, par une suture transversale, en deux moitiés inégales, la proximale plus petite, et cette division existe sur toute la longueur des bras. Les papilles buccales sont nombreuses et clles ne forment pas une rangée régulière.

La division en deux des plaques brachiales dorsales s'observe d'une manière très constante dans les nombreux exemplaires que j'ai pu étudier, aussi bien cliez les individus très jeunes que chez ceux dont le disque atteint 10 à 11 millim. de diamètre et qu'on peut considérer comme adultes. Ce caractère ne s'observe chez aucune Ophiacanthidée connue et il m'a paru suffisant pour justifier la création d'un nouveau genre.

Ophiodiplax Disjuncta, nov. sp. (Pl. VI, figs. 9, 10 et 11 ; Pl. VII, fig. 13)

Cap Royds. Profondeur, 60-80 brasses. 20 août 1908. Trois échantillons.

Le diamètre du disque varie entre 8 et 9 millim. ; les bras atteignent 40 à 50 millim. de longueur.

Le disque est subpentagonal dans l'un des individus; dans les deux autres, il est pentagonal avce les côtés plus ou moins excavés.

La face dorsale du disque est couverte d'un tégument qui cache complètement les plaques sous-jacentes et offre de petits bâtonnets assez écartés, courts, coniques et dont le sommet, émoussé, porte de deux à quatre ou cinq spinules très fines et pointues. A la périphérie du disque, ces bâtonnets s'allongent un peu et deviennent cylindriques ; leur surface est plus ou moins rugueuse et ils montrent toujours un certain nombre de petites spinules à leur partie terminale. Les boucliers radiaux ne sont pas distincts : ils sont seulement indiqués par des saillies plus on moins apparentes de la face dorsale du disque à la base des bras.

La face ventrale du disque présente des bâtonncts identiques à ccux de la face dorsale, mais plus épais que sur cette dernière, surtout au voisinage des fentes génitales où l'on distingue des plaques très fines et arrondies; ces bâtonñets se continuent, en diminuant de longueur, jusqu'au voisinage des boucliers buccaux. Les fentes génitales sont très larges.

Les boucliers buccaux sont assez grands, quadrangulaires, plus larges que longs, avec les angles arrondis; la région proximale, qui correspond au sommet de l'angle proximal, est parfois séparée du reste de la plaque par un sillon irrégulier. Les plaques adorales sont assez larges mais pas très grandes, et clles sont à peine deux fois et demie plus longues que larges; elles ne possèdent pas de lobe distal séparant le bouclier 
buccal de la première plaque brachiale ventrale. Les plaques orales sont petites et triangulaires. Les papilles buccales sont nombreuses et serrées, et elles ne forment pas une série très régulière, car, dans la région moyenne, on observe deux rangées plus ou moins distinctes; il y en a une.dizaine en tout de chaque côté. Ces papilles sont petites, coniques et pointues, et elles deviennent un peu plus longues vers l'extrémité proximale des plaques orales; la papille impaire terminale est un peu plus grande et plus forte que les voisines.

Les contours des premières plaques brachiales dorsales ne sont pas distincts. Le tégument de la face dorsale du disque se continue, en effet, sur une certaine longueur de la face dorsale des bras en recouvrant les cinq ou six premièrès plaques brachiales : il présente des bâtonnets analogues à ceux de la face dorsale du disque, mais ceux-ci sont plus courts, coniques avec la pointe rugueuse ou garnie de deux ou trois petites spinules, et ils deviennent de plus en plus petits pour disparaître finalement. Les plaques brachiales dorsales apparaissent alors et elles se montrent de suite avec leur structure caractéristique : chacune d'elles est en effet divisée par un sillon transversal légèrement convexe en deux parties inégales; la partie proximale est petite et la partie distale est relativement graude. Dans leur ensemble, ces plaques ont une forme triangulaire et elles sont un peu plus longues que larges avec un sommet proximal arrondi et $\mathrm{m}$ bord distal convexe. La région proximale de la plaque est petite, en forme de triangle à sommet plus ou ınoins arrondi : cette région est un peu plus longue que large. La région distale de la plaque est plus large que longue, trapézoïdale, avec un côté proximal étroit et un peu concave, un côté distal très large et convexe et deux bords latéraux divergents.

La première plaque brachiale ventrale est assez grande, triangulaire, avec les angles arrondis; le sommet, distal, est arrondi et la base, proximale, est convexe ; elle est un peu plus large que longue. Les plaques suivantes sont triangulaires, plus larges que longues, avec un angle proximal obtus et arrondi, et un bord distal fortement convexe; ce bord peut offrir un petit lobe inédian obtus et il se décompose parfois en deux côtés distincts. Ces plaques sont séparées dès la base du bras. A partir du premier tiers, elles deviennent plus longues que larges, avec un angle proximal aigu un peu arrondi et un bord distal toujours fortement convexe.

Les plaques latérales, assez proéminentes, portent six piquants à la base des bras: la longueur de ces derniers augmente légèrement depuis le premier, qui égale l'article, jusqu'au troisième; le quatrième et le cinquième sont un peu plus longs et leur longueur dépasse un article et demi; le sixième est un peu plus court. Leur surface est couverte de très fines rugosités qui sont un peu plus marquées vers l'extrémité. On trouve parfois sept piquants à une petite distance de la base des bras.

L'écaille tentaculaire, unique, est courte, mince, spiniforme et son extrémité est pointue.

J'ai rencontré dans les collections de la deuxième Expédition Antarctique du BIIT. ANTARCT. EXPED. 1907-9. VOL. 11. 
Dr. Chareot, un certain nombre d'exemplaires de cette même Ophiure qui n’ont permis de mieux en préciser les caractères et de m'assurer de leur constance; j'ai noté également quelques particularités qu'il est bon de signaler. La taille des échantillons peut être supérieure à celle de ceux qui ont été recueillis par l'Expédition Anglaise, et, dans certains d'entre eux, le diamètre du disque dépasse 11 millim. J'ai représenté ici deux de ces individus; dans l'un, qui est vu par la face dorsale, le diamètre du disque atteint à peine 9 millim. (Pl. VI, fig. 10); dans l'autre, qui est vu par la face ventrale, le diamètre du disque est de $11 \cdot 2$ millim. (Pl. VI, fig. 11). Les plaques brachiales dorsales sont toujours divisées, mais leur forme peut offrir des variations : tantôt elles sont plus longues que larges comme dans l'individu reproduit Pl. VI, fig. 10, tantôt au contraire elles sont un peu plus larges que longues. Les piquants brachiaux peuvent être plus développés et le piquant dorsal dépasse la longueur de deux articles, ainsi que cela arrive dans l'exemplaire de la fig. 10, dont le disque n'a que 9 millim. Dans les échantillons de grande taille (Pl. VI, fig. 11), les papilles buccales deviennent plus fortes et plus nombreuses; les plaques brachiales ventrales offrent, à partir de la deuxième, une forme pentagonale avec un angle proximal très obtus et un bord distal convexe; ce n'est qu'à partir de la dixième qu'elles deviennent triangulaires. D'une manière générale, je remarque que, sur les exemplaires de l'Expédition Chareot, les piquants de la face dorsale du disque se continuent moins loin sur les bras que sur les individus de la Terre Victoria et ils peuvent disparaître dès la troisième plaque brachiale dorsale.

L'O. disjuncta me paraît identique à une Ophiure antarctique que J. Bell a figurée, sans la décrire $(08, \mathrm{Pl}$. IV) : si elle n'est pas identique à cette forme, elle en est, en tout cas, fort voisine. D'après les dessins de J. Bell, les plaques brachiales dorsales de cette Ophiure sont divisées, à la base des bras, en deux parties inégales ; mais, d'autre part, les pores tentaculaires auraient chacun deux écailles, l'une proximale, l'autre distale, et ces écailles sont élargies transversalenent; je n'observe aucune disposition analogue sur mes échantillons et je me demande s'il n'y a pas une erreur dans les dessins de J. Bell. J'ajouterai que cet auteur considère son Ophiure comme un jeune: or sur deux dessins qui sont faits avec un grossissement de $9 / 4$, le diamètre du disque est de 22 millim. mesuré entre le fond d'un espace interradial et le bord radial opposé, ce qui correspond à un diamètre de près de 10 millim. en grandeur naturelle. Si done ces ehiffres sont exacts, les exemplaires de Bell seraient de la taille de ceux que j'ai étudiés et il me paraît bien difficile d'adnettre qu'une Ophiacanthidée, dont le disque a un diamètre moyen de 10 millim., soit un jeune.

Le savant naturaliste anglais parait attribuer à cette jeunesse des exemplaires les caractères des plaques brachiales dorsales qui ne seraicnt pas conplètement calcifiées. Je ne suis pas de cet avis: j'estime que ces plaques sont parfaitement formées et qu'elles restent fragmentées chez l'adulte, comme on l'observe d'ailleurs chez quelques autres Ophiures. 


\section{ÉCHINIDES}

\section{Sterechinus Neumayeri (Meissner)}

Voir pour la bibliographie: Mortensen (10), p. 64.

Cap Royds. Profondeur, 10-50 brasses. Juillet 1908. Quelques échantillons de différentes dimensions : le diamètre du test varie entre 58 et 24 millim.

Abatus shackletoni, nov. sp. (Pl. IV, fig. 3 à 10 ; Pl. VIII, fig. 1 à 6)

Baie du Cap Royds. 5 mars 1908. Profondeur, 10-20 brasses. Treize échantillons dont un ineomplet et eassé.

Cinq exemplaires sont d'assez grande taille et leur longueur est voisine de 35 millim., les autres sont plus petits. Dans les plus grands, la longueur totale avec les piquants varie de 34 à 38 millim.

Dans l'individu représenté Pl. VIII, fig. 3 à 5 , les dimensions sont les suivantes :

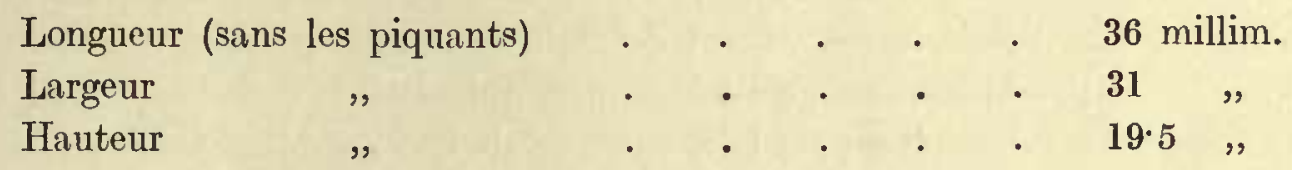

Cet individu a les poches incubatrices très profondes et il représente incontestablement une femelle. On voit, par les photographies que j'en donne, que sa forme est régulièrement ovoïde et que le corps est assez allongé. Cette même forme s'observe sur trois des autres grands échantillons et me paraît être typique. Le dernier exemplaire est relativement plus large et plus court, ainsi qu'on peut le constater sur la photographie reproduite Pl. VIII, fig. 6. Les dimensions de cet individu sont les suivantes:

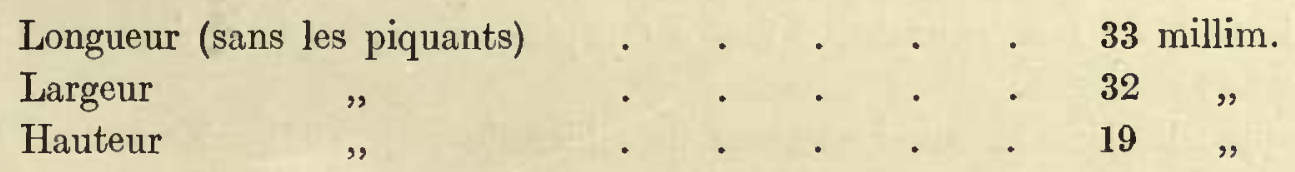

Les poches incubatrices de cet exemplaire sont beaucoup moins profondes que celles du précédent, mais je le considère néanmoins comme une femelle. Un trois ème individu, dont j'ai laissé le test intact, présente des poches ineubatrices profondes et appartient aussi au sexe femelle. Quant aux deux autres individus, ils ont les ambulacres dorsaux à peine déprimés et non transformés en poches incubatrices: ce sont des mâles.

Les antres exemplaires, de plus petite taille, ont le corps relativement élargi et moins allongé; leurs ambulacres dorsaux sont peu déprimés et tous ont le caractère de mâles. 
Voici les dimensions que je relève, piquants non compris, sur les sept échantillons qui sont intacts :

Longueur.

13 millim.

16

17 ,

17 "

$21 \cdot 5$,

22 "

23 ,

\section{Largeur.}

11.5 millin.

13

14

$15.5 \quad$,

19

$19.5 \quad$,

19

Je décrirai l'exemplaire représenté Pl. VIII, fig. 3 à 5 , que je prendrai comme type de l'espéce; j'indiquerai ensuite les quelques différences que je relève avec celui de la Pl. VIII, fig. 6, et enfin je donnerai les caractères du mâle.

Vu d'en haut, le test est assez régulièrement ovoïde; il est plus rétréci en arrière qu'en avant et la plus grande largeur s'observe au niveau de l'appareil apical qui est plus rapproché du bord antérieur que du bord postérieur.

Le bord antérieur est à peine déprimé sur la ligne médiane, le sillon qui correspond à l'ambulacre dorsal antérieur devenant de moins en moins profond à mesure qu'on se rapproche de l'ambitus; même l'échancrure, qui, dans le premier exemplaire, est à peine marquée en dessous du fasciole, entre celui-ci et l'ambitus, devient, ainsi que nous le verrons plus loin, tout à fait nulle dans le second où le sillon est d'ailleurs moins profond, comme cela arrive aussi chez les mâles.

Vu latéralement, le test offre d'abord une courbe s'élevant régulièrement jusqu'à l'appareil apical, puis, en arrière de cet appareil, il forme une proéminence interradiale assez marquée sur l'échantillon dépourvu de ses piquants, mais qui n'apparaît pas ou n'apparaît que fort peu sur les individus munis de leurs piquants; cette proéminence diminue rapidement jusqu'à l'extrémité postérieure qui est tronquée verticalement et peu élevée. La face ventrale est tout à fait plane en avant du péristome et un peu convexe en arrière.

L'appareil apical est situé en avant du milien du corps et il présente trois orifices génitaux, deux à gauche et un à droite; ces orifices sont arrondis et assez grands (Pl. VII, fig. 4). Les deux orifices de gauche sont très rapprochés l'un de l'autre tandis que l'orifice de droite est assez écarté de l'orifice postérieur gauche: il n'est pas situé exactement sur le même niveau transversal que ce dernier, mais se trouve placé très légèrement en arrière. La ligne qui réunit les deux orifices passe à 15.5 millim. du bord antéricur du test età 20.5 millim. du bord postérieur. La plaque madréporique occupe à peu près tout l'espace compris entre les deux orifices postérieurs; elle s'étend en avant jusqu'au niveau du bord antérieur de l'orifice antérieur, et, on arrière, elle dépasse le bord postérieur des orifices postérieurs. Elle est criblée de petits pores arrondis, régulièrement disposés et qui en occupent à peu près toute la surface; on 
reconnaît, en outre, un certain nombre de granules très fins et placés aussi d'une manière régulière. On distingue facilement les contours des plaques ocellaires qui sont petites, pentagonales avec un angle proximal et offrent chacume un orifice transversal en forme de croissant à concavité tournée vers l'extérieur. Les contours des autres plaques sont indistincts.

I'ambulacre antérieur impair forme, à la face dorsale du test, un sillon assez étroit et peu profond, dont les côtés se continuent par un bord très arrondi avec les régions interradiales du test et qui s'atténue progressivement avant d'atteindre le fasciole ; il disparaît presque complètement au niveau du bord antérieur du test (Pl. VIII, fig. 5). Les zônes porifères, situées sur les côtés légèrement obliques du sillon, sont droites et elles vont en divergeant quelque peu; elles ne sont pas très écartées l'une de l'autre en raison de la faible largeur du sillon. Je compte dans chacune d'elles, et jusqu'au fasciole, vingt paires de pores dont la grosseur augmente depuis la première jusqu'à la septième, puis décroit ensuite de telle sorte que les pores des deux dernières paires sont très fins. Les huit ou dix premières paires de pores sont séparées par deux ou trois granules formant souvent une petite rangée transversale; au delà, les granules diminuent ou même disparaissent complètement entre les pores, tandis qu'on voit apparaître sur chaque plaque un granule plus gros et rapproché de son bord interne. Les pores des premières paires sont disposés suivant une ligne perpendiculaire à l'axe du sillon, puis les paires suivantes se placent obliqnement par rapport à cet axe, en même temps que les pores de chaque paire se rapprochent l'un de l'autre et deviennent plus petits.

Les ambulacres latéraux antérieurs et postérieurs présentent à peu près le même développement. Les ambulacres antérieurs sont fortement divergents et ils sont presque placés sur le prolongement l'un de l'autre, tandis que les postérieurs sont très rapprochés et peu divergents; ils sont séparés par la proéminence interradiale que j'ai signalée plus haut et dont la largeur, à la base, est de 4 millim. L'axe de l'ambulacre antérieur forme, avec cclui de l'ambulacre postérieur du même côté un angle de $90^{\circ}$ environ.

Les ambulacres antérieurs sont, comme les postérieurs, très profondément déprimés à la face dorsale du test et ils constituent des poches incubatrices, allongées mais assez étroites dans notre espèce; elles ont toutes les mêmes dimensions et mesurent environ 12 millim. de longueur sur 3 millim. de largeur; les poches antérieures sont légèrement élargies sur leur région externe, tandis que les poches postérieures conservent la même largeur sur toute leur étendue. La dépression qui constitue chaque poche se fait très brusquement à partir de la troisième paire de pores ambulacraires et les parois sont à peu près verticales; elles se relient par un angle arrondi avec la face dorsale du test. La profondeur des poches est de 6 millim. La partie de l'ambulacre qui est comprise entre l'appareil apical et la poche proprement dite, ne reste pas à fleur du test, mais elle est un peu déprimée surtout dans le sens de la longueur de manierc à former un sillon oblique qui conduit à la poche. Chaque 
poche s'étend jusqu'au fasciole: en l'abordant, elle se relève brusquement pour la poche postérieure et un peu obliquement pour l'antérieure.

La région interradiale dorsale comprise entre le sillon et l'ambulacre latéral antérieur est convexe; elle se continue insensiblement avec le sillon tandis qu'elle s'arrête brusquement au bord de la poche incubatrice. Elle est recouverte de granules primaires de petite taille, de dimensions très uniformes et assez espacés; ces granules sont plus serrés au voisinage de la poche incubatrice et leurs dimensions augmentent un peu au bord même de cette poche. Entre ces granules primaires se montrent d'autres granules extrêmement fins. On retrouve ces deux sortes de granules sur les régions interradiales antérieures et postérieures, ainsi que sur la proéminence interradiale postérieure, et l'on constate que les granules primaires deviennent toujours un peu plus serrés et un peu plus gros an voisinage des poches incubatrices.

Le face ventrale est peu convexe (Pl. VIII, fig. 3). L'ambulacre antérieur est peu distinct: il est légèrement déprimé au voisinage du péristome, mais il se relève en même temps qu'il se rétrécit à mesure qu'on se rapproche du bord du test. Il offre, de chaque côté, quatre paires de pores ambulacraires rapprochés, entourés chacun d'un cercle ovalaire très apparent; ça et là se montre un granule extrêmement fin. Puis les paires s'espacent rapidement en même temps que les pores deviennent plus fins: les granules au contraire deviennent subitement plus gros et leurs dimensions dépassent celles des granules dorsaux auxquels ils passent d'ailleurs à l'ambitus. Les ambulacres latéraux antérieurs sont placés sur le prolongement l'un de l'autre de part et d'autre de la bouche; ils offrent, de chaque côté, cinq paires de pores, entourés chacun de leur cercle ovalaire, formant deux rangées convergentes séparées par quelques fins granules; puis les pores deviennent très fins et espacés, tandis que les granules a.cquièrent les mêmes dimensions que dans les interradius voisins. Les ambulacres latéraux postérieurs constituent de larges avenues n'offrant que des granules très fins et peu abondants; des granules plus gros et plus serrés n'apparaissent qu'au voisinage de l'extrémité postérieure.

Les régions interradiales antérieures et postérieures de la face ventrale sont uniformément couvertes de granules assez espacés, de taille uniforme, mais sensiblement plus gros que ceux de la face dorsale avec lesquels ils se continuent à l'ambitus; entre ces granules primaires on en voit d'autres très fins et peu serrés. Le plastron sternal est simplement convexe et il est arrondi à son extrémité postérieure, sans former de proéminence ou de pointe saillante. Il offre des granules disposés en rangées obliques divergentes partant de son extrémité postérieure et se dirigeant vers les avenues ambulacraires ventrales: ces granules sont d'abord très fins, mais leurs dimensions augmentent à mesure qu'on se rapproche des avenues ambulacraires et du péristome.

Lc péristome se trouve à peu près à égale distance entre le bord antérieur du test et le milieu de la face ventrale; il est assez profondément situé, étroit, en forme de croissant, et plutôt petit. Le labre est de dimensions moyennes; son bord antérieur 
est fortement convexe et il forme une saillie très marquée, en forme de bec proéminent, qui cache la plus grande partie du péristome; ses bords latéraux sont excavés et le bord postérieur, fortement arrondi et convexe, s'étend jusqu'au milieu de la deuxième plaque ambulacraire voisine.

La face postérieure est verticale, mais peu étendue; elle est en grande partie occupée par le périprocte (Pl. IV, fig. 6). Celui-ci, de taille moyenne, a une forme ovoïde un peu irrégulière; il est un peu plus haut que large et mesure $5^{\bullet} 1$ millim. sur $4 \cdot 6$; il offre une rangée périphérique de grandes plaques rectangulaires et deux cercles plus ou moins réguliers de plaques centrales plus petites. Il n'y a pas la moindre indication de tubes ambulacraires au voisinage du périprocte.

Lé fasciole offre un contour assez régulier, sans inflexions ni sinuosités bien marquées (Pl. IV, fig. 6; Pl. VIII, fig. 4 et 5). Il est très rapproché de l'ambitus entre l'ambulacre antérieur et la poche incubatrice antérieure à l'extrémité de laquelle il est tangent : dans ce parcours il a la forme d'un arc de cercle presque régulier, à part deux sinuosités très légères. Entre les deux poches incubatrices de chaque côté, le fasciole s'écarte progressivement de l'ambitus et devient légèrement concave; au niveau de l'extrémité de la poche postérieure, à laquelle il est également tangent, il présente un angle obtus très marqué et se dirige vers l'interradius postérieur, en suivant une direction à peu près parallèle au bord postérieur du test: il reste séparé de ce bord par un intervalle de 4 millim. environ. Le fasciole conserve la même largeur sur tout son trajet, soit 1.5 millim. environ.

Les tubercules primaires sont perforés et finement crénelés. Ils sont plus petits sur la face dorsale et plus gros sur la face ventrale. Leurs dimensions restent uniformes sur presque toute l'étendue de la face dorsale, sauf au voisinage immédiat des poches incubatrices où ils deviennent un peu plus gros. Sur la face ventrale, ils sont plus espacés et plus gros, mais leur taille diminue à mesure qu'on s'éloigne du péristome et ils passent progressivement aux granules de la face dorsale. Au milieu de ces granules primaires s'en montrent d'autres très fins, dont les dimensions restent uniformes sur les deux faces du test.

Les piquants de la face dorsale sont fins et assez courts, leur longueur ne dépassant pas 3 millim.; ils sont couchés sur le test en formant un feutrage serré; ils sont cylindriques, obtus à l'extrémité, et, vers l'ambitus, ils sont légèrement recourbés. Les piquants des bords des poches incubatrices sont plus longs, un peu aplatis et ils sont dirigés de manière à recouvrir ces poches qui sont à peine visibles sur les échantillons non dépouillés de leurs piquants. Les piquants de la face ventrale sont bien développés et leur longueur peut atteindre 5 millim.

Les pédicellaires appartiennent aux trois types tridactyle, l'ostré et globifère. Les pédicellaires tridactyles sont de deux formes différentes, mais toujours à trois valves. Les uns rappellent ceux que Mortensen a décrits et figurés chez l'A. cavernosus (10 bis, Pl. XIX, fig. 37) : les valves sont élargies en forme de cuillerons qui sont peu rétrécis à leur base et qui se touchent sur une bonne partie de leur longueur; ces bords 
sont munis de denticulations extrêmement fines et régulières. Les pédicellaires de la deuxième forme ont les valves plus étroites, recourbées, séparées sur la plus grande partie de leur longueur et contiguës seulement dans leur partie terminale qui est élargie et munie de denticulations aiguës: cette forme se rapproche ainsi des pédicellaires rostrés. Ces deux sortes de pédicellaires sont répandus sur tout le test, la première plus abondamment que la seconde; toutes deux atteignent une assez grande taille et la longueur de la tête peut être de 0.5 à 0.6 millim.

Les pédicellaires rostrés ressemblent à ceux que Mortensen a indiqués chez l'A. cavernosus (10 bis, Pl. XIX, fig. 30,38 et 45); ils ont des valves fortement recourbées, qui, à partir de la base triangulaire, restent étroites en s'amincissant fort peu jusqu’à leur extrémité qui est obtuse. Les bords sont dépourvus de denticulations mais ils sont un peu sinueux et ils se relèvent, de distance en distance, en une dent peu saillante; l'extrémité de la valve n'est pas denticulée. Ces pédicellaires sont plus rares que les précédents et ils restent généralement plus petits; la longueur de leur tête peut cependant atteindre 0.3 à 0.4 millim.

Les pédicellaires globifères sont surtout répandus au voisinage du périprocte; ils rappellent beaucoup ceux que j'ai décrits et figurés chez l'A. elongatus (08, p. 620, PI. XVI, fig. 154). Les valves sont plus recourbées que dans cette dernière espèce ; elles se terminent, comme cliez elle, par deux crochets extrêmement développés, en arrière desquels se trouve une fente allongée à la suite de laquelle vient une courte partie tubulaire. Ces valves ressemblent aussi à celles des pédicellaires globifères déerits par Mortensen dans la var. bidens de l'A. cavernosus, mais, ici, la fente qui précède les deux crochets terminaux est plus allongée. Le tige calcaire offre un peu avant son extrémité un très léger épaississement parfois à peine marqué. Les valves et l'extrémité distale du pédoneule sont enveloppées, comme chez l'A. elongatus, d'un tissu fortement pigmenté et glandulaire qui rend la tête du pédicellaire fort apparente et dont l'ensemble mesure un millimètre de longueur environ, tandis que les valves incluses dans cette enveloppe ne dépassent pas 0.35 millim.

Les spicules des tubes ambulacraires sont petits et de forme très irrégulière. Les plus simples se présentent sous forme de bâtonnets plus ou moins recourbés et assez épais, offrant un nombre variable de prolongements latéraux en forme de dents; quand ces prolongements se rejoignent, il en résulte la formation de petites plaques perforées, allongées et de forme très irrègulière.

Les gros exemplaires ont une couleur brûnatre assez foncée et uniforme; les petits sont d'un brun plus clair et certains d'entre eux sont simplement grisâtres.

L'exemplaire qui est représenté Pl. VIII, fig. 6, diffère par quelques caractères de celui que je viens de déerire. Ainsi que je l'ai dit plus hant, le test est relativenent élargi au niveau de l'appareil apical et celui-ei est plus rapproché du bord antérieur : la ligne qui joint les centres des deux orifices génitaux postérieurs se trouve à 13 millin. du bord antérieur et 20 millim. du bord postérieur du test. Les orifiees génitaux sont un peu plus petits que dans le type. Le sillon antérieur est moins profond et le bord 
antérieur du test cesse d'être déprimé en son milieu; les pores ambulacraires du sillon sont plus fins. La proéminence interradiale dorsale, qui sépare les deux ambulacres postérieurs, est aussi moins accusée; onfin le périprocte est un peu plus petit : il est sensiblement plus haut que large et il mosure 5 millim. de hauteur sur 4:5 de largeur; il se rapproche un peu de la forme que nous observerons chez le mâle.' Les tubercules de la face dorsale du test sont répartis plus uniformément que dans le type et la différence de taille que l'on observe avec ceux qui avoisinent les ambulacres latéraux est moins apparente.

Les ambulacres latéraux antérieurs et postérieurs de la face dorsale sont assez fortement déprimés, mais les fossettes qu'ils constituent sont beaucoup moins profondes que dans le type et leur profondeur ne dépasse pas 3.5 millim. Au lieu d'apparaître brusquement et d'offrir un bord proximal abrupt et vertical, les fossettes se creusent progressivement par l'enfoncement graduel des ambulacres. Je compte dix-neuf paires de pores dans l'ambulacre antérieur, depuis l'extrémité proximale de l'ambulacre jusqu'au fasciole et vingt dans l'ambulacre postérieur. La fossette postérieure gauche ne représente pas une dépression continue et unique : elle est plutôt formée par deux dépressions successives séparées par une région moins enfoncée; cette disposition est évidemment accidentelle car elle n'existe pas du côté droit.

Bien que les poches incubatrices soient moins développées dans cet exemplaire que dans le précédont, elles existent cependant et il ne me paraît pas douteux que l'exemplaire ne soit une femelle; la disposition des ambulacres dorsaux est en effet bien différente chez le mâle qu'il me reste à décrire.

J'ai étudié les caractères du mâle sur deux exemplaires de tailles un peu différentes, et dont les dimensions respectives sans les piquants sont les suivantes :

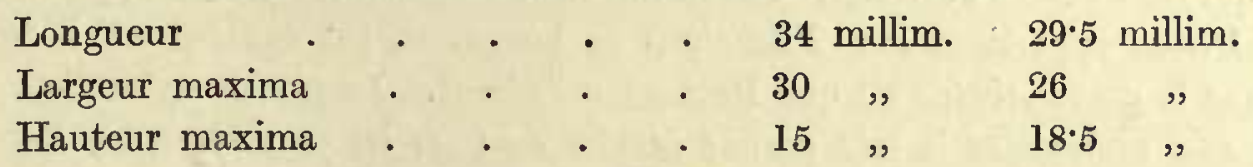

Je représente ici le plus grand individu (Pl. IV, fig. 3 à 5).

Le test est un peu plus élargi et plus court que chez la femelle qui m'a servi de type pour la description de l'espèce, mais ce caractère no doit pas être lié à une différence de sexe, ainsi que nous l'avons vu plus haut.

Dans les deux individus, l'ambulacre antérieur dorsal est à peine déprimé et il arrive à fleur du test en atteignant le bord interne du fasciole. Les quinze premières paires de pores seules sont assez développées, et les suivantes sont à peine apparentes ; les pores sont relativement un peu plus gros dans le plus petit exemplaire que dans l'autre. Les ambulacres latéraux antérieurs et postérieurs sont faiblement déprimés: les ambulacres antérieurs sont un peu plus enfoncés que les postérieurs, mais la différence est peu sensible. La dépression commence dès la première paire de pores dans les ambulacres postérieurs et seulement à partir de la deuxième ou de la troisième BRIT. ANTARCT. EXPED. 1907-9. VOL. II. 
paire dans les antérieurs. Je compte vingt paires de pores dans chacun de ces ambulacres.

Les orifices génitaux sont petits. Dans le grand individu, les deux orifices gauches sont très allongés, presque deux fois plus longs que larges, et leur grand axe est orienté suivant la direction de l'interradius : ils sont par conséquent dirigés obliquement l'un par rapport à l'autre. L'orifice droit est au contraire presque circulaire et plus petit que les deux autres; le bord interne de cet orifice est séparé du bord interne de l'orifice postérieur gauche par une distance de 1.7 millim.

Dans le petit exemplaire, les trois orifices génitaux sont petits et circulaires, et l'orifice droit est plus écarté de l'orifice gauche que sur l'autre individu, car il en est séparé par un intervalle de 2 millim. La plaque madréporique n'offre qu'unc petite plage perforée arrondie, autour de laquelle se montrent quelques tubercules, tandis que dans le grand individu, cette plaque présente la structure que j'ai décrite plus haut chez la femelle.

Le fasciole offre aussi le même trajet que chez cette dernière, mais, dans le petit échantillon, ses sinuosités sont à peine marquées.

Le périprocte est beaucoup plus haut que large: il mesure 4.7 millim. de hauteur sur 3.5 de largeur dans le grand exemplaire et 4.4 sur 3 millim. dans le petit; il est donc comparativement un peu plus haut chez ce dernier.

Je prie Sir Ernest Shackleton, commandant de l'Expédition Antarctique Anglaise, de vouloir bien accepter la dédicace de cette espèce.

Rapports et différences.-Mortensen a précisé récemment les limites respectives des genres Hemiaster et Abatus et il a fait une révision des espèces appartenant à ce dernier, espèces qui sont toutes australes. En raison de la constitution de son appareil apical, l'A. shackletoni appartient aux Ethmolysii de Loven, et, par conséquent, il doit être rangé dans le genre Abatus tel que Mortensen l'admet. Le savant naturaliste danois a rendu aux zoologistes le très grande service de fixer les caractères des différentes espèces du genre Abatus, espèces qui avaient été plus ou moins confondues par les auteurs en raison des descriptions insuffisantes qui en avaient été données. Ses recherches l'ont conduit à considérer, comme distinctes, les quatre espèces suivantes :

Abatus cordatus (Verrill).
Abatus agassizii (Pfeffer).
Abatus cavernosus (Philippi).
Abatus philippii Loven.

Quant à l'A. elongatus que j'ai décrit sous le nom d'Hemiaster elongatus, Mortensen incline à le réunir à l'A. agassizii.

L'A. cordatus provient des îles Kerguelen; les trois espèces suivantes appartiennent toutes trois à l'extrémité méridionale de l'Amérique du Sud et l'A. elongatus a été rencontré aux Orcades du Sud. 
L'A. shackletoni est dépourvu de tubes ambulacraires sous-anaux, caractère qu'il partage avec les $A$. cordatus et agassizii; il se distingue ainsi immédiatement des A. philippii et cavernosus qui ont, de plus, le sillon dorsal très marqué et il s'écarte surtout de l'A. philippii par les quatre pétales dorsaux profondément déprimés et formant des poches incubatrices également développées.

Les caractères de l'A. cordatus ont été bien établis par Mortensen : cette espèce est tout à fait spéciale aux îles de Kerguelen et elle ne pénètre pas dans la région sudaméricaine. L'A. shackletoni s'en distingue facilement par la présence de pédicellaires globifères, par le sillon antérieur dorsal moins enfoncé, par les poches incubatrices plus étroites et comparativement plus longues, par une forme différente du corps qui est plus allongé et par l'appareil apical qui est reporté en avant.

La position de l'appareil apical permet aussi de séparer l'A. shackletoni de l'A. agassizii chez lequel cet appareil est central; le test est plus allongé et le péristome est plus petit dans la première espèce, enfin les pédicellaires sont différents : je n'observe pas, sur la face interne des valves des pédicellaires tridactyles de l'A. shackletoni, cette saillie médiane formée par les mailles du réseau que Mortensen a indiquée chez l'A. agassizii.

La forme allongée de l'A. shackletoni rappelle celle de l'A. elongatus. Laissant de côté la question posée par Mortensen, de savoir si l'A. elongatus doit être réuni ou non à l'A. agassizii, il est certain que l'A. shackletoni ne peut être confondu avec la première espèce: il s'en éloigne par son appareil apical reporté en avant, par le périprocte plus grand et par une forme différente des pédicellaires tridactyles et rostrés.

Les spicules des tubes ambulacraires ne présentent aucun caractère particulier: ce sont des bâtonnets incurvés avec des dents latérales inégales qui peuvent s'allonger et se réunir pour constituer de petites plaques perforées irrégulières.

Je suis heureux de remercier ici mon excellent ami, M. le Dr. Th. Mortensen, de l'examen qu'il a bien voulu faire de cet Abatus ainsi que du genre que je décris ci-dessous ; il a eu également l'extrême obligeance de me communiquer les épreuves du texte et des planches de son mémoire, encore sous presse lorsque j'écrivais ces lignes : Echinoidea of the Swedish South-polar Expedition, dans lequel il étudie les Spatangidés antarctiques et qui m'a rendu les plus grands services pour mes comparaisons.

Aux échantillons que j'ai indiqués plus haut, il y a lieu d'ajouter encore cinq exemplaires extrêmement jeunes, dont la longueur varie entre 5 et 12 millim. et que je rapporte également à l'A. shackletoni. Ces exemplaires étaient associés à six autres Oursins Irréguliers de dimensions analogues et que je considère comme appartenant au genre Brisaster: ce sont peut-être des $B$. antarcticus Sladen, mais ils sont trop jeunes pour être déterminés avec certitude et ils ne m’ont présenté que quelqués pédicellaires non caractéristiques : je ne les signale ici que pour mémoire. 


\section{Pseudabatus, nov. gen.}

Ce genre est voisin du genre Abatus qu'il rappelle par la constitution de son appareil apical dans lequel la plaque madréporique sépare largement les deux plaques génitales postérieures, mais il en diffère par la situation des poches incubatrices. Tandis que dans le genre Abatus, celles-ci commencent à l'appareil apical ou à une très petite distance de ce dernier, ici les poches ne se forment qu'à une certaine distance de l'appareil apical, après la huitième ou la neuvième paire de pores; il reste donc, entre l'appareil apical et chaeune des poches incubatrices, une partie des ambulacres non modifiée et tout à fait à fleur du test, tandis que la dépression qui forme la poche se fait très brusquement; le bord externe de celle-ci est voisin du fasciole. L'ambulacre antérieur reste aussi à fleur du test. Les orifices génitaux sont au nombre de trois. La face postérie ure n'est pas verticale, mais elle est dirigée obliquement en avant du côté ventral, de telle sorte que le périprocte, qu'elle porte, est subventral. Dans la seule espèce connue, les pédicellaires appartiennent aux trois types didactyle, rostré et globifère. Les pédicellaires tridactyles font complètement défaut et les pédicellaires globifères sont d'une forme particulière, leurs valves ayant l'extrémité arrondie et munie de petites dents.

Bien que le genre Pseudabatus soit voisin du genre Abatus, il m'a paru nécessaire de l'en séparer en raison des trois caractères prineipaux indiqués ci-dessus : position des poches incubatrices éloignées de l'appareil apical, situation du périprocte et forme des pédicellaires.

\section{Pseudabatus nimrodi, nov. sp. (Pl. VII, fig. I à 8 ; Pl. VIII, fig. 7 à 12)}

Baie du Cap Royds. Juin 1908. Profondeur, 7-20 brasses. Deux échantillons.

Les deux exemplaires ne sont pas en parfait état d'intégrité et ils présentent des cassures, soit sur la face ventrale, soit sur les côtés du test; ils sont néanmoins très suffisants pour permettre une étude complète.

Ils ont tous deux à peu près les mêmes dimensions qui sont les suivantes : longueur, 49 millim.; largeur, 43 millim.; hauteur, 27 millim.

Dans l'un des individus, que j'appellerai l'individu A, et qui est représenté Pl. VII, fig. I, et Pl. VIII, fig. 8,10 et 12 , la face dorsale du test offre, quand on regarde l'oursin de côté (Pl. VII, fig. 1), une courbe régulière aussi bien on avant qu'en arrière de l'appareil apical, de telle sorte que le contour de cette face est régulièrement arrondi. L'autre individu, ou individu B (Pl. VIII, fig. 9), offre, dans la partie antérieure de la face dorsale, un profil simplement oblique et peu convexe, et la région interradiale postérieure est peu proéminente, de telle sorte que le test, vu latéralement, est plus conique que dans l'autre exemplaire. Chez tous deux d'ailleurs, le pôle apical est aplati. 
Vu par la face dorsale (Pl. VIII, fig. 7 et 8), le contour de la face dorsale est ovalaire mais il n'est parfaitement régulier chez aucun des deux échantillons, et le côté droit du bord antérieur du test est un peu plus proéminent que le côté gauche. Le bord antérieur n'offre pas la moindre trace d'échancrure en son milieu car l'ambulacre antérieur est à fleur du test.

La face ventrale est presque plane, et l'interradius impair postérieur est très peu convexe. Le bord antérieur du labre se trouve à 15.5 millim. en arrière du bord antérieur du test chez l'individu A; la mesure n'a pas pu être prise sur l'individu B, dont la face ventrale est brisée dans la partie centrale.

En examinant l'échantillon A de profil, on constate que le bord supérieur de la face dorsale se relie à la face ventrale par une petite face postérieure très courte et oblique ; dans l'échantillon B, cette face est un peu plus haute et moins oblique. Il en résulte que dans le premier, le périprocte est en partie placé sur la face ventrale et il est visible quand on regarde l'oursin par cette face (Pl. VIII, fig. 12); dans le second, il n'apparaît que fort peu du côté ventral. D'ailleurs dans l'individu A, le périprocte est assez petit: il ne mesure que 5 millim. de diamètre et il est à peu près aussi haut que large; son contour est irrégulièrement circulaire avec une petite pointe du côté ventral (Pl. VIII, fig. 10). Dans l'individu B, le périprocte est plus grand : il mesure 6.5 millim. de largeur sur 6 de hauteur; son contour est aussi irrégulièrement arrondi (Pl. VIII, fig. 11).

Le pôle apical est plus rapproché du bord antérieur du test que du bord postérieur. La ligne qui réunit les centres des deux orifices génitaux postérieurs se tropve à 20 millim. du bord antérieur et à 29 millim. du bord postérieur du test. Les trois orifices génitaux de l'exemplaire A sont légèrement ovoïdes et un peu plus grands que dans le second: ils mesurent 1.7 millim. de largeur et les centres des deux orifices antérieurs sont séparés par un intervalle de 6 millim. (fig. 8); dans l'exemplaire B, ces orifices ont 1.2 millim. de largeur, et les centres sont séparés par une distance de 5 millim. (fig. 7).

Les contours des plaques de l'appareil apical se reconnaissent facilement, surtout dans l'échantillon B (Pl. VII, fig. 4). Dans ce dernier, les deux plaques génitales gauches sont une fois et demie plus longues que larges; l'orifice que chacune d'elles porte est beaucoup plus rapproché du bord externe que du bord interne, et il existe un certain nombre de petits tubercules en dehors et en dedans de l'orifice. Ces plaques sont séparées, sur la moitié de leur longueur, par la plaque ocellaire de l'ambulacre antérieur gauche. La plaque génitale droite est plus petite que les deux autres et à peine plus longue que large ; l'orifice se trouve placé à peu près à égale distance du bord externe et du bord interne. La plaque madréporique, qui sépare les deux plaques génitales gauches de la plaque droite, est allongée et rétrécie dans sa région antérieure. Elle dépasse en avant le milieu de la plaque ocellaire antérieure, et elle s'arrête, en arrière, au niveau du milieu des deux plaques ocellaires postérieures. Elle offre des orifices, petits et peu nombreux, irrégulièrement disposés et se montrant surtout dans sa. 
région moyenne, tandis que sur le reste de sa surface, elle porte de petits tubercules. Les plaques ocellaires sont triangulaires, avec un angle interne arrondi et un bord externe plus ou moins excavé, vers le milieu duquel se trouve le pore qui est allongé dans le sens radiaire; ces plaques sont plus saillantes que les ambulacres qu'elles terminent. La plaque ocellaire de l'ambulacre IV, qui est placée entre les moitiés externes des deux plaques génitales gauches, a l'angle proximal plus aigu et moins arrondi que les autres; c'est la seule qui ne soit pas contiguë à la plaque madréporique.

Chez l'individu A (Pl. VIII, fig. 8), je constate, dans les caractères de l'appareil apical, quelques différences qui ne tiennent pas à une différence de sexe, car j'ai reconnu chez tous deux la présence d'œufs dans les poches incubatrices. Les orifices génitaux sont un peu plus grands et plus écartés que dans l'échantillon $B$ et ils sont aussi légèrement ovalaires; les plaques génitales portent des tubercules plus nombreux. Les plaques ocellaires ne sont pas saillantes; elles sont plus étroites et relativement un peu plus allongées que dans l'individu $B$, et leurs contours sont moins distincts. La plaque madréporique ne présente de pores que sur une plage centrale peu étendue, et tout le reste de sa surface est couvert de petits tubercules secondaires.

L'ambulacre antérieur impair reste absolument à fleur du test dans l'individu $\mathbf{A}$ (Pl. VIII, fig. 8) et i] offre, dans sa moitié proximale, une très légère tendance à se déprimer chez le second individu (fig. 7). Les zones porifères sont droites et parallèles, et chacune d'elles renferme vingt-deux paires de pores comptés jusqu'au fasciole. Les pores des trois ou quatre premières paires sont très fins, très rapprochés et disposés obliquement par rapport à l'axe de l'ambulacre; les suivants sont plus grands, plus écartés et placés transversalement. A partir de la dix-septième ou de la dix-huitième paire, les pores se rapprochent de nouveau en se plaçant obliquement et ils deviennent très petits. Les pores sont voisins des bords antérieur et externe de la plaque; quelques petits tubercules très fins se montrent, soit entre le bord interne, soit entre le bord postérieur de la plaque et la paire de pores; parmi les tubercules internes, on en remarque souvent un plus gros que les autres. A mesure qu'on se rapproche du fasciole, le nombre et la taille des tubercules augmentent et chaque plaque arrive à porter quelques petits tubercules primaires. Au-delà du fasciole, ces tubercules primaires deviennent plus nombreux et plus serrés, et, dans leurs intervalles, se trouvent des tubercules beaucoup plus fins.

Les ambulacres latéraux antérieurs sont très fortement divergents ; au contraire les ambulacres postérieurs sont très rapprochés. L'ambulacre antérieur forme, avec l'ambulacre postérieur du même côté un angle à peu près droit.

L'ambulacre antérieur débute par une partie amincie qui va en s'élargissant et qui reste absolument au niveau du test, sans la moindre tendance à s'enfoncer, cela jusqu'à la neuvième paire de pores. A ce niveau, l'ambulacre se déprime brusquement en même temps qu'il s'élargit, et il ne suit pas, en s'enfonçant, une direction verticale seulement, mais il se dirige obliquement en dedans vers le pôle apical, de telle sorte 
que la poche incubatrice ainsi constituée est en réalité plus longue qu'elle ne le paraît extérieurement, et que son bord interne, aminci, surplombe une portion de cavité qui peut atteindre 3 millim. de longueur environ. La cavité incubatrice atteint les dimensions suivantes :

\begin{tabular}{|c|c|c|}
\hline Longueur extérieure . & $\begin{array}{l}\text { Échantillon } A . \\
11 \text { millim. }\end{array}$ & $\begin{array}{c}\text { Échantillon } B \\
14 \text { millim. }\end{array}$ \\
\hline Largeur extérieure . & $5 \cdot 5,5$ & \\
\hline Profondeur maxima . & $6 \Rightarrow$ & $8 \cdot 9$, \\
\hline
\end{tabular}

Vers son tiers externe, la poche se rétrécit et son fond se relève progressivement pour revenir au niveau du test; elle se termine à peu près au bord interne du fasciole dans l'échantillon $B$, tandis que dans l'autre elle n'atteint pas exactement ce bord: il reste au moins à fleur du test une plaque ambulacraire qui sépare la poche du fasciole et le relèvement de cette poche est plus progressif.

Les ambulacres postérieurs présentent des dispositions analogues. La poche, qui se forme brusquement, et dont la face interne est également dirigée obliquement en dedans, est séparée de l'appareil apical par une partie ambulacraire non modifiée et restant à fleur du test, sur laquelle je compte neuf paires de pores dans l'individu B et huit dans l'autre; dans le premier, la poche est un peu plus grande. Les poches ont les dimensions respectives suivantes :

\begin{tabular}{|c|c|c|}
\hline Longueur extérieure . & $\begin{array}{c}\text { Échantillon } A \text {. } \\
12 \text { millim. }\end{array}$ & $\begin{array}{r}\text { Échantillon } B \\
14 \text { millim. }\end{array}$ \\
\hline Largeur extérieure . & $6 \quad$ & $6 \quad$, \\
\hline Profondeur maxima & 9 & 9 \\
\hline
\end{tabular}

Les poches postérieures sont donc un peu plus grandes que les antérieures; dans l'échantillon $B$, elles s'étendent jusqu'au bord interne du fasciole, tandis que dans l'autre individu, elles sont séparées de ce bord par une ou deux plaques à fleur du test, comme cela arrive pour les poches antérieures. Les plaques qui forment les parois des poches présentent de petits tubercules portant de petits piquants fins et cylindriques, au milieu desquels j'ai trouvé quelques œufs chez les deux individus.

Au delà des poches, les plaques ambulacraires sont uniformément couvertes de tubercules primaires entremélés d'autres tubercules beaucoup plus fins.

Les régions interradiales de la face dorsale offrent également un recouvrement uniforme de tubercules primaires rapprochés, entre lesquels se montrent des granules très fins. L'interradius postérieur est simplement convexe sans former de gibbosité.

La face ventrale est très peu convexe (Pl. VIII, fig. 12). Le péristome est assez large. Le bord antérieur du labre est saillant et large, mais il est arrondi et proémine peu en avant; il laisse à découvert la plus grande partie des plaques du péristome. Il m'a été absolument impossible de reconnaître, sur l'exemplaire où 
il est conservé, les limites postérieures du labre, même après traitement à l'eau de Javelle.

L'ambulacre antérieur ventral est légèrement déprimé; il est assez large au voisinage du péristome, puis il se rétrécit et se. relève en se rapprochant du bord antérieur du test. Il offre, de chaque côté, cinq pores ambulacraires placés chacun au bord d'une dépression ovalaire bien marquée. Les ambulacres latéraux antérieurs sont presque situés sur le prolongement l'un de l'autre. Ils sont déprimés dans leur région proximale, un peu plus même que l'ambulacre antérieur, mais ils reviennent au niveau du test vers le milieu de leur longueur. Chacun d'eux offre, de chaque côté, cinq ou six pores avec leurs dépressions ovalaires.

Les avenues ambulacraires postérieures sont larges et elles ne sont un peu déprimées qu'au voisinage immédiat du péristome, où chacune d'elles offre deux rangées légèrement divergentes de quatre ou cinq pores avec leurs dépressions ovalaires. Les plaques suivantes, très grandes, présentent comme d'habitude, un petit pore placé vers le bord antérieur.

Les ambulacres n'offrent que quelques tubercules très fins, peu serrés sur les ambulacres antérieurs, plus serrés sur les avenues ambulacraires postérieures. Les tubercules primaires n'y font leur apparition qu'au voisinage du bord du test. Les régions interradiales ventrales possèdent des tubercules primaires sensiblement plus gros que ceux de la face dorsale, avec des tubercules très fins qui forment généralement un cercle autour des précédents. Les tubercules de l'interradius postérieur ne sont pas plus développés que les autres: ils forment des files plus ou moins régulières et divergentes partant de l'angle postérieur, qui débutent par des tubercules d'abord plus petits et qui grossissent ensuite à mesure qu'on se rapproche des avenues ambulacraires ventrales ou du péristome.

J'ai dit plus haut que dans l'échantillon $\mathrm{A}$, l'extrémité postérieure était légèrement arrondie, tandis que dans le second, cette extrémité était mieux marquée et formait une petite face dirigée obliquement vers le bas; aussi le périprocte est-il plus visible par la face ventrale dans l'échantillon A que dans l'échantillon $B$, bien qu'il soit plus petit dans le premier. Les plaques qui recouvrent le périprocte sont irrégulières comme forme et comme disposition, et elles sont plus grandes vers la périphérie.

Il n'existe pas de traces de tubes ambulacraires sous-anaux.

Le fasciole se trouve très rapproché du bord antérieur du test dont il est séparé à peine par une distance de 5 millim., mais, comme la face dorsale s'infléchit très rapidement en avant pour rejoindre la face ventrale et se réunit finalement à cette face par une partie à peu près verticale, comme d'autre part le fasciole se trouve placé sur cette partie presque verticale, celui-ci està peine visible quand on regarde l'animal par en haut. Après un court trajet parallèlement au bord du test, le fasciole s'en écarte légèrement et il offre deux concavités peu profondes séparées par un angle aigu. Il atteint ensuite le bord externe de la poche incubatrice antérieure qu'il contourne et s'infléchit d'abord en dedans, parallèlement au bord postérieur de cette poche. Il ne 
tarde pas, en formant un angle obtus, à reprendre son trajet parallèle au bord du test. dont il se trouve assez écarté entre les deux poches incubatrices, puis, arrivé à 7 ou 8 millim. de la poche postérieure, il forme un nouvel angle obtus, se rapproche du bord du test, contourne le bord externe de la poche incubatrice postérieure et se dirige vers la ligne interradiale médiane en restant à 8 millim. environ du bord postérieur du test. Sa largeur moyenne est d'un millimètre environ; il s'amincit légèrement dans ses parties antérieure et postérieure et s'élargit tun peu au niveau des deux poches. incubatrices.

Les tubercules primaires ne sont pas très saillants. Ils sont plus gros sur la face ventrale que sur la face dorsale ainsi que j'ai eu l'occasion de le dire, mais leurs. dimensions restent très uniformes dans la même région; ils deviennent seulement un peu plus gros sur les bords antérieur et postérieur des poches incubatrices. Ils sont. perforés et finement crénelés.

Les piquants que portent les tubercules primaires de la face dorsale sont très courts, fins et serrés, séparés par d'autres piquants beaucoup plus petits. Ils sont un peu aplatis et élargis en spatule, avec l'extrémité tronquée et leur surface est finement striée; ils deviennent un peu plus forts à l'ambitus. Vers les poches incubatrices, les piquants deviennent plus larges et plus forts, leur extrémité est plus élargie et ils se dirigent horizontalement en s'enchevétrant avec leurs congénères du bord opposé de manière à recouvrir la poche. Ces piquants, ainsi que les piquảnts marginaux, offrent souvent une cannelure longitudinale assez marquée. Les piquants de la face ventrale sont plus développés que sur la face dorsale; ils sont allongés, aplatis, élargis. à l'extrémité et les plus gros sont cannelés.

Les pédicellaires appartiennent aux trois types didactyle, rostré et globifère. Les pédicellaires didactyles sont abondamment répandus sur tout le test,(Pl. VII, fig. 6 et 7). Leur pédoncule est relativement assez long et la tige calcaire est éloignée de la tête d'une distance qui est presque égale à la hauteur de celle-ci, qui varie entre 0.6 et 0.7 millim. Les valves sont aplaties, et leur base offre une échancrure proforde; leur face externe est convexe, et, en dedans, clles s'adossent à leur congénère par un bord droit muni de denticulations extrêmement fines et très régulières. Les perforations sont disposées régulièrement. Les pédicellaires tridactyles, que ceux-ci remplacent, font complètement défaut.

Les pédicellaires rostrés sont très abondants aussi (PI. VII, fig. 8). Leur tête mesure 0.8 à 1 millim. de hauteur dans les plus grands et la tige calcaire de leur pédoncule, élargie à son extrémité, en est très rapprochée. Leurs valves offrent une base allongée; le limbe est étroit et il conserve à peu près la même largeur jusqu'à l'extrémité qui est un peu élargie; les bords sont reployés en dedans: ils sont un peu irréguliers, sinueux et ils offrent quelques dents très petites et basses, très espacees, tandis que l'extrémité porte une rangée de dents très fines, rapprochées et. très régulièrement disposées.

Les pédicellaires globifères sont très rares (Pl. VII, fig. 5). Leur tête, qui mesure. BRIT. ANTARCT. EXPED. 1907-9. VOL. II. 
0.1 à 0.5 de hauteur, est recouverte d'un tégument glandulaire et foncé semblable à celui qu'on rencontre dans le genre Abatus. Les valves sont formées d'un tissu calcaire délicat avec de grandes perforations; elles offrent un limbe allongé, assez large et allant en s'élargissant légèrement jusqu'à l'extrémité : celle-ci est arrondie et porte dix à douze dents coniques, pointues, assez courtes, contiguës, un peu inégales et formant une bordure tout le long du bord terminal. L'orifice, très large, dépasse le milieu de la longueur du limbe, et, en dessous de lui, ce dernier constitue un tube dont les parois offrent de grandes perforations.

La couleur des deux échantillons était à peu près uniformément noire. Pour les -étudier et les photographier, j'ai dû les décolorer incomplètement à l'eau de Javelle, mais le test a conservé des taches et des marbrures: aussi j'ai éprouvé de grandes -difficultés pdur obtenir des photographies passables.

Lyos, Septembre 1910.

\section{LISTE DES OUVRAGES CITÉS}

91. Perrier, Ed., Échinodermes de la Mission du Cap Horn. Parie, 1891.

95. Lieitrold, FR, "Asteroidea der Vettor Pisani Expedition" Zeit. für wiss. Zool., Bd. LIX.

03. Ludwia, H. . Résultats du Voyage du S.Y. "Belgica." Seesterne.

05. " "Asterien und Ophiuren der schwedischen Expedition nach den Magalhaonsländern, 1895-97." Zeit. für wiss. Zool., Bd. 82.

06. Fisher, W. K. Tho Starfishes of the Hawaïan Islands. U.S. Fish Commission Bulletin for 1903, Part III. Washington, 1906.

06. KaHLER, R. . Expédition antarctique française commandée par le Dr. J. Charcot. Échinodermes.

08. " . "Astéries, Ophiures et Échinides de l'Expédition Antarctique Nationale Écossaise." Trans. Roy. Soc. Edinburgh, vol. xlvi.

08. BeLL, J. . "National Antarctic Expedition," Natural History, vol, iv. : Echinoderma.

10. Mortensen, Tl). "Die Echinoiden der deutschen südpolar Expedition, 1901-03," Deutsche siülpolur Expodition, xi. : Zoologie, iii.

10bis. " South-polar Expedition, vol. iii.: Echinoidea. 
PLATE IV 


\section{PLANCHE IV}

FIG. 1.-Cryaster antarcticus. Face dorsale réduite d'un cinquième environ.

Fig. 2.-Cryaster antarcticus. Face ventrale réduite d'un cinquième environ.

Fig. 3.-Abatus shackletoni, mâle. Vue latérale. Grossissement 1•6.

Fig. 4-Abatus shackletoni, mâle. Face postérienre. Grossissement 1.6

Fig. 5.-Abatus shackletoni, mâle. Face dorsale. Grossissement $\mathbf{1} 6$.

Fig. 6.-Abatus shackletoni, femelle. Face postérieure. Grossissement 1:5.

FIG. 7.-Abatus shackletoni. Valve d'un pédicellaire tridactyle à valves larges vue de profil. Grossissement 60 .

Fig. 8.-Abatus shackletoni. Même valve vue de trois quarts. Grossissement 60 .

Fig. 9.-Abatus shackletoni. Valve d'un pédicellaire rostré vue par la face externe.

- Grossissement 80.

Fig. 10.-Abatus shackletoni. Valve d'un pédicellaire rostré vue par la face interne. Grossissement 80.

Fig. 11.-Abatus shackletoni. Valve d'un pédicellaire globifère. Grossissement 110.

Fig. 12.-Abatus shackletoni. Valve d'un pédicellaire tridactyle à valves étroites. Grossissement 60. 


\section{R. KOEHLER : ÉCHINODERNES}

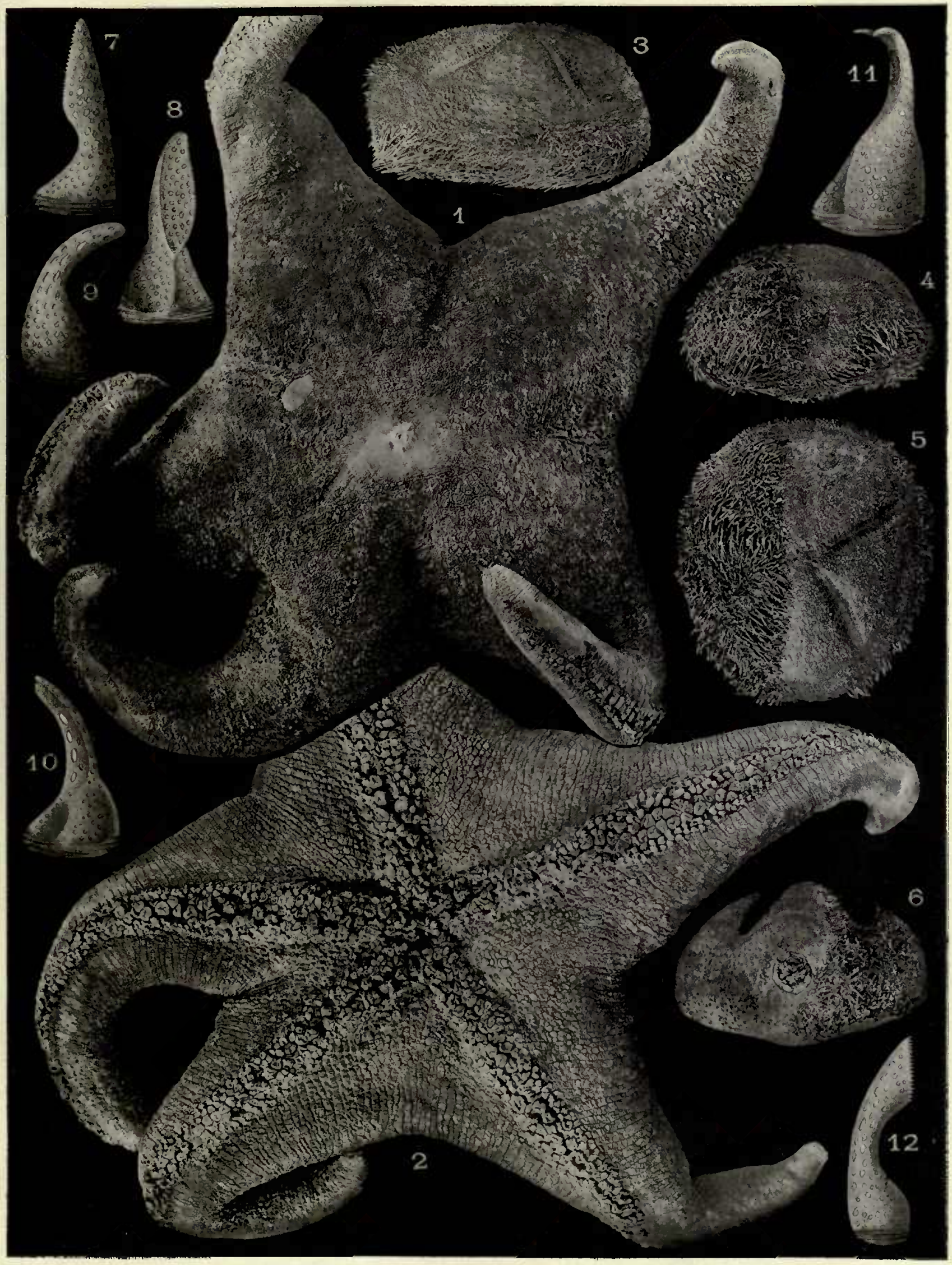

1R. Krohler fecit 



\section{PLANCHE V}

Fia. 1.-Ophioglypha flexibilis. Face dorsale. Grossissement 4.

Fia. 2.-Ophioglypha flexibilis. Face ventrale. Grossissement 4.

Fig. 3.-Coscinasterias victoria. Face dorsale. Grossissement 1•2.

Fig. 4.-Coscinasterias victorice. Face ventrale. Grossissement 1•2.

Fig. 5.-Coscinasterias brucei. Jeune individu vu par la face dorsale. Grossissement $1 \cdot 8$.

Fig. 6.-Notasterias armata. Pédicellaire macrocéphale vu de profil. Grossissement 25.

Fig. 7.-Notasterias armata. Pédicellaire macrocéphale vu de profil après traitement par la potasse qui a séparé les deux valves et la pièce basilaire. Grossissement 25.

Fig. 8.-Notasterias armata. Valve isolée d'un petit pédicellaire macrocéphale. Grossissement 40.

Fig. 9.-Notasterias armata. Deuxième valve du même pédicellaire. Grossissement 40.

Fig. 10.-Notasterias armata. Pièce basilaire du même pédicellaire. Grossissement 40.

Fig. 11.-Notasterias armata. Valve d'un autre pédicellaire macrocéphale un peu plus gros que le précédent. Grossissement 30 


\section{R. KOEHIER : ÉCHINODERMES}

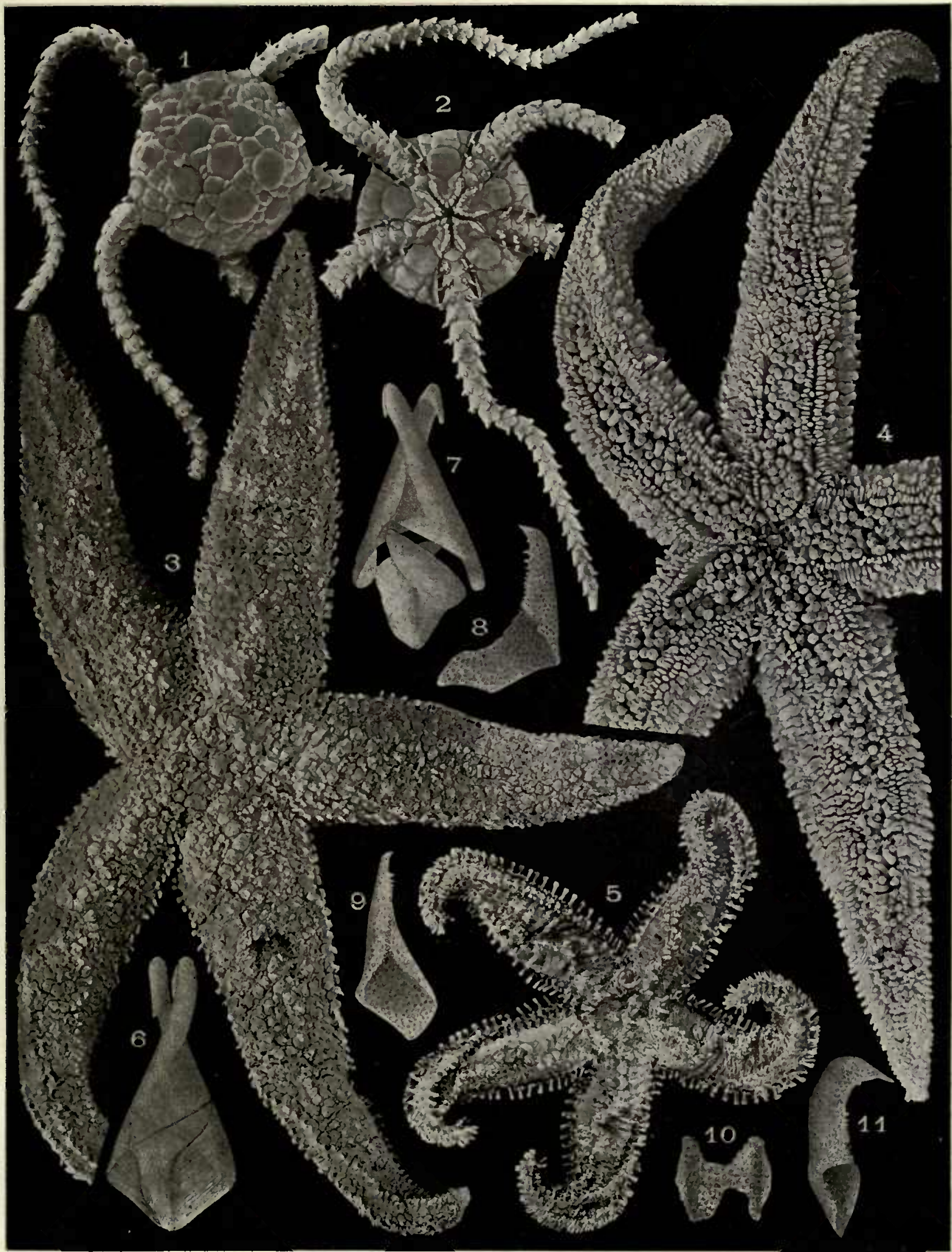

R. Koehler fecit 

PLATE VI 


\section{PLANCHE VI}

Fig. 1.-Notasterias armata. Face ventrale du plus grand exemplaire. Grossissement 2.

FIG. 2.-Notasterias armata. Face dorsale. Grossissement 2.

Fig. 3.-Notasterias armata. Pédicellaire droit du sillon ambulacraire. Grossissement 35 .

Fig. 4.-Notasterias armata. Gros pédicellaire macrocéphale entier vu de face. Grossissement 20.

FiG. 5 à 7.-Notasterias armata. Les deux valves et la pièce basilaire d'un gros pédicellaire macrocéphale. Grossissement 20.

Fig. 8. - Notasterias armata. Pédicellaire macrocéphale de taille moyenne vu de face. Grossissement 35.

Fig. 9.-Ophiodiplax disjuncta. Échantillon recueilli par l'Expédition Antarctique Anglaise; face dorsale. Grossissement 4..

Fig. 10.-Ophiodiplax disjuncta. Échantillon recueilli par la deuxième Expédition Antarctique du Dr. Charcot; face dorsale. Grossissement 4.

FIG. 11.-Ophiodiplax disjuncta. Face ventrale du même échantillon. Grossissement 4. 


\section{R. KEHLER : ÉCHINODERMES}

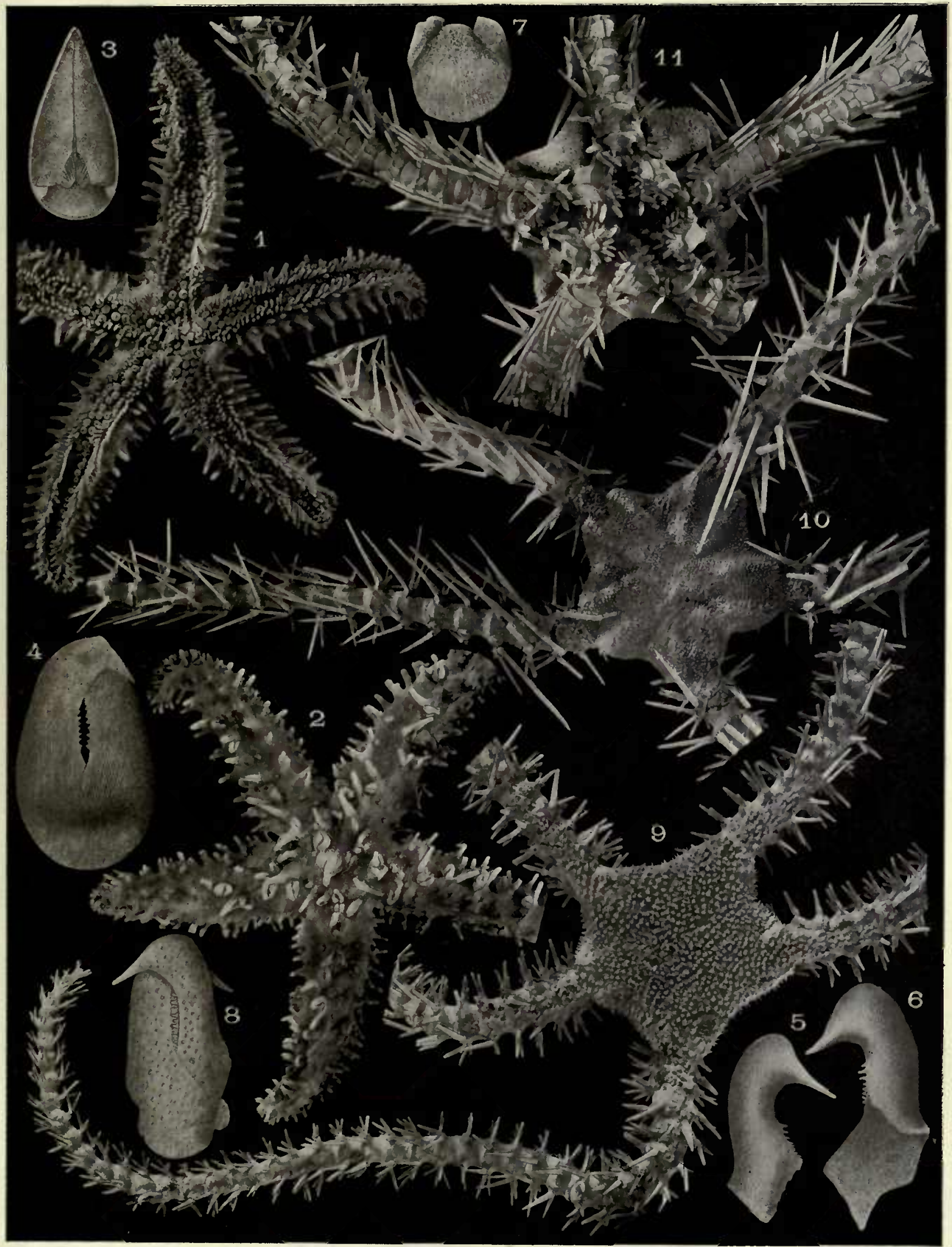

R. Köhler fecit 

PLATE VII

BRIT. ANTARCT. EXPED. 1907-9. VOL. II. 


\section{PLANCHE VII}

Fig. 1.-Pseudabatus nimrodi, individu A. Vue latérale. Grossissement 1*4.

Fig. 2.-Pseudabatus nimrodi, individu B. Vue latérale. Grossissement 1·4.

Frg. 3.-Pseudabatus nimrodi, individu B. Face ventrale. Grossissement 1.4.

Fig. 4.-Pseudabatus nimrodi, individu B. Région apicale. Grossissement 4.

Fig. 5.-Pseudabatus nimrodi. Valve d'un pédicellaire globifère. Grossissement 100.

Fig. 6.-Pseudabatus nimrodi. Valve d'un pédicellaire didactyle. Grossissement 65.

Fig. 7.-Pseudabatus nimrodi. Pédicellaire didactyle. Grossissement 35.

Fig. 8.-Pseudabatus nimrodi. Valve d'un pédicellaire rostré. Grossissement 55.

FIG. 9. Ophioglypha resistens. Face dorsale. Grossissement 3:2.

Frg. 10.-Ophioglypha resistens. Face ventrale. Grossissement $3 \cdot 2$.

Fig. 11.-Ophioglypha resistens, jeune individu. Face dorsale. Grossissement 6 .

FIG. 12.-Ophioglypha resistens. Face ventrale du même individu. Grossissement 6. Fig. 13.-Ophiodiplax disjuncta. Échantillon de l'Expédition Antarctique Anglaise; face ventrale. Grossissement 4.

Fig. 14.-Amphiura algida. Face dorsale. Grossissement 14.

Fig. 15.--Amphiura algida. Face ventrale. Grossissement 14. 
R. KOEHLER : ÉCHINODERMES

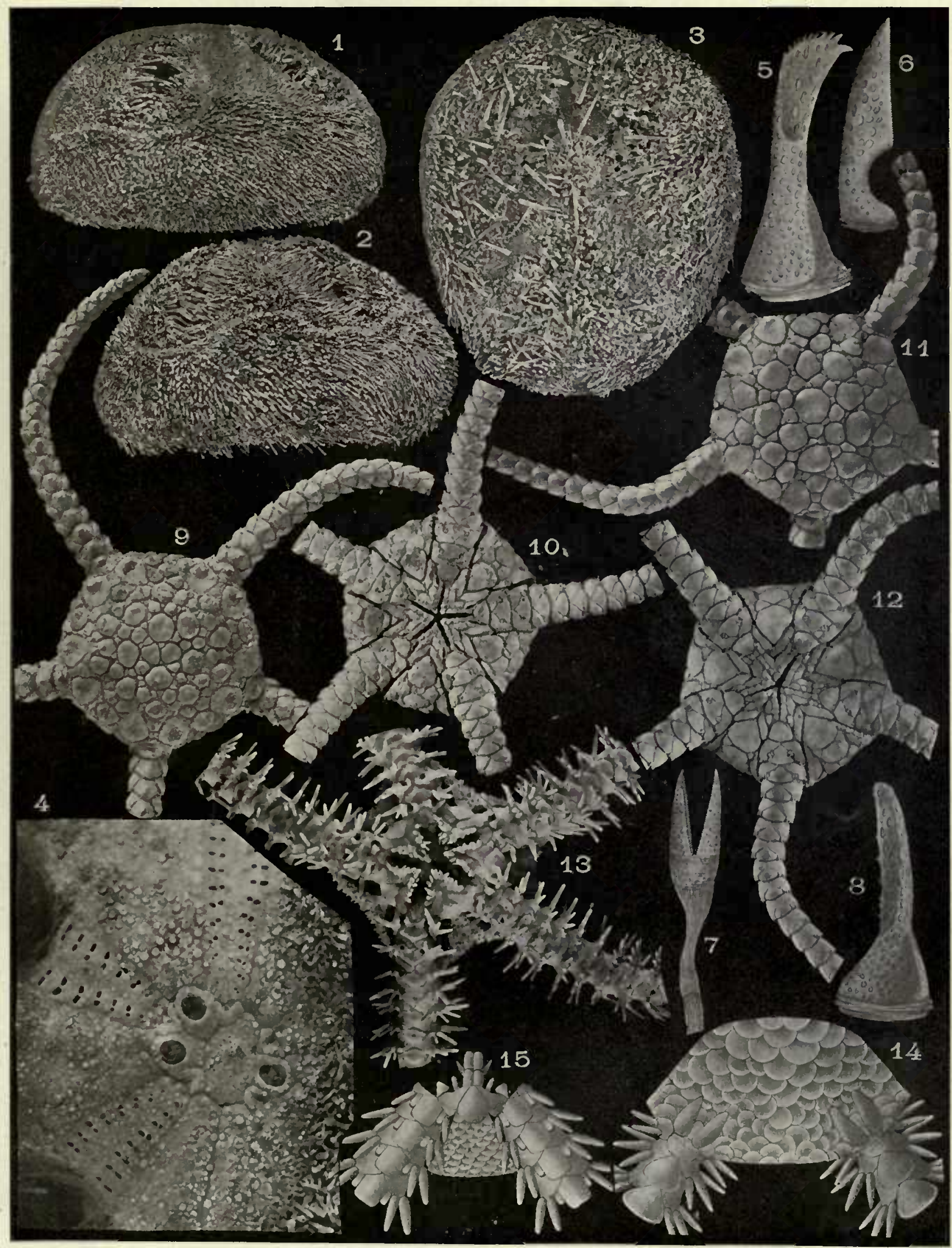

R. Koxhler fecit 

PLATE VIII 


\section{PLANCHE VIII}

Fig. 1.-Abatus shackletoni, individu femelle muni de ses piquants. Face dorsale. Grossissement $1 \cdot 6$.

Fig. 2.-Abatus shackletoni, même individı vu par la face ventrale. Grossissement $1 \cdot 6$.

Frg. 3.-Abatus shackletoni, individu femelle en partie dépouillé de ses piquants. Face ventrale. Grossissement $1 \cdot 6$

Fig. 4.-Abatus shackletoni, même individu. Vue latérale. Grossissement 1'6.

Fig. 5.-Abatus shackletoni, même individu. Face dorsale. Grossissement $1 \cdot 6$.

Fig. 6.-Abatus shackletoni. Face dorsale d'un autre individn femelle. Grossissement $1 \cdot 6$

Fig. 7.-Pseudabatus nimrodi, individu B. Face dorsale. Grossissement 1.4.

Fig. 8.-Pseudabatus nimrodi, individu A. Face dorsale. Grossissement 1·4.

Fig. 9.-Pseudabatus nimrodi, individu B. Vue latérale. Grossissement 1·4.

Fig. 10.-Pseudabatus nimrodi, individu A. Face postérieure. Grossissement 1•4.

Fig. 11.-Pseudabatus nimrodi, individu B. Face postérieure. Grossissement 1.4.

Fig. 12.-Pseudabatus nimrodi, individı A. Face ventrale. Grossissement $1 \cdot 4$. 


\section{R. KOEHLER: ÉCHINODERMES}

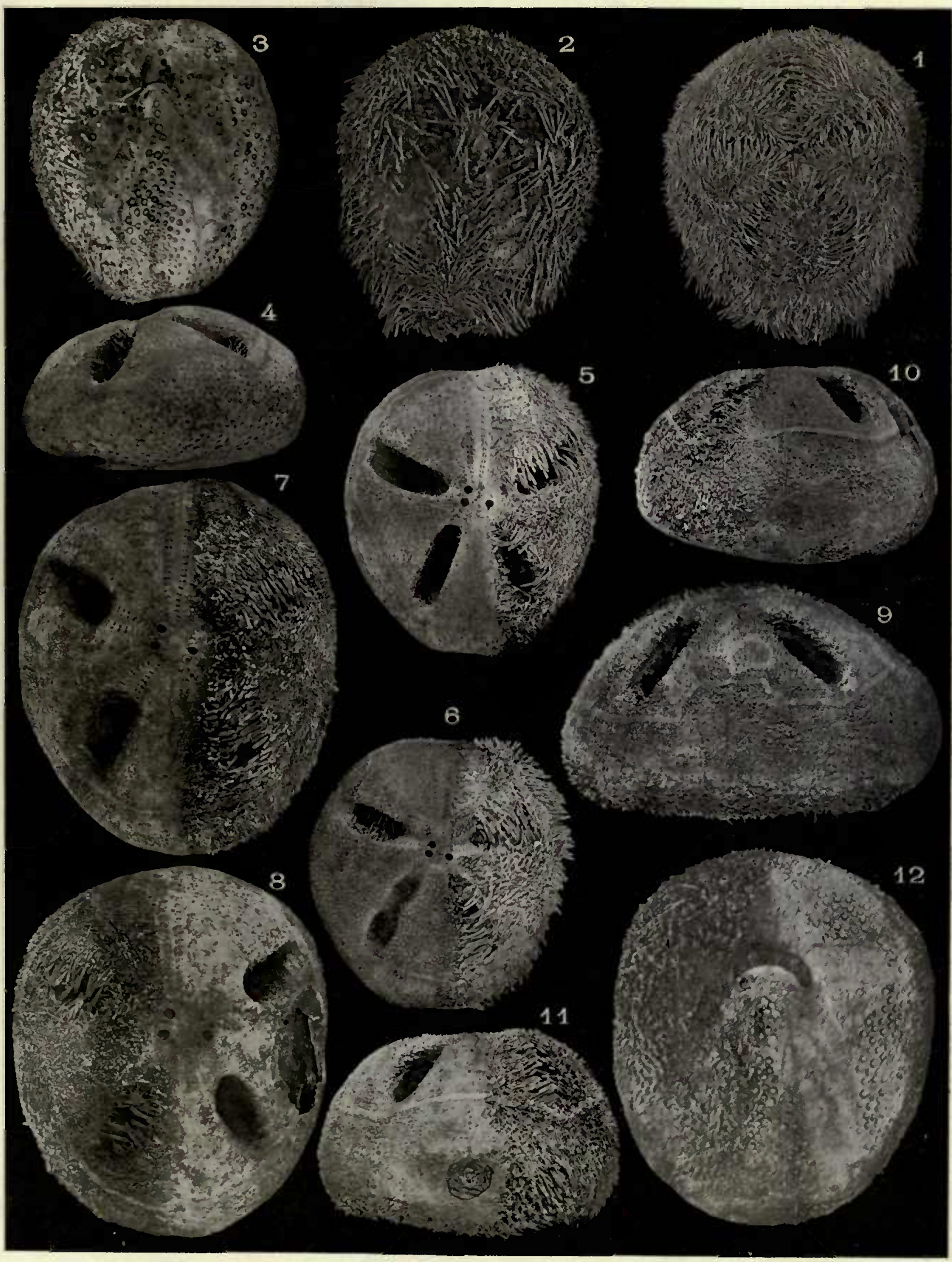

R. Kónler fecit 



\section{REPOR'TS IN PREPARA'TION}

FRESH-WATER ALGÆ. BY W. WEST, F.L.S., AND Prof. G. S. WEST, M.A., D.Sc.

LiCheNS. By Dr, O, V. DARBishiRe, NewCastle. AVES. BY J. MURRAY.

MAMMALIA. BY J. MURRAY. PYCNOGONIDA. Br T. Y. HODGSON. PLYmouth, ISOPODA. BY T. V. HODGSON, PLyмочth. AMPHIPODA. BY T. V. HODGSON, Plymouth. CUMACEA. Br Dr. W. T. CAlMAN, British Museum. VERMES. BY E. J. GODDARD, B.A., B.Sc., SYDNEY. ROTIFLRA OF NEW ZEALAND, AUSTRALIA, PACIFIC ISLANDS AND CANADA. BY J. MURRAY.

POLYZOA. Br W. D. HeNderSON, M.A., B.Sc, Ph.D., Bristol. ALCYONARIA. Ky l'kof. J. ARTHUR THOMSON, M.A., A berdeEn. PORIFERA. By R. KIRKPATRICK, British Museum (Natural History).

LIFE UNDER POLAR CONDITIONS. BY J. MURRAY.

STUDIES IN GEOGRAPHICAL DISTRIBUTION. BY J. Murray. GeNeral GEOLOGY. By Prof. T. W.E. DAVID, F.R.S., Sydney, AND R. E. PRIESTLEY.

GLACIOLOGY. By Prof. T. W. E. DAVID, F.R.S., Sydney. PETROLOGY AND MINERALOGY. BY DRs, MAWSON, WOOLNOUGH, AND JENSFN.

Tidf.S. By Sir G. DARWiN, K.C.B., F.R.S., Cambridge.

PHYSICS. BY DOUGLAS MAWSON, D.Sc, B.E.

MAGNETIS.I. By COLERIDGE FARR, D.Sc., Curistcherch, N.Z. AURORA. By DOUGLAS MAWSON, D.Sc., B.E., ADElaide.

METFOROLOGY. BY H. A. HUNT, Commonwealth Metrorologist, ETC ETC. 


\title{
THE HEART OF THE ANTARCTIC
}

\author{
POPULAR EDITION
}

THE STORY OF THE BRITISH ANTARCTIC

EXPEDITION, 1907-1909

\section{By SIR ERNEST SHACKLETON, C.V.O.}

Richly illustrated from Photographs, and with Coloured Drawings and Map, in One Volume, crown 8vo, 6s. net.

The above can also be obtained in the Original Edition, in Two Volumes, profusely illustrated in Colour, Photogravure, etc., price $36 s$. net.

Also an Edition de Luxe printed on hand-made paper, limited to 350 copies, containing, in addition, the signature of every member of the Shore Party, specially etched plates engraved at winter quarters, 1908, and pastel portraits of the four members of the Southern Party by GEorge Marston.

In Two Volumes, medium 4 to, bound in Vellum, price 10 guinecis net.

LONDON : WILLIAM HEINEMANN, 21 Bedford Street, W.C. 


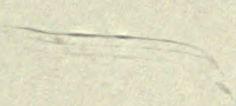

65e 

RETURN TO the circulation desk of any University of California Library

or to the

NORTHERN REGIONAL LIBRARY FACILITY

Bldg. 400, Richmond Field Station

University of California

Richmond, CA 94804-4698

ALL BOOKS MAY BE RECALLED AFTER 7 DAYS

- 2-month loans may be renewed by calling (510) 642-6753

- 1-year loans may be recharged by bringing books to NRLF

- Renewals and recharges may be made 4 days prior to due date.

DUE AS STAMPED BELOW

UN

JUN 111998

\section{APR 142000}

DEC 062006
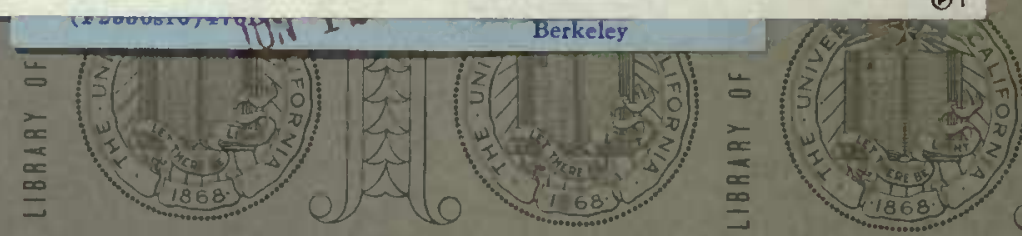

LIBRARY OF THE UNIVERSITY OF CALIFORNIA

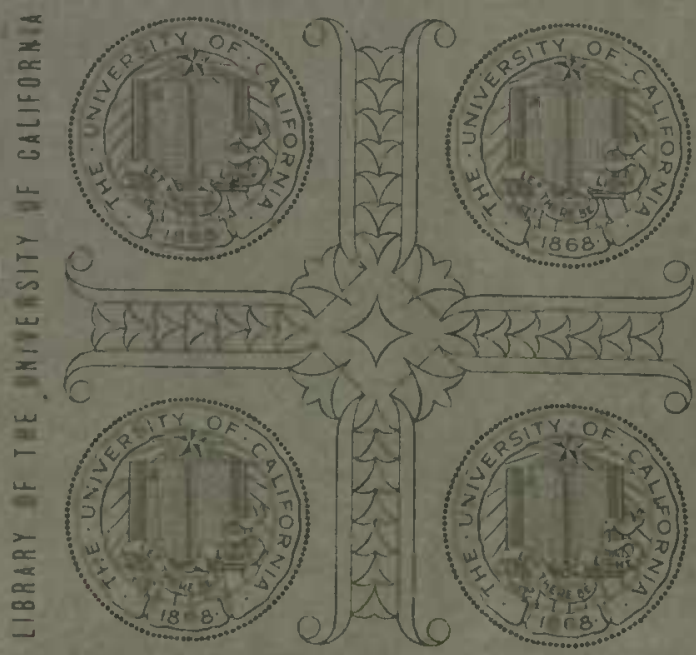

LIBRARY OF THE UNIVERSITY O

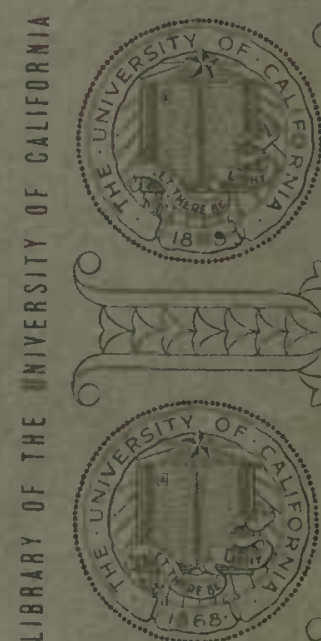


